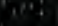

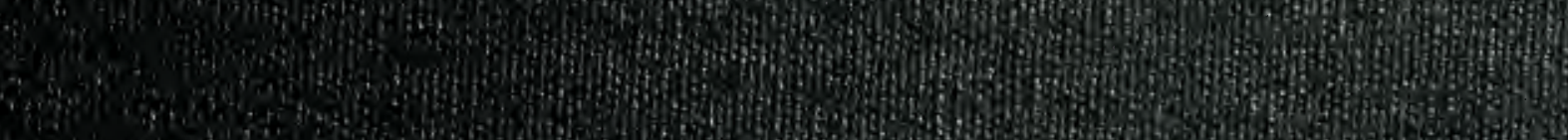
Y

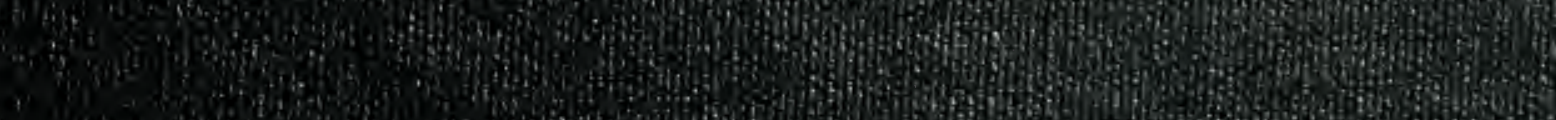
-10. (n)

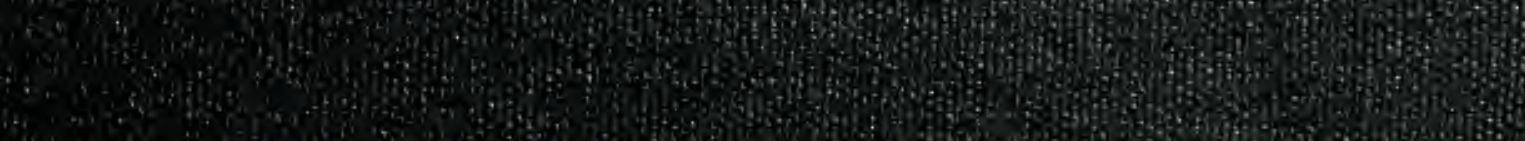
and

4. 


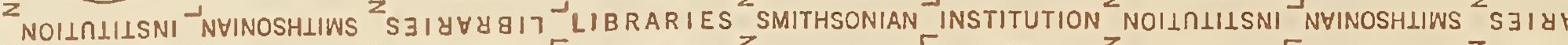
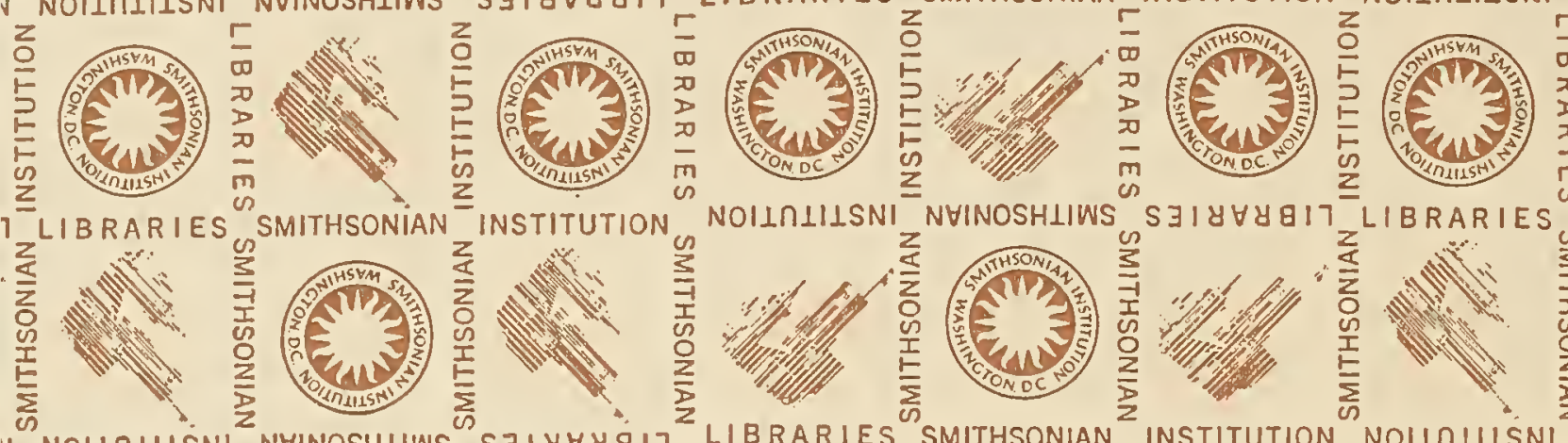

NOILIIISNI

z
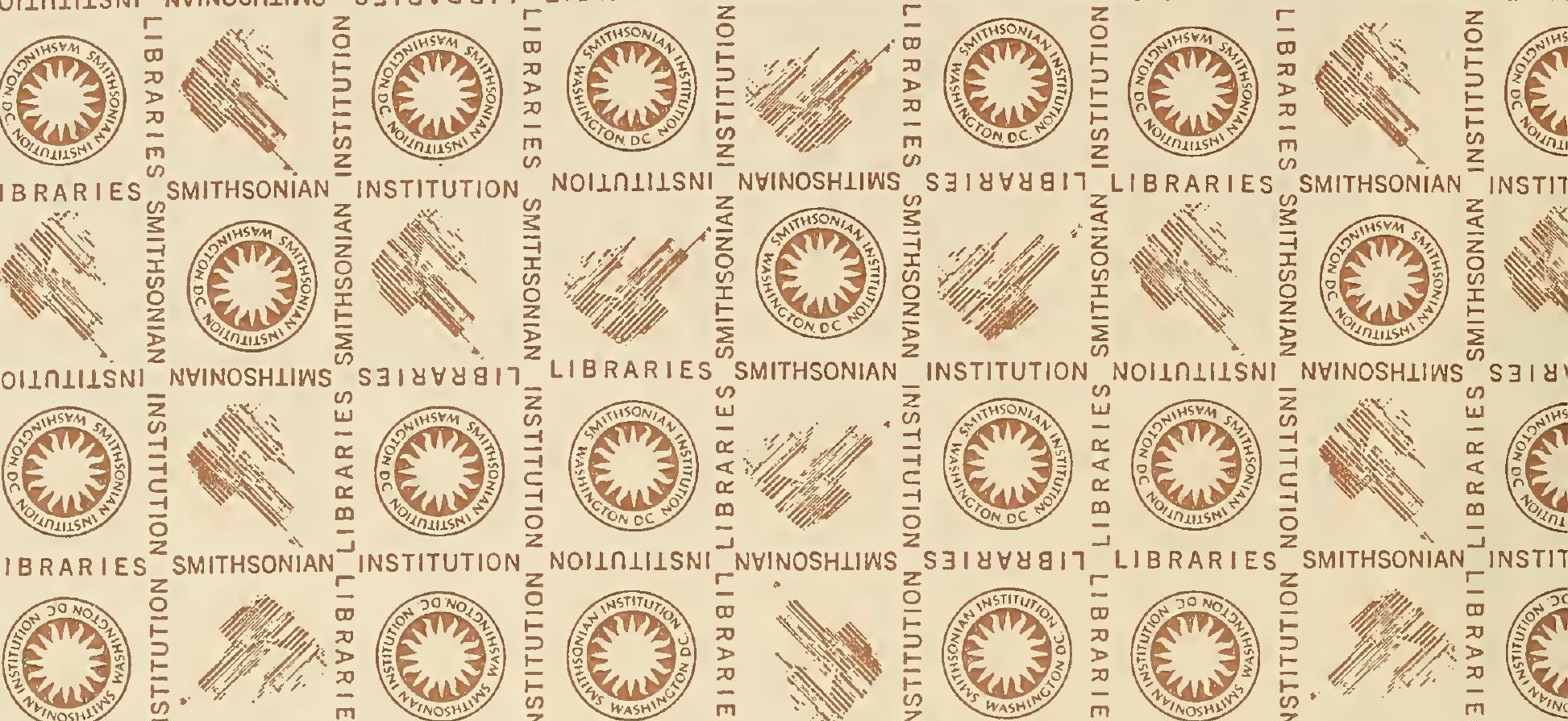

NSTIT
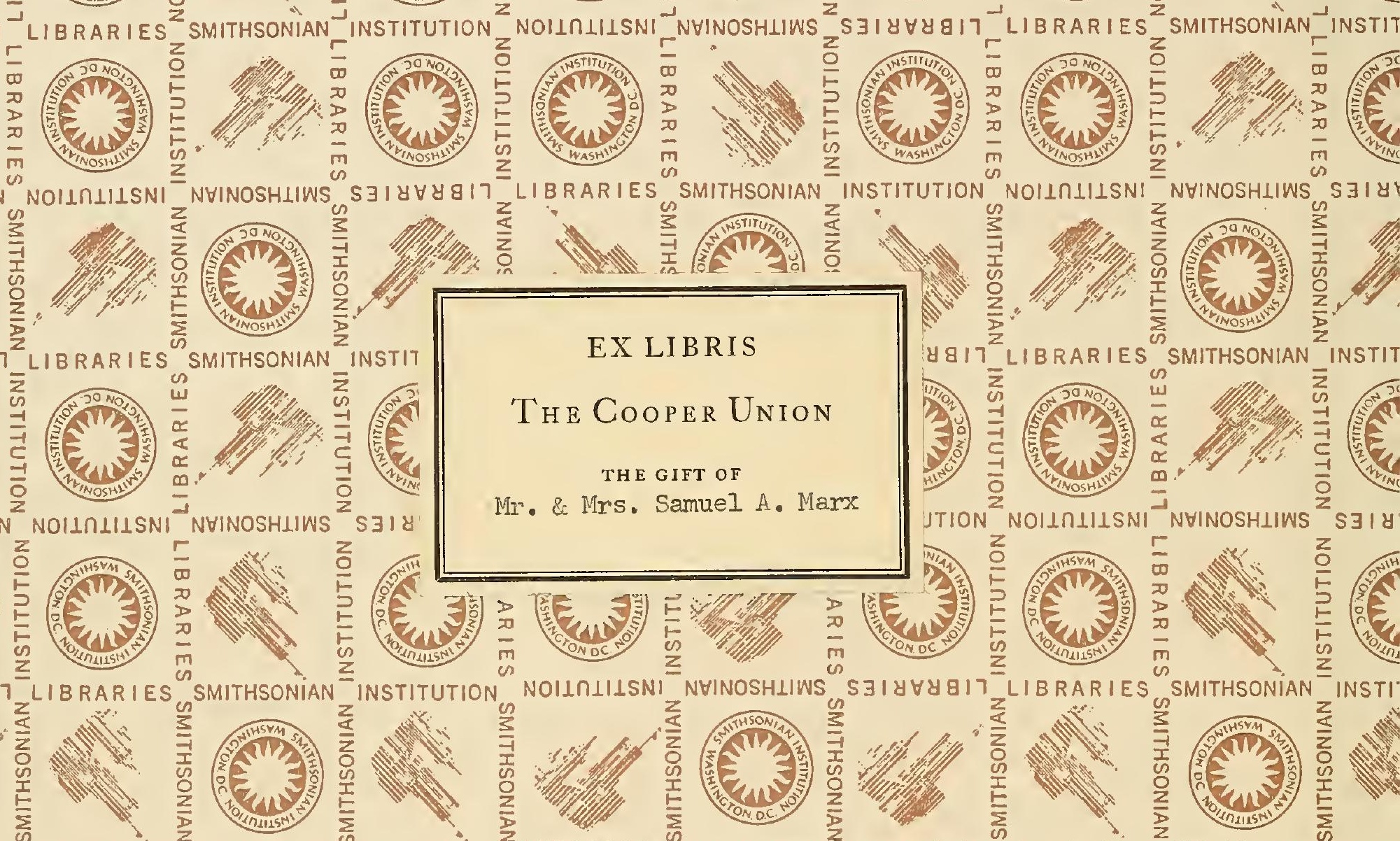

S $\exists 1$ y
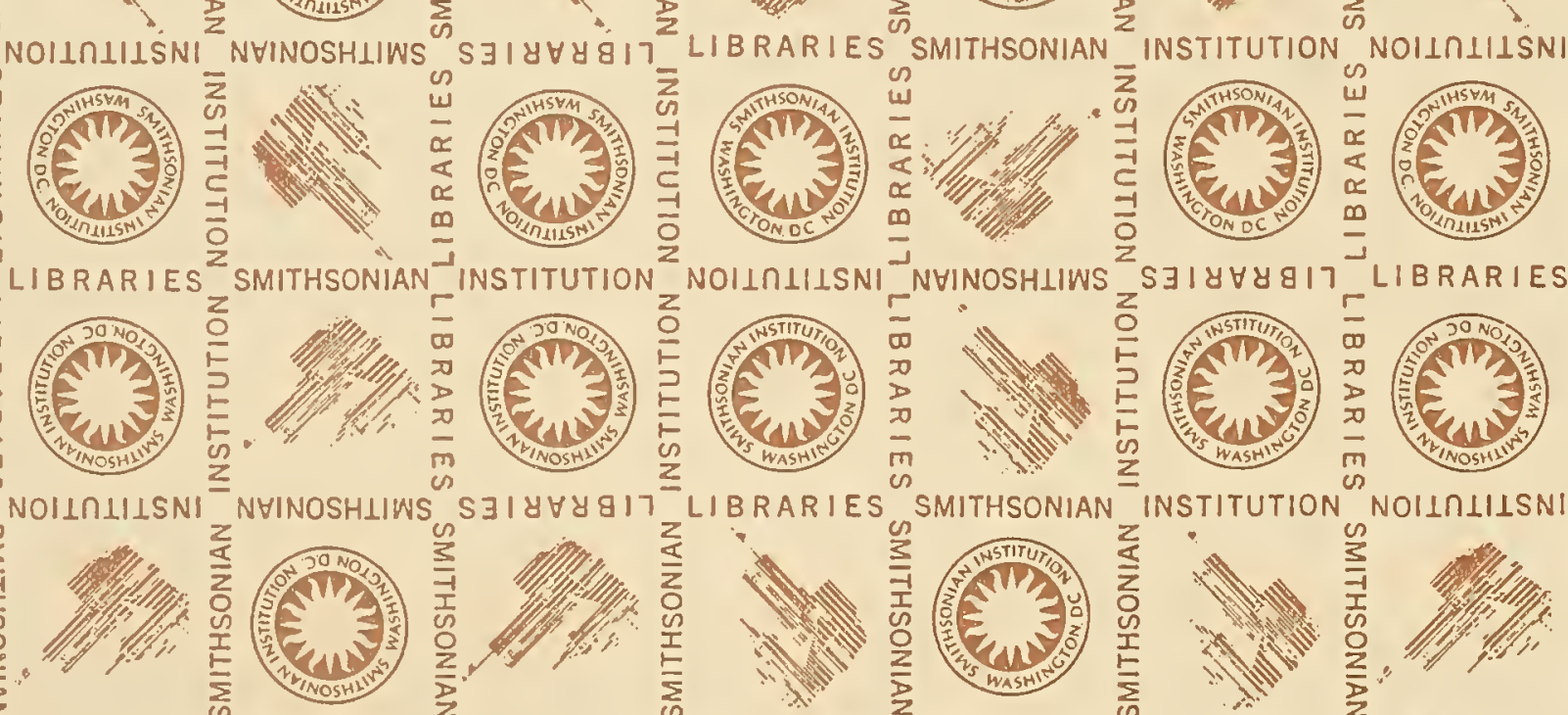

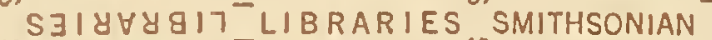
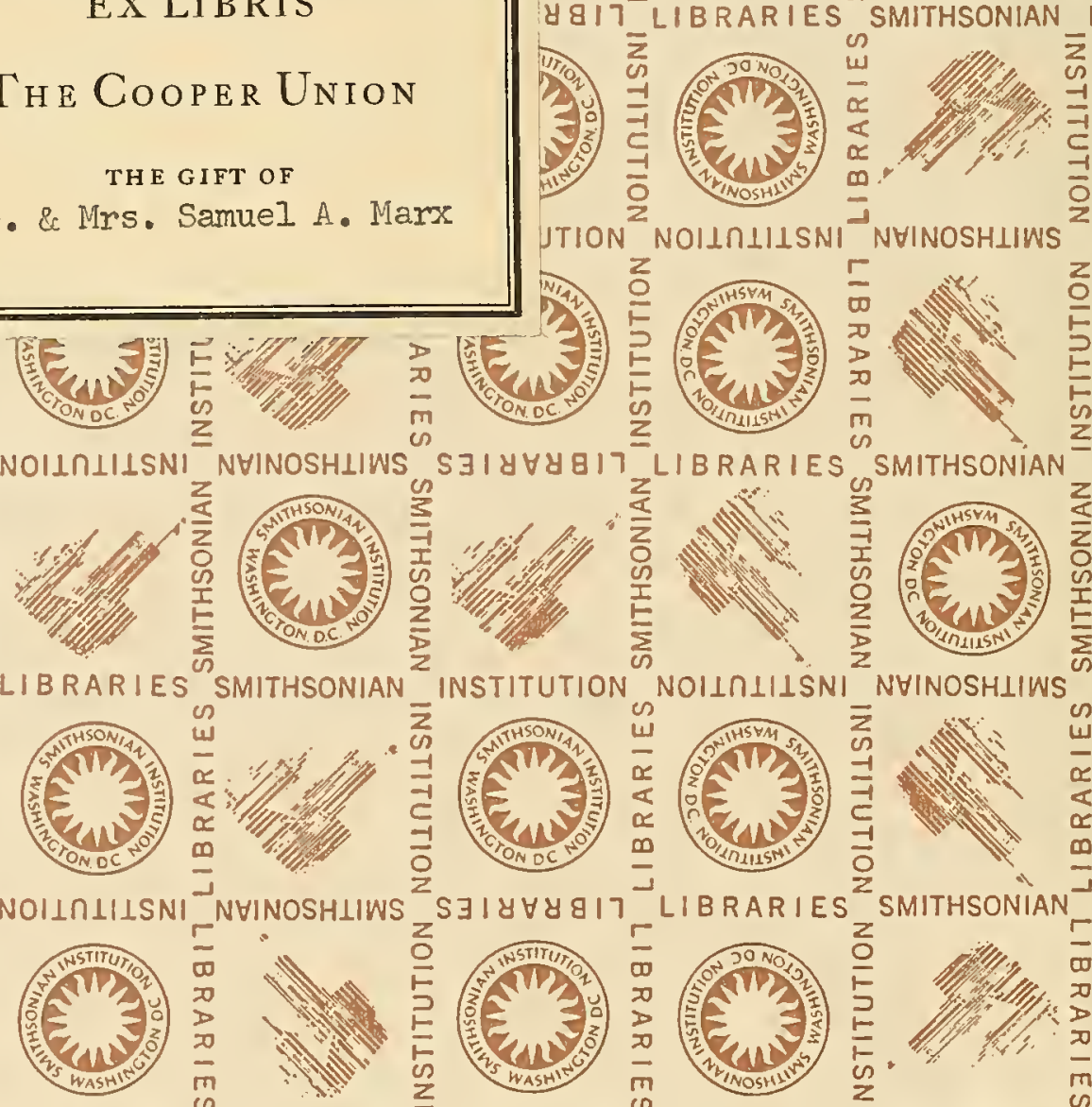

INSTIT
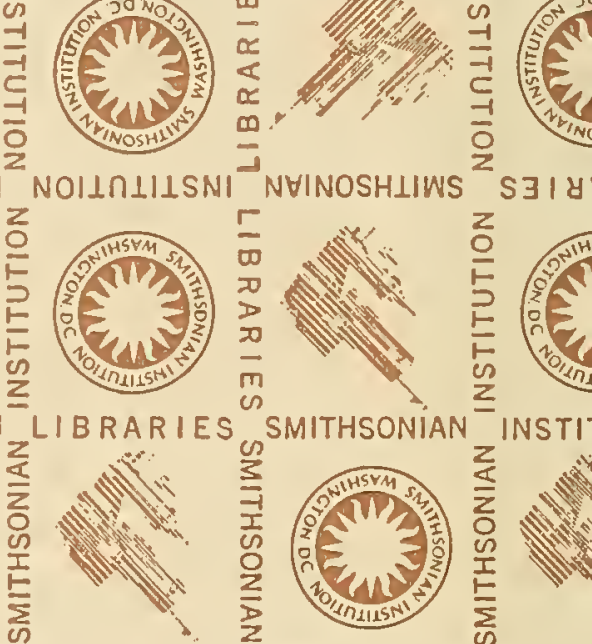

INSTI
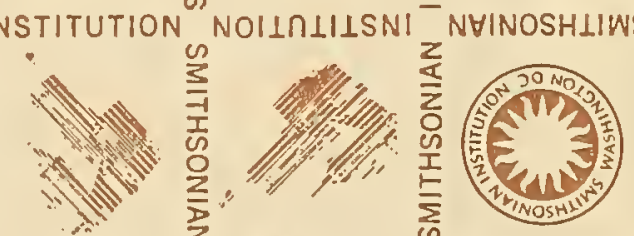

S 31

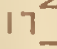
LIB Baties

sortrsonin

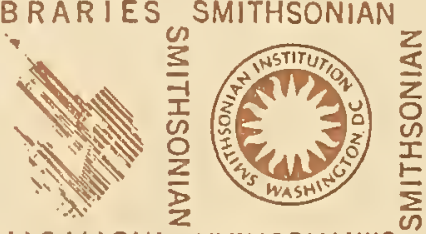







\title{
Period Furnishings
}

AN ENCYCLOPEDIA OF HISTORIC FURNITURE, DECORATIONS AND FURNISHINGS

\author{
By C. R. CLIFFORD
}

FULLY ILLUSTRATED

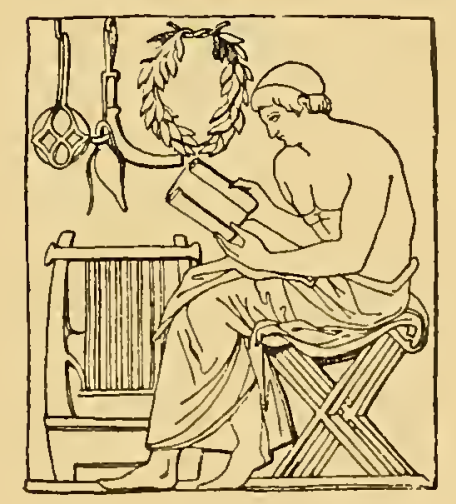

Published by CLIFFORD \& LAWTON

1 East Twenty-eighth Street, New York 
$-$

$\int 1-x$

_

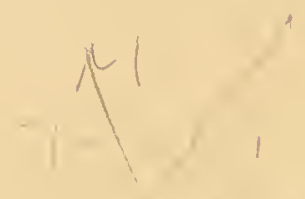

Copyright, 1911

By Clifford \& Lawton

c)

$$
\text { I } R_{1},
$$




\section{INTRODUCTORY}

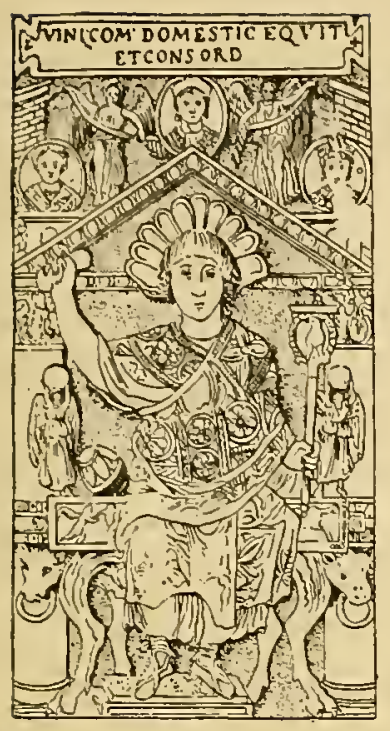

I

PRESENTING this work upon the period furnishings of the house, covcring historic furniture, fabrics, wall trcatments, fitments and accessories, I would lay emphasis upon the fact that the subject cannot be grasped by blind groping or desultory reading. IVe cannot comprehend by simply memorizing dates and incidents. We must know the underlying origin and impetus and the growth of the styles as influenced primarily by the events of history and all that makes history; the development of nations, their social customs and their characteristics. There are no short cuts to be taken in a spirit of impatience. But to the man who is not easily discouraged at the outset this line of study opens a field of world-wide and compelling interest. If he approaches the subject with an orderly mind he will comprehend from the first the broad distinctions and soon begin to differentiate in the more subtle details of decoration.

Since the study must be systematic, I have prepared charts showing the development of races as well as charts showing the devclopment of nations. These give us a retrospect of relationship which will prepare the student to comprehend the later chronological chart which shows the development of the decorative styles. The differentiation between the periods can be made in many cases only by a knowledge of historic relation. Chronological consistency satisfies one's sense of order, and this is quite as important a consideration in the decoration of a room as comfort in the furnishings.

Decoration must be consistent not only in its construction and application, but in its associations. Ancient architects laid down distinct laws of design covering the five orders, the Ionic, the Doric, the Corinthian, the Composite and the Tuscan. To-day the laws of composition upon which these orders were founded are as effective as ever, for they are not arbitrary, but are based upon the nature of the human mind, the cye and the characteristics of the materials of construction. WV must work in accordance with these principles if we are to satisfy the critical taste of men of culture and perception. The outward forms changed from period to period, expressing in their lines, ornament and coloring, the temperament and spirit of the people of the times. Art bccame through progressive stages altered by climination, by absorption, and by temperamental interpolations, evolving practically new types, new forms, but running through all these changing styles are the immutable laws of composition and proportion.

We trace with little difficulty the progress of the arts and the development of distinct periods from the days of earliest Babylonia, Egypt, and Assyria, through Greece and Lower Italy, through Asia Minor, through Bagdad and Byzantinm, into the Mongol courts of Samarkand. IVe note the influence of the Saracenic zcalots along the Mediterranean. We note the desultory expression of a struggling Gothic art through the dark period of the Middle Ages. We note the awakening finally in Italy during the Fourteenth Century, which expanded into that glorious climacteric era, the Renaissance. As the Renaissance developed, carrying with it as an underlying basis the classic arts of Greece and Rome, it was affected by local influences. Religion and commerce alike left their imprint, until funally with the opening of the Seventeenth Century distinct forms varying with the temperament of the nations and of the individual craftsmen, and affected at all times materially by the wealth of suggestion which came through the channets of foreign intercoursc, made their appearance. If we would grasp the meaning and the feeling of what, for want of a better term, we call the decorative periods, we must comprehend the influence in each period of the four prime factors in the development of art, namely, temperament, religion, commerce, and education.

If within the linits of this book I have becn able to elucidate the subject sufficiently to give the student an intelligent grasp of the essential points. I have accomplished all that I set out to do. For the benefit of those who would pursue the investigation further, I append a list of books to which I have had access and from which I have reproduced many illustrations. I wish to express my sense of personal obligation to the authors of these books, whose original investigations have made them the highest authorities, each upon his own special branch of this subject, and whose works I have found invaluable sources of information.

C. R. CLIFFORD. 


\title{
CONTENTS
}

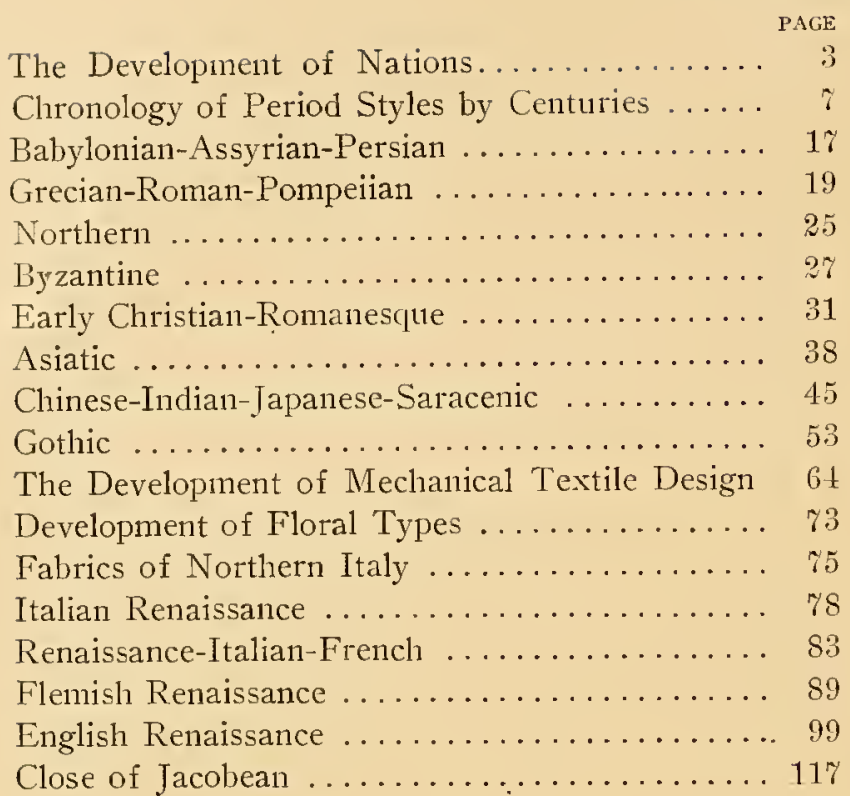

End of the Renaissance .............. 123

Louix XIV . . . . . . . . . . . . . . . . 132

Fabrics, Sixteenth and Seventeenth Centuries... 140

Louis XV . . . . . . . . . . . . . . . . . . . 144

Louis XVI ....................... 151

Transition-Directoire-Empire . . . . . . . . . 161

Printed Fabrics and Paper ............ 166

Queen Anne ...................... 169

The Trades in the Georgian Periods ........ 176

Georgian-Chippendale-Chambers ........ 17 y

Hepplewhite ..................... 185

Sheraton .......................... 193

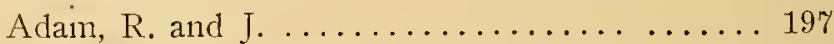

Colonial . . . . . . . . . . . . . . . . . . . . . 203

Morris, Biedermeier, L'Art Nouveau ........ 217

Mission . . . . . . . . . . . . . . . . . . 223

Painted Furniture ............... 226

Chronology of Wall and Ceiling Treatment.... 227

\section{BIBLIOGRAPHY}

\begin{abstract}
"Meycr's Handbaak of Ornament," "Mantul of Historic Ornament," by Glazier; "English Houseliald Furniture af the Geargian Periad;" "Colanial Fumiture in America," by Luke Vincent Lackwaad; "Colanial Fumiturc" by Alvan Cracker Nye: "English Funtiture, Decorations," etc., by Thamas Arthur Strange; "Encyclapedia of Furniture," by Ed. Bajat; "Frcnch Styles in Furniturc and Architecture," by Ed. Bajat; "The Decarative Wart af Robert and Jantes Adam," "All the Russias," by Henry Narman; Clippendale's Wark, "The Gcutleman and Cabinetmaker's Directar", "Ornanent af Textiles," by Fischbach, "Nature in Ornament," by Lezris F. Day; "Omanent in Eurapean Silks,". by Allan Cale; "American Mural Painting," by Pauline King; "Furniture of Our Farefathers," by Singlcton; "Indians af the Painted Descrt Regian," by Gearge Wharton James; "The Old Furniture Book," by N. Hudson Maore; "Stately Hames in America," by Desmond and Craly; "Palychromatic Ornament," by Racinet; "French Interiars, Furniture and Decoration", by Thanas Arthur Strange; "Unknown Mexico," by Canl Lunholtz; "Empire Furnitwe and Interiors," by Percier and Fontaine; "Gothic Wood Architchture", by G. G. Ingewitter; "Baraque Fumiture and Waad. Carvings," by A. Haffnann; "Baraque Woad Ornancntation," by E. Kumsch; "Empire Furniture and Ornancutation," by C. Narman; "The Madern Honc," edited by Walter Shaw Sparroz"; "Omamental Treasures," by Dalnetsch; "Mnral Painting," by F. Hanilton Jackson; "Dictionnaire du Tapissier," by J. Deville; "Adcline's Art Dictianary;" "Geschichte des .Mobels," "In English Homes," by Charles Lathann: "The Seats of the Calanists," by Willian Rotch Ware; "Ornanent and Its Application," by Lervis F. Day; "Style in Fumiture," by R. Davis Benn, with illustrations by W. C. Baldock; "Gramunar af Ornament" by Ozven Jones; "The Story of Art Throughout the Ages," by S. Reinach; "Histary of English Furniture," by Percy Macquoid; "Old English Fumiture," by Frederick Fcnn and B. Wyllie; "Georgian Periad;" "Grammar af Greek Art," by Percy Gardner; "English Embroidery," by A. F. Kendrick; "The Mansions of England in the Olden Time," by Joseph Nash; "In and Ont af the Old Missians," by Gearge Whartan James; "Chats an Old Fumiture," by Arthur Hayden; "Arts and Crafts af Old Japan," by Sicuart Dick; "Plastering," by William Millar; "Moarish Remains in Spain," by Albert F. Calvert; "English Furniture:" by W. E. Mallett; "The Wallace Callection," by A. L. Baldry; "La Dccaration an XVIII Siecle," by J. B. Huet; "Louis XVI et Empire," by H. Friling: "La Dentelle;" "Der Omamentstil," by Alex. Speltz; "English Furniture," by Frederick S. Robinson; "L'Ornementatian la Decaration an XIX Siecle," by Lienard; "Versailles and the Trianons," by Pierre de Nolhac; "Gathischer Mabcl," by A. Hubcr; "The Decoration and Fumiturc af English Mansians," by Francis Lenygan; "The Furniture Stylcs," by Herbert E. Binstead; "The English Hanse," by Walter Shaw Sparrowo; "Dccaratars' Symbals, Emblems and Devices," by Guy Cadogan Rothery: "Art in England During the Elizabethan and Stuart Periods," by Aymar Vallance: "Arts and Crafts af Older Spain," by Leanard Willians; "Anciemnes Tapis Etoffes et Braderies," by Ch. Stoll; "Ornamcntal Designs," by H. Friling; "Successful Hanses," by. Oliver Coleman; "Old Oak Furniture," by Fred Roc; "Compasitions d"Ornements," by G. Neuhaff; "The Art af the Plasterer," by Geo. P. Bankart; "Umbrian Citics of Italy," by I. W. and A. M. Cnikshank; "Nissions of Califarnia and the Old Southzeest," by Jesse S. Hildrup; "Turkey and the Turks," by W. S. Manrac; "Mediaeval Arclitecture," by A. Kingsley Porter; "Old Time Wail Papers," by Kale Sanbarn; "La Renaissance," by Rauyer; Chippendale, Sheraton and Hepplewhite.
\end{abstract}




\section{A SERIES OF TABLES TRACING THE ORIGIN AND DEVELOPMENT OF NATIONS, WITH THEIR VARIOUS ARTS, PRODUCTS, ETC.}

\section{THE DEVELOPMENT OF NATIONS. 4000 B.C.-10O B.C.}

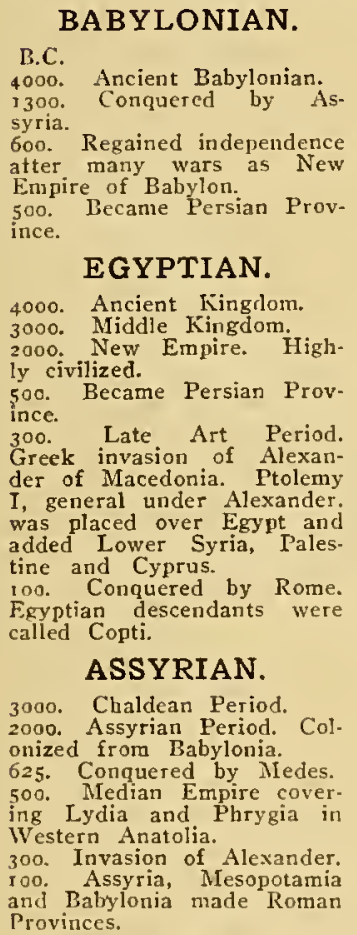

PERSIAN.

4000 . Before the dawn of history in Europe, the Ar: yan tribes of Asia migrated Fast as far as India and II'est to Greece. The Iran Platean laid between Cas. pian Sea and Indian Ocean in Central and Western
Asia. Those settling in North were called Medes hose South, Persians; those Vest, Celts.

1200. Bactrians, Medes and Persians occupied the Iran Plateau.

500. Supremacy of Median Period passed to Persians, who formed Empire. Syria Phoenicia, Cyprus, Judea and part of Arabia paid tribute. inated a vast territory from inated a vast territory from 250 B.c. to 220 A.D. Sassanian E.

\section{PHOENICIAN.}

2000. Highly civilized.

1300. Colonies in Crete. Cyprus and Rbodes.

I 100. Tyre, famous city, fell repeatedly under Assyrian rule.

500. Subject to Persia.

30o. Invasion of Alexander of Macedon.

\section{HEBRAIC.} 2000. Empire of Sbepherd
Kings on frontier of Assyria.

5yrian 1500. David King of Jeru

salem.

1000. King Solomon.

600. Kingdom divided into Israel and Juder

Israel and Judca. 500. Jerusalem Jews becamc and Rome.

200. Emancipation of Jews.

200. Emancipation of Jew's.

Pompey $(63)$; Jews become

Roman subjects.

too. Herod recognized by Romans King of Judea (40).

\section{GREEK.} rooo. Pelasgians from
Southwestern Asia Minor, original Greeks.
1100. Pelasgians called IIcl. lenes divided into Dorian and Ionian tribes. foo. Spartan Supremacy. Ionic Art Period.

290. Corinthian Art Periud. 300. Maced on having become lcading State in Greek Empire 336, Alexander of Macedon waged war against Persia and the East and conquered all Asia as far as ture, ture. Antioch, Syria, Alexandra, Rbods, Asia Ainor Greek Art. 200. Macedonia becomes Roman Province.

SPANISH-FRENCH -PORTUGUESE.

2000. Celts settled in and

about Spain.

I300. Portugal was ancient

I200. France was peopled by Teuton tribes and called Gaul.

600. Celts dominated Spain. 500. While the Celtic tribe and the men of Gaul (originally Teutons) were all termed Gallic people, they gradually formed distinct di

too. At the opening of Christian era all the Gallic country cane under Roman

\section{ROMAN.}

700. Mythical Period.

too. Empire dismcmbered. 200. Conquest of Spain and raul.

oo. Destruction of Maccdonian Monarcby by Rom ans. Invasion of England.

\section{ETRUSCAN.}

1200. Aryan tribes of Asia living North of Rome and in country now Tuscany. 600. Period of highest development.

Subjugated by Romans, 35I B.C

\section{TEUTONIC.}

6oo. Tribes of barbarians called Teutons occupied ter ritory now Germany, Prussia, Holland, Belgium, Bavaria, Scandinavia, North-

500. Scandinavia, covering Denmark and Sweden, occu picd by Finnish tribes. In Denmark dwelt Saxons, Angles and Jutes.

200. Dominated by the Romans.

\section{CELTIC}

2000. Aryall tribes from Asia living North of Rome and in country now Tusto settle in Wicsterl Europe. They occupied the conpe. Tbey occupied the conntry Gaul, and together tou tribes who found their way WVest and settled there, way West and settled there, Gallic people. Period of highest development.

600 Subjusated Spain

500. Reacbed Great Brit.

ain.

100. Gallic tribes formed divisions distinet from Celtic tribcs and at opening oi Christian era were conquered by Cacsar, Emperor 


\section{H R O N L O G Y SHOW I N G TH E}

Batayians, 78; British, 86; Burgundians, 28; Byzantine, 9; Danes, Swedes, Norwegians, Finns, 65; Franks, 37; German Kingdom, 33; Saracens, 62; Saxons, Angles, Jutes, 66; Scandinavians, 65; Scotch, 82; Slavs and Finns,
A.D. ROMAN.
BYZANTINE.
100 (1) Destruction Pompeii (9) In 500 B.c. Byzantium and Herculaneun, 79 A.D, was conquered by the Greek Roman Empire extended and Atherian over Greece, Italy, the Gre- cian Islands, Cyprus, Crete, Rhodes, Cyrene, Carthage, Spain, France, Germanic Asia, including Armenia Asia, Mesopotamia.
200 (2) Hadrian successor to Trajan abandoned Armeni and Mesopotamia.
300 (3) Constantine, Emperor, (10) Byzantine Empire un- became protector of Cliris- Jer Constantine. Byzantium tians. Accepted Christian changed to Constantinople. religion 328 . 330 changed This constituted the Easter capital of Empire to Byzan- Division
tium. (See 10.)

400 (4) Roman Empire dismem- (See 16, 17, 18.) bered 455. Invasion of Vandidals. (See 28 .)

胥

营

500 N(5) 590. Gregory I Bishop (II) 527. Justinian began twenty-year war which destroyed influence of
ITALIAN.

TEUTONIC.

(14) Italy originally a term (25) Tentons occupied ter- (35) Roman province. divided into Upper, Cen- varia, Bohemia, Saxony, church at Lyons. tral, Lower Italy and Isl- Hesse, Holland, Hanover, ands, Sicily, Sardinia and Prussia, Swiss and Tyrol Corsica. At opening of Alps and Scandinavia. Recentury Italy was included ligion of nature worship. in Roman Empire.

(26) Many small tribes in close relation with Romans.

(15) 320. Langobards were located on lower Elbe. (See tribes.

(27) 320. Beginning of (37) 350. Invasion of

of Germanic Franks. ${ }^{350}$ (See 28.)

(28) Alani located on lower Volga; East Goths, Southern Russia; West Goths, Eastern Hungary; Vandals, Southwestern liungary; Sievi, Bohemia, Moravia and Bavaria; Burgundians on th e Rhine; Ripuarian Franks, both sides lower Rhine; Sole Franks at nouth of Rhine.

(16) Invasion of West (29) West Goths laid waste Goths 400 .

17) 476. Odoacer became nvaded Italy, 400

(30) Langobards on lower 18) 452, Huns wnder At- Edo. 476. Odoacer recoglounded by Italian refugees. nized by Eastern Emperos as Prefect of Italy. (See I and is.)

(19) 568. The Langobards conquered Italy south to Tiber. (See 67.)

(20) 590 . Gregory I Bishop Papacy.

600

$\begin{aligned} & \text { (6) } 700 \text { Rome independ- } \\ & \text { ent. First Papal States. } \\ & \text { (See 2I and 48.) }\end{aligned} \mid \begin{aligned} & \text { (I2) 700. Lombards (or } \\ & \text { Langobards) conquered the } \\ & \text { greater part of the Byzan- } \\ & \text { tine Empire in Europe. } \\ & \text { (See 48.) }\end{aligned}$

800

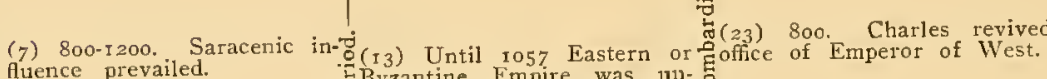
prevailed. Euzantine Empire was u11Æder Macedonian rule. Byz-! ithe conquest of the Eastern $\leftarrow$ Empire. Mubammed II decern Empire, in I 453.

900 (8) 966. Dominated by (22) 773. Lombardic Kingdom destroyed by Charlemagne, Charles the Great, who became King
(See 48 and 67. )

\section{ह}

(24) 961. First Empire.
(21) 75I. First Papal States.
(32) See 5o.

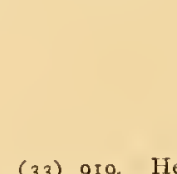

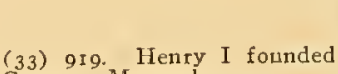
German Monarchy. (38) 400. Invasion of Van-
dals, Suevi and Alian. (See 443. Burgundians, Visigoths and Franks settled in upper Rhone. (See 28.)

(40) 450. Huns under At(4I) 486 . Monarchy estab(4) by Clovis. (42) 511. Division of Kingdom with four court camps Metz, Paris, Soissons and Orleans. Austrasia with capital at Rheims. Population chiefly German. Neustria capital Orleans, Population of last two Celtic

(44) 620. Dagobert

(45) 620. Dagobert. Anstrasia, principally GerFrance, not reckoning BreEtagne and Burgundy. (46) 687 . Pipin of AusKingdom of Franks.

(47) 732. Martell, son and successor of Pipin, drove out Arabian invaders. (48) 75I. Langobards (Lombards) having conquered almost all Byzantine territory, in Europe, excepting Venice, Ravenna, Naples and Rome, Pope Stephen III songht aid of Pipin the Short, who drove back the Lombards and was rewarded by being placed at (49) 772. War with SaxSamon land (See 66.)

(5o) 843 Empire divided minto East and West Franko ish Empire, which eventual. ly became Germany and Erance.

Ư (5I) 986. Hugh Capet chosen king of French mon-

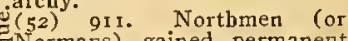
Wormans) gained permanent foothold in Normandy with govereignty over Brittany, (see 92). 
DEVELOPMENT OF NATIONS

ITALIAN.

1000 1000. Western Enrope, ened by the Northmen Hungarians and the Saracens as well as by the Fendal system which evied heavy taxes upon cities to Fief, banded together in protective leagne and a were the result. cnice, Genoa and Pis the East. A Lombard the Last. A $A$ tomed of the exiled Milanese and a number of the cities of North Italy. ro32. Kingdom of Germany, Kingdom of Burgundy conEmpire, Germany extending Mediterranean Sea north to Denmark.

1100 rroo. Venice, which had it beginning in 400 in the hut of refngees who fled from

1200 iz61. Period of greatest prosperity for Genoa. 126 I. Michael Palaeulogus
out an end to the Latin out an

1300 300. Venice at heiglt of her power. Supreme on the Mediterrancan Sea up to Fifteenth Century, when Turks destroyed her Eastern relations and the trade went to the countries fur went to the

1400 40o. Florence famous for its manufacture. Fell int

EARLY RENAISSANCE

I400-I600. Florentine Renaissance. Mitanese Renaissunce. I 450 . Italy came to the
close of the Middle Ages with no national govern ment. The greater part of the poptuation was divided between the five States, the Duchy of Milan, the two nominal republics of Venice and Florence, the Papal States and the Kingdom of Naples in the Soutly.

1500 1444-1643. Roman Renais-

1453. Flight of Greek scholars to Italy, where they taught Grecian arts, science and literature.

1500-1540. High Renais. sance. 1540.1643 . Late Renais sance.

1600

1809. Papal States siezed by Napoleon. United Italian prov-

186r. First Italian Parliament. Victor Emanuel first King of Italy. Kingdom. I870. France withdrew support of the Pope, Rome Kingdom of Italy and Italy became a united ration. I871. Papal troops wer disbanded. Pope was give the atican as a residence and secured in the exercis
FLEMISH-DUTCH

10oo. Netherlands (Low Middle Ages were divided nto a number of petty principalities.

oo. Flanders came into possession of House of Burgundy and soon all of the other petty provinces were Bold, the last Duke of Bur gundy. At his death the Netherlands fell to his daughter Mary and finally into the possession of her son, Emperor Charles V of Spain. The great cities of this country were Ghent, Tournai, Courtrai, Brussels and Antwerp of the South provinces and Haarlem, Utrecht and Rotterdam o the North. Some of them

1500. During reign of Charles V, I5I5-1555, the Northern Netberlanders were treated with great srowth of Protestantism as well as subjugate the people who denied Spanish authority. The struggle lasted for forty years. Gelderland and Utrecht, the northern provinces of the Netherlands, entered into union eventually the found ing of the Dutch Republic. 1577 . All provinces united
to drive the Spanish soldiers from the country. Help furnished the Hollanders by the English. 1579. The States of Northern. Netherlands became known as the seven united provinces. The Sonthern tinued Catholic and loyal to Spain. France and England 609. France and England ympathy with the Nether ands, Plicip III granted truce which became an acknowledgment of the independence of the Northern Netherlanders, who formed the Dutcli Republic. The Dutch hecane famous as great sailors, replacing the of the trading posts in the 813. Formation of Kingdom of the Netherlands and Austrian Belginm. I 830 . The Belgians de. clared themselves independKingdom of Belgium was established.
SPANISH-
PORTUGUESE

PORTUGUESE.

ıoo. Spain divided by many petty governments, kingdoms, Asturia, Castile, Navarre, Aragon, as well as medan States. Portugal part of Spain. 1095. County of I'ortugal der Burgundian control. Son of Count Henry of Burgundy made King o Portngal. 1096. County of Portugal r 140 . Kingdom of Portugal.

1238. The Moors in Spain the Iringdom of Granada.

I383. Greatest power of Porngal. Conquered Tangiers. Formed Christian Kingdom in North Africa. Voyages and discoveries. Following the Turkish conquest of Constantinople, diropean traders endeavored to discover a direct ocean eventually to the discovery of America. 1400. Throngh the Fifteenth Century Portugal sailors penetrated into the mysterious tropical seas and coast of Africa.

I492. Spain conquered Granada. Columbus presented to Portugal plans of exploration, and failing assistance, was about to offer services to France or England when the capture of Granada promised the necessary means form the counwith the result known to history.

SPANISH RENAISSANCE. sance.

r500. Opened possessions in Persia and Indja. Active in America. Subjugate parts of South America.

600. Spanish withdrawal I6ro. Moors expelled from Spain. Following the loss of the Netherlands, Spain lost Portugal.
GOTHIC PERIOD. I 108-1137. Louis VI. II $37-1180$. Lonis VII.

1223-1226. Louis VIII. 1226-1270. Louis IX. I270-1285. Philip IV. 1314-1316. Lonis X.

13r6-r322. Philip V.

1322-1328. Charles 1 .

I350-1364. John II.

$1364^{-1380}$. Charles V.

I380-1422. Charles Vi.

I $422-146 I$. Charles VII. I 46 I-I483. Louis XI. $\begin{array}{ll}\text { I } 483-1498 . & \text { Charles VII } \\ \text { I } 498-1515 . & \text { Lonis XII. }\end{array}$

FRENCH RENAISSANCE 1515-3547. Francis I. I 529 . Reformation. Gobelins manufacture tapestry. 1549-1559. Henri. II. 1559-1560. Francis II. I574-I 589. Henri III

I589-16io. Henri IV.

1604. French East India Co. established.

1611, 1615, 1642. French East India $\mathrm{Co}$. chatters re-

643-1715. Louis XIV. Gobelins become royal prop. Le Brun dictator of styles. Beauvais Tapestry Works established.

Chinese characteristics in roduced.

1685. Revocation of the Edict of Nantes and consequent flight of many Protestart work people.

I7I5-1774. Lonis $X V$ (Rococo Period).

1774-1792. Louis XVI. Revolutionary Period.

1795-1804. Directoire or Transition Period. David the prime influence in deco-

ration.-514. Empire. David dictator of style.
ENGLISH.

ro66-1087. William the I087-s I00. William II.
1100-1135. Henry I. II35-II54. Stephen.

EARLY ENGLISH GOTHIC. I 89-I I 99. Richard I. I99-1216. John. III.

307. Decorated Gothic 1307-1327. Edward II. I327-1377. Edward III. 1377-1399. Richard I. I399. Florid I399-1413. Henry IV.

ENGLISH RENAISSANCE. I 509-1547. Hen r y VIII (John of Padua, architect). 1534. English Reformation 1547-1553. Edwar
$1553^{-1} 558$. Mary.

Elizabethan. Elizabeth.

1413-1422. Henry V. 1422-146I. Henry VI. 1483 . Edward V. I483-1485. Richaid r 485 -r 509 . II en ry VII
(founder of Tudor line).

602. Dutch East India Co. established.

r6o3-1649. Jacobean (many Flemish and German work 


\section{THE PERIOD}

\section{Beginnings}

OLD BABYLONIAN 4000

EGYPTIAN 4000-324

CHINESE 3500

ASSIRIAN 2286-608

Chaldean Period 2286-1300

Assyrian 1300-625

Median 640-558

Babylonian 608-538

INDIAN 2000

GREEK 1900 B. C. -168 A. D.

Doric 700 , Ionic 600 , Corinthian 290

JAPANESE 1200

ETRUSCAN 1044-238 B. C. (Tuscan)

ROMAN 753 B. C. -455 A. D.

Following the Greek orders, Doric, Ionic and Corinthian; also the Tuscan and Roman Composite

PERSIAN EMPIRE 558-330

BUDDHA PERIOD, India, 500

CELTIC 200 B. C. -1100 A. D. POMPEIIAN

PARTHIAN EMPIRE, Persia, 250 B. C. -220 A. D.

NORTHERN AND SCANDINAVIAN 100

ROMAN GERMANIC 100-700

SASSANIAN EMPIRE, PERSIAN, 220-641

BIZANTINE $328-1 \pm 53$

ARABIAN 571

MOHAMIIEDAN PERSIA 641

MIOORISH $711-1610$

RONANESQUE $\approx 00-1100$

FLEMISH $850-\mathbf{1 7 5 8}$

FIRST GERMAN EMPIRE 961-1806

SI'ANISH, FIRST CHRISTIAN KINGDOMS $103 \%$

NORMAN OR ENGLISH ROMANESQUE 1066-1189

GOTHIC 1100-1550

FRENCH GOTHIC 1108-1515

Early English Gothic 1189-1307
Developments

FORTIETH CENTURY B. C.

THIRTY-FIFTH CENTURY B. C.

Mythic Period 3500-2200

Egyptian Middle Empire 3000-2100

TWENTY-SECOND CENTURY

$$
\text { B. C. }
$$

First Enpire Clinese 2200

Assyria included the Medes, Persians, and Babylonians

Chaldean Period 2286-1300

TWENTIETH CENTURY B. C. NINETEENTH CENTURY B. C. Graeco-Pelasgic 1900-1384

FOURTEENTH CENTURY B. C. India Brahma Period 1400-500

THIRTEENTH CENTURY B. C. Assyrian 1300-625

TWELFTH CENTURY B. C.

TENTH CENTURY B. C. SEVFNTH CENTURY B. C Greek Doric ro0

SIXTH CENTURY B. C.

Japanese Enpire 660

Median Empire (Assyrian) 640-558

Empire of Babylon 608-538

Greek Ionic 600

FIFTH CENTURY B. C.

Chinese Confucius 500

THIRD CENTURY B. C.

Graeco-Roman influence

Greek Corinthian 290

Hellenistic 290-168

Etruscan cities subjugated by Rome 350

SECOND CENTURY B. C. FIRST CENTURY B. C.

Greek Arts absorbed by Romans

Doric, Ionic, Corinthian, Composite and Tuscan: the "five orders"

Purc Greek 100 B. C.-79 A. D.

Egypt became Roman Province SECOND CENTURY A. D.

Roman Empire extended over Greece Germanic Countries, Italy and Western Asia. Sec Chronology of Development of Nations

THIRD CENTURY A. D. FOURTH CENTURY A. D.

Constantine changed name of Byzantium to Constantinople 330 FIFTH CENTURY A. D.

ORIENTAL ROMAN

Result of absorption of ideas from Armenia and Mesopotamia.

SIXTH CENTURY A. D.

Beginning of Mollammedanism $5 \pi 1$

Best Byzantine Period 550-1000 SEVENTH CENTURY A. D. EIGHTH CENTURY A. D.

Saracenic Conquests in Byzantiue Enpire, Persia, India and Spain

Saracenic Conquest of Spain 711

Caliphate of Cordova enjoyed brilliant art period until 1031 NINTH CENTURY A. D.

Arabian or Saracenic Conquests affecting Sicilian Arts

Russia wnder Byzantine influencc 800

Independent Conntship 850-1404 TENTH CENTURY A. D.

Russia under Celtic infuence

ELEVENTH CENTURY A. D.

William the Conqueror 1066-10si

William II 1087-1100

Active trading with the East

WVars of the Crusaders 1096-12\%0 TWELFTH CENTURY A D.

Continuation Romanesque Period

Henry I 1100-1135

Stephen 1135-1154

Henry II 115t-1189

Late Byzantine

Saracenic and Sicilian arts merged
BY CENTURIES

Endings

CIIINESE Mythic Period, 2200

CHALDEAN Assyrian 1300

GRAECO-PELASGIC 1384

End of Assyrian Period 625

Dissolution of Assyrian Empire 608

BRAHMIA Period, India, 500

MEDES Conquered by Persians 558

BABYLONIAN EMPIRE incorporated by Persians 538

ETRUSCAN 238

EGYPT became Greek Kingdom 332 Etruscan Art Period 238

GREEK 168

PARTHIAN 220

ROMAN EMPIRE dismembered \pm 55

SISSANIAN EMPIRE $6+1$

ROME Independent. First Papal State

ROMIAN GERMANIC

BEST BIZANTINE PEROD ended 1000 
Benginnings

\section{ALHAMBRAIC PERIOD IN} SPAIN 1200-1300

OTTOMAN EMPIRE ESTABLISIIED IN ASIA 1258-9. Supremacy 1298

ENGLISH DECORATIVE GOTHIC 1307-1399

English Florid or Perpendicular

Gothic 1399-1458

FLANDERS 1404

EARLY ITALIAN RENAISSANCE $1400-1500$

FLORENTINE RENAISSANCE 1400-1600

MILANESE RENAISSANCE 1400 1600

ROMAN RENAISSANCE 1444-1643

TURKISH EMPIRE 1453

Byzantium conquered by the Turks

ENGLISH RENAISSANCE 1458 1603

ELIZABETHAN 1558-1603

HIGH ITALIAN RENAISSANCE 1500-1540

LATE RENAISSANCE 1540-1643

FRENCH RENAISSANCE 1502-1643

SPANISH RENAISSANCE 1500

PORTUGUESE RENAISSANCE 1500

GERMAN RENAISSANCE 1550

JACOBEAN 1603-1649

DUTCH REPUBLIC 1609

(Composed of the seven United Provinces)

CROMWELLIAN

LOUIS XIII, 1610-1643

LOUIS XIV, 1643-1714

QUEEN ANNE, 1702-1714

GEORGIAN, 1714-1820

COLONIAL, $1727-1820$

ROCOCO PERIOD, 1715-17\%

LOUIS XVI, 1774-1793

DIRECTOIRE, 1795-1804

EMPIRE, 1804-1814

COLONIAL LATE CLASSIC PERIOD, 1804-1820

VICTORIAN, 1837

ART NOUVEAU, 1898
Developments

Endings

THIRTEENTH CENTURY A. D.

Height of Moorish Art

Arabians and Saracens dominated by the Turks and Turkish dominion in Asia established 1258

Ottoman Empire

Venice became famous as an art center

FOURTEENTH CENTURY A. D.

Covering reigns of :

Edward II, Edward III, Richard II, Henry IV, Henry V, Henry VI Edward IV, Edward V, Richard III FIFTEENTH CENTURY A. D.

Great Trading Period of Flanders and Italy

Florence famous for manufactures

Gobelins established dye works 1440 , which afterward became famous for manufacture of tapestries

SIXTEENTH CENTURY A. D.

Age of Oak 1500-1660

Portuguese opened East India Trade 1500

Henry VII, Founder ENGLISH TUDOR Line, 1458-1509

Henry VIII, 1509-1547

Elizabeth, 1558-1603

Founded by Louis XII, 1502-1515

Francis I, 1515-1549

Henri II, 1549-1559

Francis II, 1559-1560

Charles' IX, 1560-1574

Henri III, 1574-1589

Henri IV, 1589-1610

In 1576, Holland, Zealand, Utrecht Gelderland, Groningen, Friesland and Overyssel became known as the Seven United Provinces and asserted independence. The Southern Provinces, which form modern Belgium, including Flanders, which fell to Spain after the abdication of Charles I, continued under Spanish domination.

India, Mogul Empire, 1525-1748

Russian Empire, 1547

The Reformation, 1529

Portuguese Settlements in Persia

SEVENTEENTH CENTURY A. D

Age of WValnut, 1660-1700

Moors Expelled from Spain, 1610

Dutch and East India Trading Companies Organized, 1600

New York Settled by Dutch, 1613

James I (founder STUART

PERIOD), 1603-1625

Charles I, 1625-1649

Inigo Jones, dictator of English styles, 1625-1652

Commonwealth England, 1653-1659

Inception Queen Anne, 1660. Sometimes called Stuart Period.

Charles II, 1660-1685

James II, 1685-1689

Villiam and Mary, 1689-1702

Dutch and East India furnishings largely imported through Dutch and English Trading Companies'

Revocation of the Edict of Nantes brought many French and Flemish weavers and woodworkers to England

EIGHTEENTH CENTURY A. D.

Age of Mahogany, 1730

George I, 1714-1727

George II, 1727-1760

George III, 1760-1820 (Age of Chippendale, Sheraton, Adam and Hepplewhite)

Flanders subjugated by the French, 1758

Russian Arts under French influence

NINETEENTH CENTURY A. D.
Early English Gothic 1307

English Decorative Gothic 1399

Byzantine 1453

English Florid or Perpendicular Gothic 1458

FRENCH GOTHIC $\mathbf{1 5 1 5}$

High Italian Renaissance 1540

VENETIAN RENAISSANCE ended 1600

English Renaissance 1603

MOORISH 1610

Late Italian Renaissance 1643

French Renaissance 1643

ELIZABETHAN 1603

JACOBEAN 1649

Cromwellian 1659

CHARLES II 1685

William and Mary 1702

Louis XIII 1643

OUEEN ANNE 1714

Louis XIV 1714.

Rococo 1774

Louis XVI 1793

FLANDERS subjugated by the French

INDIA MOGUL EMPIRE 1748

Directoire 1804

EMPIRE 1814

GEORGIAN 1820

COLONIAL 1820

VICTORIAN 1901 


\section{CLASSIFICATION OF THE PRINCIPAL RACES AND PEOPLES AND DATE OF THEIR ORIGIN}

Black Race,
(Ethiopian or $\left\{\begin{array}{l}\text { Tribes and peoples whose true home is Central and Southern } \\ \text { Africa. }\end{array}\right.$

YelLow RACE, (Mongolian or Turanian),

(I) Chincse (3500 B.C.), Burmese, Japanese, and kindred peoples of Eastern Asia; (2) Nomad: Tartars, Huns, Parthians, Mongols, etc., of Northern and Central Asia and of Eastern Russia ; (3) Turks, Magyars, Hungarians, Fimns, ancicnt *Scythians, Lapps and Basques, of Europe; (4) Malays of Southeastern Asia and inhabitants of many of the Pacific islands; (5) Esquineaux and American Indians.

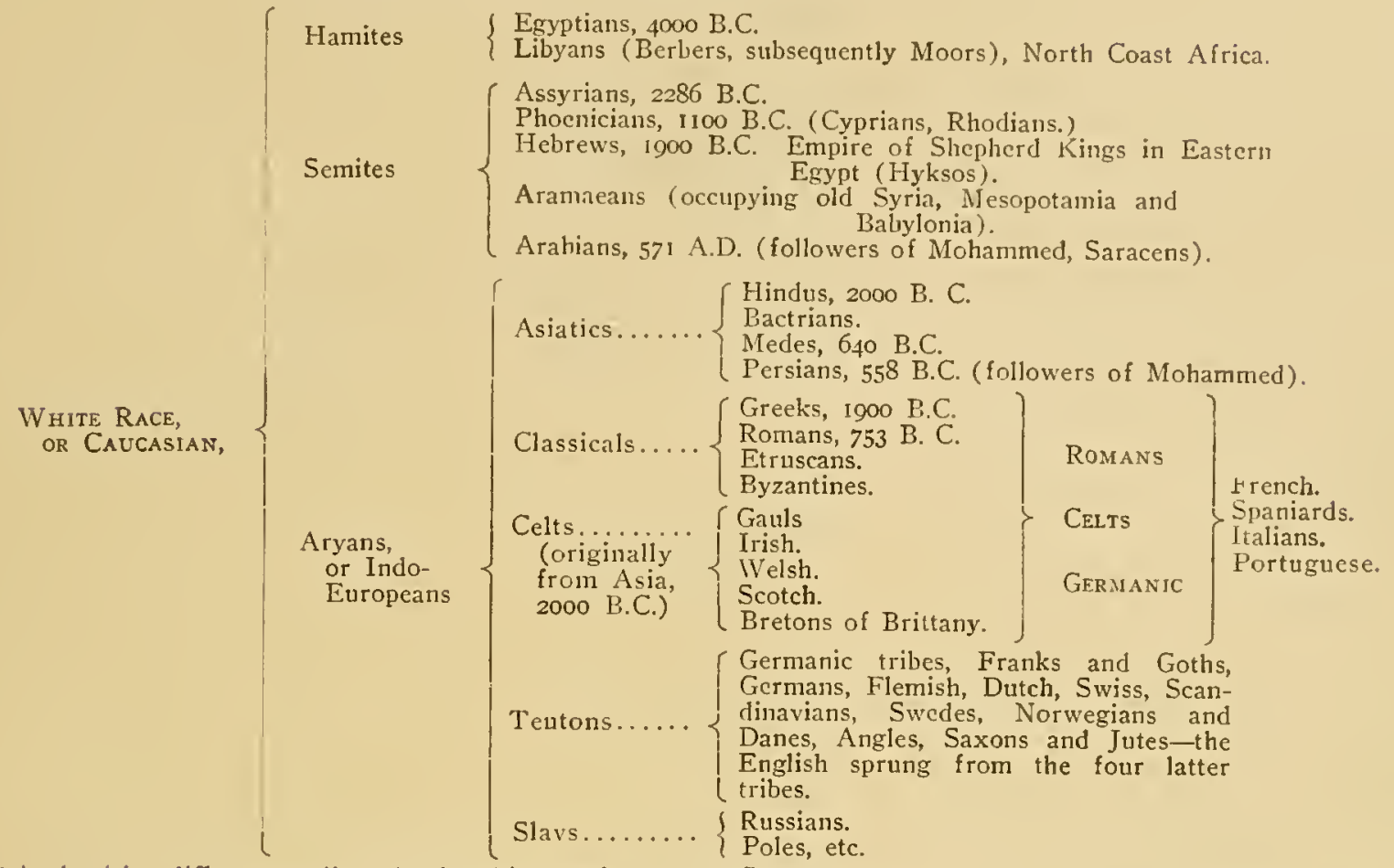

* Authorities differ regarding the Scythians, who 2000 B.C. occupied a vast section of Europe north of the Black and Caspian Seas. Some believe the Scythians were Mongols, others maintain Aryan origin, from which the Slavs descended.

\section{B A R B A R I G D E S I G N}

\begin{tabular}{|c|c|}
\hline $\begin{array}{l}\text { BABYLONIAN } \\
\text { AKCHAIC }\end{array}$ & $\begin{array}{l}\text { PHGENICIAN, } \\
\text { OLISARAMAEAN }\end{array}$ \\
\hline X & k $k$ \\
\hline 4 & 99 \\
\hline & $71 n$ \\
\hline$\theta \wedge$ & $\wedge 1$ \\
\hline & \\
\hline
\end{tabular}

HEN man the barbarian carved some mystic sign upon his club or battle-axe, he had no art in his soul and no conception of Ornament. For centuries that are gone and are still to come, designs or signs or marks, may be regarded as designs, to express thought, without any conception of an artistic idea. Hence we must not regard Design and Ornament as analogous terms. Ornament cane with civilization, Design was of ntilitarian impulse. It was symbolical.

If we contemplate some phases of Oriental art, especially the tribal forms, we find innumeralule examples of design that are far from ornamental.

Long before the dawn of history we find two distinct races in Asia, the Turanian or Mongolian, and the Cancasian. The Mongolian or Yellow race includes the Chinese, the Tartars, the Mongols and
Turks; the Caucasian race includes the Egyptians, Assyrians, Arabians, Hindus, Persians, Greeks and Romans. The broad plateau of Iran in Asia was inhabited on the north by the Medians and on the soutl by the Persians. Many of their people, together with broken tribes of other Aryans, traveled east to the dis-

\begin{tabular}{|c|c|c|c|c|c|}
\hline \multicolumn{2}{|r|}{ MEANING } & $\begin{array}{l}\text { OUTLUNE } \\
\text { CHARACTER, }\end{array}$ & $\begin{array}{l}\text { ARCHALC, } \\
\text { CUNEIFORM, }\end{array}$ & ASSYYIAN, & $\begin{array}{l}\text { LATE } \\
\text { BABYLONIAN, }\end{array}$ \\
\hline r. & The sun & & & रा & $\$$ \\
\hline 2. & God, heaven & * & & M & MT \\
\hline 3. & Mountain & & & & \\
\hline 4. & Man & $\triangle 1 D$ & 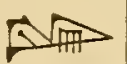 & $E$ & 3 \\
\hline 5. & Ox & & & El & Fर \\
\hline 6. & Fish & & & & Fe \\
\hline
\end{tabular}


trict adjoining India, and in the great sub-division of the Turanian races of China great hordes traveled west, until the Aryan and Turanian characteristics were merged in broken clans, the class that we now term Turkoman.

Where civilization advanced and the arts flourished we have design as a concrete form of decoration and best exemplified in the work of Persia and Arabia, but with the hundreds and thousands of nomadic tribes design had been used to express an alstract thought or symbolism without heed for beauty, and these pictorial forms were at best crude ornament.

As a means of expression the nomads or wandering tribes as well as the savages of all countries early devised a form of picture language, and certain signs understood by them became in time tribal marks or involved possibly religious feeling. Thousands of these people living only by conquest traveled about from place to place in vast ravaging hordes. One can comprehend the conqueror of one band adopting with pride some symbol from the trappings of his fallen foe because this predatory instinct and boastfulness was manifest in the Empire styles, when bits of Italian or Egyptian decoration were strung together to commemorate the conquests of Napoleon.

Then, again, in the crude interchange of tribal courtesies and in the common assimilation of migratory people signs, ideograms and phonograms, having no meaning beyond being the reminder of some experience, were much used. It is natural, moreover, that in the use of simple signs or designs the same thing should be commonly used by many people in many remote parts of the world, and parts of squares and circles have been used universally for thousands of years to indicate various ideas, making it impossible

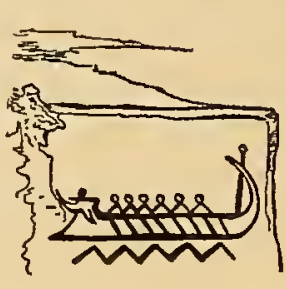
The above is from a Greek tablet and shows apparently the origin of three borders - the water line border, the barber pole and the reciprocal trefoil border.
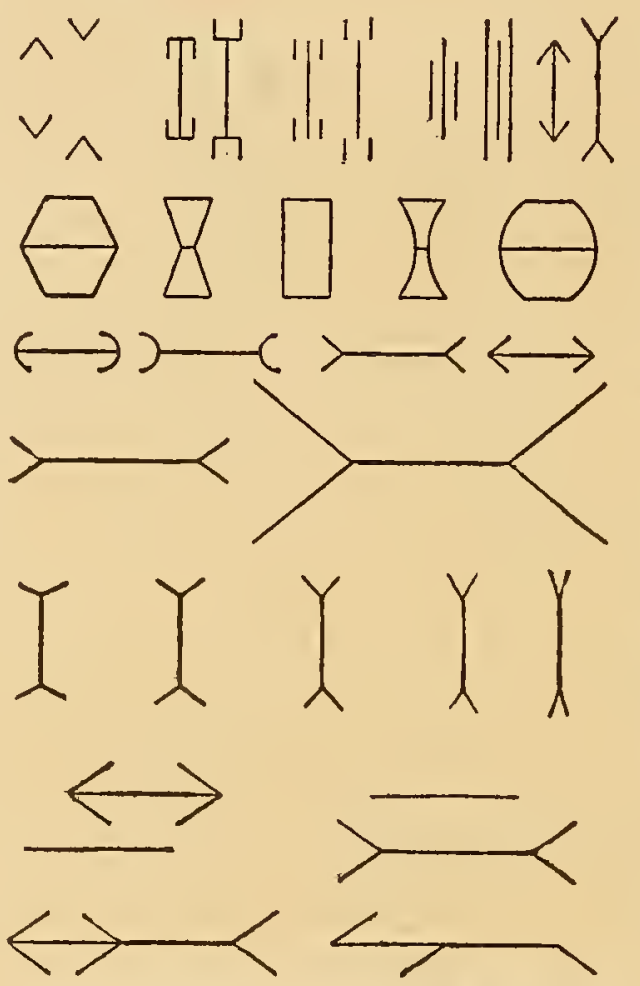

A series of illusions respecting straight lines and angles; similar figures appear in Kurdistan rugs.

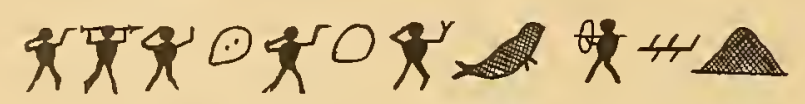

Alaskan. "Record of a hunt." See text. and of all countries, and are not sufficiently intricate to constitute an original thought.

Perhaps the most important influence on the use of design was the common employment of picture-writing. The researches of the Bureau of Ethnology, Washington, incline one to believe that picture language was introduced by prehistoric America to China. Alexander Speltz, in his great work on "Styles of Ornament," encourages this belief by many examples of prehistoric design from North and Soutl America.

The native designs of old Mexico suggest the Anatolian. The native designs of the Aztecs suggest Egyptian, and we commend the reader for further study of this subject to "Unknown Mexico," by Carl Lumholtz, or to the Government Exploration Reports on the Tussayan and Hopi Indians, descendants of those living centuries ago in the deserted villages of Arizona and Mexico, Central and South America.

In the illustration of old Maya designs it is not difficult to trace motifs identical with those of the Mongol districts of the Caucasus. The Maya Indians were the most advanced of the North American aboriginal races. They for one to fix a definite meaning for these designs or to determine by their presence a definite point of origin.

The writer some time ago had occasion to illustrate the illusions which arise from the use of angles, and with no thought but to accomplish this purpose

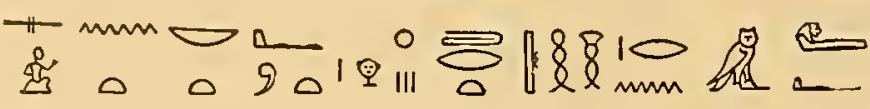

Egyptian. had books, paper, picture language, were sun worshippers, built well and carved well, had paved roads of stone and communicated by couriers. Their houses were decorated and the temples of Yucatan were built, if we are to believe the archæologists, when Egypt was a wilderness. 
The Smithsonian Institute has given to us a great number of illustrations showing the sign language of the Maya, and we find here also the tree of life, the latch-hook, the squarc and thomboid, the octagon, the ovcrlapping wave design, the fret, the swastika and the trefoil.

We can turn to Aztec and Peruvian decoration and find designs almost purc Turkestan and Caucasian. Forms of a cross that are often seen in Caucasian rugs are illustrated by Lumholtz as representing conventionalized forms of the Mexican toto blossom. Mexican water motifs are the same as Caucasian, and the use of florals and geometrical figures gives evi-. dence of a common inspiration-an inspiration that nature gives to the primitive mind. There is further interest in the fact that in all countries some flowerthe iris, the lotus, the lily, the acanthus, the palm, the poppy, the toto blossom-is utilized for its symbolic significance. With the Mexican Indians flowers, blossoms and birds have a strict religious meaning. Indeed, the Huichol Indians never pluck a flower mless with pious intent. It is safe to assume that no savage ever sat down to the work of ornamentation unless it expressed thought, and such thoughts were naturally simple and confined to simple means. The records of an Alaskan hunt we reproduce as an example from Meyer's "Prehistoric Times." The translation follows:

I go by boat (indicated by a paddle held upright) - I sleep one night (land at side of head denotes sleep) - on island with two hutsI go to another island-two people sleep there-a sea lion I hunt with harpoon-I return by boat with companion (indicated by two oars) to my lodge.

In this system of writing the characters are rude pictures of material objects and no extensive vocabulary is required to cover the needs of a savage people. A picture of an eye would indicate the order of sight, or the personal pronoun, or vigilance, or other meanings, according to circumstances. A lot of zig-zag lines falling from a parallelogran would indicate rain.

The great chasm between picture writing and sign writing was partially bridged by the Chinese who, as early as 2000 B.C. employed a system wherein every word of the language was represented by a symbol. Then cane the Egyptian system and the Babylonian
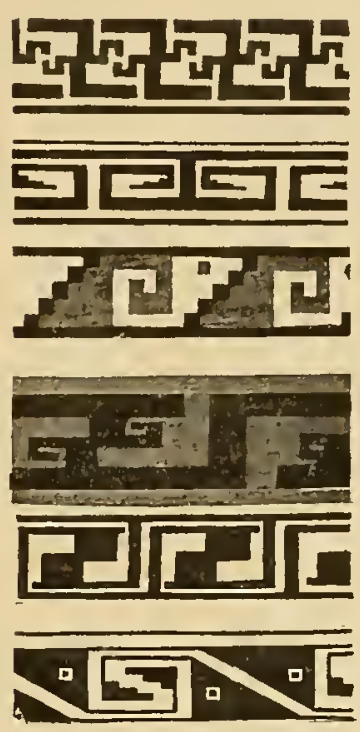

Mexican.
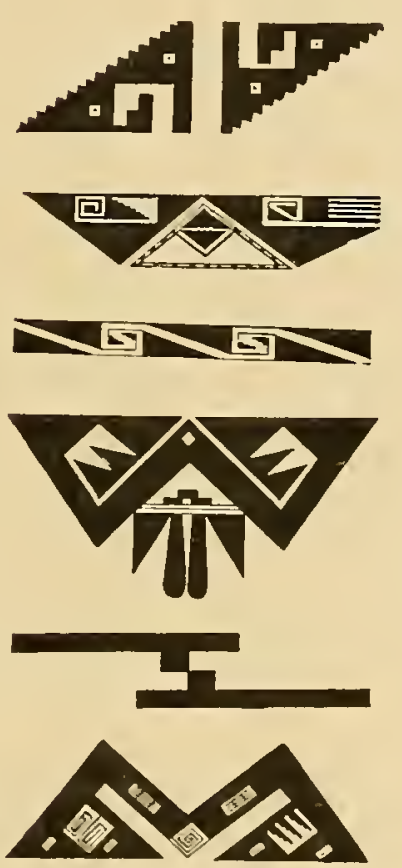

Hopi. American Indian.

system of cuneiform writing, 2000 B.C., a system generally adopted in Western Asia, employing the use of a wedgeshaped stylus. Much of the writing was stamped upon clay. For thousands of years the cuneiform system of writing was lost. In 16r8 de Sylva Figueroa, of Spain, investigated the inscriptions and fixed them as Turanian. Hence it is reasonable, in view of the purely angular character of Mongol decoration, to trace much of its inspiration to the early knowledge of cuneiform writing.

In the excavations of ancient Troy, the buried cities of Illios and Hissarlic, certain decorative forms of these cuneiform records, found upon coins and tablets, have been adopted as fetislies of the people, especially in the Kurdistan district, much as the people of America adopt the swastika under the vague impression that it is a good-luck sign.

From the coins and tablets of these old Trojan ruins of Asia Minor we find the swastika so common and in so many forms, or rather alterations, that we believe that the latch-hook of this district and the Caucasus, and even of the Turkoman district, is a lingering swastika in fuence and not a wave sign. We find in Asia Minor the swastika in its true form as well as distortions of these forms, sprawly shapes, sometimes representing stars or trees or animals. It is impossible to trace the meaning of the signs because we find them among so many people at periods widely separate. The term is thought by some to mean eternity. The swastika enclosed within a circle gives a suggestion of flight, progress. IVe have seen the swastika with the extending lines leg-shaped, sometimes eiglit and ten instead of four legged.

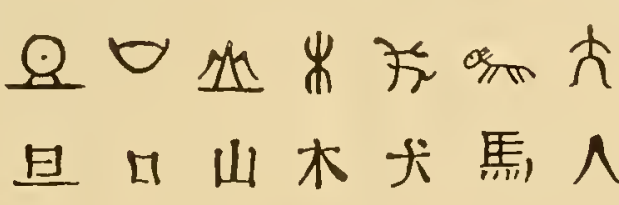

Chinese.

Zmigrodski, the anthropologist, classifies these distortions under what he calls related swastikas. Unquestionably the swastika originated as a thought expression, which in time became a fixed symbol of general world use.

The United States Government, in the Smithsonian report of 1894 , publislied the results of its research and showed that the swastika had been found in almost every part of Europe and was identical with the same form used in prehistoric America. It was known in India and ancient Bactria (East Turkestan), in Rhodes, Northern Europe, Southern Europe, Asia 
Minor, Greece, Rome, Byzantine, Northern Africa, Great Britain and America. Ancient Troy was full of the swastika, and it appeared on the coins of the classic Orient, Babylonia, Assyria, Chaldea and Persia.

The French Government discovered the swastika throughout Armenia and in the Caucasus district. So any assumption that it has a restricted or local meaning is untenable.

In scarching for the origin of the star, the octagon and the triangle we are brought frequently to the doors of Constantinople. We may go back to India and the Brahmans and we find the triangle as a sectarian mark. The combination of two triangles gives us the six-pointed star. The combination of two squares gives us the Mohaminedan eight-pointed star, and the five-pointed star is supposed to be a Christian symbol. Yet if we go back to the period of Christian enthusiasm in the Byzantine Empire we will find the Brahman and Mohammedan eight-pointed star in universal use. The marble mosaic which covered the floors contained geometrical shapes innumerable. The five-pointed, six-pointed and eight-pointed star is simply a geometrical combination of squares and circles. After the fall of Constantinople the beauty of its decorative system was promptly copied by the Mohammedans, quick to perceive a means of beautifying without the use of animal forms, interdicted by the Koran, and we trace this Byzantine influence through the Anatolian Peninsula and the Caucasus.

Tradition states that the crescent was adopted and used in Constantinople as an omen of protection like the winged asp and ball of Egypt. When the Macedonian hordes approached old Byzantium by stealth the crescent moon arose and revealed their presence and saved the city. The crescent was then adopted generally as a good-luck symbol. In after years when Constantinople fell to Turkish dominion the crescent was seized upon as a valuable symbol.

Geometrical design had a wide influence upon the arts of all Asia, with the exception of Persia. The Arabians developed a remarkable system of strapwork, scroll and circular design strictly geometrical, and even when the Arabian system became floriated it was the juxtaposition of floral details geometrically arranged and interwoven. We find the same system in China, where geometrical forms of the fret similar to the Greek fret, geometrical circles and diamonds and octagons are used universally, but have no relationship with similar designs of the Greek and Roman Empires. We find in China the eight-point decoration that is adopted generally through the Turkoman district and found frequently in Afghanistan rugs. It implies Mongol influence. The same thing is common in Gothic decoration.
Design is not always decoration, but decoration is always design. There is much that interests us in

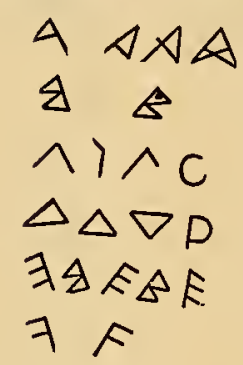

Greek. aboriginal design in the effort to express some material thought or idea of beauty. But there is greater satisfaction in contemplating a perfected system of decorative unity.

Decoration represents a development of civilization and culture. The Arabians as world conquerors left the imprint of their decorative art for thousands of miles around them, but they absorbed little, and to the end Arabian art was true to its ancient forms.

With Persia, however, the best period of its art progress may be traced direct to the influence of Shah Abbas, who in the Sixteenth Century sent his best artists to Italy, where they studied under the tutelage of the great Renaissance designers. All that is most beautiful in Persian art may be ascribed to the Renaissance and Arabian influences.

We do not forget that for centuries before Christ the Persians were in close intercourse with the Assyrians and Egyptians and their art flourished accordingly, nor that carly Persian art was strongly Assyrian and Babylonian. But this was not the art that became in years afterwards indigenous to the soil, the art which, freed of Mohammedanism, embodies the presentation of nature forms, floral and animal, and presents a unity of design brought into coherent relationship by the principles underlying the best Italian school.

We can continue the work of Arabian and Persian design satisfied with the decorative charm that it possesses. But the mere fact that with most of Oriental design we search for the meaning, the symbolic underlying story that is told shows on its face that the mind is not satisfied; that as a decorative composition it does not appeal to us, but interests because enigmatical.

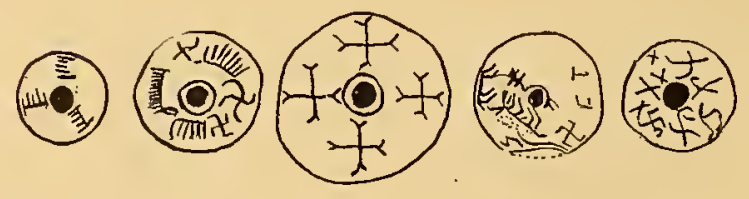

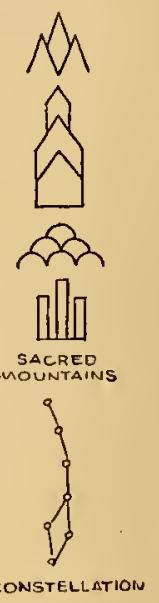

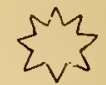

CAUCASIAN
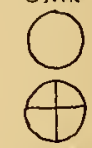
WORLD

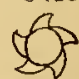
WINGEP

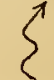

IGHTNING
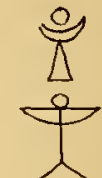

(1)

101

a

ALTARS

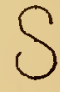

SUN

U

STORM

UIV

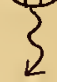

RAIN

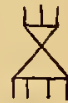

ता

FGHANISTAN

]

SWASTIKa

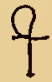




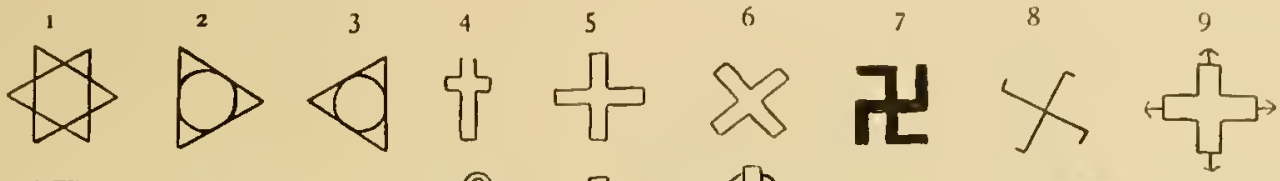

(1)

$\begin{array}{lllllllll}10 & 11 & 12 & 13 & 14 & 15 & 16 & 17 & 18\end{array}$

I, 2, 3. Marks of Brahma.

4. 5, 6. Latin, Greek, St. An-

drew's Cross.

7. 8, 9. Chinese and Indian Swastika.

9. Ideogram of Ancient Troy.

I0. Maltese Cross.

I1. Monogram of Christ.

12. Ta1: Cross or Thors Hanmer, top line sometimes bent $Y$ shaped.
I3. Egyptian Cross

I4 and I5. Celtic.

16. Swastika.

1\%. Ancient Troy.

18. Amcient Georgia.

I. Moslem Comb and Star of

Bethlehem, Turkish.

2. Knot of Destiny, Chinese origin.

3. Effulgent Star, Caucasian.
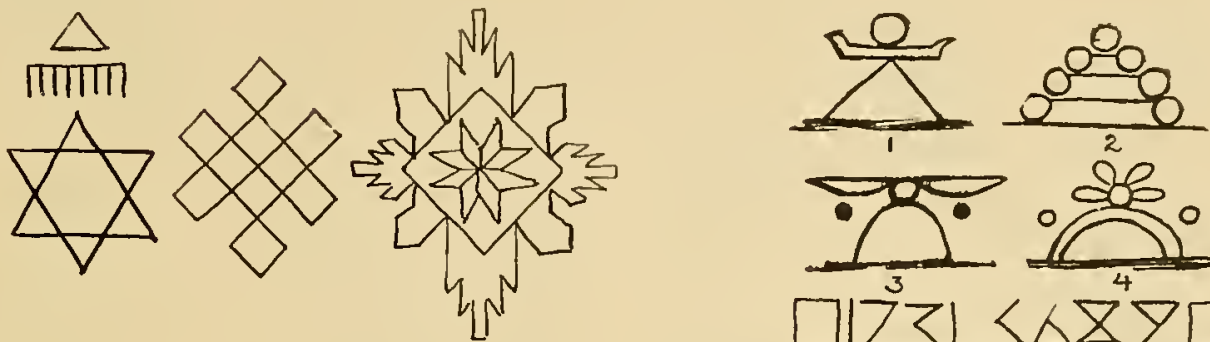

3

$\overbrace{2}$

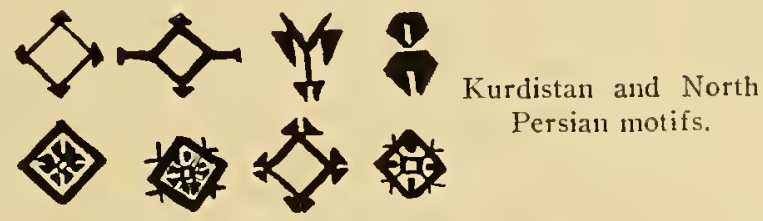

$\left.\int_{6}^{2}\right|_{8} ^{2}$

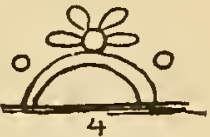

$\square 1 Z 3 L \leq \triangle X \nabla \square$

$1,2,3,4$. Aitar designs.

5. Solomon's Signet.

$6,7,8,9$. Forms of altar, or tree of life.

osdd d + 8

Gothic geometric claracteristic of

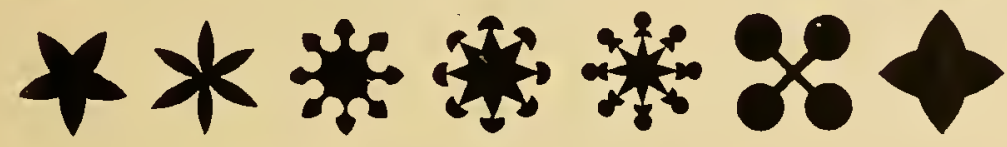
Afghanistan.

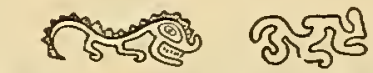

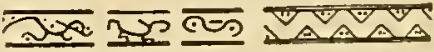

old Mexico.
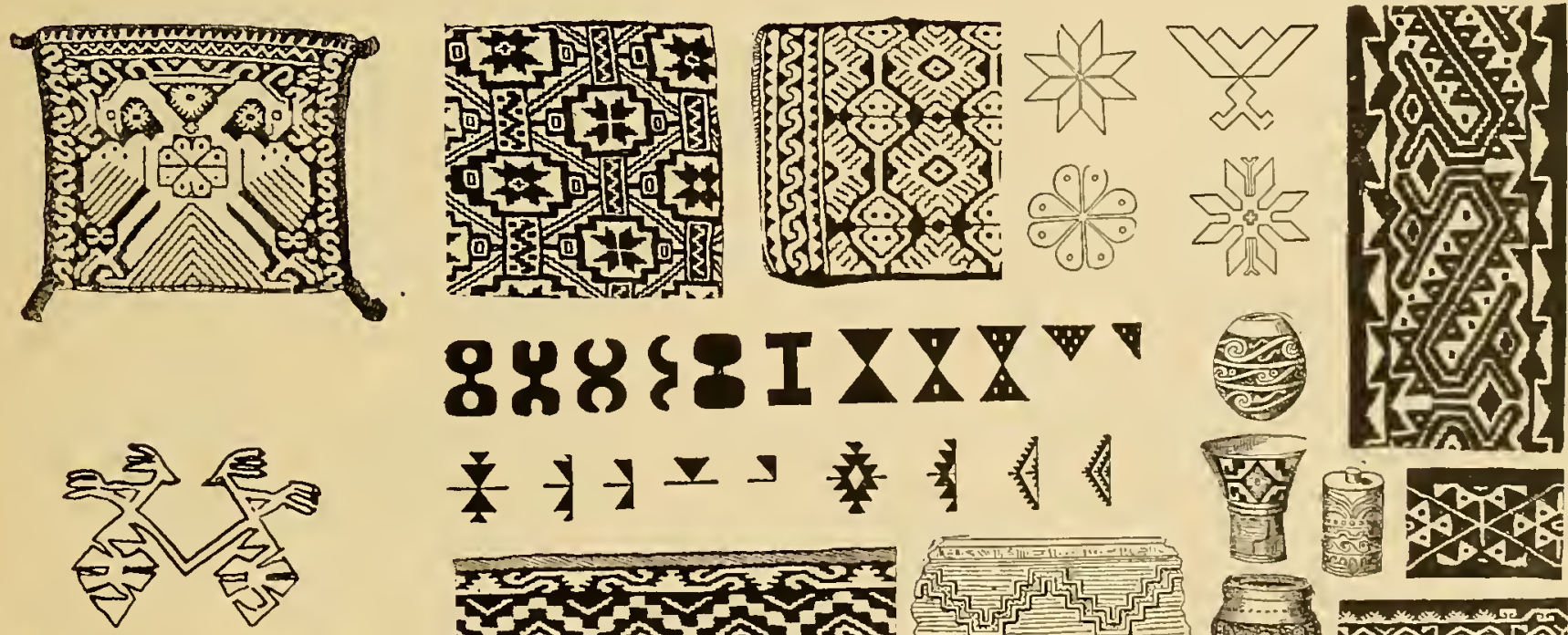

क्यें

$8 \% 8\{8 I \mathrm{IXY}$

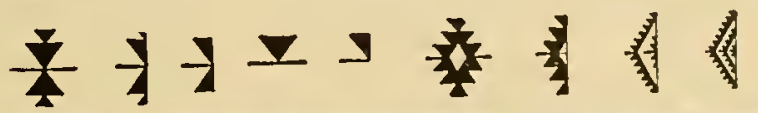
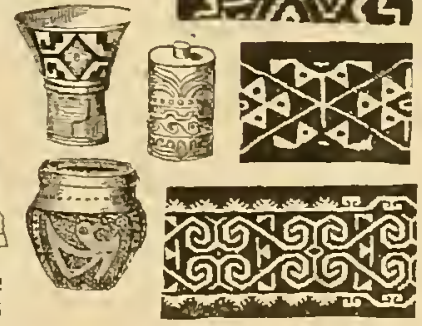

Old Mexico (Huichol). Note similarity to Turkoman, Caucasian and Chinese. 


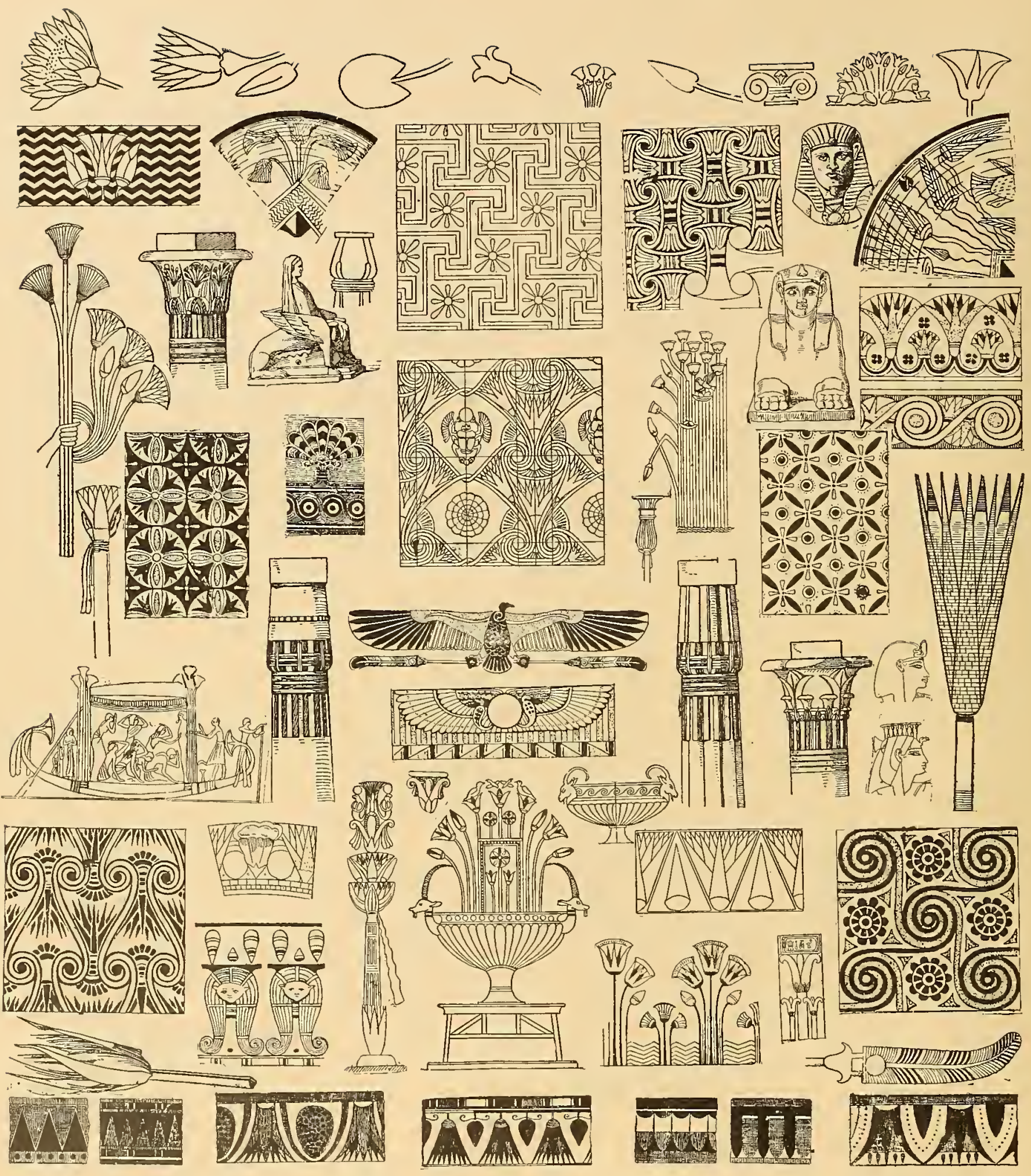

EGYPTIAN DESIGN DETAILS.

The top line shows the lotus bud, pad and blossom. 

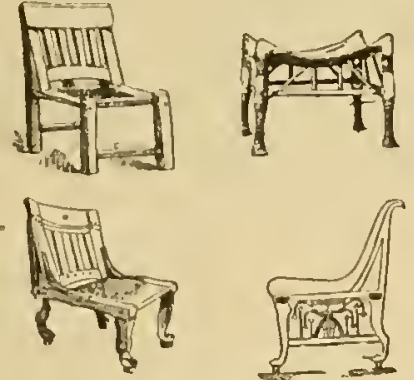
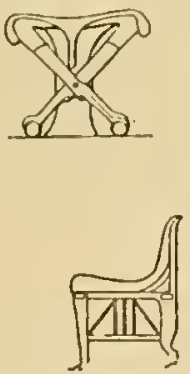
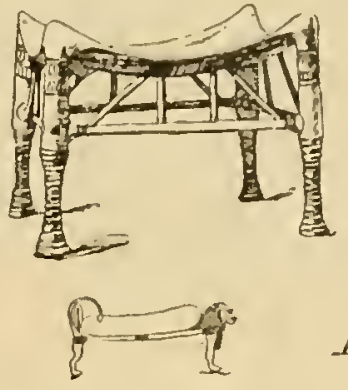
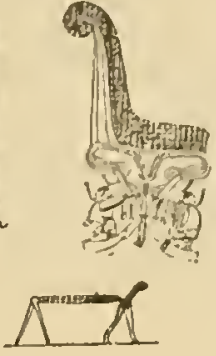

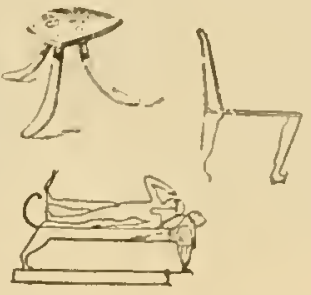

Egyptian.

\section{E G Y P T I A N}

EGYPTIAN-Old Empire, 4000-3000 B.C. Middle Empire, 3000-2100 B.C. New Empire, 2ro0-324 B.C. Graeco-Roman Revival, 324 B.C. to 300 A.D.

Egypt, 332 B.C., became a Greek kingdom; 30 B.C. became a Roman province until the Mohammedan invasion, 640 A.D.

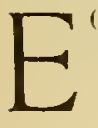

CIPTIAN wearing most ancient known industry. Egyptian linens famous, embroidered with gold, silver and purple.

The moment we leave the age of savagery and man clothed in animal skins, we reach the stage of weaving. Clothing was the first necessity of mankind.

Tombs of Egypt, 2800 B.c., illustrate weavers at work. One shows a man weaving a checkered rug. Nonuments of ancient Egypt and Syria show the manufacture of rugs and fabrics, $2+00$ B.c.

Nine lundred and eight B.c., Egyptian canopy cloths of fine cliaracter, embroidered and of a patch cluaracter.

The history of lace begins definitely with 900 A.D., but drawn-work and nettings were of prehistoric origin.

Fabrics dating Iooo B.c. are preserved in the Louvre, Paris.

Three thousand five hundred and fifty B.C., building of the pyramids. Following the Stone Age, came the Age of Copper, Age of Bronze, Age of Iron.

As early as 2100 B.C., Egypt was highly civilized. In buildings moldings were seldon used. Chambers were decorated with illustrations representing industries.

Carvings, instead of standing out in relief, were sunken and the ground stood out, a system exactly opposite to the Assyrian system, where the ground was depressed and the subject stood out in relief.

Decoration full of gold and brilliant colors, the triad form being popular (black, yellow and red), (red, blue and white), (dark blue, light blue and white), (cream color, blue and black), (dark red, medium yellow and blue).

Ornaments were frequently in hieroglyplics.

Among motifs and designs were the sun, the beetle, the cobra or serpent, feathers, papyrus buds and reeds, lotus, date-palms, the lily, zigzags for water ways, herbs, animals, fan-shaped ornaments, nude figures, winged human figures, liuman faces, the ram, sparrow hawk, sacred tree.

Late Egyptian furniture had rope or rush covered seats.

Egyptian wall treatments, confined to frieze decorations against plain walls. Couches were made low; no foot boards; small rests at head to fit under the neck. Stools often had wooden bottoms, but couches were alvays plaited. Six hundred B.C., seats were of narrow strips of leather plaited; furniture often wood inlaid with metal. Seats were curved to fit the figure.
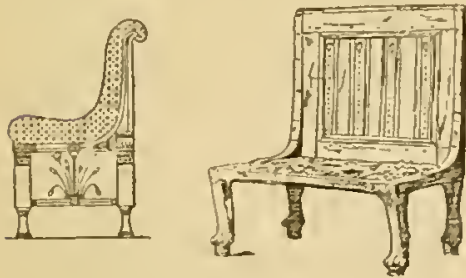

Egyptian.
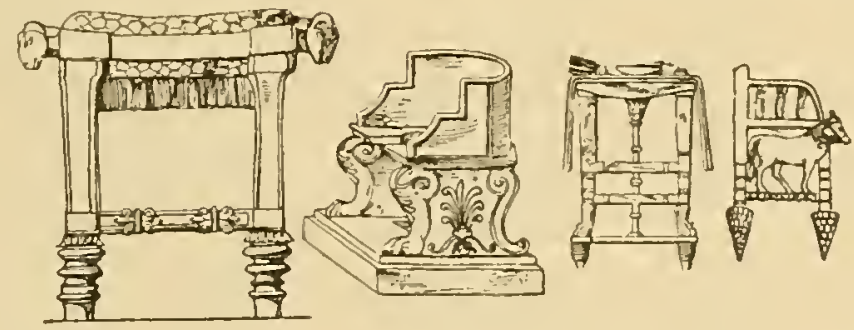

Babyionian-Assyrian.

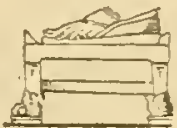



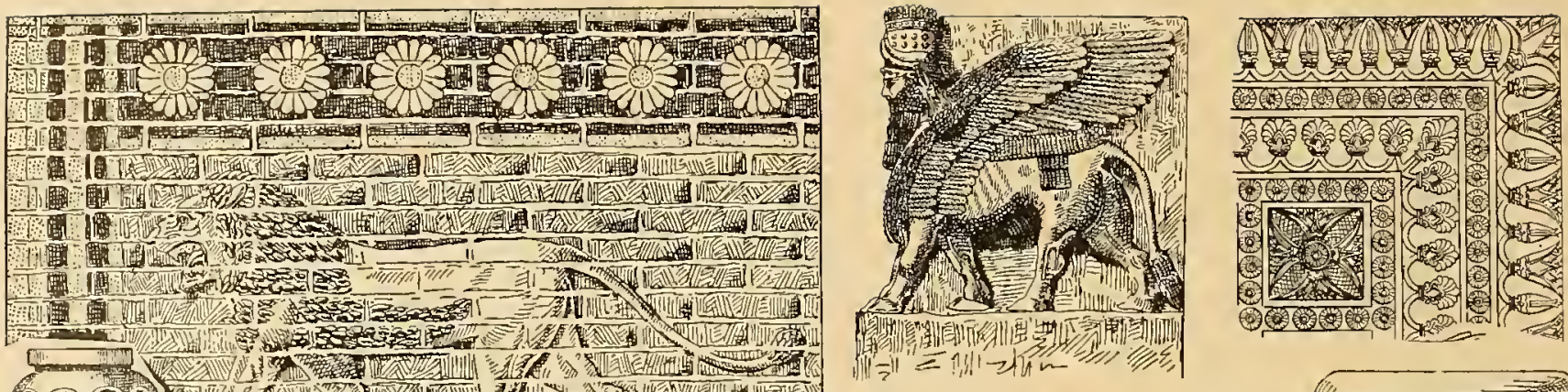

(1) (1)

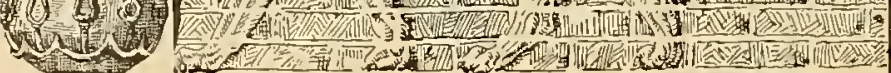

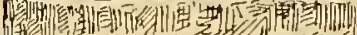

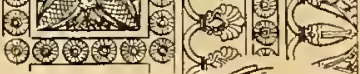
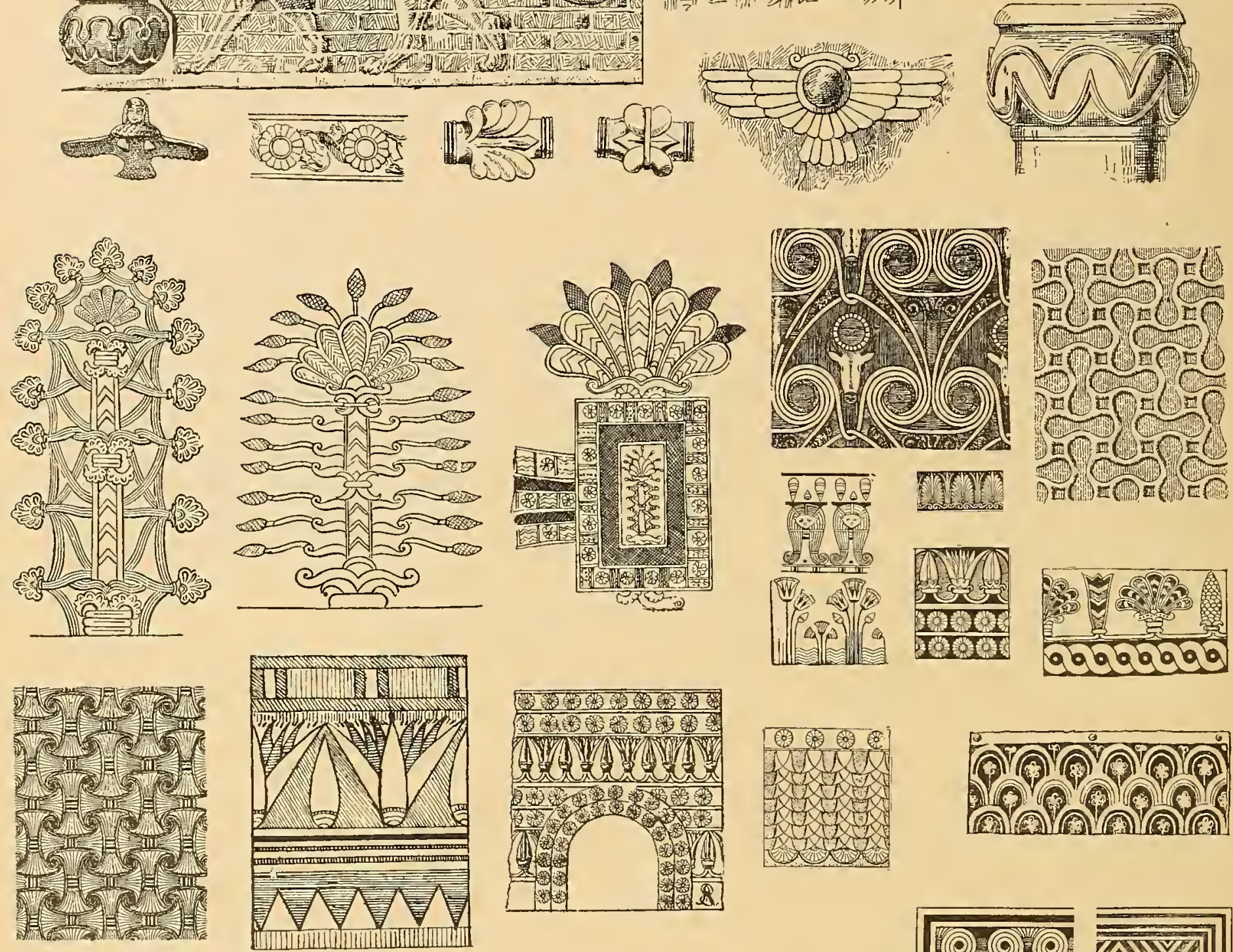

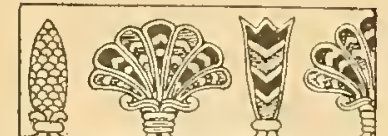
9999960

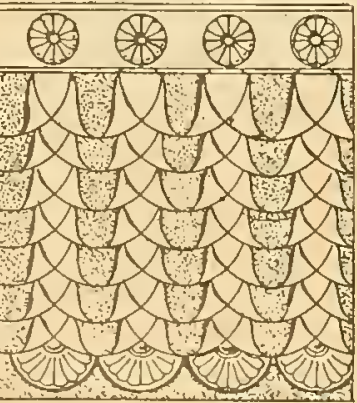

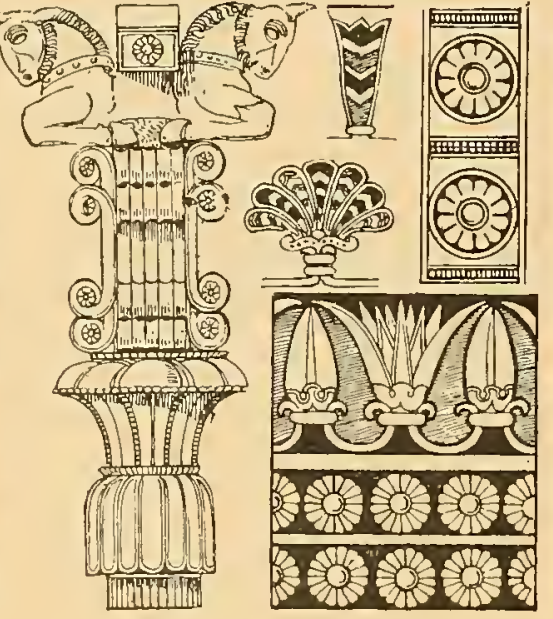

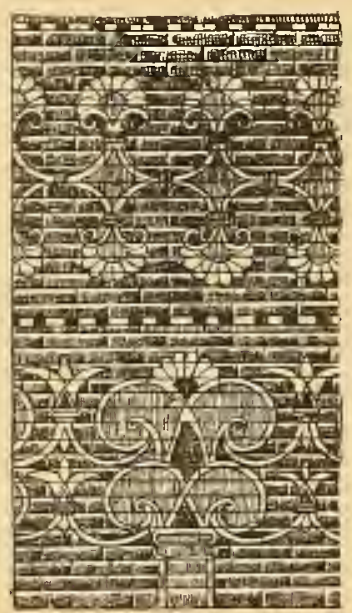

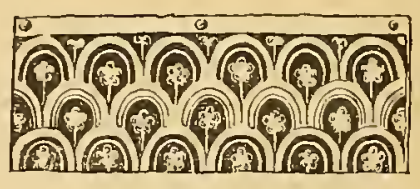
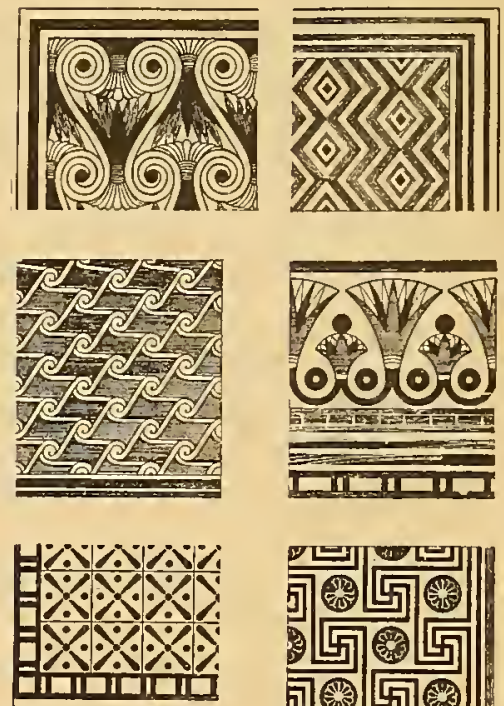

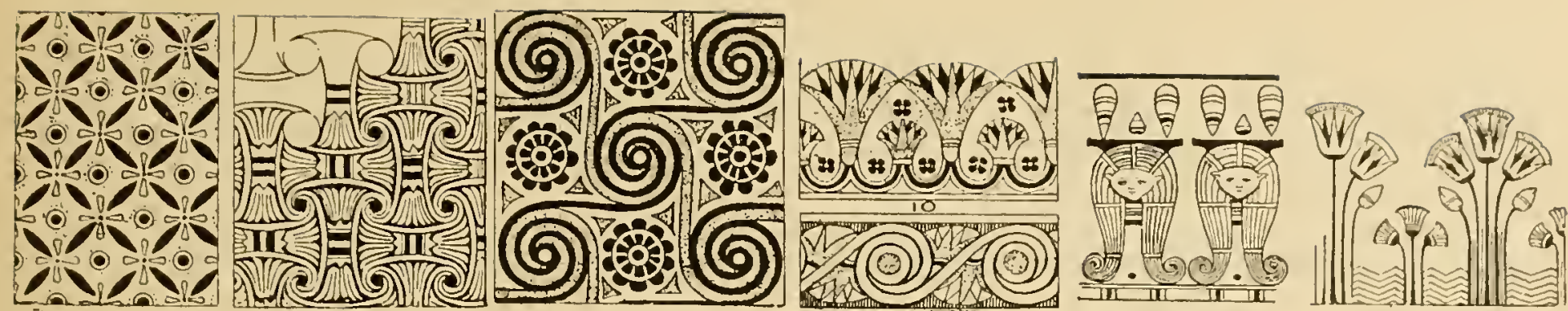

\section{B A B YLONIAN-ASSYR I A N-PERSI A N}

$\Lambda^{S S Y}$

SSYRIAN, Persian, Babylonian and even Egyptian arts in the Early Centuries B.c. were so merged as to be indistinguishable to all but the most careful archaeological student (see "Chart of origins"). The illustration below is Persian, although it contains distinct Egyptian as well as Assyrian characteristics.

Persian ornament in the popular conception dates from the Islam or Mohammedan period in the Seventh Century A.D.

\section{BABYLONIAN-ASSYRIAN-}

Old Babylonian, 4000 B.C.

Chaldean Period, 2286-I 300

B.C. Assyrian Period, I300-

625 B.C. Median Period,

640-558 B.C. Late Baby-

lonian, 608-538.

Excavations in Ninevel,

bad afford proofs of the existence of civilization in Babylonia 4000 B.C. But in this wide country, embracing Assyria, Babylonia, Egypt, Chaldea, Media and Persia, there was such a mixture of peoples, each successively subjugated by first one then another, that the arts of all must be regarded as common to the whole.

Three thousand B.c. in Southern Babylonia a number of independent cities; Erech, Ur, Larsam; Agade, Babylon. Kingdom of Elam, East of Babylonia, supreme 2300 B.C. About I 900 B.C. Kingdom of Semitic Assyrians founded, which later developed the great cities of Asshur and Nineveh.
Six hundred and sixty-eight B.c. Esarhaddon king, Assyria became world power. As in Egypt, so in the adjoining river-valley countries, the lotus fower or the lily played an important role in ornamentation.

In the earliest periods Assyria was famous for its weaving. It is impossible to fix the date of $\mathrm{cm}$ broideries or fancy needlework, but it is fair to assume that as weaving was next to the building of the lut and the making of the battle-axe, the first industry, it was likewise first to partake of decorative character.

In the early period the furniture was of metal and wood or wood inlaid with metal.

Seven hundred B.C. magnificent epoch. At Koyunjik the palace had seventy-one

halls and chambers, two miles of wall decorations Conspicuous features of de-

sign were bulls, lions and eagles. At Nimroud the beams of the palaces were of cedar wood carved.

It will be noted that in 993 the walls of King Solomon's Temple were covered with carved cedar and olive wood in styles like the Assyrian stone sculptures, utilizing much winged decoration and lily forms. At this period Hiram of Tyre was famous for his bronze work. Much gold was used in ornamentation. Fabrics were ornamented in minute diaper patterns with bands or borders. The faces in the mural deco-
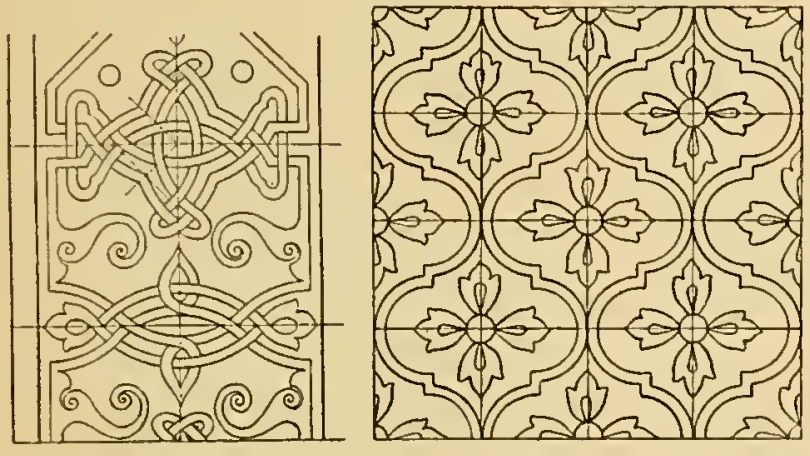
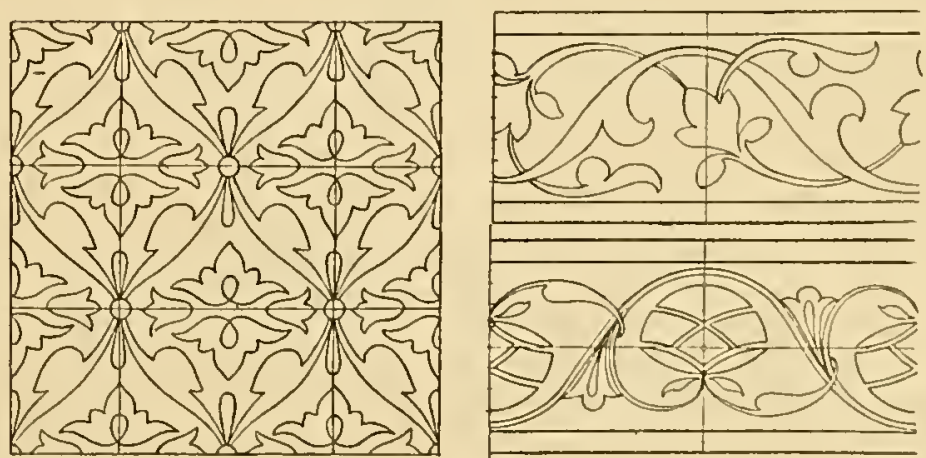


\section{PERSIAN-PHOENICIAN-HEBRAIC-INDIAN.}

rations were in profile. The palm, date, vine, fig tree, fern, lily and tall grass were much used. The sacred tree was conspicuous in design, with wave and guilloche ornamentations; fir cones radiated from rosette centers. Carved ivory was plentiful; iron seldom used; emblems usually bronze; ornamentation of vivid color, gold and silver and delicate painting; eagleheaded lions, winged bulls, human figures with wings and eagle heads. Babylonia and Assyria in constant war; their arts were merged. Assyrian ornament copied much that was Egyptian.

Examples of Assyrian furniture are very rare, as the climate did not contribute to the preservation of
Asia Minor. The art that we regard popularly as Persian is the later Islam art of Molnammed.

\section{PHOENICIAN.}

The Phœnicians were commercial people. Two thousand B.c. they were settled on the coast of Syria and had trading stations and colonies in Greece, Italy, Gaul and Africa. They were traders and had no art beyond that of local jewelers.

\section{HEBRAIC.}

7 He Hebrews of Palestine were dependent on the Phonicians for their technique, the Mosaic laws forbidding pictures and images prevented the free de
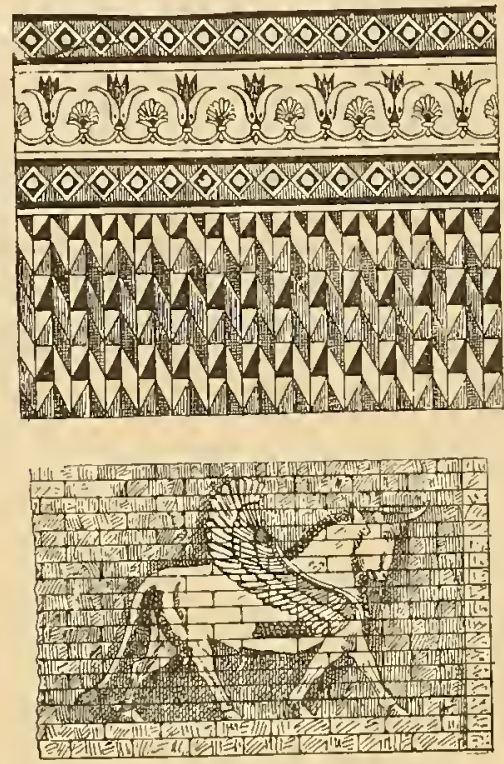
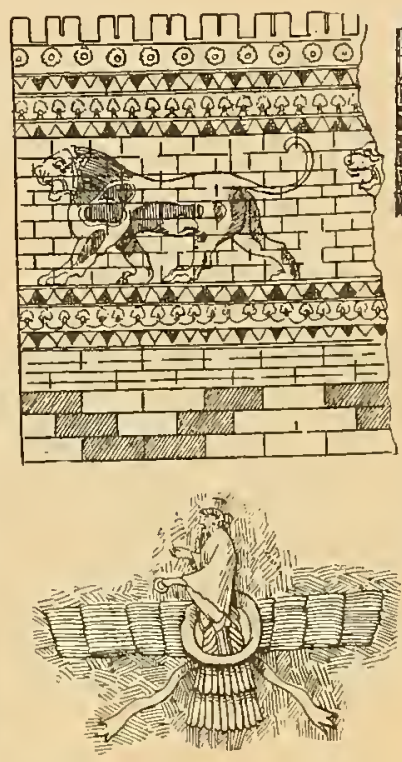
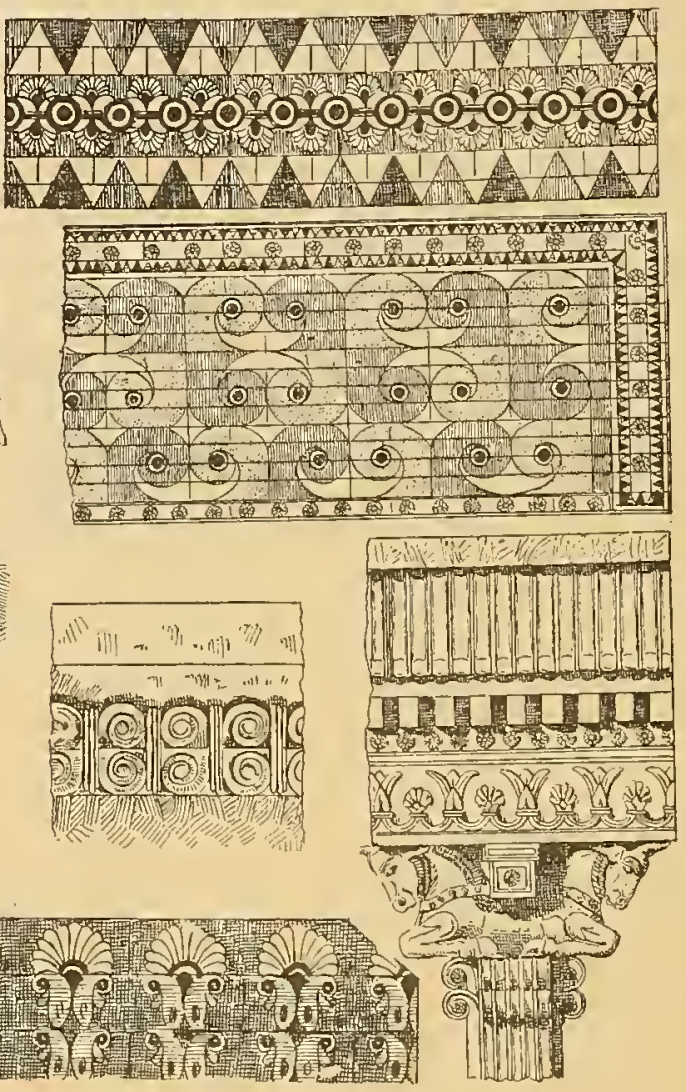

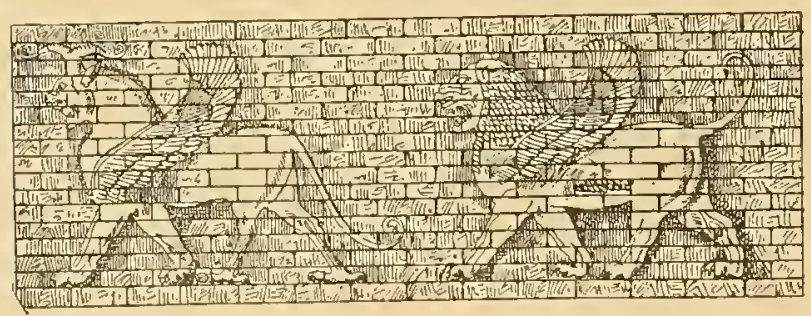

Ancient Persian, showing Assyrian origin.

woods, which occasionally in Egypt lasted through the centuries. In many places only the bronze and ivory mountings of feet and ends of chairs have been found.

The furniture of the Hebrews was, in the early centuries, of the same character as Assyrian.

PERSIAN-558 B.C. Persian Empire, 558-330 B.C. Parthian Empire, 250 B.C.-220 A.D. Sassanian Empire, 220-64I A.D. Mohammedan Persia, 64I A.D.

1 ISUNION and unrest, in the Asia of olden times, confused the arts. Ancient Persian Ornament shows few claracteristic peculiarities, Egyptian, Assyrian, Babylonian and Grecian influence being all discernible. Indeed, the buildings of the Persian kings were erected by men who were prisoners in the countries of Babylonia, Egypt and the Grecian colonies of velopment of art among the Jews. King Solomon's palace and the temples were the work of Phonicians.

INDIAN-2000 B.C. First Period, 2000 B.C.-1525 A.D. Brahma, T400-500 B.C.; Buddha, 500 B.C. Mogul Empire, 1525-I748 A.D. English Control, I748-1858 A.D. English Empire, $185^{8}$ A.D.

1 RCHAEOLOGICAL research reaches no further back $A$ in India than a few Centuries B.c. This early art was influenced by Persian and Grecian. The term Indian is geographical and has no ethnological significance. There is no such thing as homogeneous Indian art. It was a country of many races, Aryan and Turanian, of Brahman, Buddhist and Mohammedan development. The Mohammedan plase, which was the most lasting, will be considered later. 


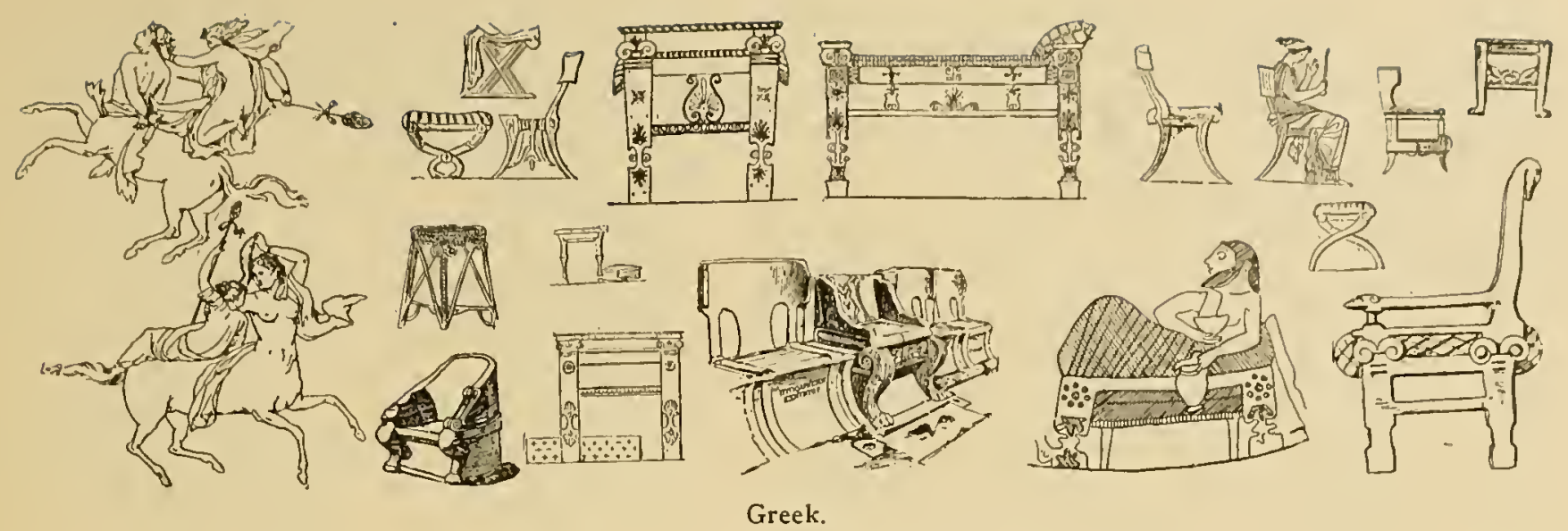

\section{GRECIAN-ROMAN-POMPEIIAN}

GRECIAN-Graeco-Pelasgic Igoo B.C.-1384 B.C.; Doric, 700 B.C.; Ionic, 600 B.C.; Corinthian, 290 B.C.; Hellenistic, 290 B.C.-168 B.C.; Etruscan, 1040 B.C.-238 B.C.

REEKs inlerited the arts of Persia and Babylonia. I Starting with Igoo B.c., the Pelasgic period was based on Assyrian. Early Greek couches nothing more than large stools. In the Sixth Century B.c. Greek and Roman beds were of marble, terra-cotta, bronze, wood, bone and ivory; used for reclining at neals as well as sleeping. Ancient Greeks learned their art from Egyptians, but a purely decorative Greels device is the anthemion, which with the acanthiss can be traced back hundreds of years in Egyp- tian forms. 'The Greeli system was to build within squares. Firets were common. Decorators painted in fresco and in strong colors; blue and Tyrian purple much in use. At an early date conceived a system of applying blue in proportions equal to yellow and red combined, yellow in three parts, red five parts and blue eight parts. First Greek and Roman couches covered with skins or felt materials. Mattresses used Third Century B.c. with coverlets and draperies, in broad stripes of solid colors; pillows various shapes covered with linen, wool, leather and silk. Pillows filled with refuse wool, vegetable fiber, feathers. No record of uses of cotton. Silk much used and draperies described
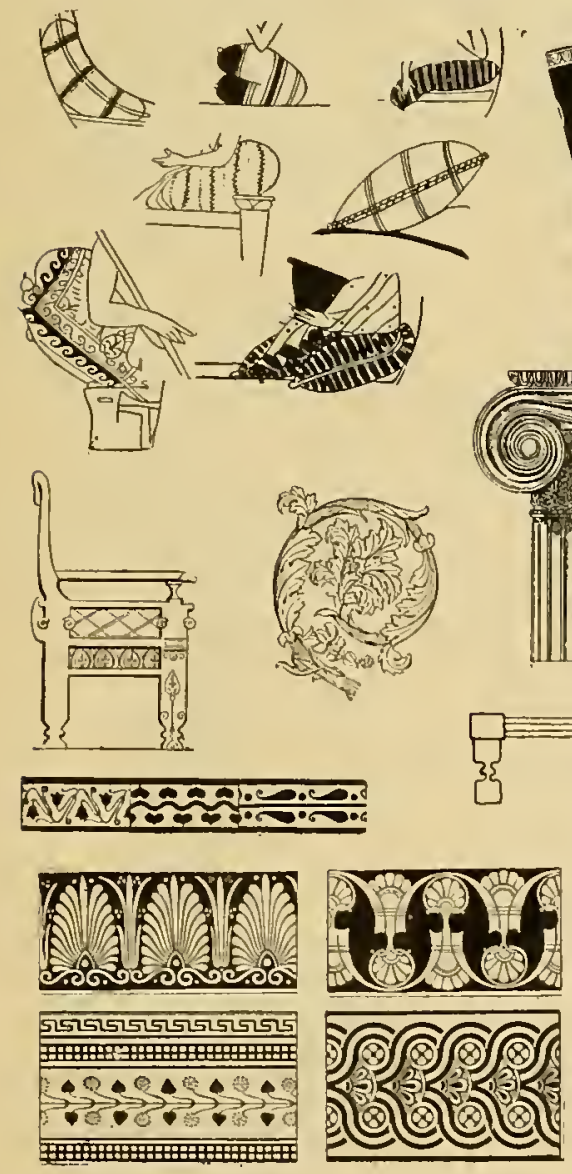
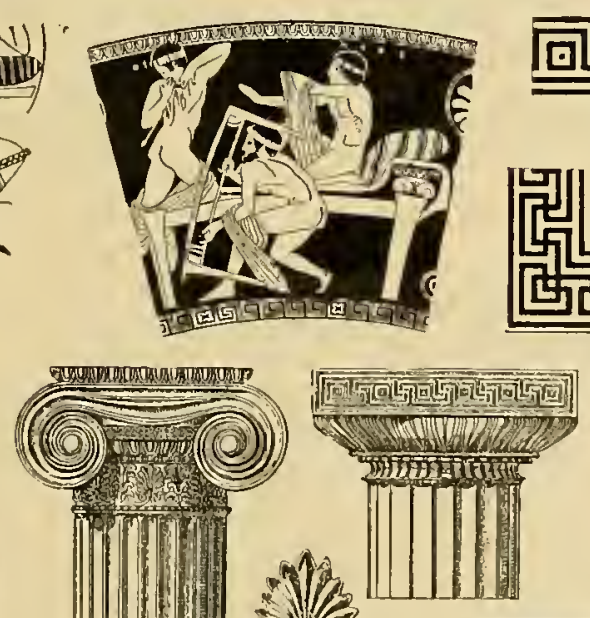

.
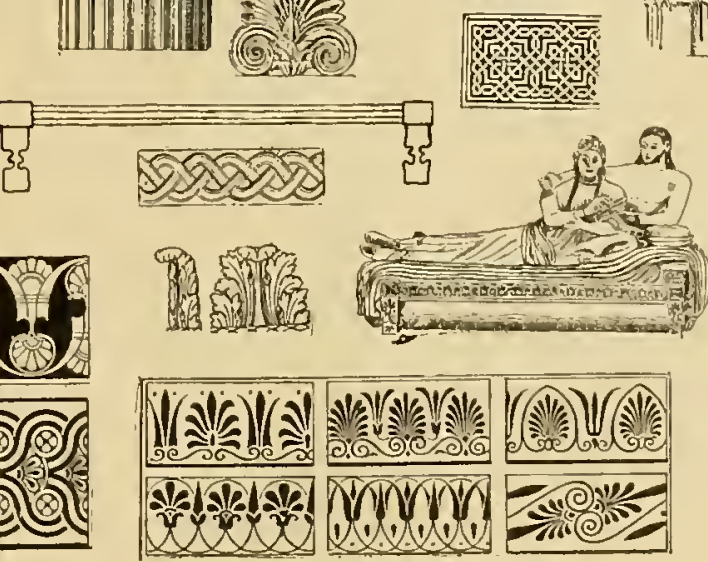
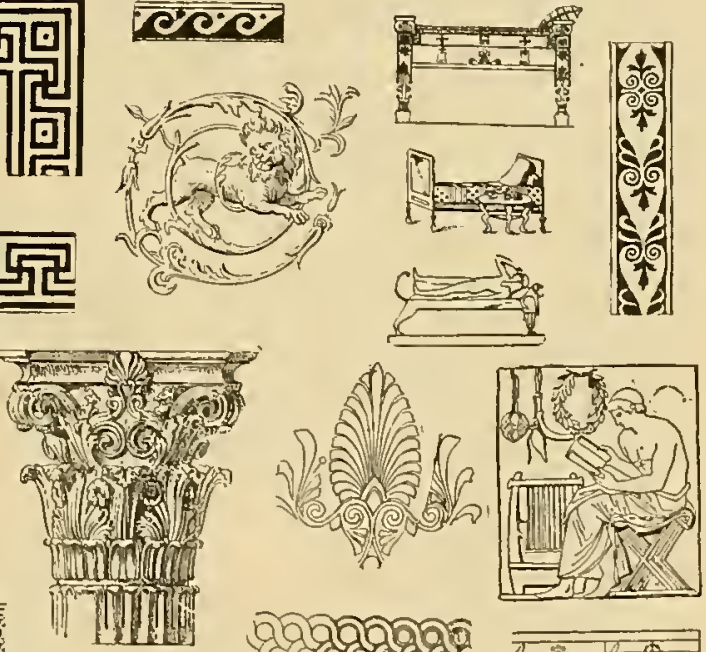

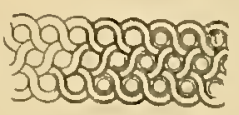
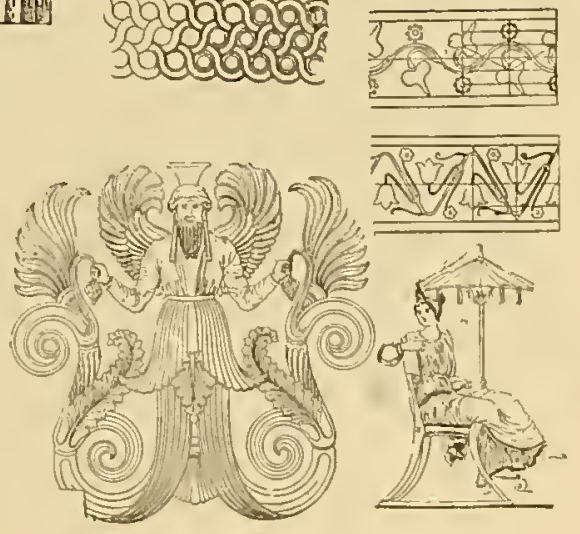

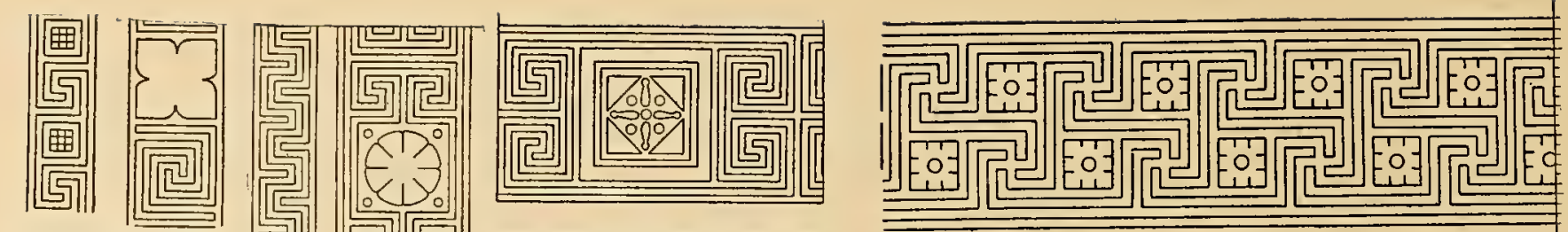

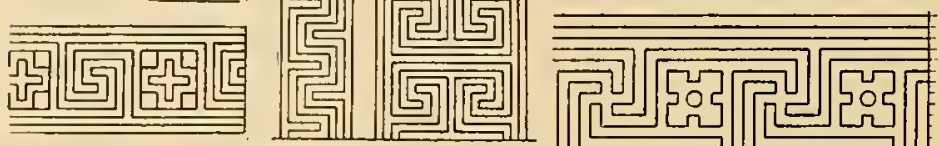

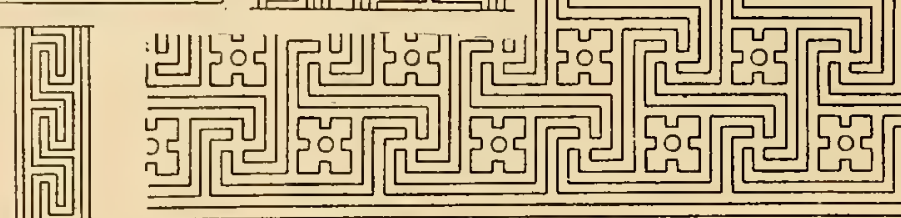
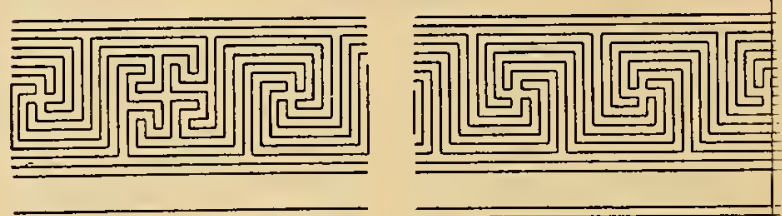

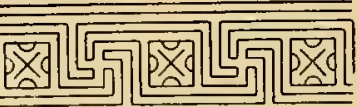

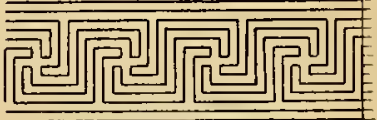

Greek.
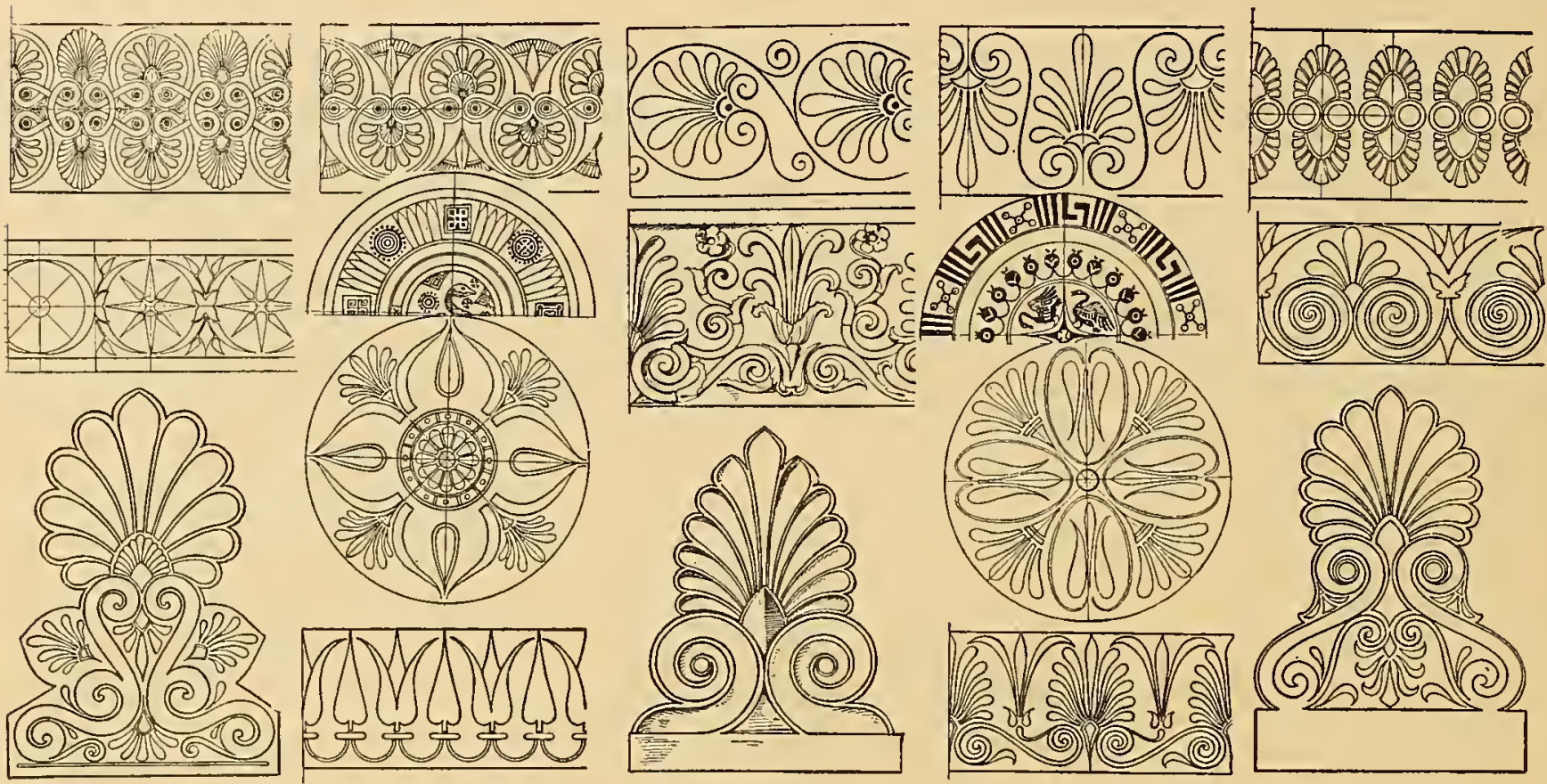

Greek.
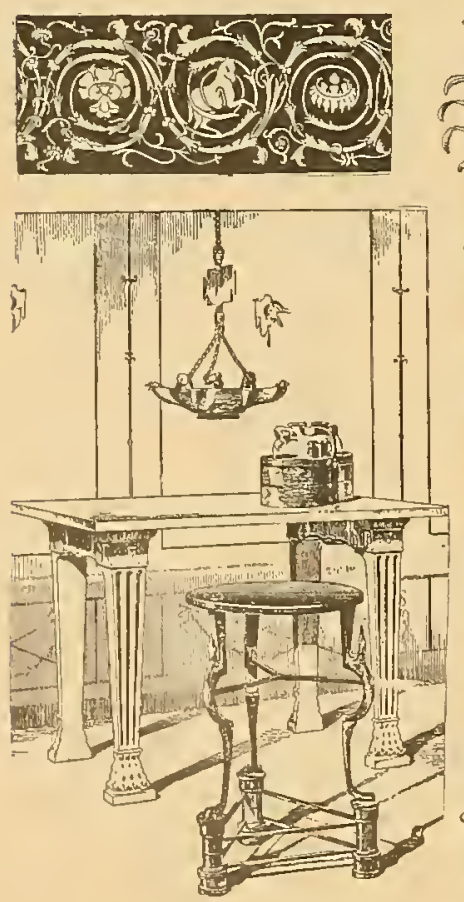

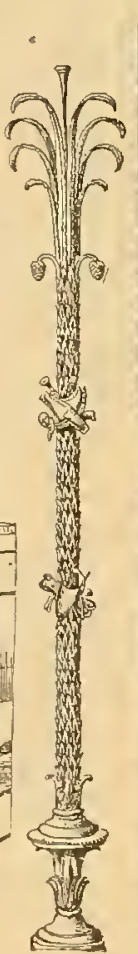

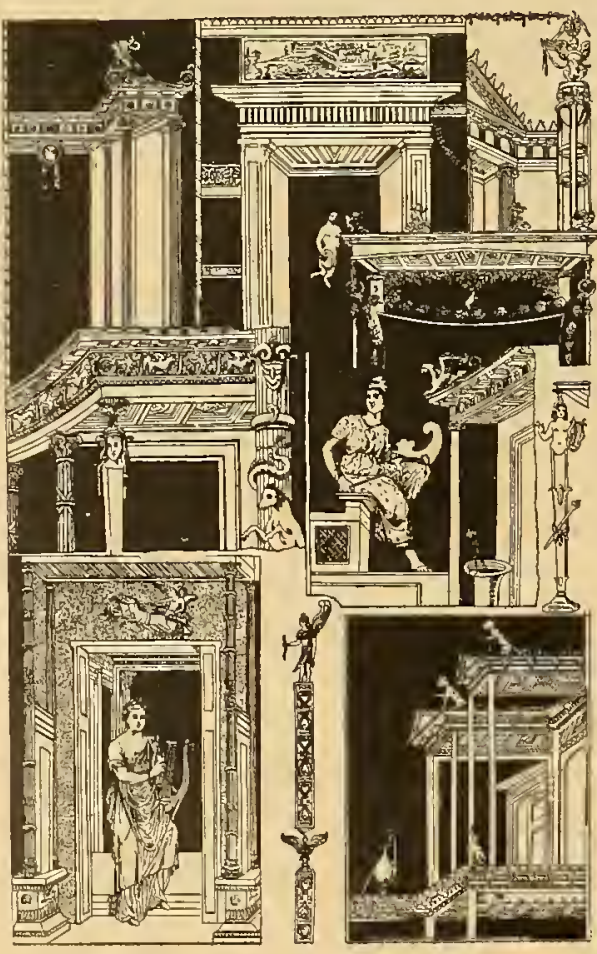

Pompeiian.
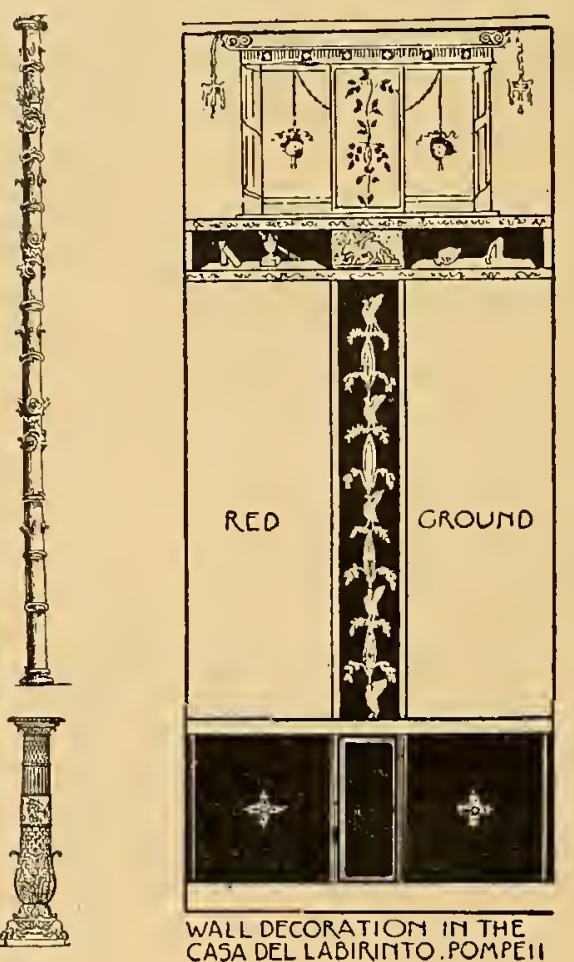

WALL DECORATION IN THE CASA DEL LABIRIMTOO.POMPEII 


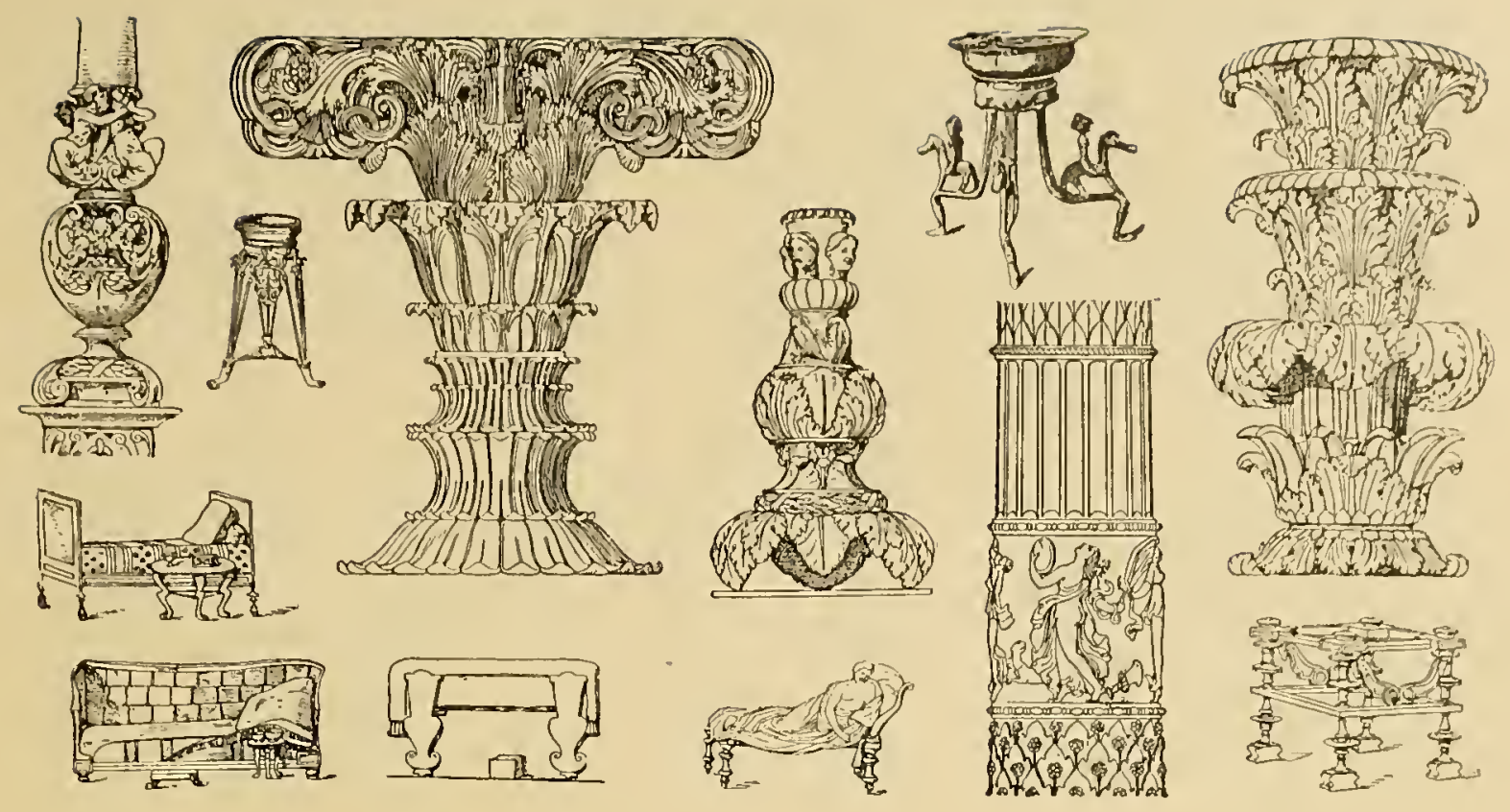

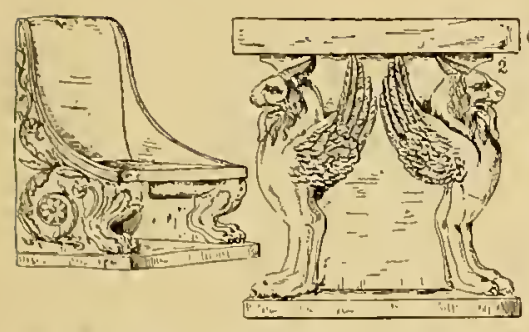

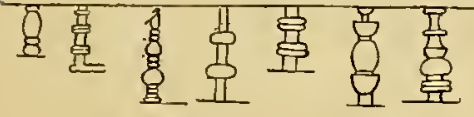
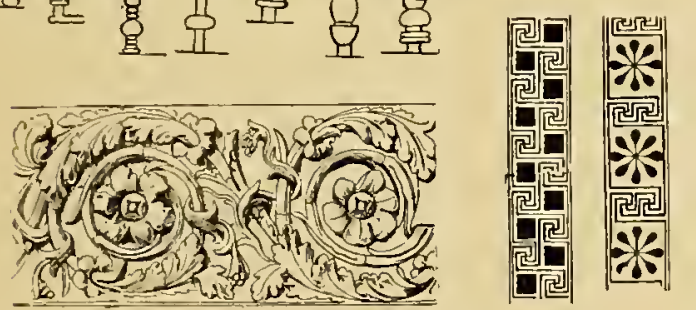

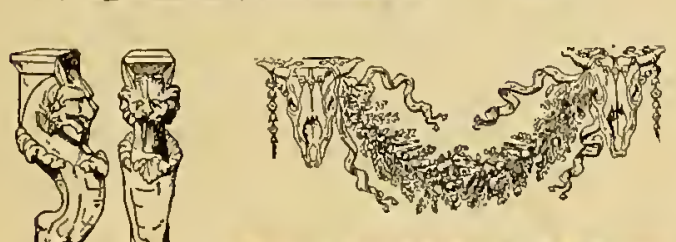
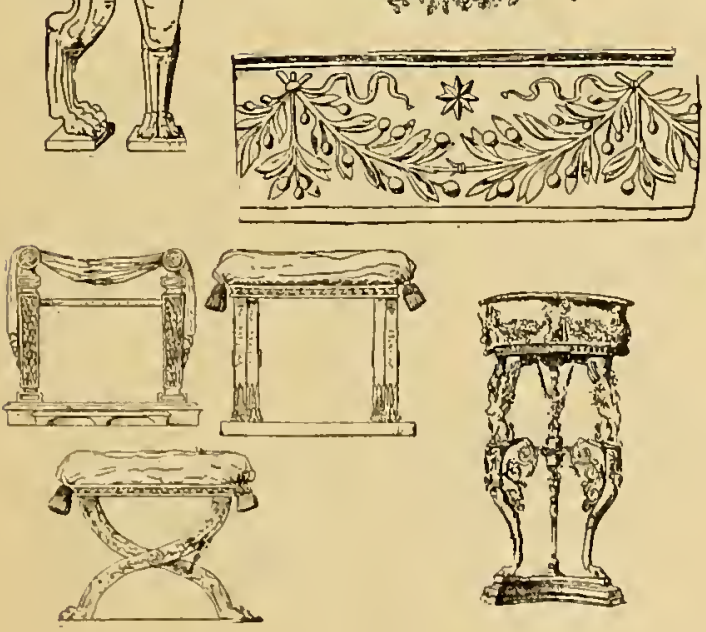

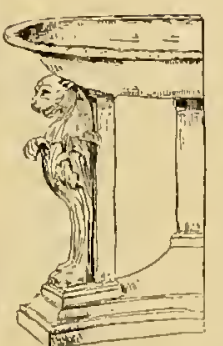

鞤
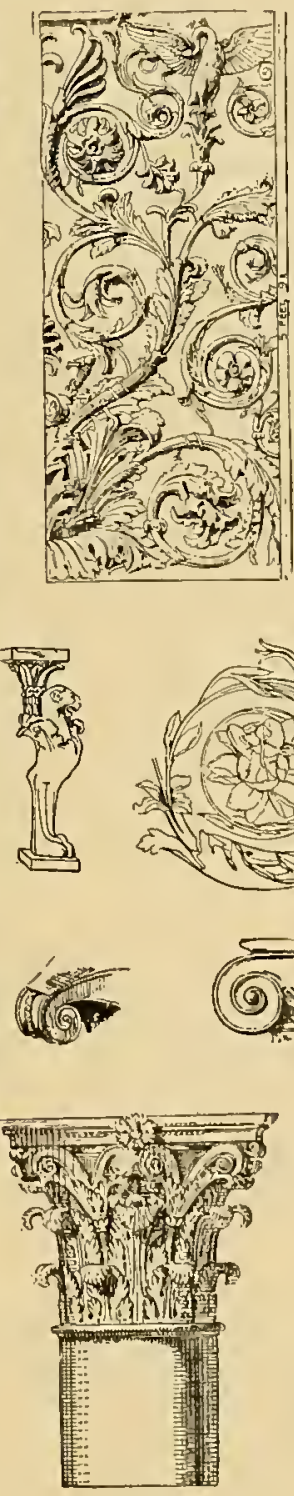
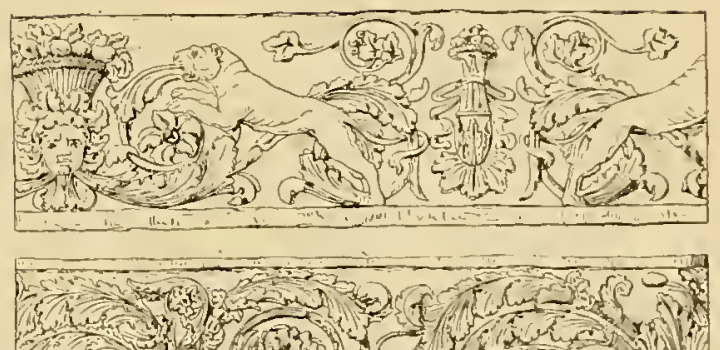

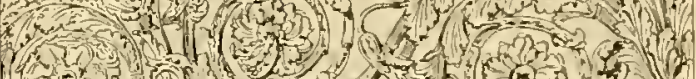
(f)

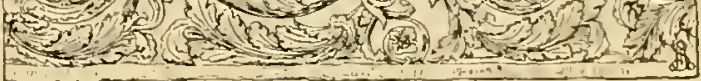

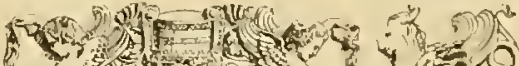

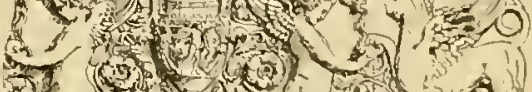
1) (5) E

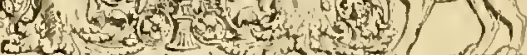
ctiction

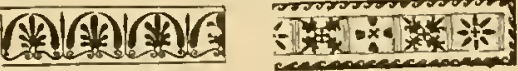

3.

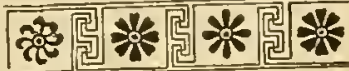
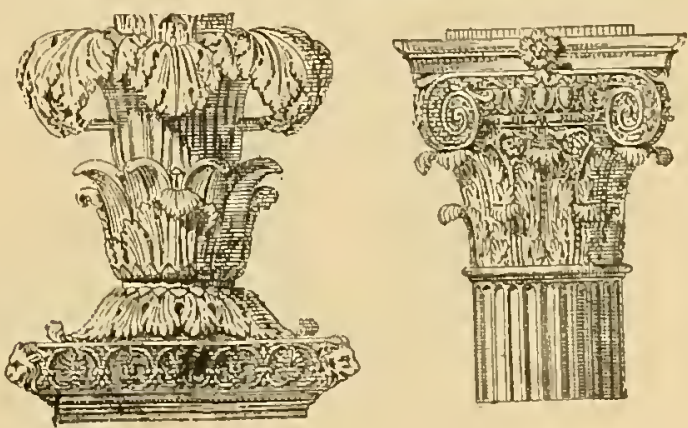


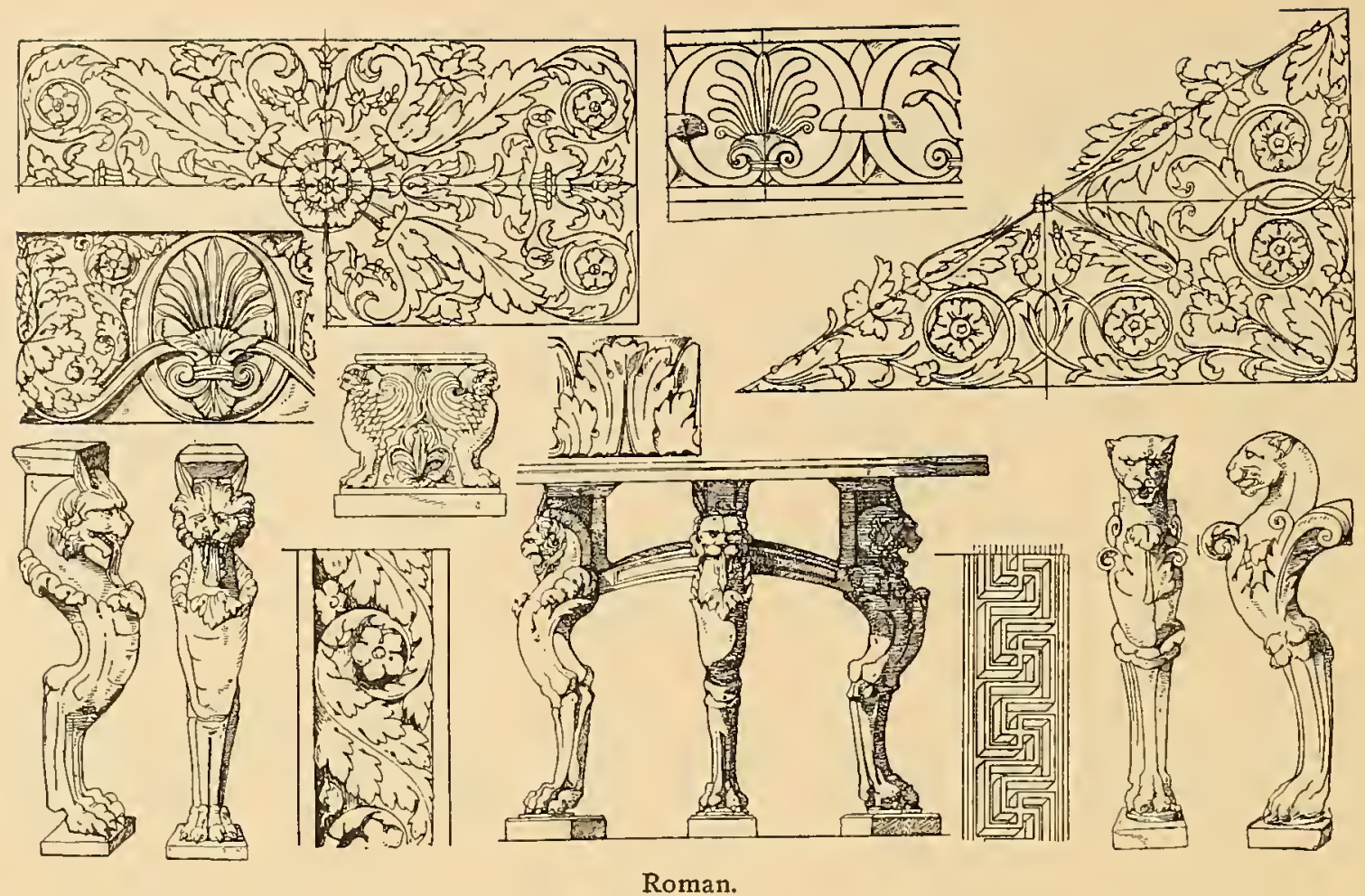

as having nap on one or two sides (velvet) in colorings of purple, scarlet and gold. Fabrics woven in pattern or embroidered. Thin linens, tapestries. Much material brought from Babylonia.

Greek furniture inlaid, with precious metals; bronze and polished silver mirrors. Beds of wood often ornamented in tortoise shell, veneers of fine wood. Wood finished in oil, wax and stains, sometimes painted, never varnished; solid carvings.

Tenth Century B.c., Homer the poet referred frequently to the bed.

Seventli Century B.C., couches were made with lerges built on a rectangular plan as well as with turned ledges. First they were frame works ledged with a flat surface upon which furs were piled up. Then the upper part was furnished with headboards and footboards.

Sixth Century B.C. gives us beds so draped that the construction of the frame is hidden.
In the Fifth Century в.c. beds and furniture were common, rectangular and turned legs being used. Wood, bronze and other metals. Some authorities maintain that iron was used in beds as early as 427 B.c.

Four hundred B.C., Greek embroiderers produced beautiful results.

Pelasgic Greek was largely based on Assyrian ornamentation. The Greek honeysuckle can be traced to Assyria, also the vitruvian scroll and the guilloche.

Etruscan-A bronze Etruscan bed exists from the Seventh Century B.C.

\section{ROMAN-753 B.C.-455 A.D.}

Roman. 753 B.c., Roman houses divided into sep$R$ arate rooms for dresses, cupboards, lockers, lounges, articles of luxury. Fabrics of many linds developed the Greek style. Great love of pomp and splendor. Elaborated the Corinthian principles; utilized pineapple, vine, palm, ivy, poppy, winged dol-
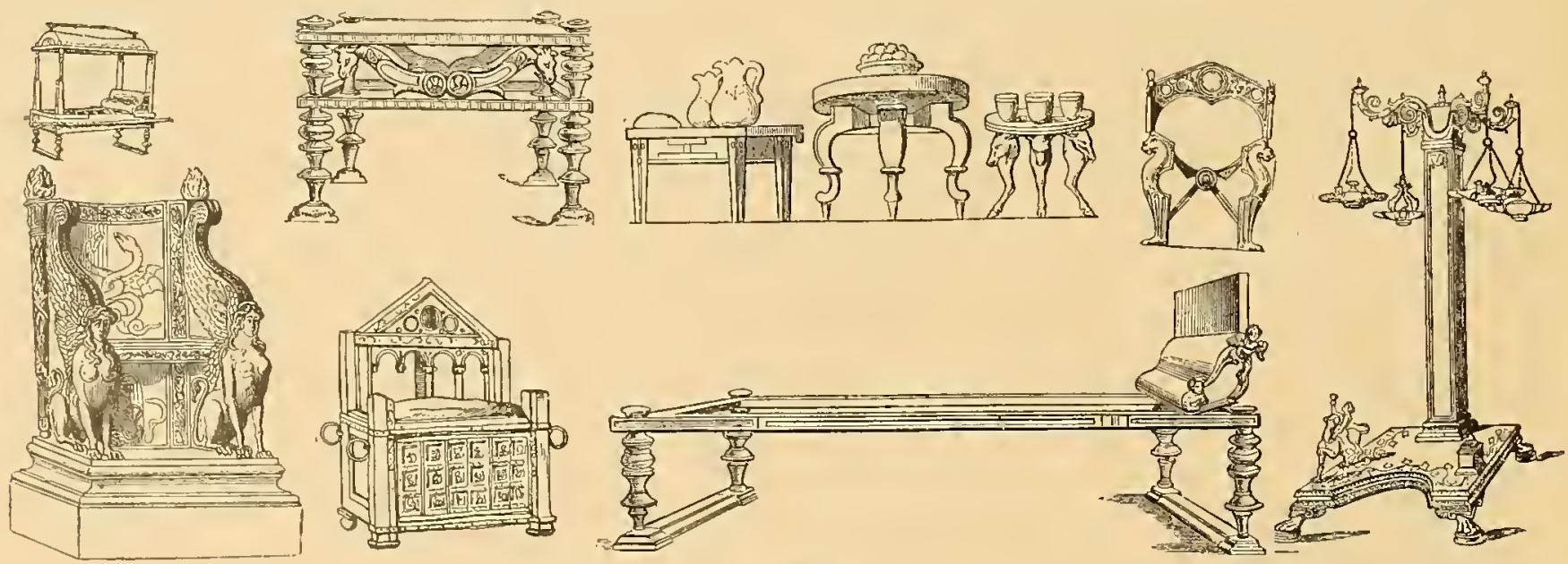

Roman. 


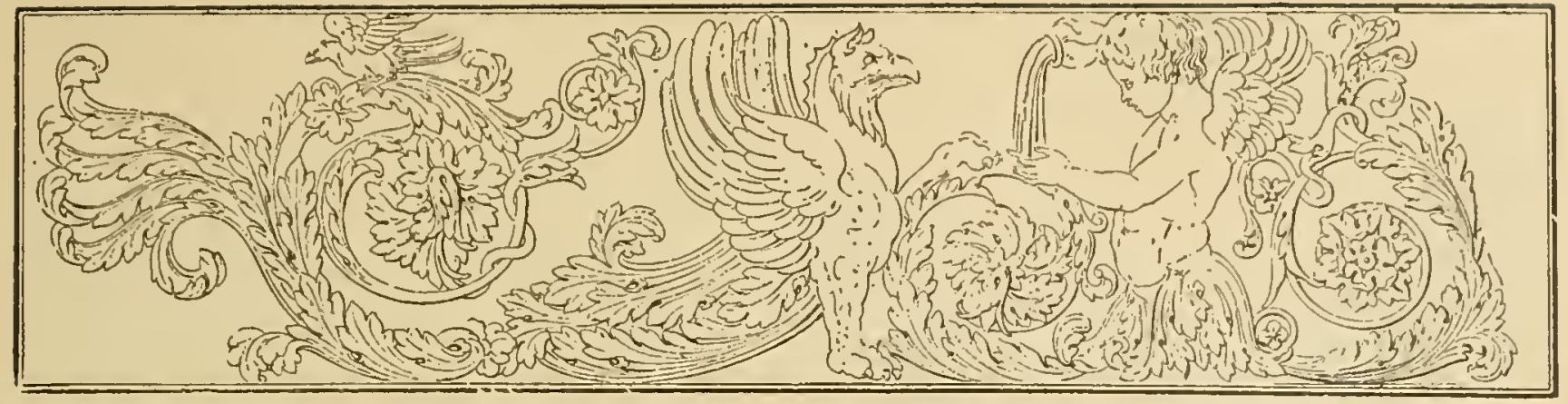

phins, winged horses. Like the Grecians, the Roman wall treatments were confined to frieze decorations against the plain wall. First couches covered with wool material and skins, in time became elaborated heds with head and foot pieces. No upholsterings except novable pillows. Marble couches were common, and wood beds ornamented in precions metals, tortoisc shcli and ivory. Late Roman furniture had rush and reed plaited seats. Beds used for reclining at meals.

Roman furniture was decorated with paintings and inlay veneer, Tarsia work forming complex decorations. Roman houses were furnished with cupboards, shelves, wardrobes, lockers and general furniture superior in comfort to Fourteenth and Fifteenth Centuries, Europe.

Ancient Phrygian and Lydians occupying western Anatolia made embroideries at a period prehistoric. The Roman word Phrygio means cmbroiderer.

POMPEIIAN-IOO B.C.-79 A.D.

Domperian. Development of the Roman arts which finally became almost pure Greek; beautiful mosaics, still life, human and divine figures, complete pictures on the walls which were frequently painted in reproduction of oil paintings by Greek masters. Pompeiian wall space divided into dado, middle and upper section, dado generaily black with simple ornaments; purple. green, blue or violet middle space enlightened with one or more figures or landscapes, having one or more bordcrs. Upper space usually white. System of dark dadoes and light friezes generally employed. Delicate garlands, fruits, masks, animals, imitating nature. (In England $1762-1792$ the brothers Adam almost reproduced Pompeiian style.)

\section{WALL DECORATION.}

Grecian and Roman-In Greece much modeling in plaster and stucco, drawn upon a coat of wet plaster spread on the wall and built up. Fresco and tempera or distemper painting widely practiced. Decorative borders frescoed and painted in subjects religious as well as legendary, showing hundreds of Greek and Roman gods; modern or superior deities; the Genii and inferior deities; the demi-gods and heroes, and illustrations of events in Greek and Roman mythology. Statuary and sculpture, as well as paintings, partook of these subjects. Greeks love color. Used it in extravagant proportions in their paintings and frescoes. Massive walls show not only historical and religious subjects, but paintings of still life, city and country scenes, flowers and nature showing perspective. Unlike Egypt and Assyria where walls werc all covered, Greek and Roman walls were usually treated with deep friezes or upper thirds. Ceilings were elaborate, divided into geometric sections, octagon forms and squares. Mosaic brought to its greatest perfection for wall pictures, pavements and floors.

Pompeian-Pompeii and Herculaneum were centers of late art of highest Roman type. Myth and religion subservient to the beautiful. Perspective scenes elaborately painted; gods, hill and valley, palaces and cottages, water-views, mountains, scenes of travel, commerce and warfarc. High dadoes filled with model figures. In private houses walls were frequently completely covered by paintings executed direct on plaster. Sometimes divided into panels with small pictures in minute panels above larger panels. Mosaic work of most exquisite character.
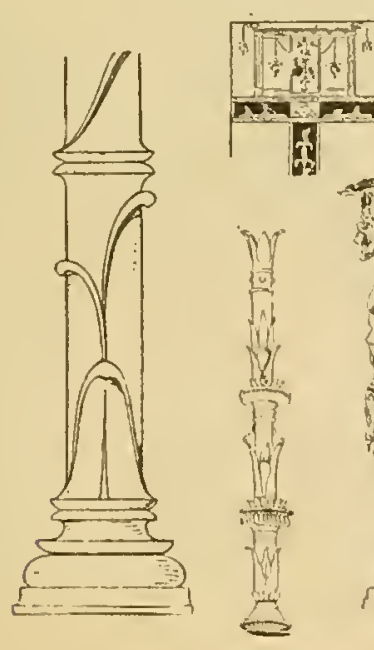

$[23]$
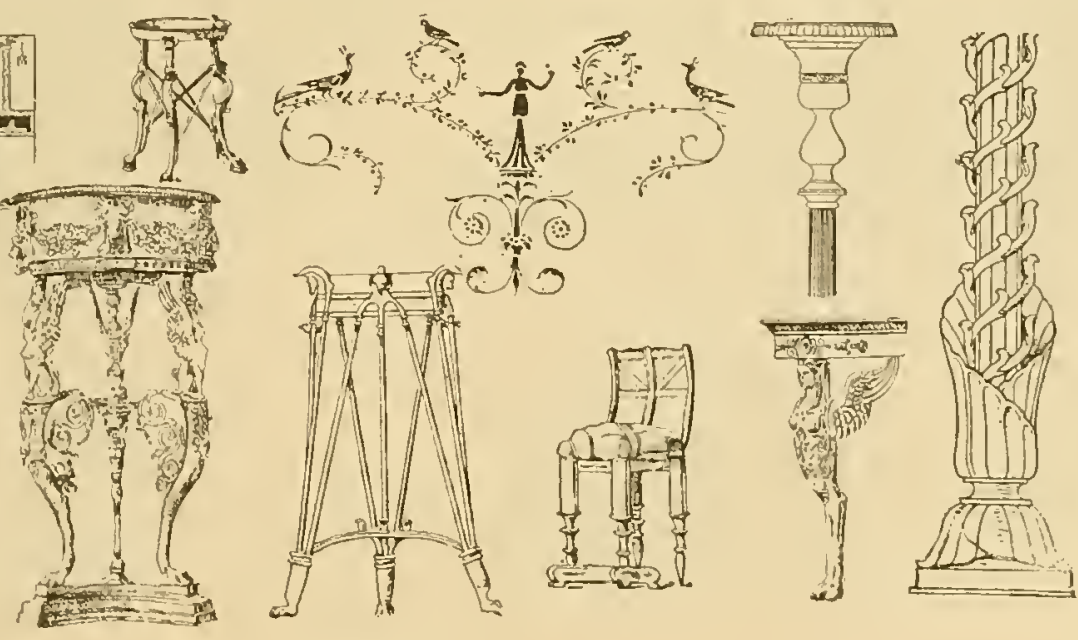

Pompeiian.

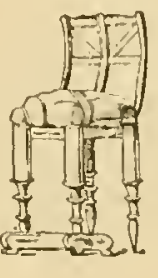

西 


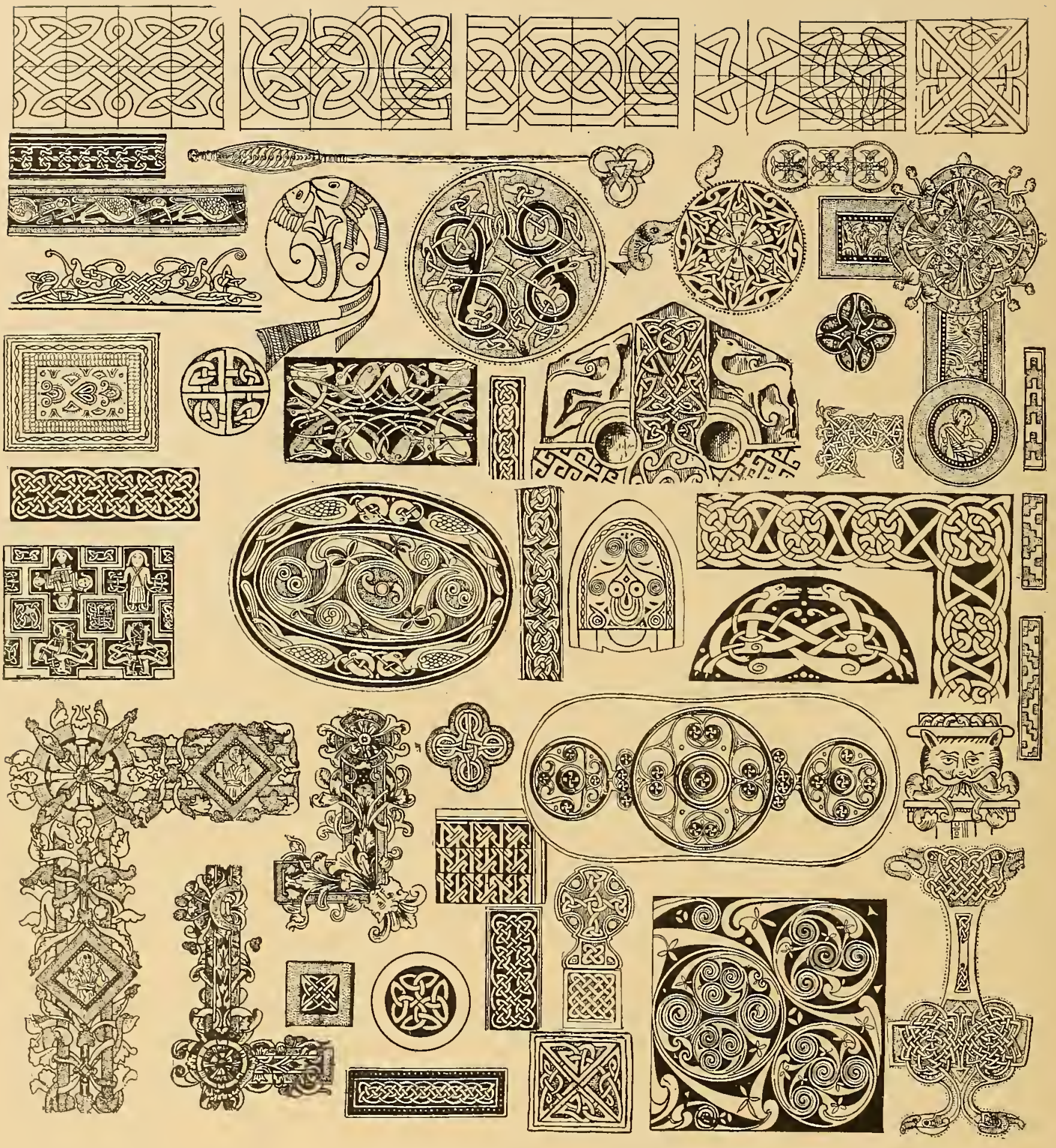

CELTIC ORNAMENT.

The foriated form is the Romanesque influence developing about 700 A.D. The animal form is the Scandinavian influence. 

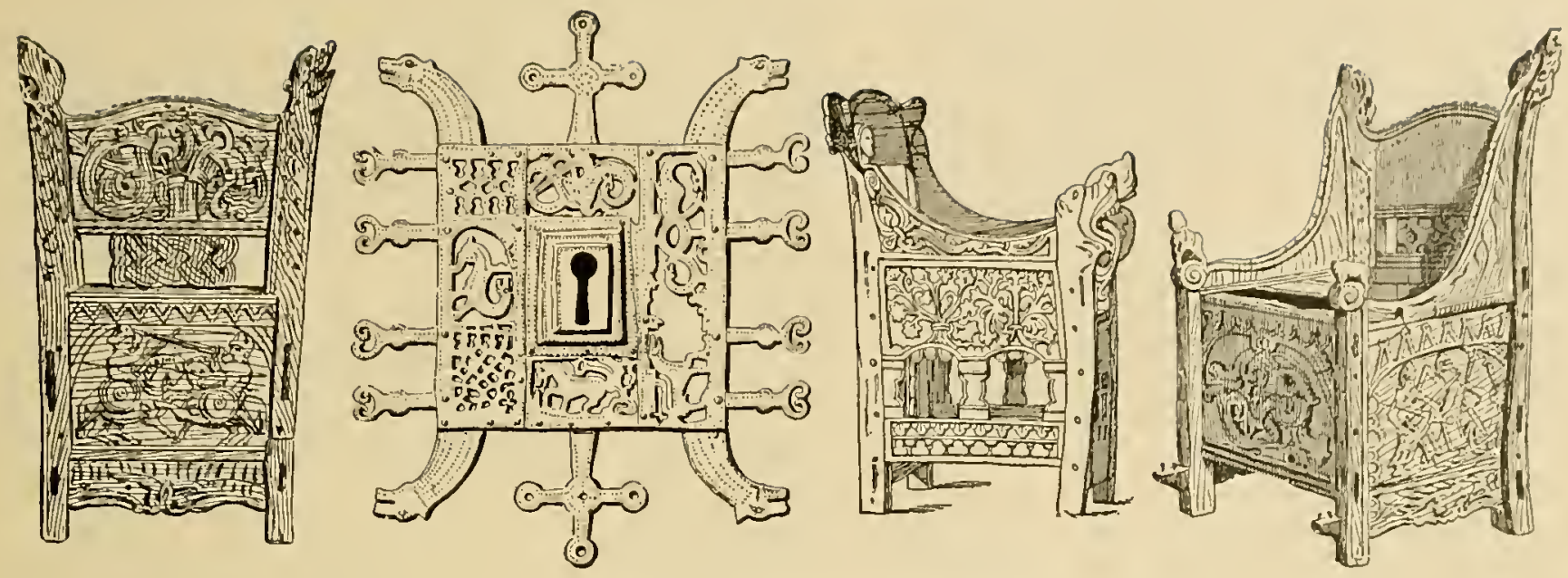

Types of Scandinavian Furniture.

\section{N O R T H E R N}

SCANDINAVIAN OR NORTHERN-100 A.D.-1299.

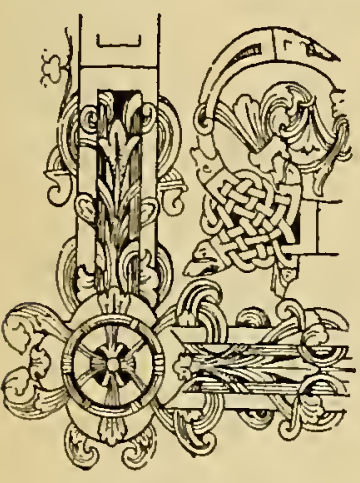

the Gallic country.

Scandinavia until nearly I000 A.D. was pagan. Its art reflected in a realistic manner the traditions of the country.

According to Scandinavian legends there were wrapped in the history of the cotnntry's origin intrigue, treasure and murder. It is umecsesary to tell the story (see history), but decorative art util- ized a system of interlacements not balanced like the Celtic, but confused lines and chaotic traceries intermingled with figures of the otter, the dragon, the horse, bags of treasures, human figures in conflict.

The Celts and Scandinavians became in time closely related. From I000 to I IOO A.D. Celtic influence was felt on account of the Celtic missionaries who went north from Ireland and preached the doctrines of Christ in the North country. But after the year I 100 we find plant life introduced, realistic verdure of Roman character, the same that prevailed among the Normans and Anglo-Saxons who at this time were enthusiastic in religion and naturally absorbed the art characteristics of the papal states.

\section{CELTIC-2000 B.C.-II00 A.D.}

THE Celtic nation of Western Europe was annihilated before the Christian era, but the Celts settling in Great Britain, principally in Ancient Hibernia (Ireland) left lasting evidence of their art even
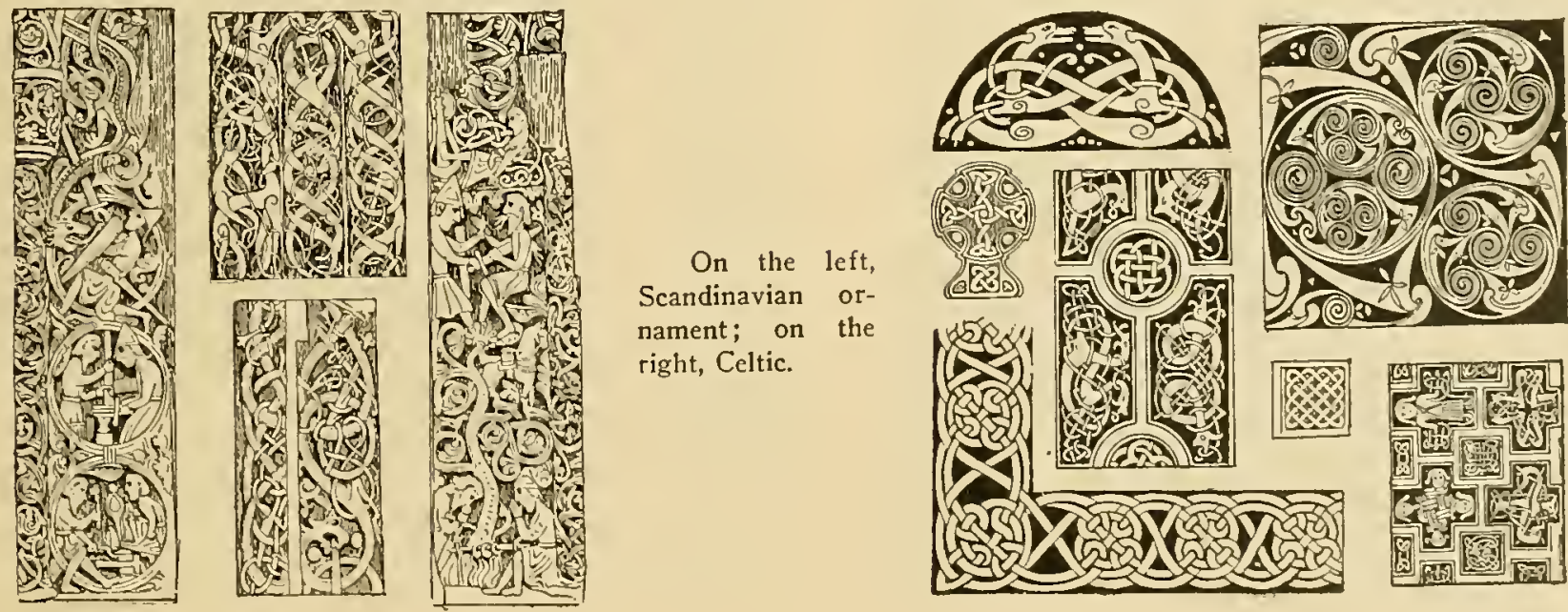

Scandinavian ornament; on the right, Celtic. 


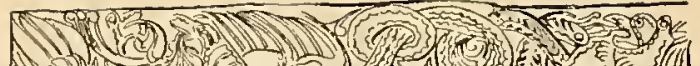

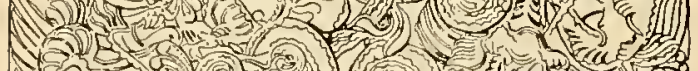

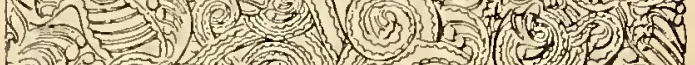

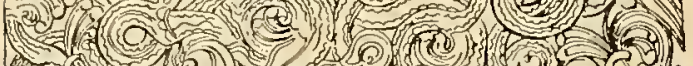
(1) N. (2) (4.3) (

(1) (1) 1 (v)

(3) 10151

(3)

1. $=1$

(rit)

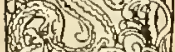

(3) $)(50$

,

(1)

corde

(3)
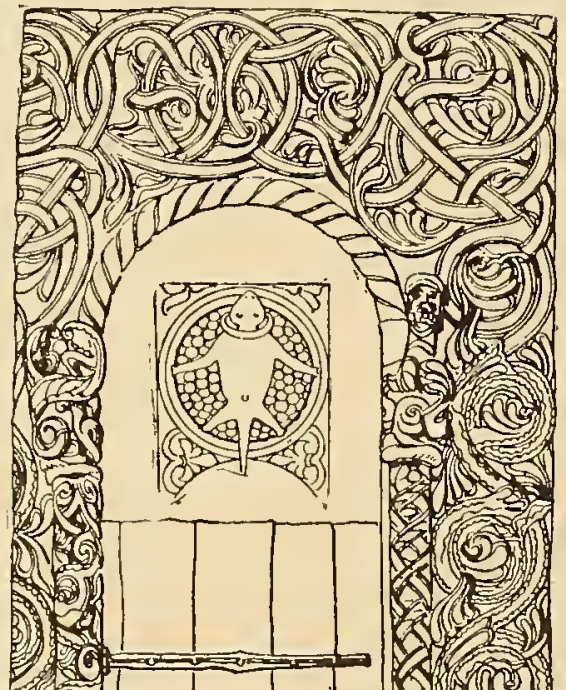

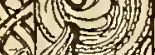
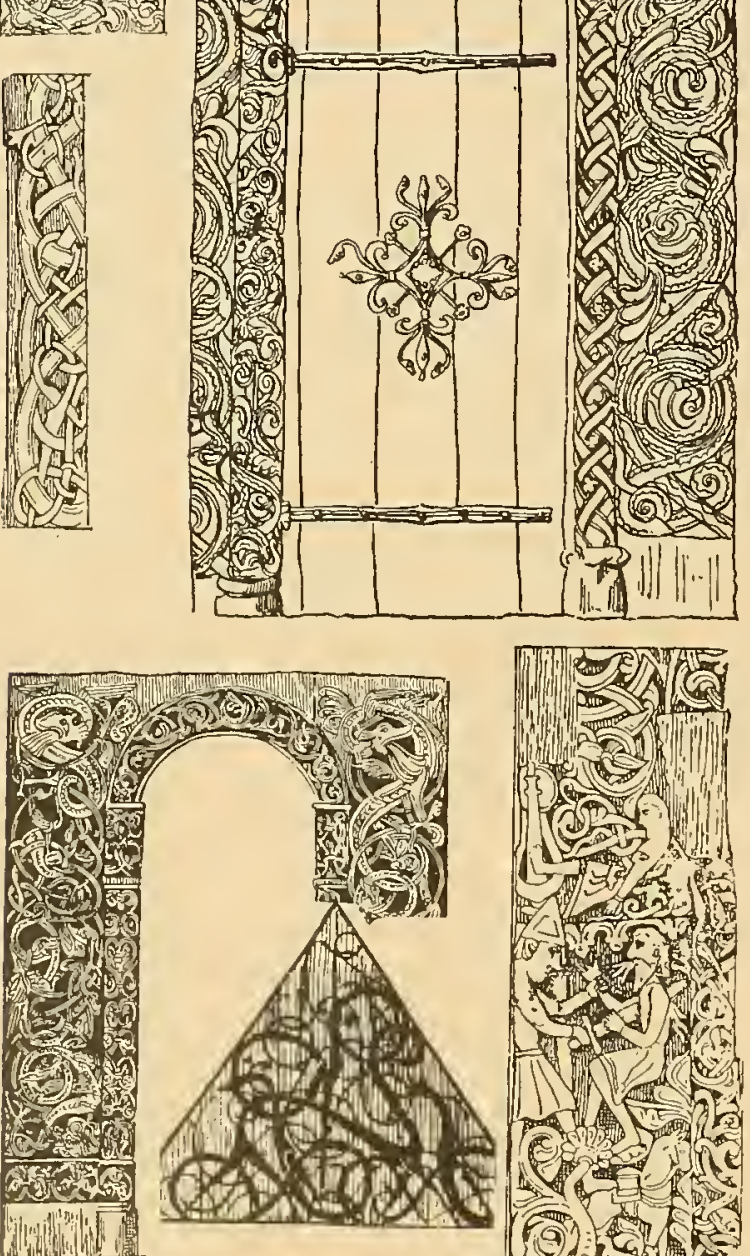

m

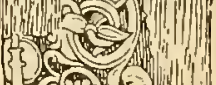

5 (5)

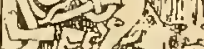

(1)

o 51 .

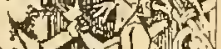

Lo 12

$1 \mathrm{x}$ -

4 .

(i) :

1510 10

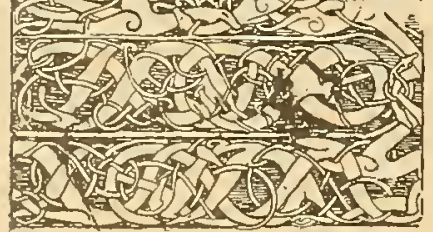

(c) (3) U

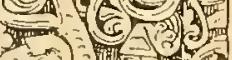

o o i in

(1)
(1) 15 (J)

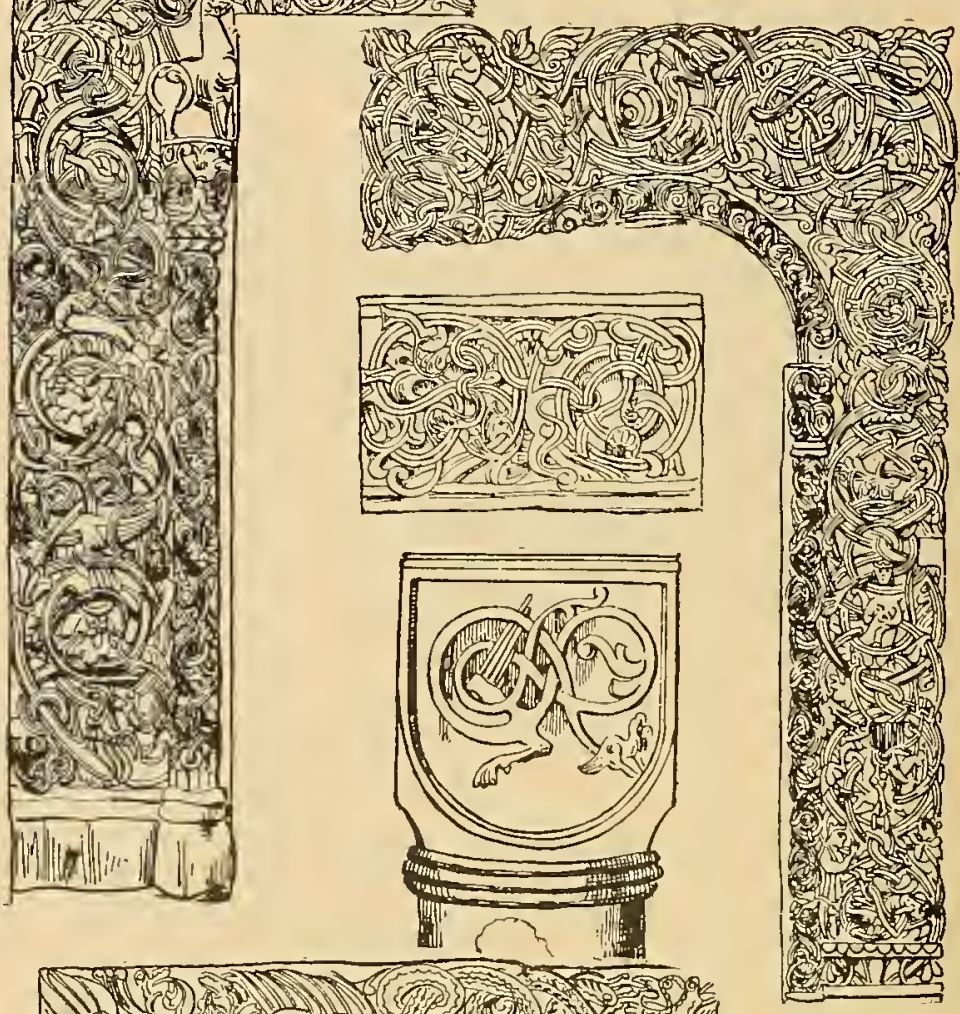

- M

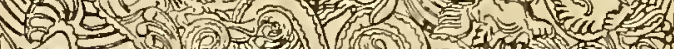

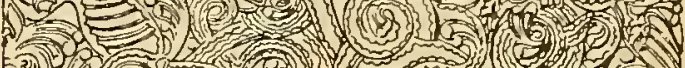
2) (a) (c) (1) 3 (2) B.

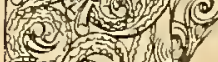

a(c) 2 (6)

(c)

(I) 1 (

(a) 120

1) 1020

$=1$

(n.

法

(1)

(5)

(5)

(1)

S

( )

2

(2) 5

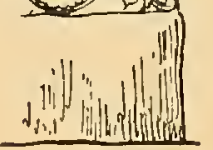

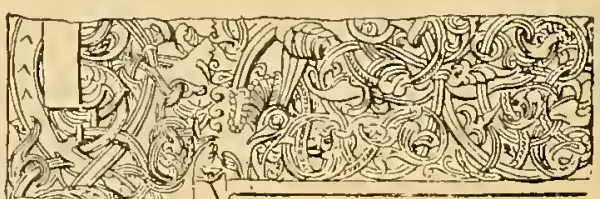

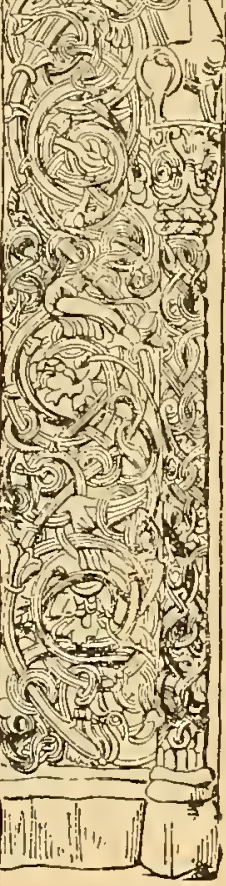


during the sway of paganism which prevailed up to 400 A.D. Celtic art showed interlaced curved liues sontetimes utilizing exaggerated bird forms interwoven, but, unlike Scaudinavian, the interlacements showed balanced relation.

Fron 900 to I IOo A.D. Romanesque influence was strong in Celtic art, due to the enthusiasm and preemincuce of the Irish in religion, art and education. Ireland, independent $11 \mathrm{p}$ to 1172 , was conquered by the English. Celtic art underwent a radical change by the introduction of Romanesque floral characteristics during the Tenth Century. Intersection was characteristic of the art as in Moresquc and Arabian, but intersection in Celtic art, nnlike the geometric Moorish, or the llat conventionalized vegetation and leat forms sugrgested by Arabian, is always intersection of simple circular or curved bands, sometimes introducing ani. mal or bird forms. When dragons and animal forms are introduced one may detect Scandinavian influence.
Balanced relations prevail in Celtic intersection design.

\section{RUSSIAN-500 A.D.}

RNAMENT of Celtic character is often seen in what is known as Russian art. Russia was settled 862 A.D. by Scandinavians. Russia developed during the Romanesque period up to I IOO, a period of high religious fervor, and this period affected the characteristics of Scandinavian art. Subsequent to I100 Oriental influence was strong in Russia.

\section{NORMAN, ENGLAND-1066-1189 A.D. (See Roman- esque.)}

The Normans were the Norsemen and inherited the early Scandinavian arts; but at the time the Normans gained a foothold in Normandy, 91 I A.D., and at the time they conquered England, 1066, they were under the French-Romanesque art influence.

\section{B Y Z A N T I N E}

BYZANTINE-328-500, Roman-Christian. 550-800, Oriental splendor. 850-roo5, Macedonian or Roman Classicism.

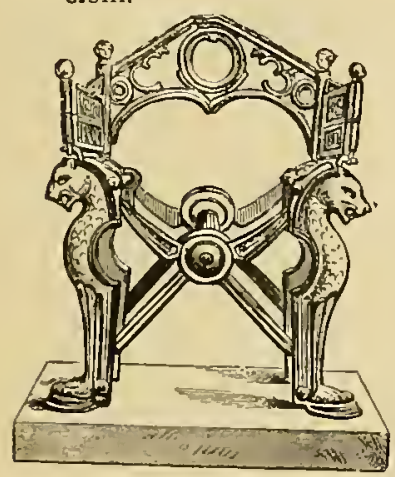

Chair of Dagobert; Seventh Century.

B YZANTINE ornamentation covers three periods. The first from 328 , when Byzantium, under Constantine, became capital of the Eastern Division of the great Roman Empire, and Christianity was made the established State religion. Most distinctive epoch under Tustinian, was from 527 to about 600 . A period of torpor followed until 850 , when under Macedonian rule it became classic.

The close historical relations between Byzantine and the Roman-Italian people naturally merged the arts, and we have terms confusing.

Medieval art is arbitrarily fixed between 450 and II 50 .

Romanesque art is the art influenced by the Romans from 700 to 1100 , when Gothic began.

Lombardic Romanesque, the Romanesque of the Lombards, began 773 .

Early Christian began 330, extending over 200 years.

Norman Romanesque was the Romanesque of the Normans, beginning 9II and finding its best expression in England subsequent to the conquest of the Normans, 1066 hence sometimes called English Romanesque.

Prior to $55^{\circ}$ the term Early Christian applied to that period when Christianity was accepted as the State religion by the Byzantine Empire. Christian symbolism soon found its way into Byzantine art, and from the dismemberment of the Roman Empire, 455, these Christian characteristics of design were absorbed and adopted generally outside of Byzantium, but especially by the Goths who ruled Italy until 555, as well as by the Lombards who settled in Northern Italy 568.

Byzantine art was cliaracterized by sharp acanthus foliage united with Christian cmblems, circle, cross, crowı, vinc, dove, peacock; figure sculpture

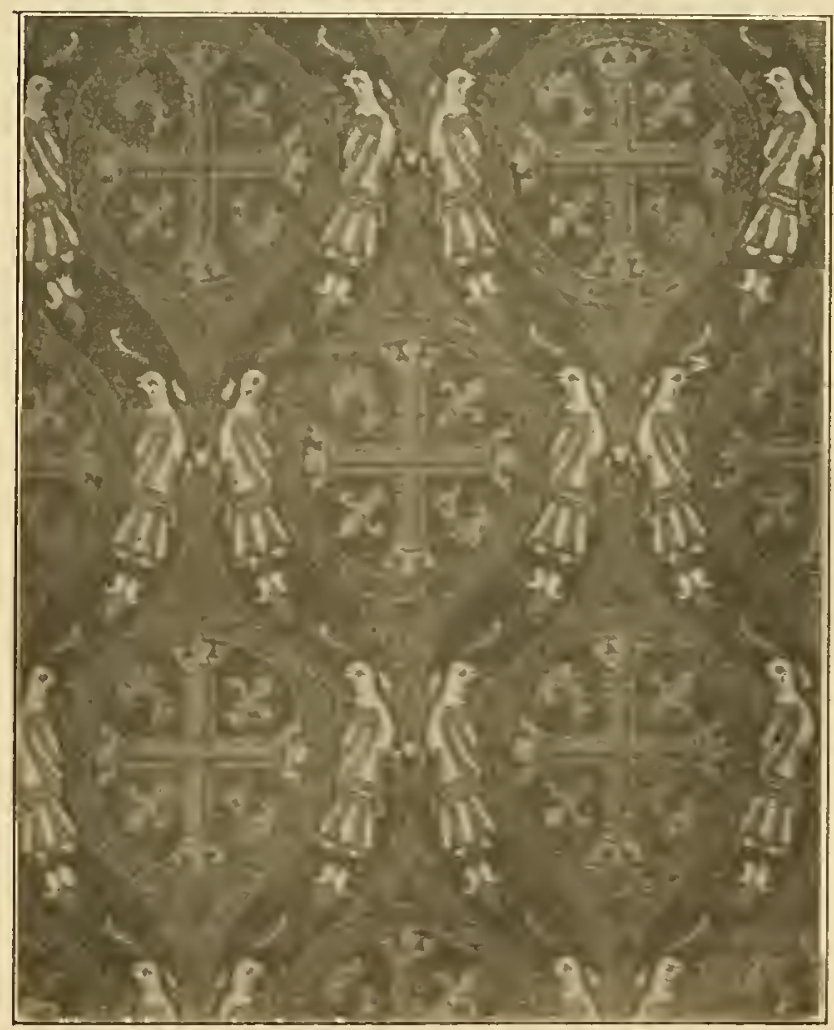

Byzantine fabric, showing the ogival form of design. 


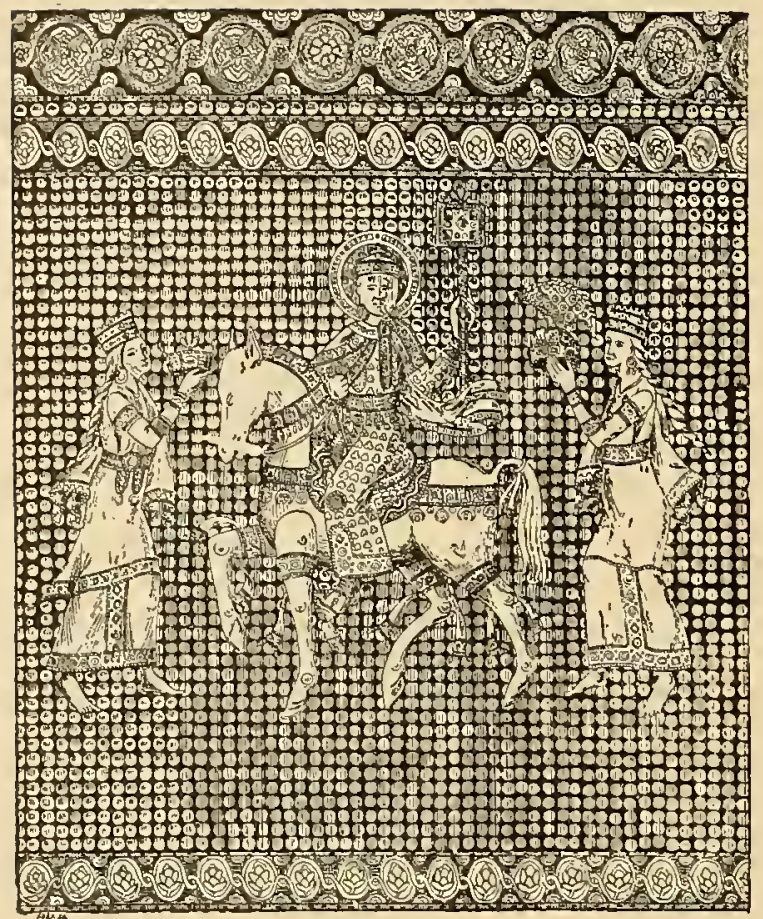

Byzantine embroidery from the tomb of Gunther, Bishop of Bamberg, preserved at Ratisbon.

rarely used, group figures done in mosaics. Interlacing circles, interlacing crosses in fret work, interlacing guilloches finally conspicuous.

\section{FABRICS.}

Fabrics precedent of paintings. Ancient Babylon renowned for its needlecraft. All other nations learned their art from Babylon, beginning with decoration of animal skins, embroidering, mat-plaiting and finally weaving.

We can go back to 3000 B.c. for a simple weaving produced by a simple interchange of warp and weft, but the complex manipulation of shuttles producing figures without embroidering or other extraneous aids was not known until 200 A.D., when it was, unquestionably, undertaken by Syrian weavers of the Eastern Roman Empire.

Wool. Egypt, mistress of advanced civilization, employed wool, hemp and flax.

CotTon. Greeks unacquainted with cotton until 333 B.C. The plant was indigenous to India, and not until the invasion of Alexander the Great did it become known to Europe.

Embroidery. In the earliest ages animal skins, before the age of weaving. frequently embroidered or decorated with stitches. Early Assyrians used embroidery. Egyptians and Greeks famous in the art. Ancient Babylon, Egypt and Chaldea understood the art thoroughly.

Beginning with Christian era an active commerce introduced Indian and Chinese stuffs, and the Italian, Teutonic and French craftsmen were quick to adopt Oriental methods. Art of embroidering became gen- erally understood. Appliqué work was also undertaken as well as.tapestry weaving. Byzantine Empire from 350 to 700 A.D. knew no limit to extravagance; decoration conspicuous in griffins, unicorns, lions, tigers, elephants, eagles, peacocks, large and small cir. cular bands, medallion shapes, golden apples, palms, shrubs and flowers. Textile design decorated with wheels or circular bands, lozenge patterns, squares, hexagons, octagons, stripes, beasts and birds.

Biblical and mythological subjects; fabrics largely used for hangings between colonnades as portières.

A favorite arrangement of pattern employed pairs of animals, or pairs of birds confronted and separated by the sacred tree of the Persians.

SILK. Although commonly woven in China, I 200 B.C., not woven in Europe until 500 A.D., when the Emperor Justinian secured through two Persian monks a number of silk cocoons and worms which they smuggled from China.

Six hundred A.D. Sicily, as well as Northern Egypt, was making silks.

Four hundred A.D. Egyptian and Roman tapestries well known. Roman silks, possibly Syrian or Persian manufacture, were sarcenets and taffetas, damasks, brocatelles, lampas and velvets, and the same period produced admirable tapestries and embroideries. Byzantium became the seat for European silk cultivation, and for five centuries, together with Corinth and Athens, was prolific in weave craft.

\section{FURNITURE.}

Tables, chairs and beds followed the Roman style, the legs often of turned wood. Ivory, carved and inlaid, and metal, much used; enanels and gold, bronze and inlaid woods employed. Chair of Dagobert (600) a fair example of the elaborateness of the period. It is of gilt-bronze and one of the earliest pieces.

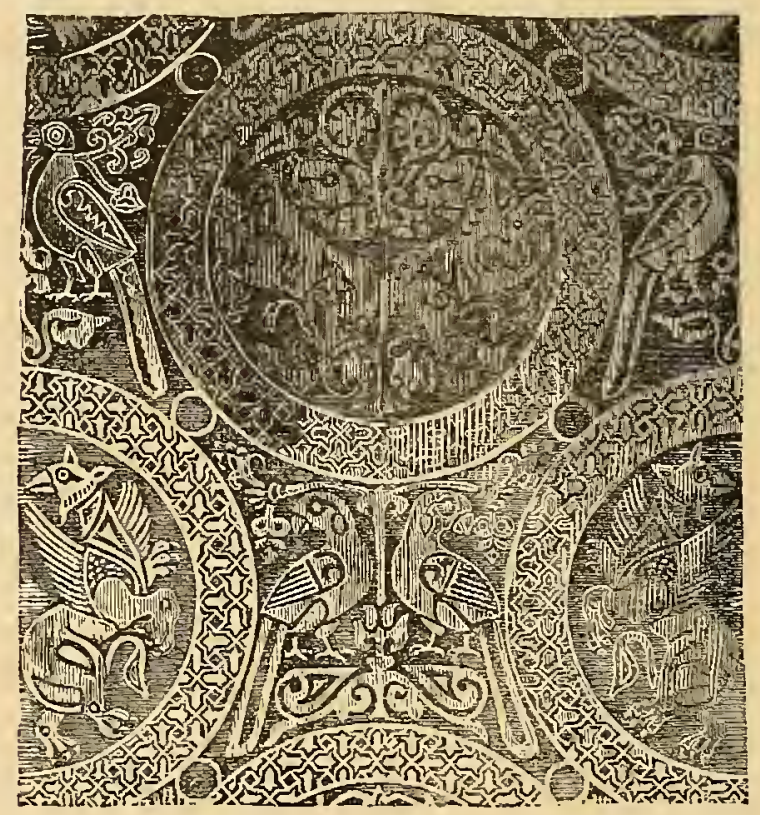

Saracenic. Eleventh Century Silk Damask, Showing Persian and Byzantine Influence. 


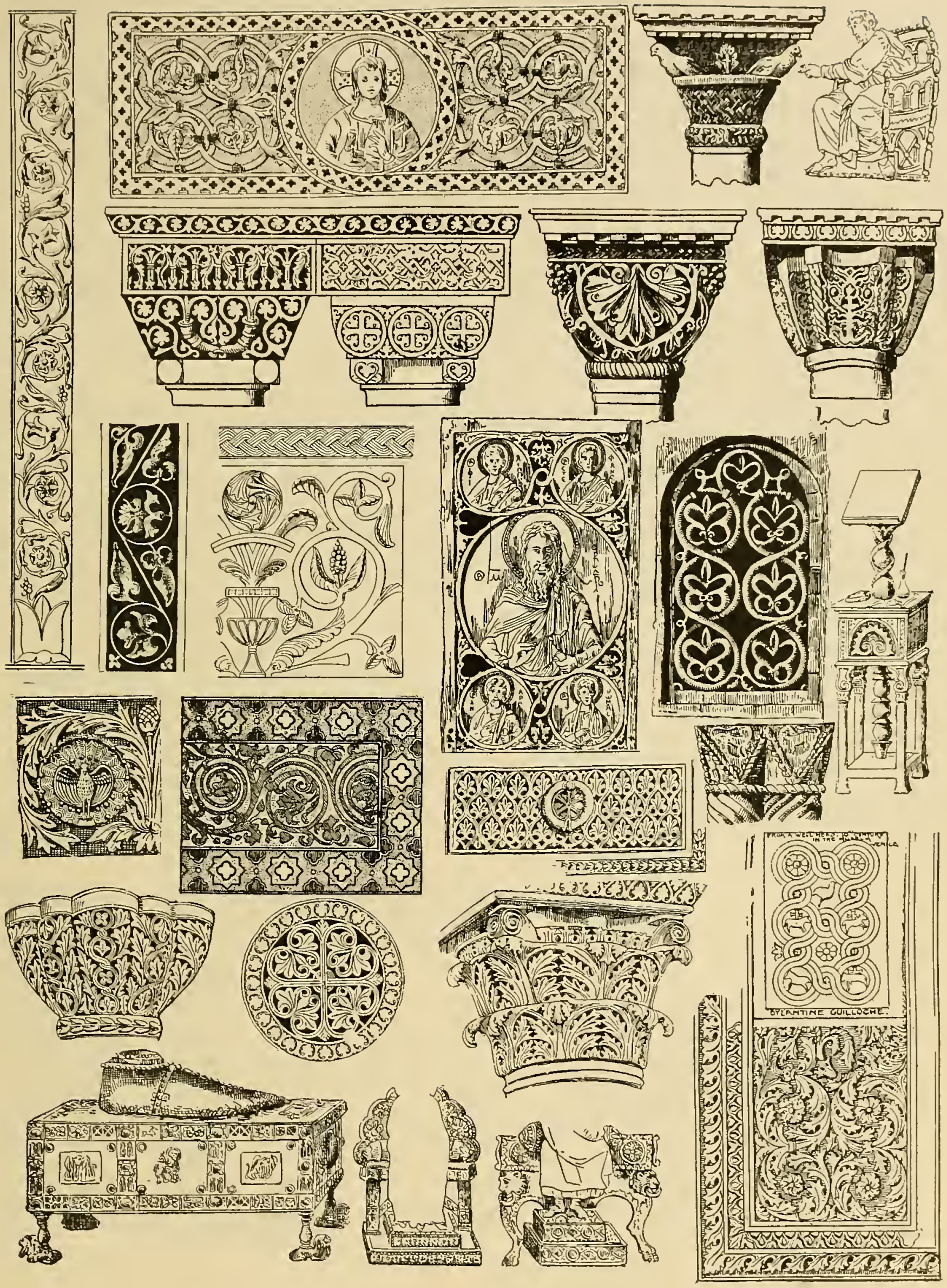

B Y Z A N T N E OR N A E N T.

Showing Oriental as well as Classic influence of Tenth Century. 

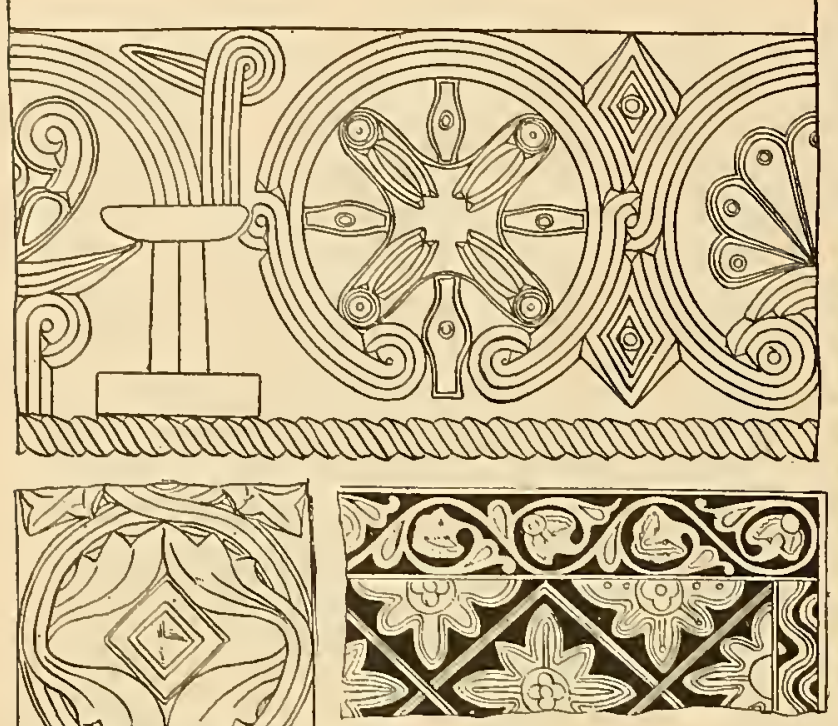

Yrive
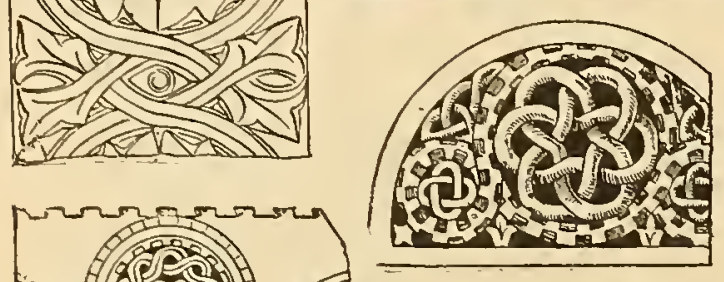

(5)

49 1960.

PA

t4.

F⿻.

4f.

$\left.7 t^{2}\right)$ Ning:

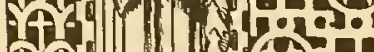

AP

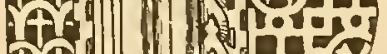

A9) If

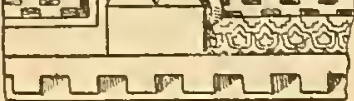
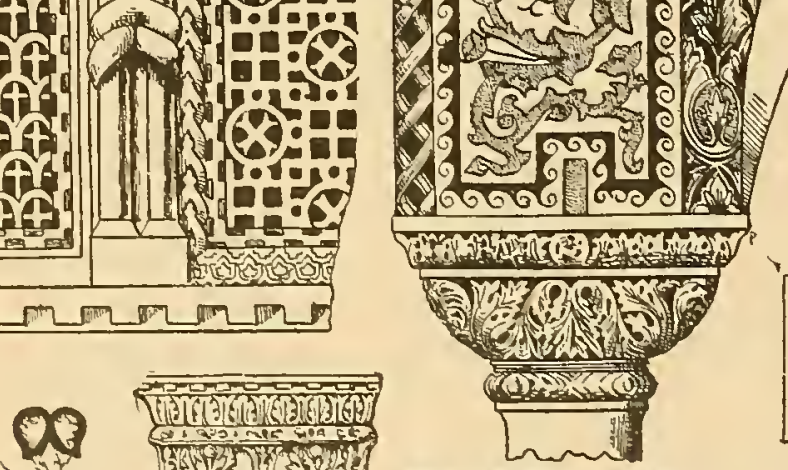

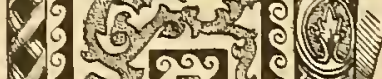

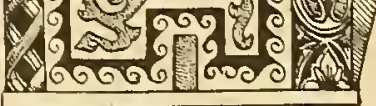

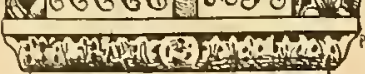

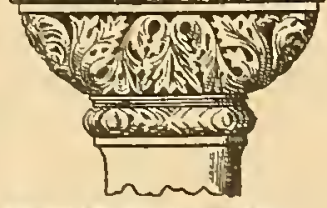

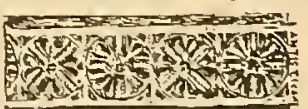

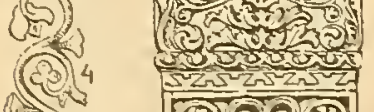

(1)

(1)

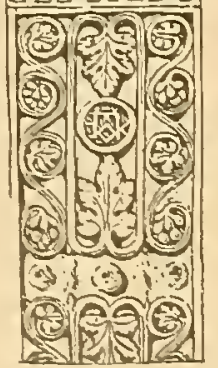

7.7.

(2).

1.6.

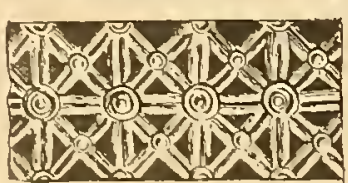

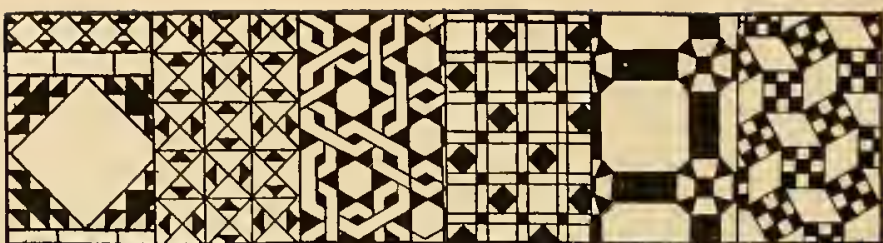

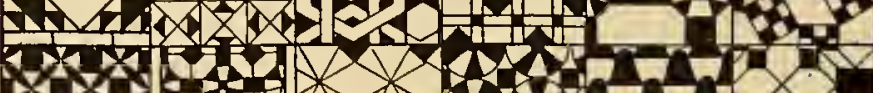
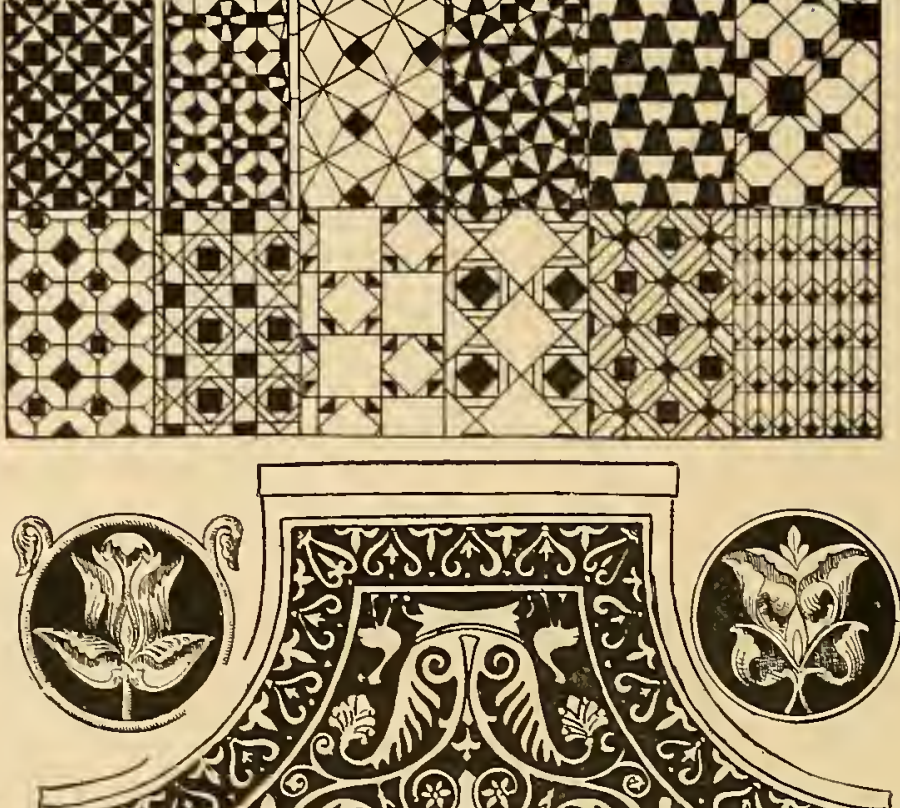

5.5.

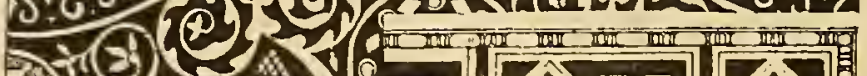

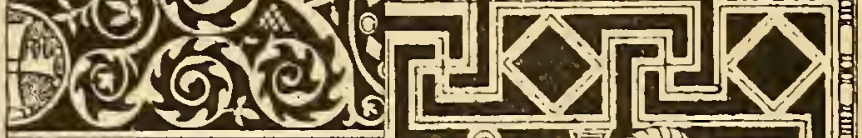

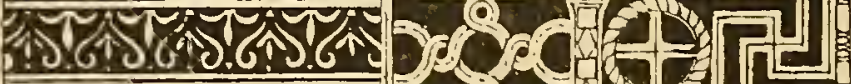
(4)

2.x (r)

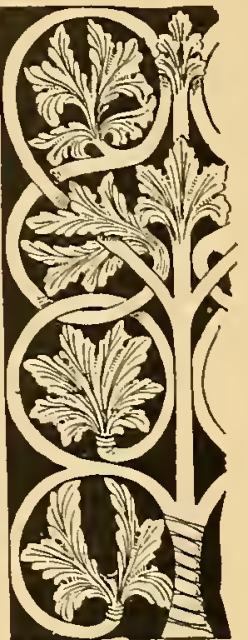

1.1.
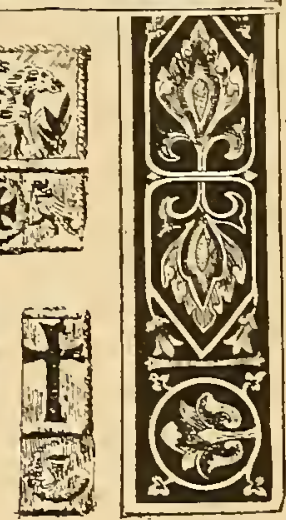


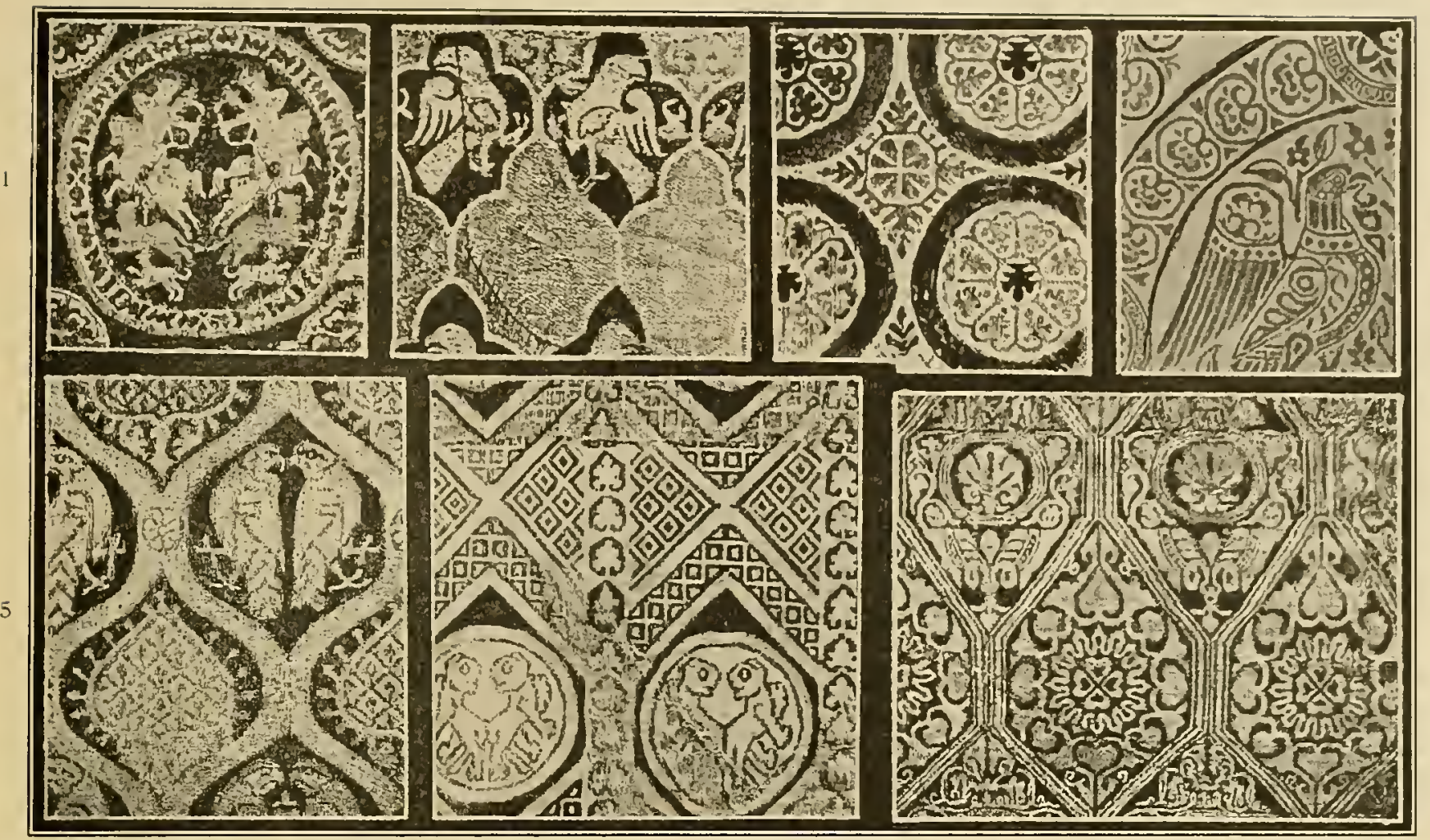

No. I. Perso-Byzantine, 700 A.D. No. 2. Romanesque, I roo A.D., style of pattern evolved by system of intersecting circles; popular at the beginning of the Gothic period. No. 3. French or German Romanesque, I100 A.D. No. 4. Section of style showing circles joined together by smaller circles; a system of design in vogue 1000 A.D. No. 5. French, Saracenic infuence, iroo A.D. No. 6. French-Romanesque, i100 A.D. No. 7. Hispano-Saracenic, I200 A.D.

\section{EARLY CHRISTIAN-ROMANESQUE}

I

N THE study of Early Christian, Byzantine and Romanesque art one must never lose sight of the fact that at the beginning and the end of these periads the Orient wielded an influence. In 328, while preparing for battle, Constantine, Emperor of Rome, saw a cross in the sky, and accepting it as an omen he embraced the Christian religion. The capital of his new Empire was Byzantium, which name he changed to Constantinople, and the Byzantine Empire at the outstart covered much of Asia Minor, Arabia, Egypt, North Africa and the country now Bulgaria and Greece. Georgia, that portion of the Caucasus frequently called Iberia, appears first in authentic history in the time of Alexander the Great, but in the Fourth Century it was part of the Byzantine Empire.

From $55^{\circ}$ to 800 Byzantine art was gorgeous in Oriental splendor. The Saracens carried Islam art throughout Persia, Palestine, Syria and Egypt in the Seventh Century, over Africa and Spain in the Eighth Century, and Lower Italy in the Ninth Century.

To arrive at a definite understanding of the char- acter of design employed during the early Christian and Romanesque periods we must consider two essentials, Origin and Use.

In the Romanesque period there was no direct relationship between the designs of mosaic, tile, stained glass, furniture, carving, rugs, tapestries, silks and other fabrics.

Tiles had been made for centuries and patterns had been repeated and re-repeated. Colored glass was made by the Egyptians 2000 years B.C., but the earliest stained-glass windows are recorded as 525 A.D. None, however, are known to be still in existence made prior to IIO8. Early examples found in Romanesque windows of this date have little medallions with primitive figures and ornaments, the patterns reflecting the spirit of design which had been done in textiles four and five hundred years previously.

In mechanical weaving, a repeated pattern must have fixed dimensions, a restriction not affecting embroidering, tapestry making or mosaic work.

We have already seen that wools and linens, tapestries and cmbroideries were employed back in the 

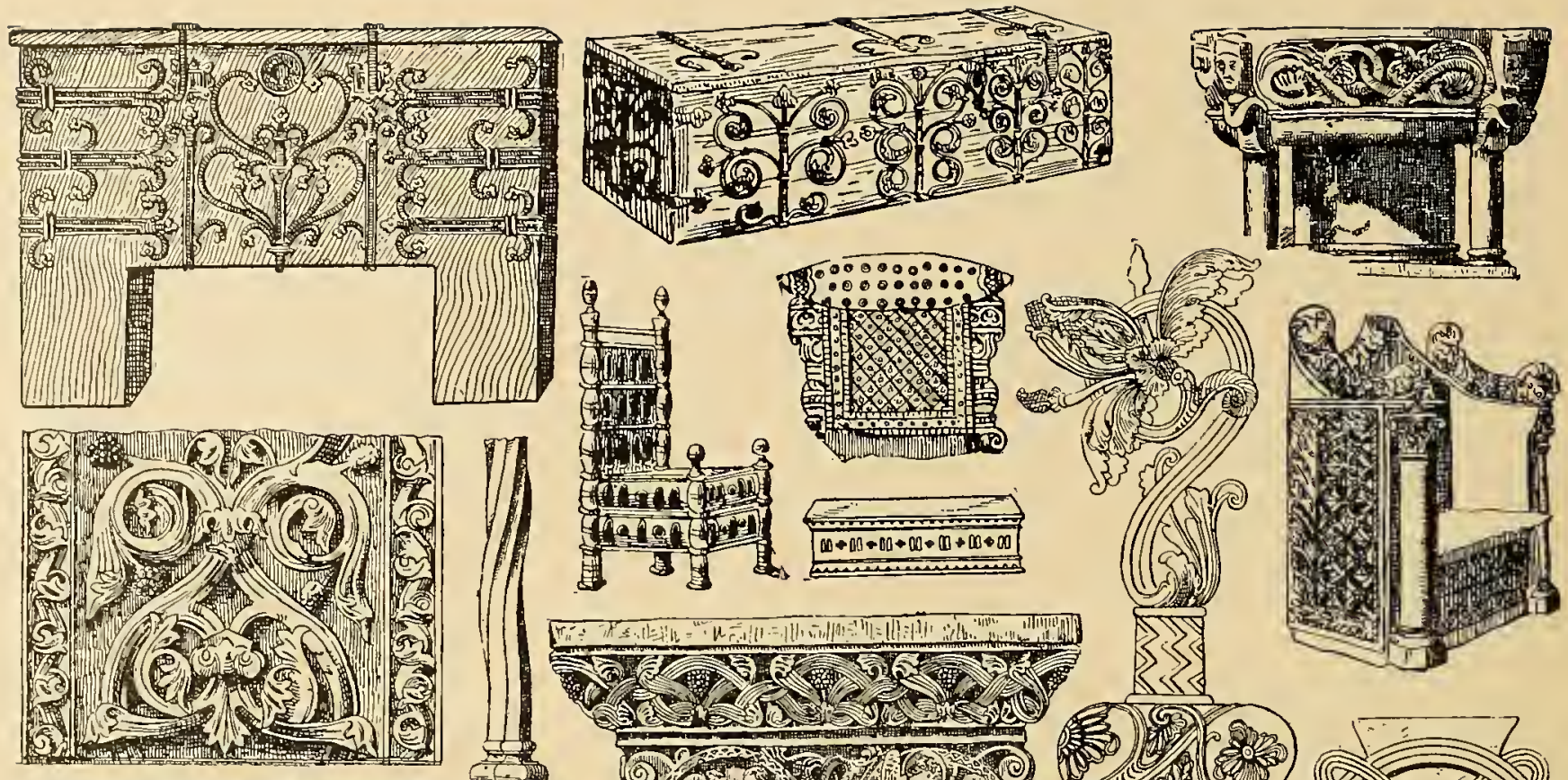

i) 30
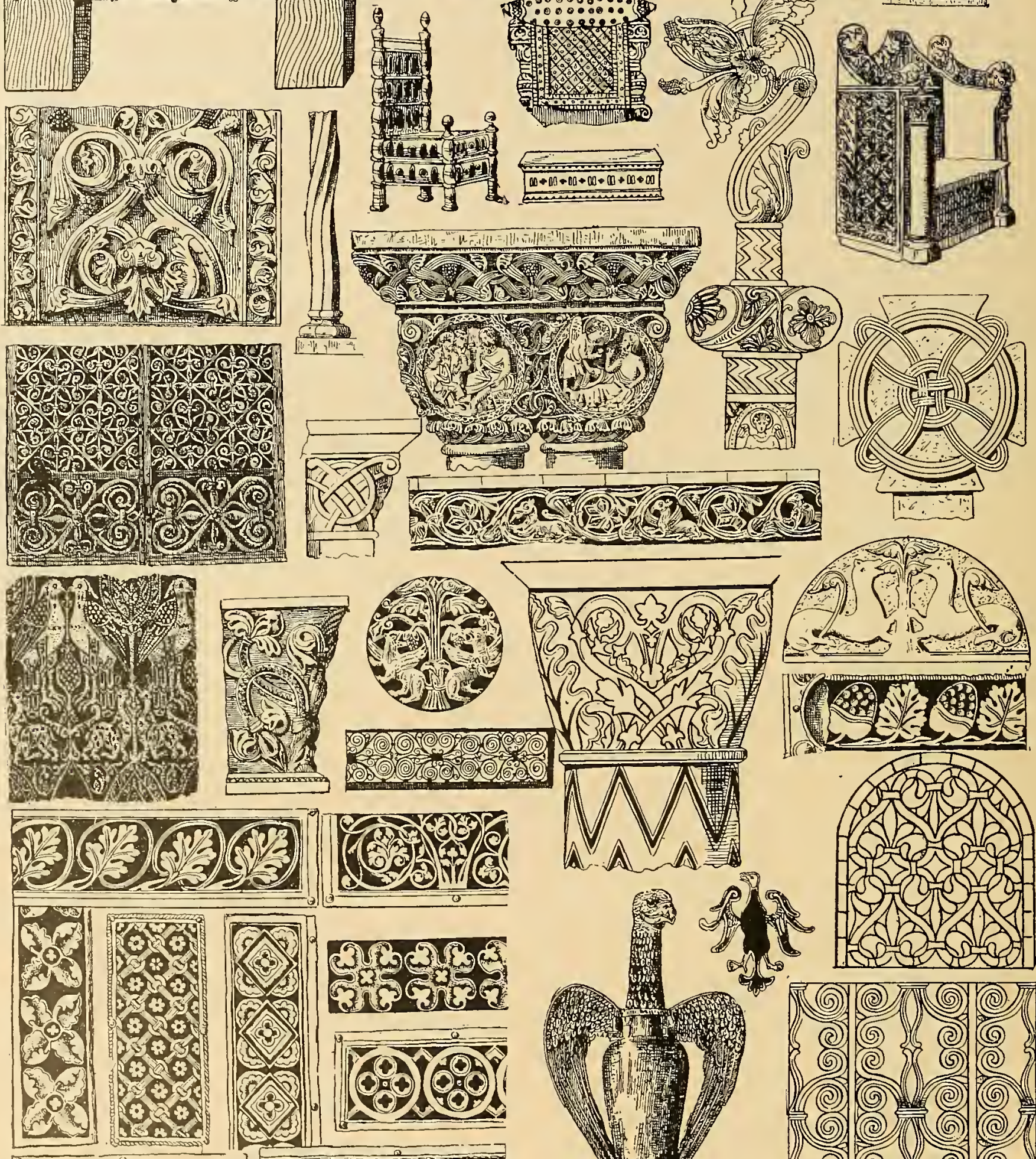

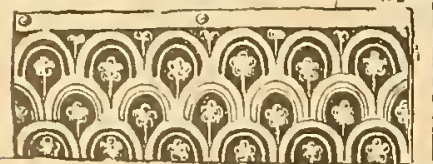
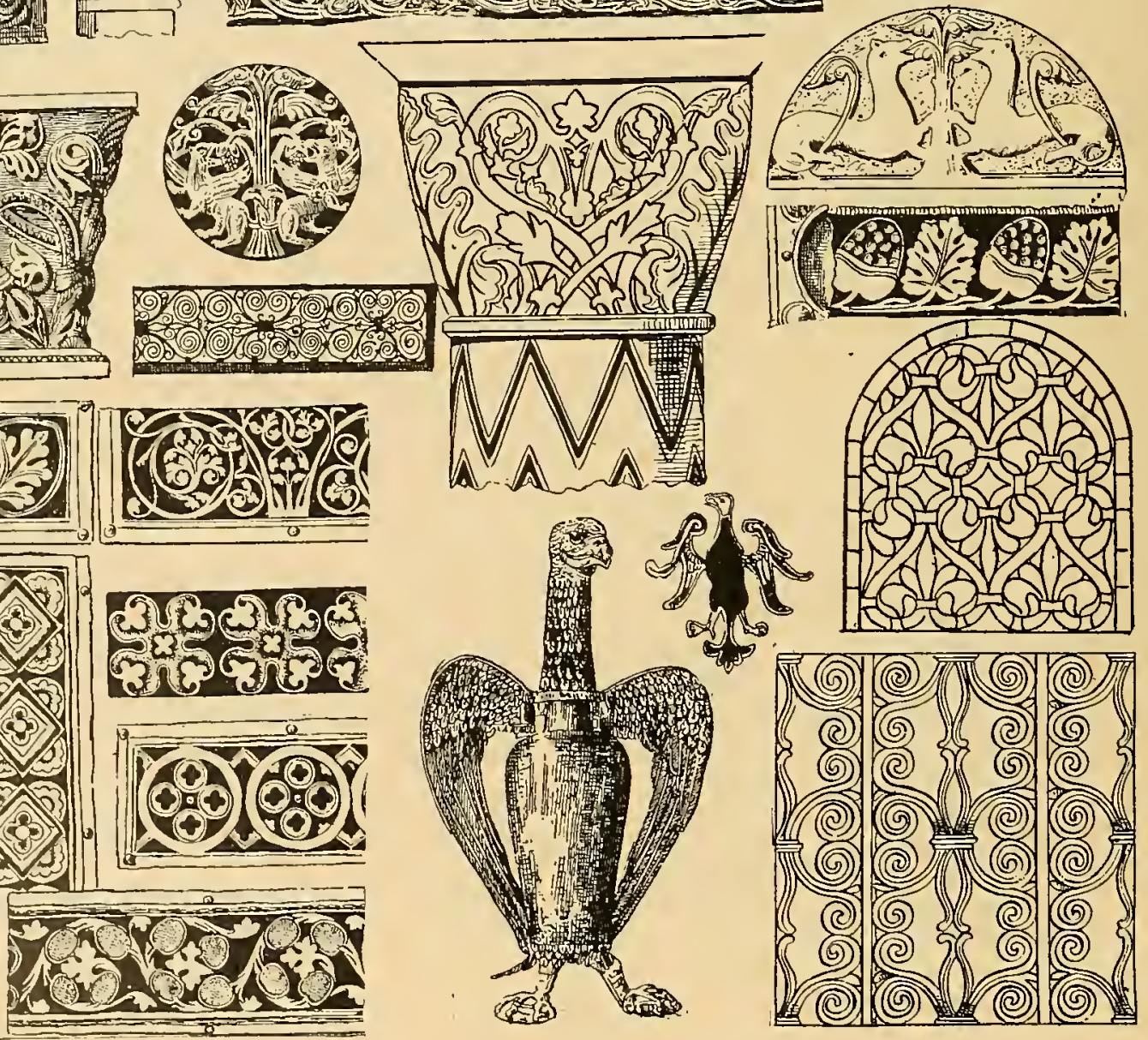

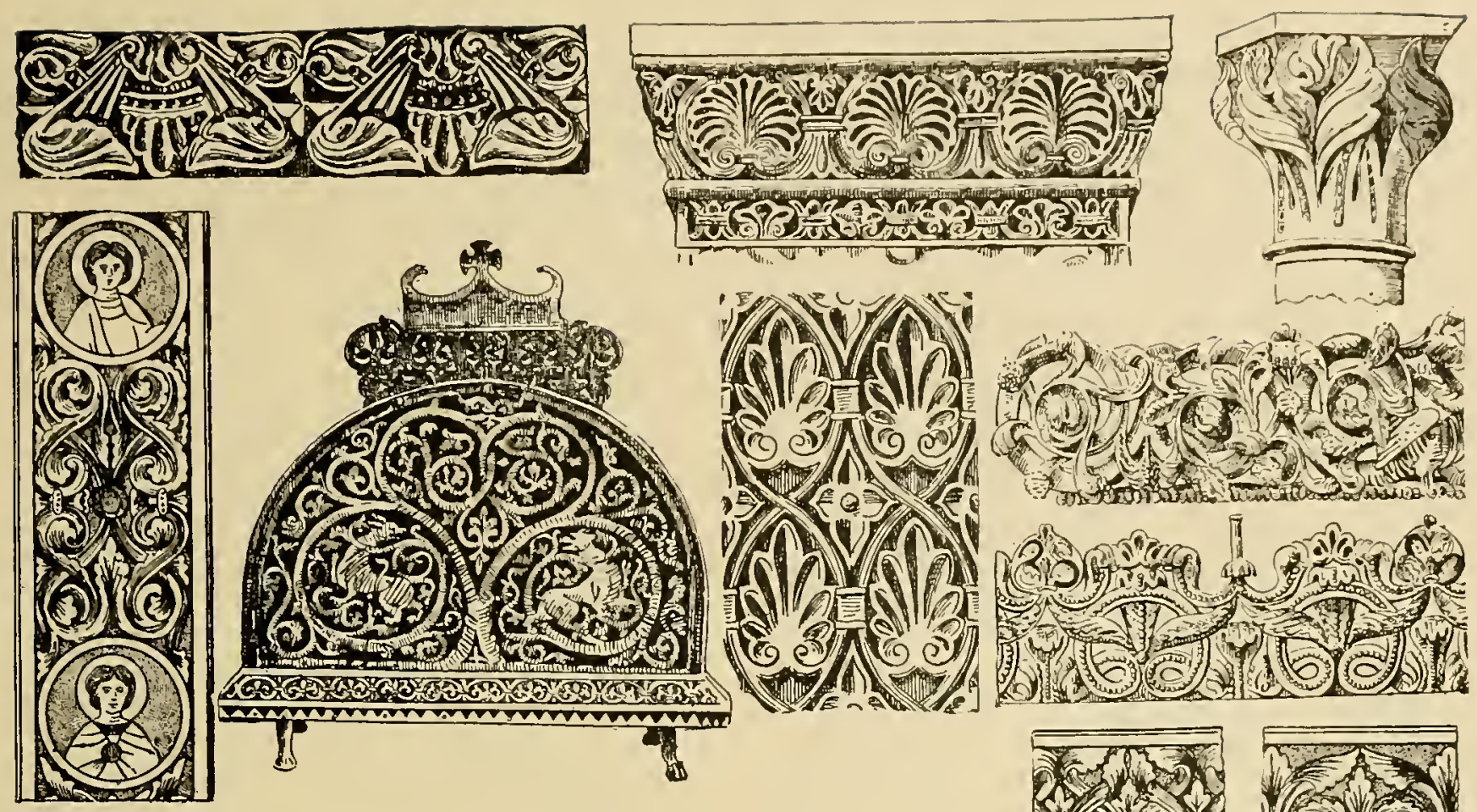

1 - Ma A I

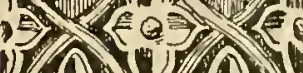

(1) 1 (1) (6)
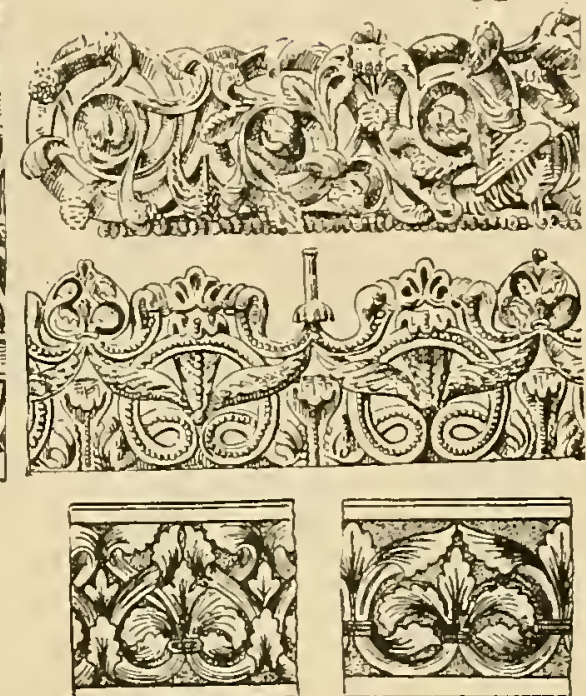

GERMAN ROMANESQUE. I000-I I0o.
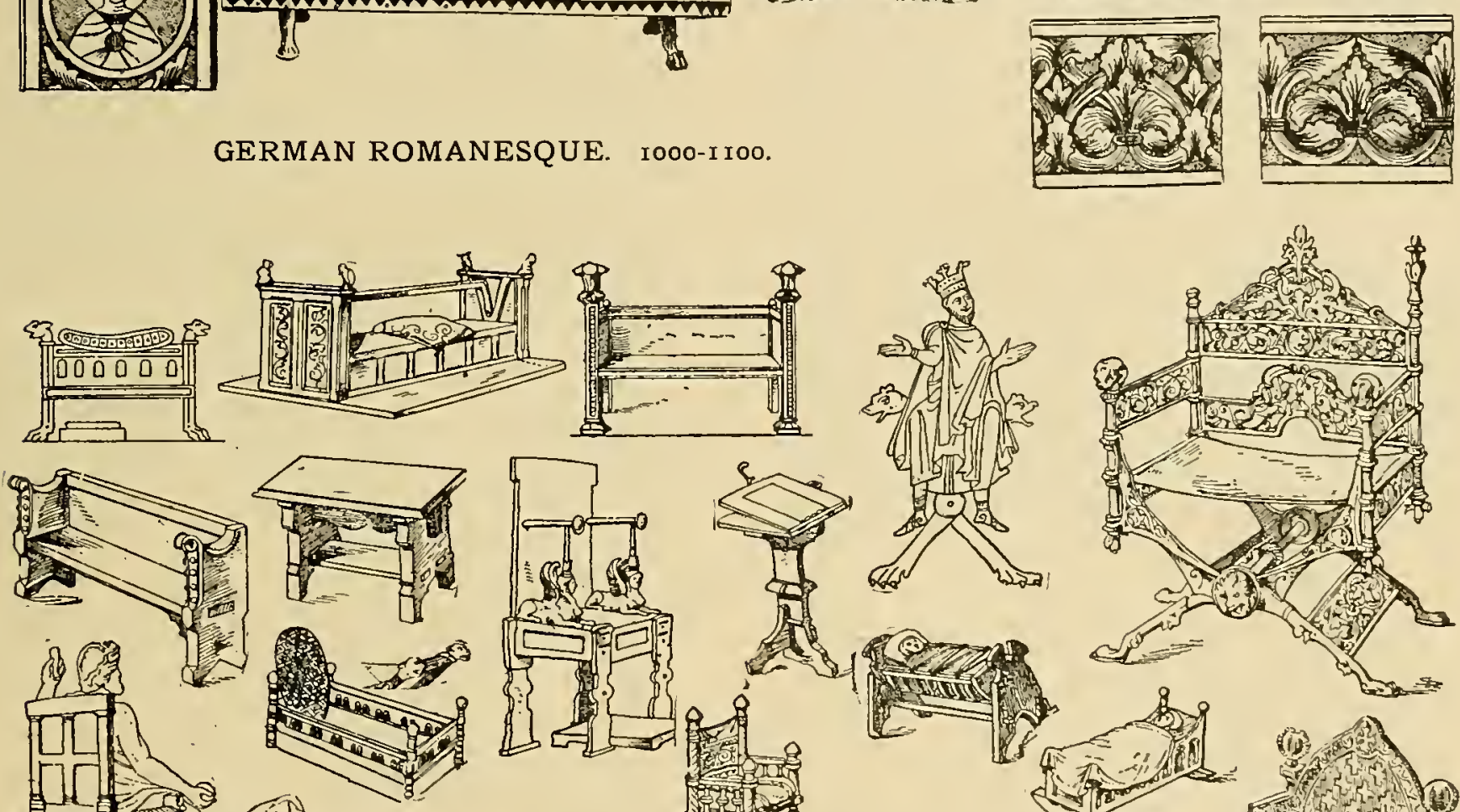

of
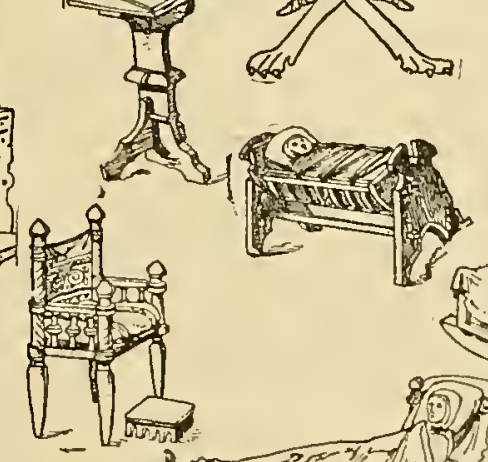

些
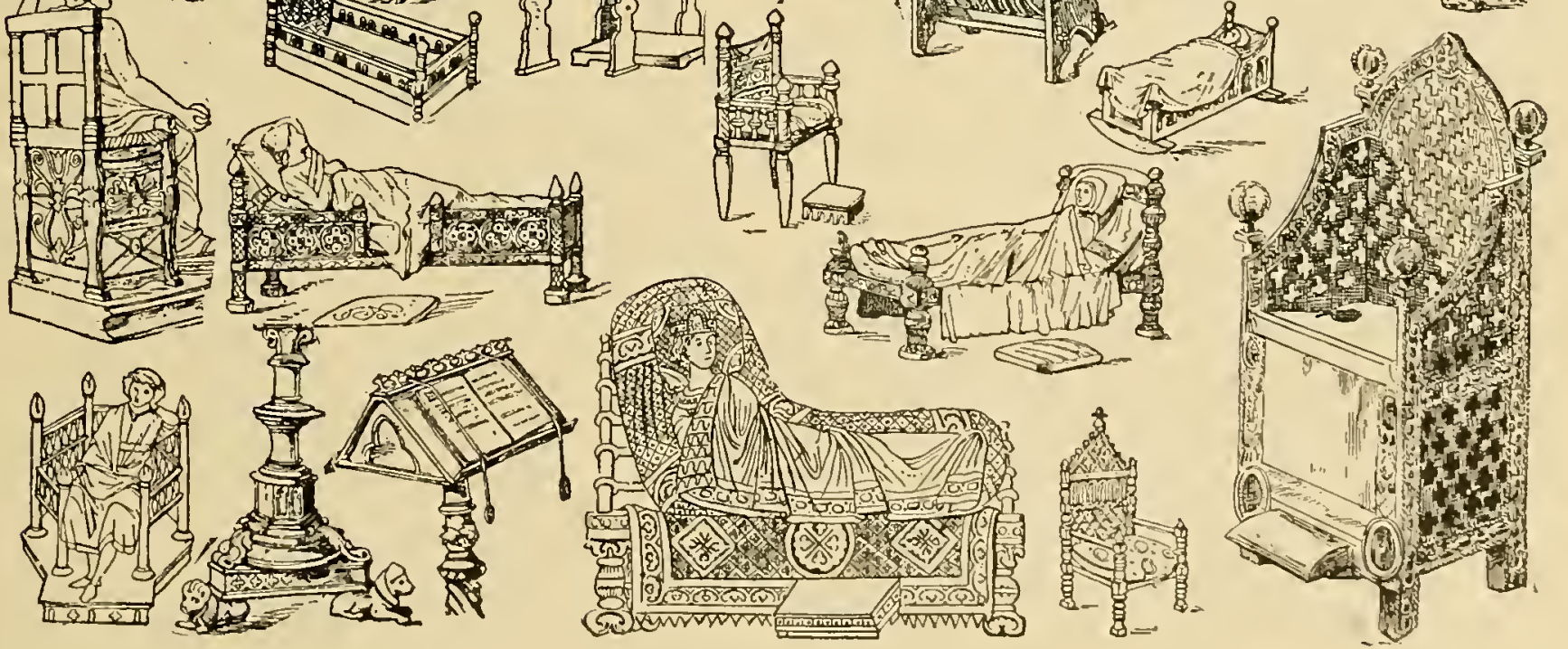

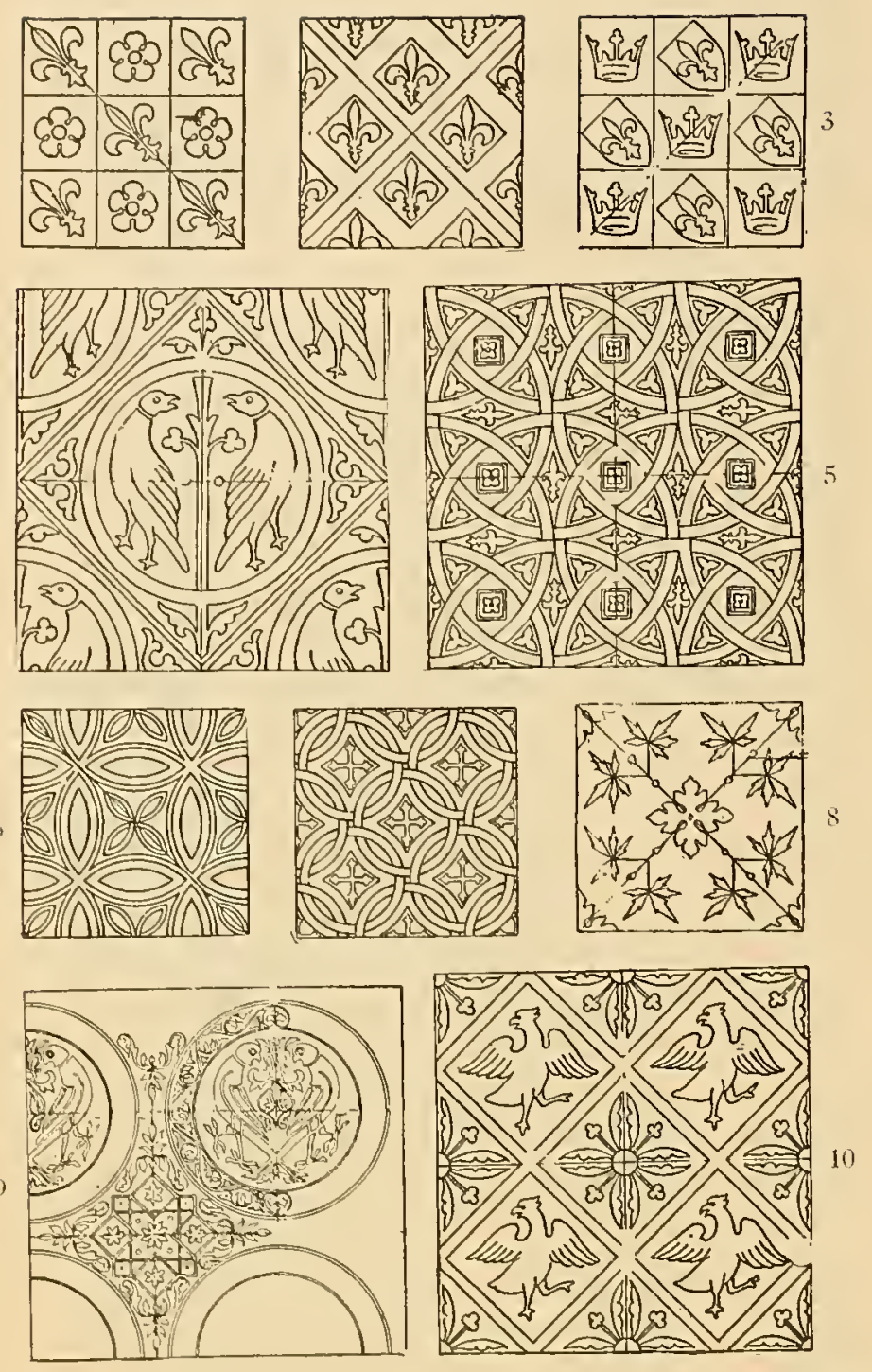

ROMANESQUE. $900-1100$.
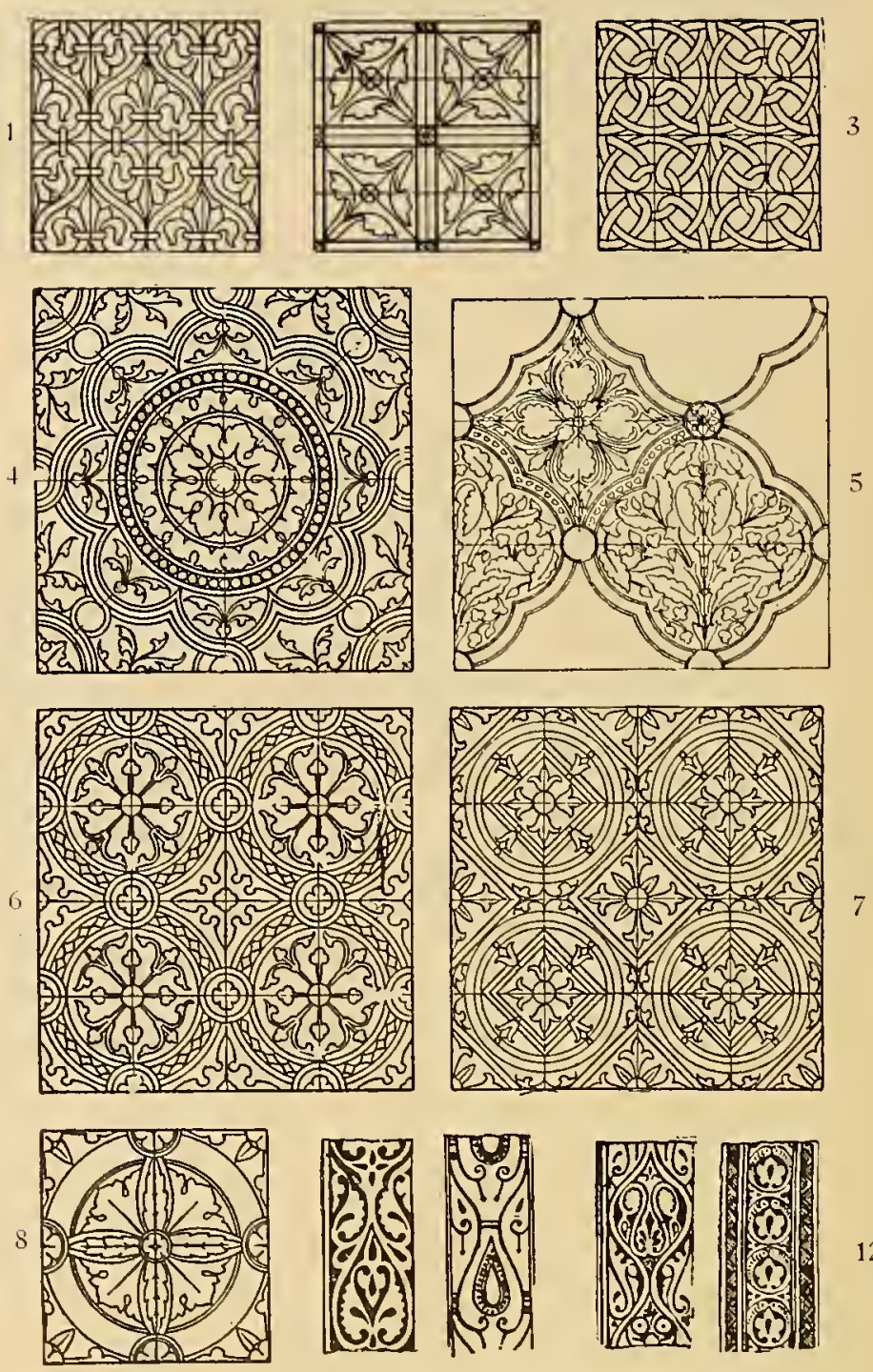

12 lllustrations I, 2, 3 are doubtless tile illustrations, following the simple forms used in mechanical textile weaving 200 A.D. The motifs here used are, however, heraldic. The heraldic forms were adopted during the period of the First Crusades, I0g6 (the seven Christian Crusades ending I270).

Illustration 4 follows the textile forms of the early Byzantine, but the details filled in suggest the Saracenic.

Illustrations 5, 6, 7 follow the interlacement system, which beginning with the Roman was revived with the Romanesque and developed with the Gothic.

Illustration 9, like illustration 4, is of Byzantine origin with Romanesque development 1000. earliest ages. Simple mechanical weaving was known in Egypt 3000 R.C., but the complex manipulation of shuttles whereby figures were produced without embroidering was not practised until $200 \mathrm{~A}$. D.

THE DEVELOPMENT OF MECHANICAL TEXTILE DES1GN.

THE development of design was necessarily slow; for many years repeat patterns were of the simplest character.
Illnstrations $1,2,3,4$ and 7 Romanesque, direct Roman origin.

Illustration 5 shows the framing which developed just prior to the Gothic, IIoO.

Illustrations 6 and 8 are Romanesque, showing connecting circles, 800 .

Illustrations 9, Io, II represent the Arabian or Saracenic development of the ogival form of design conspicuous in Lower Italy, 900-1000.

The "ogival" form relates to the form of design developed from 800 to $1100 \mathrm{~A}$. D., where joining circles were brought to acute angles at points of junctures, forming ovals or ogival shapes.
B.C. Design consisted (I) of repeated lines, spots, bands or stripes; (2) crossed lines or stripes; (3) by changing colors of lines, checks and trellises were produced; (4) by changing proportions, plaids were produced; $(5)$ then came rectangular patterns and diamond shapes.

IOO A.D. Development of circular or square frame.

200-600 A.D. Squares or circles filled possibly with floral detail suggested by the Persian and Syrian weavers. The same sort of thing was repeated 
again five hundred or six hundred years afterwards in simple stained-glass effects.

400-600 A.D. Broken circles or circles joining the upper and lower segments and spread out to form bands.

600-1 100 A.D. The use of circles continued, but they were now linked togetler, large circles being joined together by smaller circles at the points of contact. The designs in and out of these circles lecame more ornamental, developing by the end of the Romanesque period great elaboration, and hexagons (Saracenic) arranged with geometrical nicety and elaborated in design.

$U_{p}$ to and including 1100 a common type of design was the persistency of balanced groupings of birds, animals or men, facing or back to back.

From 800 to 1100 saw the development of the ogival form or that form of design where the joining circles were brought to acute angles at points of juncture forming ovals or ugival shapes. The ogival form continued, developing greater and greater elaboration through the Gothic periorl.

\section{E V E L O P M E N T O F T E X T I L E W W A A V I N G}

3000 B.C. Weaving was understood in Egypt. Possibly earlier in Babylonia. Silk weaving introduced from China, where it was practised at a remote period.

200 A.D. Complicated mechanical weaving done by Syrian weavers in the Eastern Roman Empire.

300 A.D. Silks well known to Romans. Persian as well as Syrian manufacture. Egyptian and Roman tapestries in use.

500 A.D. First production of European ornamental silks-sarcenet and taffeta ; Roman and Byzantine. Constantinople imported looms for weaving silks in the Persian and Indian styles. Introduced sericulture from Chinese cocoons smuggled into Constantinople by Persian monks, and became a seat for European silk cultivation and manufacture. Produced taffetas, damasks, brocatelles, lampas, velvets, embroideries, tapestries, and for five centuries Constantinople, Corinth, Thebes and Athens were prolific in weave craft.

600 A.D. Northern Egypt made silken fabrics.

700 A.D. Spain in latter part of 700 made progress in silk weaving. Syrian silk merchants opened warerooms in Paris.

Soo A.D. Daughters of Charlemagne, France, taught to weave silk.

800 A.D. Abdul-Raman II introduced the use of "tiraz" (silk stuff embroidered).

900 A.D. Sicily and Spain alike showed Saracenic design treatments in fine silks.

(Continued on page 39.)

\section{EARLYCHRISTIAN-BYZANTINE-ROMANESQUE}

THE accompanying chart shows better than anything else the related periods of design which followed the Byzantine and developed finally into the Gothic.

Early Christian naturally expressed the Byzantine or first Christian expression in art where that art symholized the Christian faitb. As time progressed the Romanesque period developed, which was a period of Roman revival.

BYZANTINE.

328-500 Roman Christian Period. Constantine, Em Cbristians and the Emof Cbristians and the Empire constituting the Eastern pire, $55^{\circ}$.

550-800. ORIENTAL PERIOD. This period was largely affected by the OriByzantine.

850-1005. CLASSIC PERIOD. Reflecting the Roman spirit, which had already affected the Italian, German and Frencb arts. Christian symbolism did not again become

[35]

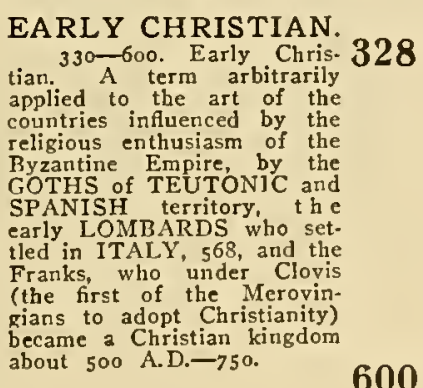

about 500 A.D. $\rightarrow 750$. $\quad 600$

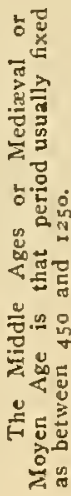

700 ROMANESQUE. 7 II 71. THE GOTH kingdom of Spain was destroyed by the Moors and from this developed a Spanisli art which was largely Moorish affected by the ROM.INESOUE

774 In 774 Charlemagne destroyed the Lombardic Kingdon and became Governor of Italy. The LOMBARDS had entered Italy from Scan. dinavian territory and founded powerful nation 568 A.D. They con. quered almost all of the Byzantine Empire, except Venice, Ravenna, Naples and Rome, and in later years their ROMANESQUंE art be. Naples and Rome, and in later years their R.A. came more strongly BYZANTE and ROMANESOUE character.

In the Southern sections of their territory, especially Sicily, there 9 I developed by the invasion of the Mohanmedans a SARACENC art NORMAN was the ROMANESQUE of the Normans who 911 and Brittany. In 1066 conquered England where NORMAN ROMAN.

1066 ESQUE was often called ENGLISH ROMANESQUE.

1100 End of Romanesque Period and beginning of Gothic. 

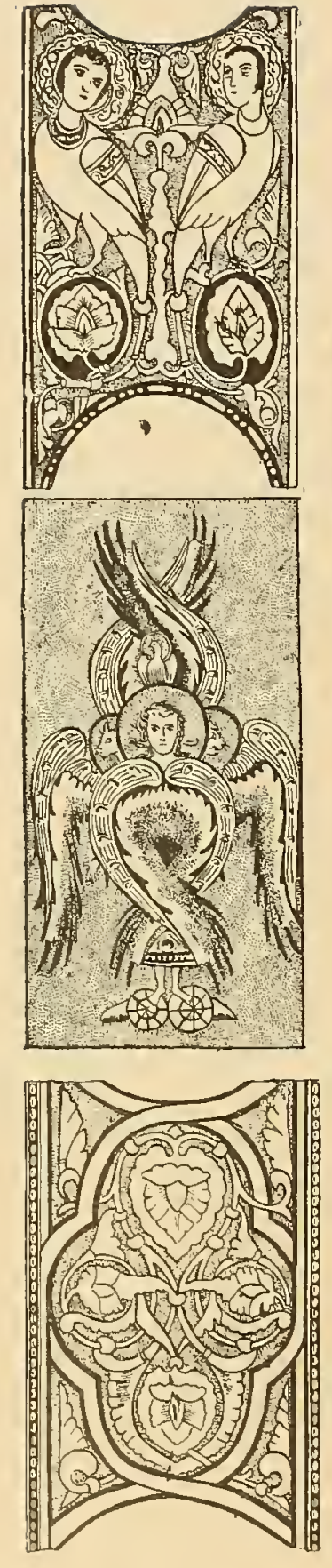

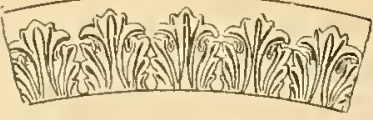

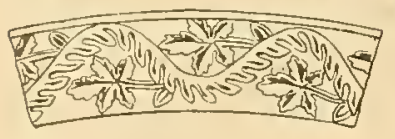

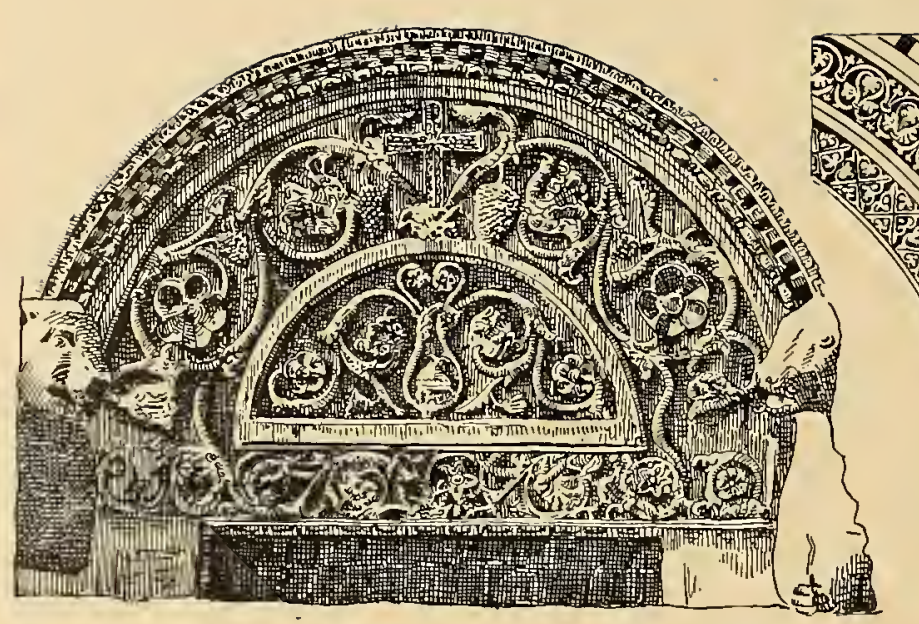
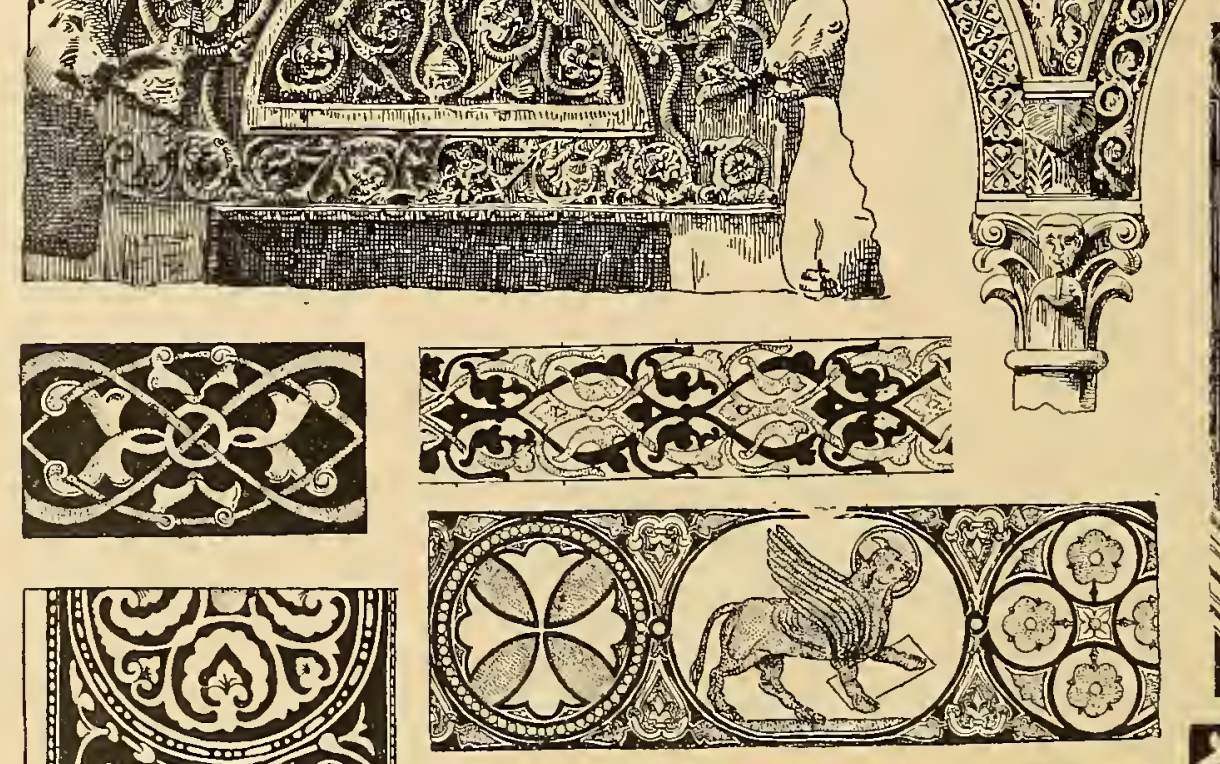

$1 \frac{2}{2}$

(1.) A) $\rightarrow$ (n) Th -
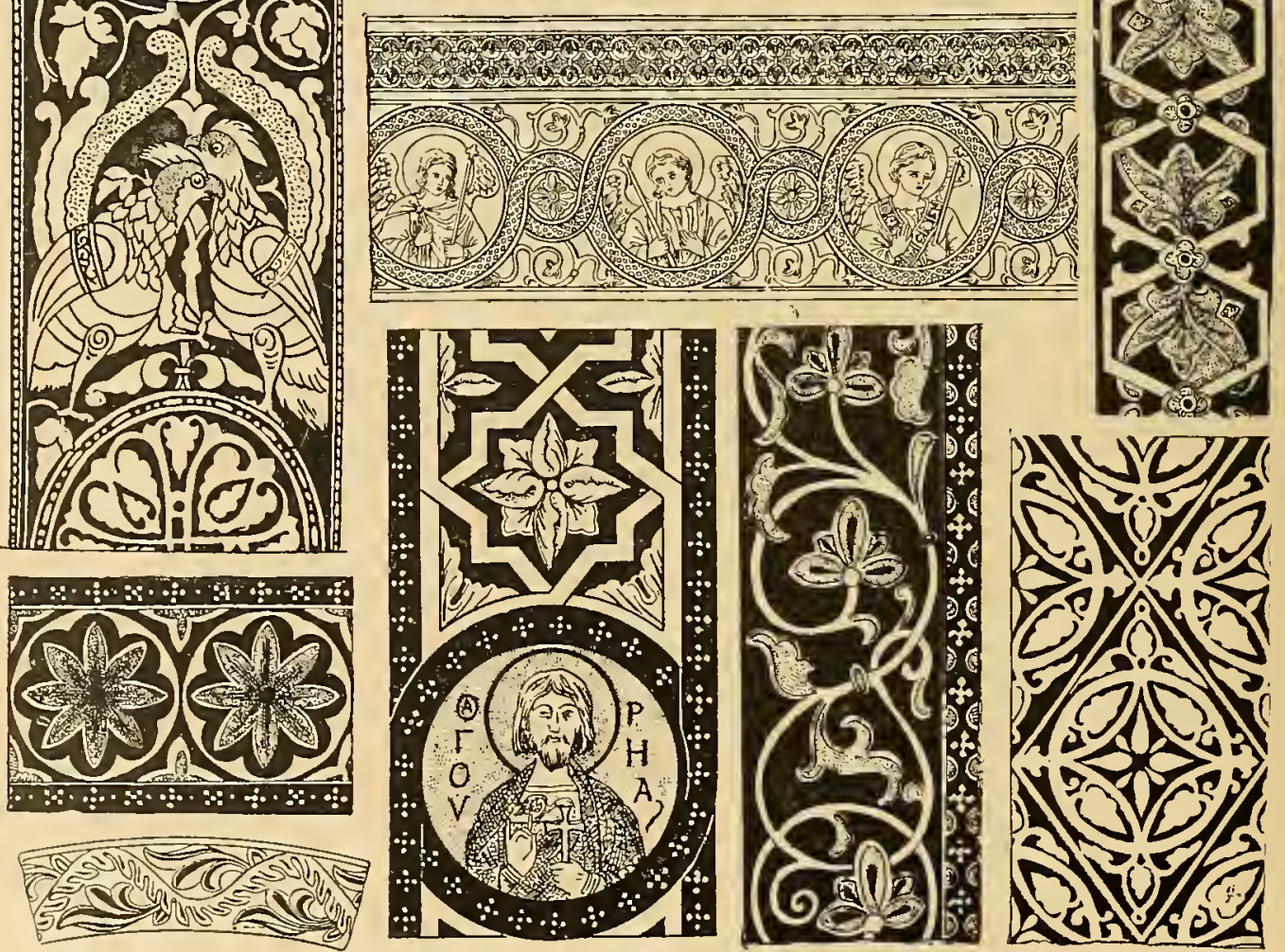

LATE ROMANESQUE OF LOWER ITALY.

Showing Saracenic Influence. 

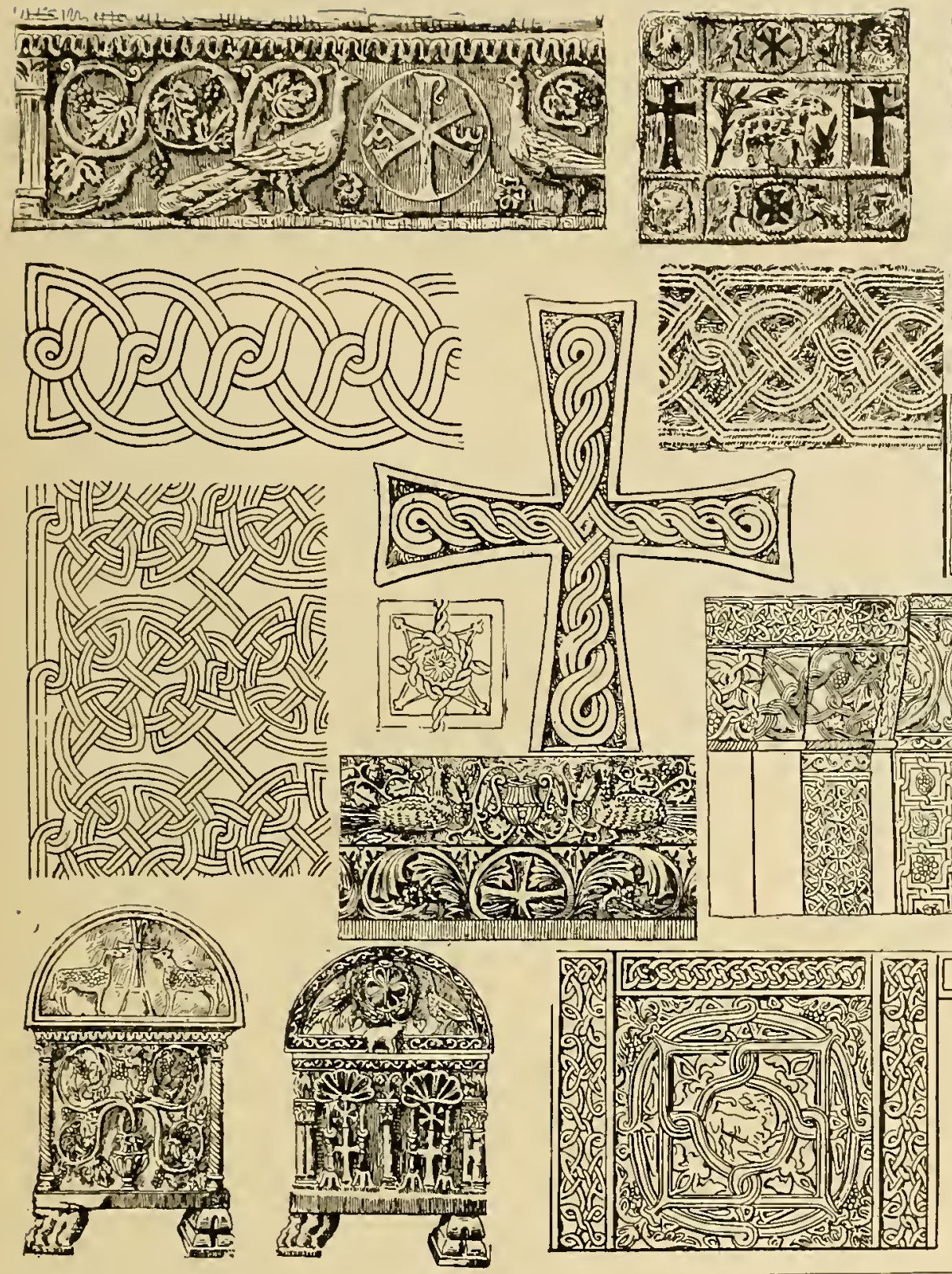

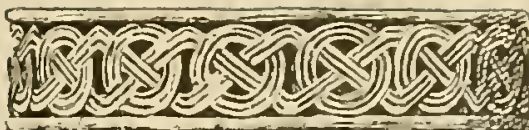

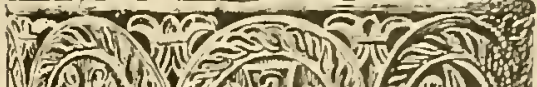
(-)

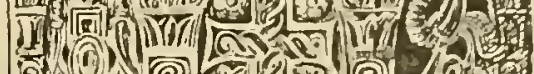

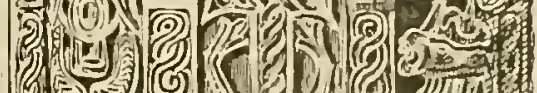

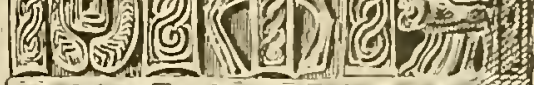

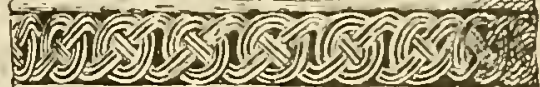
(3)
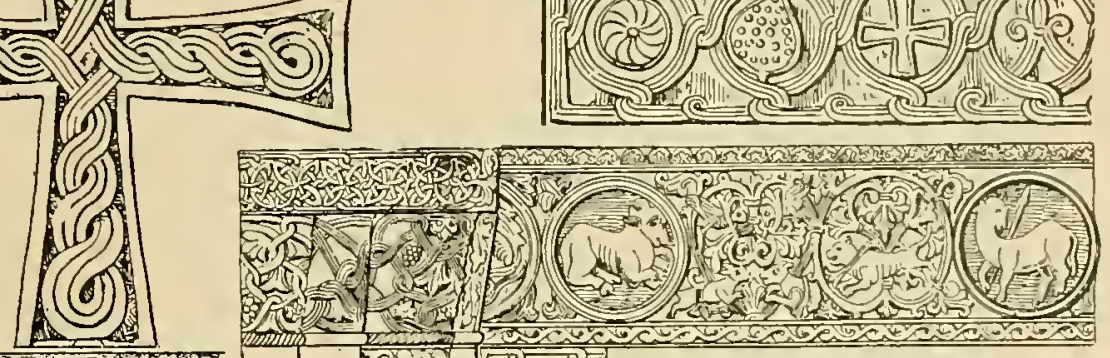

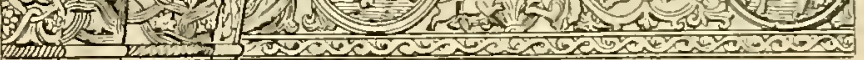

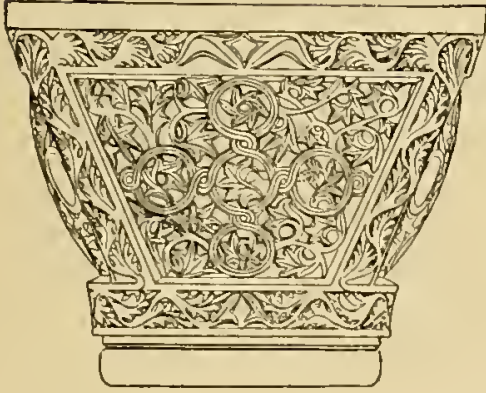

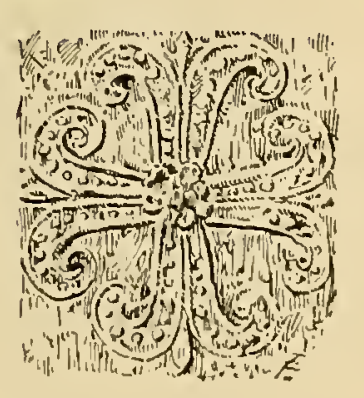
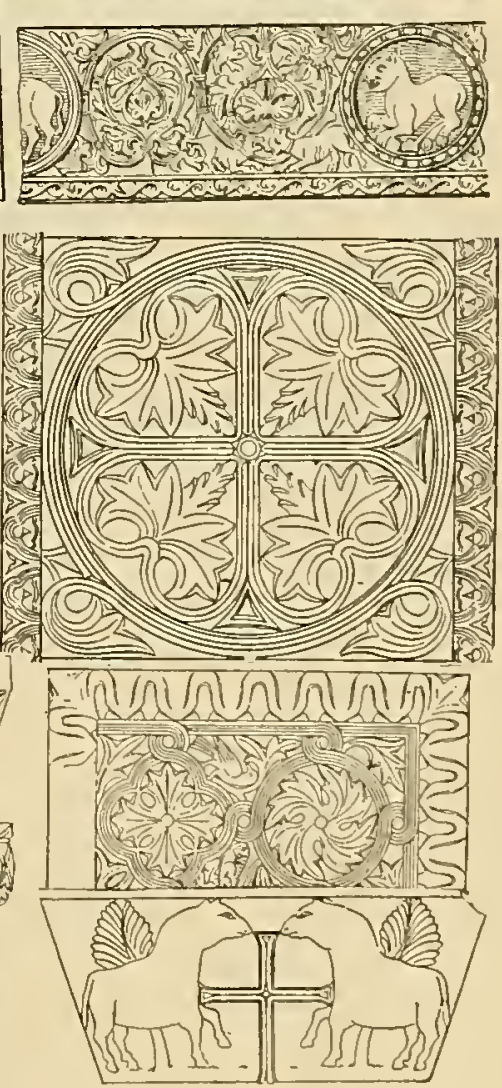

EARLY CHRISTIAN. 330-600. 

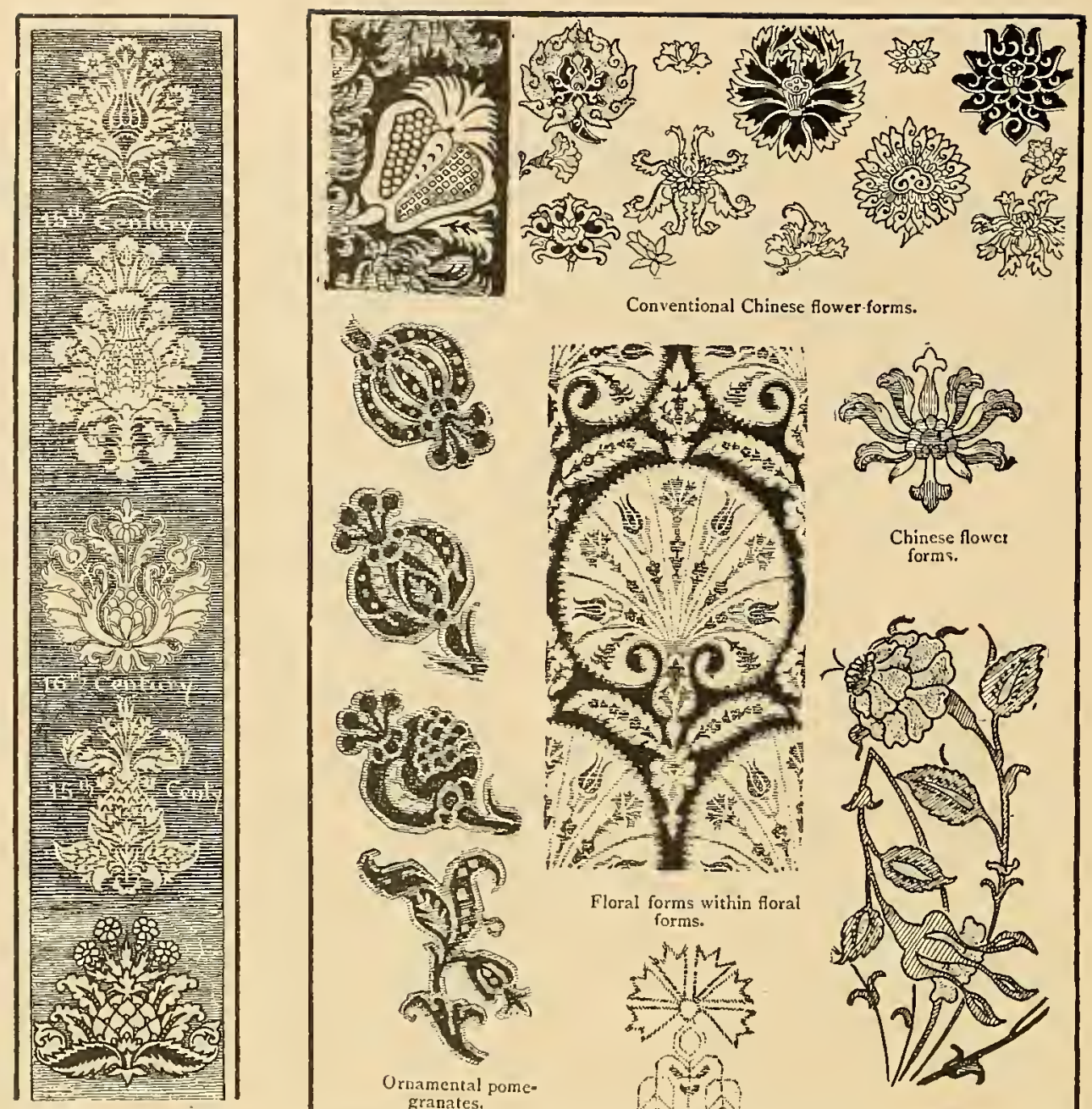

Conventional Chinese flower forms.
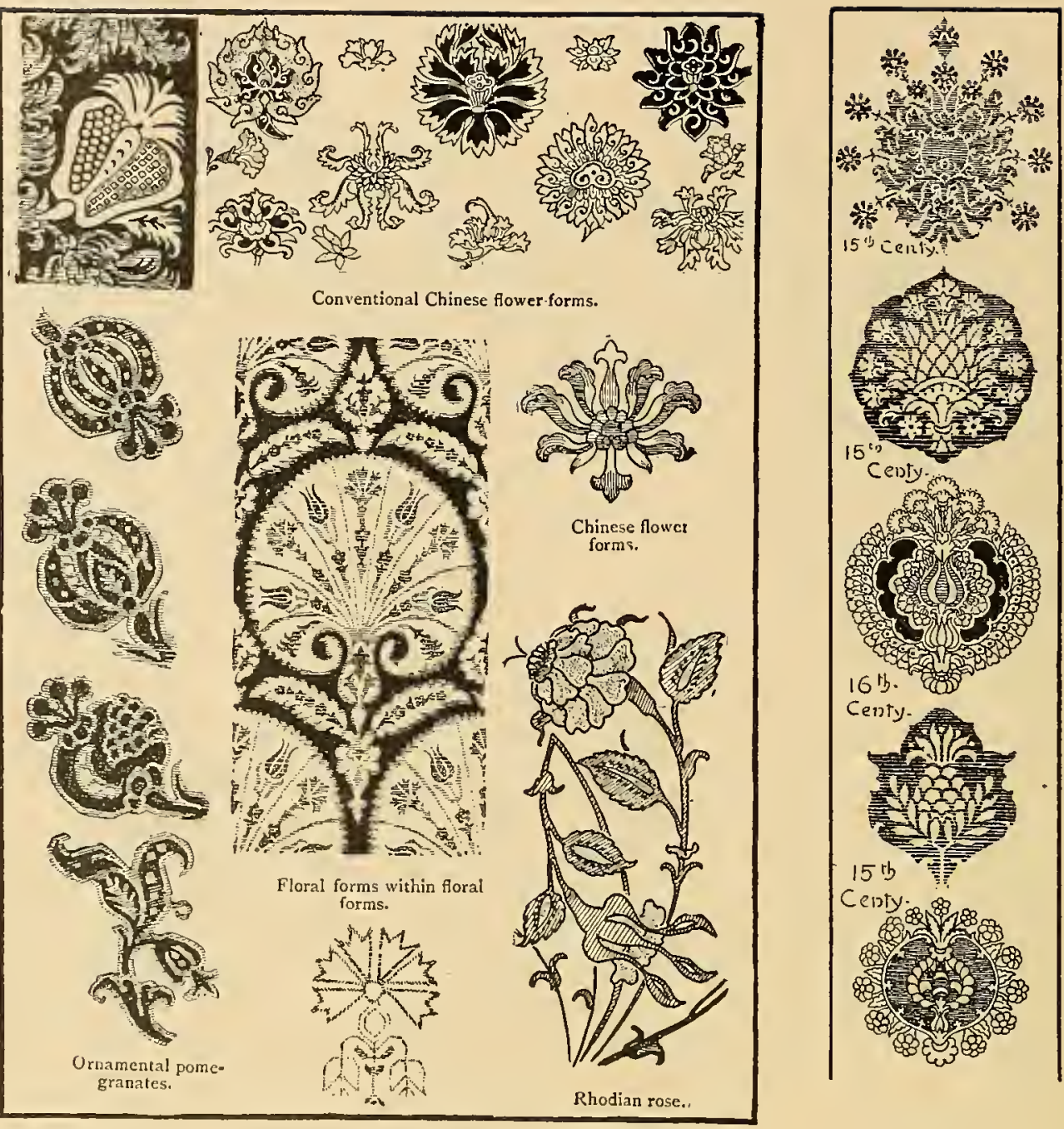

Persian Characteristics.

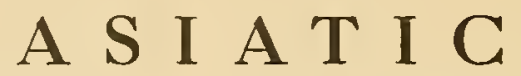

ORIENTAL-ISLAM-MOHAMMEDAN.-Arabian 57I A.D. Saracenic 571. Moorish 711. Alhambraic I200. Turkish 1096. Ottoman 1360. Persian 641.

ORIENTAL_-ISLAM ORNAMENT.

The term Oriental relates to the Far East or Asia.

The term IsLAm relates to the religion which began with the birth of Mohammed, 571 A.D.

ARABIAN.

Native of Arabia. Arabian followers of Mohammed, born 57I, were called Saracens and located at Medina; established Mohammedan religion 622.

\section{SARACENIC.}

634. Saracens conquered Syria, Palestine, Phoenicia and Egypt.

641. Persia overthrown by Arabians, who also conquered Northern Africa and captured Rhodes.

700. Saracens conquered Byzantium and Northern Africa; the Berbers accepted Moham- medan religion, and with inhabitants of Greek and Roman descent, became amalgamated with the Arabians under the name of Moors; 7 I $I$, crossed to Spain, establishing the Caliphate of Cordova. Saracenic conquests for many years extended over Southwestern Asia up to the Mediterranean, influencing the arts of Spain, Southern France and Southern Italy.

MOORISH.

The arts developing in Spain were called Moorish, or Moresque.

755. Caliphate of Cordova; brilliant period of supremacy.

I236. Kingdom of Granada founded and the Alhambra built. The art here followed, called Alhambraic, reached its height I250-I300.

Spanish Renaissance or Moorish Classic I 500. Moors expelled from Spain I6ı. 
TURKISH.

Turks originally Tartan tribe, 226 B.C. Seljuk Turks, a term applied to Western Turks who in $I 096$ held empire by conquest over many parts of Persia and the West Coast of Arabia.

\section{OTTOMAN.}

A band of wandering Turks aided the Seljuk Turks, or Western Turks, in battle and conquered the Arabians 1250. This was the beginning of the Ottoman Empire and the arrest of the Arabian conquests in Asia.

1360. Ottomans conquered Asiatic posses- sions of the Byzantine Empire and Turkey in Europe.

T453. Surrender of Constantinople to the Ottoman Turks.

I480. Ottoman supremacy on the wane.

PERSIAN.

Islam effect upon Persia began 64I, when

Persia was overthrown by Arabians.

750. Independent principalitics sprang up in Persia.

I605. Shah Abbas, ascending throne of Persia, drove out the Ottoman Turks and Mongols and recovered the country.

\section{ISLAM ART CHARACTERISTICS}

ARABIAN.

Arabian followed the use of flat conventionalized interlacement of geometric accuracy, thus unlike Celtic or Scandinavian, and unlike the Ottoman form or later Turkish type. The Mohammedan religion interdicted the use of animal forms, and the law of the Koran was strictly followed by the strict Mohammedans, hence Arabian art was confined to conventionalized forms, with occasionally Arabic inscriptions.

SARACENIC.

The arts influenced by the invasion of the Arabians assumed a form more or less Arabian, and this form was called Saracenic.

\section{MOORISH.}

The Moors were the Saracen converts from Northern Africa who in $7 \mathrm{I}$ I crossed to Spain. The arts are sometimes called early Spanish.

1250. The Alhambraic period. By I200 the Moorish form of ornament embodied Arabian ornament superimposed upon geometrical background framework.

I6ro. Moors expelled from Spain.
TURKISH.

The Turks had no art excepting the art horrowed from Persia and Arabia. (Sce Ottoman.) OTTOMAN.

The Ottoman arts were the arts of the Ottoman Turks or the Turks of the Ottoman Empire, established I259. Ottoman art was the development of the Arabian with strong Byzantine influence even to the interdiction of animal life. A characteristic was the use of conventionalized pea forms and leaf and pod.

PERSIAN.

Islam effect upon Persia 641, when Persia was overthrown by the Arabians. As long as Persia was dominated by the Arabians Persian art was latgely Arabian; but in 1605 , with the downfall of the Ottomans, Persia, through Shah Abbas, developed to its fullest the native tendencies, even to the adoption of European Renaissance forms and human, animal and bird forms. Persian art had been always liberal, and even when under Arabian control was never flat and conventional, but realistic with florals, notably pinks, hyacinths, tulips, roses, palms, pines, pomegranates, pineapples and dates.

\section{THE DE VELOPMENT OF TEXTILE WEAVING}

(Continued from page 35 .)

I000 A.D. Constantinople, Corinth, Thebes and Athens practically monopolized the making of fine fabrics.

1000 A.D. Roger Guiscard organized a silk factory at Palermo, Sicily, Hotel des Tiraz, with Thebian and Corinthian weavers, and according to some historians it became the greatest silk manufacturing city in the world. Scarcely less renowned were Malaga, Murcia, Granada and Seville. Many Italian towns also took up silk manufacturing, Florence, Genoa, Venice, Bologna and Milan. Saracenic and Greek silk weavers located in Germany, the Netherlands, France and Great Britain.

[39]
I Ioo A.D. Towards the end of the Twelfth Century Flemish weavers began the manufacture of wool tapestries. Art developed to Arras, Valenciennes. Tourney, Audenarde, Lille and Brussets. The oldest tapestries in existence are of this era. Two are in the Cathedral, Halberstadt, Germany.

I200 A.D. Persian sills famous throughout Europe and copied generally.

I200 A.D. France began manufacture of tapestries.

I268 A.D. Madrid, Spain, organized a tapestry factory.

I 300 A.D. Spain began to degenerate as a producing country. 
I300 A.D. Arras, city south of France, made valuable wool tapestries up to 1477 .

I300 A.D. Lucca, famous for silk weaving, Lucchese weavers emigrated to Germany, the Netherlands, France and Great Britain, in which countries silk manufacture flourished up to $\mathrm{r} 500$.

1300 A.D. Velvet is mentioned in the English inventories and French documents.

I300 A.D. Genoa, the center for Italian trade in the East, introduces Eastern design.

I 400 A.I). Spanish and Italian writers referred to "velvets" or velvet stuffs. (See I 500.)

I 400 A.D. Asiatic fabrics were taken in great quantities by Europe. During Fifteenth Century Constantinople and Byzantium were the chief markets for supplying Oriental stuffs to Europe.

I 400 A.D. While Italian wool tapestries were designed by native artists, the workmen came from Flanders. During I400, when the Ottomans conquered Constantinople, they infused Orientalism into South-eastern Europe, and the manufacturers in the Ottoman towns-Anatolia-went into the markets of Italy and France, Spain and Flanders. This spirit brought political changes, new commercial relations and the influence over the decorative designs and decorative fabrics of all Europe. This Ottoman type was more Persian than Saracenic. It was strongly floriated.

I 432 A.D. Silks of Damascus were famous.

I466 A.D. Lyons, France, established silk looms. Under Francis I silk weaving was encouraged and many Italians employed. Turkey pre-eminent for silks of Broussa, Diarbekir, Beyrout, Aleppo and Damascus, Assyria.

I480 A.D. Beginning of needle-point lace work in Italy.

1500 A.D. Spain weakly reflecting the character of French and Italian styles.

I 500 A.D. France, Germany, Holland and England weaving fine silks.

I500 A.D. A continuance of inscriptional styles in gold, "velvet," and satin, superseding brocaded silks of early date. Materials heavier.

1500 A.D. According to the revenue records of Italy, cloths of silk, satin damasks and velvets plain and cut, were made "in a way unknown to the ancients." Prior to this date velvet was a material that had been simply roughed up so as to appear fluffy. England attempted during I 500 to make satin damasks, velvets and cloths of gold, but soon abandoned the enterprise.

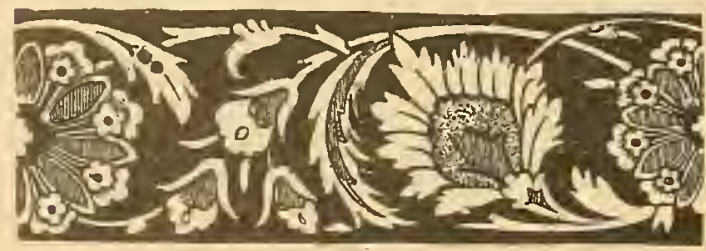

Persian.
I5I5 A.D. Pope Leo $\mathrm{X}$ had tapestries made in Brussels after cartoons by Raphael.

I 539 A.D. Francis I established tapestry factory. This was the beginning of Gobelin manufacture.

I600 A.D. Beginning of point Venise laces in Italy. At this time similar laces were made in France and in Flanders and Russia also.

I600 A.D. Showing Italian character of design, strongly influenced by Oriental.

Italian and Sicilian towns famous in silk manufacture. Also Tours, Nimes, Lyons, Avignon, Paris, France. Flemish and Dutch were more traders than producers.

I6I9 A.D. Mortlake Tapestry Works were established near London by James I. Existed up to Charles I.

I6I9 A.D. Gobelin Tapestry Works became royal property of France.

I650 A.D. Under Colbert many lace factories established in France for the making of net laces.

I6go A.D. or thereabout, Beauvais Tapestry Works established.

I 700 A.D. French characteristics prevailed in French manufactures. Many towns in France undertook manufacturing. The French influence in designs spread to Spain, England, Holland, Germany and Sivitzerland during the flight of the weavers from France at the time the Edict of Nantes in France was revoked.

I 700 A.D. Netherlands, Bruges satins famous.

I700 A. D. Flanders famed for its tapestries.

I750 A.D. Thousands of silk-weaving looms established in England-in Spitalfields, Cheshire, Yorkshire, Essex, Derbyshire, Lancashire and Norfolk. Large quantities of Chinese and Indian silks used in England.

I759 A.D. Manufacture of printed linen authorized and encouraged by French Government. The most famous became known as Toile de Jouy.

I800 A.D. The Germans were great producers at Crefeld, Elberfeld, and Barmen.

I 800 A.D. Austria began the manufacture of silk and I 500 looms were soon in operation by imported labor from Genoa and Lyons.

r8oo A.D. Some silk was made at Stockholm, but neither Norway nor Sweden had made history in this business.

I80o A.D. Moscow and St. Petersburg established silk looms in Russia.

I818 A.D. Bobbinet first made by machinery.

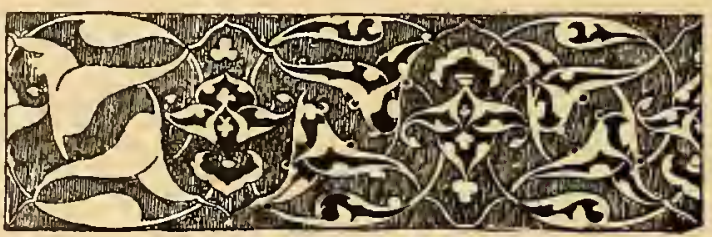

Arabian. 
A
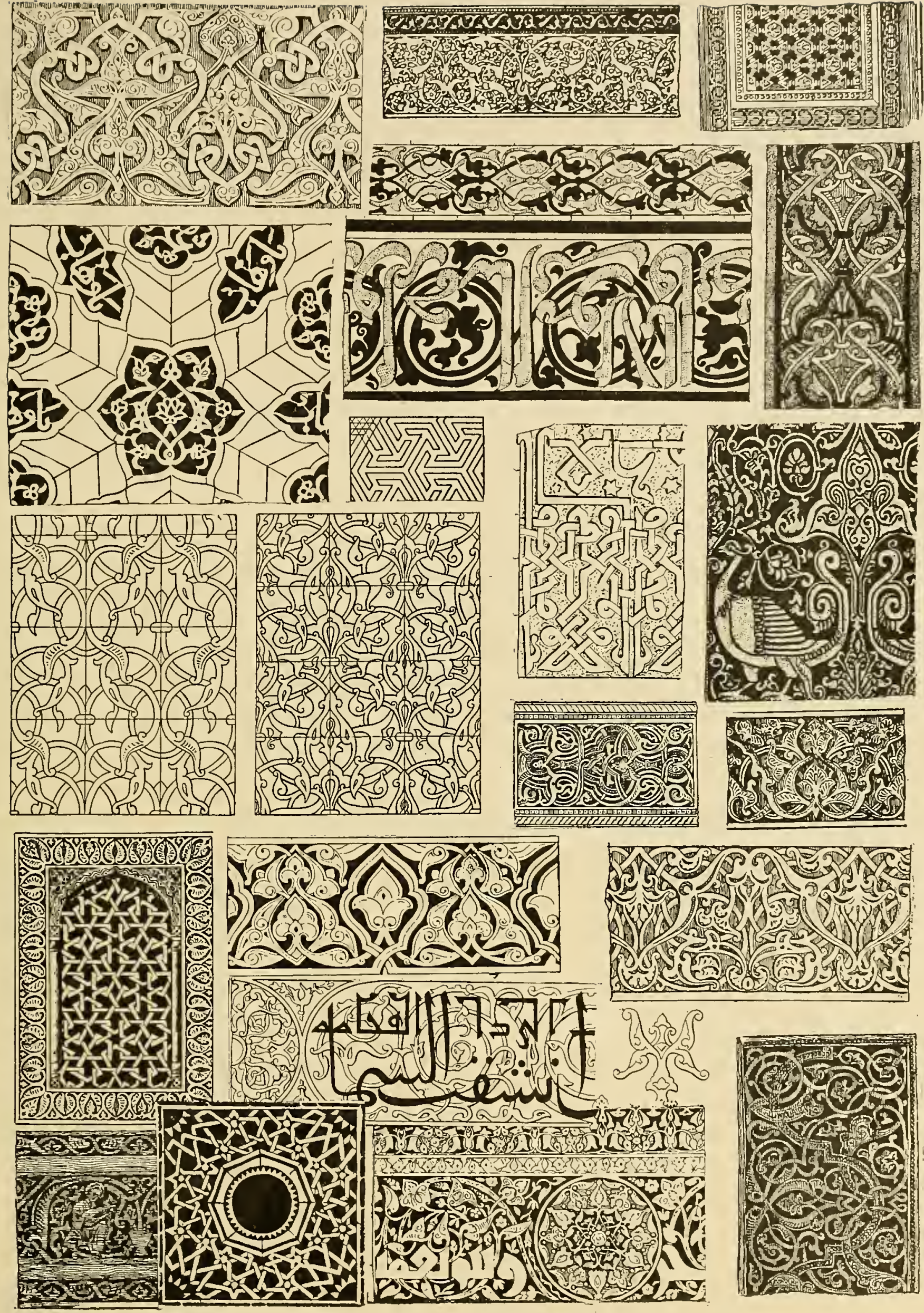

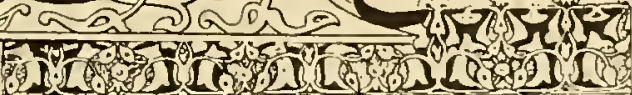
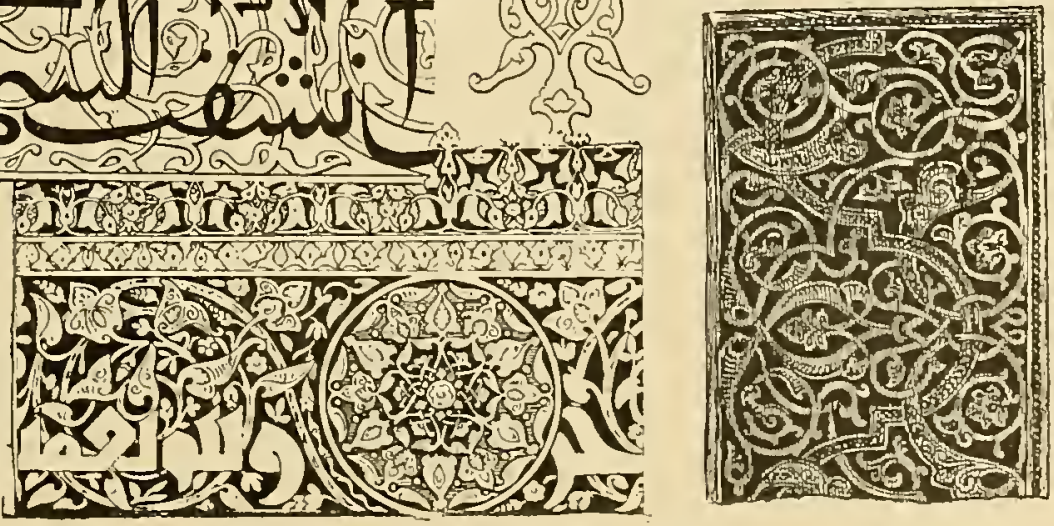


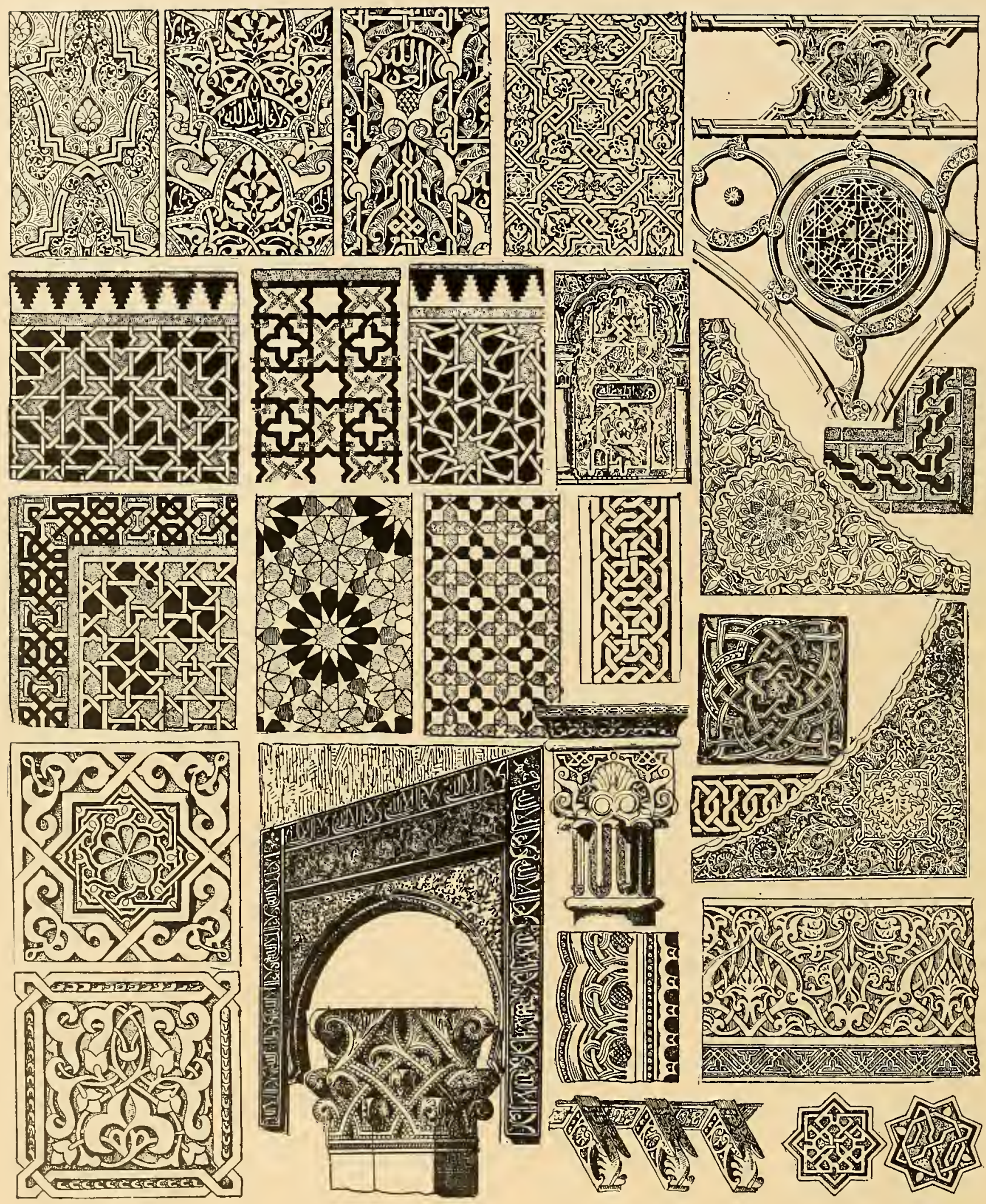

MOORISH OR N A M N T.

Moorish (Arabian origin) developed finally the Alhambraic, an elaborate form. 

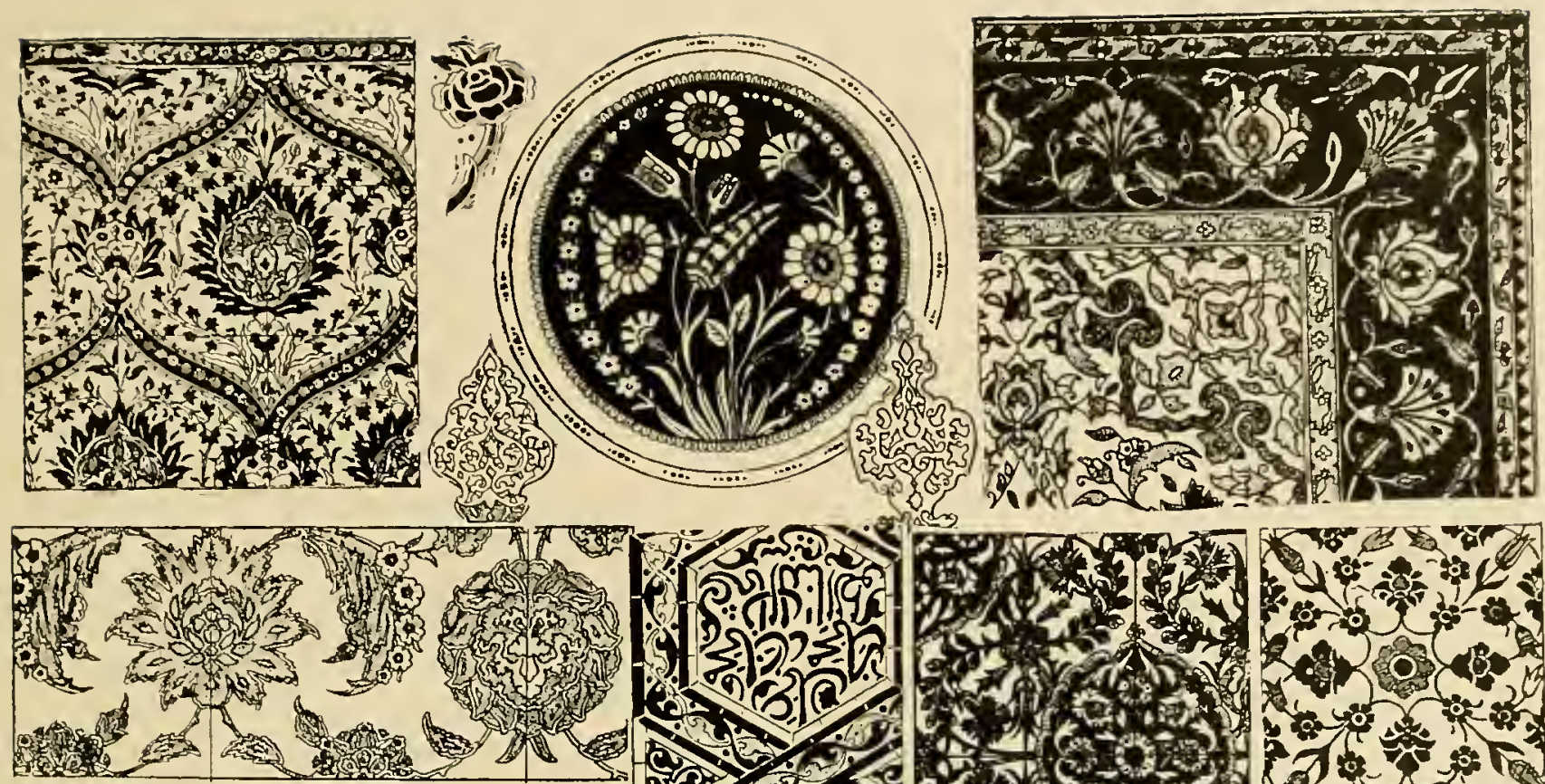

: $3=0$

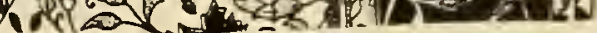
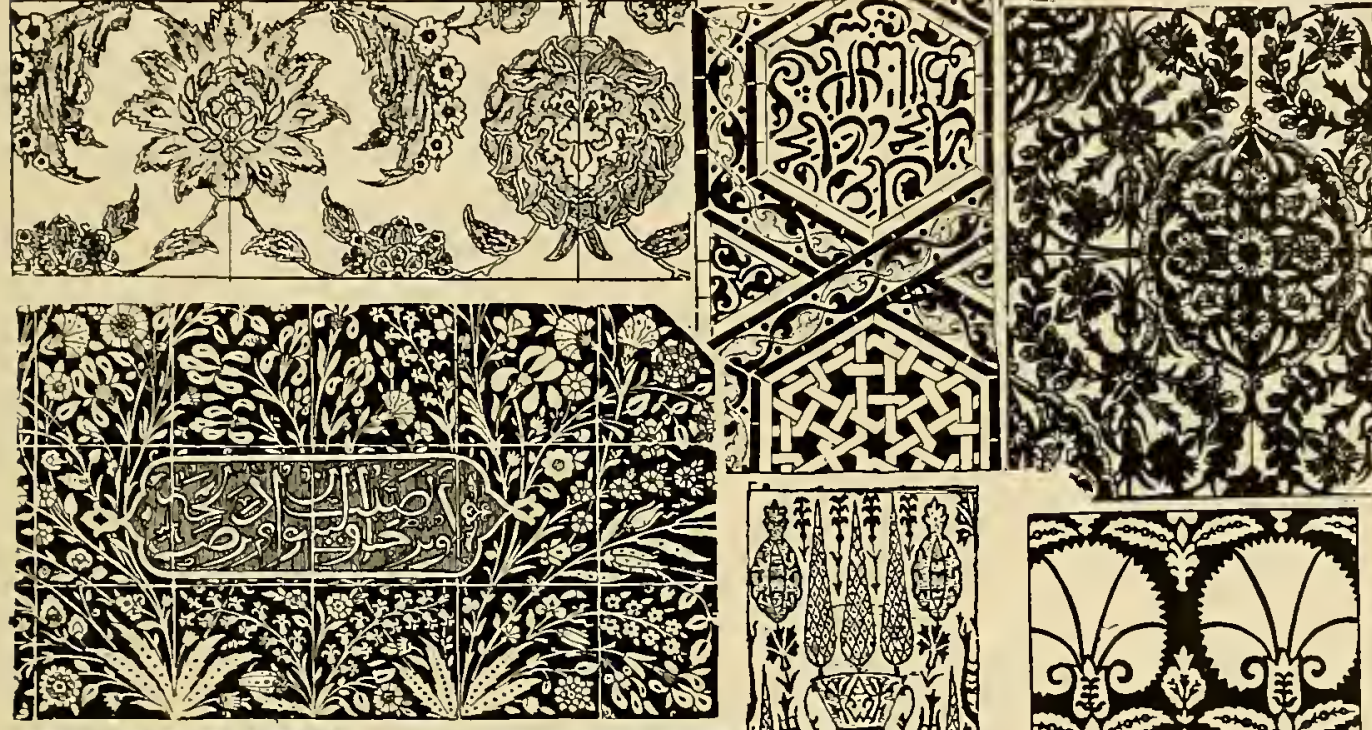

10 - 4 ( )

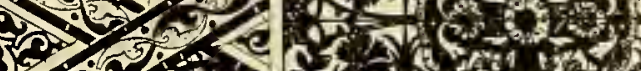
(-) (a)

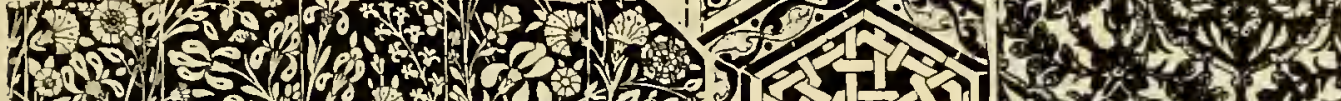

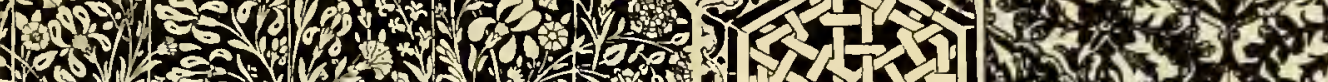

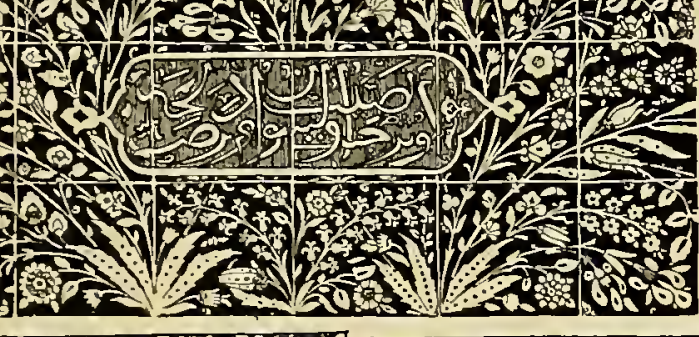
1.9. (1) 1 . - 18020 310.1010

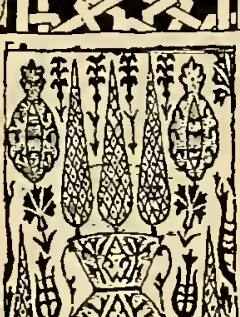

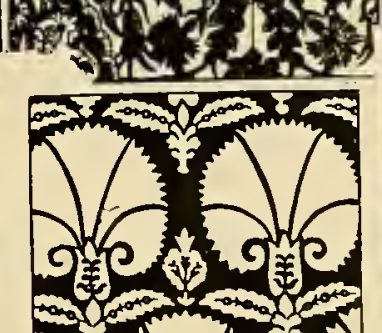

तर

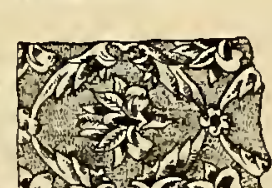

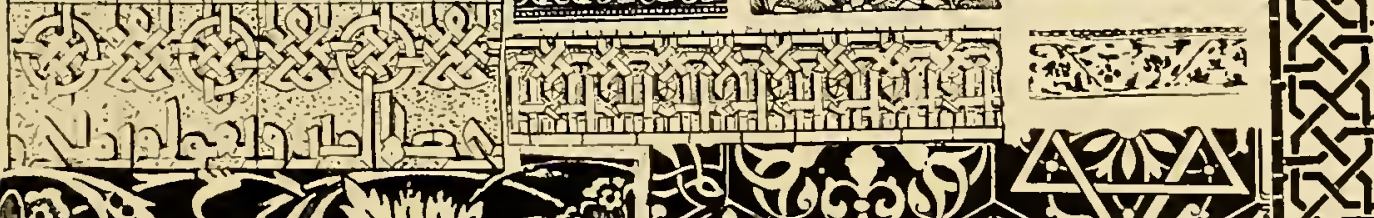

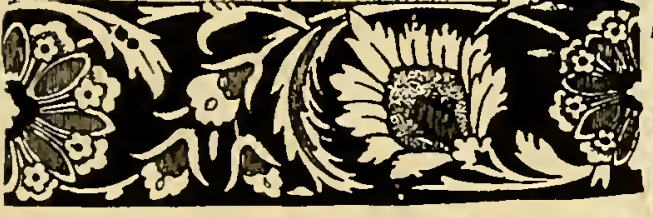
(2)

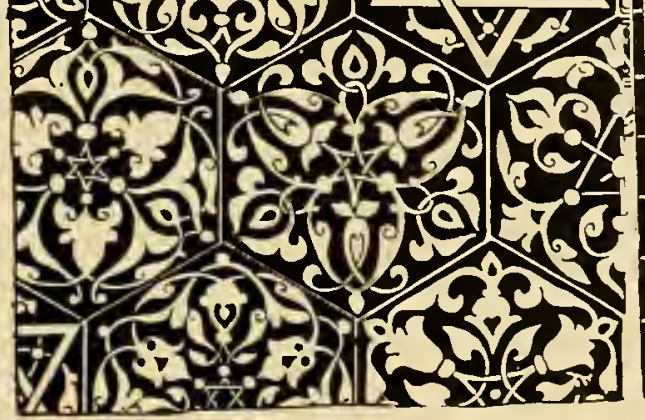

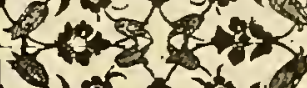
$-10^{2}+5$

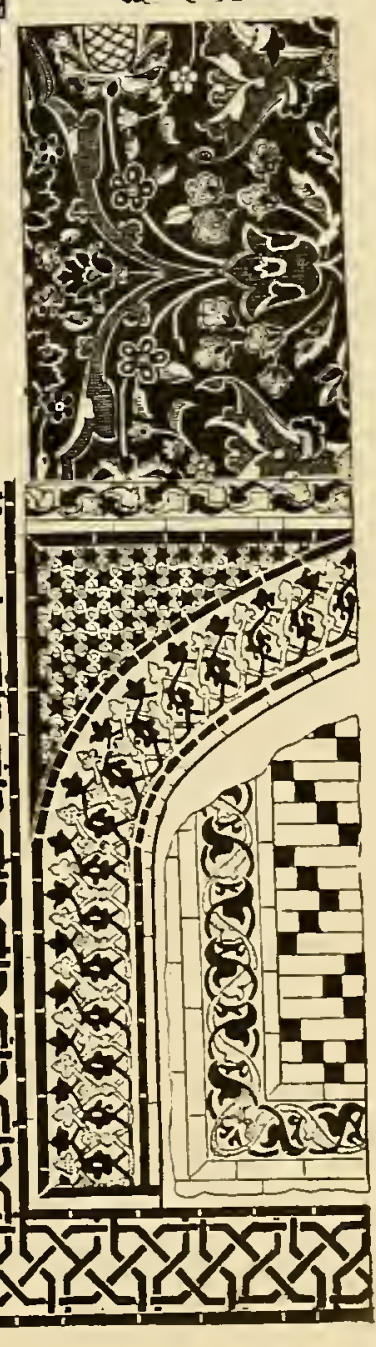

PERSIA N O R A M E N T 


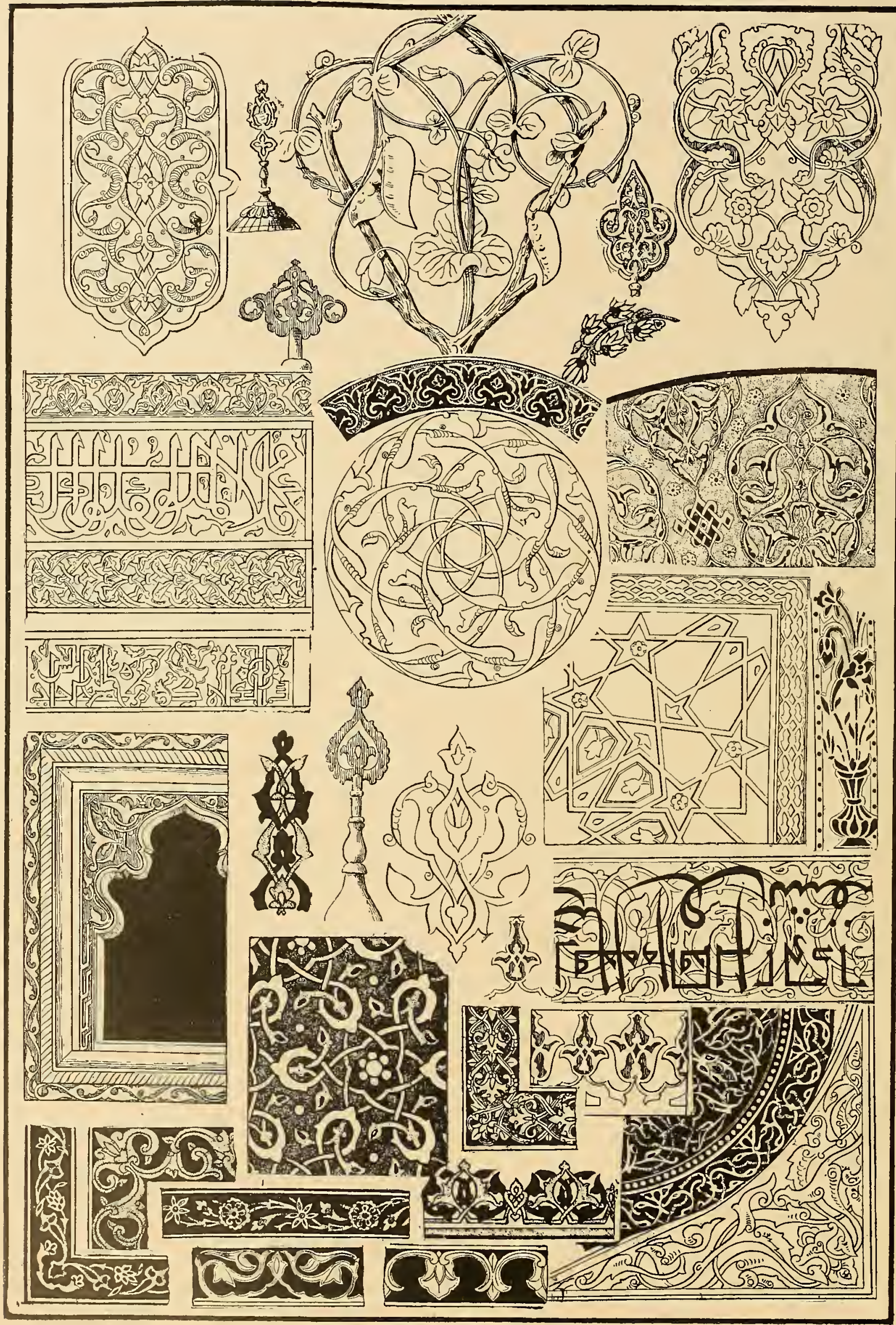

OT TOMAN ORNAMENT.

Ottoman Turkish developed a floriated Arabian form, with the pea vine and leaf as motifs. 


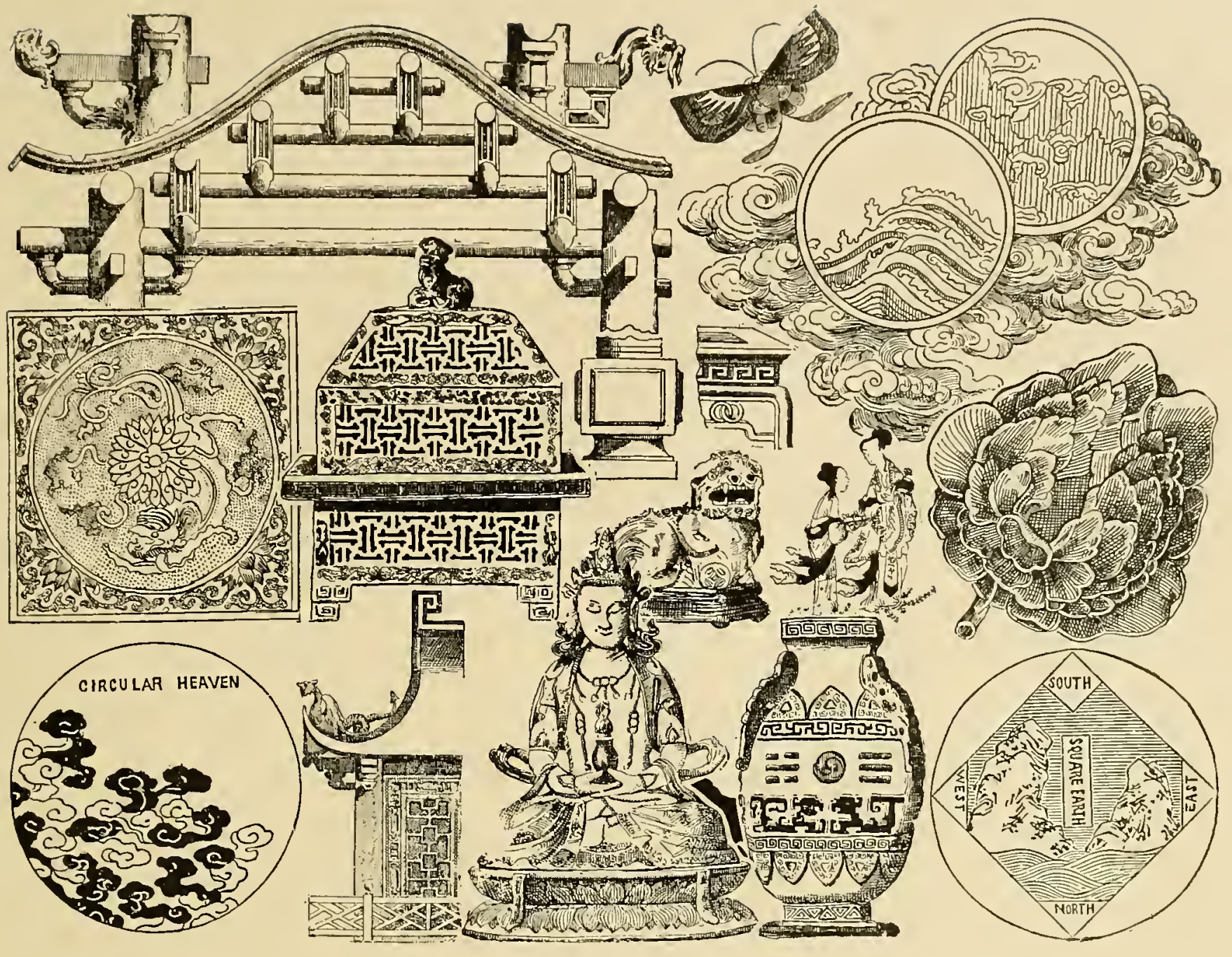

Chinese Ornament.

\section{CHINESE-INDIAN-JAPANESE-SARACENIC}

CHINESE-Mythic Period 3500 B.C. First Emperor 2200 B.C. Confucius 500 B.C.

Dynasty of Yonen 1260-1368 A.D. Dynasty of Ming I368-1620 A.D. From the end of the latter dynasty to the death of Khang-Hi I620-1722 A.D. Under the reign of Yung-Tching and Kien-Long I7221796 A.D.

C HINESE and Indian art are frequently confused because they have much in common. Possibly this condition may be accounted for by the influences of Buddla. The Chinese employ an endless list of deities, demons, monsters. They have eight immortals and the figure eight is a favorite. They have eight lucky emblems, eight Buddhist symbols, eight ordinary symbols. IVe note also in Chinese frets and geometrical details, forms identical witl Greek.

Mythological art is an art of great study. To comprehend its meaning one would have to be a Confucionist, a Taoist and a Buddhist. Stripped of its symbolism, Chinese art is an art of extravagant nature forms, and in the past four centuries these forms were undoubtedly influenced by Persian nicety and decorative consistency.

INDIAN-200 B.C. Brahma i400 B.C. Buddha 500 B.C. Arabian Invasion 711 A.D. Mogul Empire 1525 A.D. English Control 1748 A.D.

W $\begin{gathered}\text { oven brocades and silks of India were not de- } \\ \text { veloped as decorative arts until the Sixteentl] }\end{gathered}$ Century. While Indian art goes back to the remote past, the art as we understand it is Islam. Having the typical Molnammedan divisions of space, but more flowing, having more freedom and grace, it is less confined than the Arabian style. The Arabian invasion of India began 7II A.D., and from that date Mohammedan domination prevailed; but beginning with -1500 Indian art broke away from the Koran restrictions and we have the elephant, lion, tiger, the peacock and the human figure common accessories in 


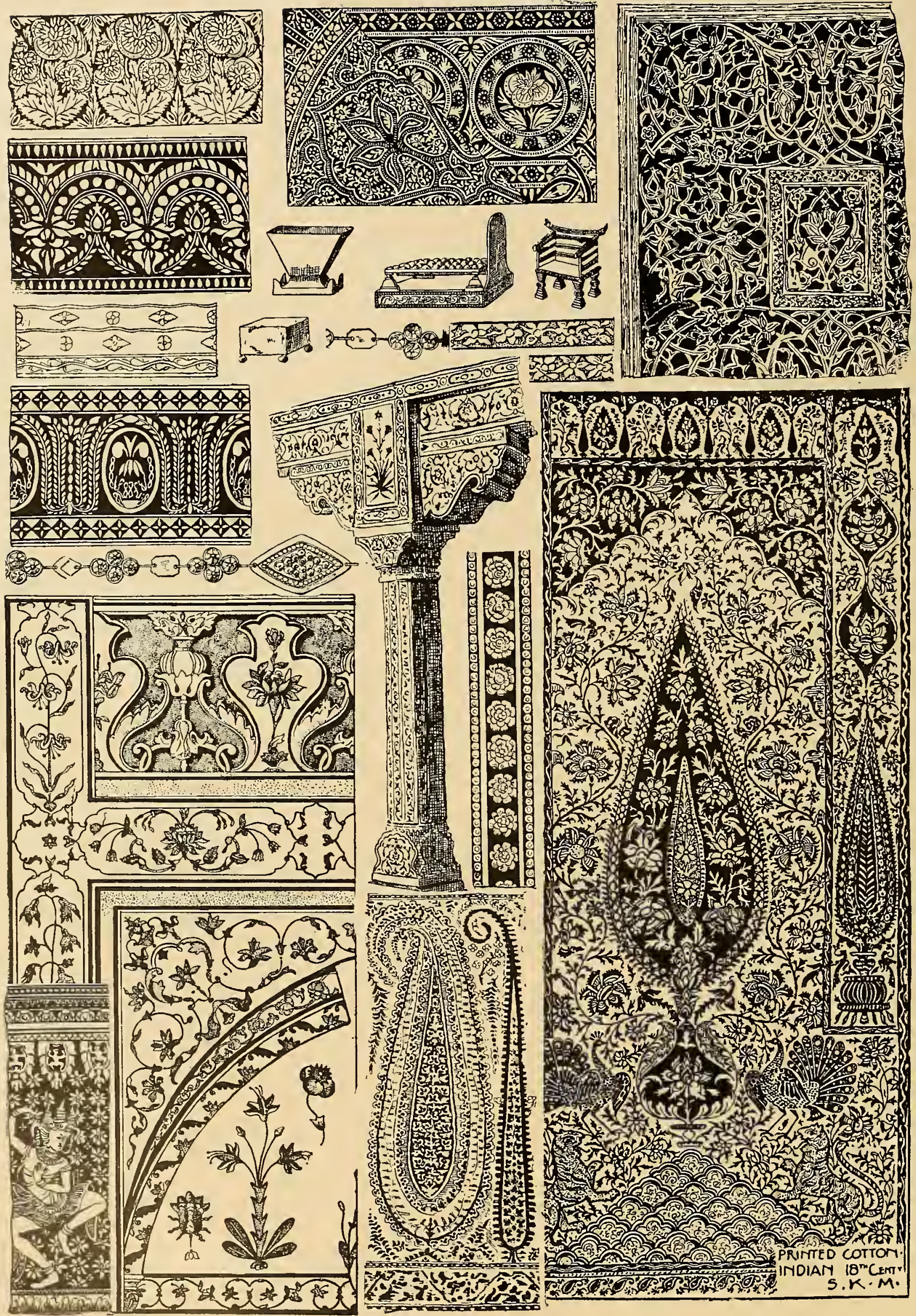




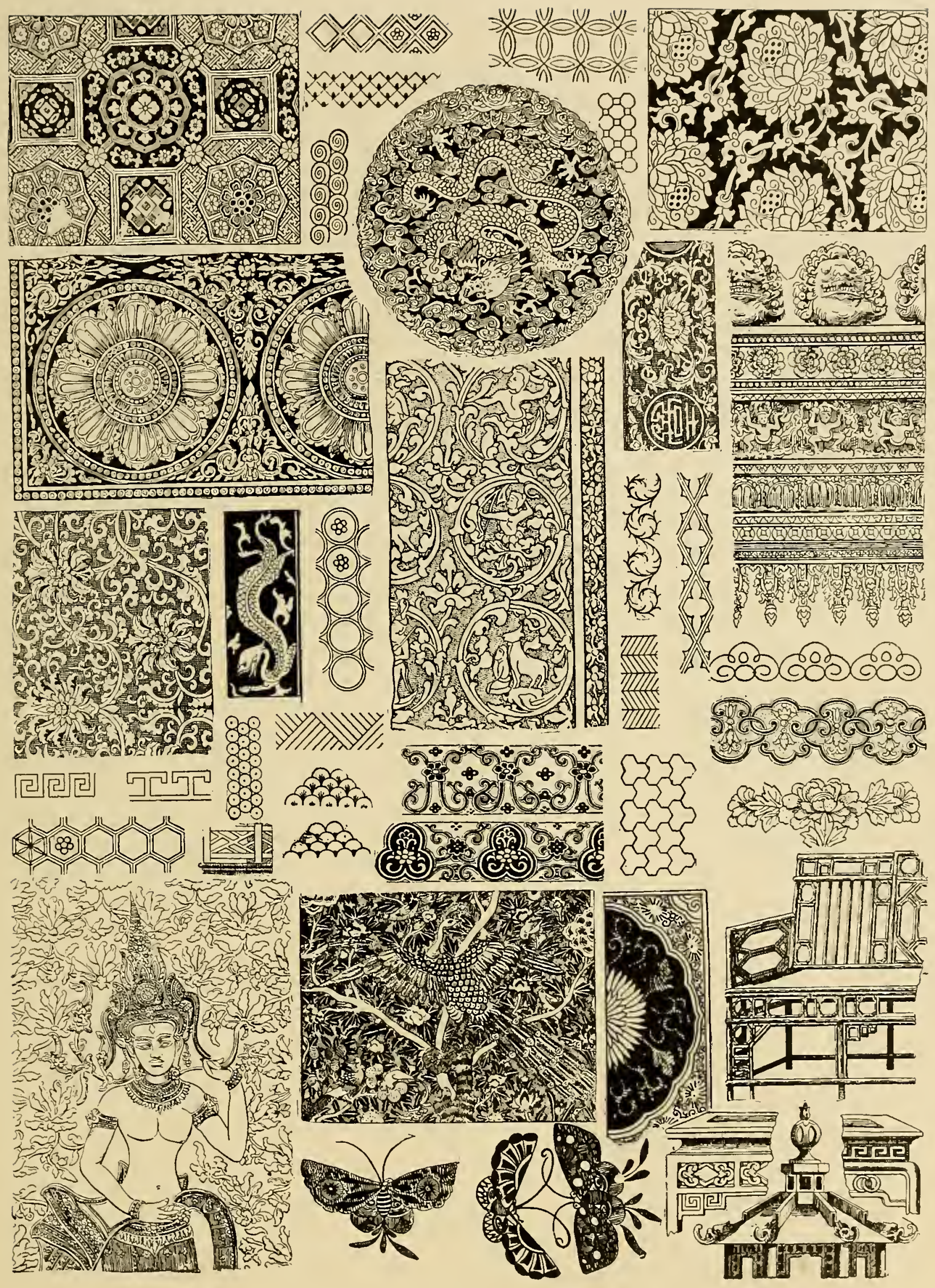

C H I N SE ORNAMENT. 


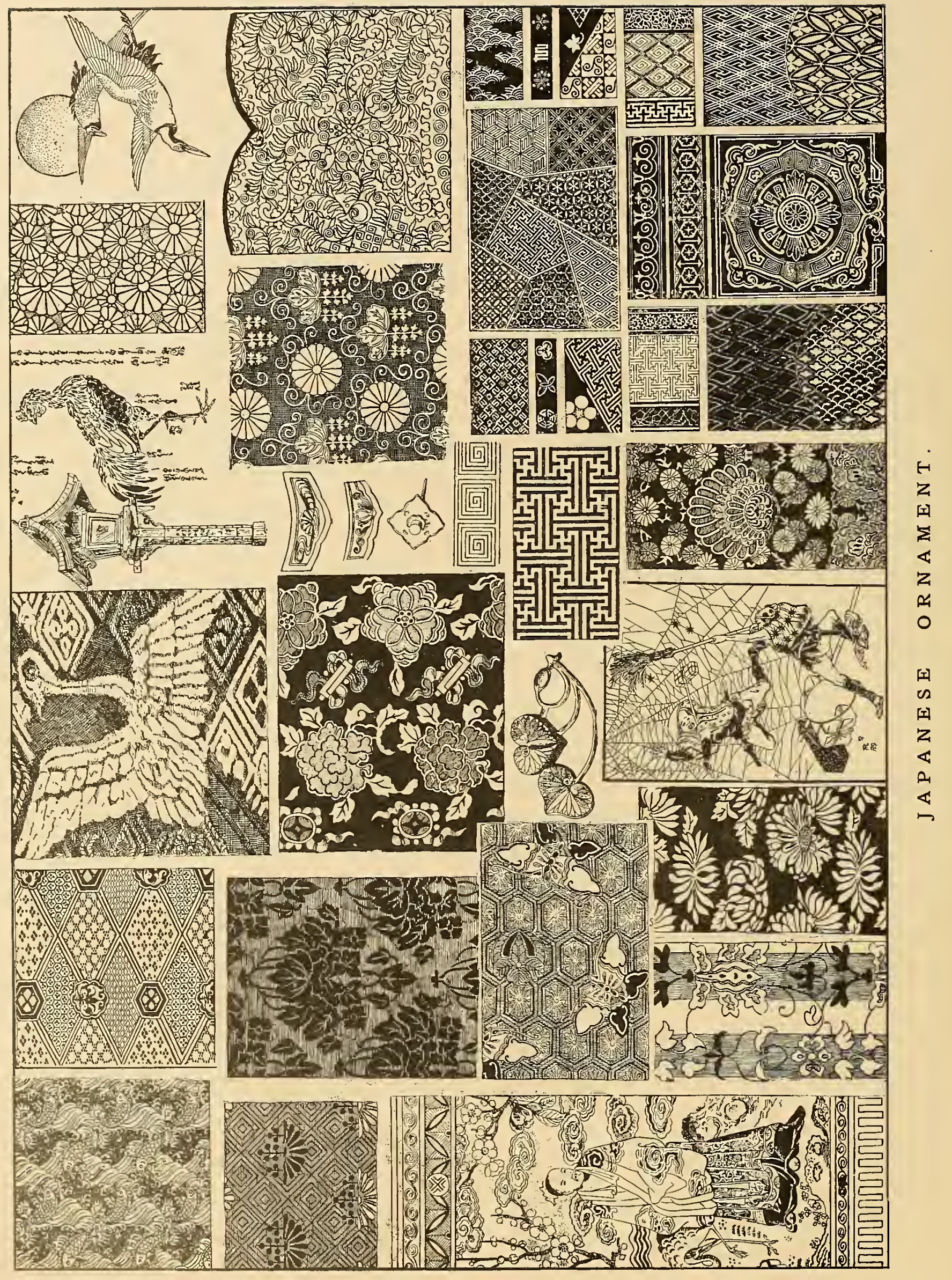


decoration. Indian ornament followed a profusc floral system, and block prints in silk and cotton reached a high degree of perfection during the Seventeenth and Eighteenth Centuries. The details arc always worked ont finely.

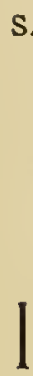

SARACENIC - 641 A. D.
Persia was conquered by
the Saracens or Arabians,
who by 71l had invarled
Indlia, Spain, Turkestan
and Northern Arica.
827. A.D. Saracens set-
tled in Sicily. Early in
Tenth Century extended
their incursions into ltaly.
T is impossible to class-
ify Saracenic clesigns under one grouping, for the reason that the term applies to the Arabian infuences covering many years and many countries. (See Romanesque, Gothic and Italian.) To comprehend the term Saracenic one must study the chronological history of the Orient. Wherever the Arabian or the Saracen conquered there he left his influence. The term is arljective. It may apply to much that would be otherwise classified as Romanesque, Norma n, Gothic, or Sicilian if the Arabian characteristics permeate the composition. In Southern Italy and in Sicily the style which developed in the Ninth Century

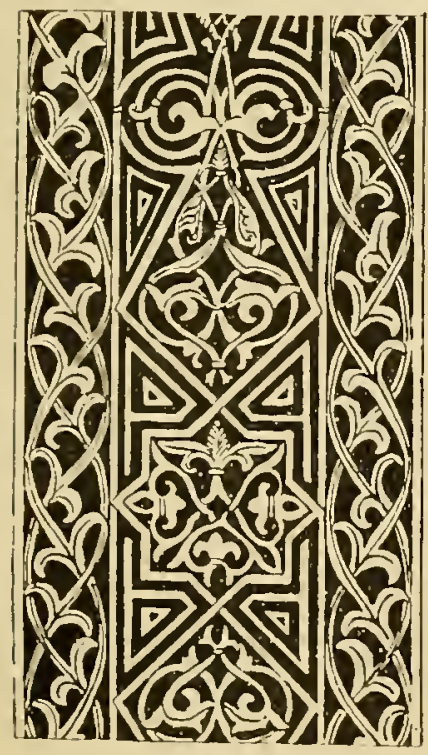

Saracenic. was distinctly Saracenic. If we study the Romanesque and the Norman we find in the origin of each the Saracenic superimposed upon Roman or Byzantine and we have as a result a confusion that is often hard to analyze.

A design, therefore, Norman, Ronanesque or Byzantine that is conspicuous by its Arabian influence is called Saracenic.

Under the Saracens, textile fabrics reached a high development in color and ma-

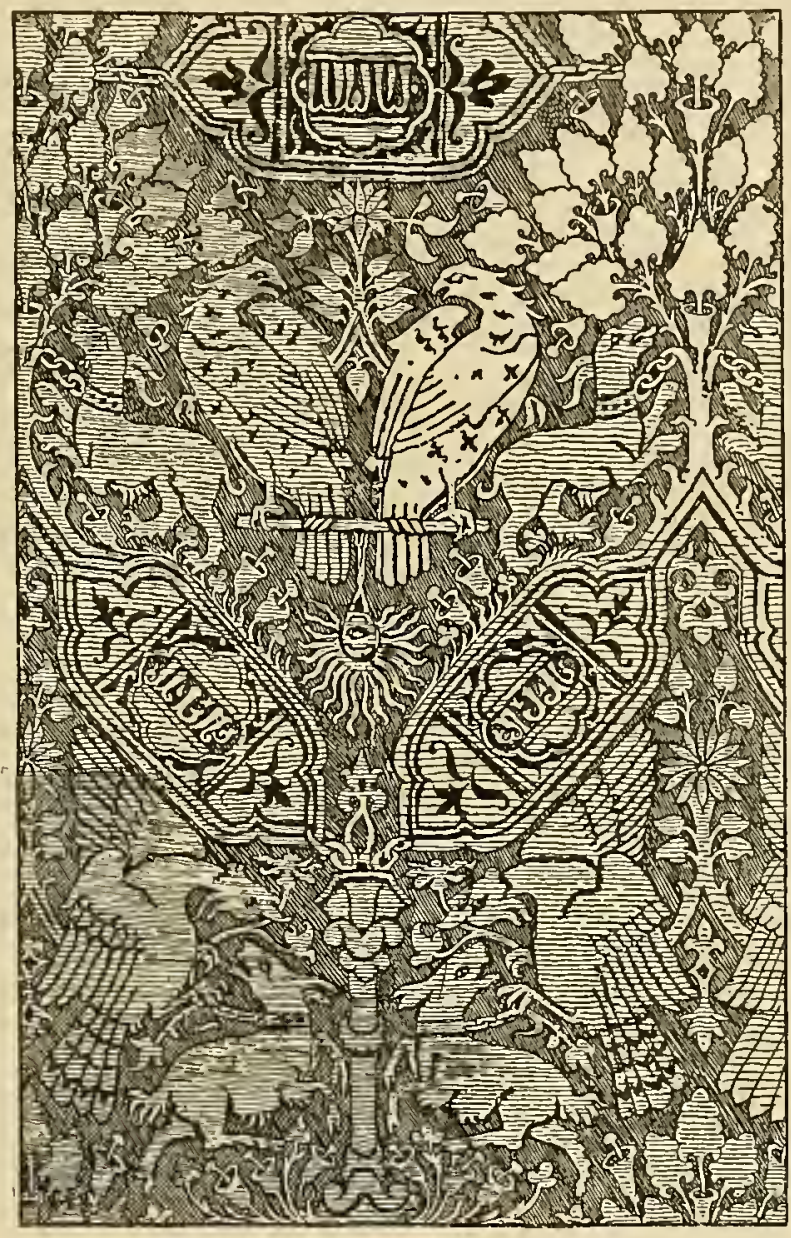

Saracenic. terial. The arts culminated in the period 900-1200 Though Mohammed forlade the wearing of silk, it was largely used, and to cvade the injunction cotton was interwoven with it. Sicilian or Siculo-Saracenic fabrics showed bands of birds and animals, foliage, inscriptions, in blue, green and gold on red ground.

Drawn gold thread was not used in early fabrics, but gold leaf on paper and then rolled around a fine thread of silk was manipulated. Sicilian fabrics of the Thirteenth and Fourteenth Centuries are frequently in purple ground of twilled silk witl birds and foliage formed by gold thread weft. Saracenic or HispanoMoresque fabrics of Spain are distinguished by the splendid crimson or dark blue conventional patterns of silk upon yellow ground, and by the frequent use of strips of gilded parchment in place of the rolled gilt thread. Undoubtedly under the influence of the crusades the Sicilian weavers of the Thirteenth and Fourteenth Centuries produced many fabrics enriched with

winged lions, crosses, crowns, rayed stars, harts, birds, linked together with floriations or armorial bearings. Late in I 200 this character of design was introduced into Northern Italy. Genoa adopted much that was Persian from the Twelfth to the Serenteentl Centuries, and in the Fifteenth Century, when Louis XI encouraged the art of weaving in France at Tours and later at Lyons under Francis I, the
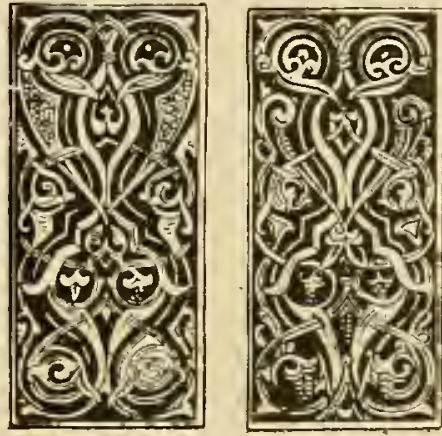

Saracenic.
Persian and Italian fab-

rics were closely fol lowed, and the vase pat tern was adopted.

The Oriental char acter of design in tcx tiles did not entirely disappear until the gardens of Versailles and the Trianons un der Louis XIV gave inspiration to the use of European flora. 


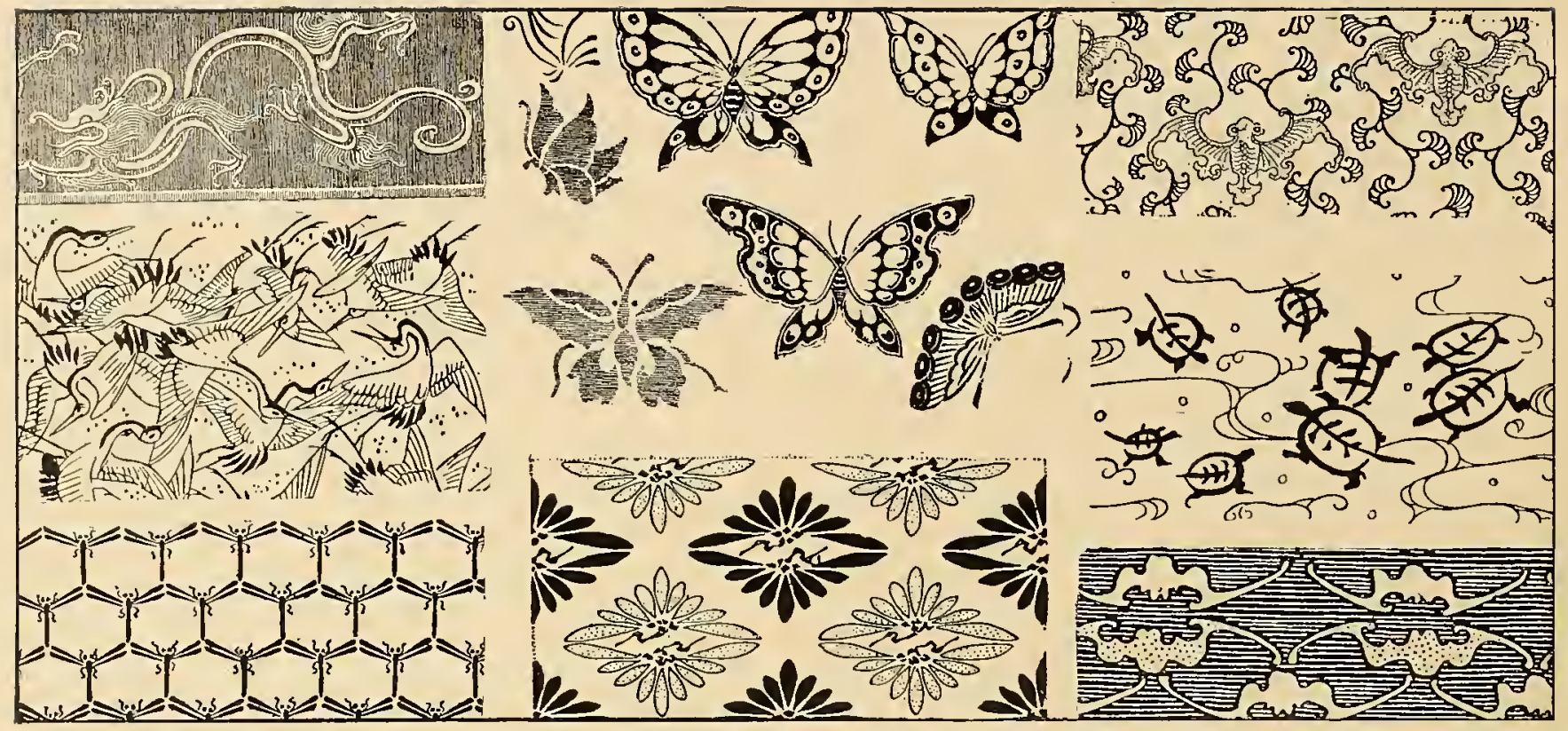

Japanese Ornament.

JAPANESE-I200 B.C. Empire Established 660 B.C.

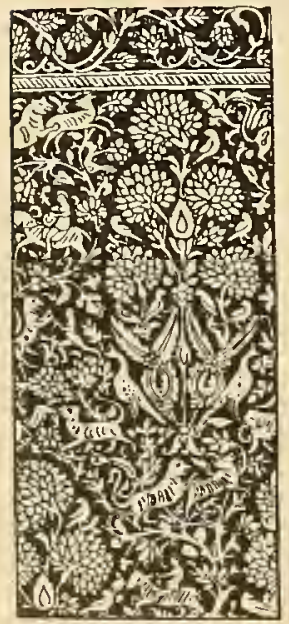

Indian.

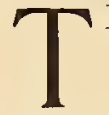

between the Indian and

Tapanese arts, for Budd-

hism, introduced from India, exercised pronounced influence upon the people of Japan. We are in clined also to broadly associate the Chinese and Japanese arts; incleed the differences are not easy to determine.

In $x 200$ B.C. the Ainos, people occupying islands east of Asia, were conquered by bands from the mainland. The conquerors became known as Japanese, but for centuries their early arts were stimulated by they developed a great love of detail, a nice accuracy of expression foreign to the Chinese spirit. They employed less conventionality and more nature. We nevertheless find in both Chinese and Japanese art forms that are almost identical, and where that is the case we can trace it to the influences of India.

We find in indigenous work of the Japanese a great deal of nature study-butterflies, cranes, dragons, peacock-feather patterns, flowers, tortoises, waves -in fact, almost everything in nature, and the methods are in most cases picturesque rather than fixed and formal.

During the last fifty years Japan has studied and complied with the demands of European taste, and native art has consequently weakened.

At its best, it followed the methods of China and India and in most cases was content with reproduction.
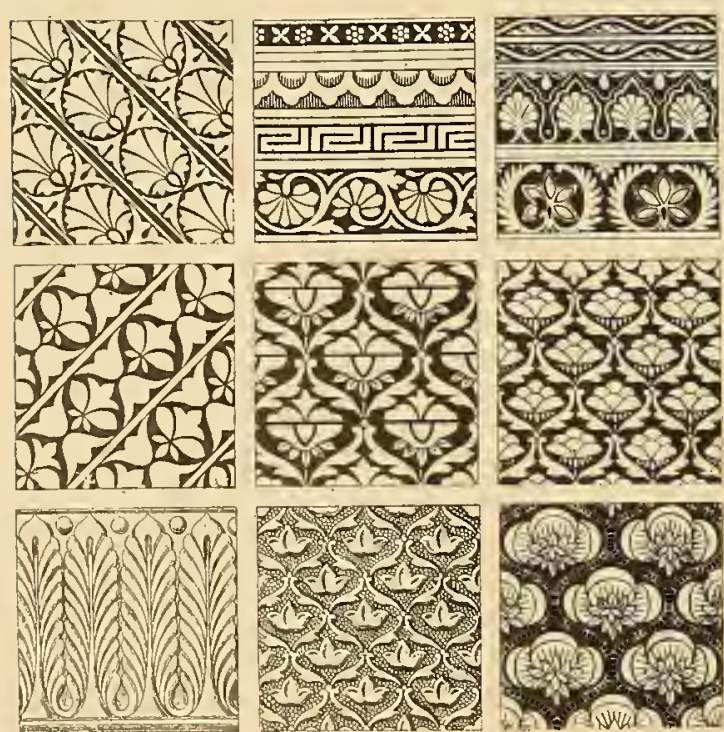

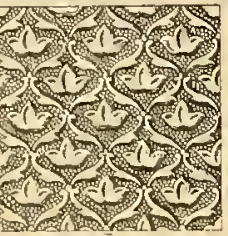

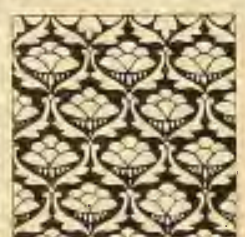

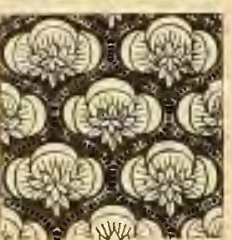

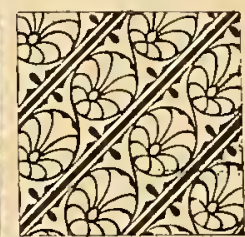

romaro

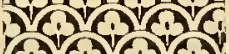

iveresica

iscosic

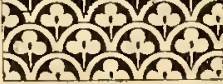

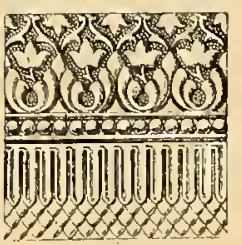

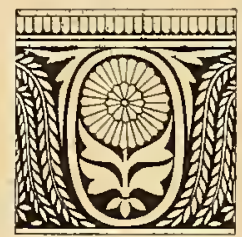
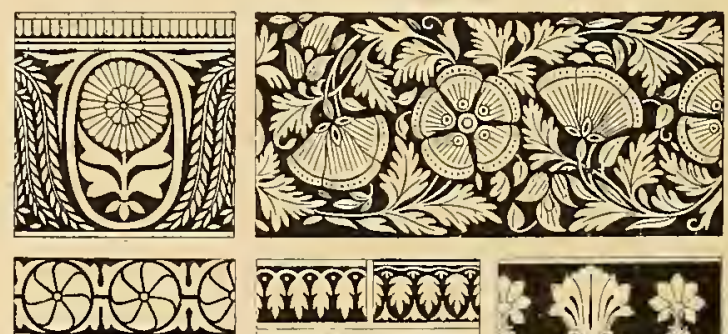

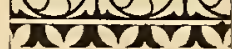

arative

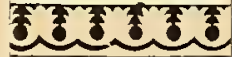

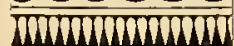

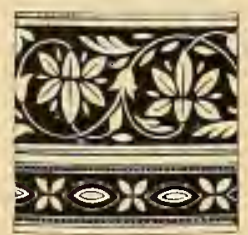

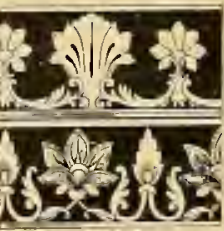
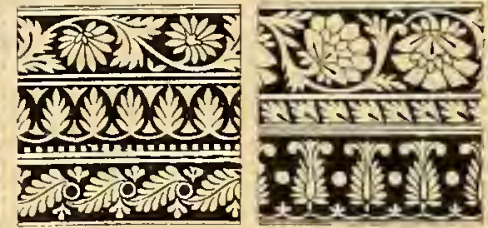

Indian Ornament. 


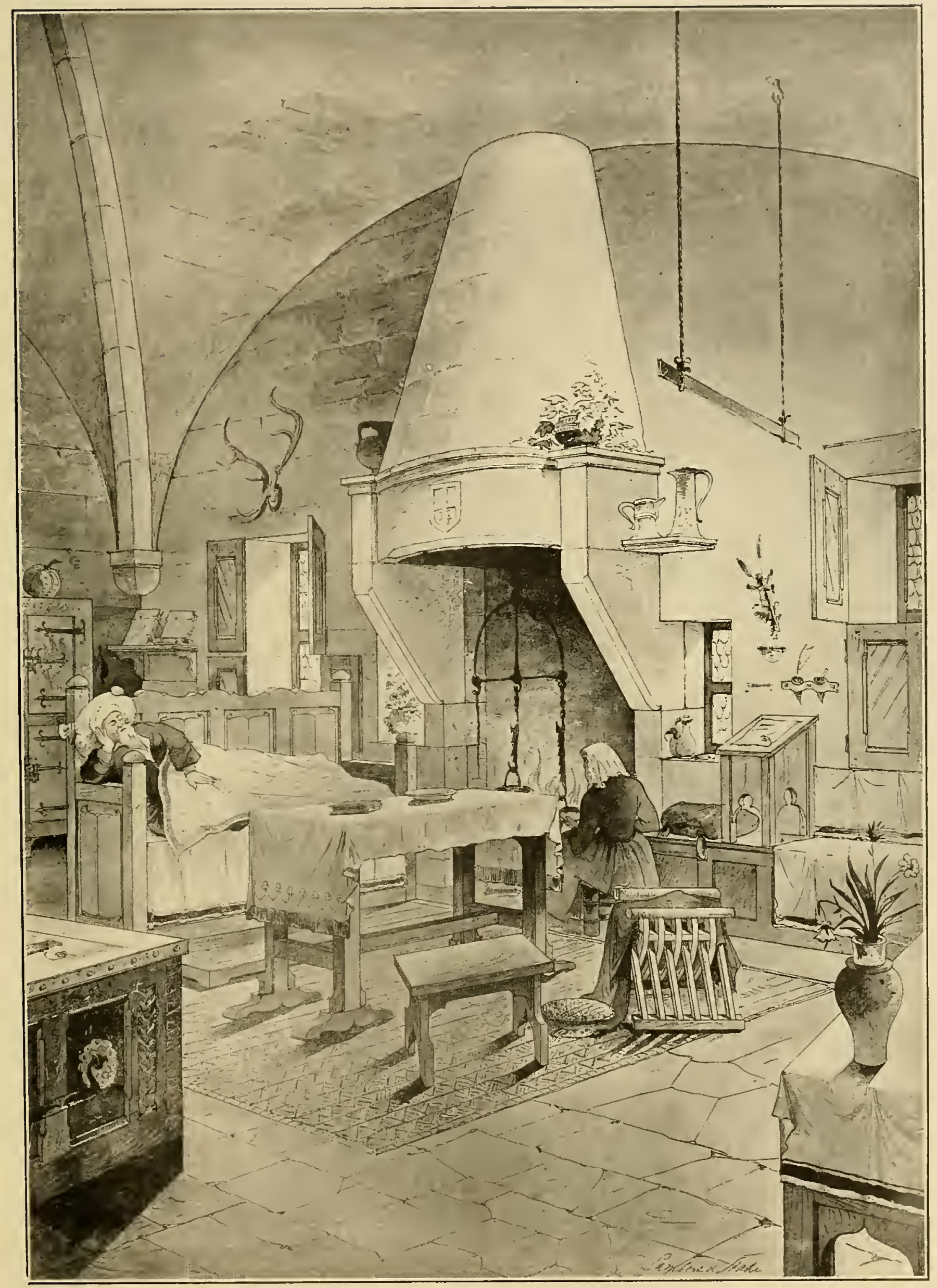

GOTHIC INTERIOR, I 300 .

From on old painting in Stuttgart, Germany. 

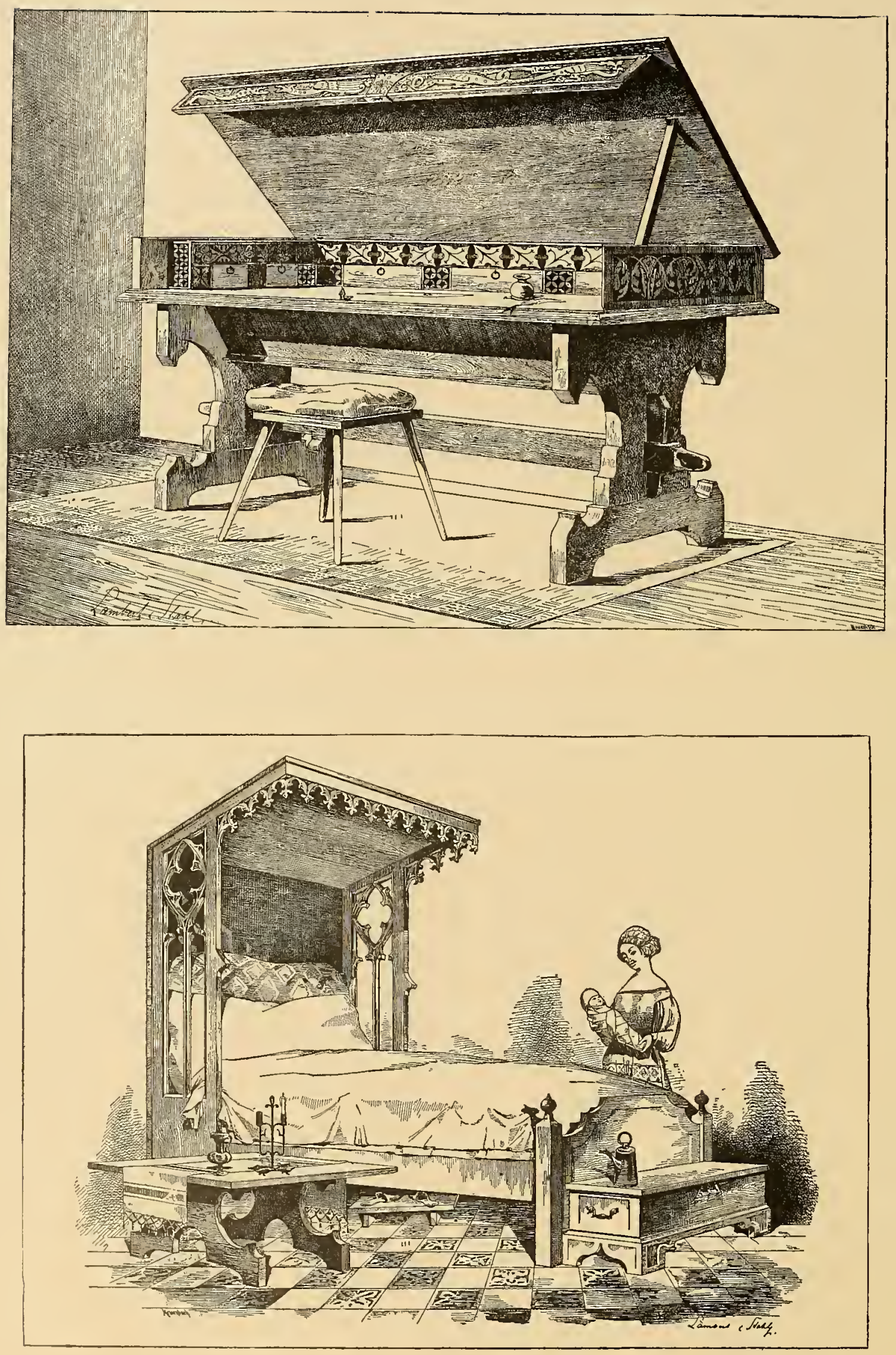


\section{FRENCII:}

Gothic style originated in France: Abbcy Churcl of St. Denis, first cxample 114I. Cathedral of Notrc Danc, Paris, 1163-1182, is a line example.

Early Period, II50.

Secondary, $1200-1300$.

Flamboyant, I300-1400.
IENGLISII :

GiELMAN:

Early Gothic or Crude Gothic, Began, 1250. $3189-1300$.

Decorated or Ornamental, 1300I.400.

Florid or Perpendicular, $1400-$ I 500 .

Tudor Gothic, $\mathrm{I}_{4} 85$.

S[D.NISI] AND PORTUGUESE :

Began, 3250.

Doninated by Noorisli Character.
ITALIAN :

Began, 1250.

But never freed itself from Classic and Byzantinc influences Gollic style had litle development in ltaly

DUTCH, BELGIAN AND TYROL

GOTHIC.

Developments of French and German.

\section{G O T H I C}

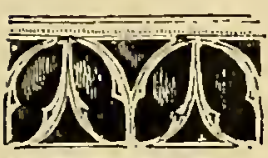

(1)

Romanesque or

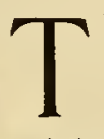

\section{$\mathrm{H}$} Eothic style was the art expression having root in the spread of the Christian religion, and is full of Christian symbolism. At first crude and heavy, it yielded later to a highly Round-head Gothic. ornate form of treatment.

Regarding the Gothic development there is much confusion. It developed directly from the Romanesque, a style which grew up in Northern Italy; naturally the Romanesque characteristics $]$ in gered in its construction. Indeed, the late Romanesque is called the Round - Head Gothic, its arches in

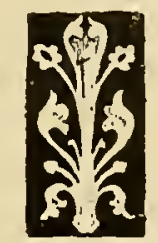

Gothic Fleurs-de-lis.

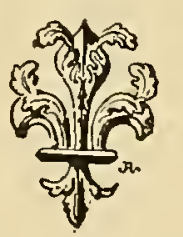

architecture being seni-circular, as distinguished from the later Gothic development of pointed arches.

The Gothic period, extending as it did from I 100 to $155^{\circ}$ and influenced as it was by the Byzantine,
Saracenic, and finally Romanesque, naturally absorbed many architectural characteristics as the style traversed France, Gemany, Spain, Italy and England. And yet all phases possessed a common floriation and universal religious symbolism-the trefoil, the quatrefoil, curves and arches, circles, triangles, religious figures - are conspictuons whether of the Gothic of Spain with Moorish arcly, or the Gothic of France with pointed spires, or of England with its lancet as well as squat Tudor vaults. One cannot too strongly emphasize the fact that

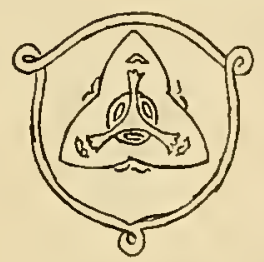

Three in one.

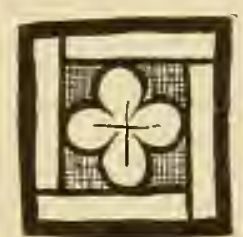

Quarry. Gothic art was an architectural art. It was the art of the builder, the sculptor, the wood-carver, as distinguished f rom the art of the weaver, who up to this period took inspiration mainly from Asia. Thus we find frequently in the furnishings of a church. palace or cottage, Gothic characteristics in all that was of the honse or building proper or of the cabinetmaker, and com-
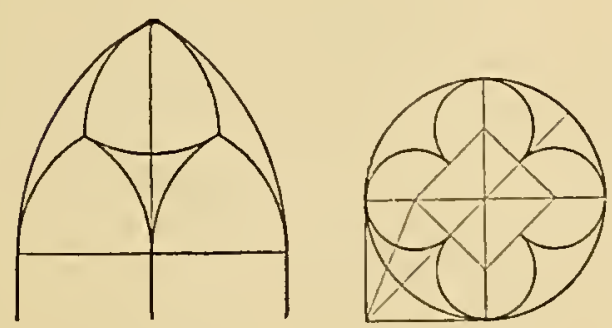
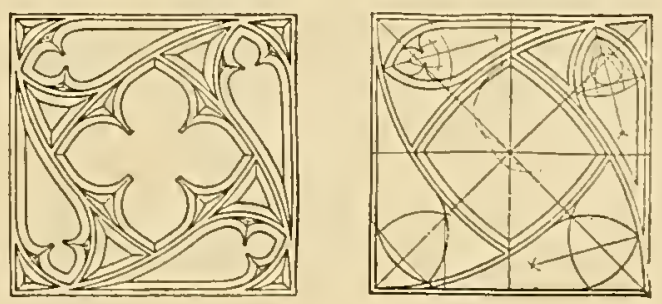

Gothic Characteristics of Design. 
bined therewith textiles and art treasures brought in by the Flemish and Italian traders from far Asia.

It is somewhat difficult to understand the terms used descriptive of the Gothic epochs. In order to assist in a comprehension of these terms we reproduce the classifications of Sharpe, Rickman and De Caumont. IVe prefer, however, that the student sliall follow

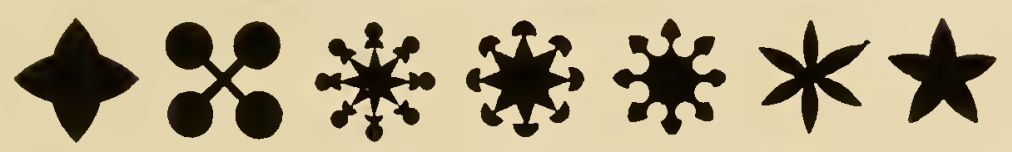

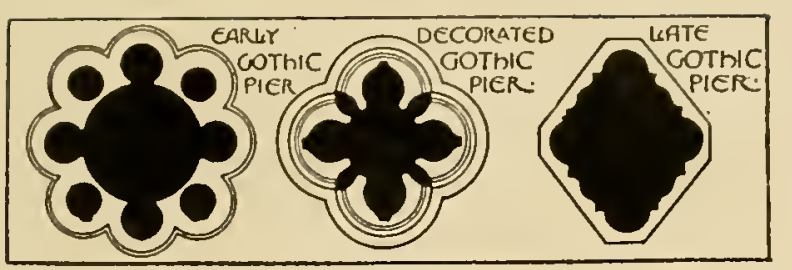

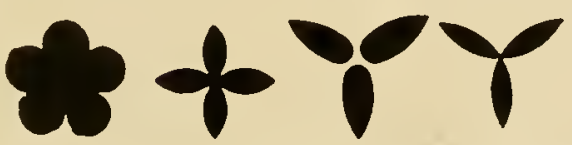

Gothic forms from which the trefoil and quatrefoil details
W ITI the beginning of simple crochet form, as it is called, a terminal floriation. At first crude, it soon developed into the Decorative type, characterized by natural foliage of many kinds, with flowing, undulating $1 \mathrm{ines}$, truer to nature than Early Gothic and treated in richness and profusion. Then came the Perpendicuour own classification. The term "Transitional lar Gothic, arranged with more fixed geometrical rules Gothic" as shown by Sharpe is the same as "Norman," applied by Rickman. "Perpendicular" and "Flamboyant" are one and the same. The classifications are as follows:

SHARPE.

Romanesgue: Saxon, 1066 A.D.; Norman, 1066 I I $45 \mathrm{~A} . \mathrm{D}$.

Gotilc :

Transitional,

I I45-I Igo A

D. ; Lancet,

I I 90-I 245 A.

D.; Curvi -

linear. I245-

I 360 A.D.;

Rectilinear,

$1360-1550$ A.

D.

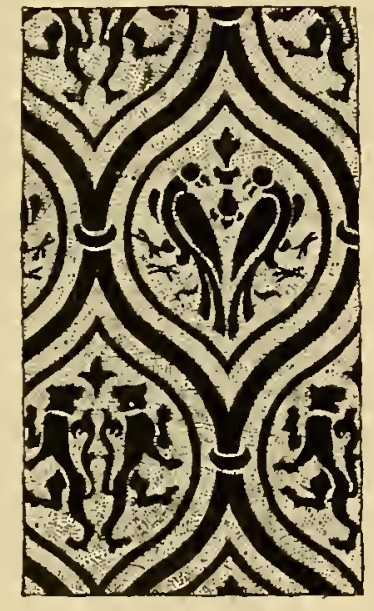

Group IV (G).

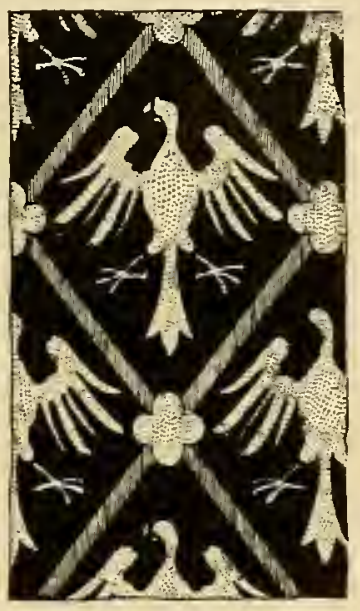

Group IV (G). of construction, and introduced as motifs we find heraldic forms, shields, badges and crests. The space to be carved was divided into rectangular or lozenge shapes and filled with ornament systematically.

At the time of the Norman conquest English houses were usually one room. A hole in the roof
served to carry served to carry

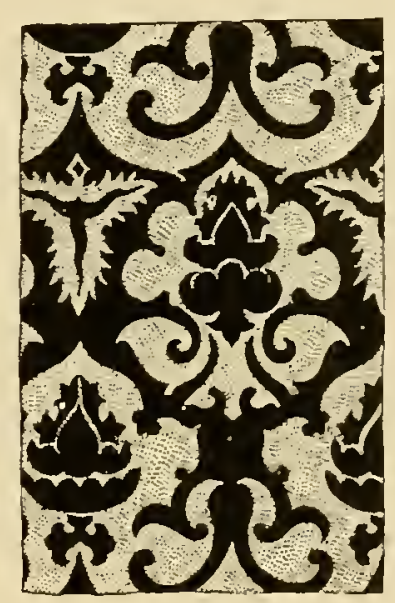

Group V. I I 89 A.D.; Early English, I I $89-1307$ A.D.

Gotilc: Decorated, I $307^{-1} 379$ A.D. ; Perpendicular, I379-1 483 A.D.; Tudor, I $483^{-1} 546$ A.D.

$$
\text { DE CAUMONT (FRENCH). }
$$

Romanesque: Primordiale, 400-900 A.D.; Secondaire, 900-I I00 A.D.; Tertiaire, I I00 A.D.

PoIntFo: Primitive, I200; Secondaire or Rayonnant, 1300: Tertiaire or Flamboyant, I400 A.D. out the smoke
from the fire.

and indeed

man y houses

lacked chimneys in England as late as I 500 .

The tables used were mere planks on trestles.

Chests were common articles of furniture, and may be divided into three classes, which are defined as follows:

First, the chest of the Early. Gothic following the Romanesque stylc banded in iron more for strength than ornament.

Second, the chest heavily banded in iron and painted. These wcre common during the Thirteenth and Fourteenth Centuries.

The third type began with the Fifteenth Cen-

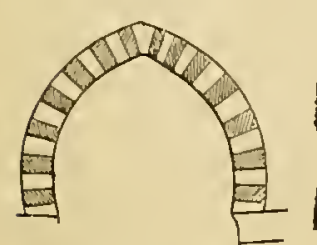

Arabian.

[55]

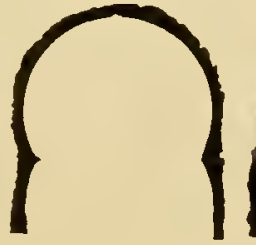

Moorish.

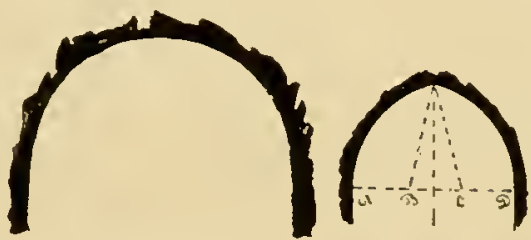

Romanesque or Early English. round-head Gothic

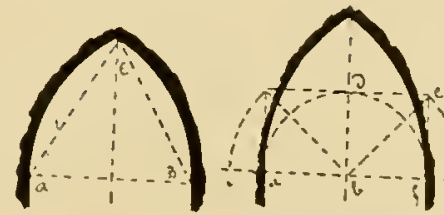

Perpendicular.

Lancet.

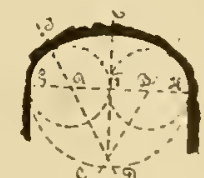

Tudor. 


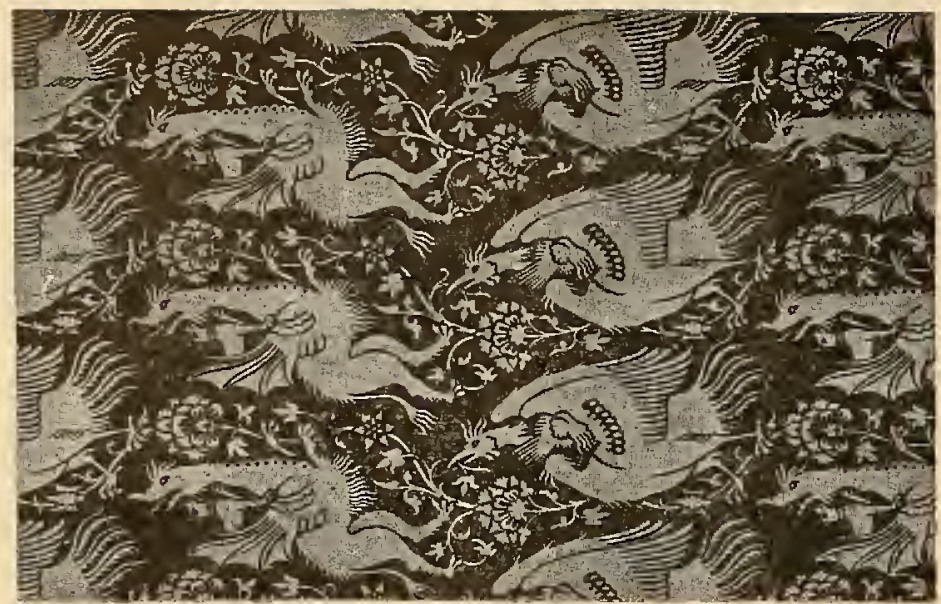

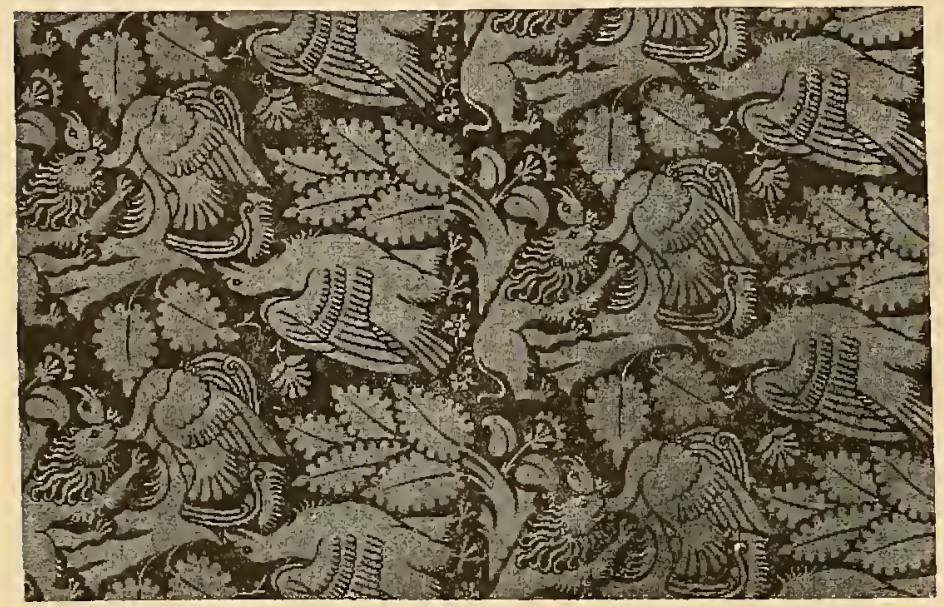

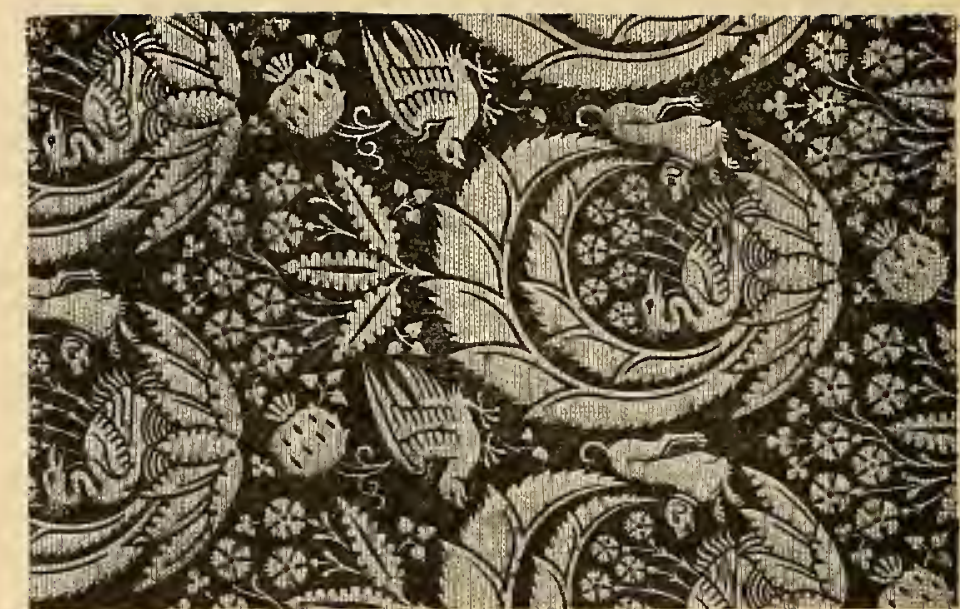

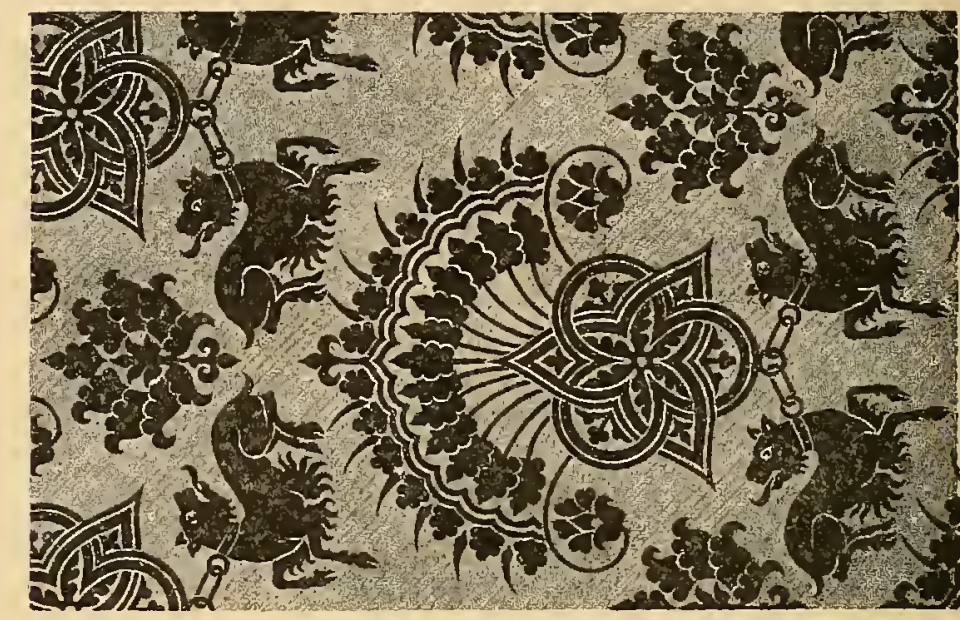

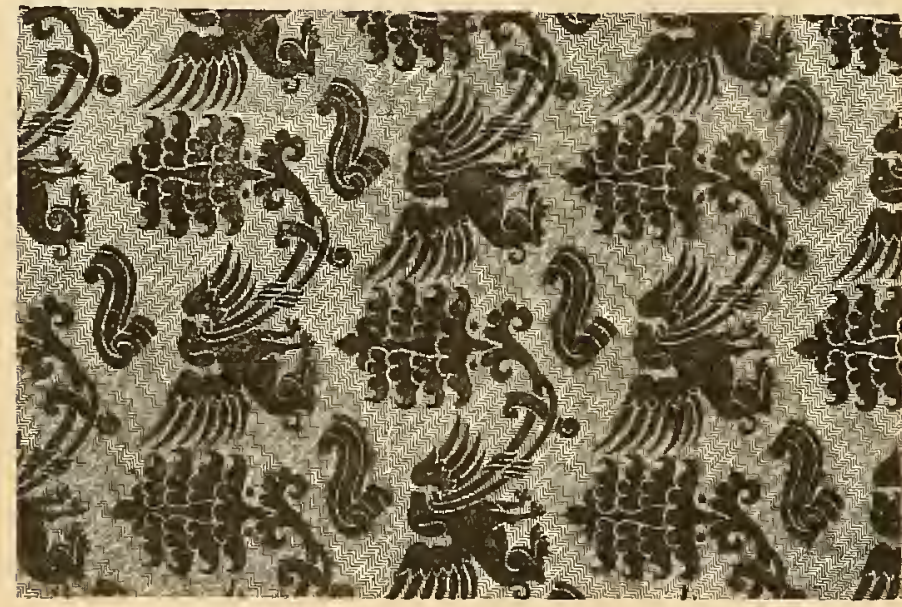

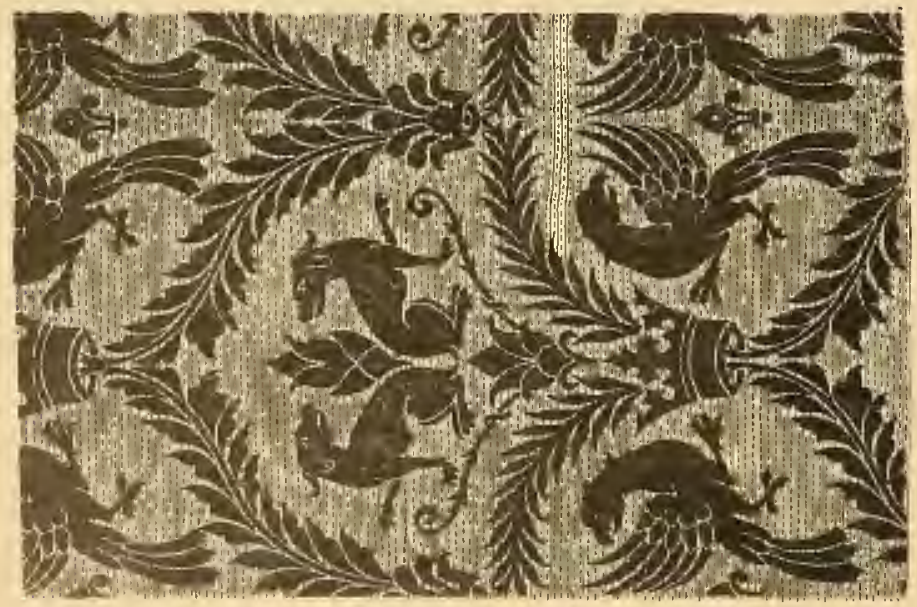

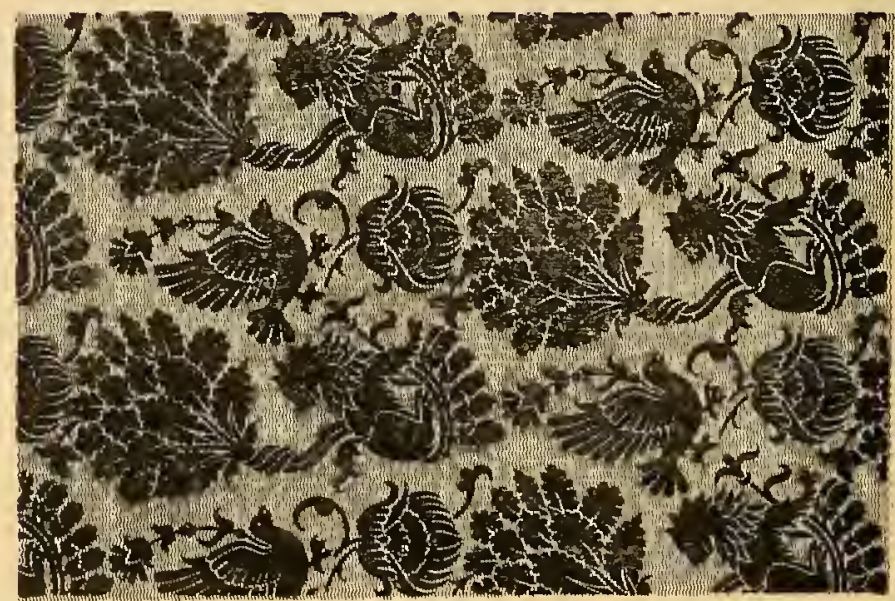



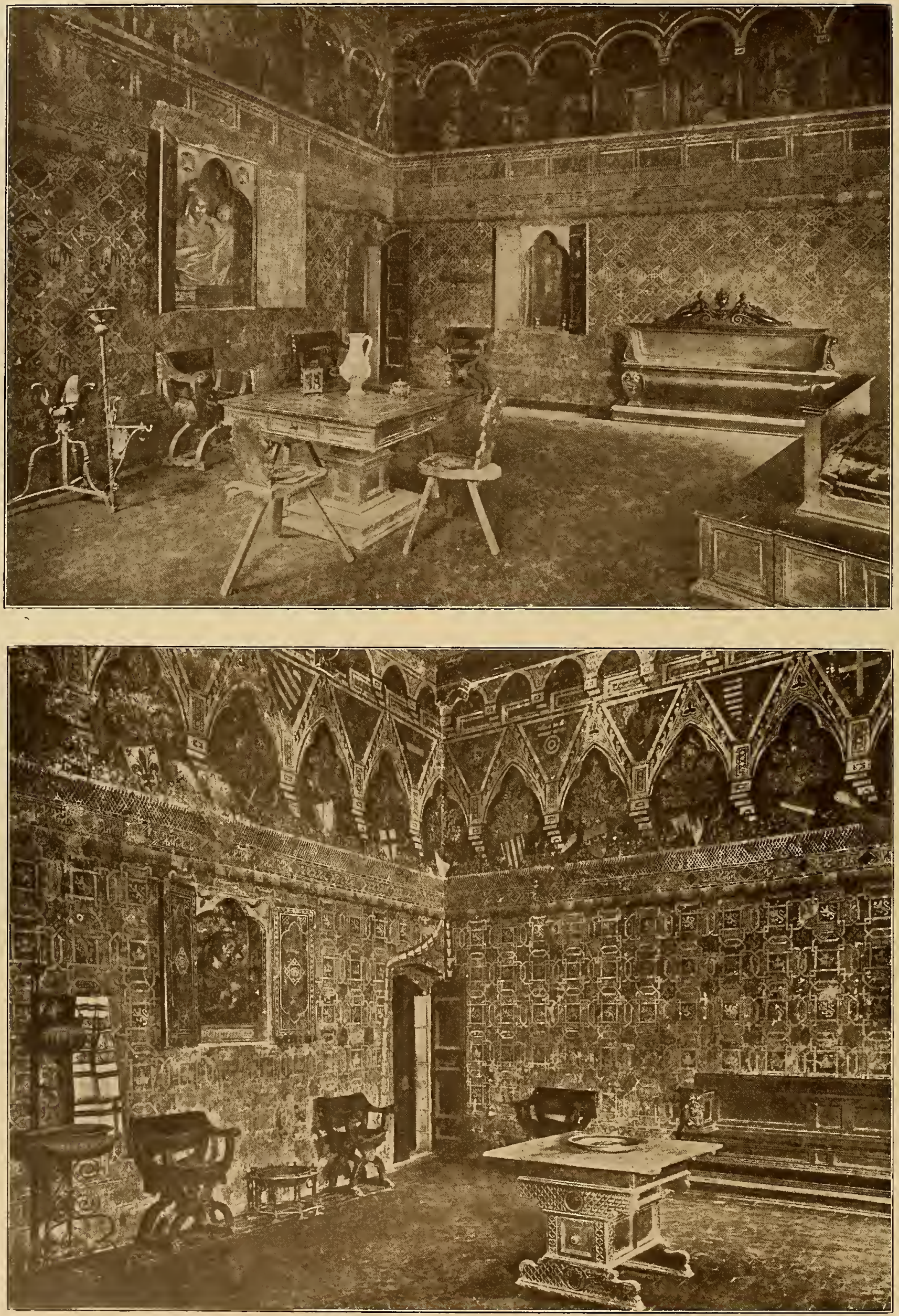

A Fifteenth Century room in the Volpi Vusenm, Florence, the first illustration showing round arch Gothic, the second illustration Transition Gothic. Walls of cosmatic mosaic introduced in the Thirtecuth Century by Giovanni Cosmato. Floor, tiles. Furniture Sixteenth Century. 
tury and was carved, following the architectural forms.

Beginuing with 1200 the walls of the houses were wainscoted and painted, often decorated with subjects romantic, biblical and traditional.

The very rich used colored glass windows; the wainscotings of the rooms being primitive were frequently lo ung with tapestries to check drafts.

Domestic furuiture was often painted in bright colors $\mathrm{or}^{-}$ rendered in tempera or wax. Cu p b o a rds showed Gothic details of simple character with perforated doors for ventilation, as food was of te $n \quad k e p t$ therein.

In 1400 the lower-floor room of a house was a combination dining-room and bedroom. The furniture consisted of a table, a long bencl (with canopy called a dossier) seating $\mathrm{four}$ persons, a standing cupboard, a bed with heavy curtains at the foot, two buffets, a table for holding toilet articles, a few stools and a pric-dicu. The floor was strewn with rushes, or

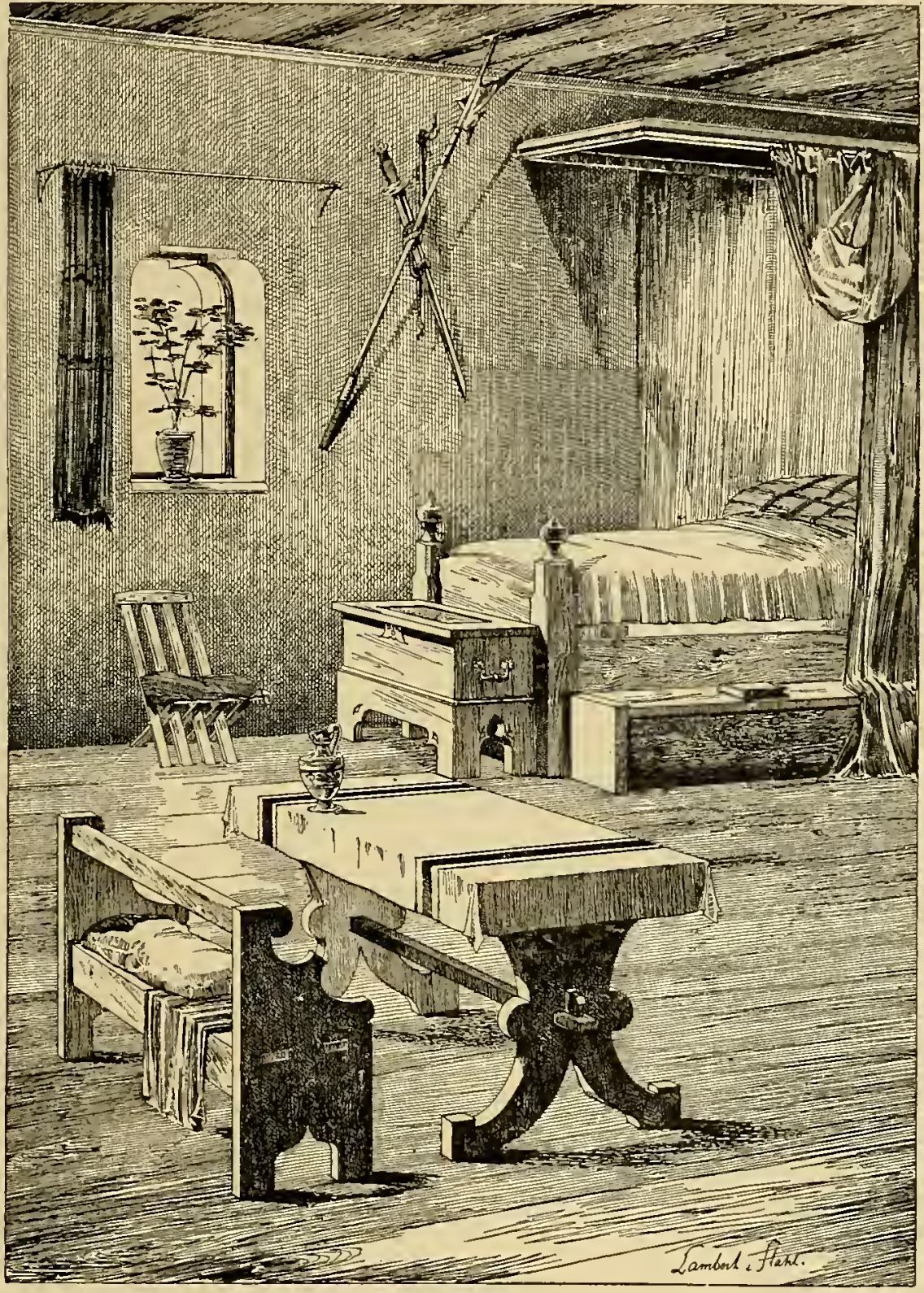

German, Fifteenth Century. room combineel, furnished with a long table, and dussicr.

Chests, benches and settles with occasionally an in dividual chair, a buffet, a side table, sereen and onc of more cupboards, completed the furnishings.

'lhis furniture was primitive, drawers in tables not being introduced until late in 1400, nor was an extension table or a table with added leaves in use prior to I 500. The chest was a favoritc piece of furniture. In the Royal presence it would have been a breach of etiquette to sit on a chair, but proper to sit on chest or coffer. Towards $t h \mathrm{e}$ middle of I 400 these chests became decorated with linenfold panels in the form of carving that looked like folds of linen. The linenfold pattern was first used in screens in the churches. Thongh Flemish in origin, it quickly became identified with Englisl.. It was carried well into the Renaissance and lasted from about - I450 to I550. Towards the close. bunches of grapes and profuse floriation were introducel.

TENTLE DESIGNS. carpets.

Clothing was kept in an adjoining room, while the bath was taken in a wooclen tub drawn up to the open fireplace.

About I 500 the large hall of the house was the general sitting-room, reception-room and dining-
TIlE terms Gothic, Saracenic and Renaissance are laxly applied.

In architecture and woodcarving. Gothic for example, defines an accurate development, but the fabrics used in Gothic environment. even fabrics woven in Italy, Germany and France, have little Gotlic signifi- 


\section{1.}

20130

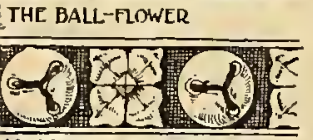

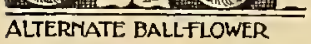

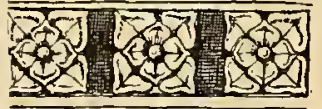

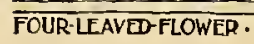

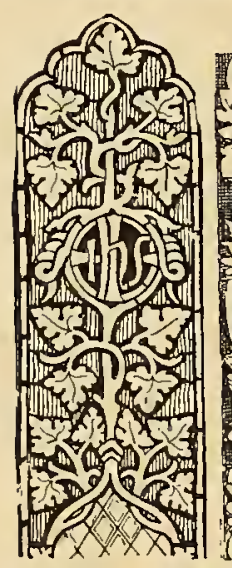

(2)

(

Fis

(t)

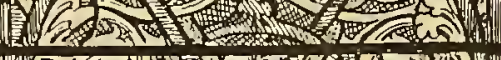

(1) (4)

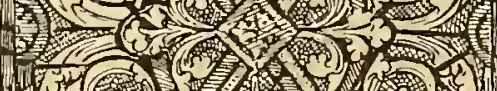

(tas)

113 , of

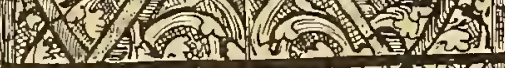

(1)

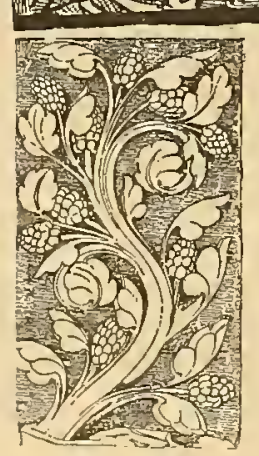

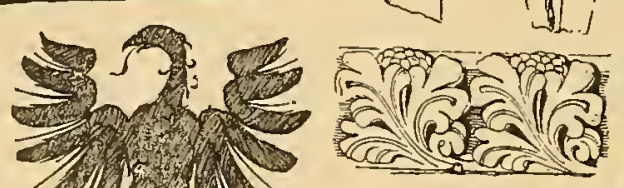
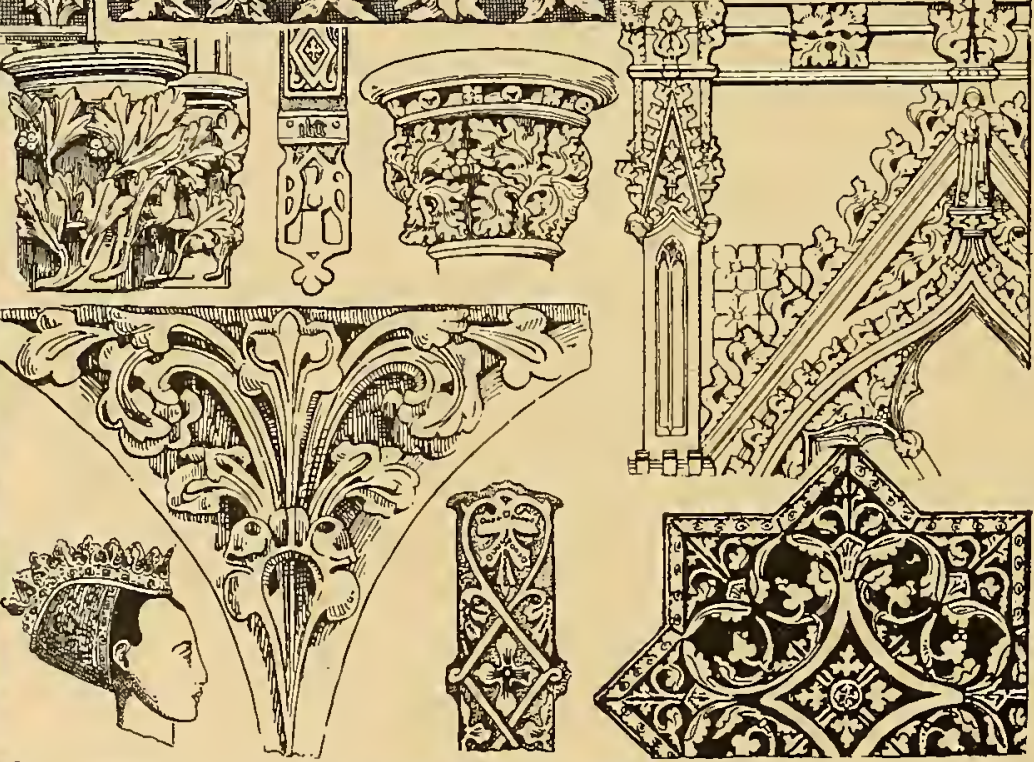
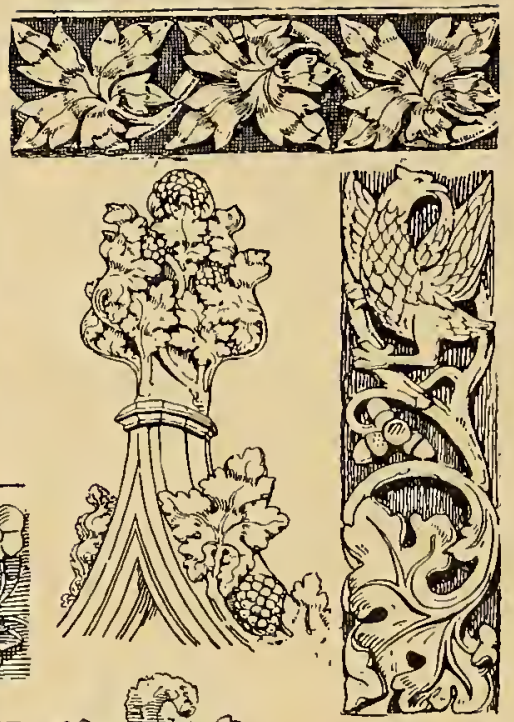

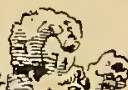

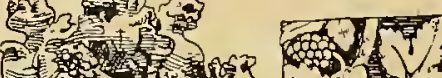
1) 1. 1 (1) की win 1 s. in sestre $\overline{1}$
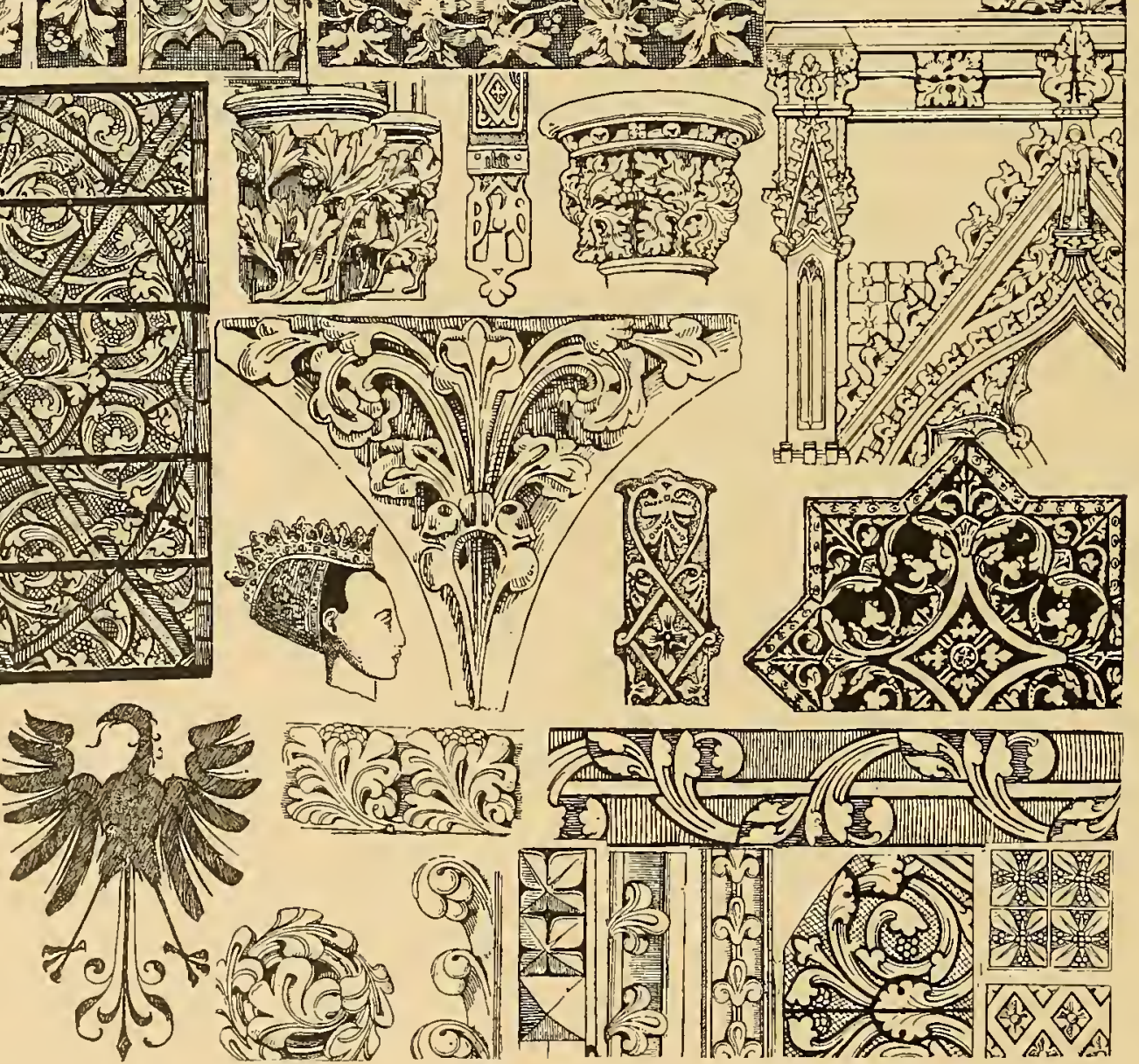

EARLY ENGLISH GOTHIC II89-I307.

To this floral form is added, in ecclesiastical work, religious symbols, the Circle, the trefoil, quatrefoil, triangle, crucifix, 


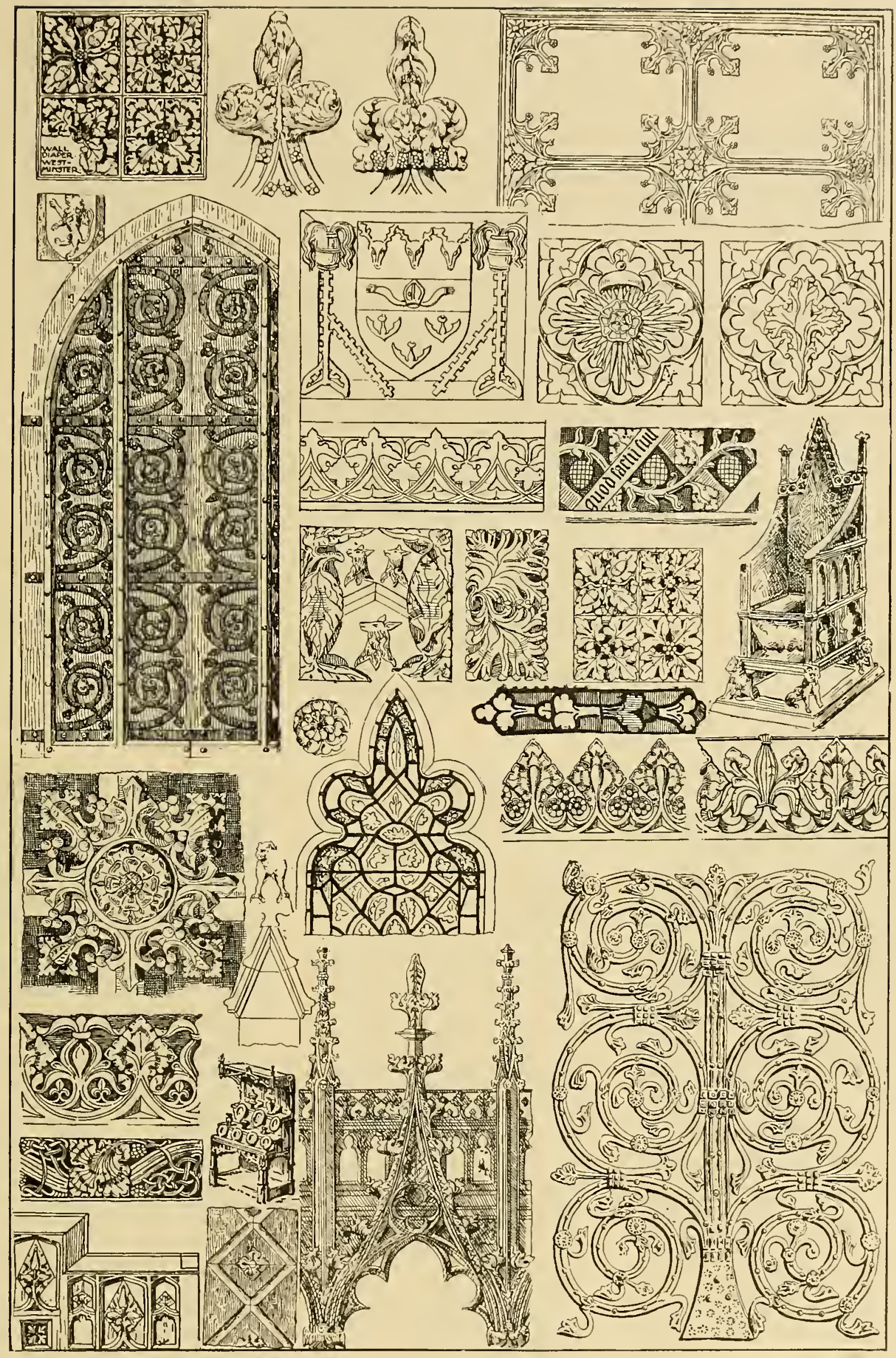




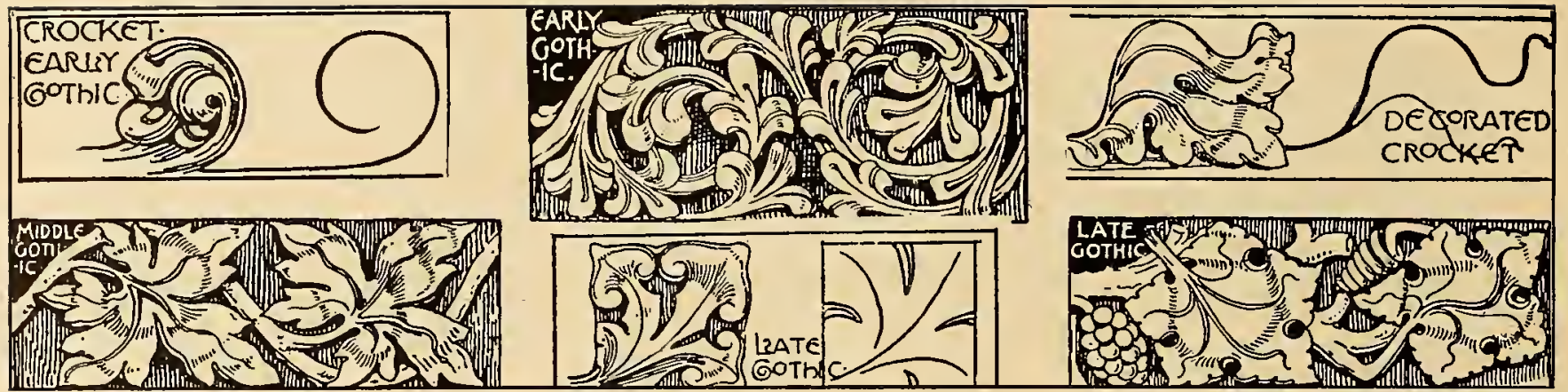

cance. Throughout the European countries dominated by Gothic feeling, weaving was strongly influenced by the Saracens. In lower Italy, Sicily and Spain this fact is obvious; the weavers perpettrated in their arts the Saracenic style long. after all traces of the Orient had been obliterated by architect and sculptor. The traders of Flanders and Italy, up to the fall of Constantinople were active in the importation of Oriental stuffs, which served as a stimulus for European workmen.

It was not until the Ital

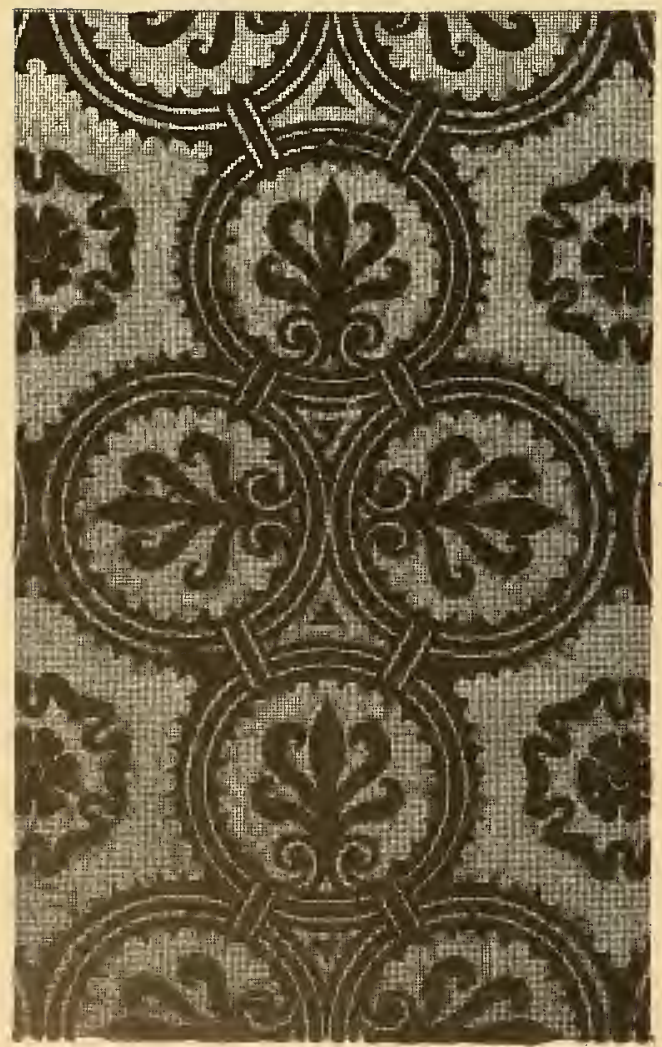

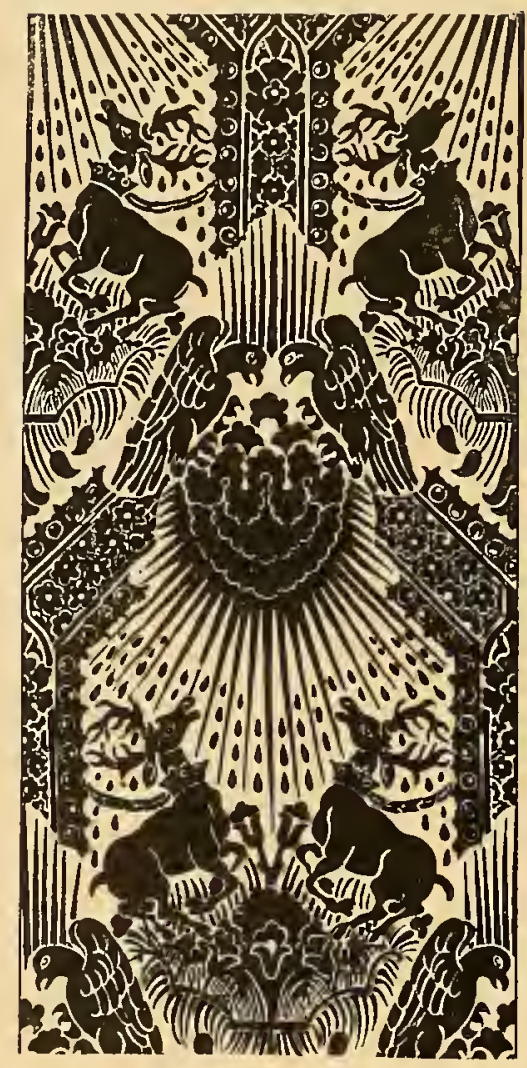

North Italian, 1200. ians and French had practically lost their Oriental commerce that they turned their attention to home manufactures; and not until this condition arose, were designs produced, consistent with the character of the prevailing arts.

The acanthus forms were taken as motifs.

The Anthemion was generously utilized, as well as fleur-de-lis. Laurel leaves and wreath shapes were adopted, and toward the end of the Sixteenth Century European flora, crowns and urns were a common source of inspiration. (See page 7т.)

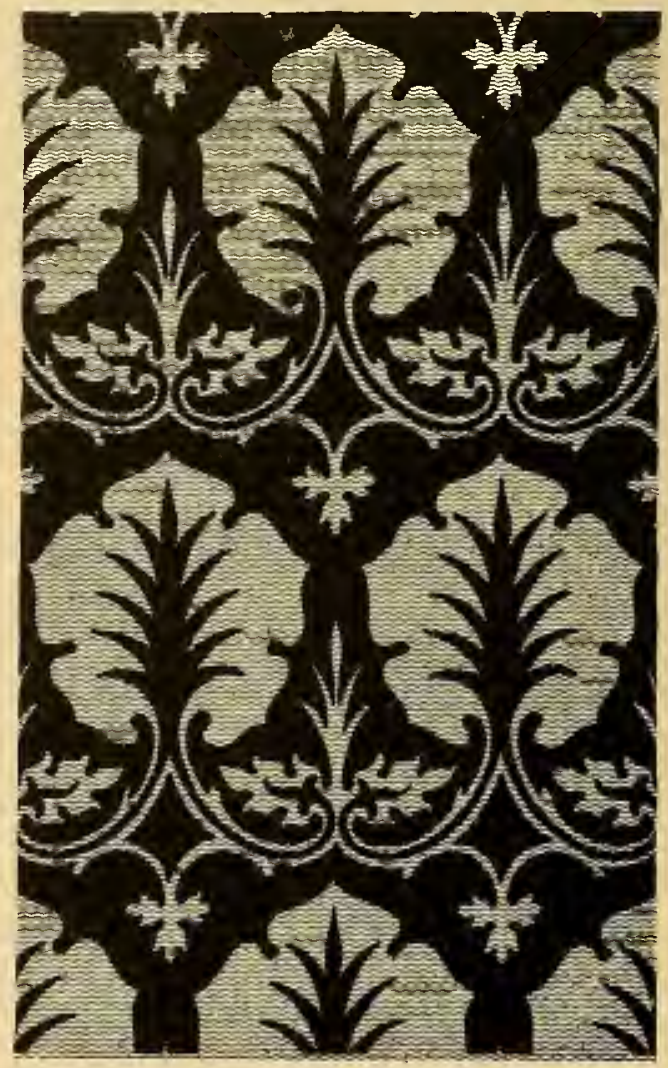

I400. 


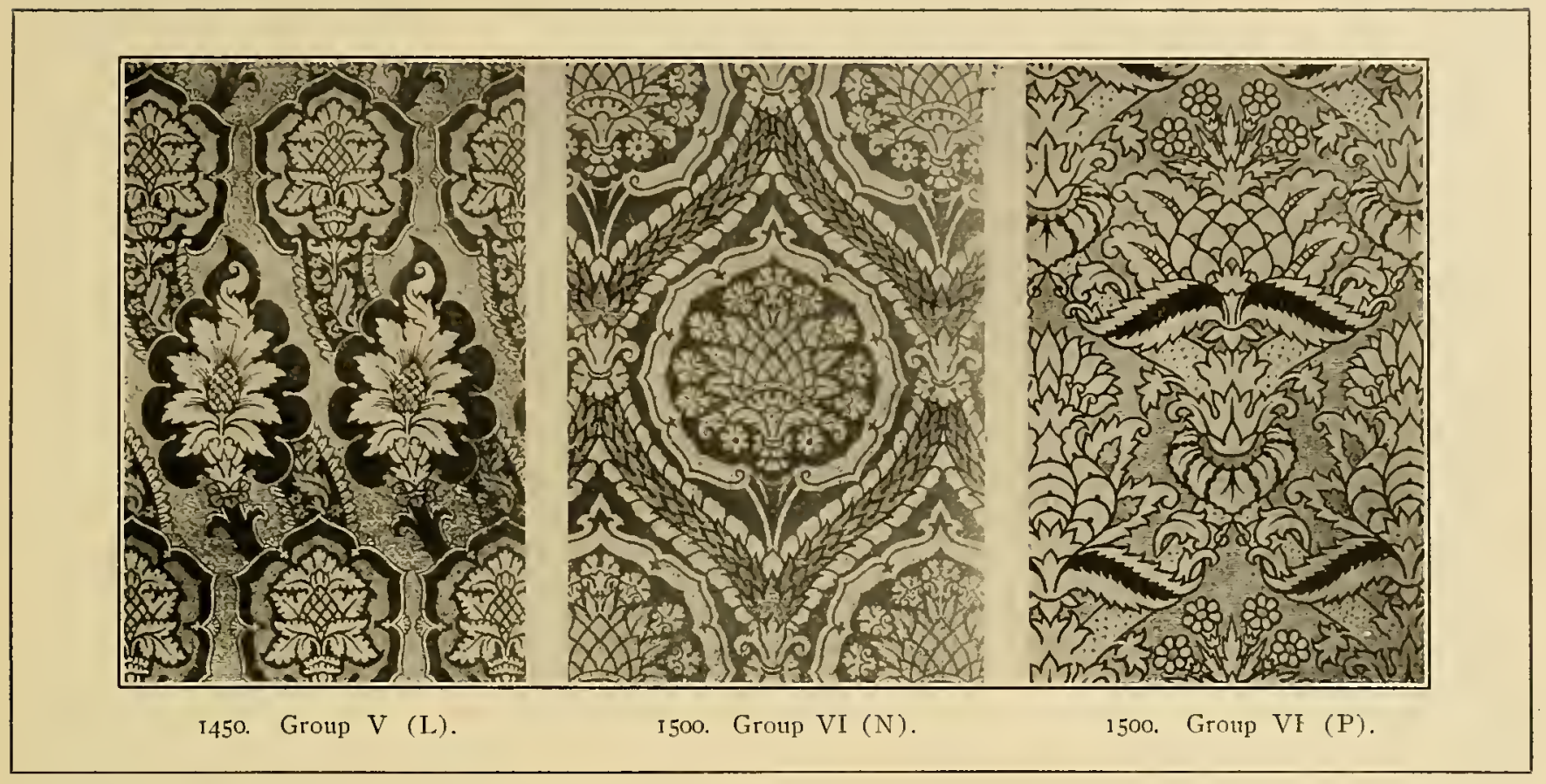

Late English Gothic developed finally the style known as Tudor (Tudor Gothic), the arches of which were low and squat instead of angular. The panelings showed linen-fold effects and the

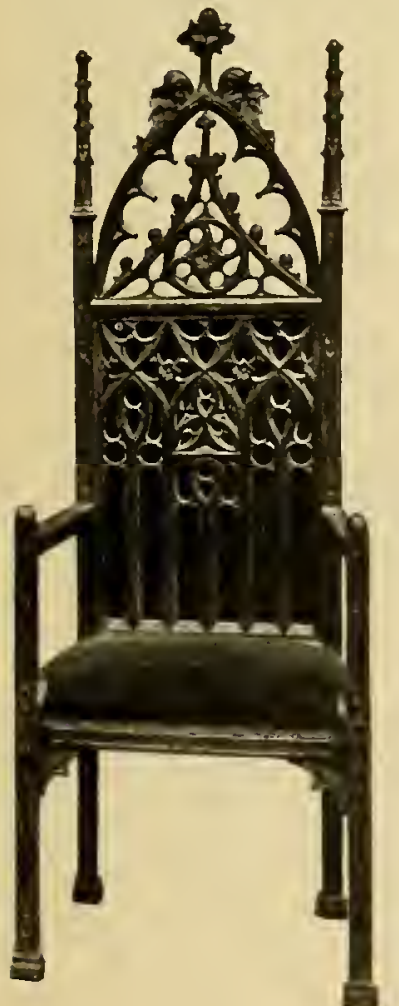

Late Italian Gothic. tops of the folds were often elaborated by floral details. Outside the ecclesiastical forms, leaf motifs were the predominating Gothic characteristic. Where the work had religious significance the design liarked back to the Byzantine, Romanesque and Celtic. Thus in manuscript decoration of even a later date we frequently note the pea and pea-tendril types, the penman funding special opportunities in the elongated siveeps of the vine.

FRENCH-French architecture was bold and elaborate showing doorways enriched with statues. As a rule the floral leaves were rounded and more full than the English leaves. Clustered pillars were almost 11 known in France; observable in Germany and England.
Netherlands-Tyrol-The arts of the Netherlands were influenced by France and Germany. Wrought iron decoration in leaf and plant form was popular. Tyrol Gothic, a type simple and effective, generously utilizing the work of the wood carver.

Germany-Although Germany followed Late-Gothic tendencies, it was not until $135^{\circ}$ in possession of an established style. It followed the vertical more than any other and at an early stage developed a fine system of strap work in metal, in which Gothic lines were closely followed. The use of birds in conjunction with leaf forms was common and twisted spirals and faces and armorial details were often used.

Gotilic FABRICS.

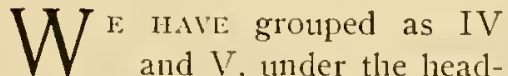
ing, "Development of Mechanical Textile Design," page 64, all that may be regarded as contemporaneous with Gothic. Group IV representing fabrics between 1000 and I350. Group $\mathrm{V}$ between $\mathrm{I} 350$ and 1500 .

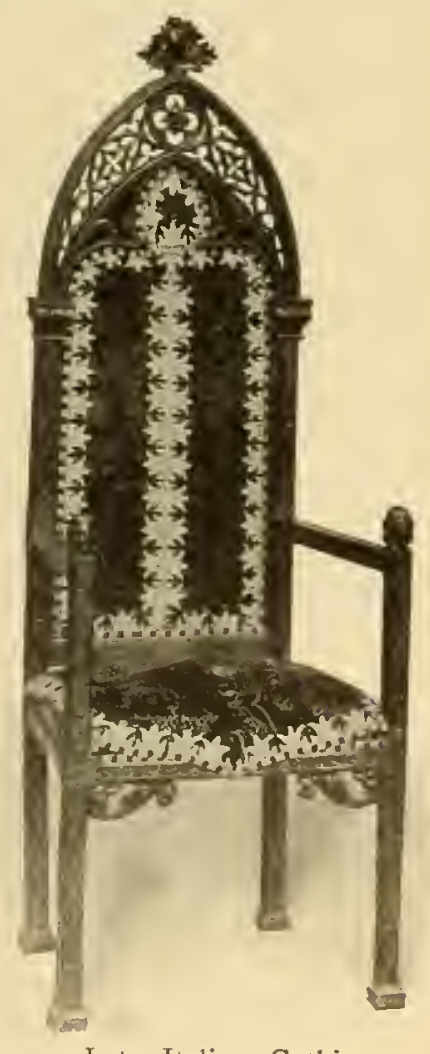

Late Italian Gothic. 


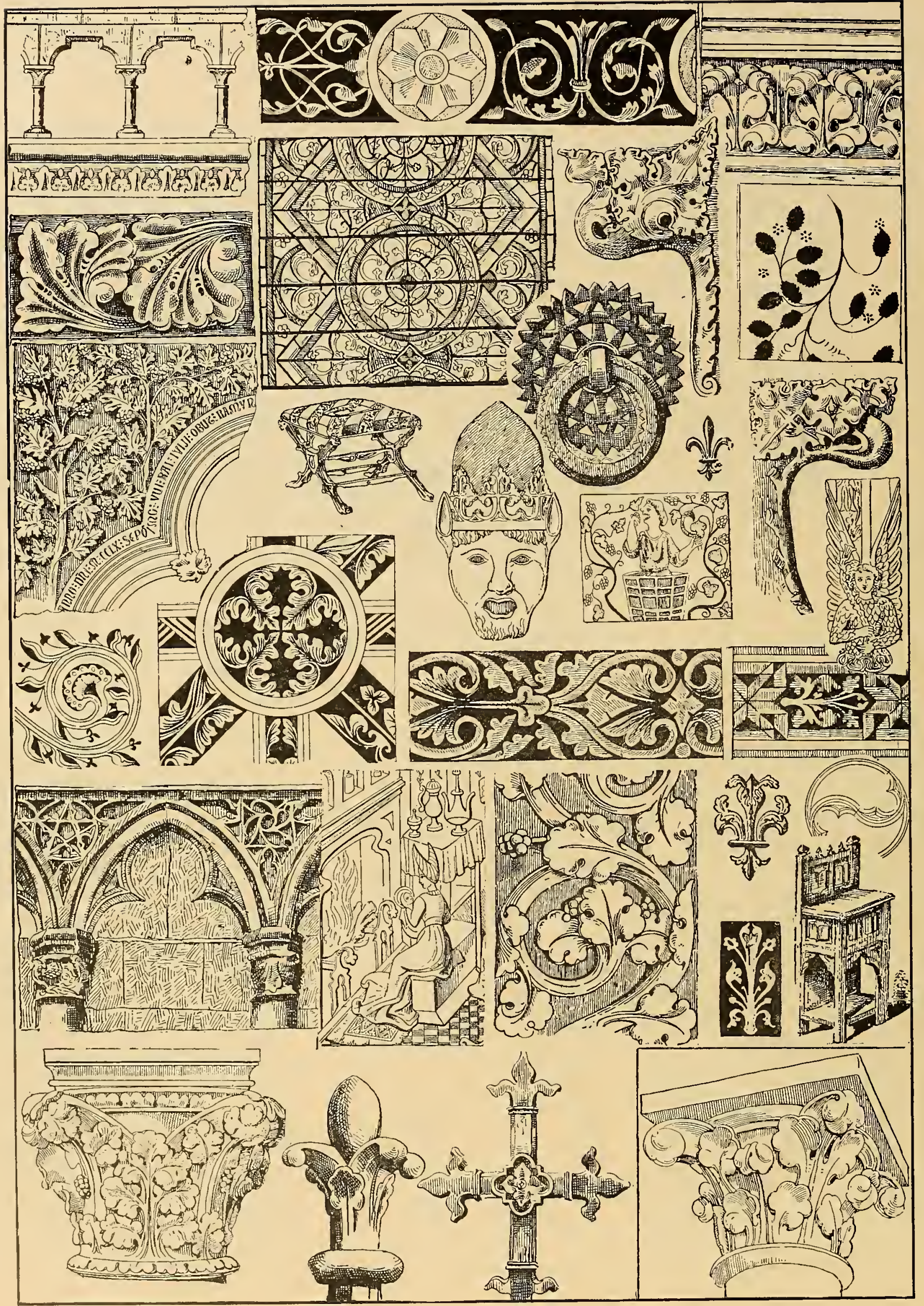

F R N N H G O TH I C. 


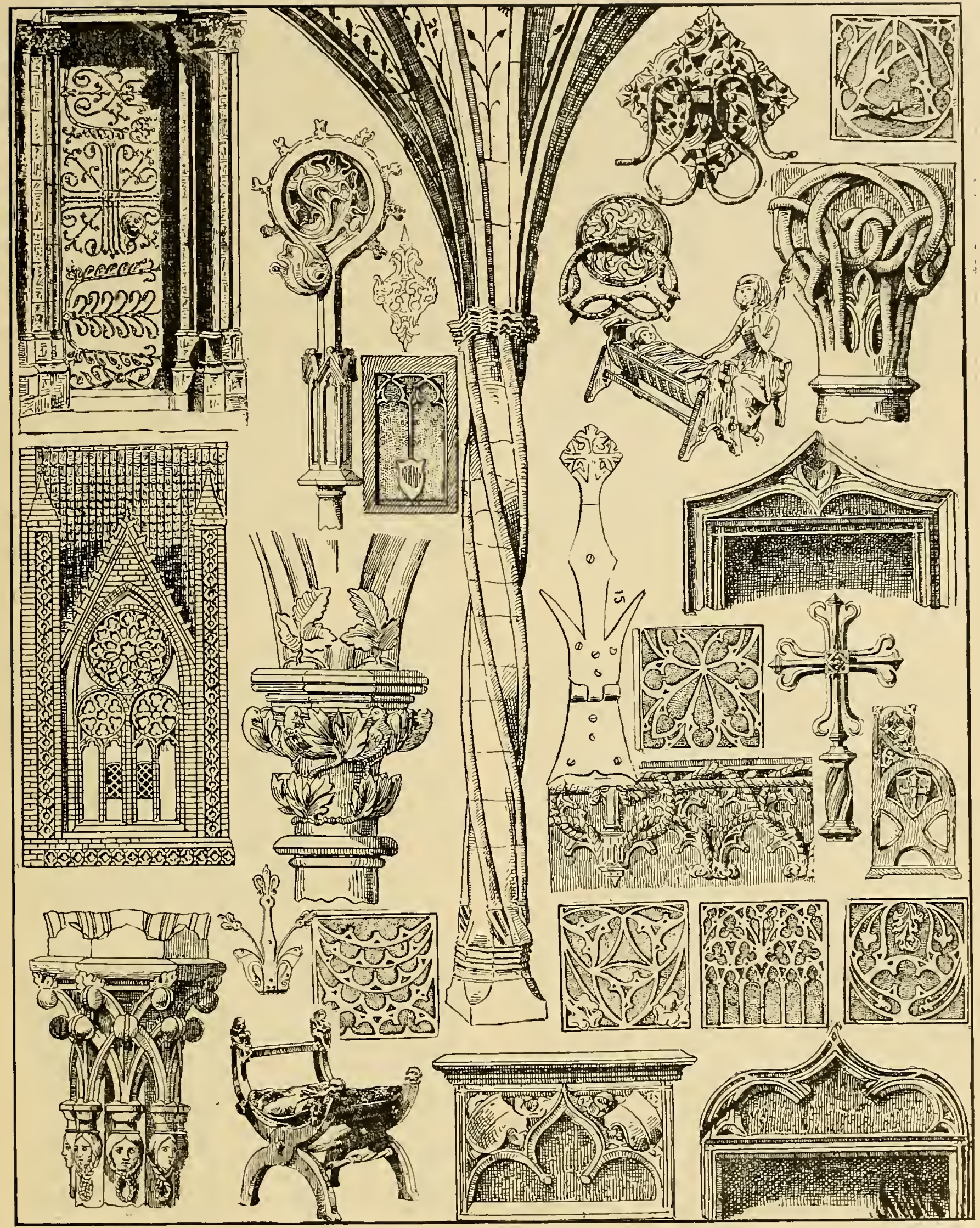

GE R A N G O T H C. 


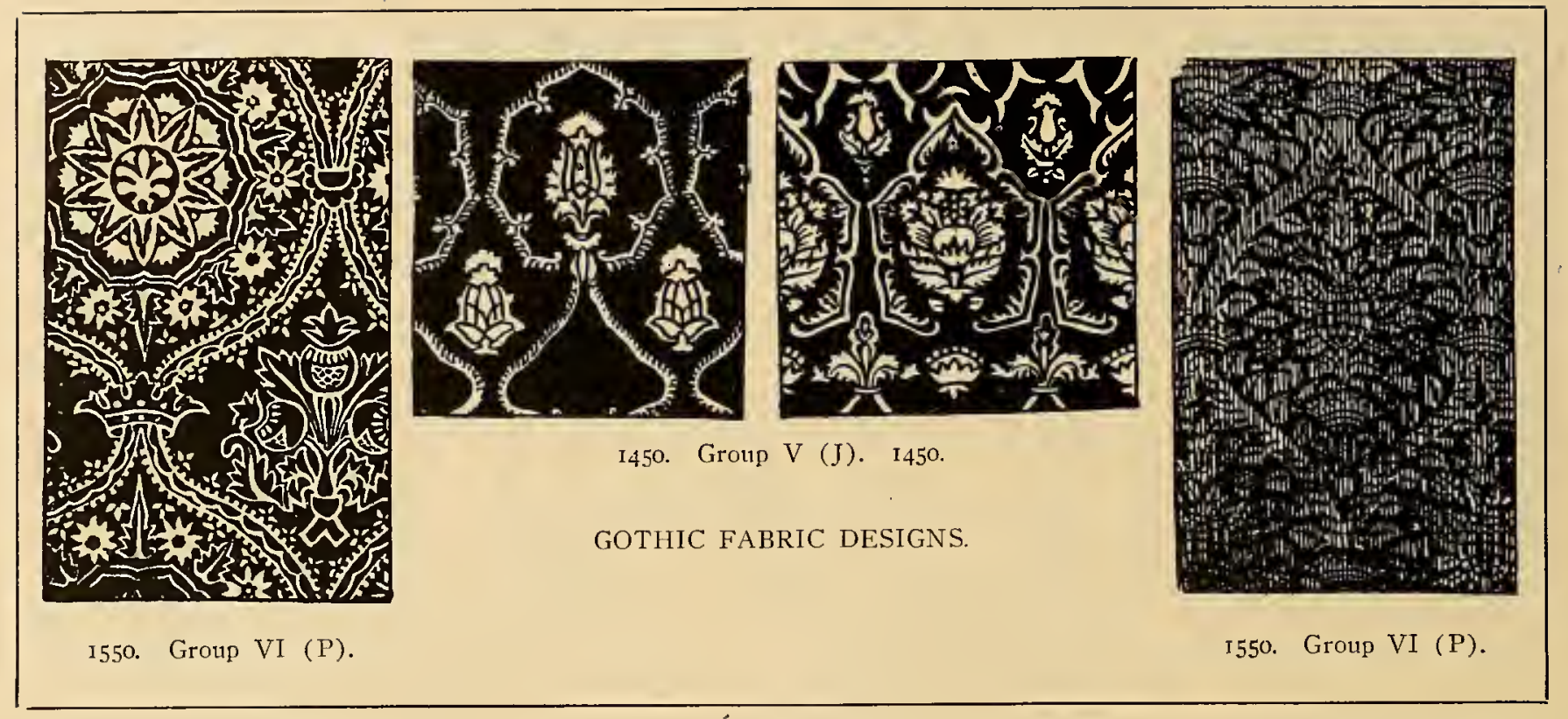

\section{THE DEVELOPMENT OF MECHANICAL T E X T I L E D E S I N}

E HAVE traced the subject through three dis-
tinct stages up to I IOO A.D. See page 34.

In 1000 A.D. Constantinople, Corinth, Thebes and Athens practically monopolized the making of fine fabrics. Towards the end of the Twelfth Century Flemish weavers began the manufacture of wool tapestries. France and Spain also undertook the manufacture during the Thirteenth Century. The Orient up to I 400 was famous throughout Europe for its fabric creations, the Crusades being largely responsible for the distribution of fine examples. European weavers copied liberally the Asiatic styles, and when in the Fifteenth Century the Ottomans conquered Con-

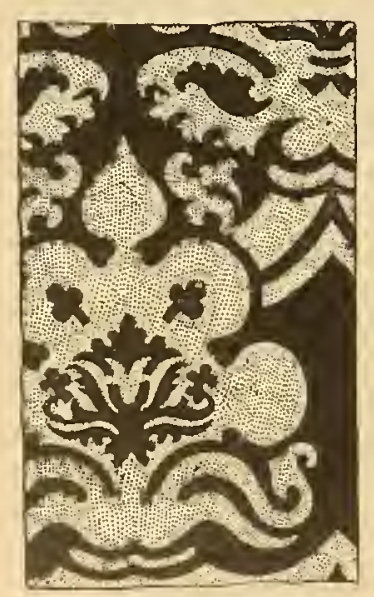

I500. Group VI (O).

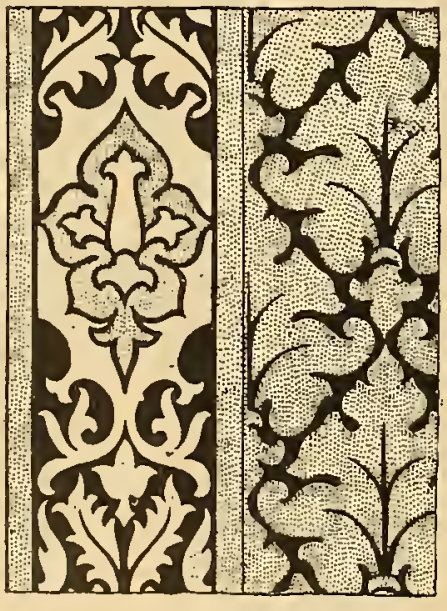

1400. Groutp $\mathrm{V}(\mathrm{J})$. stantinople, Orientalism was still further infused throughout Southeastern Europe.

200-400. Group I (A) The development of circle and geometric frames, sometimes filled with simple floral, bird or animal forms.

400-60o. Group II (B) The utilization of broken circles spread out to form bands.

600-1000. Group III (C) The use of circles linked by smaller circles, with ornaments inside and out, developing at length (D) the ogival form; often (E) hexagon frame work.

I000-1350. Group IV (F) Repeated parallel bands of ornamentation-detaclied details.

(G) Patterns animate and inanimate, enclosed

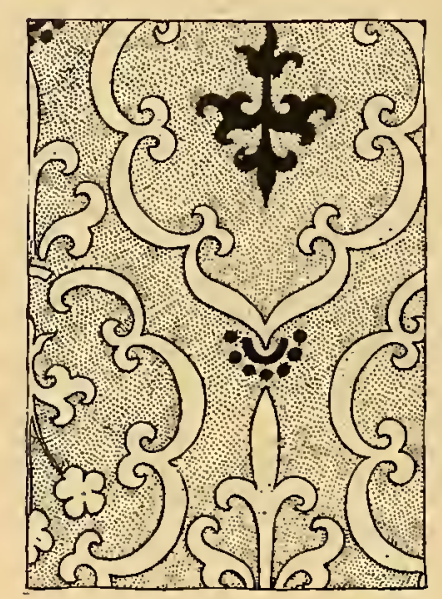

1400. Group V (J).

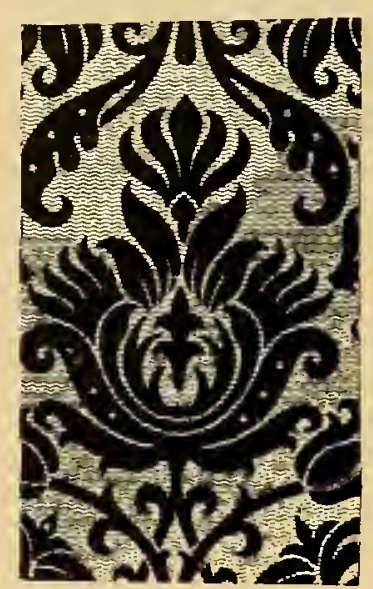

1500. Group VI (P). 


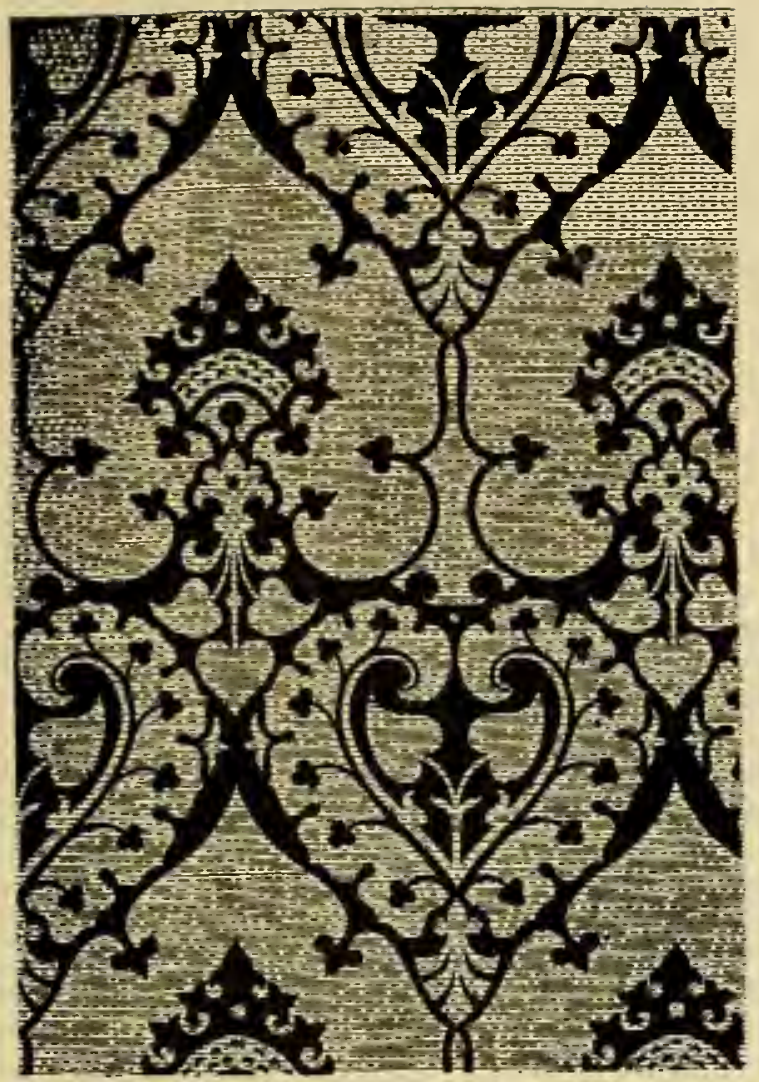

I500. Group VI (M).

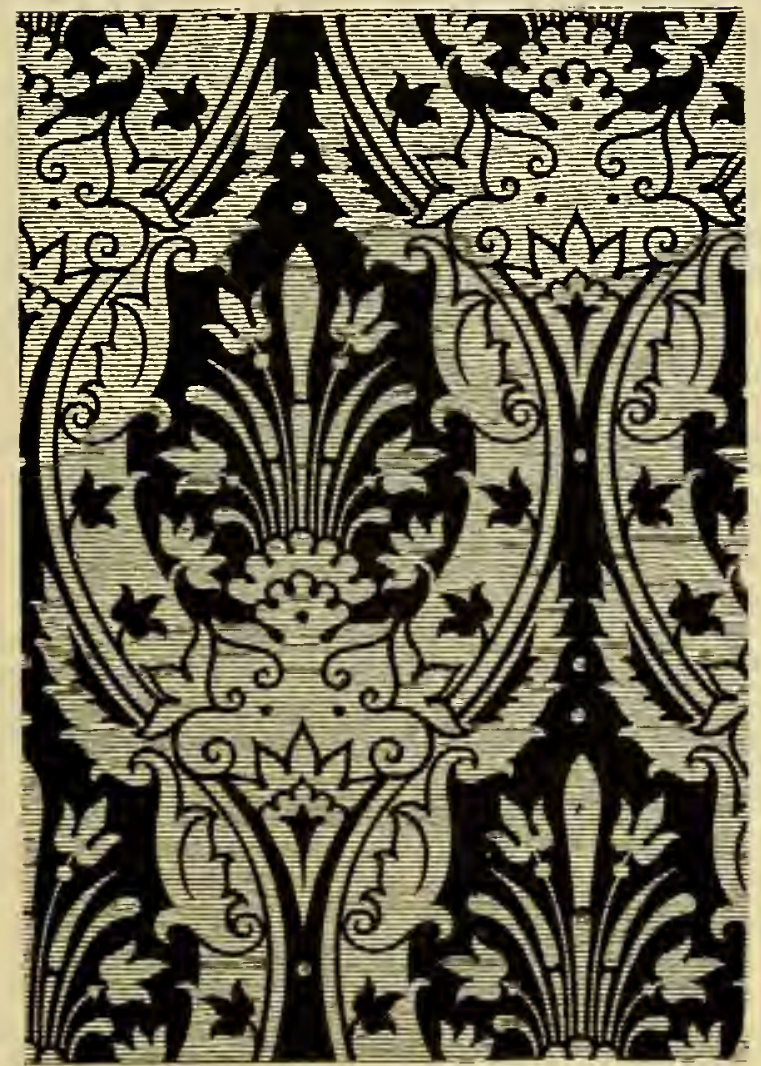

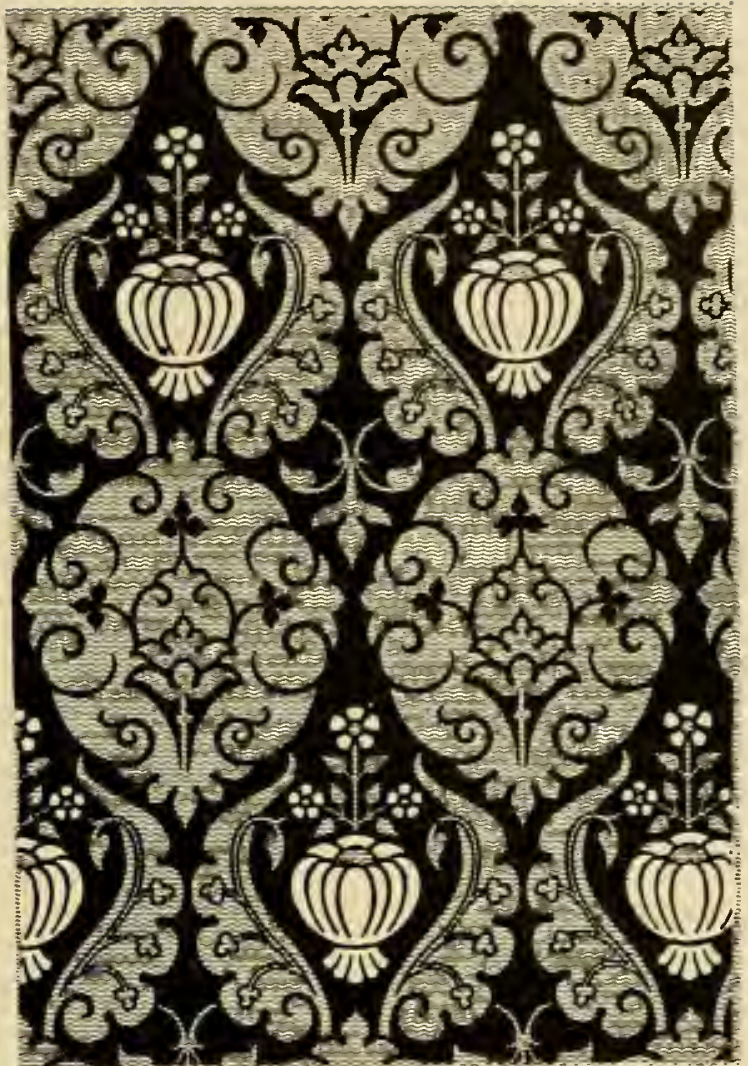

I500. Group VI (M).

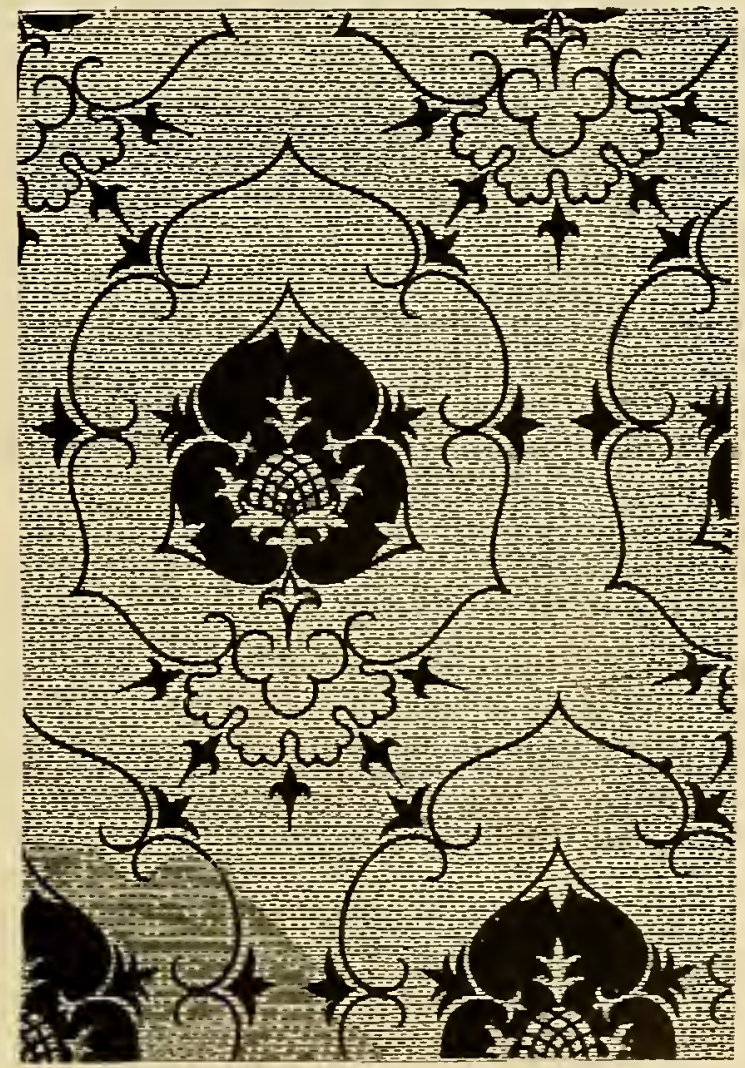

I450. Group V (K). 


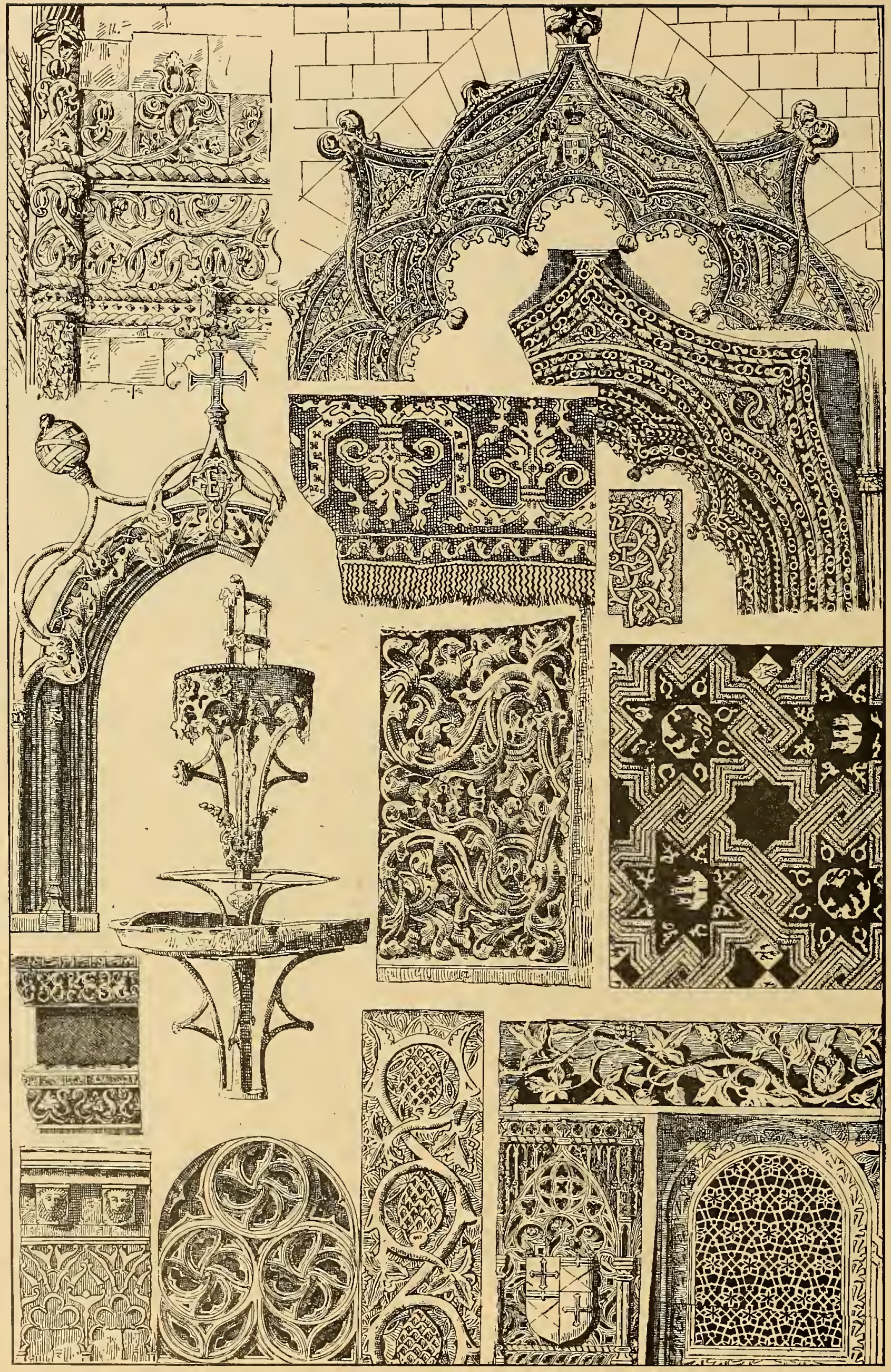

S PANISH GOTH I C. 

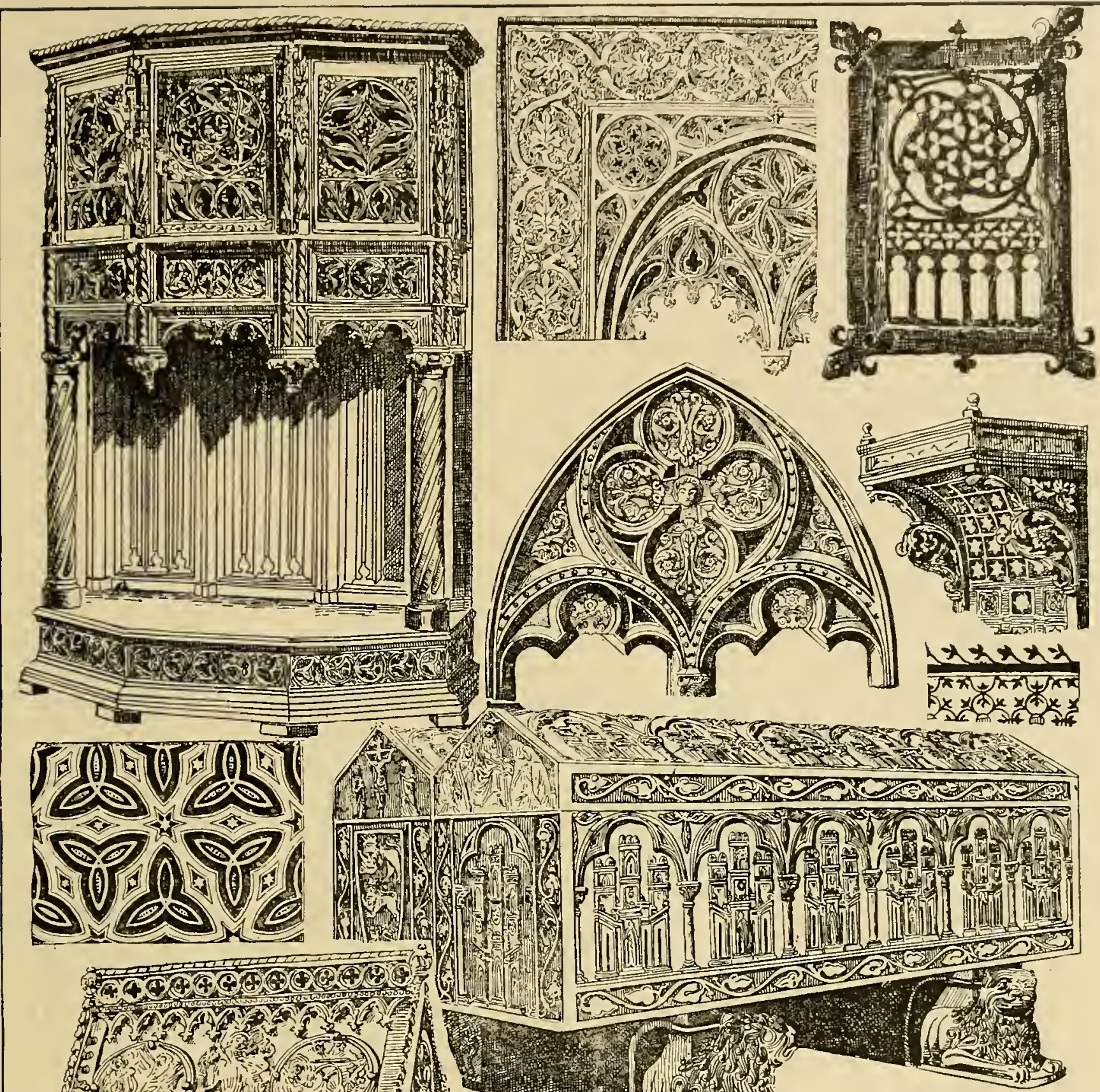

(10)
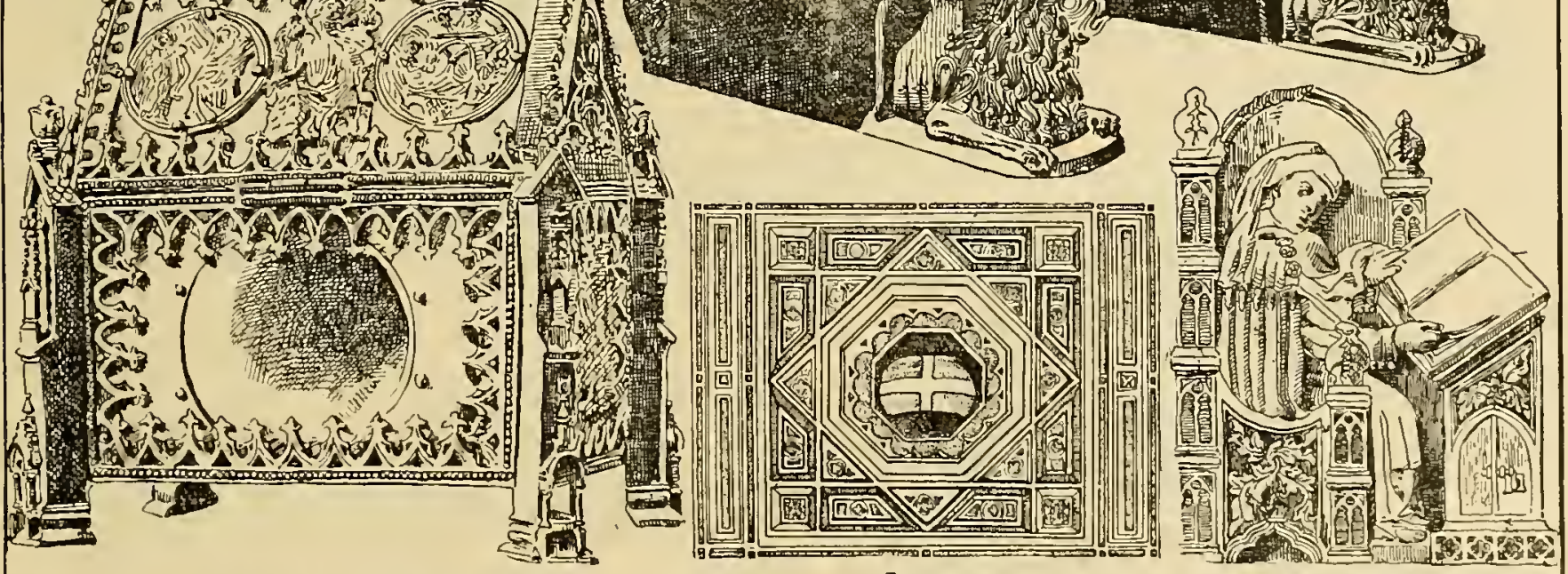

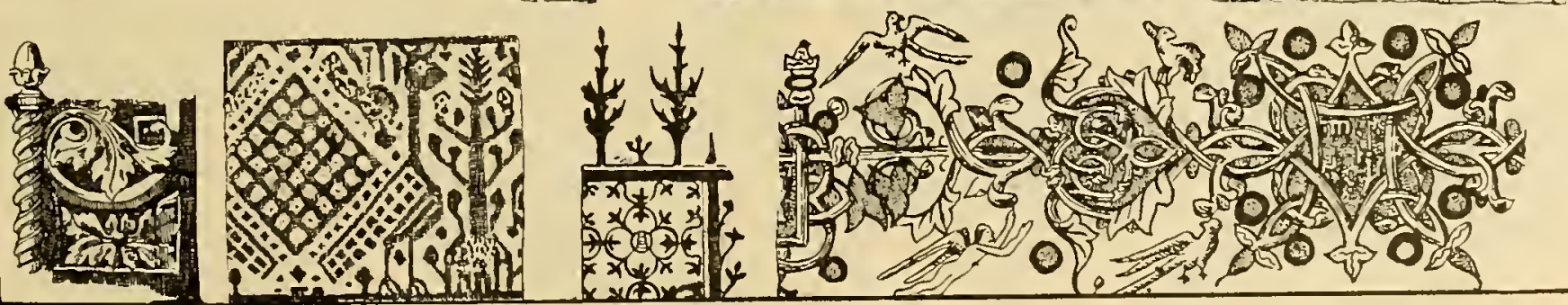




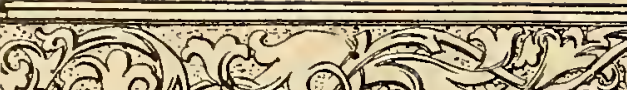

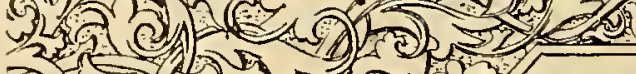

(10) (5) ans

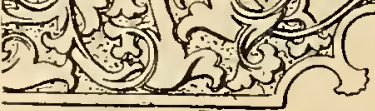

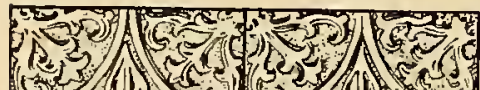

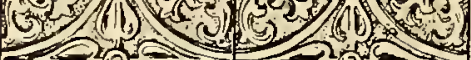

Po 60 (5)

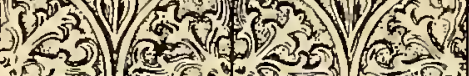

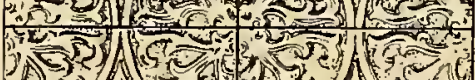

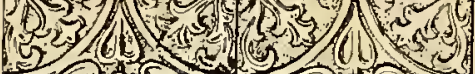

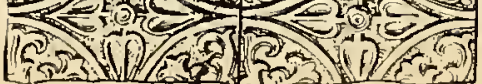
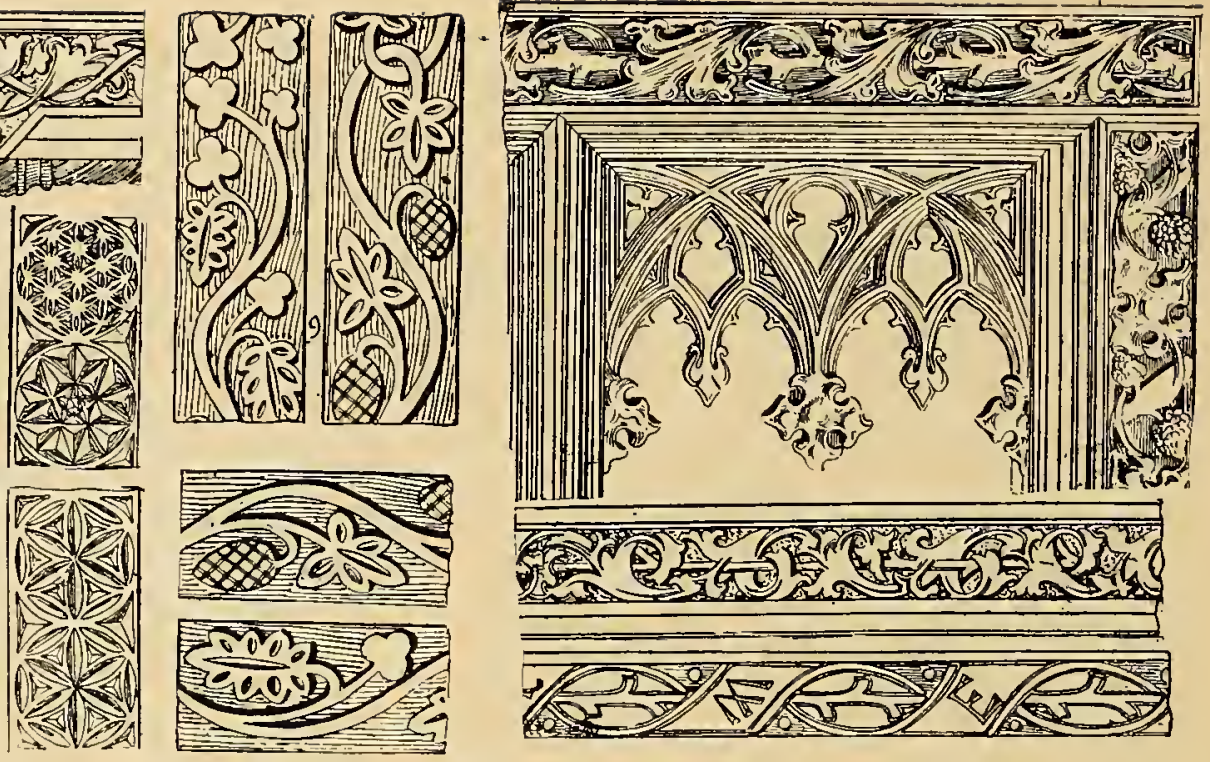

TYROL GOTHIC.
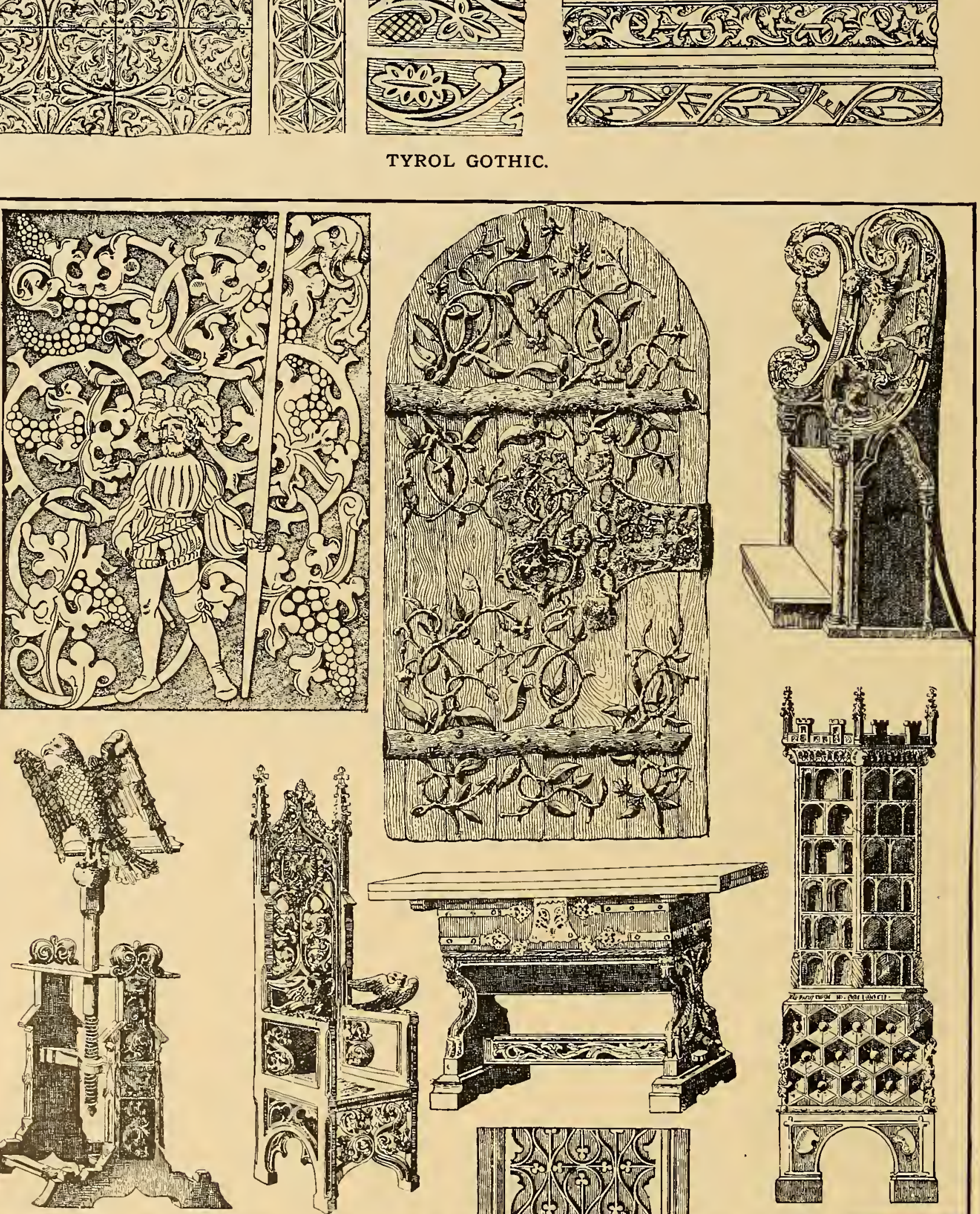


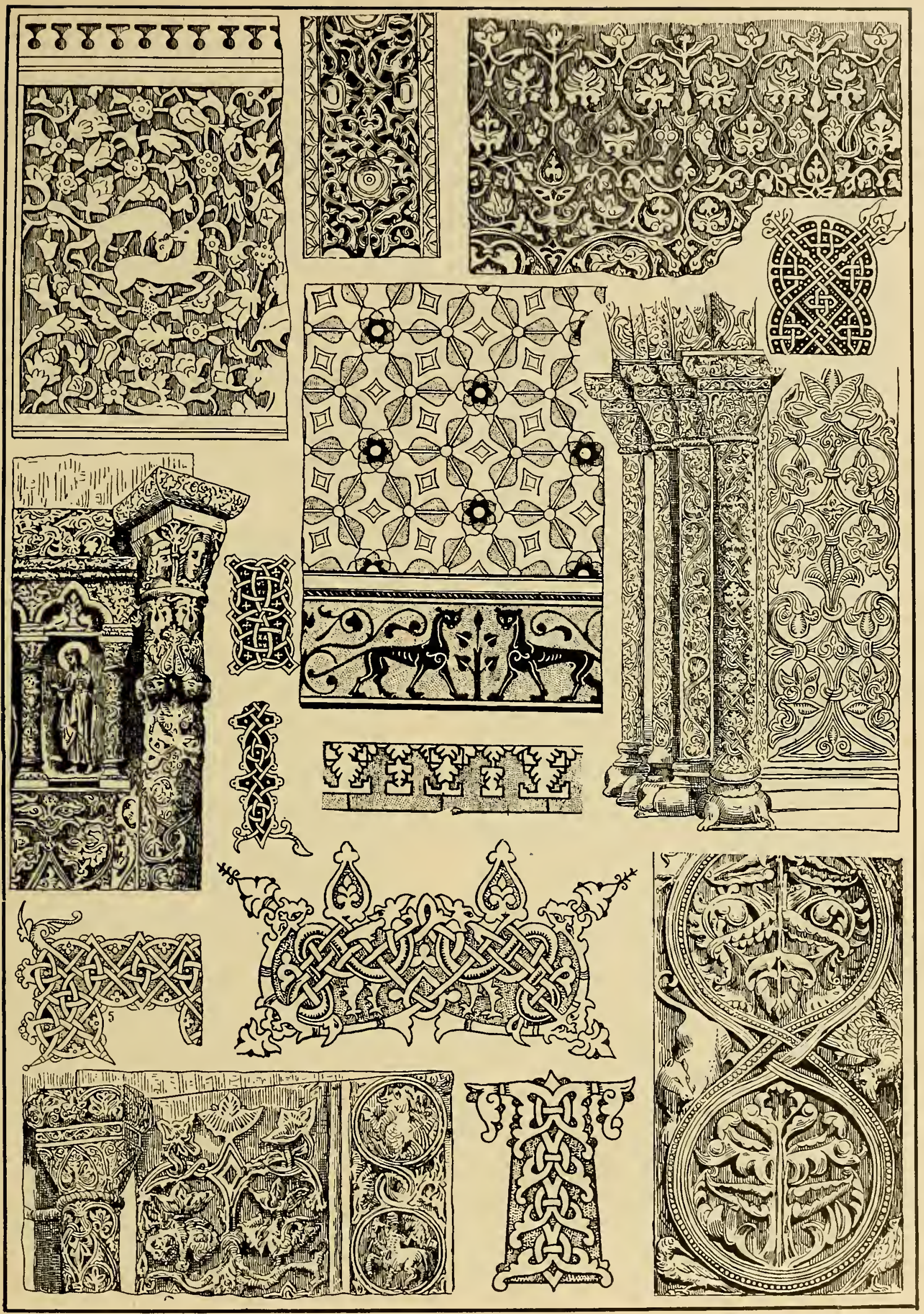




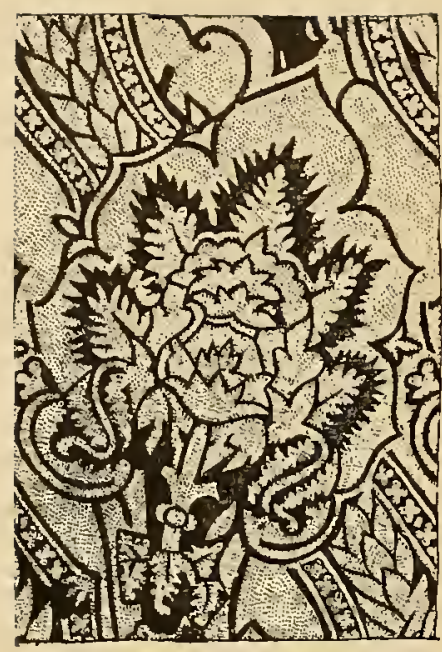

I400. Group V (L).

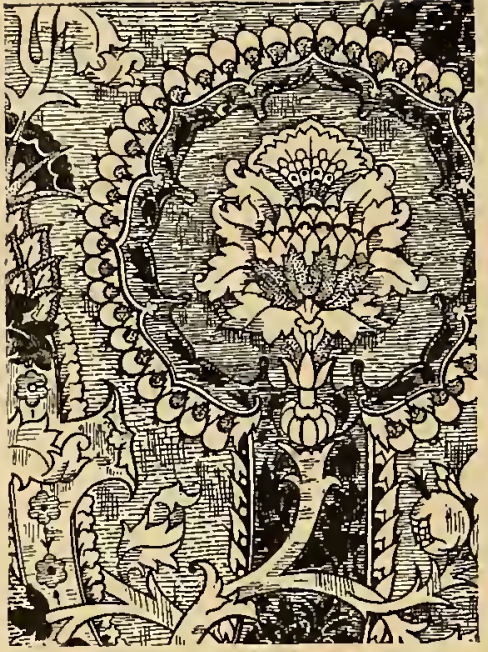

I400. Group V(L).

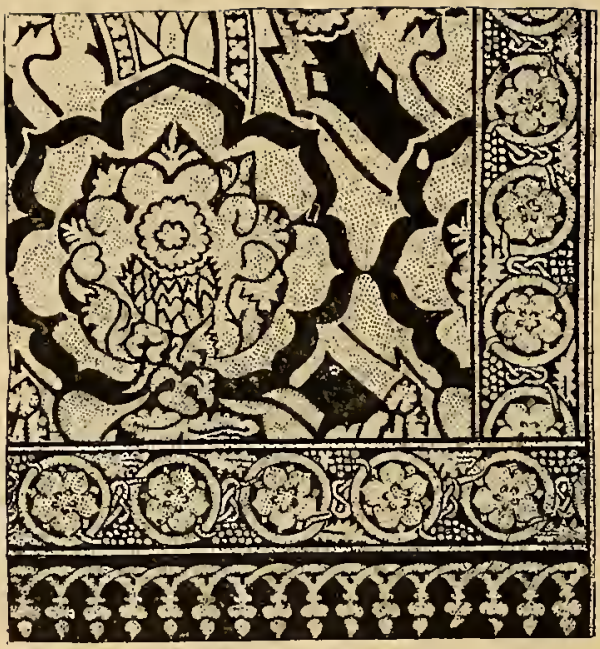

I400. Group V (L). in ogival framing and (II) combination circles or scale patterns as well as geometric straight line framing.

I200-I300 introduced as features of design (I) eagles, falcons, shields, hounds, swans, foliated crosses, crowns, rayed stars, lions, harts, boars, leopards, sun's rays and castle motifs, especially in the fabrics of Italy and Sicily.

I350-I 500. Group V. A characteristic design of the Fifteenth Century was the use of $(J)$ reversed curves so arranged that they made frames.

This form utilized the Hogarth line of beauty. ( $\mathrm{K}$ ) Another form was the intersection of a Hogarth panel by two bold curving stems coming up through the bottom of the panel and capped by a cone, pineapple or fruit device.

Still another (L) showed a serpentine stem or winding trunk which ran through the Hogarth pattern in the midst of a variety of botanical forms.
I 500. Group VI. Designs adopted a free treatment. (M) The plans of previous centuries were combined and elaborated.

$(\mathrm{N})$ Ornament was arranged within ogival frames, springing ont of the base of the frame to which it seems to be attached.

(O) Interlacings of two frames of which one is ogival.

( $P$ ) Ogival frames of leaves and flowers enclosing a large concentric pattern.

(Q) Elaborated ogival frames caught together by crowns.

( $R$ ) The use of vases, urns, crowns and animals became common.

I600-1700. Group VII. (S) During I600-I700 we find an elaborate use of European garden flowers instead of the purely tropical Persian verdure, following, however, the general ogival form of arrangement.

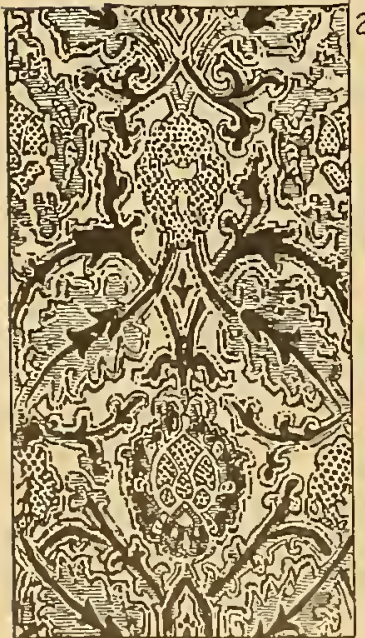

I500. Group VI (M).

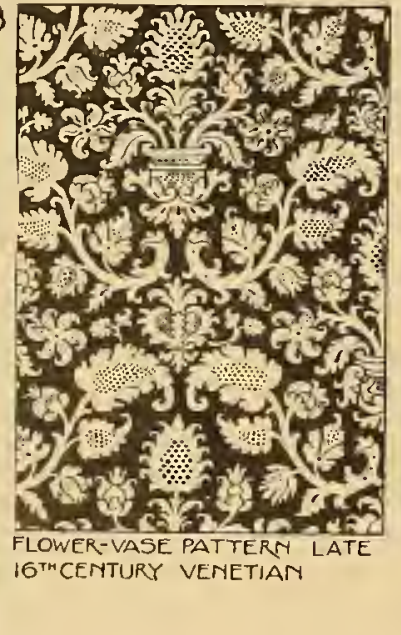

I500. Group VI (R).
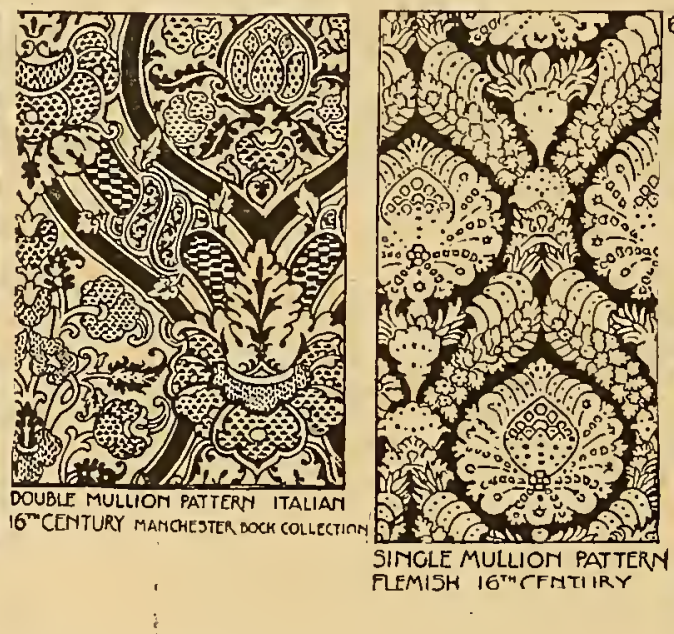

1500. Group VI (P). 1500. Group VI (P).

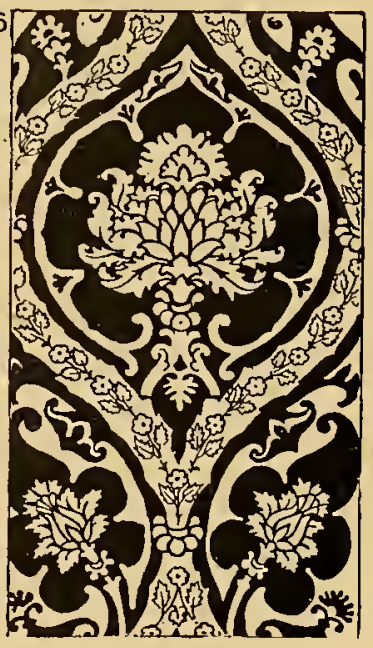

1500. Group VI (N).

[70] 

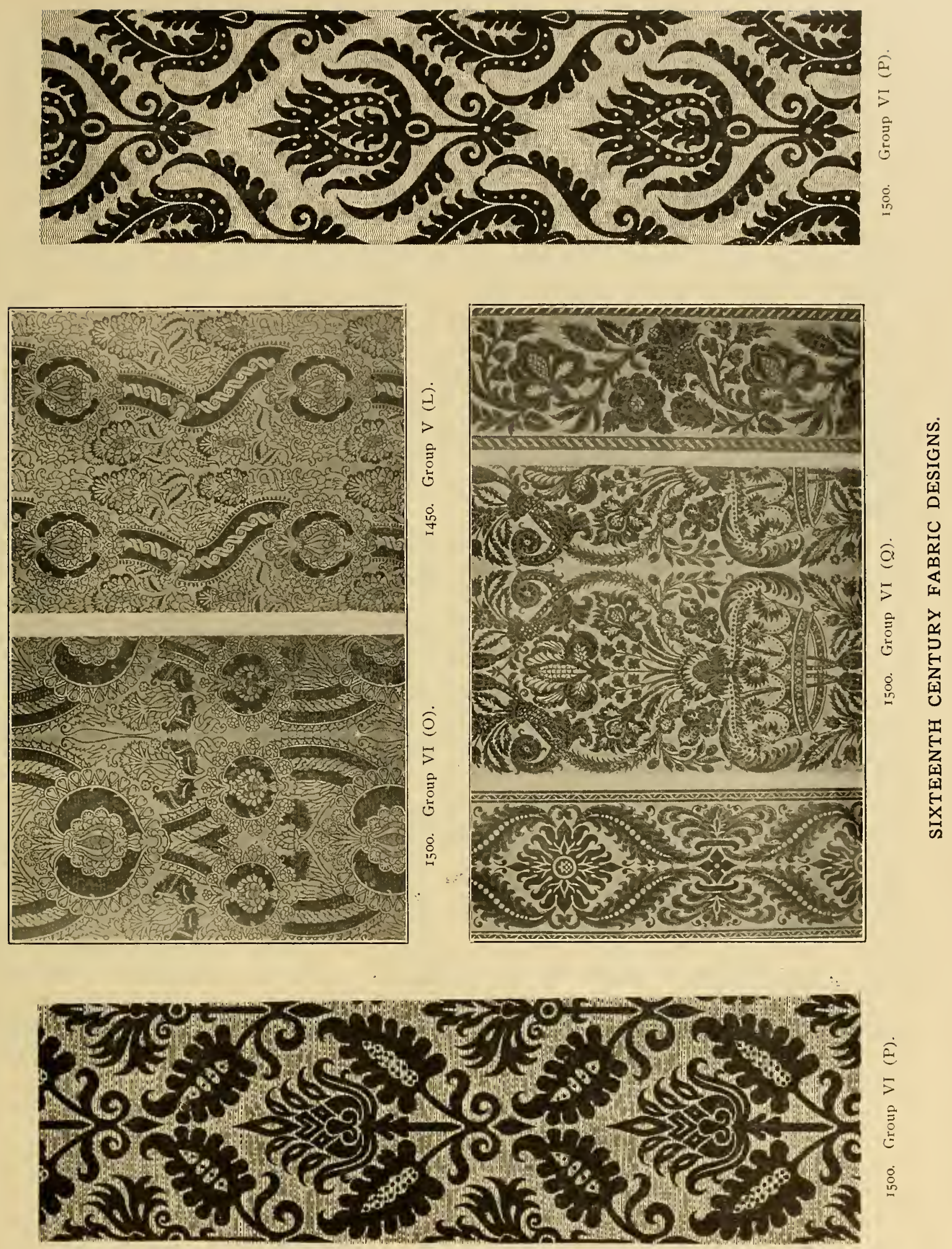
1700. Group VIII. (T) Pictorial tapestries and prints. (U) Pure Renaissance styles or developments of that style-Louis XIV or XV.

(V) Oriental characteristics of either the French or English styles, as shown in the scenic bits of Chinese or East Indian life.

(W) Louis XVI.
(X) Classic revival examples as expressed by the late Louis XVI, Directoire or Transition period in France and the Adam school in England. This period overlapped into 1800 and was generally adopted in the Americaí colonies.

I80o. Gröup IX (Y) Empire and Empire influence. (Z) Art Nouveau.

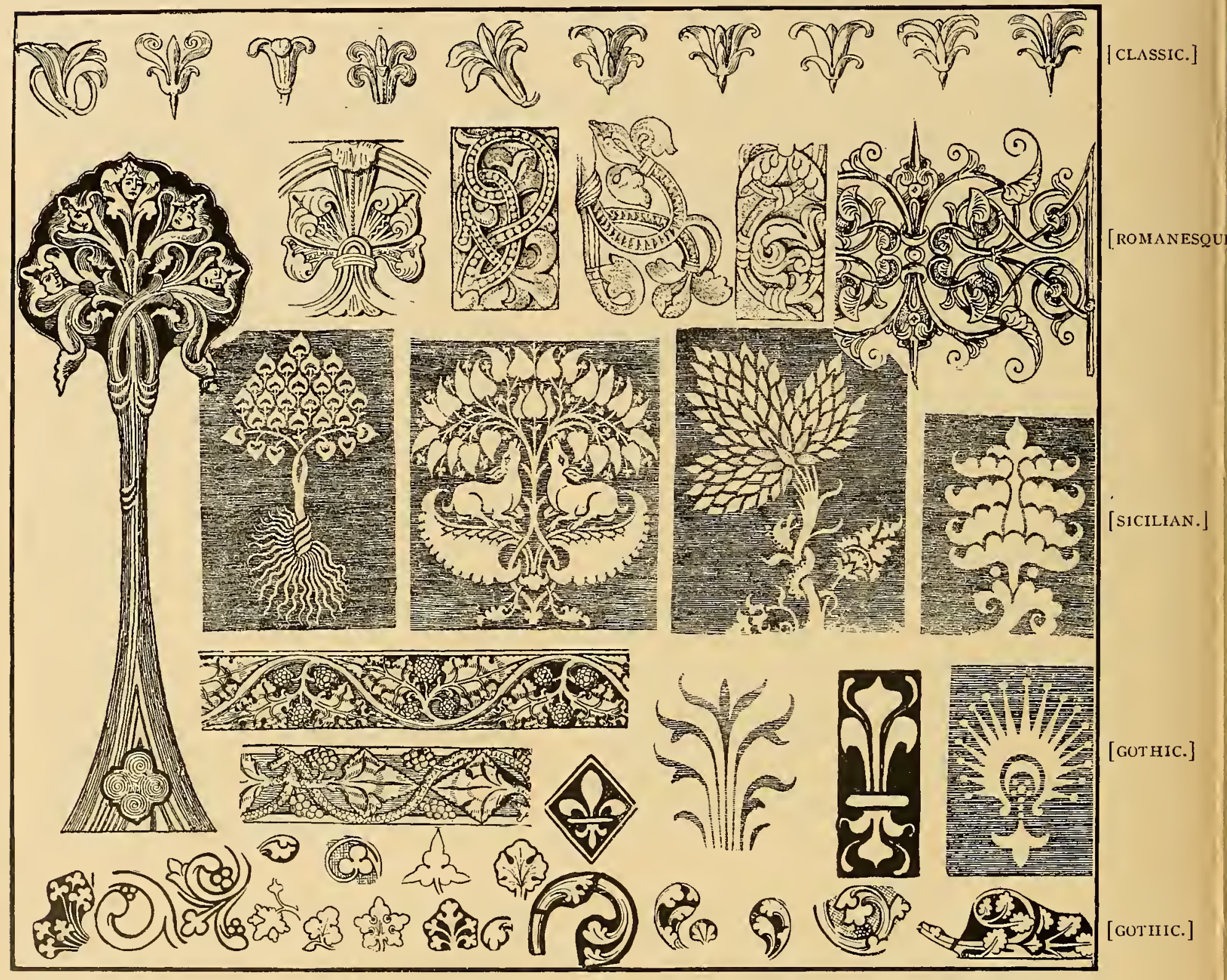

DEVELOPMENT OF FLORAL MOTIFS. 


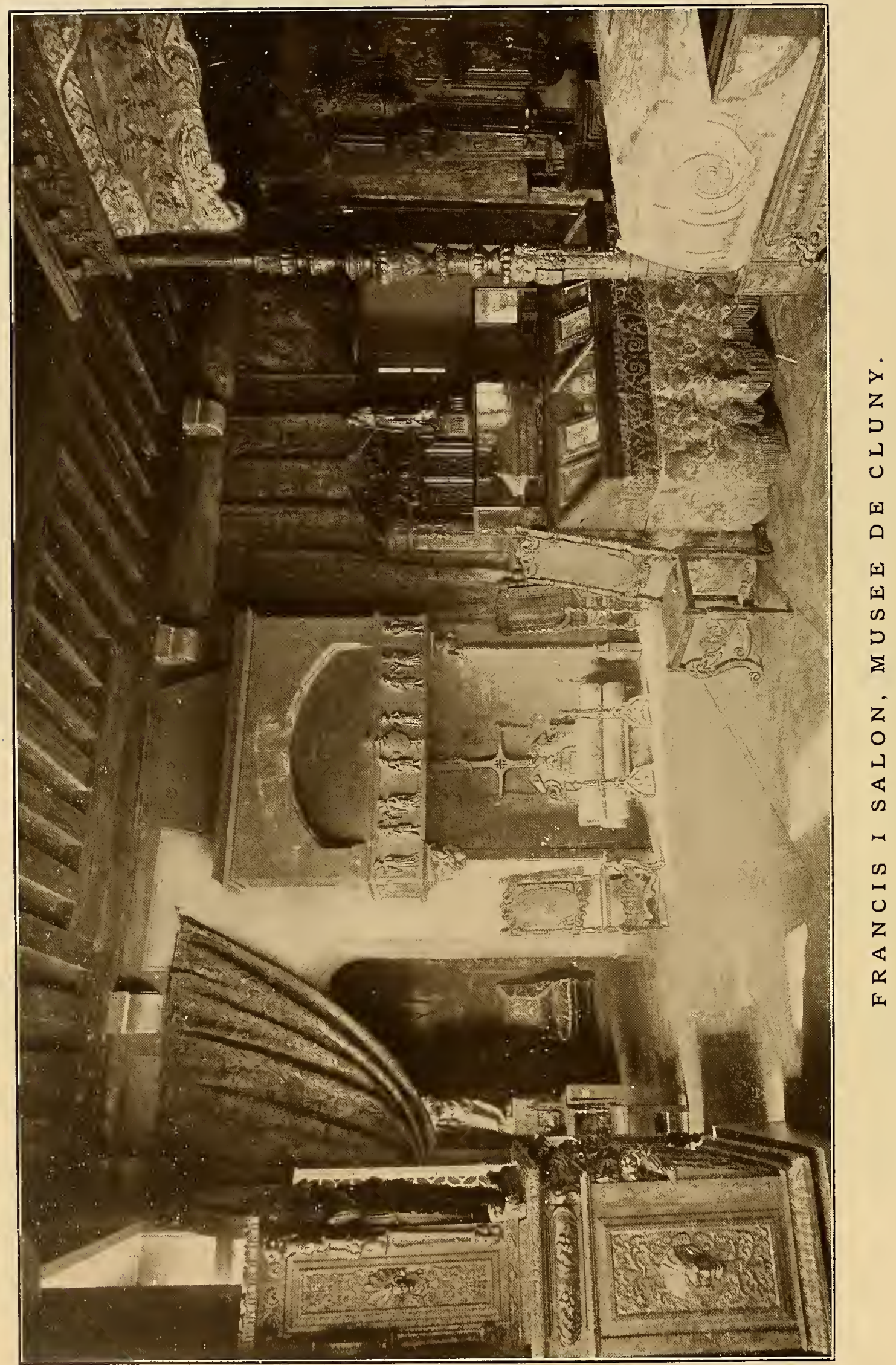




\section{DEVELOPMENT OF FLORAL TYPES}

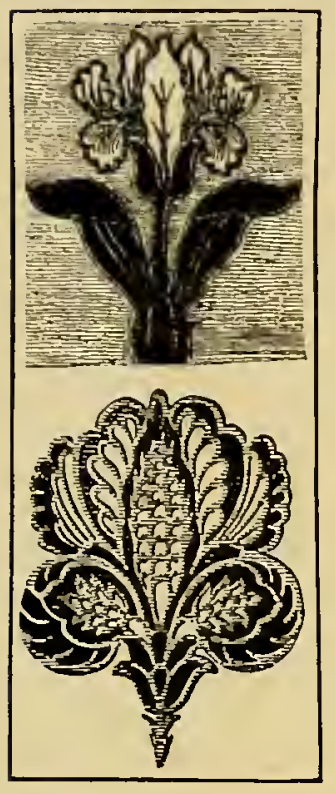

Iris, or fleur-de-lis. Seventeenth Century Venetian.

Italy (I 400$)$, in France (1500), in England and Spain (1500), and in Germany (1550), and the Persian pink and rose, the Rhodian lily, the pomegranate, cone and palm, gave way, as motifs, to the Roman, Greek and Egyptian details, the anthemion, lotus, iris and acanthus.

(b) During the Renaissance much confusion of types was precipitated by the commercialism of the Netherland States and the explorations of the Portuguese, who in II 40 had revolted from Spanish rule, under which they had been a province, and estab-lislied the kingdon of Portugal; the Portuguese during the Fourteenth Century became famous sailors, and early in 1500 opened possessions in Persia and India.

Portuguese-Persian is the type of design ( I 500) showing the Persian influences merged in the Portuguese, which at that time was developing the Renaissance spirit.

For centuries prior to the opening of the East by Portugal, the twenty-one provinces of the Netherlands

[73] lad been active in commerce and famons for the great cities of Ghent, Mechlin, Antwerp, Brages, Amster(lam, Leyden, Delft, Brussels and Rotterdam. After the forty years war with Spain, the Northern provinces, which had been known early in the Seventeenth Century as the Seven United Provinces of the Netherlands, formed the Dutch Republic and replaced the Portuguese in the settlement of trading posts in the East Indies (1610).

During the Sixteenth Century, involved as they were with the Netherlands and, subsequently, with France and England, who sympathized with the Netherlands, the Spanish, their sea power gone, had 110 means of continuing the commercial enterprises of

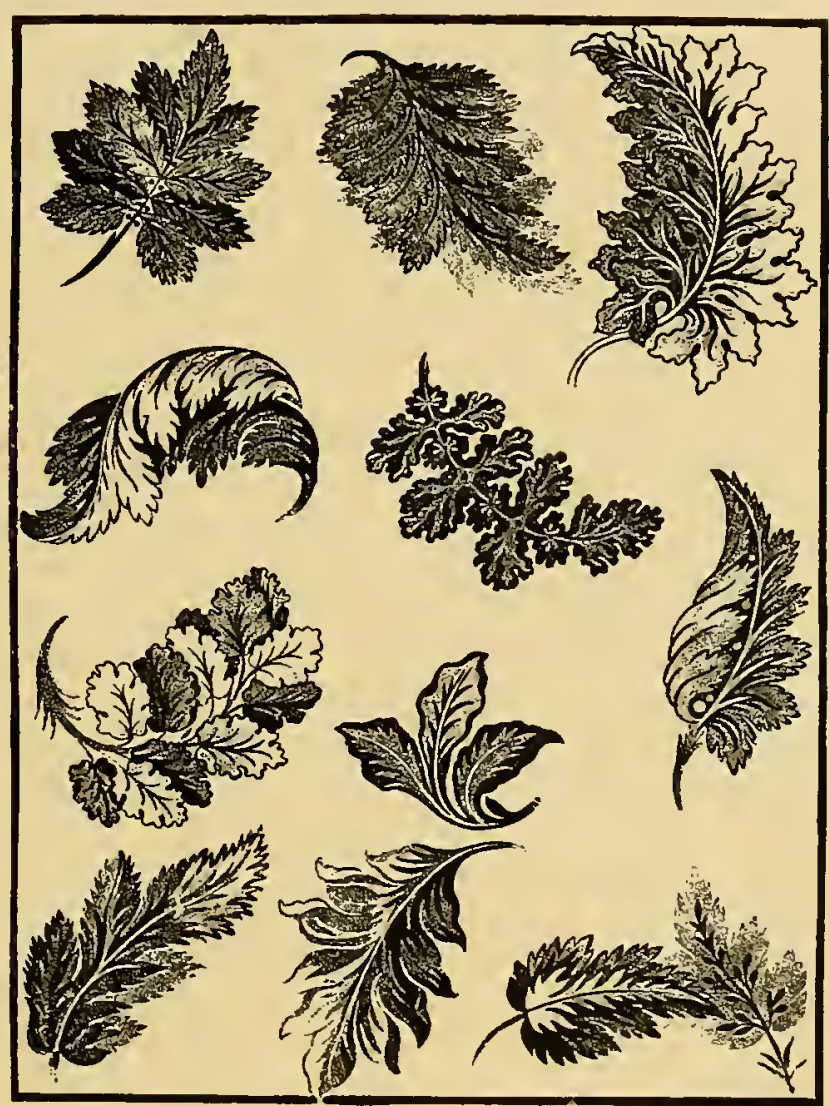

Examples of Old Silk, 1750 . Portigal, and the Dutch became paramout on the seas.

(c) The French developed still another form (the European floral) beginning about 1650 under Louis XIV, presenting the ferns and flora of Europe, especially the exquisite examples cultivated in the Royal Gardens.

Oriental inflnence in design has been stimulated at various periods by political and commercial derelopments. The Dutch brouglit East Indian types into England under the Elizabethan, Jacobean and Queen Anne periods, and English women perpetuated Oriental art in their embroideries. It seems like an anachronism in this Renaissance age. Chinese influence was strong during the period in France under Louis XV, and in England under George II and George III.

Then again as late as 1760 British rule in India began to stimulate a demand for Indian goods. periods.

These pluases must be considered in studying the

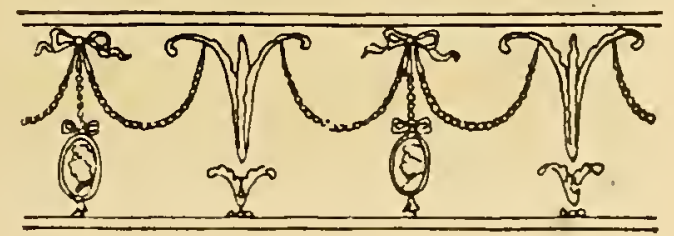




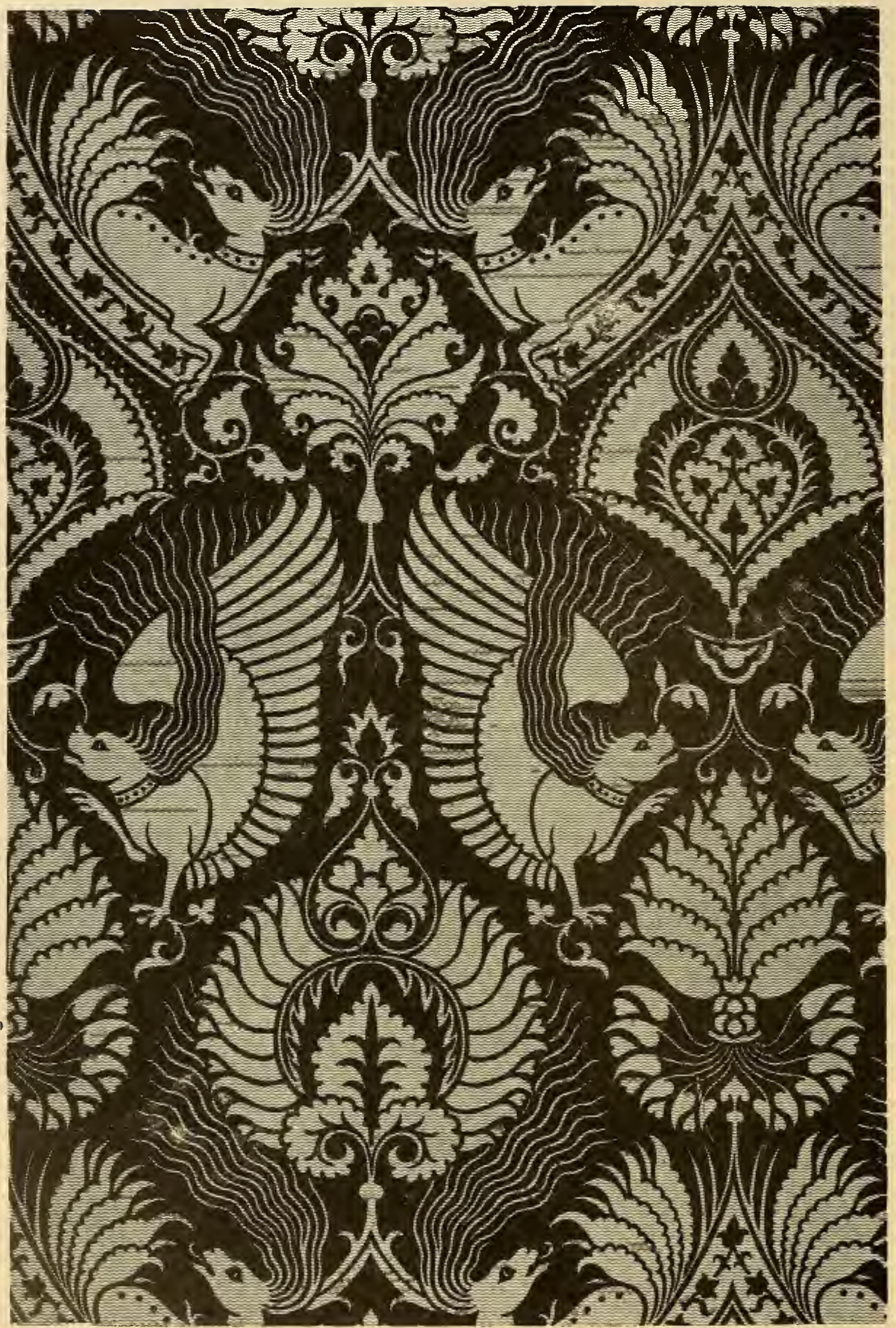

I200. Group IV (I). Saracenic Influence

I T A L I A $\mathrm{N}$ G O T H I C. 


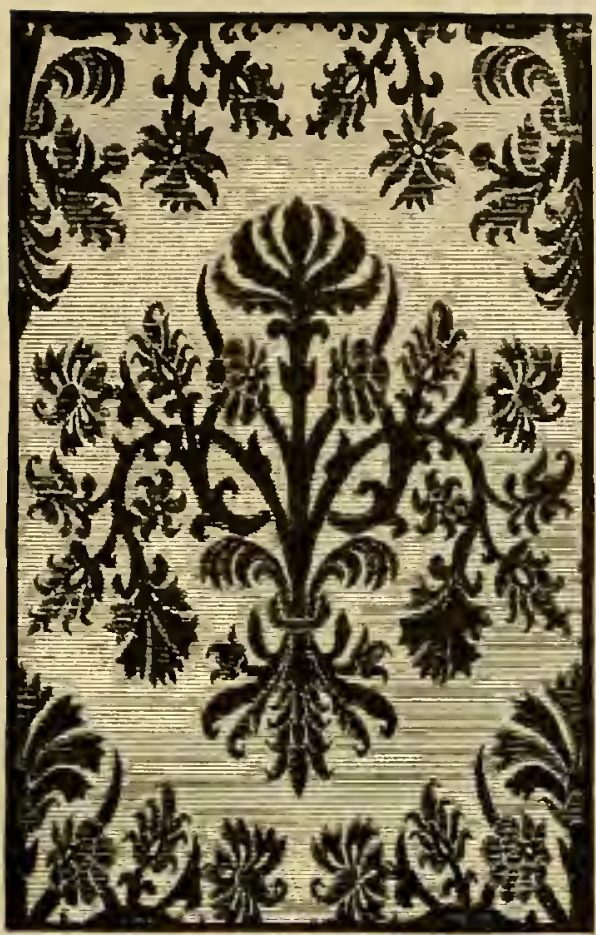

Fig. V

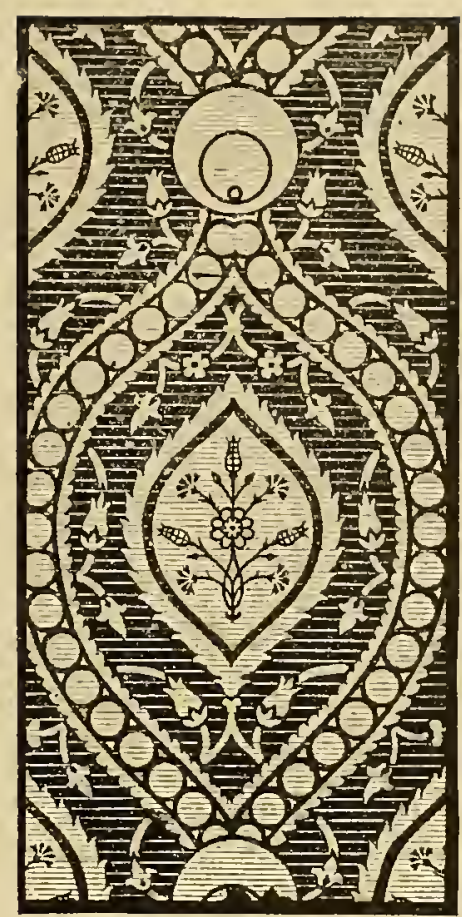

Fig. IV.

(See description on next page.)

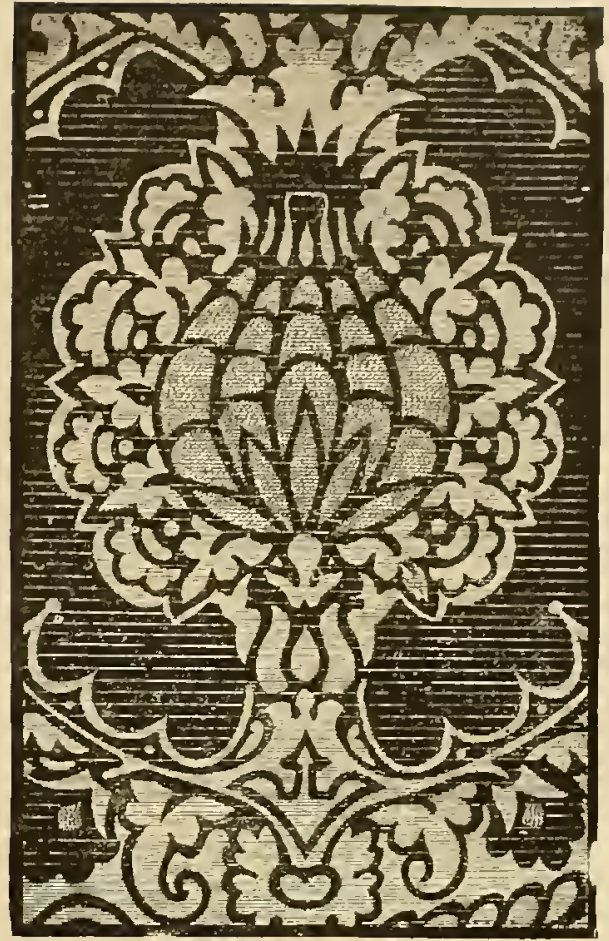

Tig. III

\section{FA B R I S OF NORTHER N I T L Y}

\section{FIFTEENTH-SEVENTEENTH CENTURIES.}

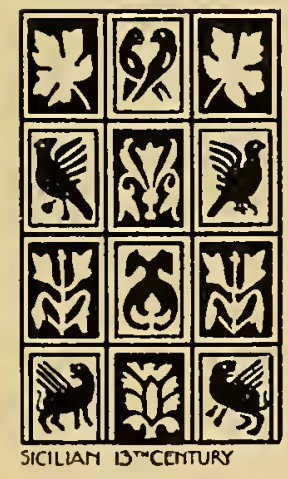

brought great prosper-

ity to Italy. Foreign enurts adopted Italian customs and costumes. Vast quantities of rich hangings were used, and the most gorgeous form of dress was affected. John the Calabrian was famous for a silk loom used in the Fifteenth Century and this loom was imported into France during the reign of Louns XI (-I475) by the manufacturers of Tours. I loom associated with the name of Dangon appeared at the beginning of the Seventeenth Century and was lrailed as remarkable in its ability to facilitate the weaving of fabrics in several colorings. Is early as the Thirteentli Century Borghesano of Pologna had invented a spinning machine to which was due the superiority of Italian thrown silks. The processes of manufacture were, at this period, greatly improved. In 1500 armures became singularly rich. Clotlis of gold were made, figured velvets, damasks with broché effects and fancy velvets.

When the Arabs under Mohammed had con- quered the countries of Persia and Syria they found the manufacture of silk a flourishing industry. From this period mntil the Fourteenth Century the silk industry was carefully fostered by the Mohammedans. Next in importance and value to the precious stones the chief treasures of the Caliphs of Bagdad, Cairo and Cordova were their silken goods. Silk fairs or marliets were held periodically at Antioch, Rey, Orzeroum, Ispahan, Jerusalem and Mecca. The Jews then, as now, were the bankers in the Mohammedan districts and the purveyors of articles of huxwry of the wealthy Romans of the South, the Gallic Romans of the W'est and the Goths of Northern Europe.

The Italians were first to travel over Asia Mlinur. and together with the Jews, brought Mohammedan products into Italy. Spain. France and England, eventually establishing silk manutactories in Europe. Notably in Sicily and Italy. Palemo, silk factory started 3100 ; Linca, famous for silk wearing 1300.

Persia was the original seat of art. and thence l'ersian design spread and was adopted and adapted in North Africa, Sicily and Arabia.

In the Thirteenth Century Italian designers were inspired by Oriental art. In the Fourteenth Century. they modified their treatment of animal motifs, aban- 


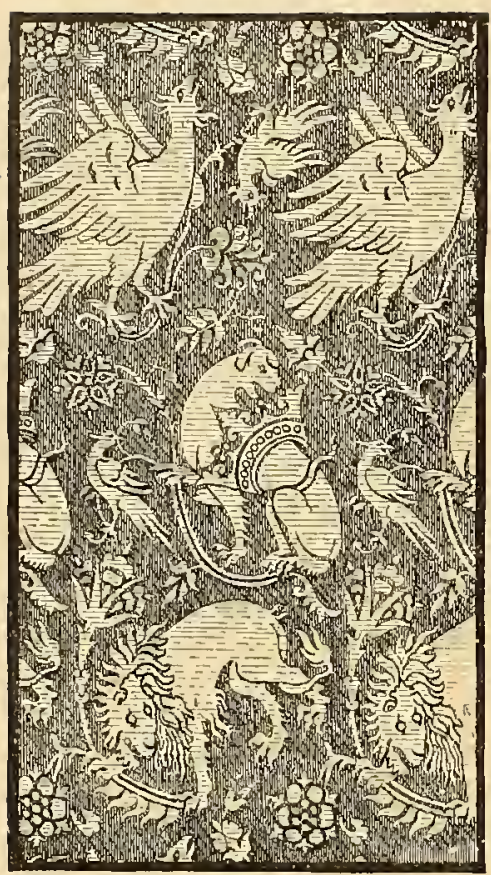

Fig. I. doning the fantastic type (See Fig. 1) and arlopted a new school of Hora, employing the vine and oak leaf. Ven ic e gave special attention to compositions for altar decorations. (See Fig. 2.)

Specimens of the Fifteenth and Sixteenth Centuries dis play a lingering trace of Oriental art types which appeared and reappeared for possibly commercial reasons. (Sce Fig. 3.) Lobed leaves, rather Gothic in character, appeared in the Fifteenth Century and were abandoned in the Sixteenth Century. Thistles and flower artichokes often formed the center of the composition, and around the central motif the old geometrical lines were replaced by foliage forms: forming curvilinear or ogival borders.

The magnificent Venetian velvet shown in Fig. 4 illustrates a varied ornamental framework of the character described. Floral effects were in some cases the principle motif, in others the accessory ormament.

In Fig. 5 we show a fancy velvet of the Sixteenth Century; a pale yellow ground is in silk armure, the design produced by the cut velvet is in two delicate colors, manve and light green. The design is known as the flowered Indian meadows, on account of the numerous shades employed.

Sixteenth Century designers were artists having remarkable facility of invention. The nutliplicity of rich silken stuffs illustrates very forcibly the luxury

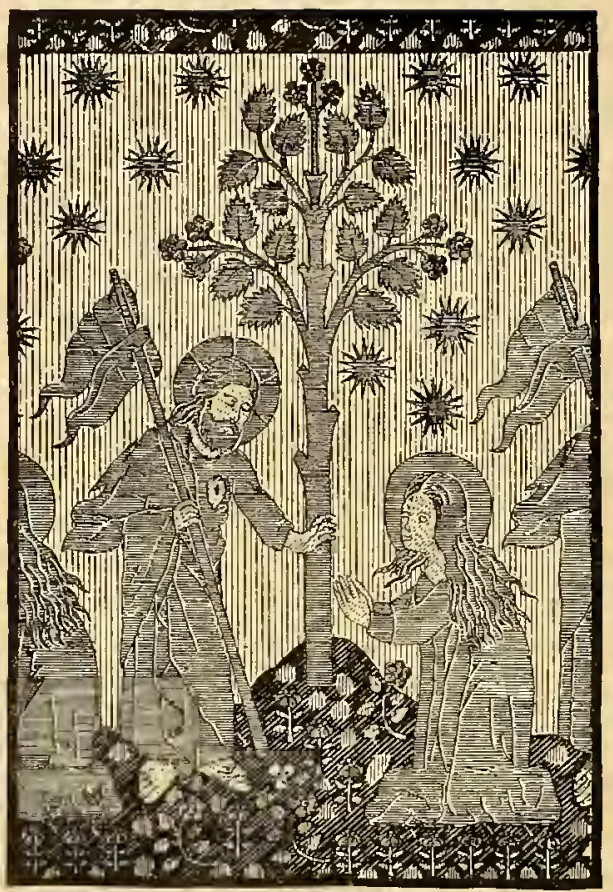

Fig. II.

in dress. Where gold or silver did not figure in the design it appeared in the form of embroideries on satin or velvet. It was a period of great prosperity in Italian manufacture, especially the factories of Lucca, Florence, Venice and Genoa. Italian workmen, moreover, were in demand and taught their arts contemporaneously at Avignon, Lyons, Tours, Barcelona, Briges and London. Even at the end of the Seventeenth Century (I685) official Lyons records speak of Italian silk fabrics as forming the ideal models which the weavers of Lyons were to keep always in view as the standard of perfection.

During the Seventeenth Century, however. fashions were no longer dictated from Italy. Paris became the center and home of taste, and witl the abandonment of long dresses the vogue for large designs had vanished. Sunaller compositions were executed not only in dress but in upholsterings, and little by little Italy lost its prestige.

\section{KEY TO FABRIC ILLUSTRATIONS.}

Fig. I.-Italian cloth of gold of the Fourteenth Century. Fabric with two wefts following each other; the green silk weft forming the ground with the warp likeness in green silk; the gold weft forming the design.

Fig. II.-Italian cloth of gold of the Fourteenth Century: with figures. The ground is in satin weave, presenting a glazed effect; the warp is light yellow, the weft crimson. This crimson weft and the gold weft succeed each other. In the figures the face, the hand and the feet are executed with a supplementary weft of white silk. The turf is formed by another supplementary weft in green, producing a twilled appearance.

Fig. III.-Fancy cloth of gold, with velvet ground, of Italian manufacture of the Fifteenth Century. Pomegranate design. The cut velvet is of crimson shade; the design being formed by the gold weft. The center of the pomegranate, which is in small points, is in knotted gold weft; also called bouclé or frisé.

Fig. IV.-Fancy Venetian velvet, with gold ground. The cut velvet is in crimson; the design, produced by the gold weft, being raised.

Fig. V.-Italian fancy velvet, of the Sixteenth Century. Detached floral effects, 

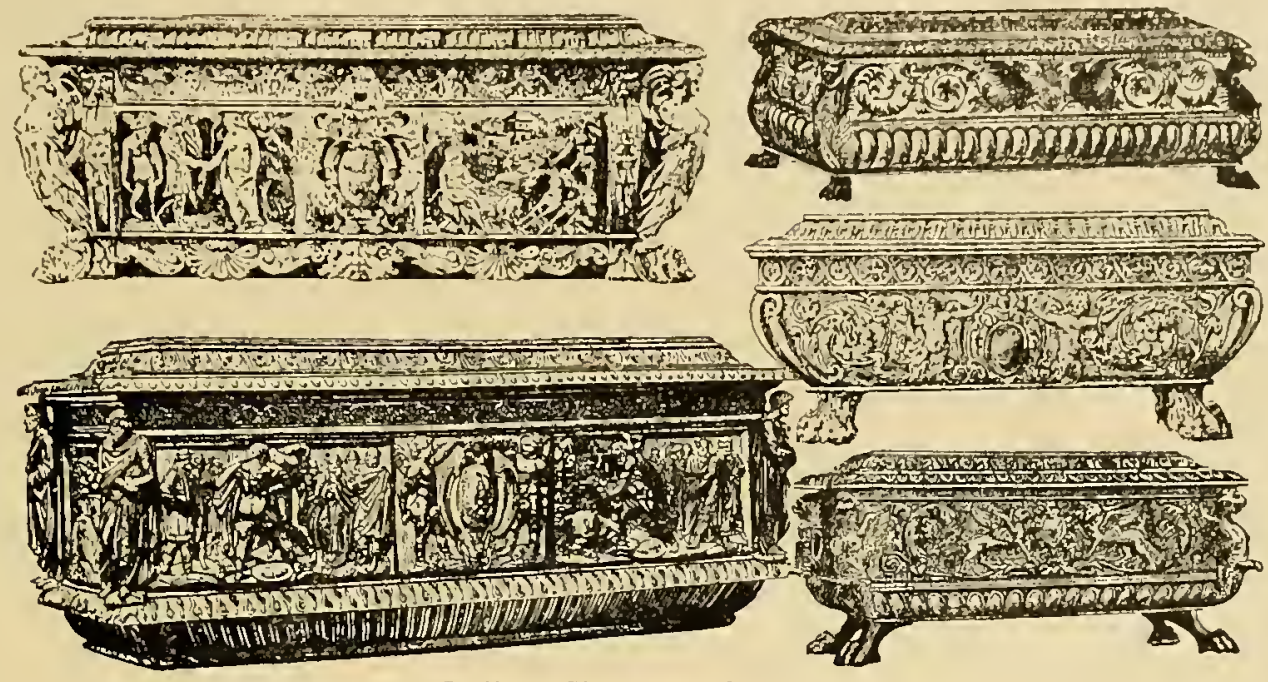

Ttalian, Sixtecnth Century.

\section{DEVELOPMENT OF THE RENAISSANCE}

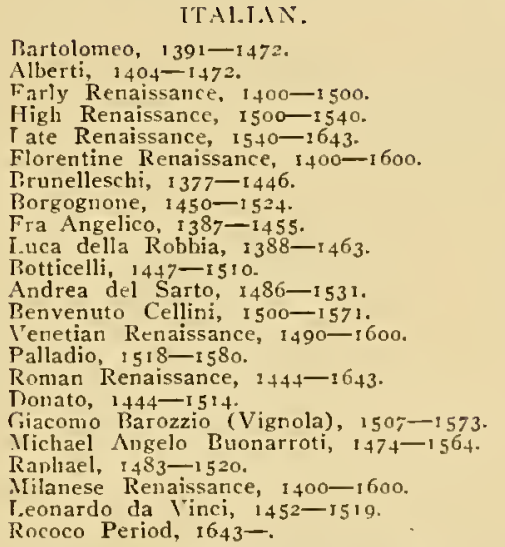
French Renaissance, $1502-16+3$, a freely ornamented Gothic introduced by Fra Giaconda, 1502 , under Louis XII, de veloped by Francis I, who reigned $1515-1549$. Leonardo
da Vinci, Seralio, Cellini, Italians, influencing the style. ENGLISH.

English Renaissance, 1509-introduced by Fienry l'III, through his architect, John of Padua. FLEMISH.

Flemish Renaissance, $5507-$

Antwerp was destroyed in $15 S_{4}$ and the famous manufactories Dutch Reporsed.

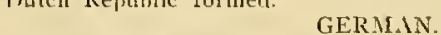
German Renaissance, 1550-founded by Albreclit Durer. SPANISIF.

Spanish Renaissance, 5500 -reflected the character of the Flemish Renaissance introduced by Flemish artists. Carlos I was born and educated in the Netherlands and upon attaining the crown his advisers were Flemish. The style was termert and classic details.

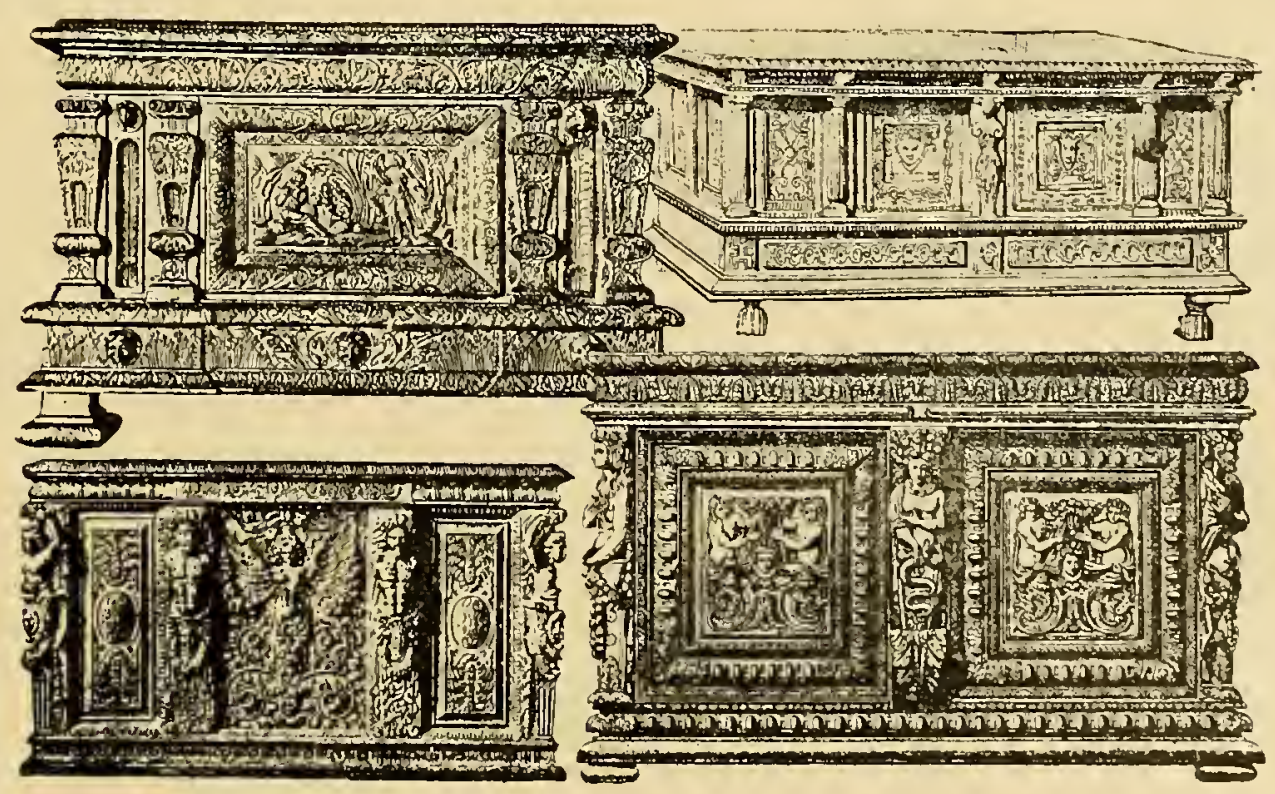

Italian, Sixteenth Contury. 


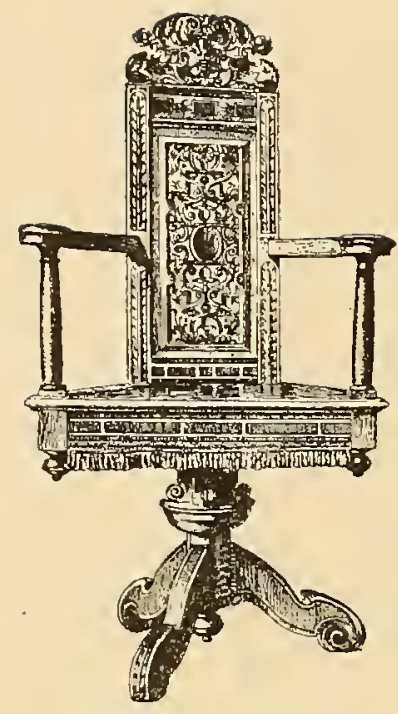

Francis I, 15rg.

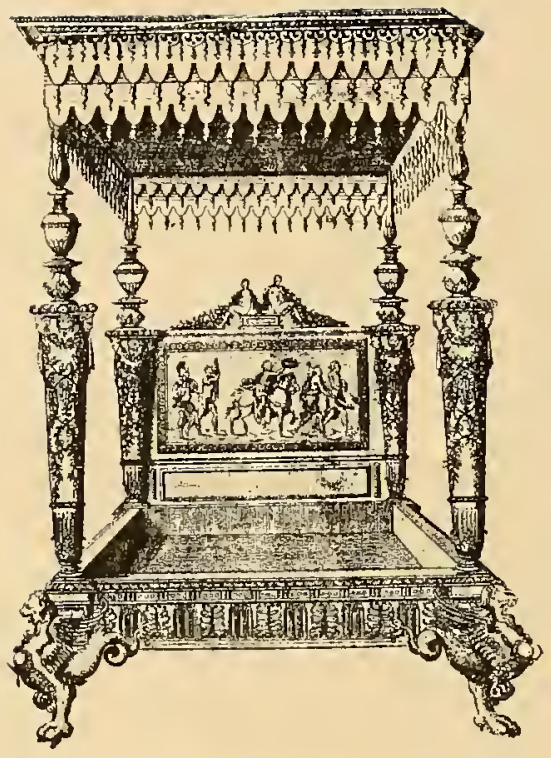

By Du Cercean, France, 1550.

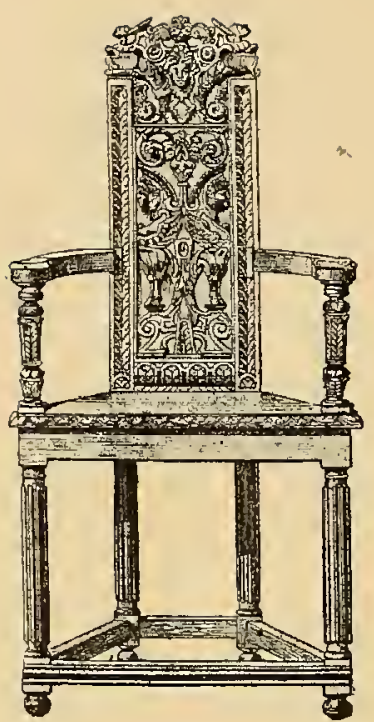

Francis I, 1519.

\section{T A L I N R E N A I S A N C E}

$\mathrm{D}$ URING the Fourteenth Century religion, art and science expanded. Humanity broke the feudal fetters and a new social life prevailed, stimulated by the study of the ancient arts and sciences, and wider propagation of the Christian religion. This period was the revival period (Italian. Rinascimenta; French, Renaissance).

ITALiAN-Brtnelleschi was the first artist to study the monuments of classic-art., To his genius we owe the Early Renaissance in Florence. The labors of Prunelleschi and his followers were soon felt in other Italian art centers, Rome, Milan, Bologna and Venice. Its spirit was bronght to Rome by Donato. the teacher of Raphael. It supplemented the brick-

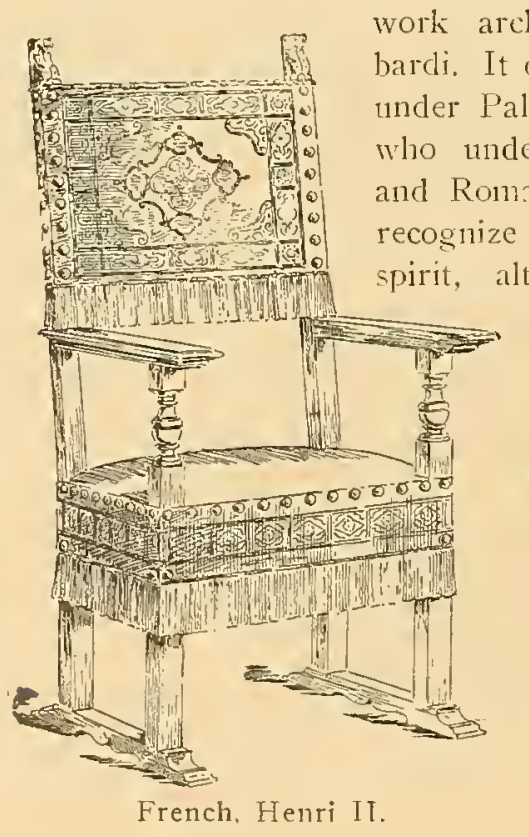
work architecture of Lombardi. It developed in Venice under Palladio. The student who understands his Greek and Roman will very readily recognize the Renaissance spirit, although outside of Italy the classic motifs were often liberally interpreted in combination with cartouche, strap forms and shields; survival of Crusader motifs.

The centaur, showing the fore part of a man and the hind part of a horse, was frequently combined with a liberal system of scrolls. Masks, the female form, birds, animals and trophies were conspicuons.

The furniture was sometimes supplemented by painted decorations on gilt grounds prepared in a gesso material.

Italian tarsia (inlay) work was a characteristic type. Sometimes the inlays represented floral ornament, sometimes landscapes and buildings. The technique came from Persian sources, but the designs developed chiefly by the Venetians were usually classic. In the decoration of tables, chairs and cabinets ebony, ivory and metal were employed.

The marriage coffer, often in carved walnut, was a popular article of furniture. Chairs often carved and all gilt. Cab-
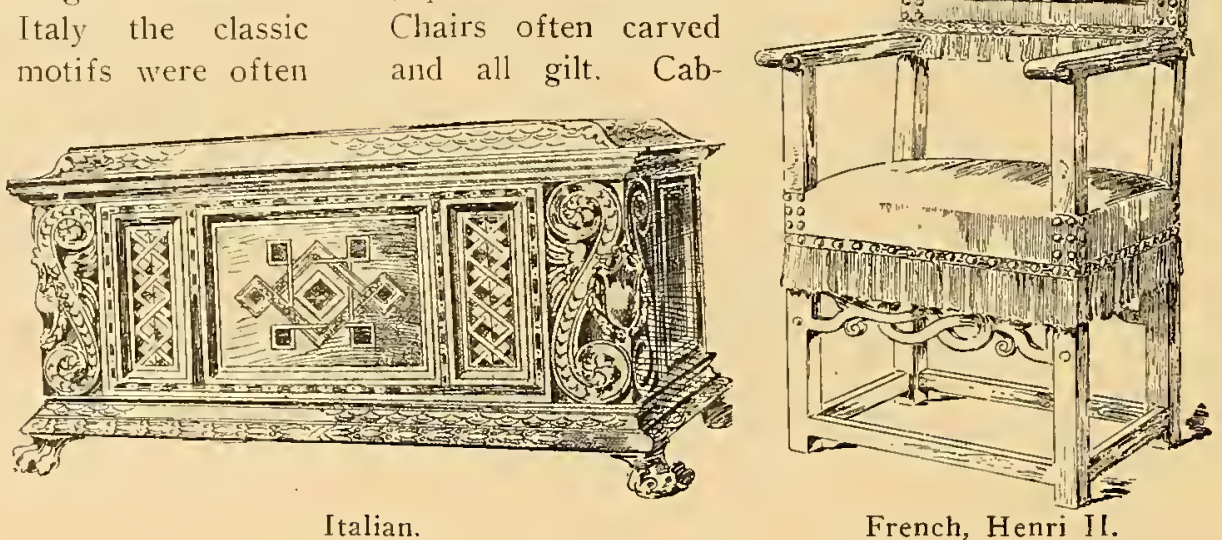

French, Henri Il. 


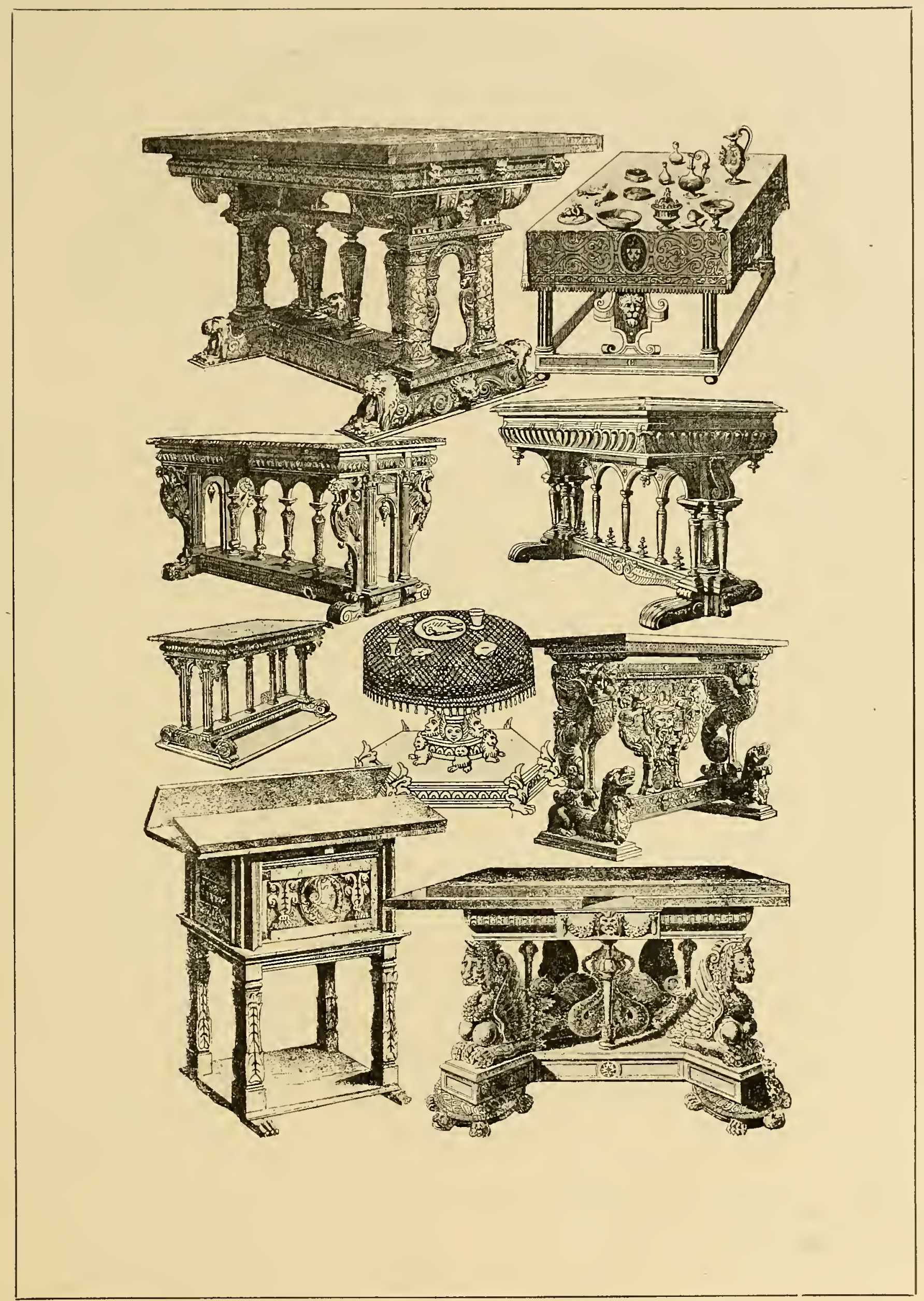




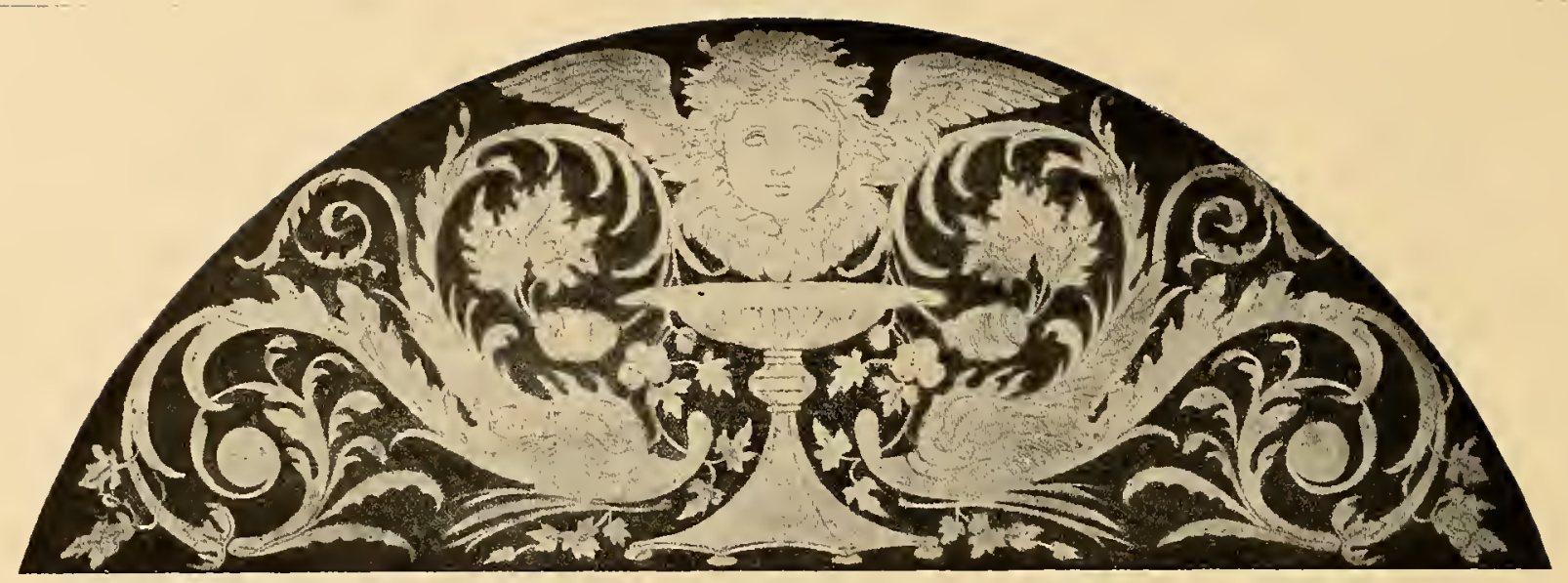

Italian Tarsia or Intarsia Work.

inets were made with veined marble tops and panels. In the Seventeenth and Eighteentl1 Centuries painted plaques of porcelain took the place of these marbles.

In the Sixteenth Century Venice was renowned for its glass manufacture. Mirrors were invented in 1507 by two Murano glass makers hamed Andrea and Dominico, who were given sole privilege to "make mirrors of crystal glass for a term of twenty rears." Previous to this time mirrors were of polisher metal. The frames of these Venetian nirrors were carved to represent doorways or windows, pilasters, friezes and cornices; sometimes all gilt. The beds were bften four-posters.

Discoveries of the stuccoes of ancient Rome aroused the Italian architects to a spirit of emulation and the mural work became extravagantly eiaborate. Ground colors were laid on while the ktucco was wet and the details heightened. Sometimes gilt frames enclosed magnificent paintings. The work of Raphael and his followers was often applied to wall decorations. The superb friezes and panels constituted the best work the world has ever seen.

The age of oak extended from about I500 to about 1650 . The age of walnut was then generally taken up and extended to about 1700.

In 1530 furniture

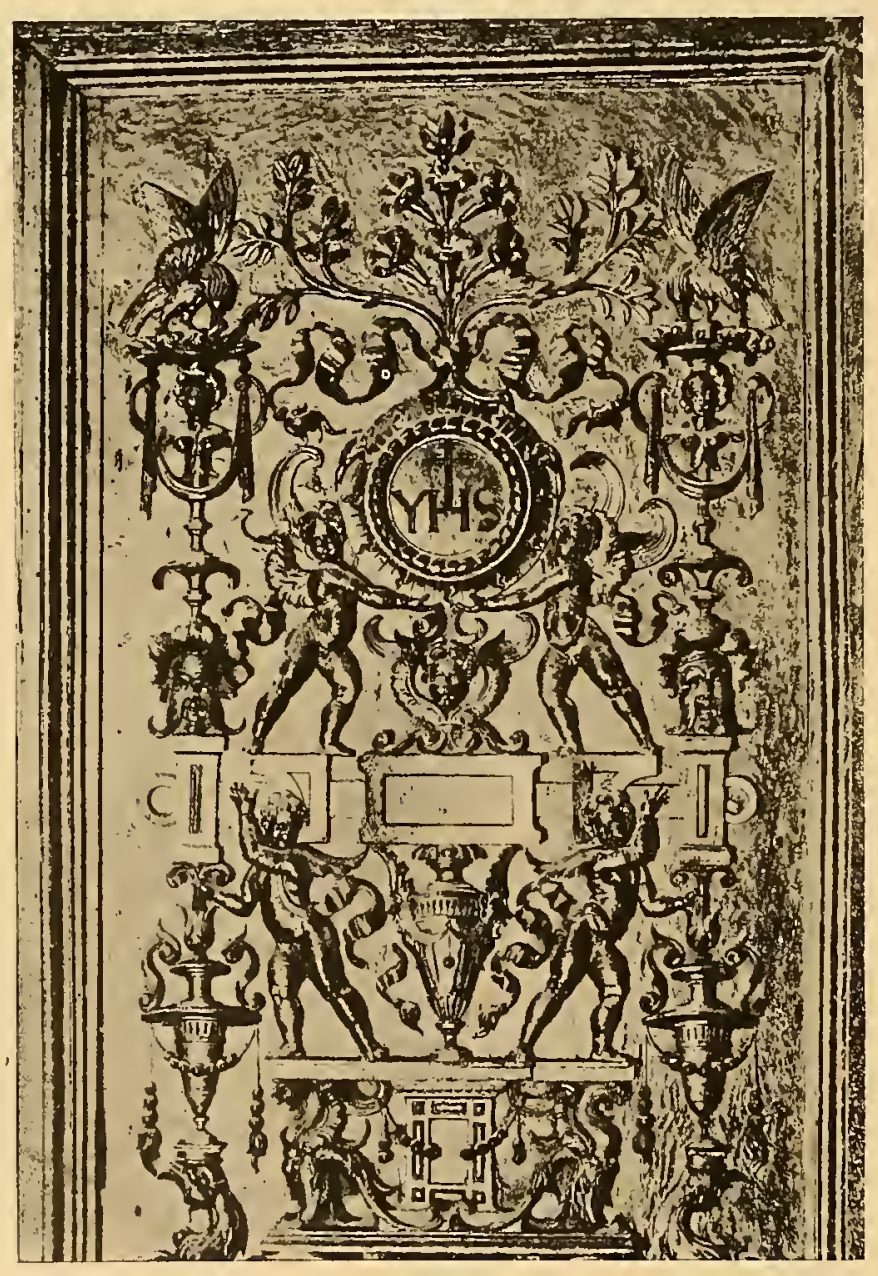

Italian Stucco Ornament. with a framework and panels as well as chairs began to adopt a really new order. Pieces of furniture became more complex, with columns, porticos, pediments, $\mathrm{niches}$, friezes, cartouches, caryatids, etc., constituting veritable little monumental façades.

In France the Italian and Flemish tastes influenced development. In decorative art the form of Renaissance known as Jenry II lasted for half a century.

In England the Jacobean period, whic'i was contemporary, lasting from 1603 to 1690 , was a mixture of the Renaissance and Gothic. The heavy wooden chairs were followed by the spiralframed chairs known in England as the Cromwell chair. Brass nails were used to trim Genoa velvet, silk, serge, needlework. A square rail usually connected with the legs at the base. In the time of Elizabeth the Italian spirit prevailed in England,

It is absolutely impossilbe to fix the identity of many pieces of furniture, especially the simpler ext amples of chairs. They were of Italian origin, adopted in France and subsequently brought to England. 


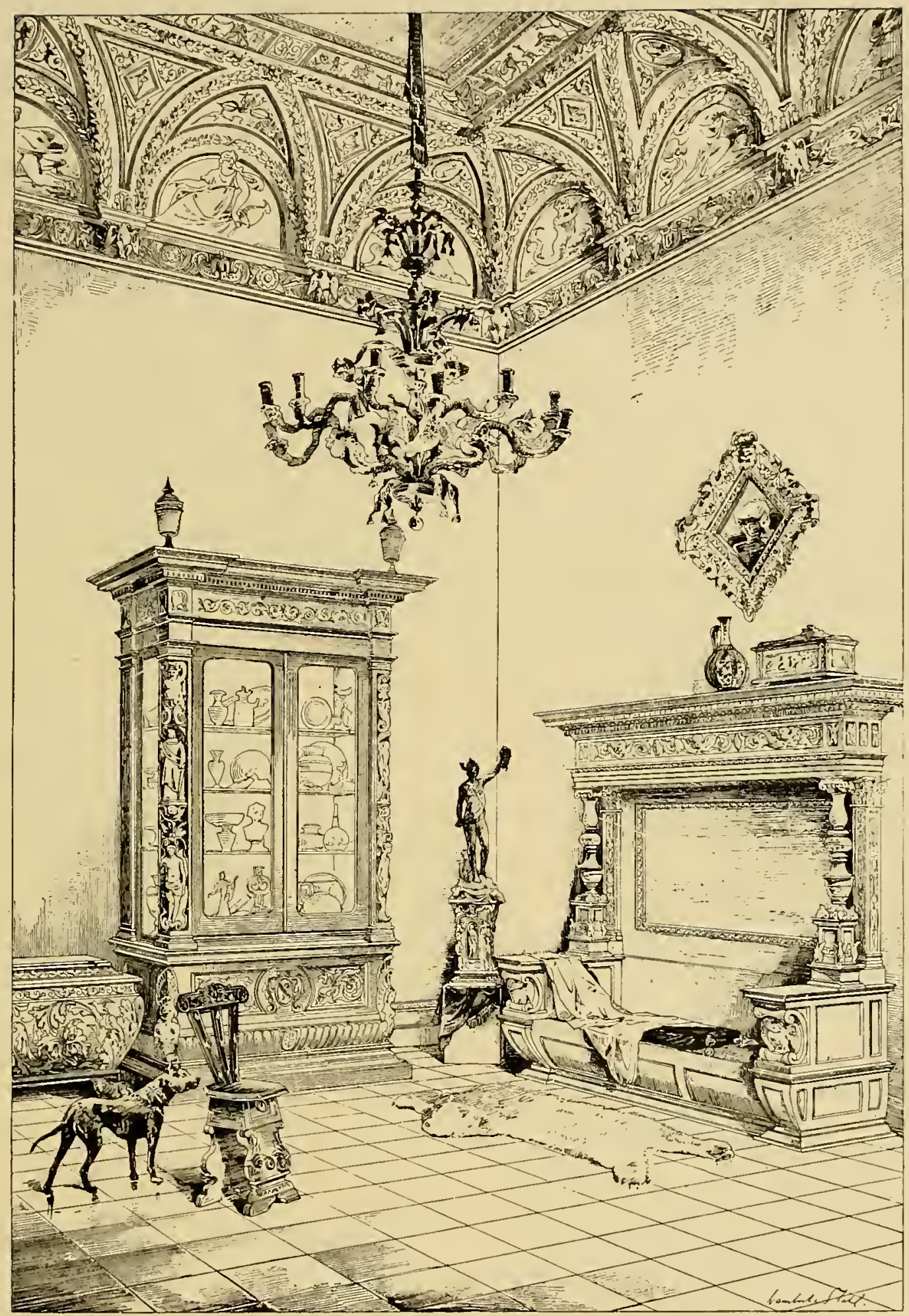

AN ITALIAN RENAISSANCE INTERIOR (I550). 


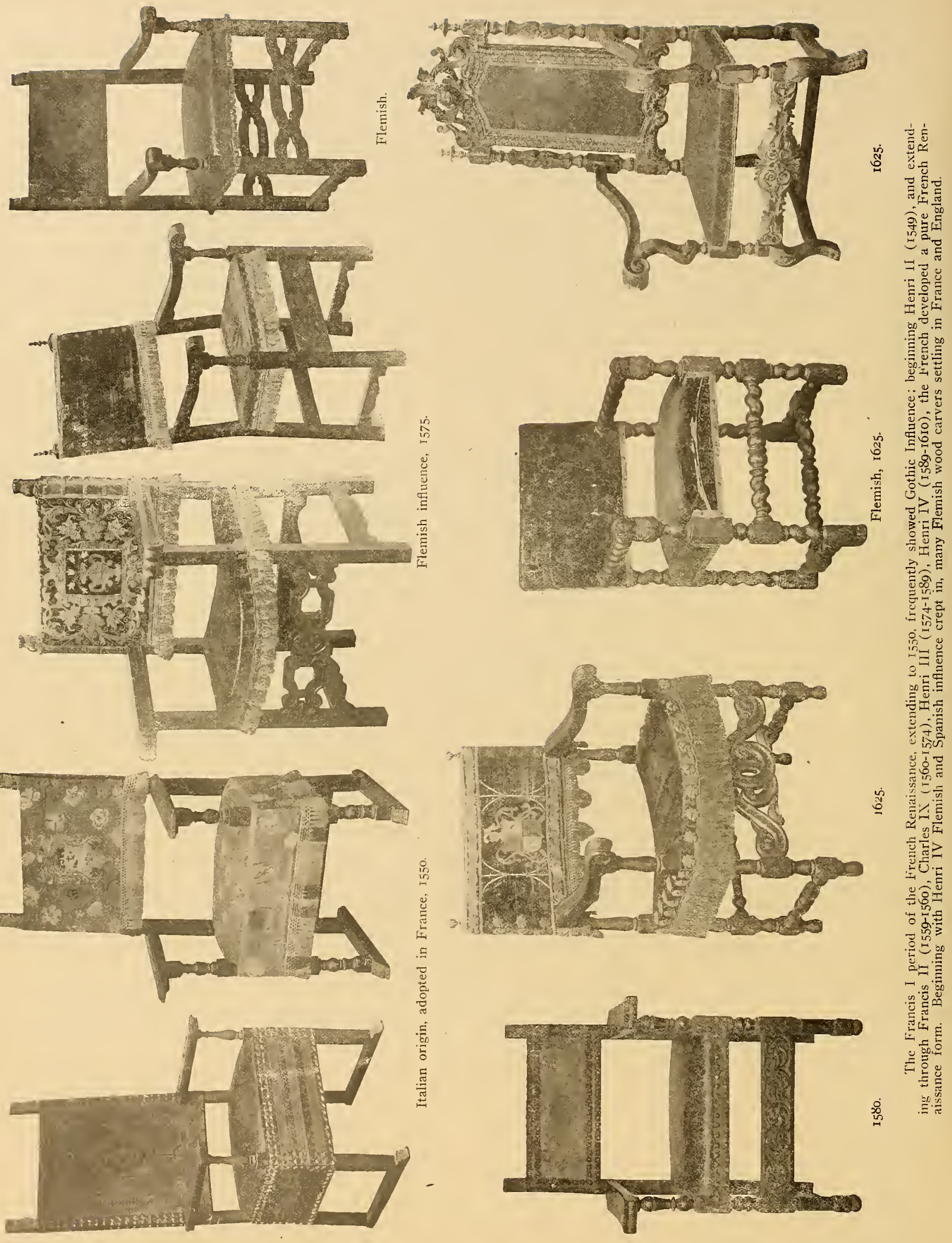




\section{RENA ISSANGE-ITALIAN-FRENCH}

$I^{1}$ IS difficult to differentiate between Italian and the late French Renaissince. The French were saturated with the Gothic spirit and for it time it was difficult to displace the Gothic feeling. The new art was finally establisher in France through Cellini. Serlo, Primaticcio, Ilrosso and others who came from Italy and by French artists who finally went to Italy to acquire the newer style evolved from the classic remains of ancient Rome. The great Frencl carvers of this period were Jean Goujon, Nichlos Bachelier, of Toulonse, Jean Codsin, Germain P'ilon. Philibert Delorme, Du Cercean, who publisherl designs for all kinds of decorations and carvings, and Hugues Sambin, of Dijon. Towards the and of the Sixteenth Century and during the early half of the Seventeenth the superb furniture was covered over with fabrics to such an extent that little by little the frame construction ceased to be visible.

llood carving was one of the great glories of the Filemish art throughout the Sixteenth Century. A Flemish chair of the second half of the Sixteenth Century is illustrated on page 88 , and yet it might safely be regarded as Italian. During the Seventeenth Century the Flemings levoted themselves mostly to the carving of large pieces, chairs and small furniture being produced frequently by means of turning lathes not requiring the skill of the carver. The style was naturally I talian, atthongh Spanish infuence made itself felt during the Spanish occupation of the Nether lands in the latter part of the Sixteenth Century.

The term Renaissance in France, includes, ac cording to many writers, the style of Louis Xill. An over-upholstered form eliminating the carved features may be said to characterize much of the furniture of Francis I, Henri II. Francis II, Clarles IX, Henri $11 \mathrm{l}$ and Henri IV.

IVe are disposed to recognize boulle of the Louis XIV period as the promoter of marquetry work, but inlays went back to the tarsias of Italy, Fifteenth Century, and during the period of Francis I a great deal of Indian work, inlays of mother-of-pearl, was introduced by the Portuguese mercliants.

Inlays in exotic woods, ivories, ebony and metal were aiso used in France, although French cabinetmakers, as a rule, confined themselves to carving in relief and ignored the Italian colored marquetry in the style of tarsia, intarsia pittoric and certosina. The Gothic type lingered until i525, and French Renaissance frequently showed Gothic traces. Unquestionably many Italians and Flemings were employed in France. As early as 1503 (lressers, trestles, wooden berlsteads and wooten clairs were upholstered appropriately: It is difficult to identify native French work becanse the cabinetmakers travelled frequently from one town to another wherever building operations might call them and goorl wages were paid. Thus the Italians were scattered orer France and the work that they produced was handed down to native workmen who copied. French design may he characterized an an over elaboration of the more classic Italian forms, which latter copied the old Roman and Greek in strict conformity to tradition.

We fail to find any means of determining definitely the characteristics of the Norman school, the Lyons, Tours, or Burgundy. We lo well if we determine approximately, a style like that of Francis I, by the end of whose reign Gothic characteristics, and especially those of the pointed arch had practically disappeared.

It must be recalled that the French had had broarl experience in wood carving and naturally soon developed a boldness and freedom of execution which gave to their late Sixteenth-Century work, characteristics in no way to be confused with the more minute, and restricterl treatment of the Italians.

The castles of Francis I, Blois, Clambord and Fontaineblean were masterpieces of the French Renaissance.

French life under Henri II, Charles IX and Henri III, all semi-Italian princes, dominated by their Florentine mother, Catherine de Medici, was luxurious in the extreme.

Both Henri II and Henri IV styles showed a prevalence of interlacerl strap work, delicate reliefs and the use of the cartouche.

Below, chair of Henri II : walnut covered with English Einbroidery.

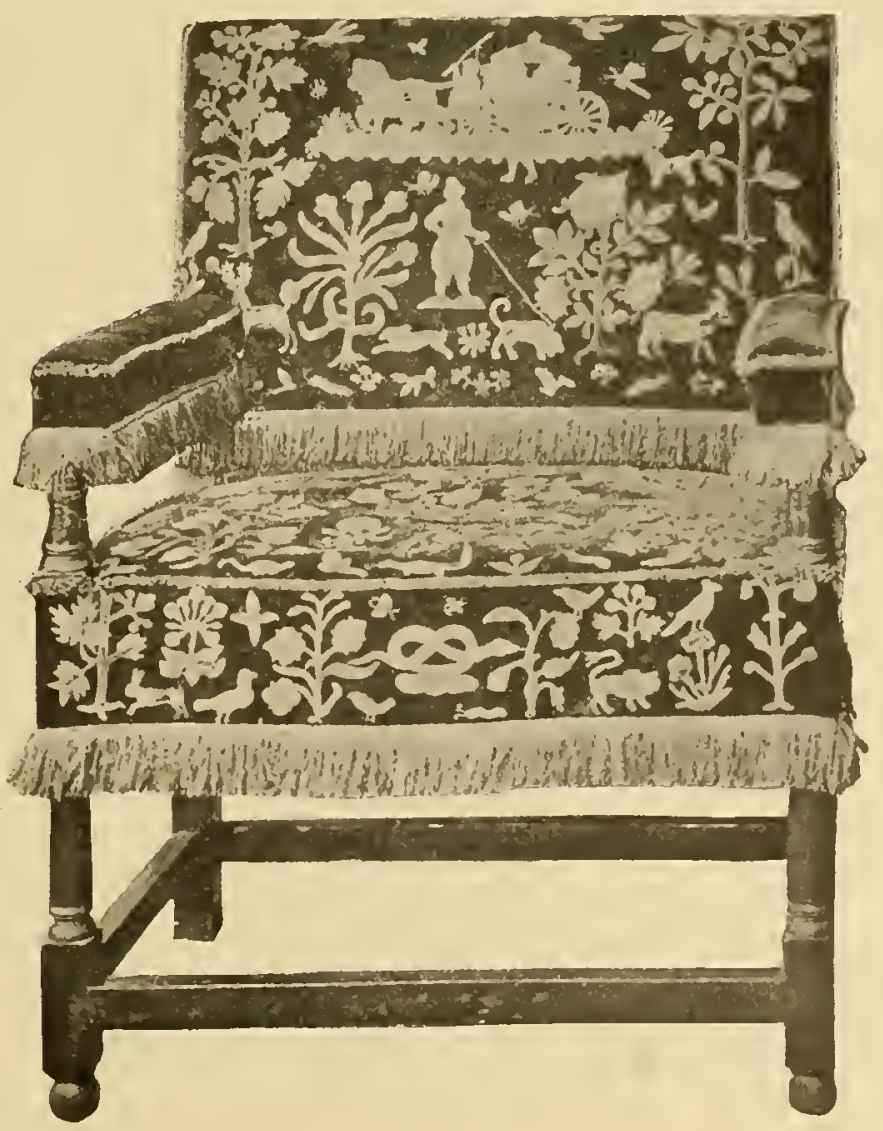




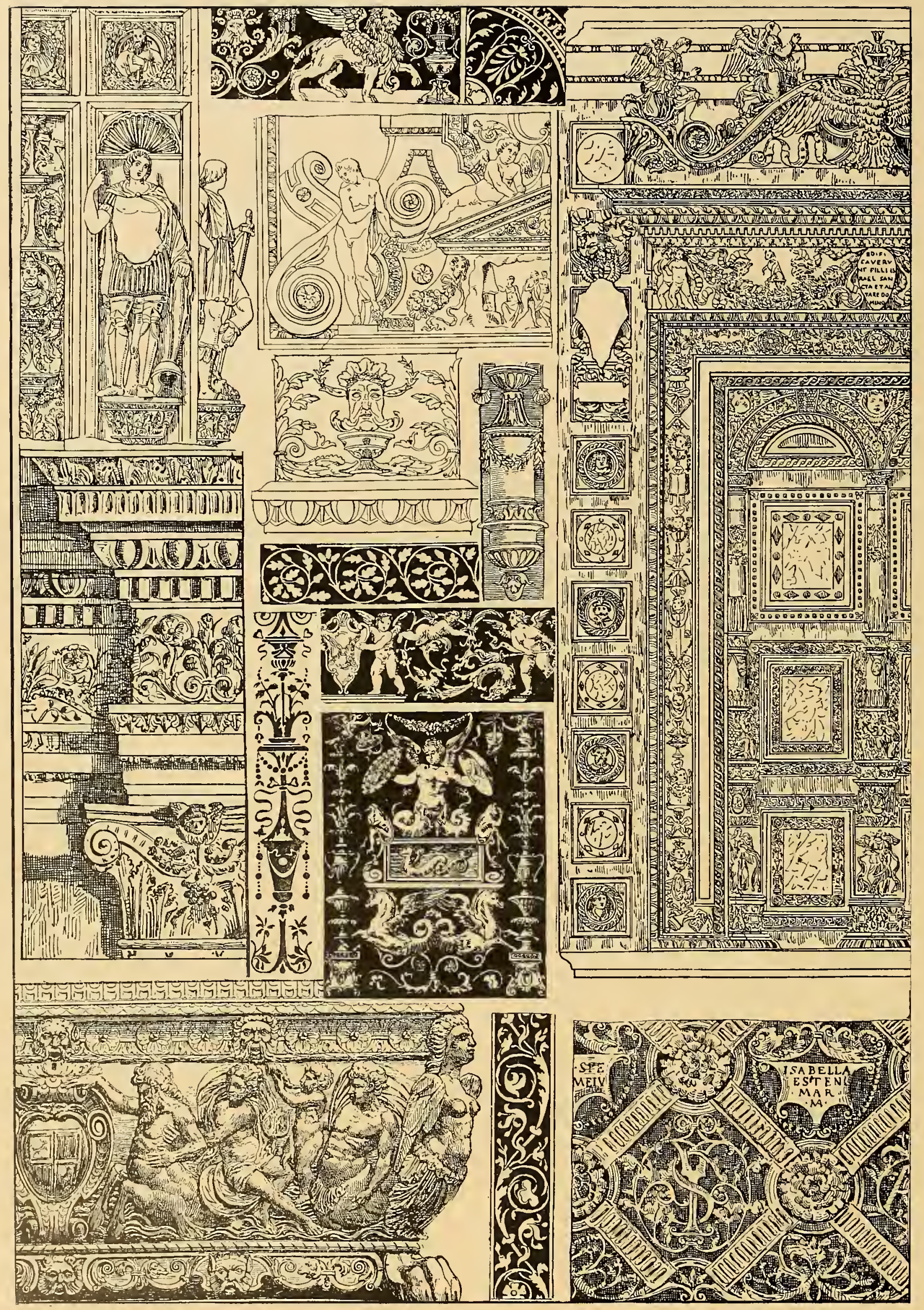




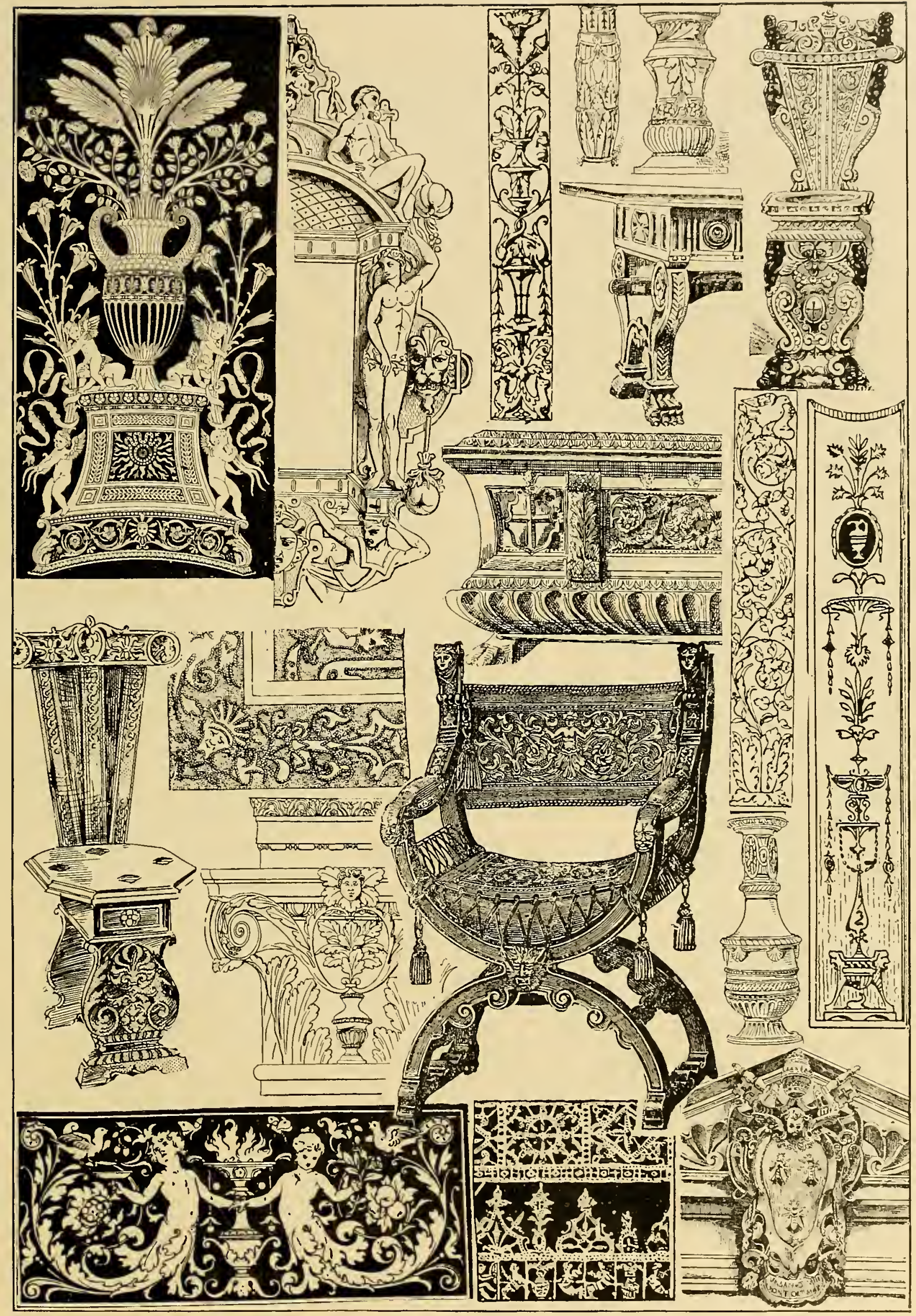

I T A L I N R E A I S A N C E. 


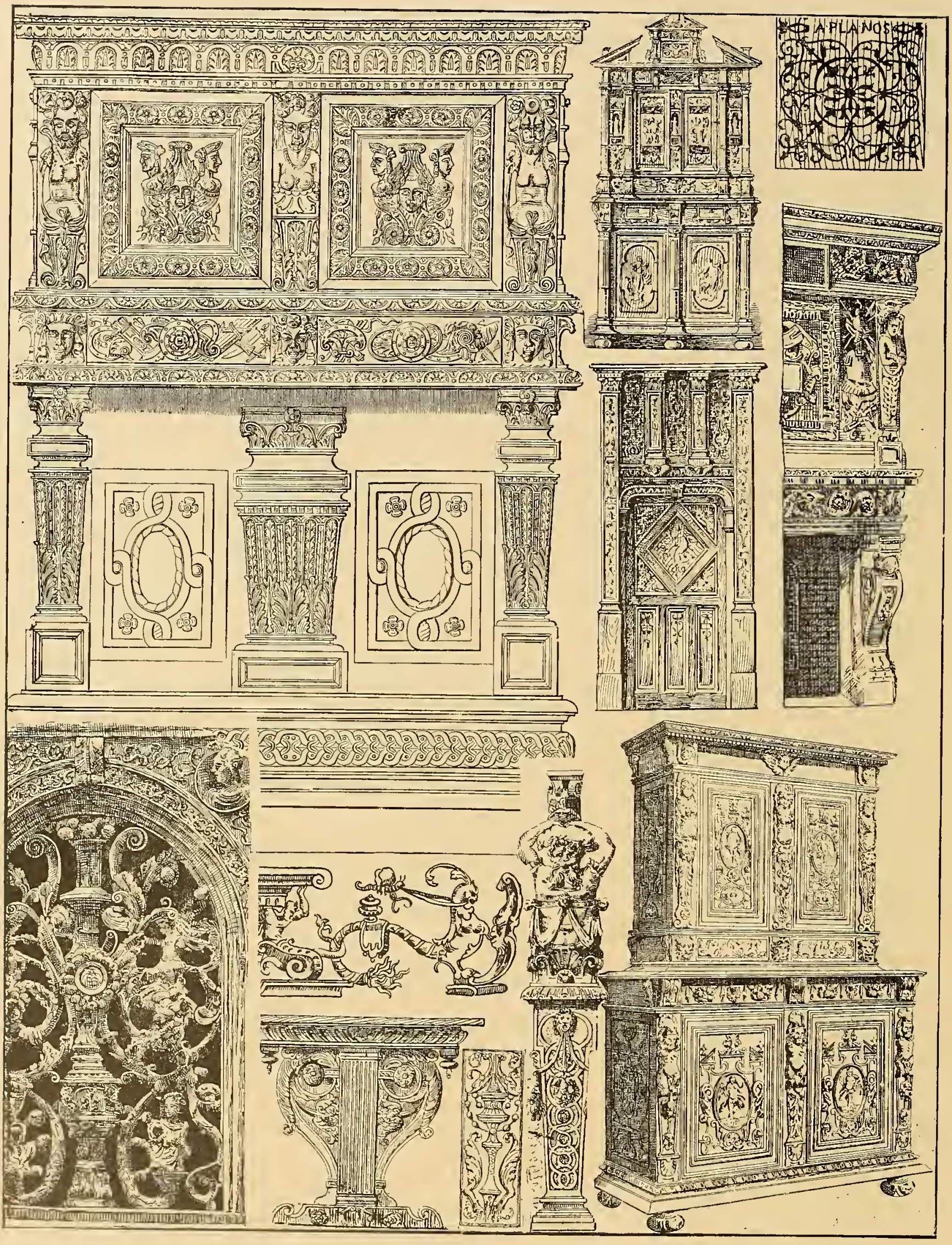

F R E C H R E A I S A N E O R A M E N T. 


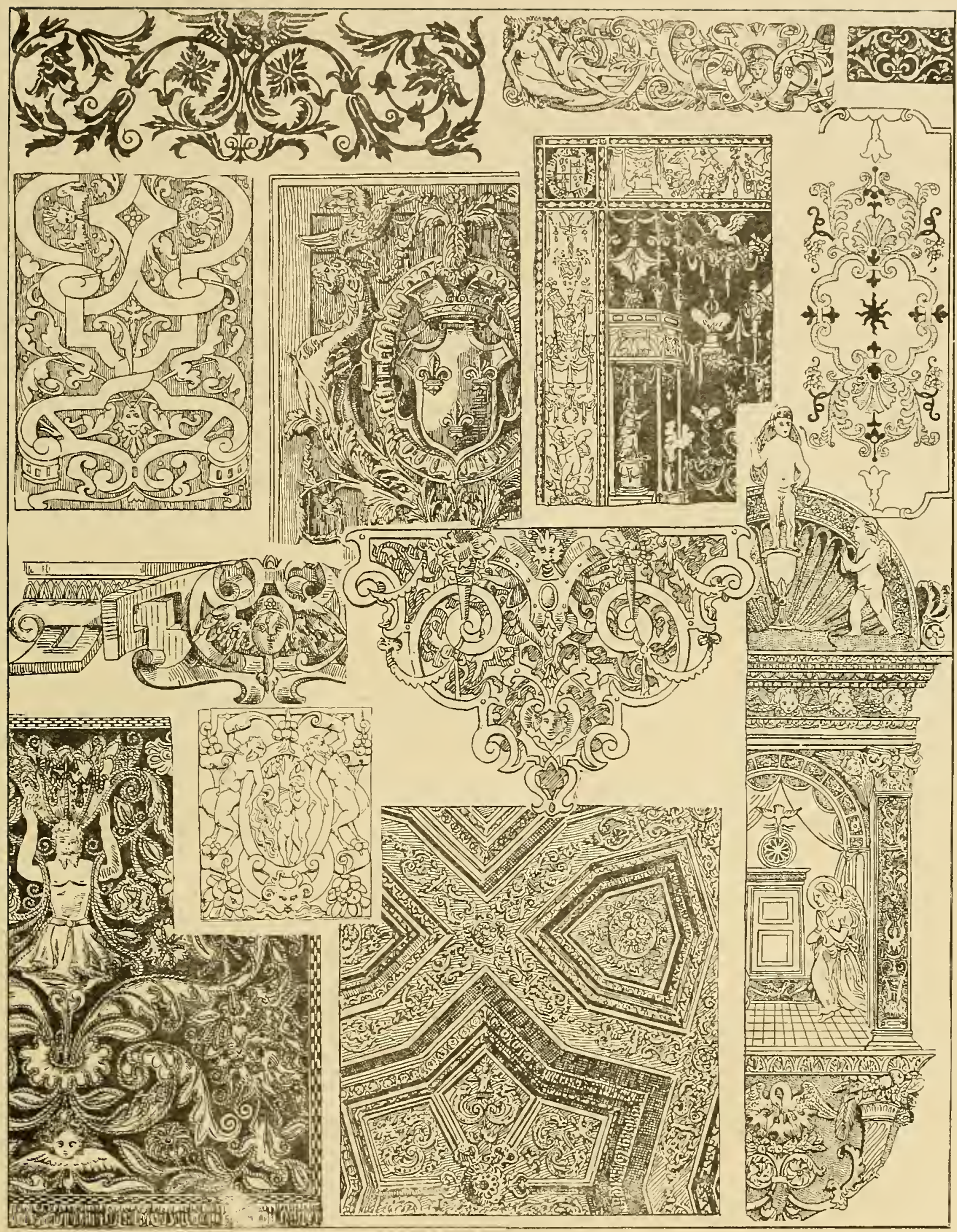

R E N A I S S A N E O R N A M E N T. 


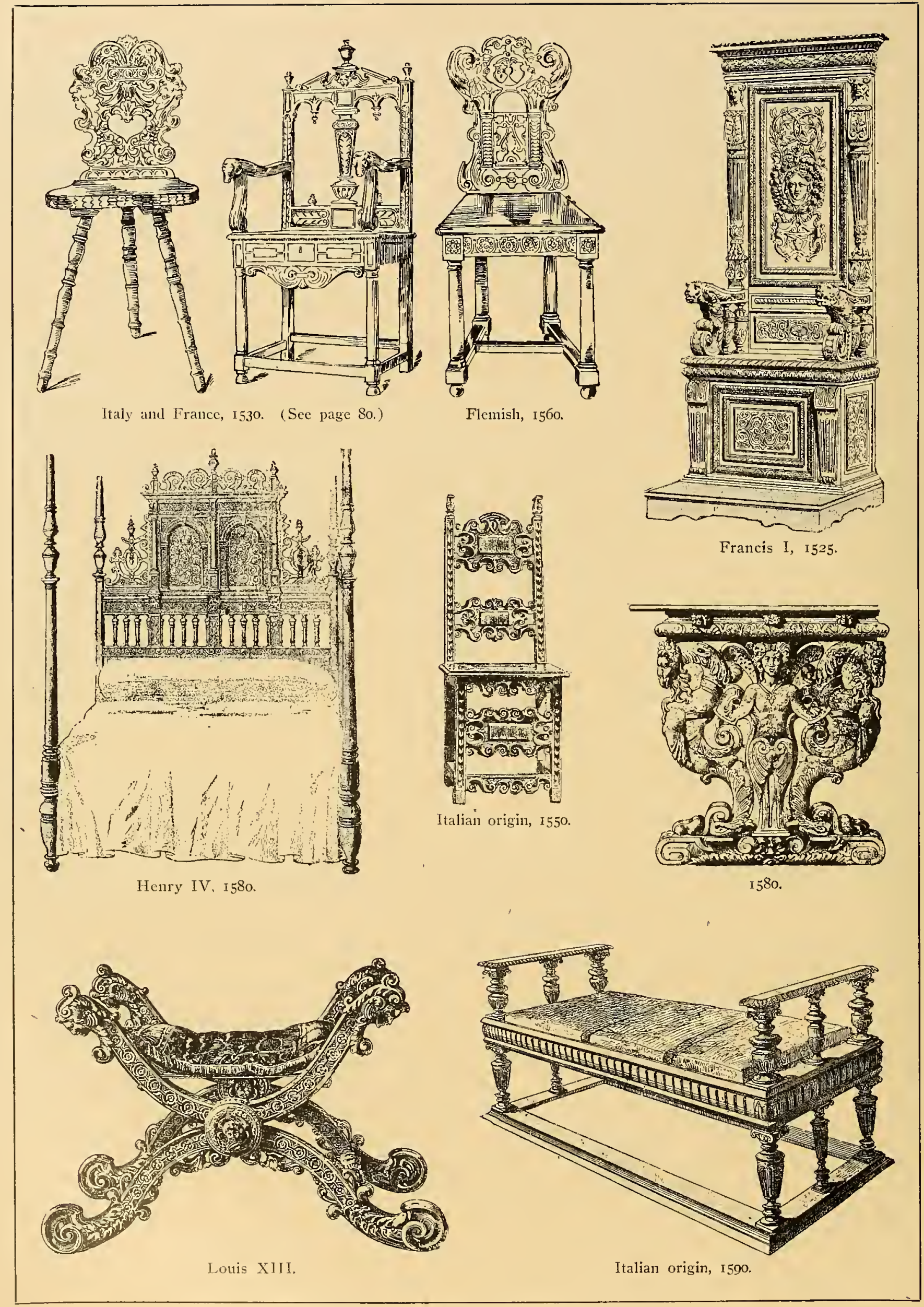

F R E C H RE NAIS A N C E. 



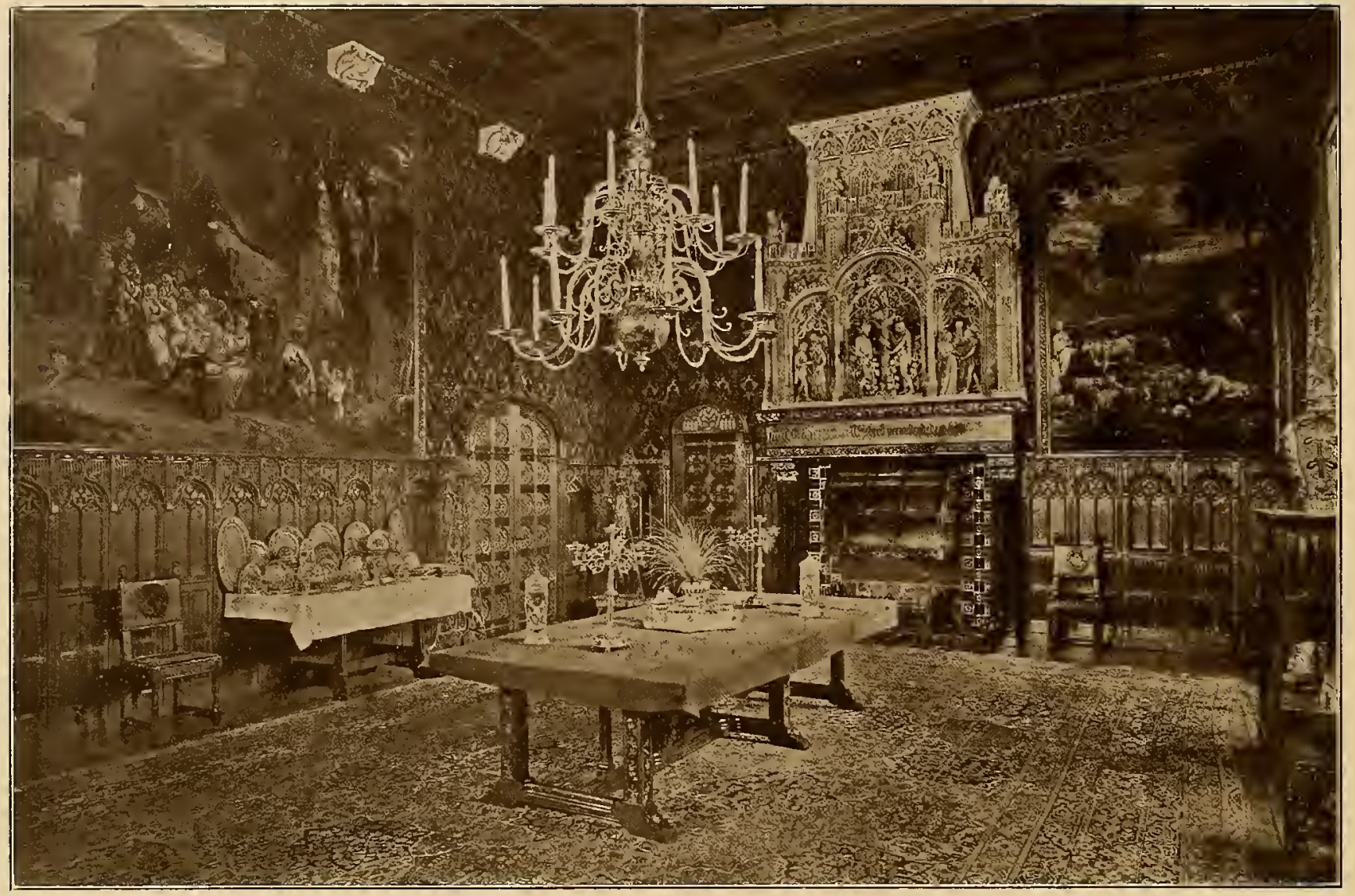

GOTHIC DINING-ROOM OF THE CHATEAU DE HAAR A HAARZUYLENS, NEAR UTRECHT.

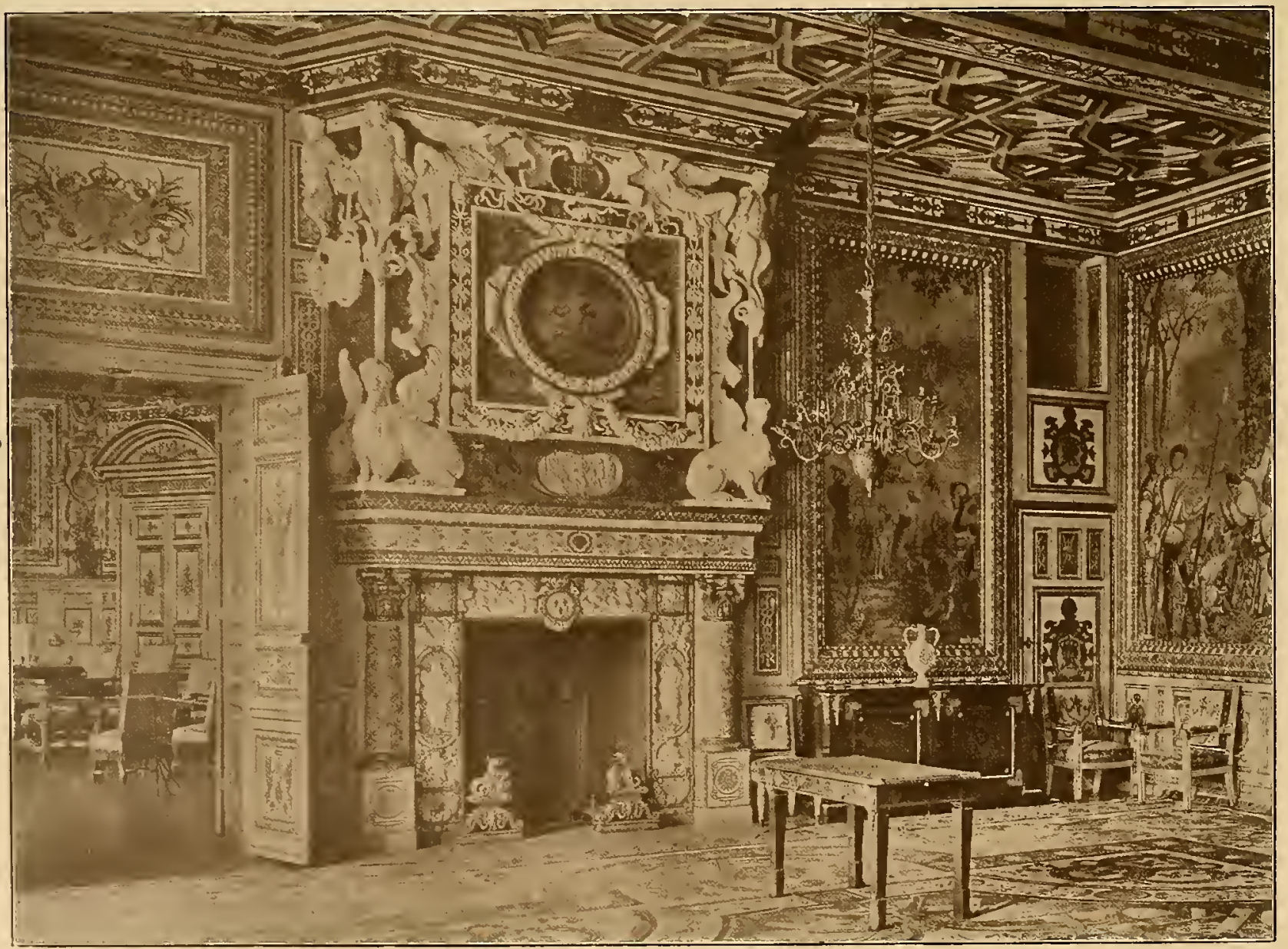




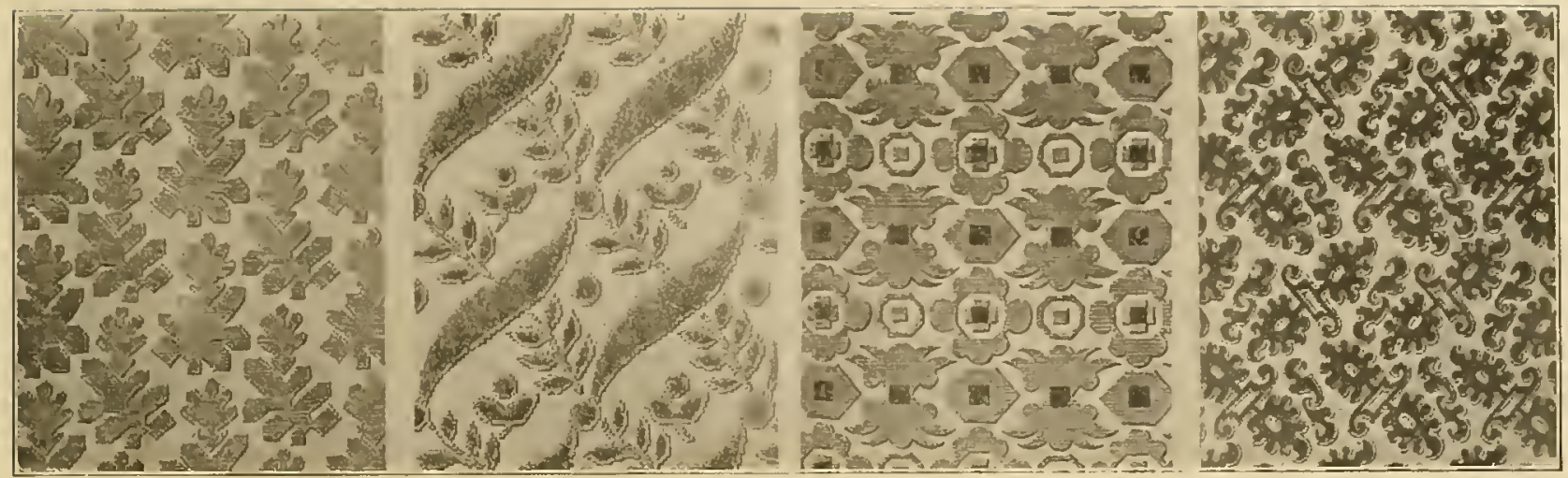

Venetian and Genoese velvet and gold brocades of the late Sixteenth and Seventeenth Centuries. Originals in the Museums of Berlin, Vienna, Munich, Dresden and Nuremberg.

\section{F L E M I S H R E N A I S S A N C E}

\section{DEVELOPED FROM THE ITALIAN I507.}
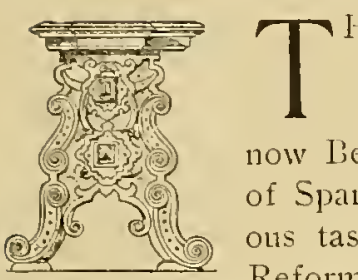
HE North country, now Holland, and the South country, which included Flanders, now Belgium, were, up to the period of Spanish domination, of homogeneous taste and character. With the Reformation came a gradual division of interests and sympathies. The North country, including about two-thirds of the Netherlands, established the Dutch Republic, while the South country, alienated from her Northern sister, soon lost supremacy in the arts. Upon the traders of Holland fell the mantle of the Portuguese voyagers, and, in India especially, they opened great avenues of trade.

For centuries the products of Flanders and later the products of

"Portuguese Chair." Period, Charles II, English, 1670. Charles Il's wife wa. Portuguese. The chair on the left is Italian: the chair on the right Flemish. about 1600 .
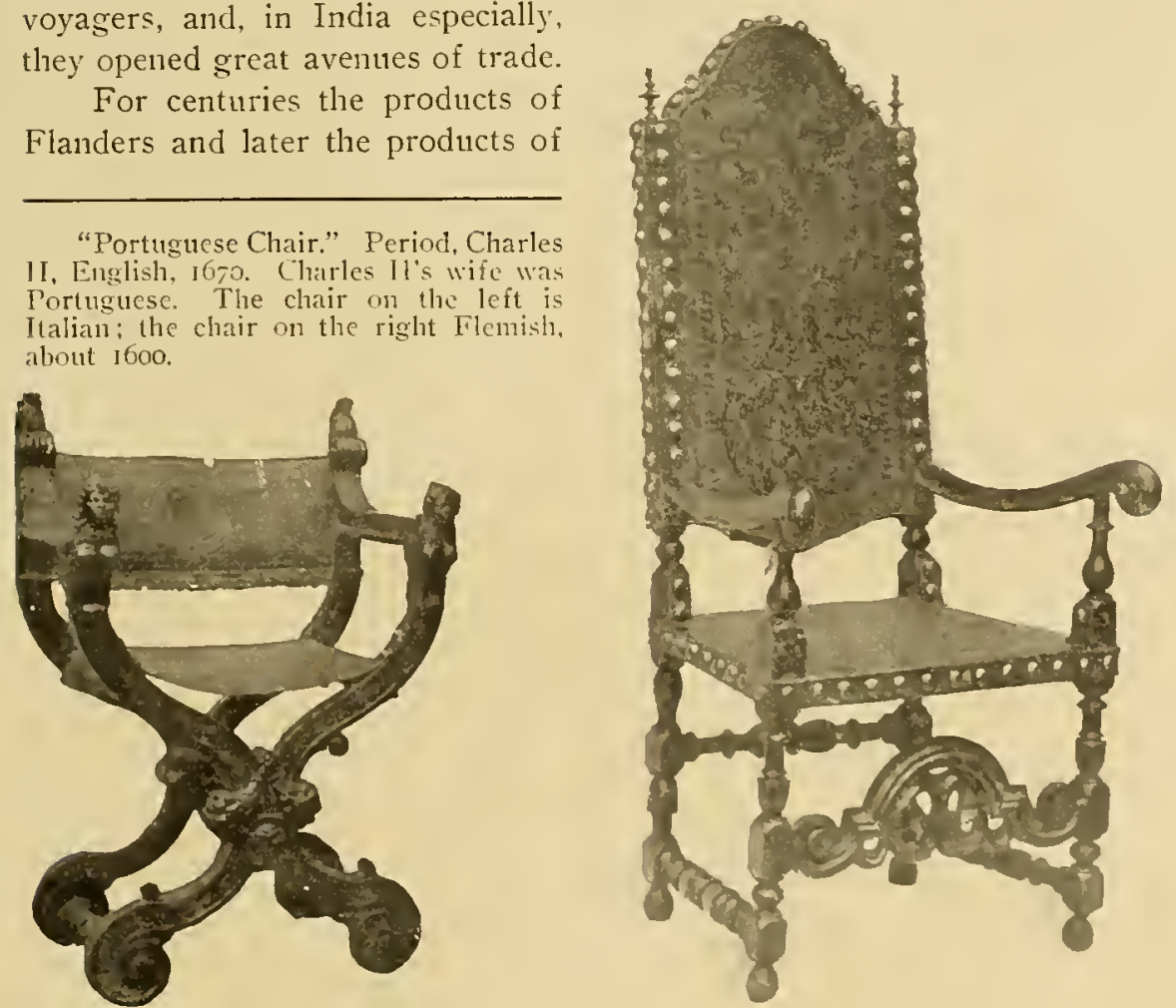

Holland poured into Great Britain. England supplied most of the wool used in the manufacture of Flemish lapestries, and in Medieval days could always depend ipon the support of the Flemings by her control of the wool situation.

From the date of the Dutch conquest over Spain, I6oo, accomplished with English aid, the relations of the two countries became still more intimate, affecting materially the decorative arts of England from Elizabeth down to William and Mary.

In the Eleventh Century Cordova leathers, superbly gilded and painted, were introduced into Flanders; the term soon applied to similar leathers produced in Portugal, Flanders, France and Italy. Spanish leathers (Cordova proper) were usually in high relief and Saracenic de-

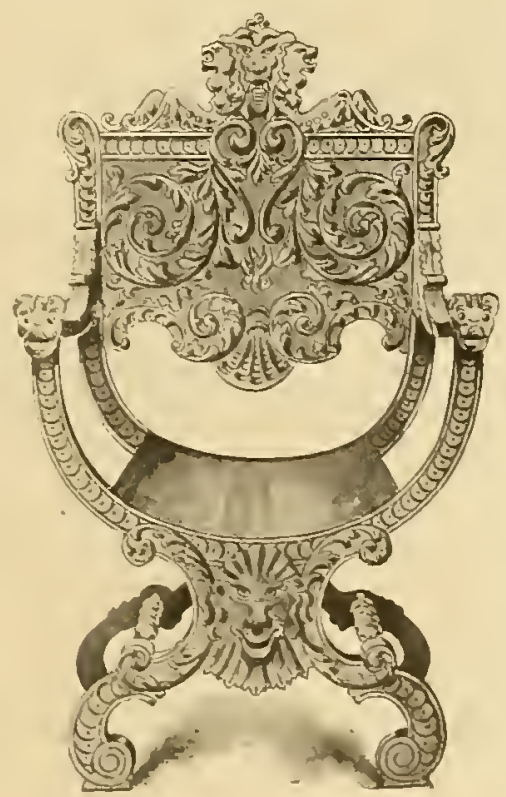

[89] 


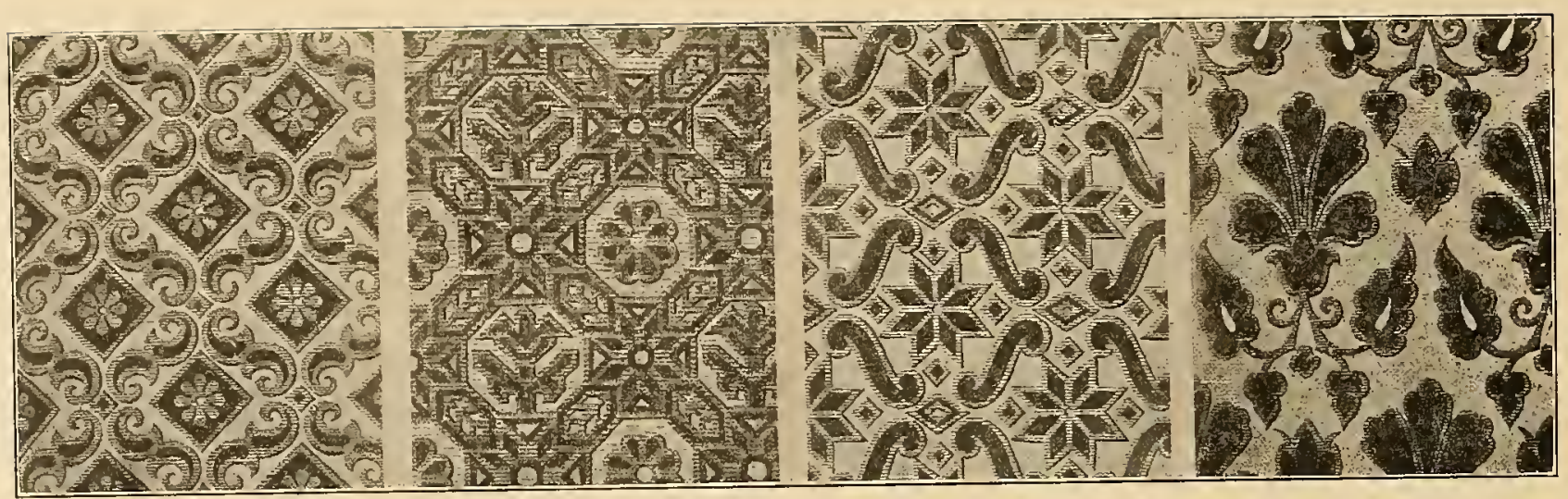

THE illustrations above, as well as those appearing at the head of page 89, are reproductions of Venetian and Genoese velvets and gold brocades of the Sixteenth and Seventeenth Centuries. The reproductions are one-quarter the size of the originals which show colored motifs on gold ground.

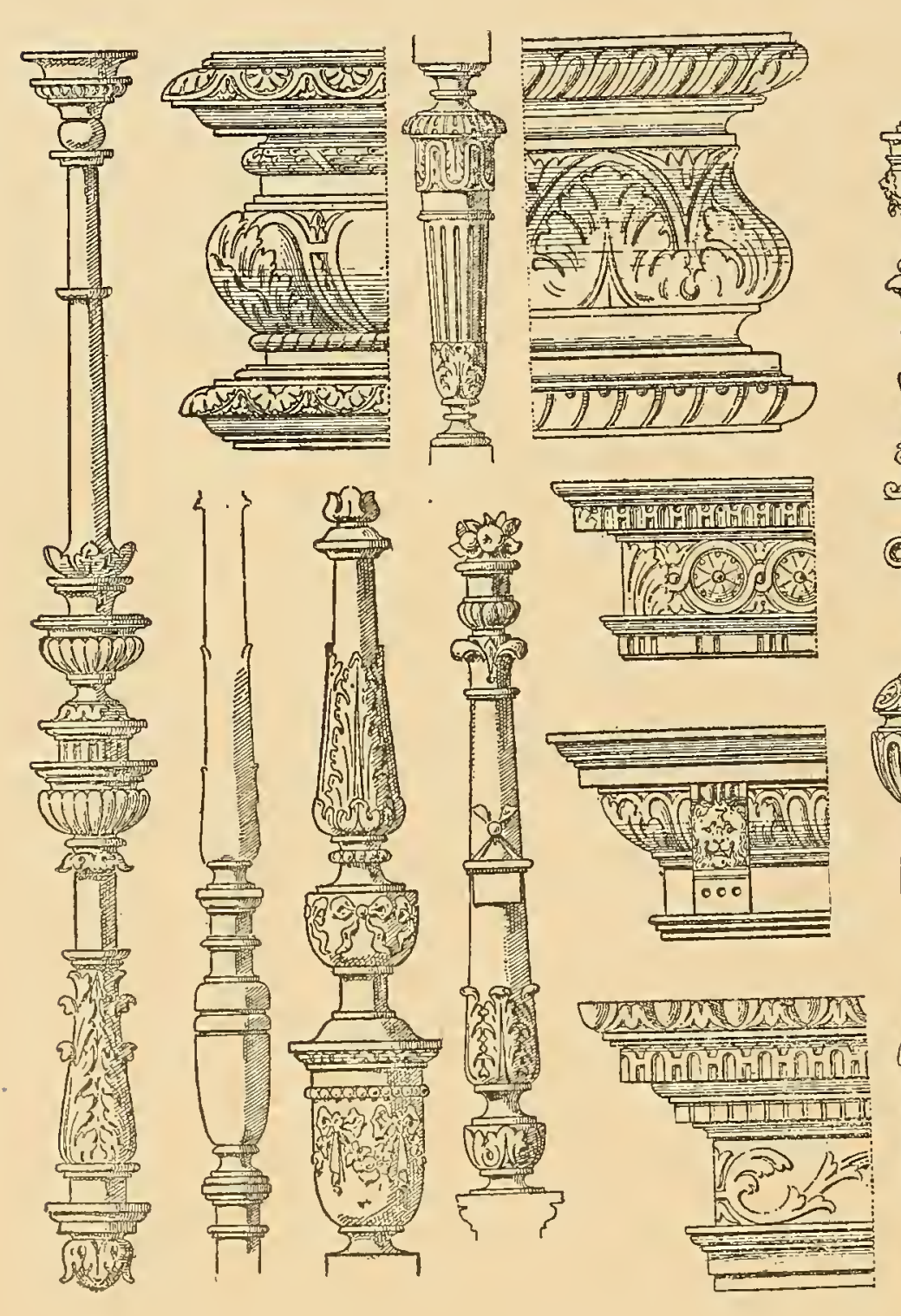

F R A N C I S
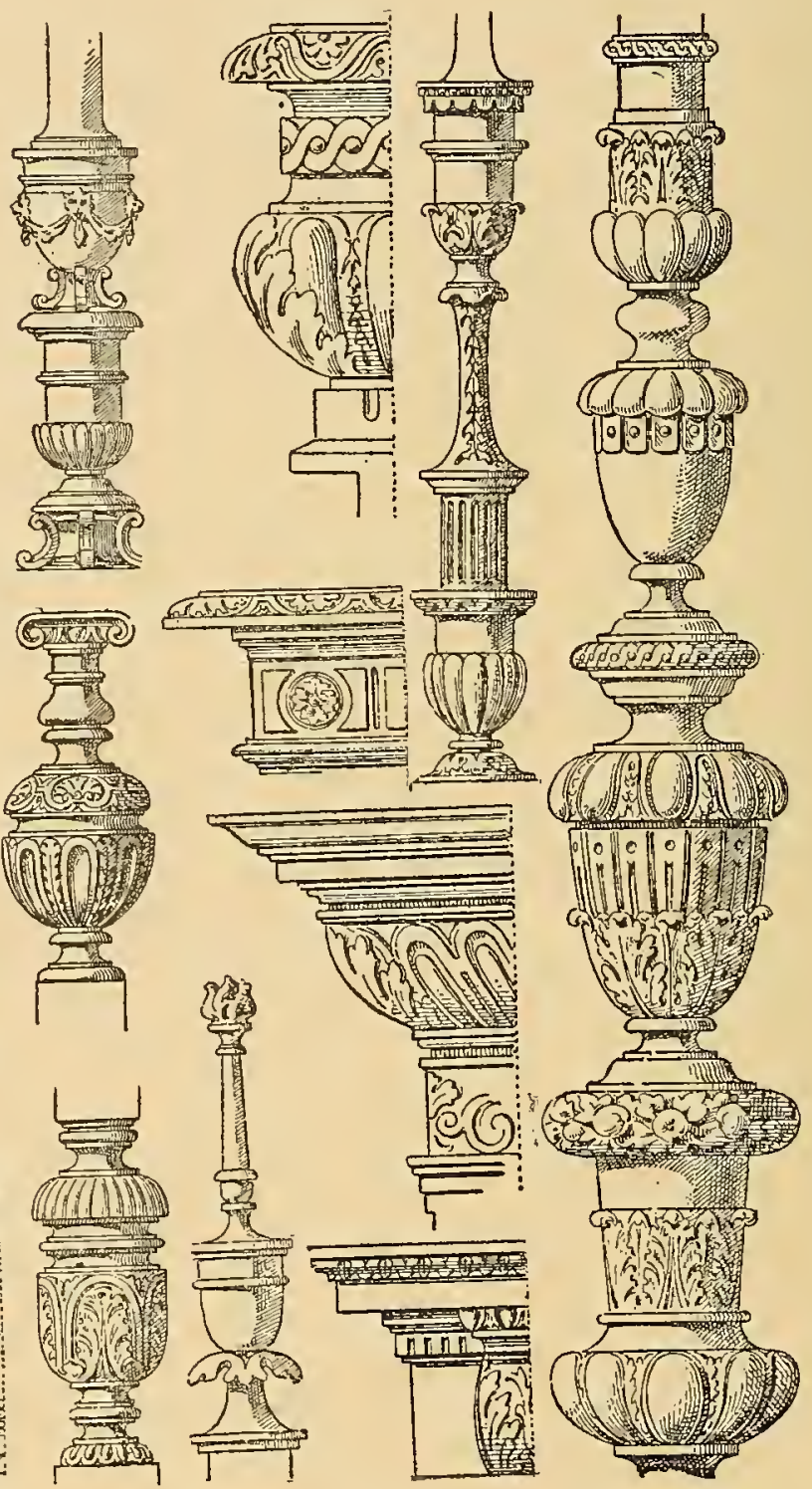

(6)
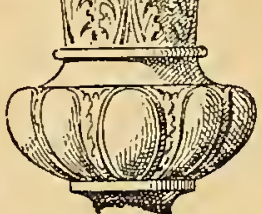


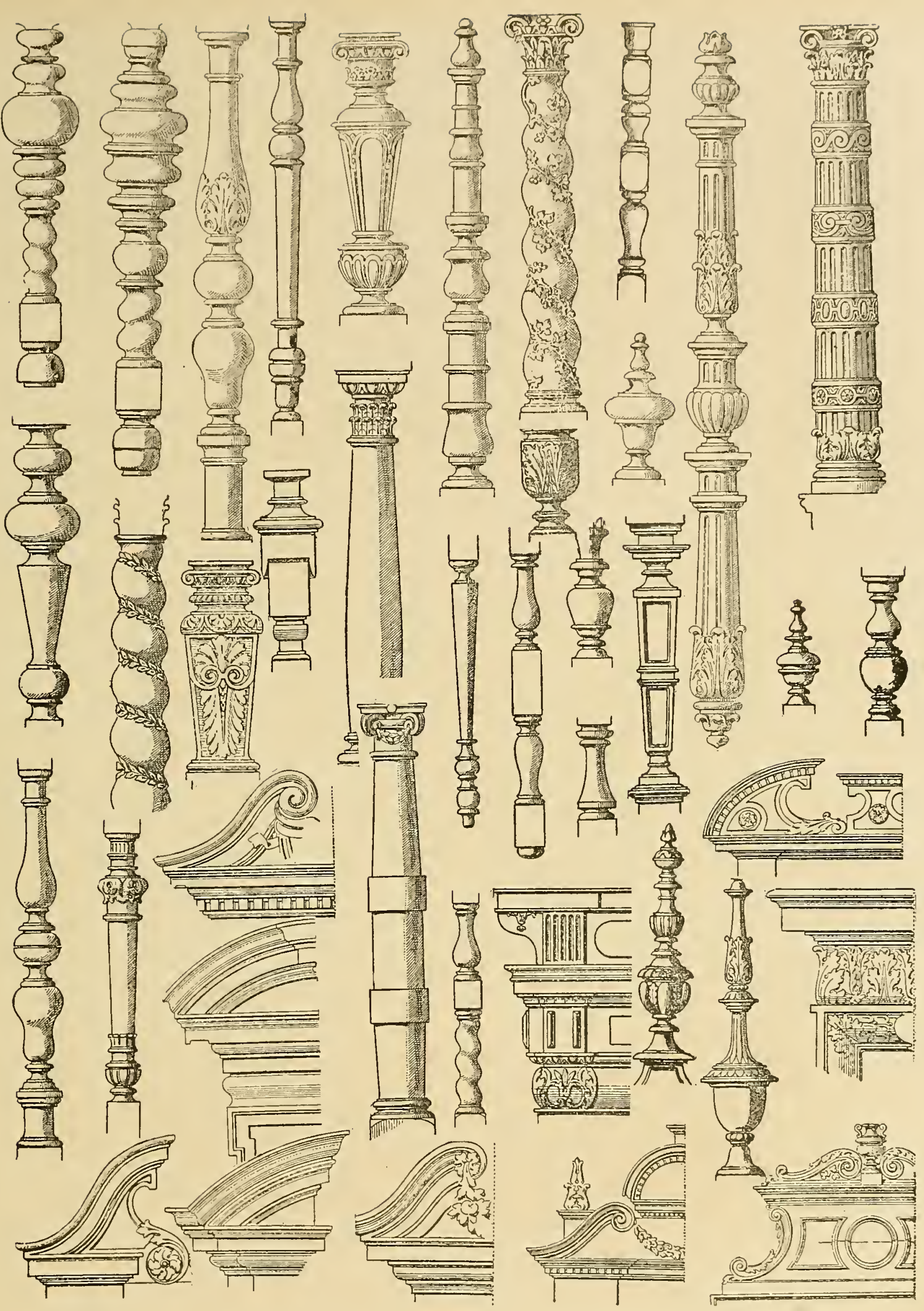

H E N R I I V. I 589-I 6 I O. 


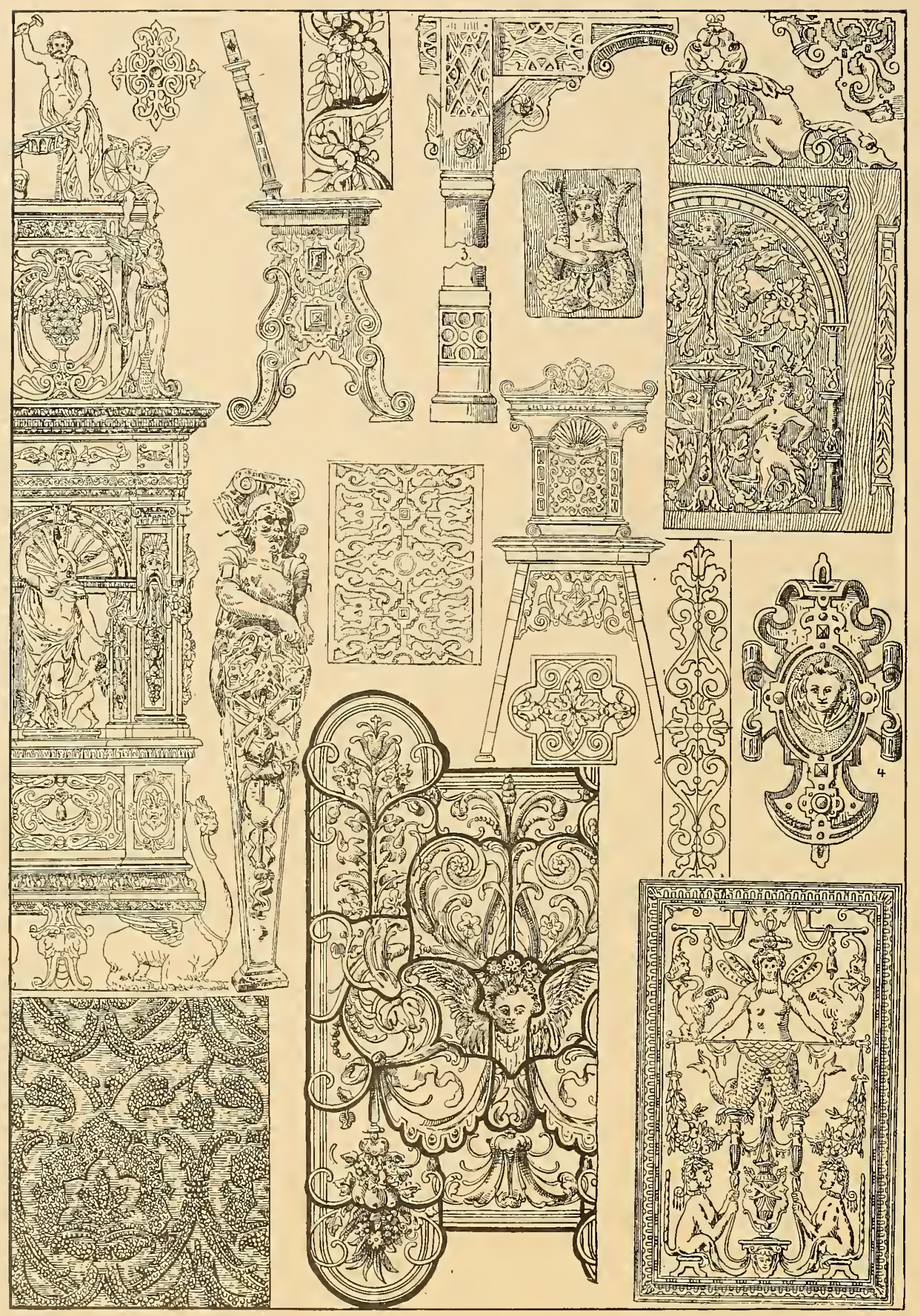

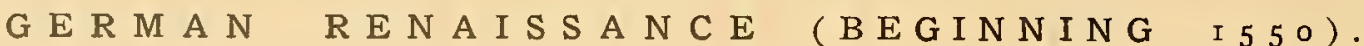


sign; leathers of Flanders and Italy, frequently of calf, were of low relief in exceedingly delicate design, mythological or ecclesiastical.

The earliest woven tapestries of Europe were Flemish ( 1100 ). On account of the great importance of the arts, the Duke of Hurgundy atopted the Golden Fleece as the title of the great order of knighthood. In the Fifteenth and Sixteenth Centuries the tapestry makers of Italy, France, Germany and Spain borrowed the tapestry arts from Flanders.

The furniture of Medieval days was mostly of a fi $x$ e d character. Cupboards, wardrobes and larders were built into the panellings. Up to I 300 the carver and carpenter were one and the same. Then came a division of labors. Carving was usually a plied to fixed parts of the house.

Crude beds and benches were supplied with cushions carried in the chests. Walls were hung with printed linens and tapestries.

In the Fourteenth Century we find not only carved oak but inlays of ebony and ivory.

$\mathrm{H}$ a ng ings were the $\mathrm{chief}$ feature of the interior decoration. The Italians had a monopoly of the trade with the Orient, and Europe was supplied by them with Oriental rugs. Up to 1400 there was little movable furniture to be found even in the palace-simply benches, trestles, chests and forms. The plain box or chest when raised on feet or legs was a dressoir, credence or sideboard. The armoire was developed by building chest upon chest with open fronts. In some old Medieval manuscripts we find chests so large that, covered with skins or matting, they were used for a bed. The difference between a dressoir and buffet was simply that the lressoir was used for display; the buffet for use.

The number of shelves on a dressoir was regulated by etiquette. The common people could use a dressoir with two shclves, the nobility with three shelves, the royalty four or five slielves.

In 1420 we liear of Cordova leat hers being used on the floor, around the bed, and of leathers for chamber liangings. Charles $V$ of France (1380) used leathers on the floor in Summer $t$ im e, and throughout the period we find leathers used for upholstering. During the Fifteenth Century Flemish workmen emigrated in great numbers to Eng land, Spain, Italy a nd even Hungary.

The Flemish were almost as celebrated for their leathers as for their tapestries. Gold and painted leathers were common, a $11 \mathrm{~d}$ red morocco leathers from Spain were, from the beginning of the Sixteenth C e n tury, generally used for wall hangings and table covers. In I 539 the tapestry
factories of France sent to Flanders for her weavers. The flemish cabinetmaker, architect and weaver was in great demand during the Renaissance, and in Spain, France and England be found congenial residence.

In the Seventeenth Century the Dutch commerce in the Far East not only brought into Europe vast 


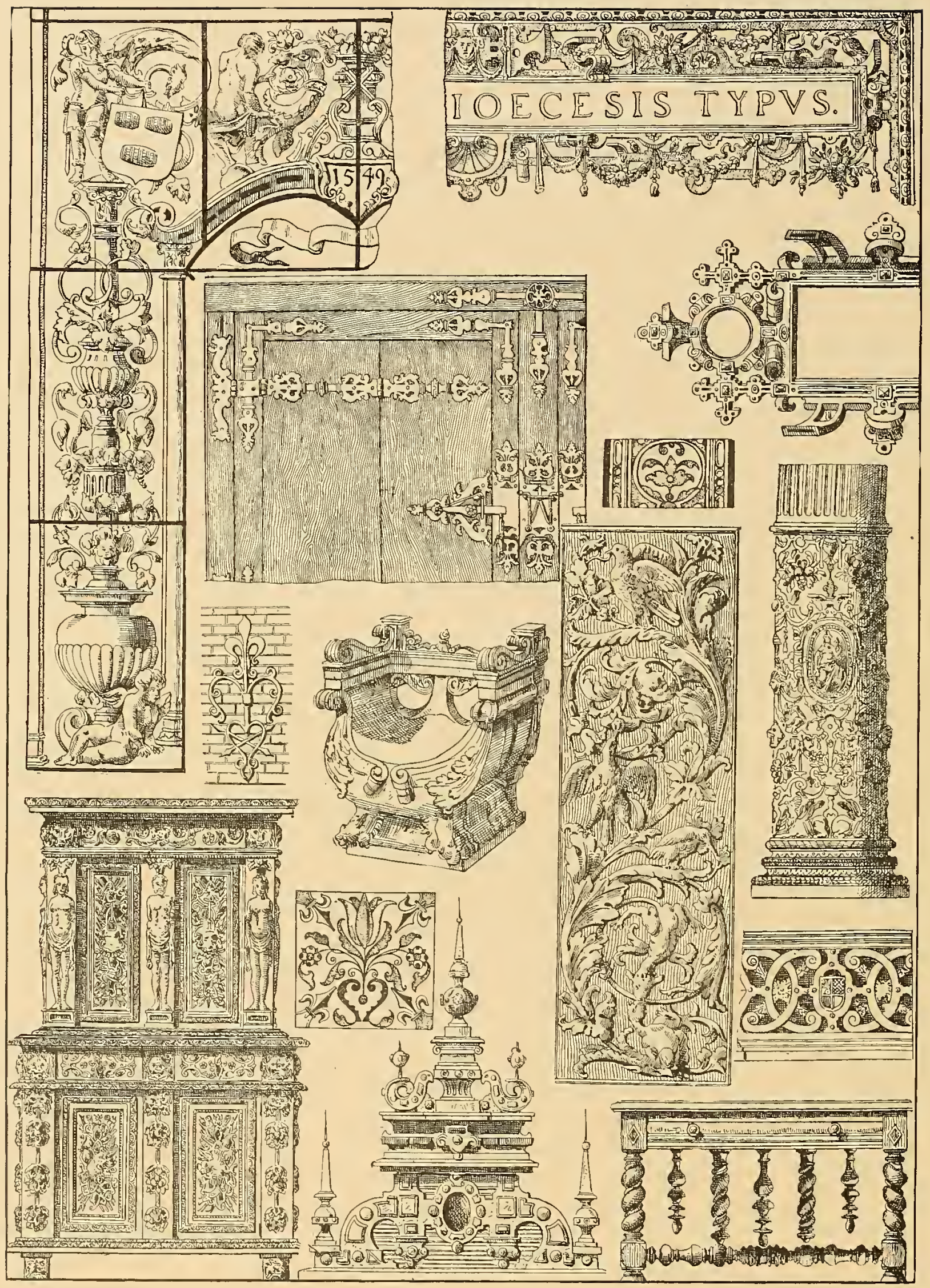

FLEMISH RENAISSANCE (BEGINNING I50\%). 
stores of Indian art, but the masters of vessels were commissioned by nobles and potentates to bring home

In 1609 , the East India company issued letters for reserving "all strange fowls and beasts to be found there, for the Comncil." The cockatoo and the parrot in wicker cages were much in evidence in the paintings of that period. Naturally the artists were much impressed, and the Dutch embroideries and prints of that age were full of Eastern character, floral and animal.

France owerl much to belgium and Holland during the first part of the Seventeenth Century, when Flemish and Dutch artists contributed so materially to upbuilding the French industries. $\quad B \| \mathrm{t}$ France repaid with interest, for in 1685 the revocation of the edict of Nantes sent 50.000 families of $\mathrm{t}_{1 \mathrm{e}}$ best French blood. intellect, art, culture and craftsmanship into voluntary exile.

Re:sI.IN RENiIss.xce - The Ren a is a n $\mathrm{cc}$ reached $R u s s i a$ through Italian artists, who worked always subordinate to Oriental and Scandinavian influences. J'olish art, however, was more susceptible to ltalian fecling, and the Renaissance ormament of Poland was furer.

Spanish and Portuguese Rexalssince-Spain [95] monkeys, parrots, peacocks, pheasants, cats and dogs.

was for many centuries accustomed to Moorish art, and the new motifs which came from lirance and Italy at the end of the Fiftenth Century were not easily assimilated. In time, however, the Moorish cliaracter rlisappeared, and what was left, termed the Plateresque style, was a minutely-rletailer and

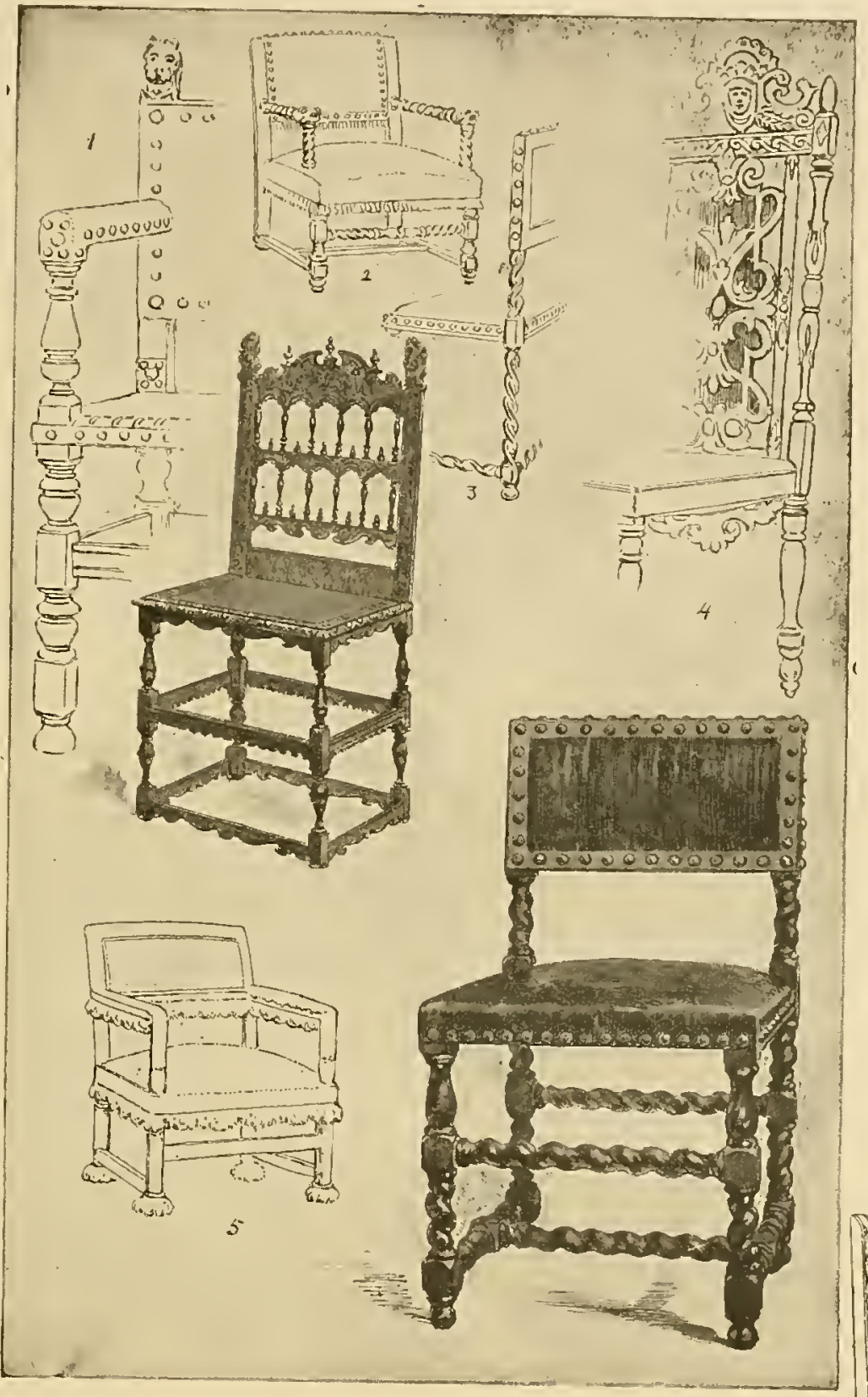

Italian turned rail furniture. Illustrations I, 3 and f. Italian. Adapted by Flemings, Period Henry IV, France. Rail back chairs were common in Flanders, England, Jirance, 1660 . In the latter country called Chaise
Noklleghax Rexais SIXCE-Norway and Denmark took the Renaissance feeling from Flanders. Norway peasants were natural woodworkers.

sumpuluous mingling of Gothic and Renaissance in delicate Arabesque. In furniture the Spanish and Portuguese types as a rule reflected the Flemisl. The most familiar type of chair was highbacked and furnished with a ridged foot as distinguished from the ball or claw foot.

The Gothic tendencies clung to the cabinetwork of Spain, and barbaric suggestions were in common evidence.

In decoration neither Spain nor Portugal have left numch worthy of consideration except the HispanoMoresque and Allambraic types of the earlier centuries.
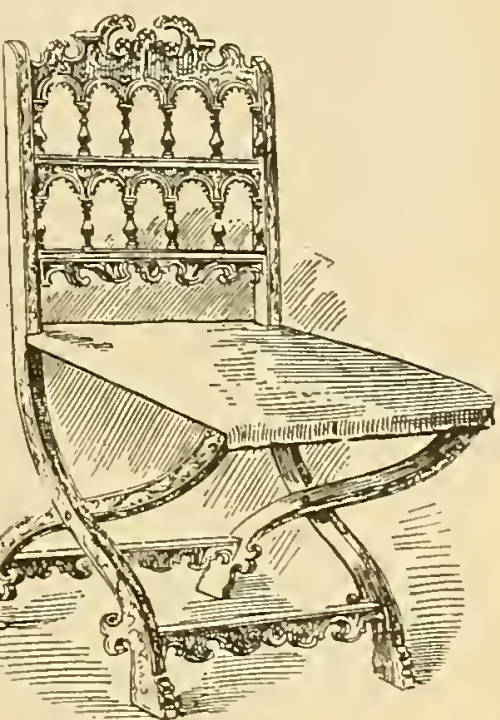


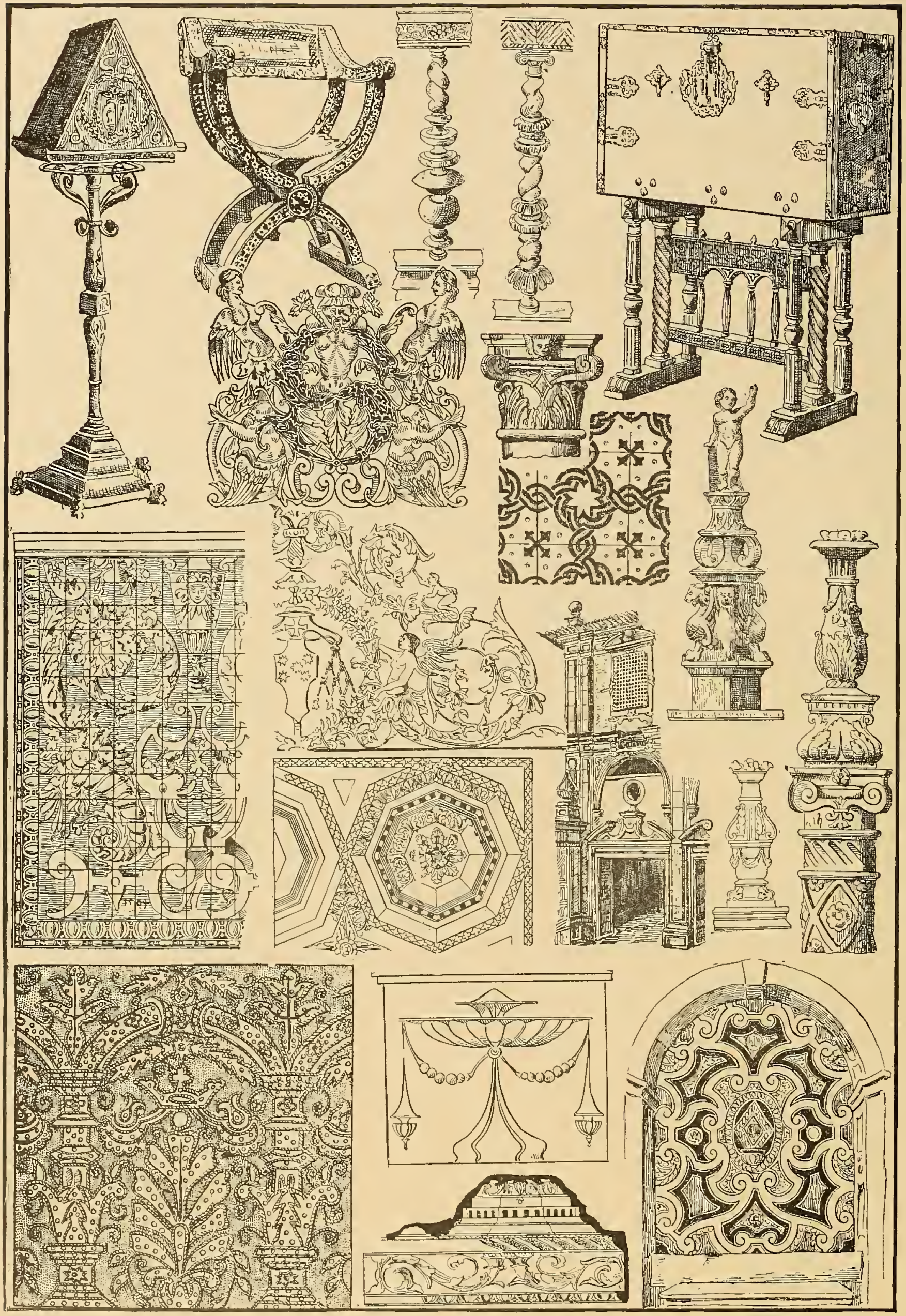



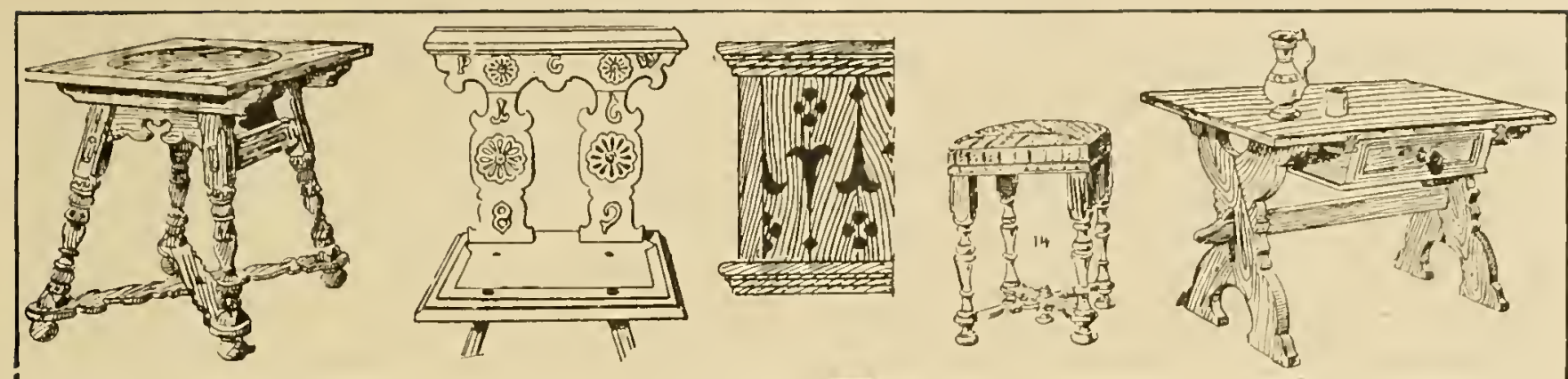

SWISS RENAISSANCE.

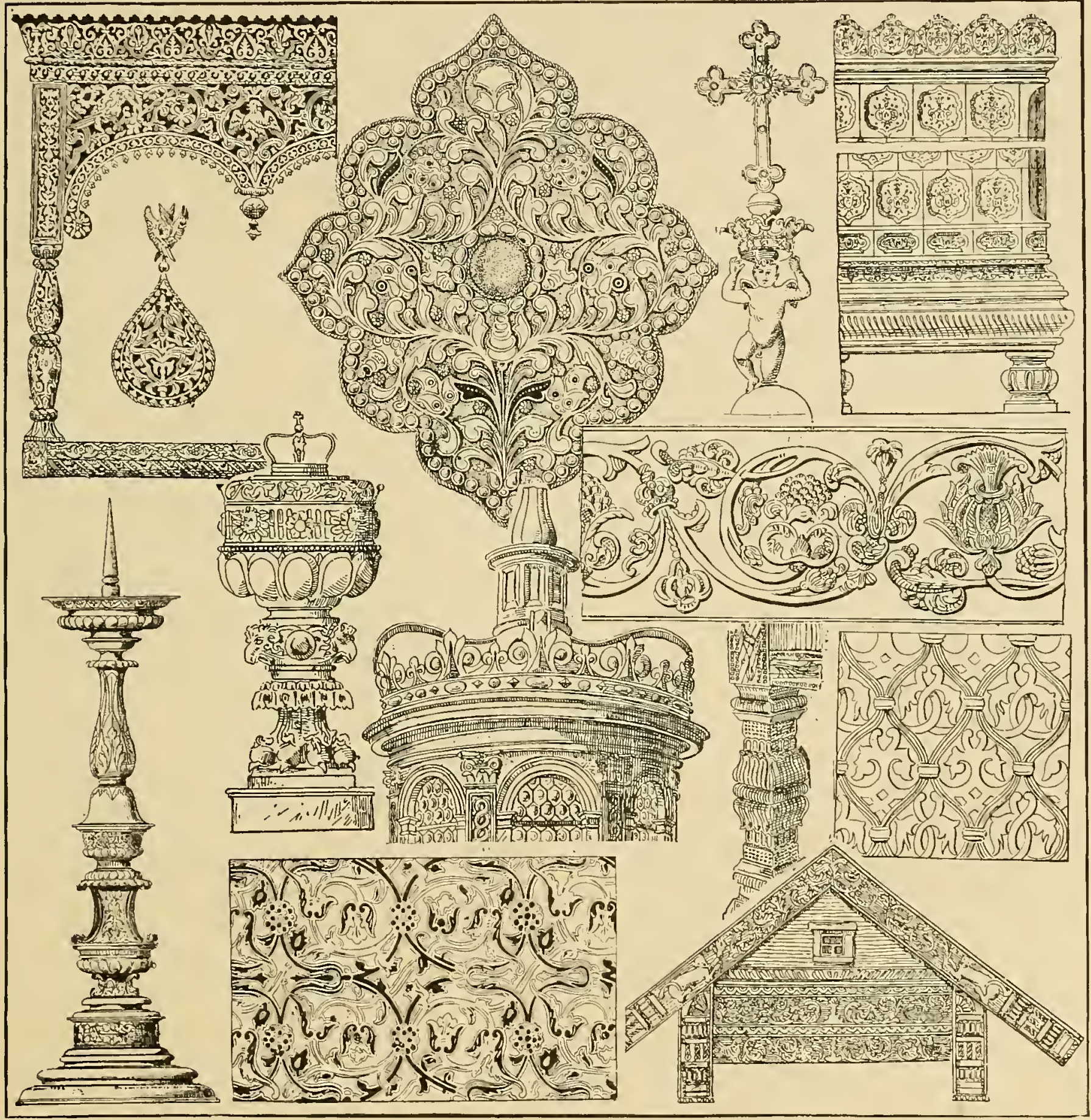



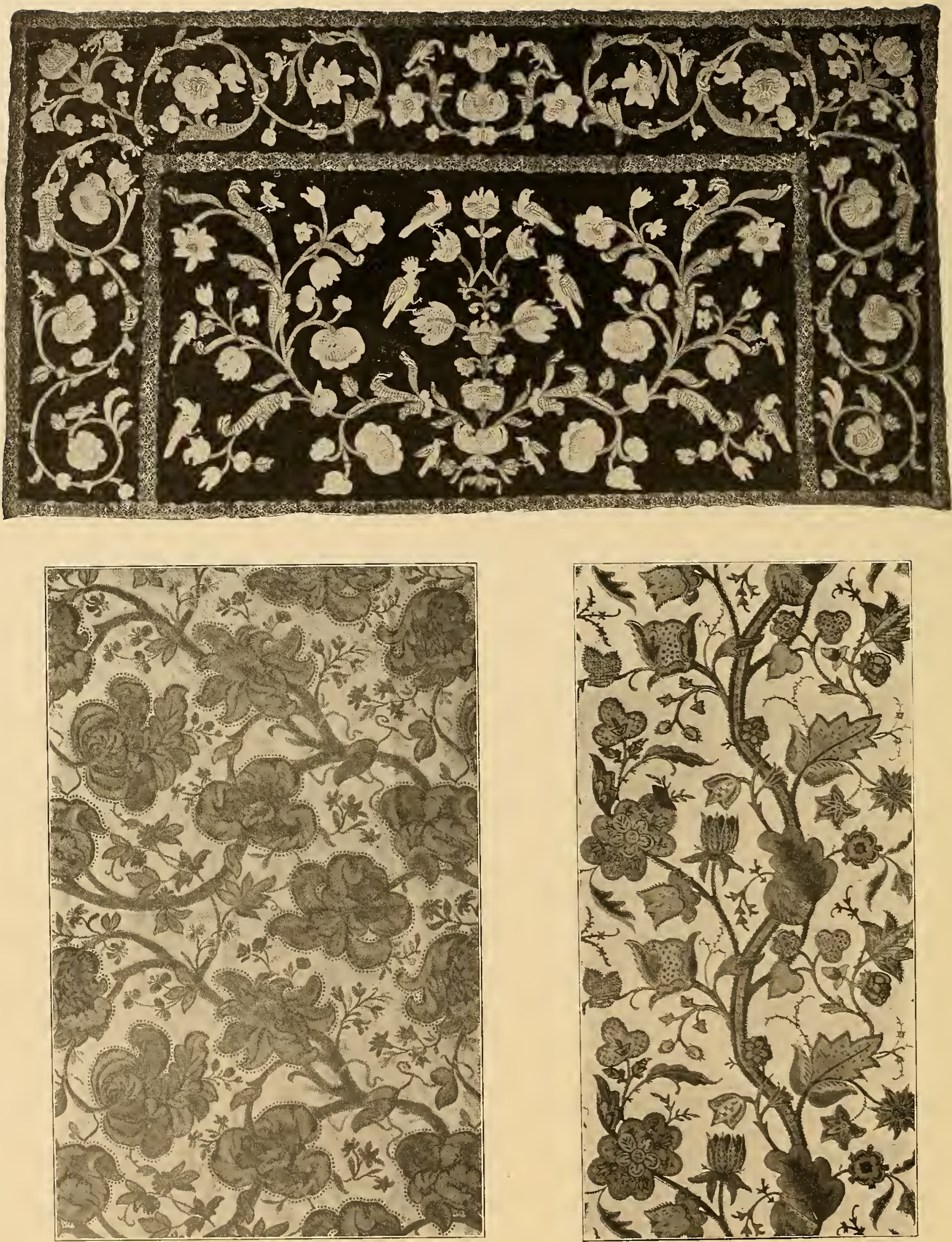


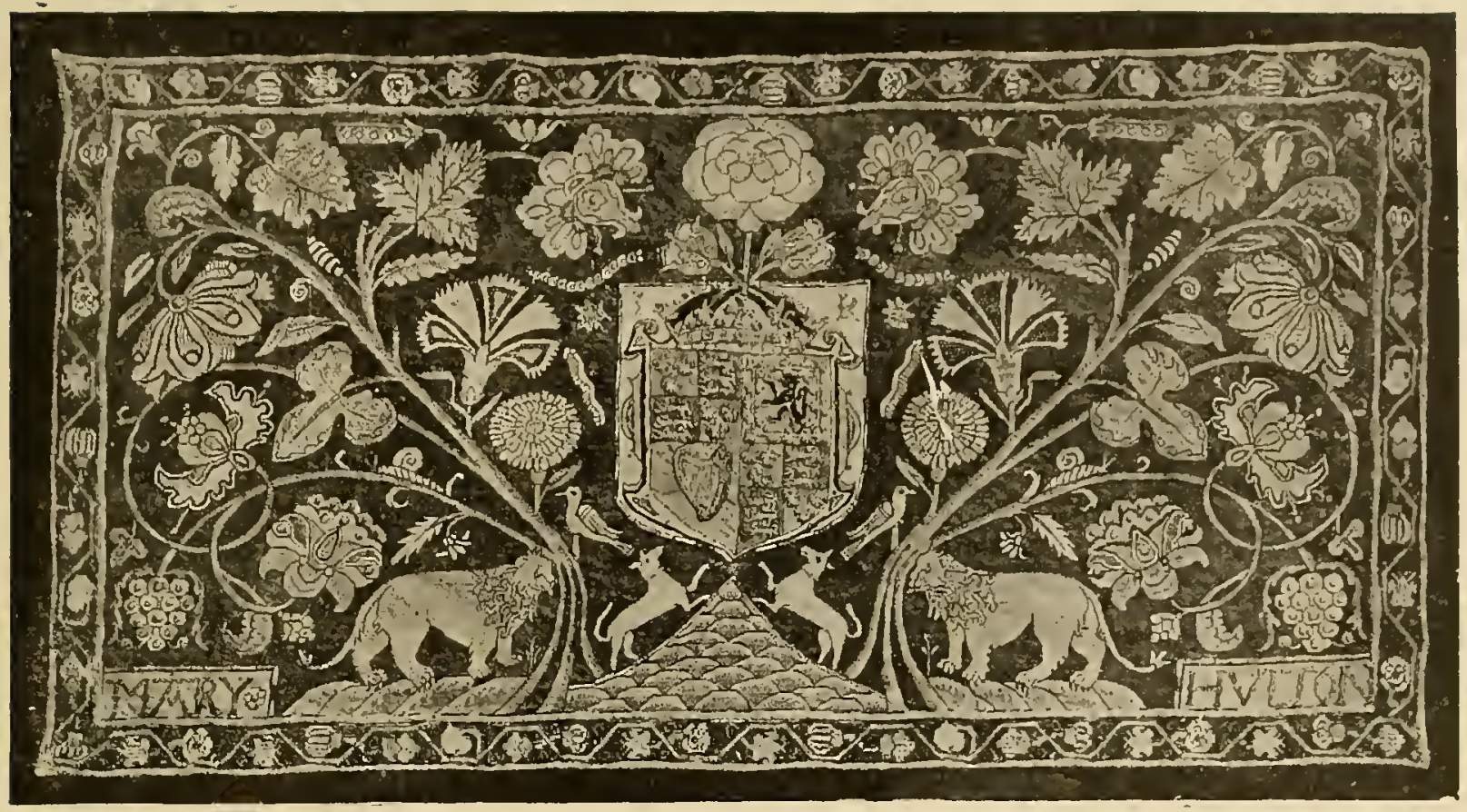

Elizabethan Embroidery.

\section{E N G L I S H R E N A I S S A N C E}

\section{ELIZABETHAN-JACOBEAN-STUART-CROMWELLIAN.}

A LIBERAL interpretation of what constitutes the English Renaissance must carry the student back to the reign of Henry VIII, and at the outset one must understand that the Renaissance covers all that period beginning with Henry VIII and extending through the Elizabethan (the reign of Elizabeth, $1558-1603)$, and the Jacobean (the reign of James I, Charles I and the Cromweil period, I603-1659), the Italian classicism of Inigo Jones and the French classicism of Sir Christople r Wren, through the Stuart or Jacobean period well into the reign of George II. Indeed, what is generally regarderl as the Georgian period, prolific with French Renaissance floriation, is really the termination of the English Renaissance.

The entire Renaissance development in England is full of confusion because subdivided by historical data in many cases confusing.

Lnder IIenry VIII, Torrigiano, Ronezzano and John of Padua introduced the Itatian style 1512-1536, but following upon Henry VIII's quarrel with the Pope, the consequent change in religion and the im- poverishment of Engand, the Italians, now regarded with ill favor, returned home, leaving but little or no infuence behind them, and their field of occupation was soon filled by Germans and Flemings.

Beginning with $155^{8}$, we have what is arbitrarily called the Elizabethan, but Elizabethan, although the reign ended with 1603 , extended as a type clear througlı the Jacobean period, and the term Jacobean means simply, if it means anything, an Elizabethan development. The term Stuart relates to that period beginning with James $I$ and extending down to Queen Anne-all subdivisions of the Renaissance.

As early as 1556 great quantities of Flemish cabinet fronts and other cabinet work

were imported into England. acobean Chest. Elizabethan houses were built by German and Flemish architects. Strap-work designs were common, male and female figures with strap-work on the front in lieu of clothes. To the Flemings we attribute the diamond-shapes superimposed, in moldings, on square panels; the numerous juttings, and angles; the extensive use of turned work plain and carved frequently 


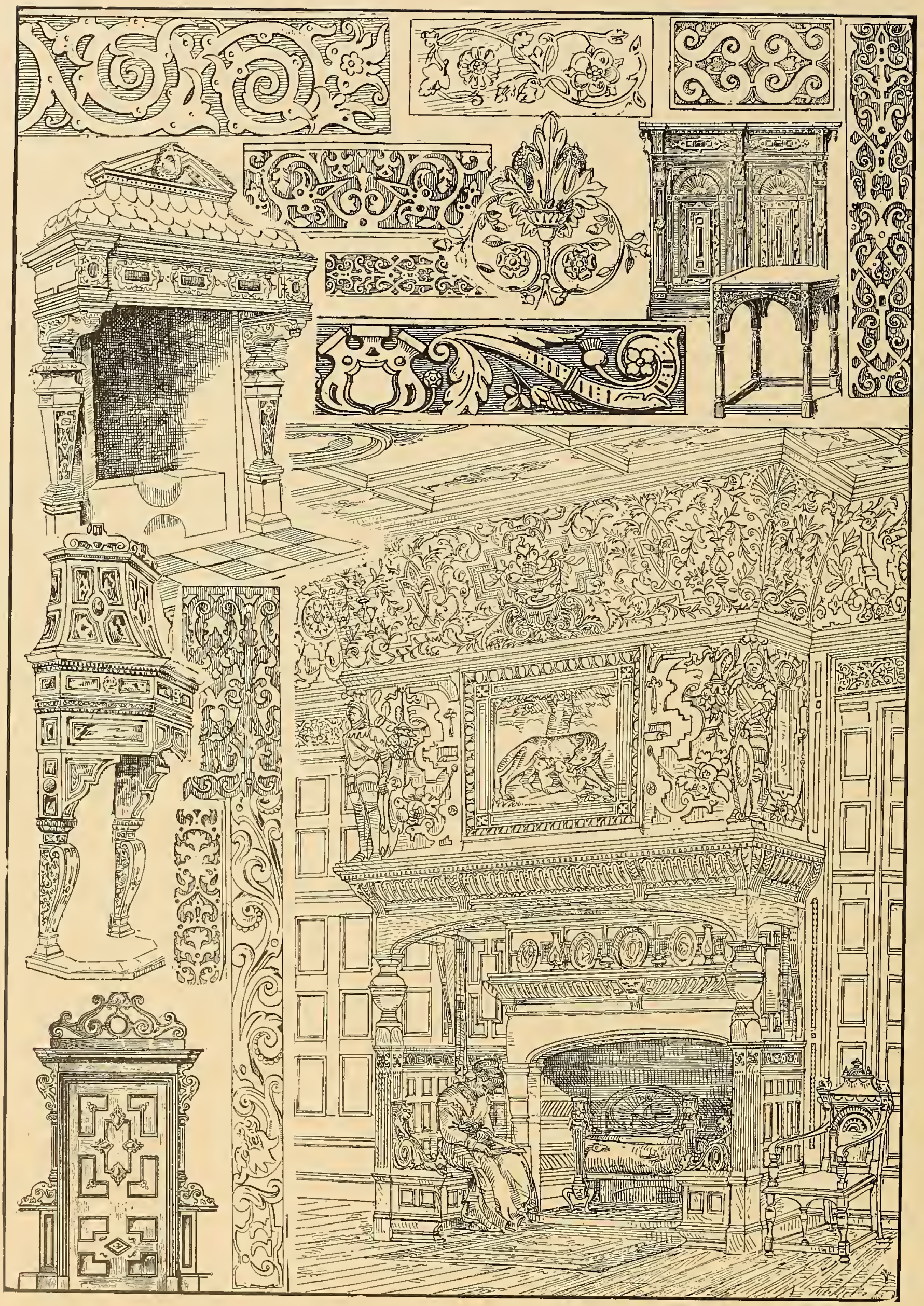




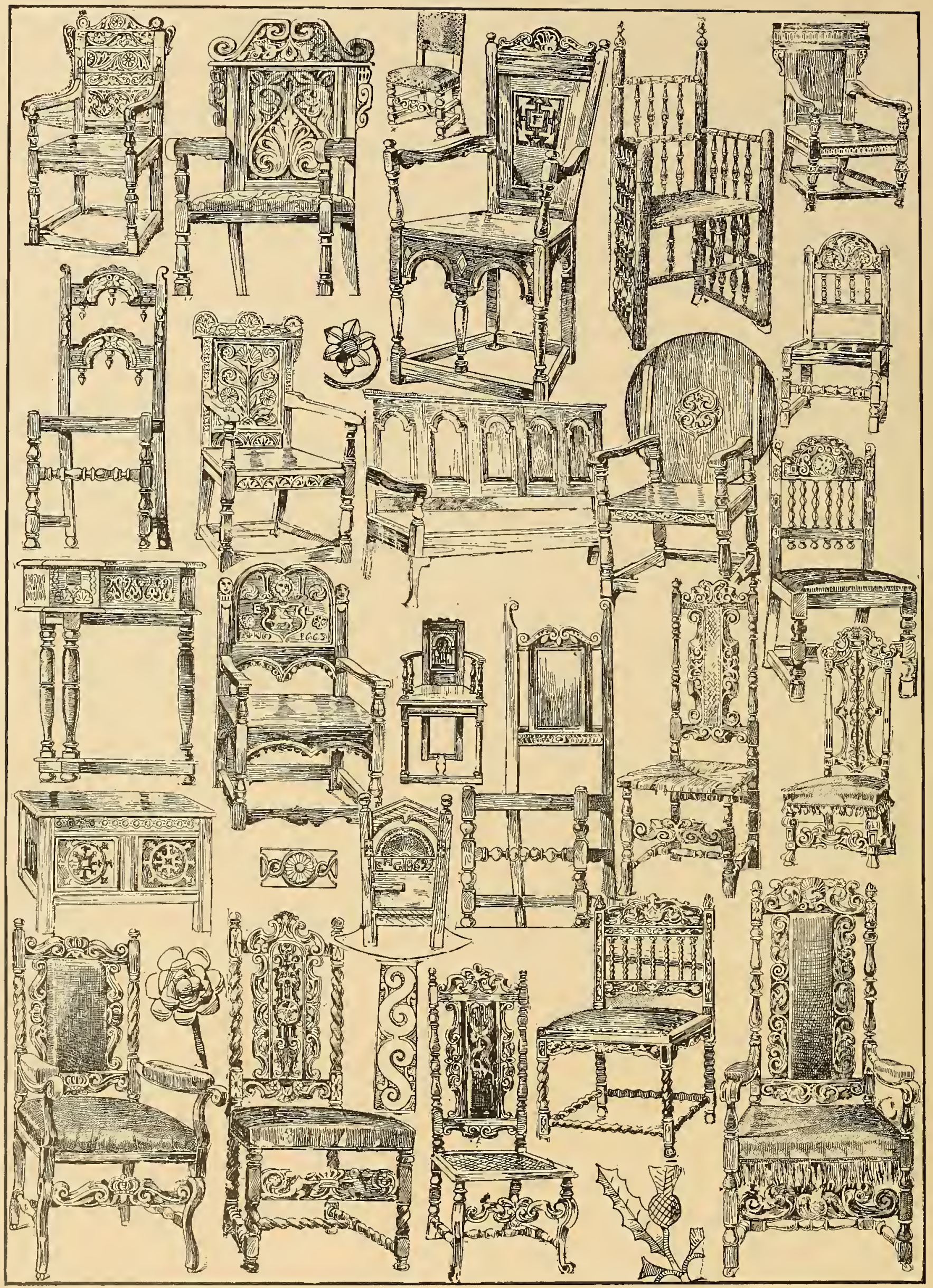

RENAISSANCE-ELIZABETHAN-The chairs on the top row represent the types prior to i6ro, Elizabethan or Jacobean. The second chair from the top is an English type beginning about 1650 . The chairs of the bottom row are Charles II type, 1675 or thereabouts. The formation of the legs shows the French spirit, although the carving is of Flemish origin. 


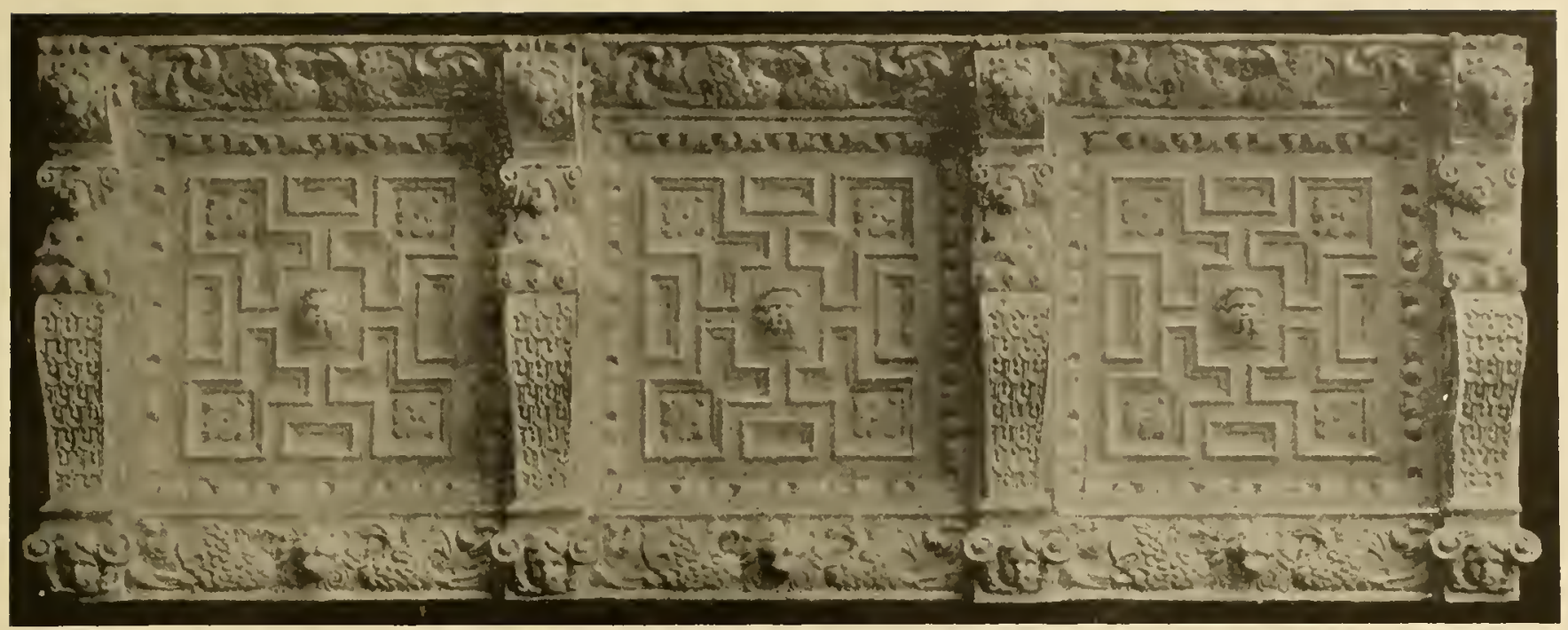

Flenish Frieze, a style approximated in the Elizabethan era of Renaissance art.

glued upon panels on beds, round applied buttons; and pendlants and ovals set in relief upon panels, as well as drop ornaments added below the table frames or the center of arches in panels.

It was all Renaissance, whether from Italy or through the more obscure channels of Germany and Flanders. The Renaissance movement, developed under Elizabeth, was contemporary with a sinilar movement in France, Flanders and Germany. Hence the presentation of styles closely related. $\mathrm{We}$ associate with the Elizabethan liberally-paneled rooms and atuccoed. ceilings. $\mathrm{We}$ find the guilloche, common in Assyrian and Byzantine art, and other simple details, much used at this time owing to the fact that English workmen, who copied the foreigners, were restricted in their work to simple details, necessitated by the use of oak instead of the softer walnut, and this fact will aicl one to determine the origin of work of this period.

Great importations

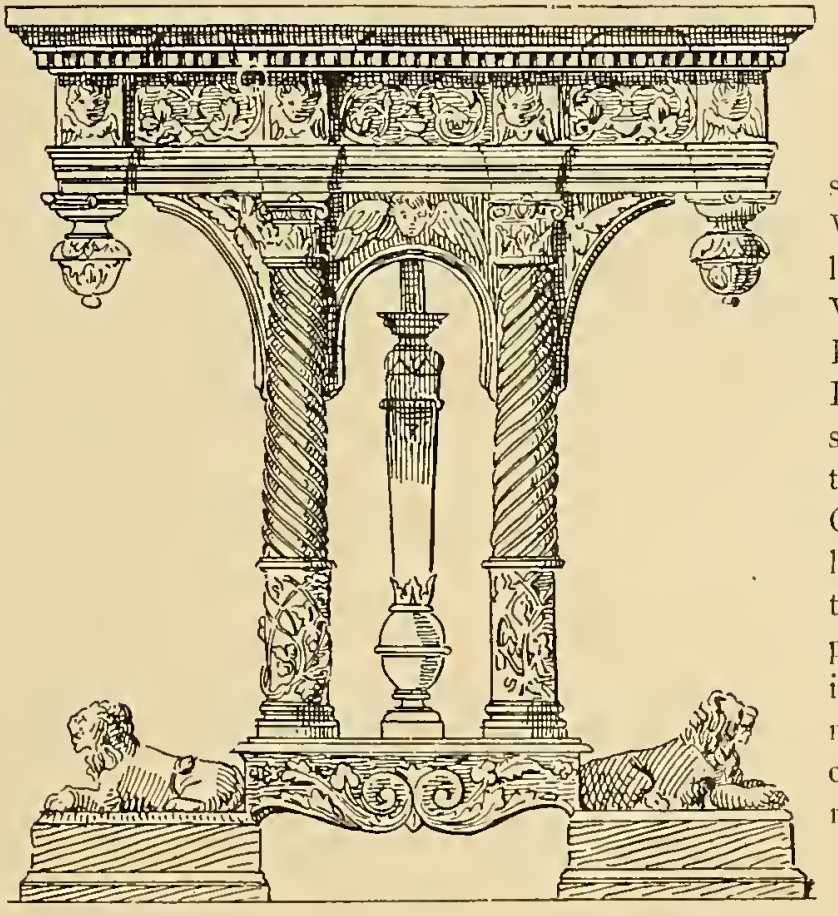

Flemish. much of this patch-work furniture, and there was much use of the "S" curve in cabinetmaking. Carving was in low relief. The " $\mathrm{S}$ " curve, the semi-circle pattern and the interlaced semi-circle pattern and " $\mathrm{C}$ " curves became more common with this period.

From the architectural standpoint this period is conspicuous with the work of Inigo Jones (born 1572 died 1653), probably the first English architect who practiced the Renaissance style in its simplicity. Tralpole says of him, "England adopted Ilolbein and Van Dyke; she borrowed Rubens, but she produced Inigo Jones." Inigo Jones studied closely the work of the Italian Palladio, and Charles I encouraged him liberally. Here we have, then, during this Jacobean period furniture and furnishings the work of the cabinetmakers which was of a decidedly hybrid type, and far removed from the exquisite, clignified and artistic work purely Italian that was accomplished by Jones and his contemporaries.

Inigo Jones died in 1653 , and a few years later cane from Flanders, so great in fact that Elizabeth introduced prohibitive measures to stop the imports and encourage English workmen. Elaborate interiors were of terra-cotta. Stuccoed ceilings were of great beauty, but the work was confined mostly to palaces.

The same characteristics followed through the Jacobean period, I603-1652. The cabinetmakers made

[103]
Sir Christoplier Wren became famous in a further development of the Renaissance feeling. Sir Christopher studied in Paris and was saturated with the French Renaissance spirit, hence he was profuse where Jones showed restraint. His style was almost Baroque. Pendants of flowers, shells and fruits were 
used in a prodigal spirit. Carving was of an overelaborate and highly-ornamented character. It gave the reputation to Grinling Gibbons, who was responsible for so much that was good in carved foliage, birds, fruits, shells, cupid faces, etc., that Charles II employed him on the palace work and subsequently, I714-I721, he was "master carver in wood" to George I, with a salary of eighteen pence a day.

While we frequently refer to this prolific form of work made famous by the efforts of IVren and Gibbons as Georgian, we must understand that it developed in the late Renaissance and was a part of the Renaissance period,

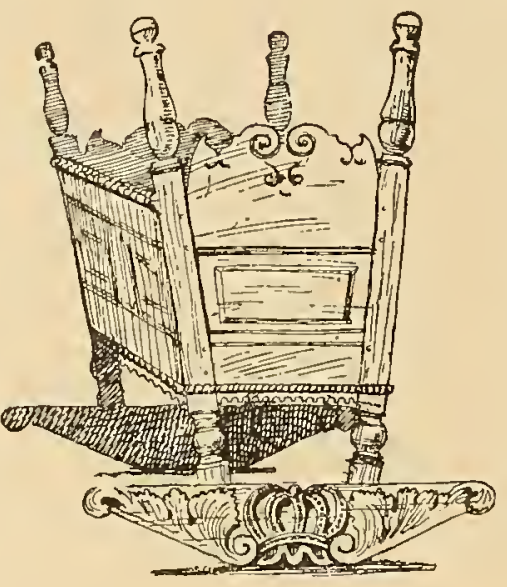

work done by the architect, but the work was not carried into the furniture, which was usually of

Wood-paneled chairs were not generally displaced until the middle of the Jacobean period. Then the Flemish carved type appeared, which in England is sonetimes called Jacobean, sometimes Charles I, and if caneseated, Charles II. It is easy to trace the Flemish origin even if English details, crowned cupids surmount the back: and where the legs and the underbracing convey something of the Louis XIV suggestion, we can account for the French influence. IVith the return of the cavalicrs to England, just and the Jacobean, Cromwellian and Queen Anne belong in architecture to the Renaissance schools; thus we are confronted by confusing data, throughout this entire English history of decoration. The furnishings were of a commercial character and seldom, if ever, connected with the architectural spirit.

Frequently there was consistency in the wood trims of the

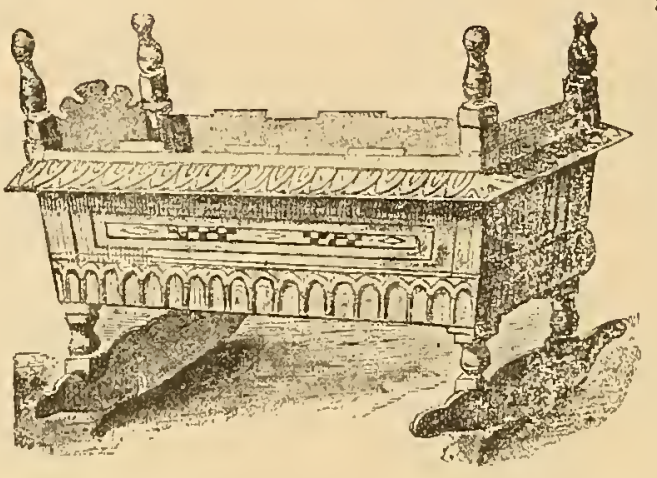
after Cromwell's downfall, I660, the royalists brought back with their furnishings from France a good deal of its furniture, and thus we can trace the French spirit in what we now regard as the Charles II type.

This spirit was further accentuated at a little later period when, in I685, the Edict of Nantes was revoked and the Protestant artisans of France, inhouse, mantels, panelings, wainscoting and stucco cluding many Flemish born, fled to England.

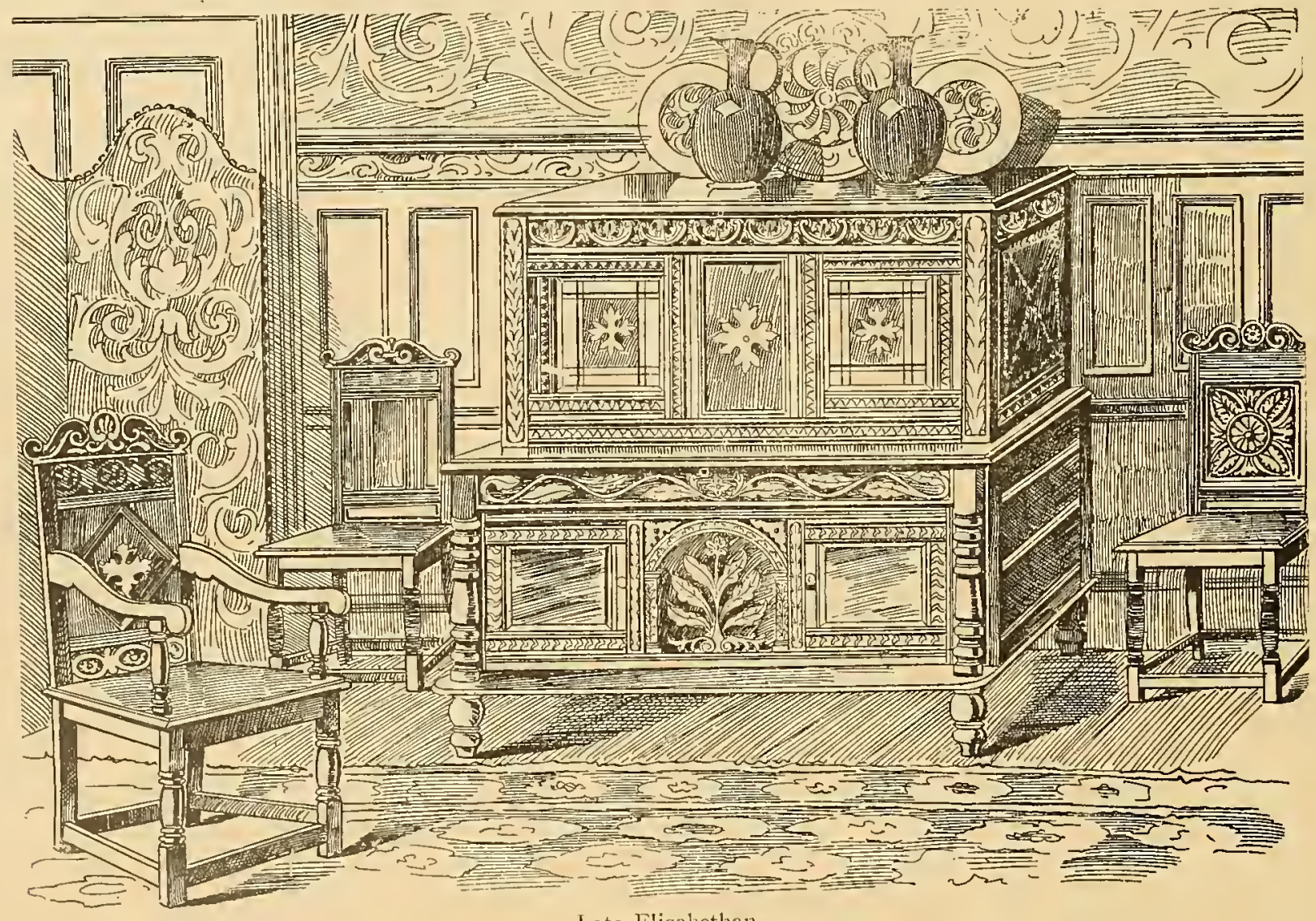

Iate Elizabethan. 


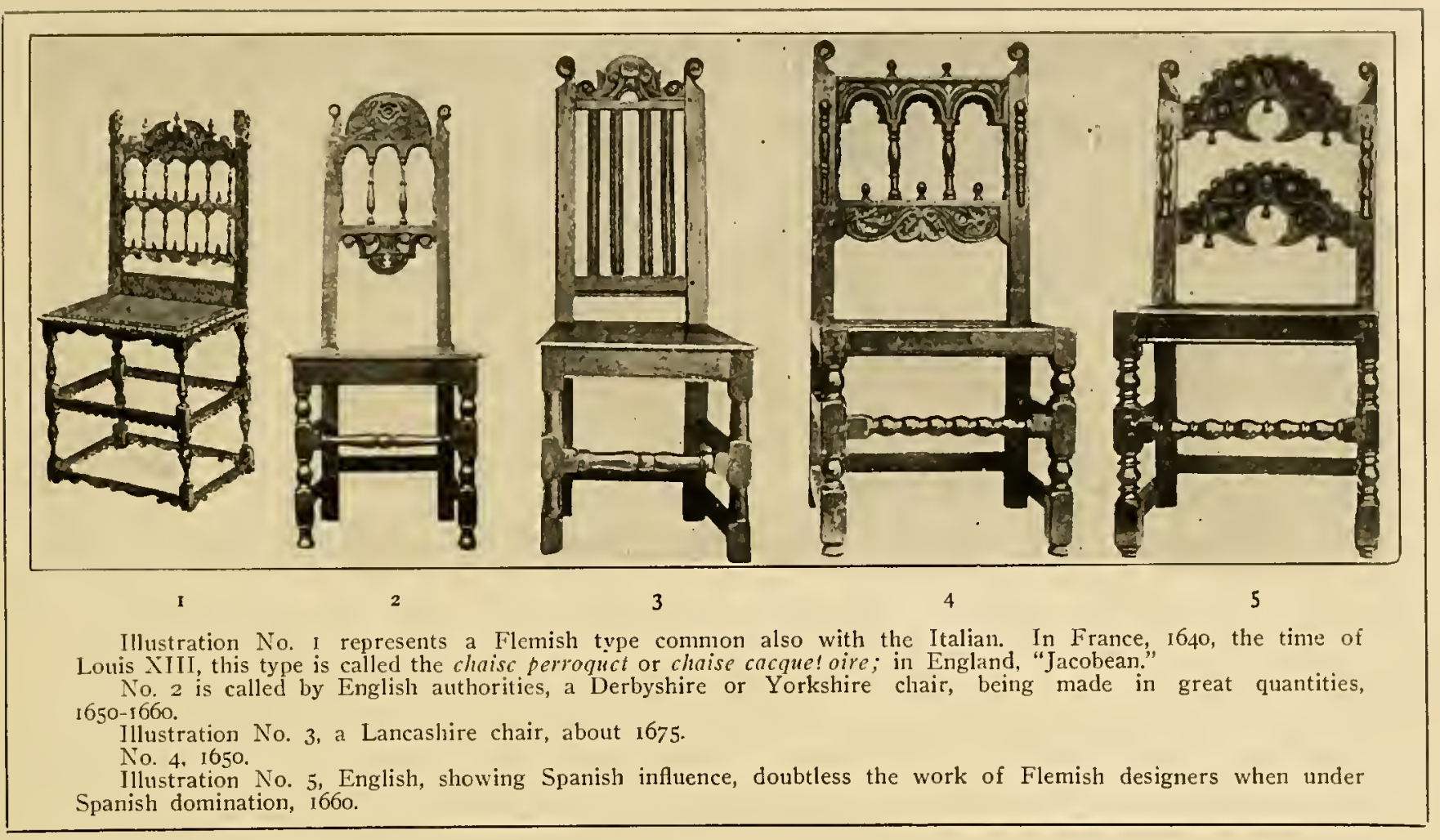

JAMES I, 1603-1625, founder Stuart Period. CHARLES I, 1625-1649, Commonwealth to 1659.

$\mathrm{T}$ $\mathrm{HE}$ evolution of the spindle or rail-back chair comes from the Italian through the Flemish and French to the English, where it is arbitrarily called Jacobean and even localized as Derbyslire. Lancashire and Yorkshire.

Where the crown appeared, sometimes crown and cupid, it was a Royalist design, and followed Charles II's restoration. S and C shapes were frequently seen upon chairs that were unquestionably of French inspiration, a development following the social rclations contemporary with Charles II.

Following the $\mathrm{S}$-forms and the $\mathrm{C}$-forms from 1585 to 1665 , we find a chair with the top of its back finished off fan-shaped and later still shell-shaped. but this takes us well into the reign of Queen Anne.

The use of applied moldings in furniture was common throughout the Seventeenth Century, but seldom used at this late date in chairs.

Cane seats came in through the trading of the East India Companies, but the exact date cannot be fixed. It was in the neighborhood of 1640 in England, 1620 France; the poet Chancer, in his "Canterbury Tales," 1400 , mentions wicker chairs. Nahogany. was not used until after I 700 . Inlay and veneer work were popular during Charles I's time.

It must be recalled that all ceremonious and pretentions form was confined to castles, and not until late in the Seventeenth Century did the work of the

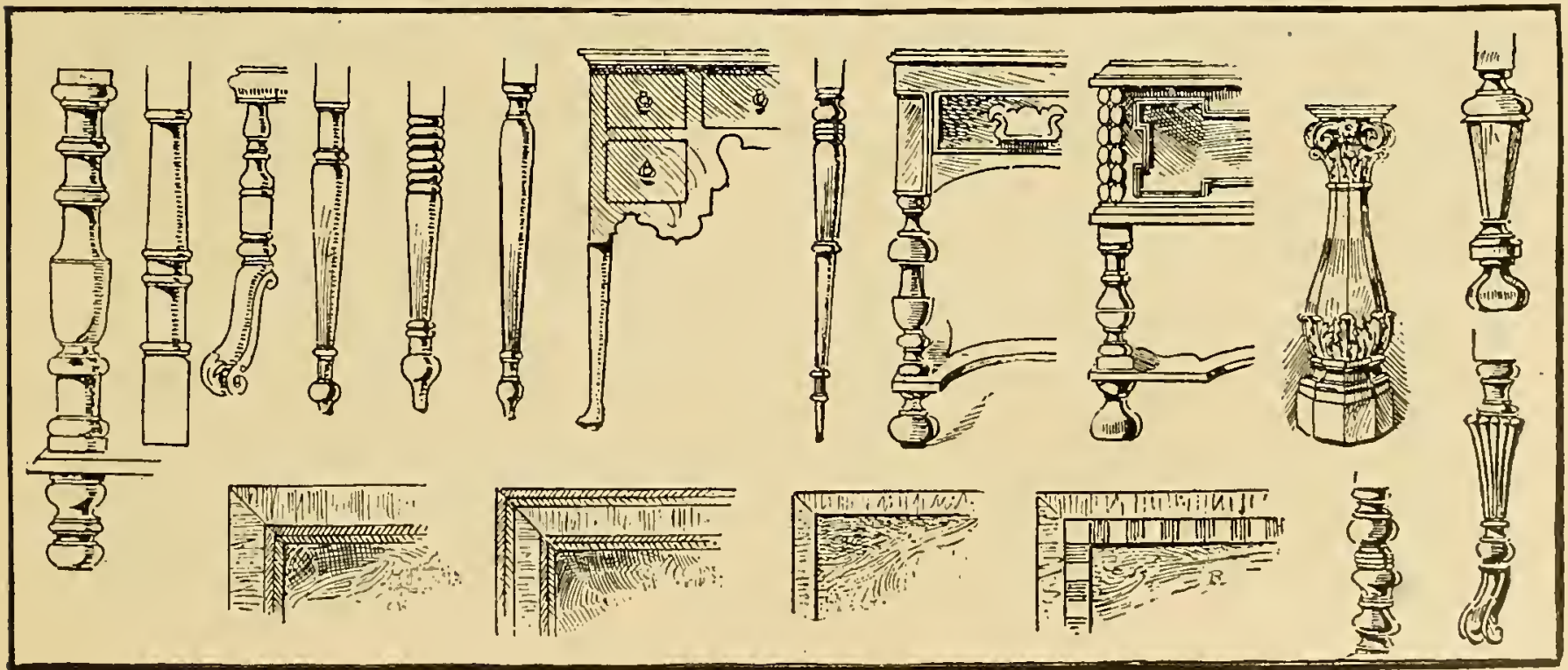

16801690. Note the French spirit in third table-leg, also those on extreme right. During the William and Mary period, about I690, veneering became popular. 


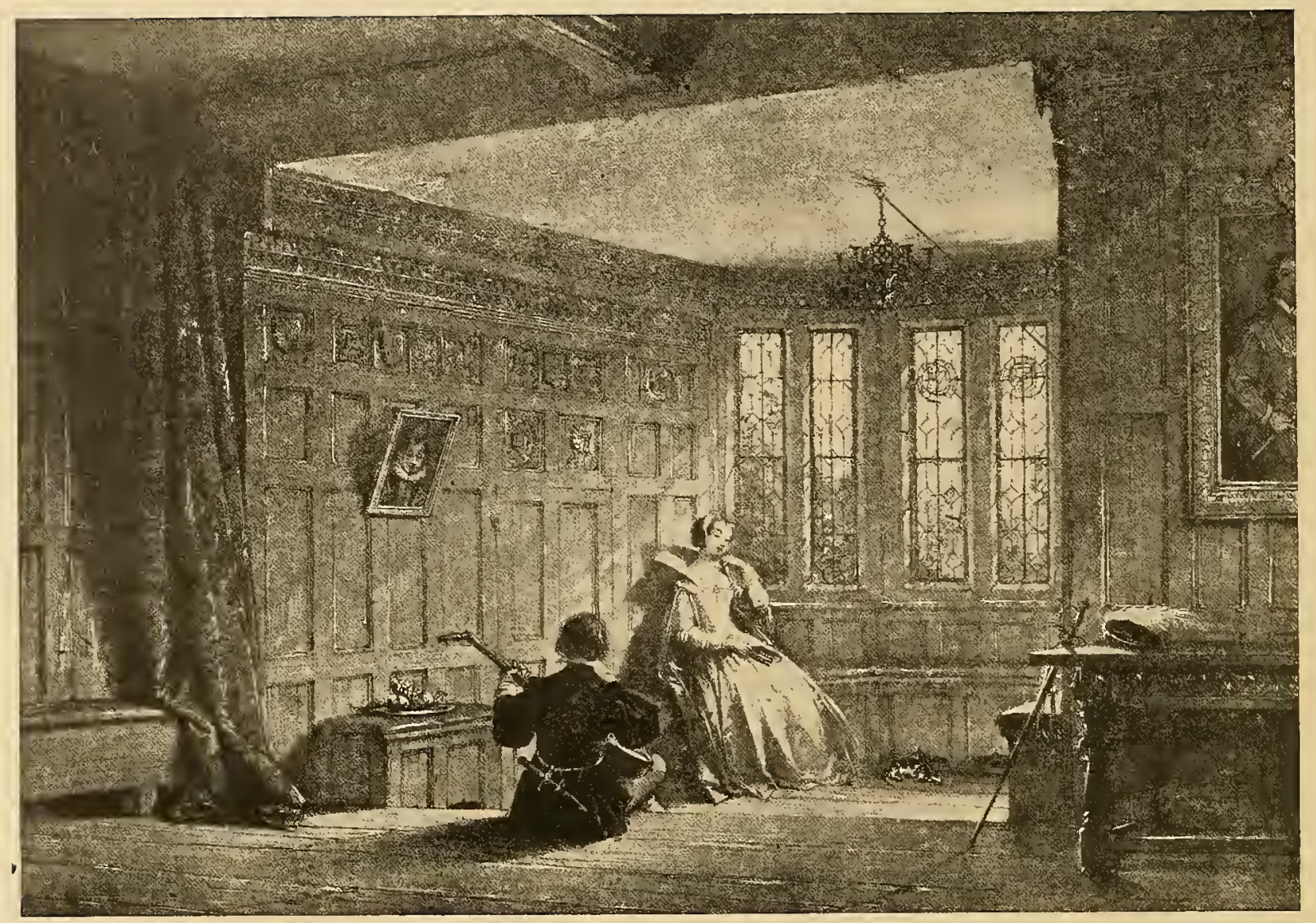

INTERIOR IN AN ELIZABETIIAN DINING-ROOM.

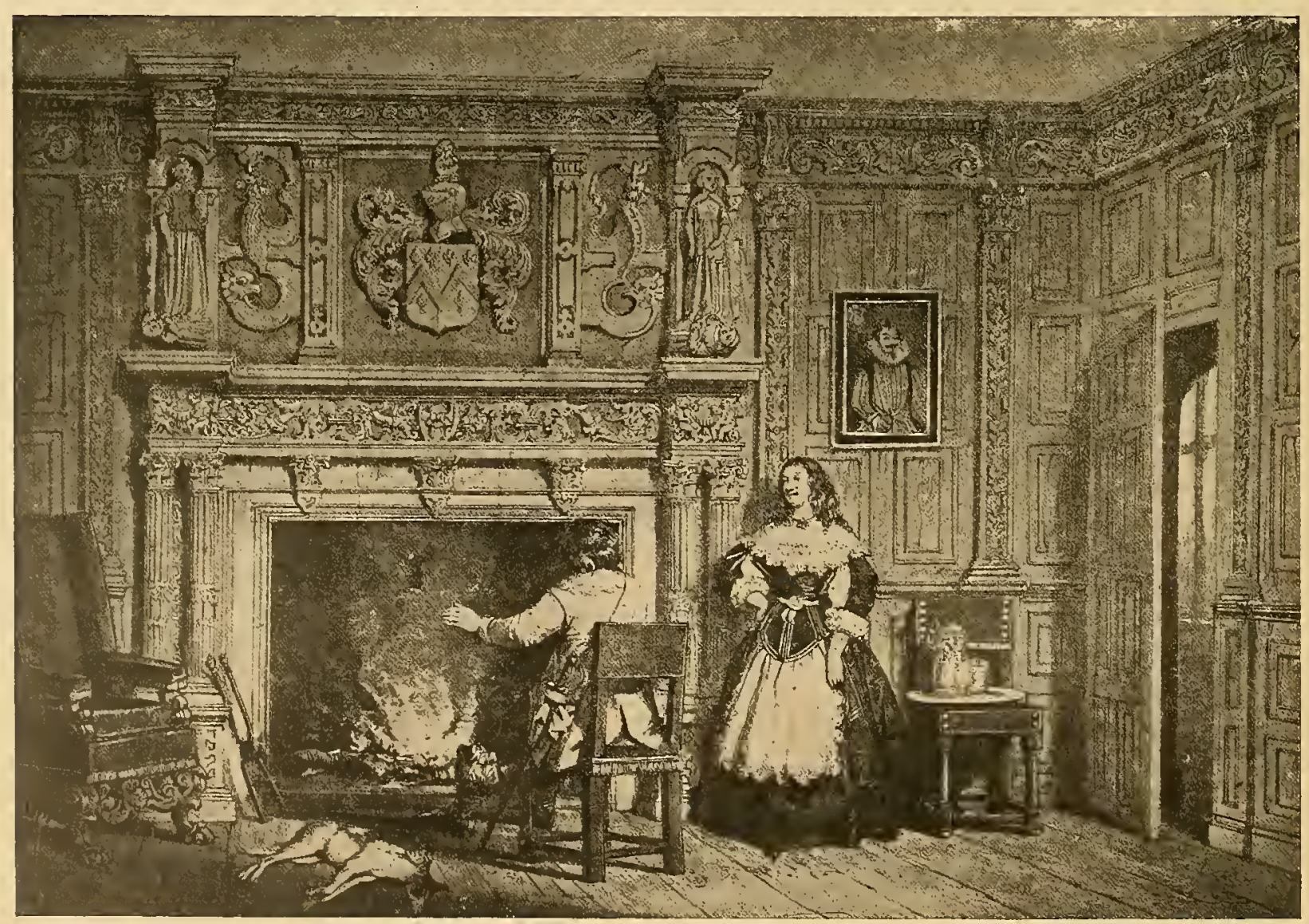

POSTLIP HALL, GLOUCESTERSHIRE

From Nash's "Mansions of England in the Olden Times."

ELIZABETHAN INTERIORS. 

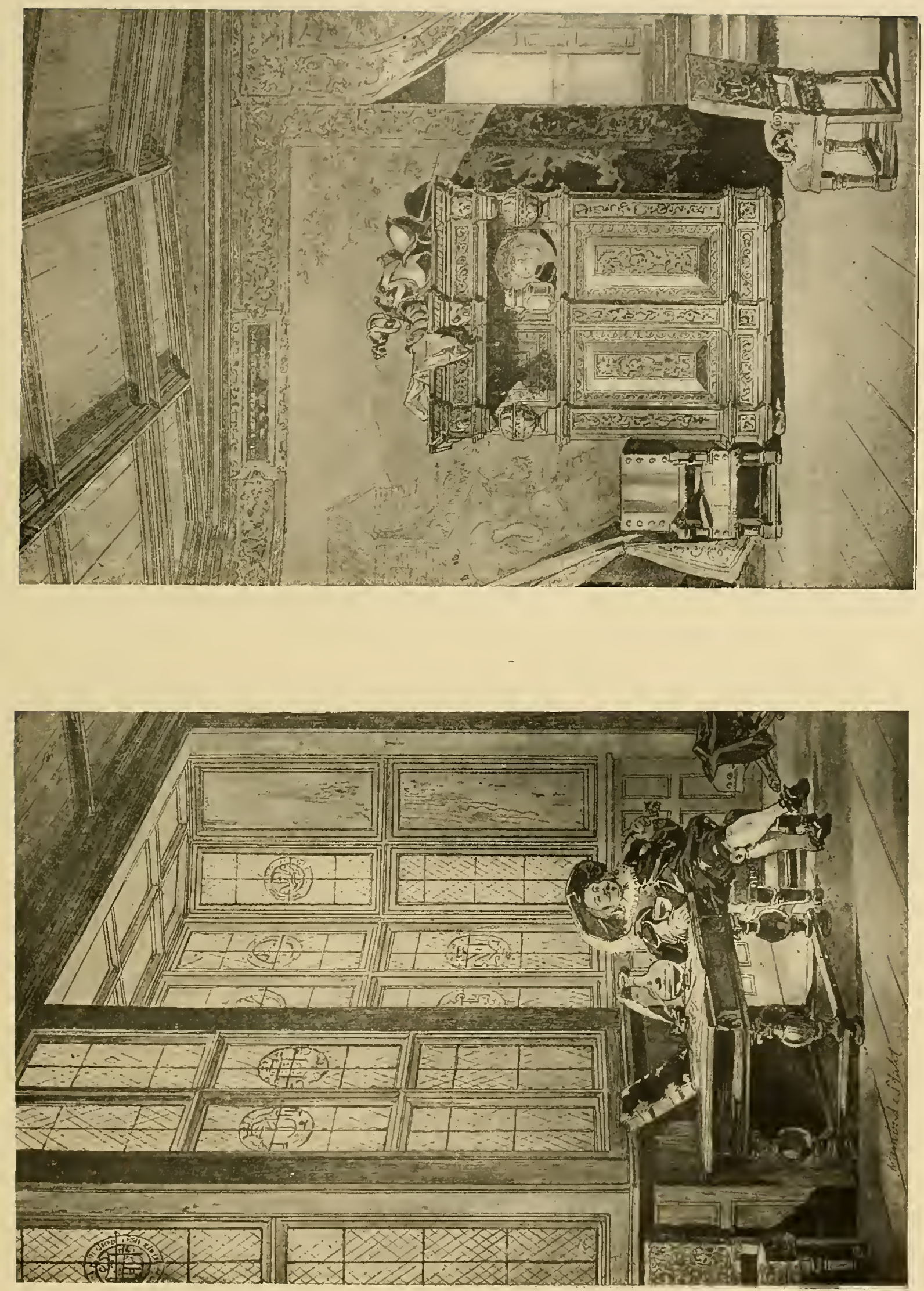


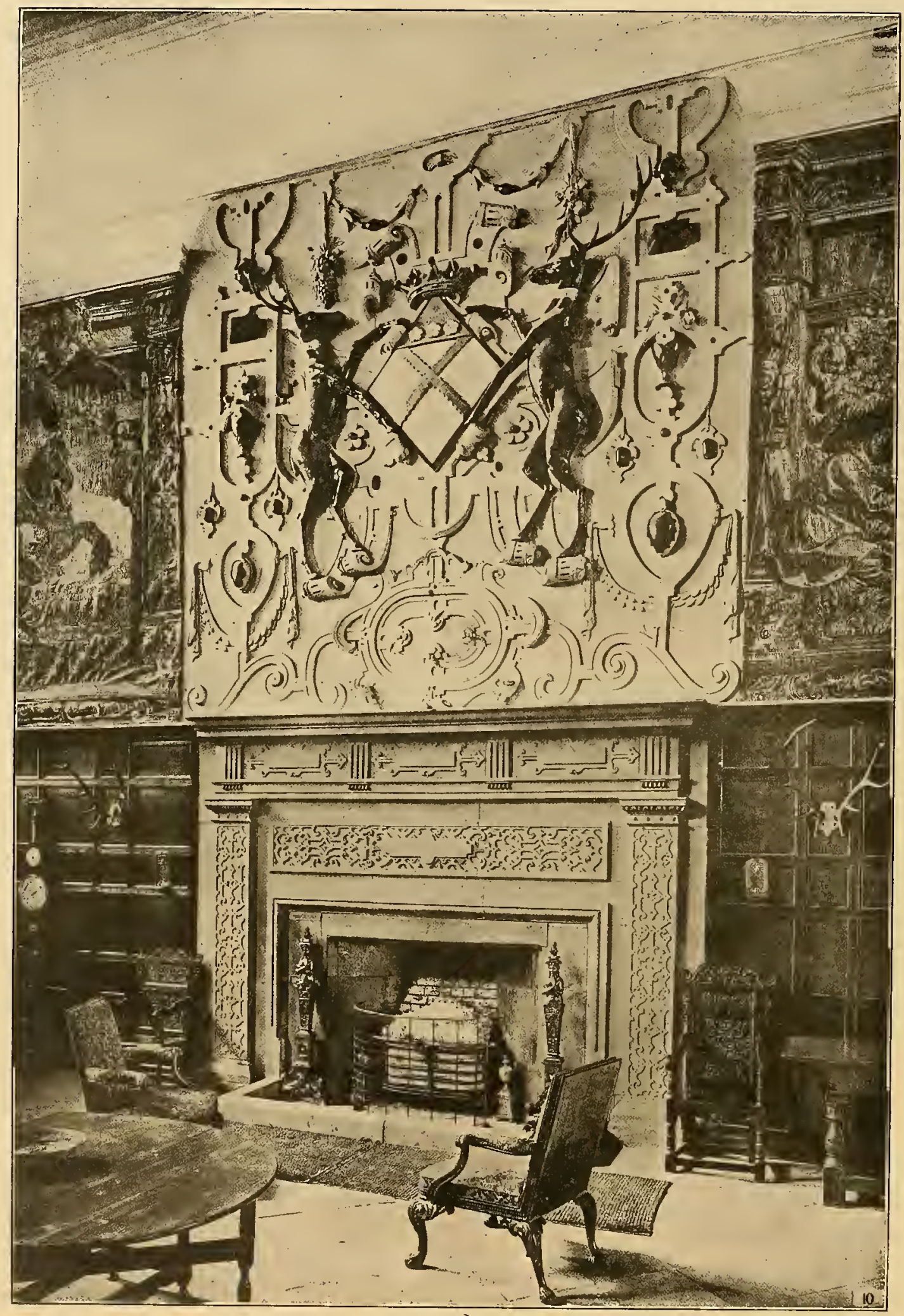

HARDWICCK HALL-ELIZABETHAN, I599. 


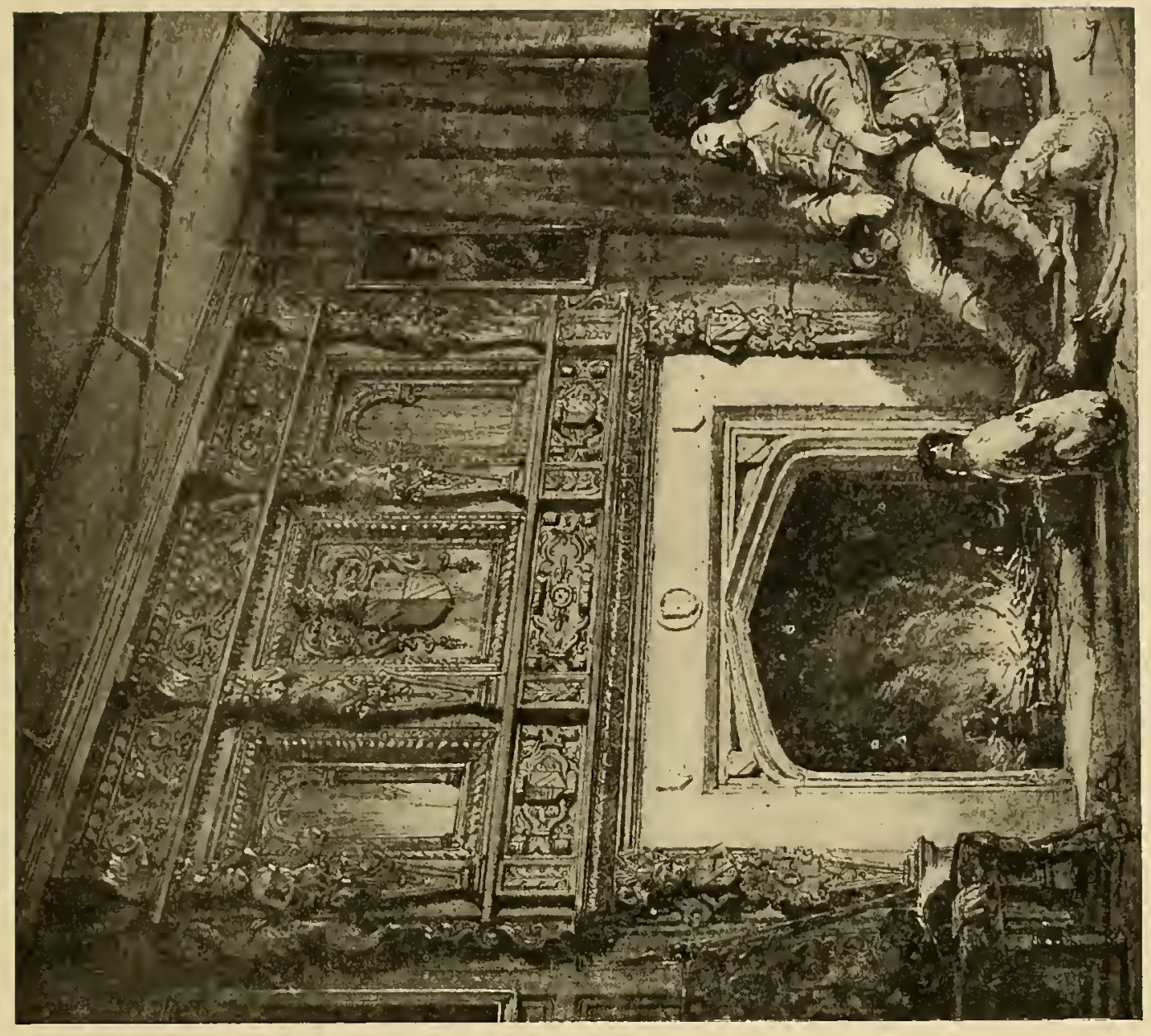



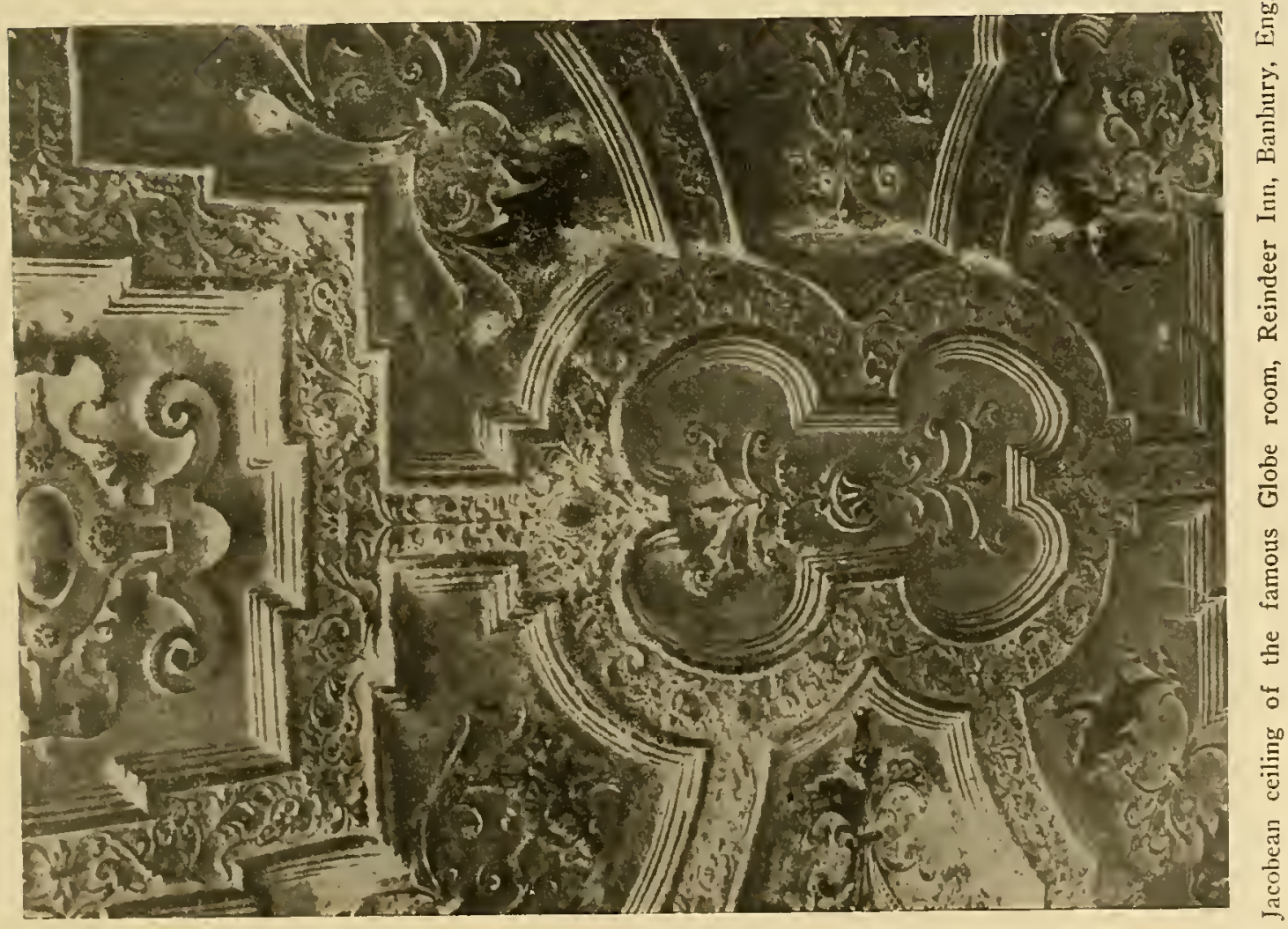

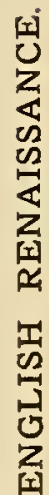




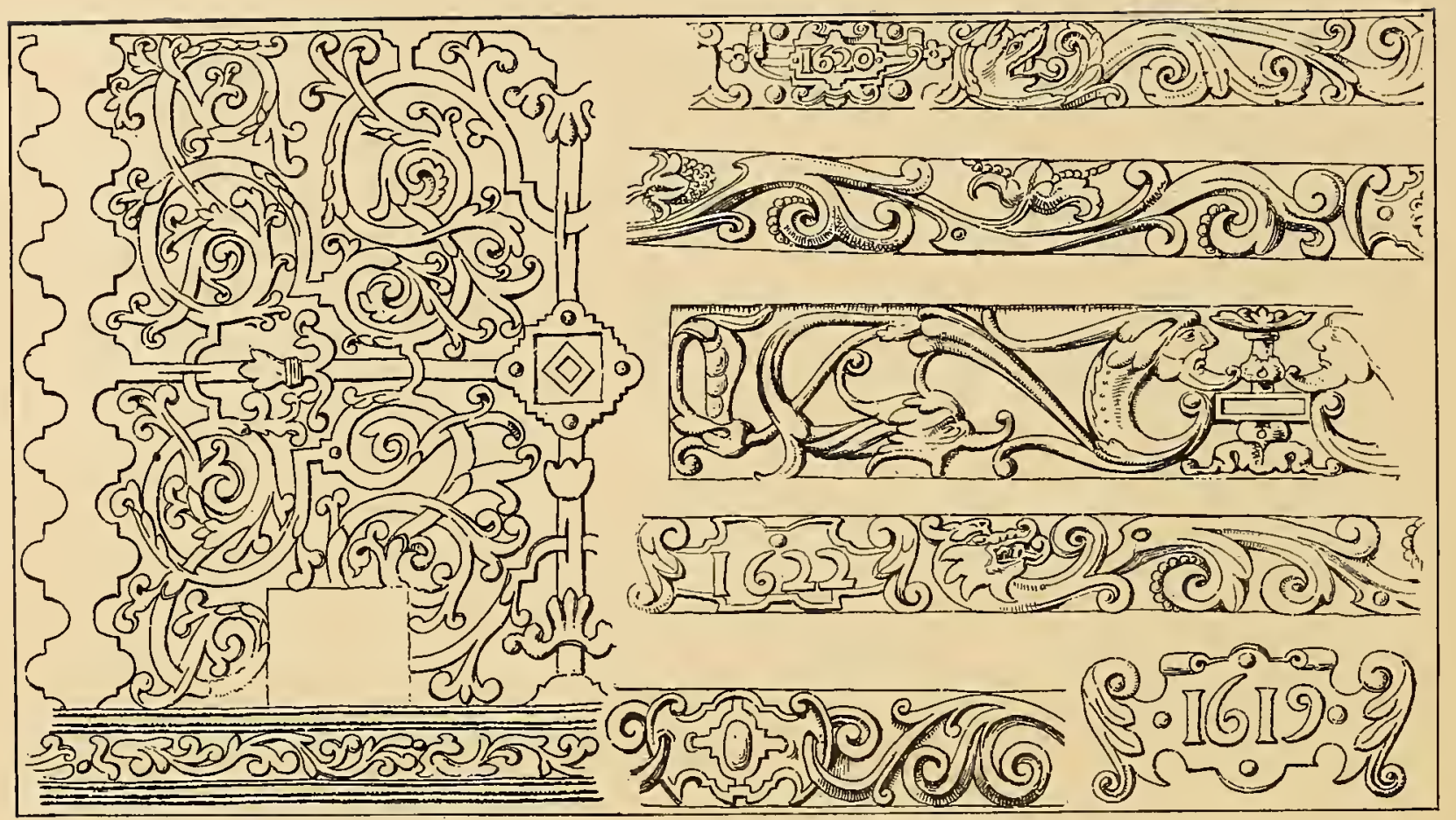

decorator extend beyond the homes of the nobility. In the palaces the ceilings were superb, the interior woodwork was of a most elaborate character; one must realize this and in watching the development of furniture and furnishings one must not confuse the commercial work of the artisan with the more pretentious work of the architect.

In the homes of the wealthy the walls were frequently hung with tapestries, ceilings elaborately stuccoed often colored. Fabrics of elaborate character, velvet, brocades and damasks were used and the floors were covered with Oriental rugs, excepting in chambers for public use, on the floors of which they scattered rushes. It was an age of embroidering; Flemish leathers and embroideries of many varieties were used. Panels were full of heraldic devices and crests. In small rooms chintzes from India were used. India prints in the Oriental spirit were con-

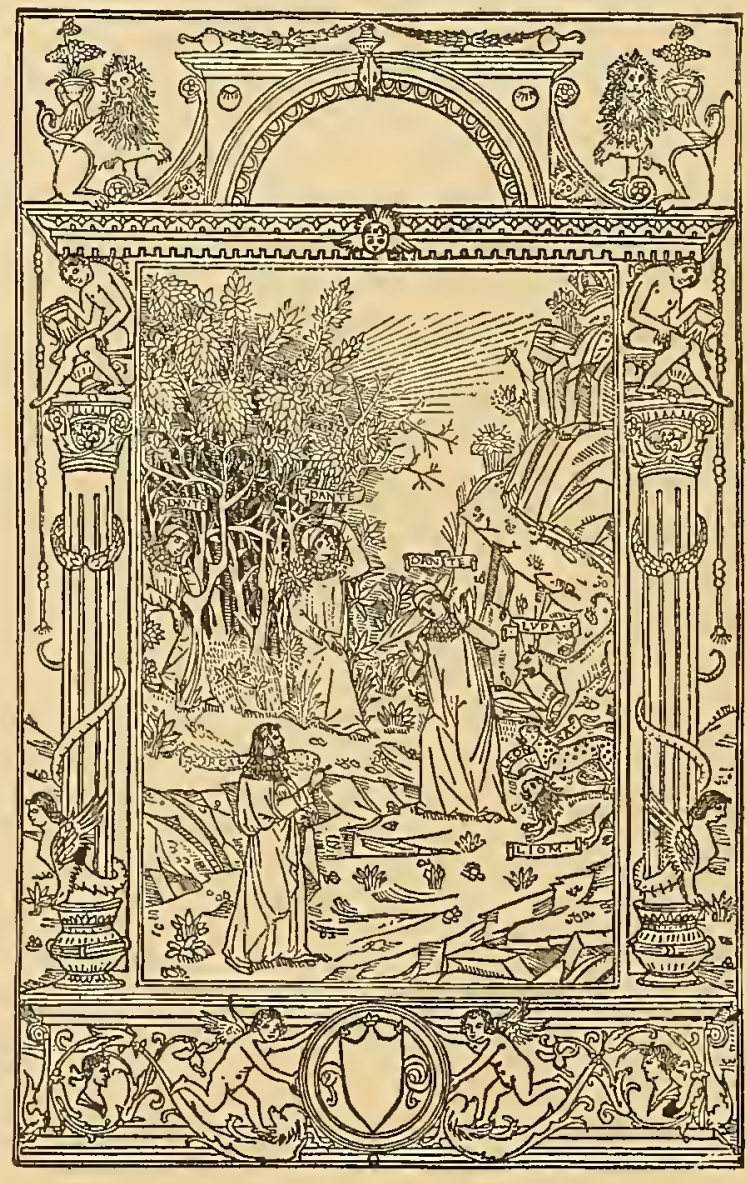

Italian, wood-cut illustration from Dante's "Inferno," 1400 . spicuous in bed coverings, portières, table covers and balustrade hangings. There were no wall-papers used, but prints of cotton or linen or embroideries were in general favor.

The upholsterings were all that can be imagined.

Fabrics of every sort were manufactured.

Glass mirrors we re made in Venice, $\mathrm{I}_{507}$, when methods had been discovered of applying the metal leaf. Mirror makers had their own corporation.

D uring Elizabeth's time a mirror was a rare possession and worthy of a rich frame, but about 1685 the Duke of Burgundy installed a number of Venetians at Lambeth, where they made looking glasses.

Grandfather's clocks also appeared about I680. Queen Elizabeth had chartered the East India Company in 1600 , but it suffered serious competition with the Dutch, French and Portuguese companies.

The chair foot or the leg terminal indicates, in 


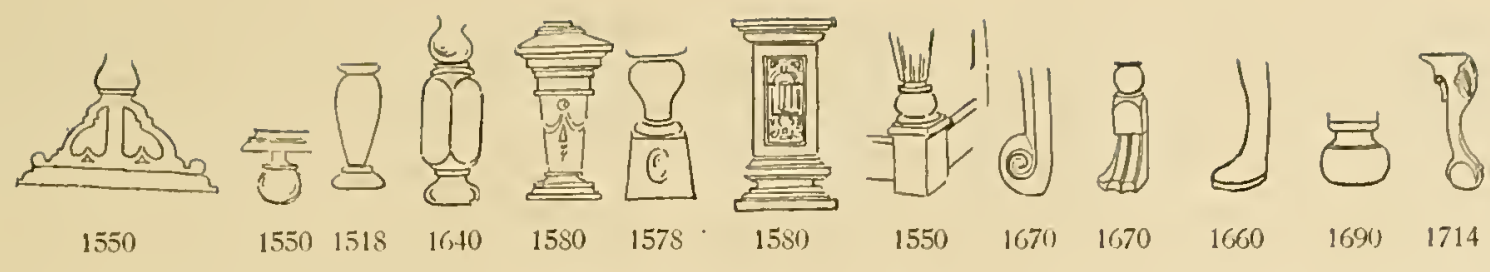

some measure, the period of the furniture. The scroll foot was Flemish with French influence, of the type that came in about 1670 .

The fluted foot was Spanish in origin and goes back to $1600-1700$.

The ball foot or bulb foot is Early Dutch or Flemish.

What is known as the spade foot came in with the Sheraton and Hepplewhite period, late in the Eighteenth Century.
The Renaissance feet were sometimes square blocks, discs or balls in flattened form. Frequently the legs rested upon parallel bars.

Various animal-feet were generally used by the Greeks and Romans and we therefore find them together with scroll feet in good Renaissance examples. They were not associated generally with Queen Anme until the Eighteenth Century. Sometimes we find the cabriole leg and claw foot in old Spanish pieces of the Seventeenth Century, but they can be distinguished

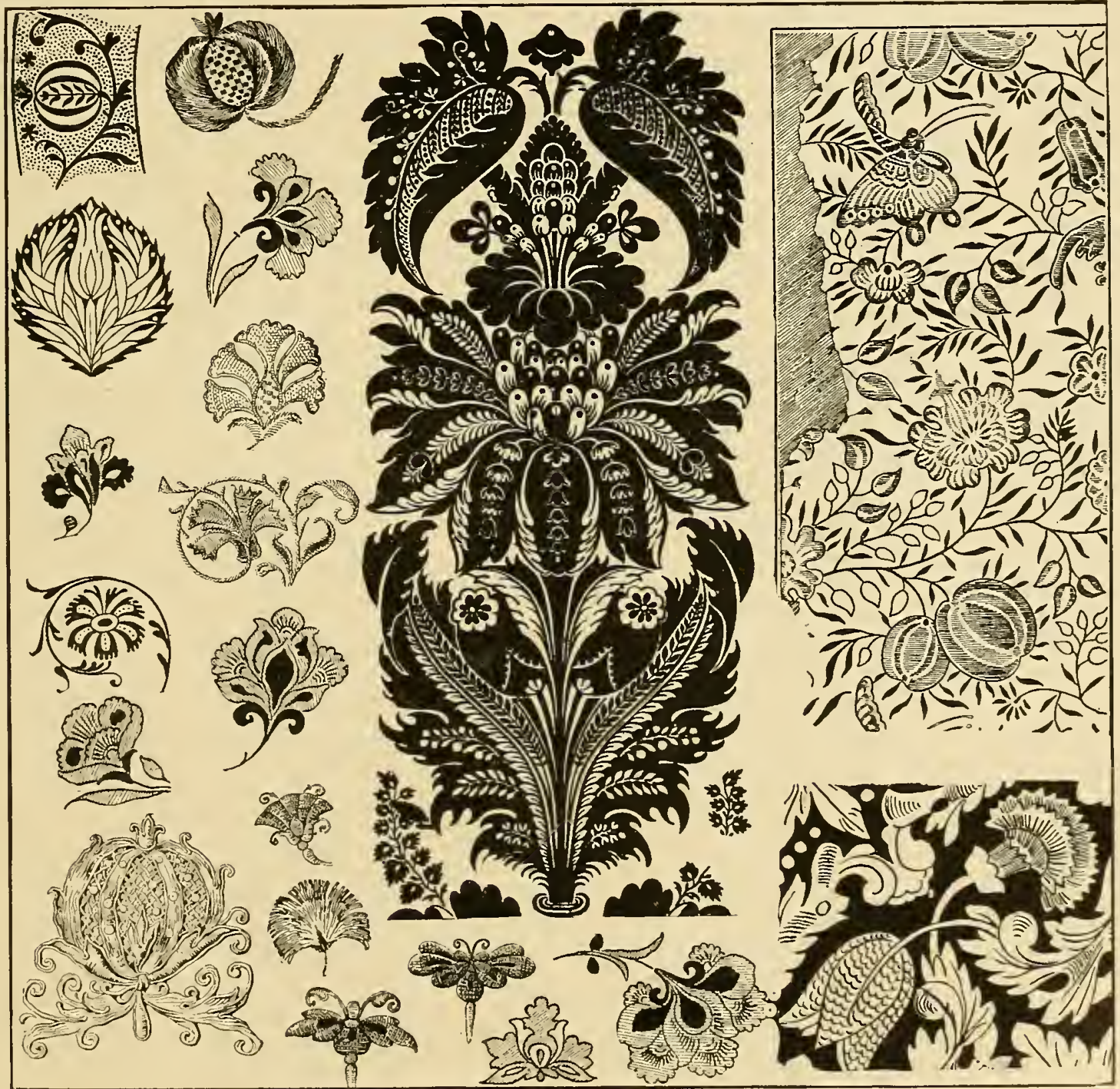


from the Queen Anne styles by the front, back and side stretchers that connect them near the base. The claw-and-ball foot was distinctly Queen Anne, but the form came through Louis XIV and late Jacobean.

\section{FABRICS.}

Tapestries applied above high wainscoting were in common use. Sometimes tapestry hung down over the panel. For a while during the Wars of the Roses tapestries were abandoned in England but under Henry VIII fresh impetus was given and later some superb examples were introduced in the Mortlake factory established by James I. Another very popular fabric was a "painted cloth," canvas painted in mottoes.

In "Much Ado About

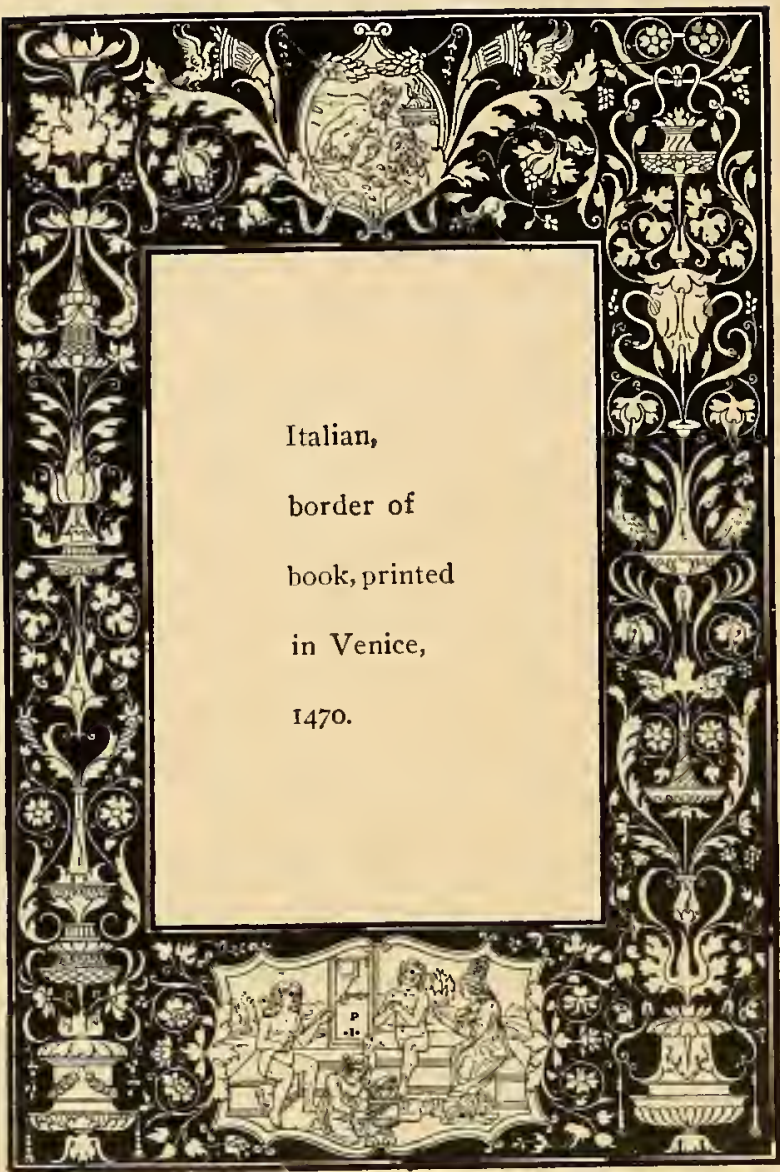

.Nothing," Beatrice says that she "got all her wit from the painted cloth hangings." Embossed and gilded leather, cloths of gold and the richest kinds of silks and velvets were in use and what is referred to as a novelty is quoted by Pepys in his diary, I663, "I bought my wife a chint, that is a painted Indian caliro for to line her new study." The term study at this period must have referred to a sort of boudoir or library, although in some houses there were

On the right, typical of Elizabethan embroideries, Sixteenth and Seventeenth Centuries.

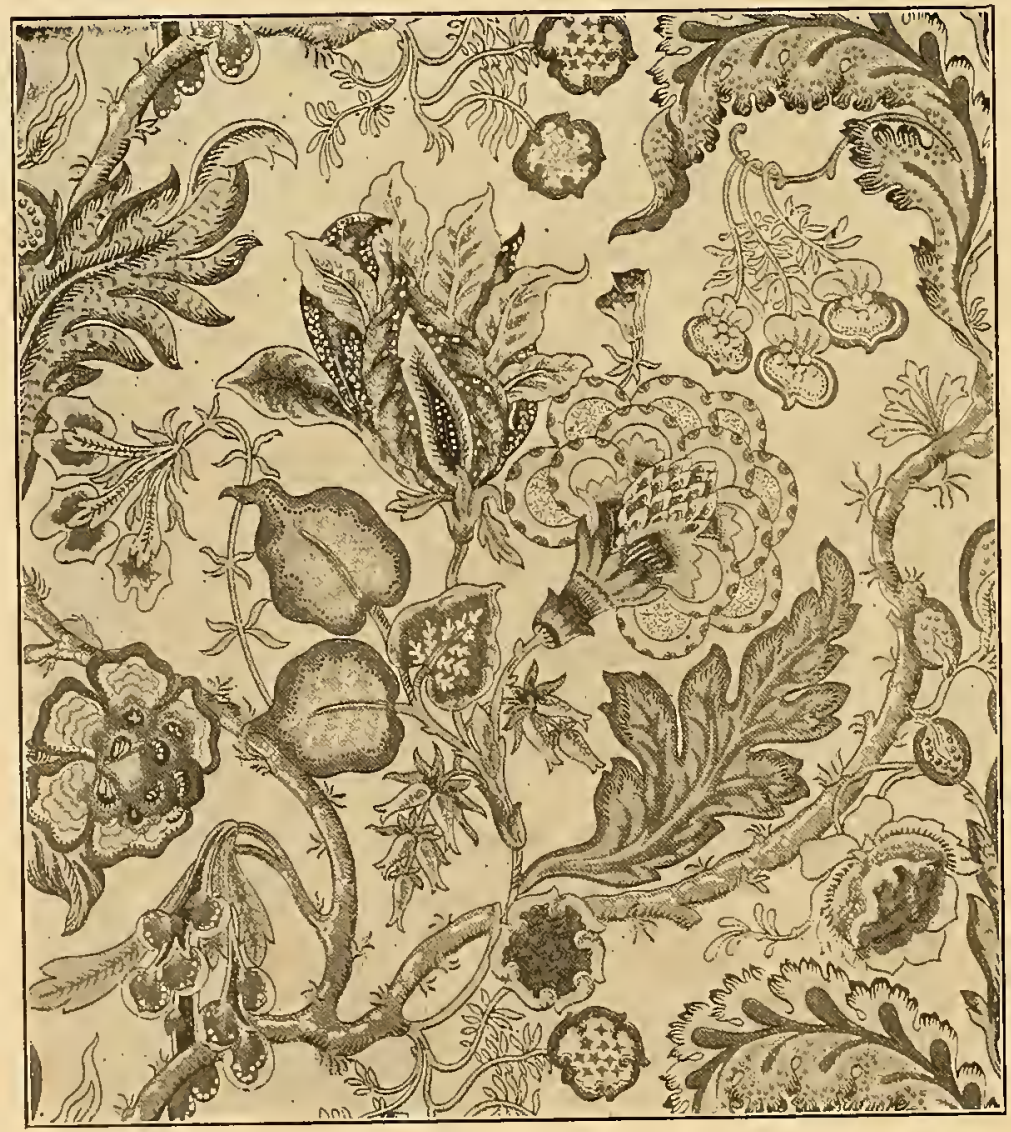

rooms set aside for study.

In a few houses ceilings were carved elaborately, which style was imitated in plaster. WVindows were furnished with little diamonds or squares of glass and often in the center were armorial pieces. Even at this time floors of private chambers were of inlaid wood. Green, yellow and crimson were favorite colors for bed and window draperies and the materials were silk damask, worsted damask, satin, silk, or serge.

The names are not easy to define. We know that of the silken stuffs there is a constant reference in old documents to lustering, paduasoy, doubtless Padua soic (silk), tabby, taffeta, sarcenet, cheney (China). In woolen goods we have reference to serge, dorneck (linen print), perpetuana, 11 o ha i $\mathrm{r}$, camoca or camak, camlet, say, serge, rep, watchet, fustian, damask, and kitterminster or kidderminster, some of which were mixed with camel's hair or threads of $\mathrm{silk}$. There were also d i m it y, flowered chintz, and callimanco (a glazed linen), as well as Turkey and "wrought - work" (which, of course. w as needlework). East India goods, such as printed calico and seersucker were of this period.

White curtains for the bed were rarely employed, in- 


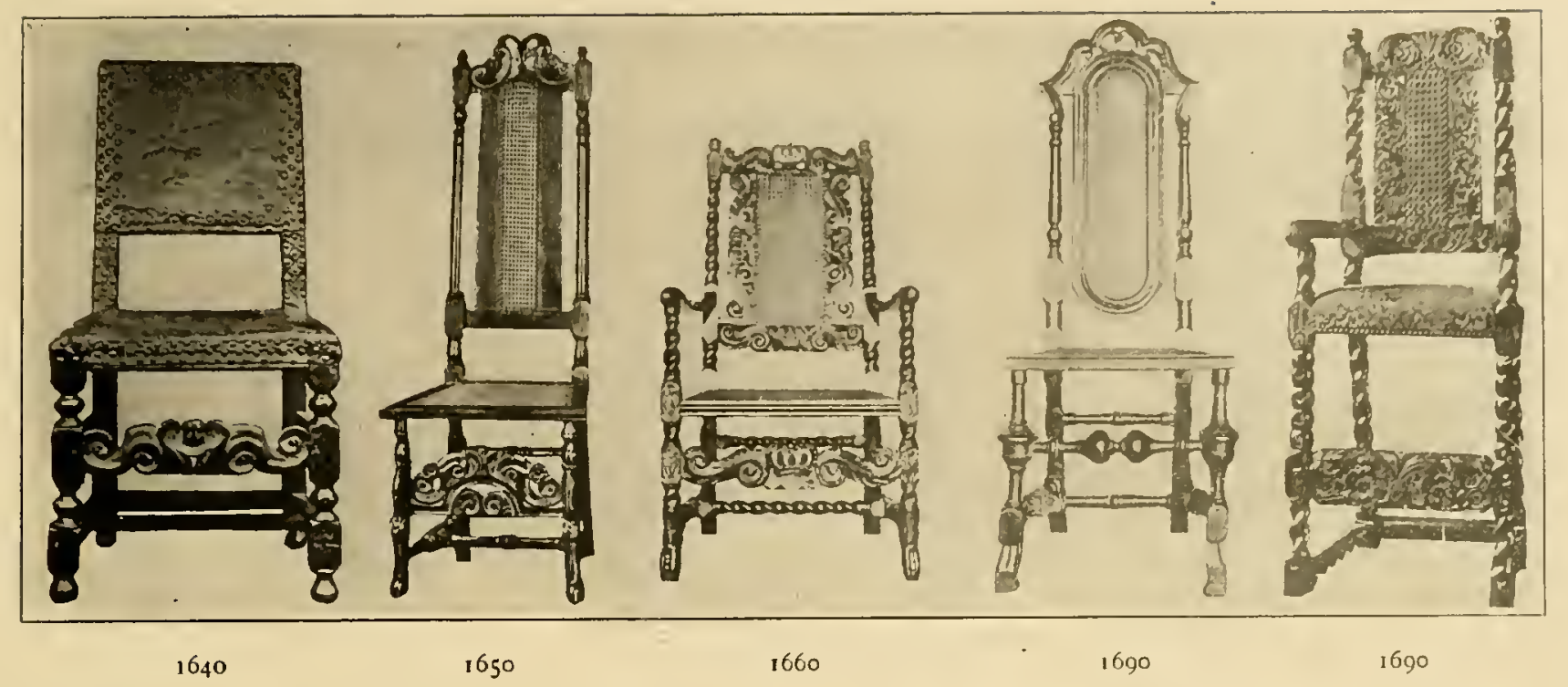

variably satin and dimity being employed. worked in colored crewels or worsted.

Valances were much used; leather, velvet, brass nails, needlework, embroiderings were all popular.

As early as I 300 velvet is mentioned in English inventories and French documents. At that time it was a flock-like material. In Italy, beginning 1600 , design was still influenced by the Orient, and France was a great producer of velvets and damasks.

While silken stuffs had been made in Europe at an early date (see page 35, chapter on Development of Textile (Veaving), it was not until the commencement of the European trade with the East and the introduction of silk culture in Italy and France that the lower price of the raw material encouraged the manufacture. In the time of Queen Elizabetl a charter was granted to the Dutch settlers in Norwich for figured loom iveaving, and damasks, flowered and striped, were made. The revocation of the Edict of Nantes, I685, strengthened the English trade, and by I 700 Flemish and Huguenot weavers settled in London, Spitalfields, Cheshire, Lancaster. Derlyshire, Kent, Essex and Norfolk.

The illustrations on the right show the Jacobean panel work of $1600-1620$. The rest of the pieces show the French development immediately following the restoration of Clarles II, I660, and then bulbous formations. distinctly William and Mary.

The eight-legged chair could be properly called Louis XIV. probahly made by Frencls exiles, who settled in England in 1685 . These IVilliam and Mary styles were usually walnut, and need never be confused with mahogany of a later period.
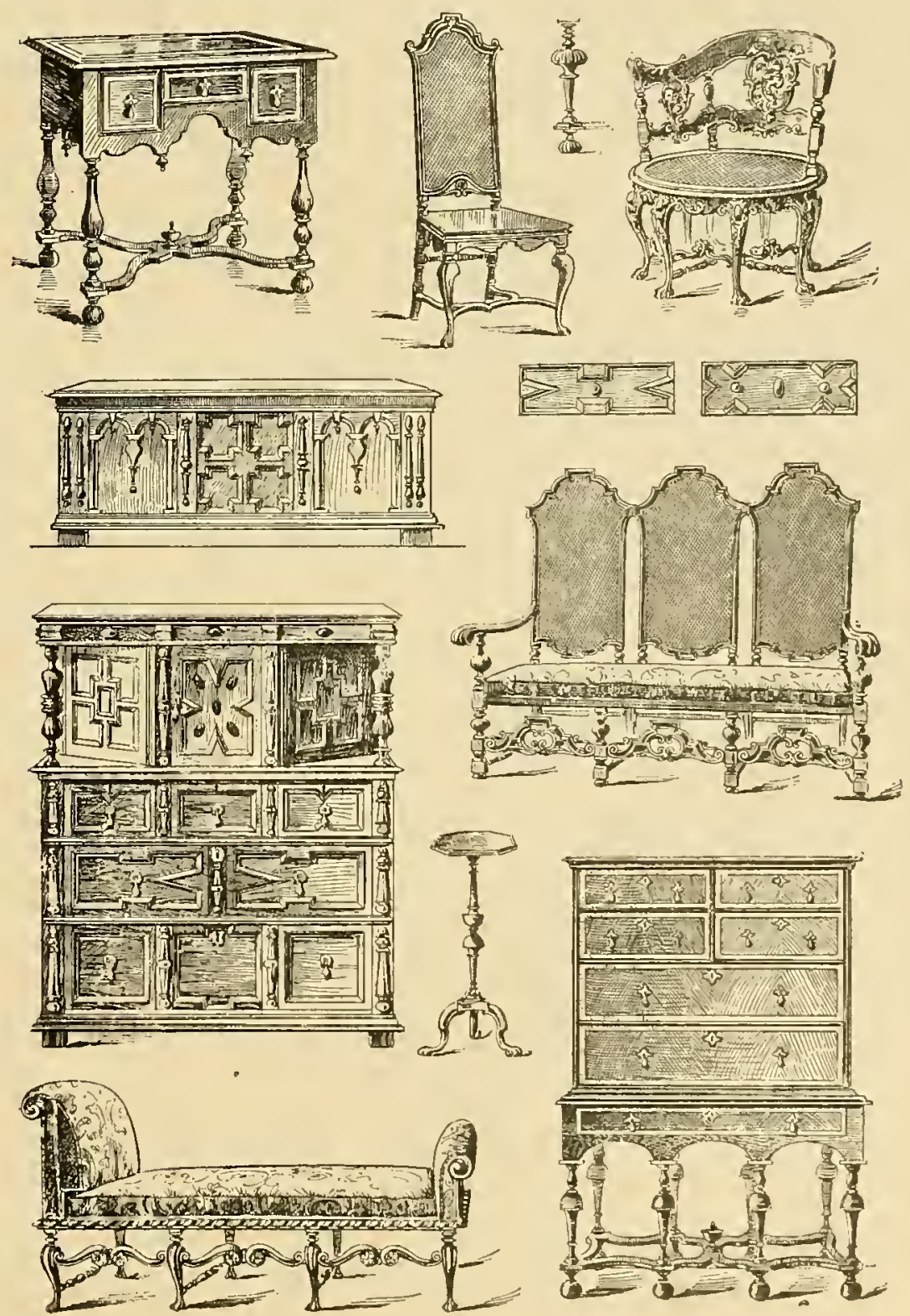
ITALIAN.

FRENCH.
FLEMISH.
I400-1600. Florentine Renaissance: Brunelleschi, I377-I446. Borgognone, I450-I524. Fra Angelico, I387-I455. Luca Della Robbia, I388-I463. Botticelli, 1447-I5IO. Andrea del Sarto, I486-I53I. Benvenuto Cellini, I500-I57I.

I400-1600. Milanese Renaissance:

Leonardo da Vinci, I452-I519.

I444-I643. Roman Renaissance. Donato Lazzari (Bramante), I444-

I5I5.
Giacomo Barozzio, 1507-I573.

Michael Angelo Buonarroti, 1474I 564 .

Raphael, I483-I520.

I490-1600. Venetian Renaissance: Palladio, I5 I8-I580. (See England, 1603-I649, for Italian influence.)

I500. High Renaissance.

1540-1643. Late Reriaissance.

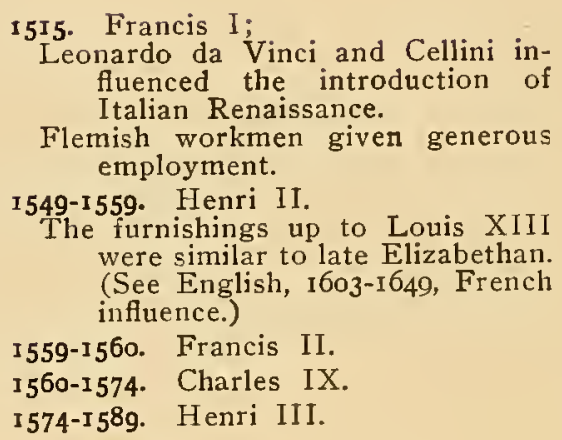

Leonardo da Vinci and Cellini influenced the introduction of Italian Renaissance.

Flemish workmen giver generous employment.

I549-I559. Henri II.

The furnishings up to Louis XIII were similar to late Elizabethan. (See English, I603-I649, French influence.)

I559-1560. Francis II.

I560-I574. Charles IX.

I574-I58g. Henri III.

I589-1610. Henri 1V.

Edict of Nantes granting religious freedom. I604. Organization of East India
Trading Company.

I6I0. Louis XIII.

I643-I7I5. Louis XIV.

1642. Richelieu's East India Company.

1653. English cavaliers settled in France after downfall of Charles I, and on returning under Charles II, brought back French influence in art.

I685. Daniel Marot, one of the most talented decorators who flourished during the reign of Louis XIV, fled with other Protestants at the time of the revocation of the Edict of Nantes, a measure originally granted by Henry IV to allow toleration of worship. When revoked in 1685 by Louis XIV thousands of Protestants fied to Holland and England. The French style of Marot and his confreres became conspicuous in the English period just prior to Queen Anne.
I507. Development from Italian.

1576. All Netherland province united and drove out the Spanish.

158I. Formation Dutch Republic. Consisting of Holland, Zealand, Utrecht, Gelderland, Groningen, Friesland Overyssel.

1584. Antwerp destroyed. Famous manufactures dispersed. Flanders Brabant, Limburg, Luxemburg, Artois, Hainault, Namur, Zutphen, Mechlin became finally merged as Belgium.

Dutch traders ruled the commerce of the world.

r6oo. Spanish dominion overthrown. 1602. Dutch East Indian Co. incorporated. East Indian textiles and pottery furnished Oriental motifs for embroidery.

16r3. New Amsterdam, America, settled by the Dutch.

I648. Republic of the United Province of the Netherlands recognized by Spain.

I664. New Amsterdam was seized by Duke of York, brother of Charles II and name changed to New York. 


\section{E V E L O P M E N T}

SPANISH.

1500. At first Moorish or HispanoMoresque. Italian style was adopted gradually, developing what was termed the Plateresque, a sumptuous mingling of Gothic and classic details.

I550. Carlos I was born and educated in the Netherlands, and upon attaining the crown his advisers were Flemish, and the late Spanish Renaissance showed Flemish characteristics.

I500-1600. Portugal enjoyed monopoly of trade with India.

I6oo. Spanish withdrawal from tise Netherlands.
GERMAN

ENGLISH.
1550. Founded by Albrecht Durer. Perpetuated by Holbein and Peter Fischer.
I509. Renaissance introduced by Henry VIII, who employed many Italian artists. This period is sometimes called Early English or Tudor, Henry VII having founded the Tudor line, 1487.

I534. Reformation. Departure of Catholic Italian workmen from England. Italian influence was soon forgotten in the employment of German and Flemish artisans.

I558-I649. Elizabethan style. Development along German and Flemish lines. Protestant element. Dutch commerce made such inroads that Elizabeth took measures to check it. The full development of Elizabethan style included what is popularly called Jacobean.

I6oo. English East Indian Trading Company incorporated. Charter renewed several times, and active up to ISI3.

I603-I649. Jacobean (J a c o bus, James), a continuance and full development of Elizabethan. Under James I came the classic development of Inigo Jones (I625-I652), who studied under Palladio, Italy, and Christopher IVren (1632-I723) who studied in France. Thus we have in this period, especially in the architectural treatments of pretentious interiors, the classicism of France and Italy. The Puritan settlers in America were of this period I620-60.

I625-I649. Charles I. Charles beheaded 1649 , and many royalists fled to France.

I653. Cromwellian.

I66o. Charles II. To the Flemish spirit was added French characteristics through the sentiments absorbed by the exiled royalists wlio now returned to England.

New Amsterdam seized (see Flemish).

I685-I689. James II.

I689-I702. WVilliam and Mary. 


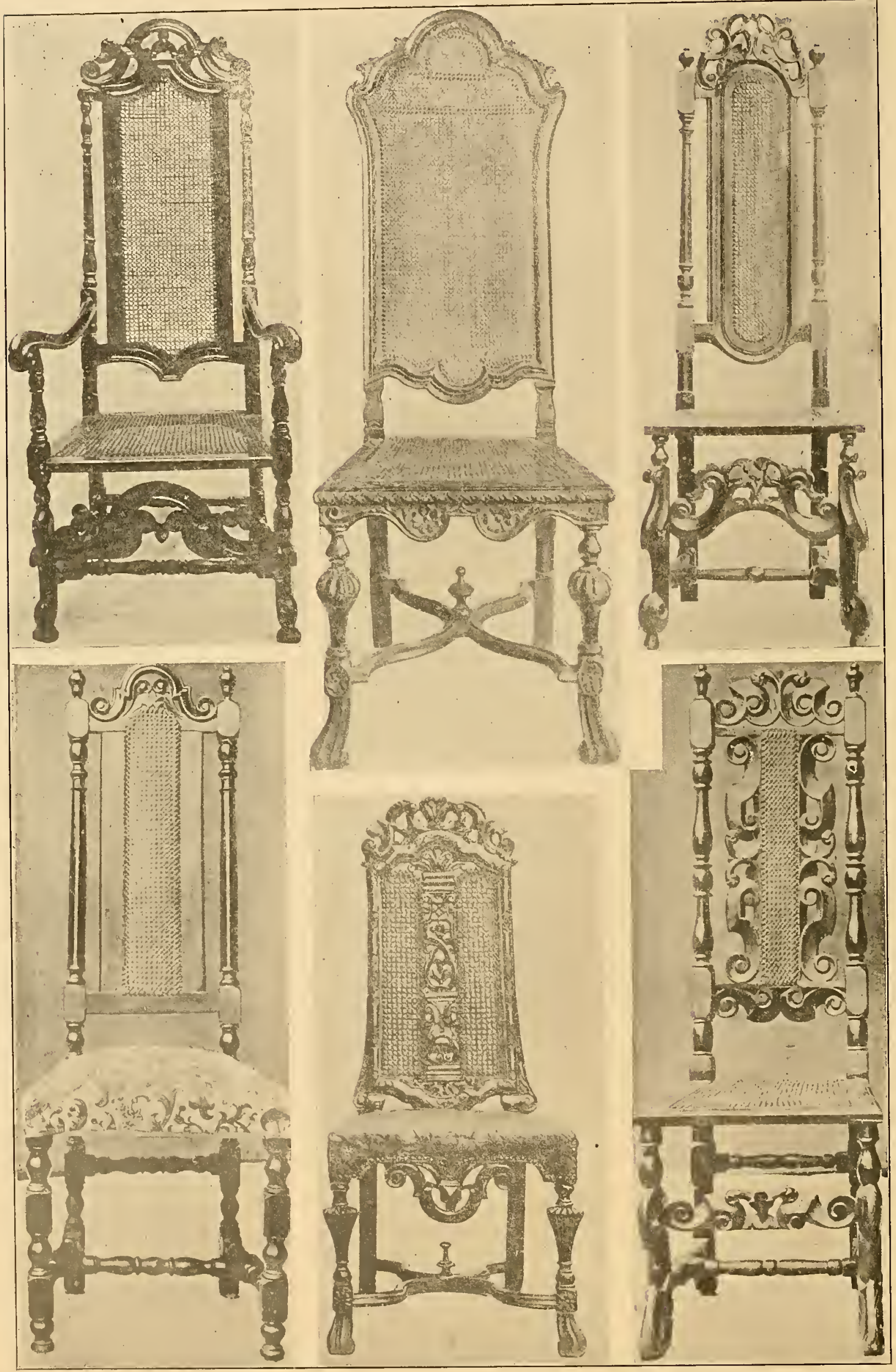

WILLIAM AND MARY PERIOD, ABOUT I6go. 

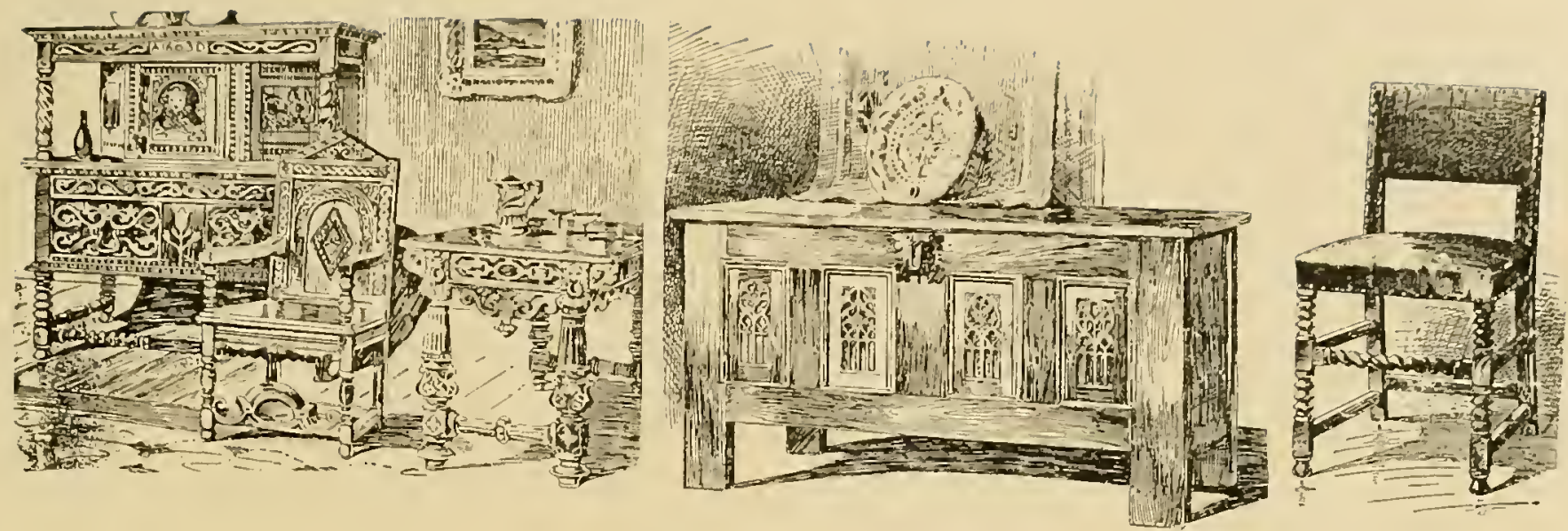

Early Jacobean.

\section{L O S E O F J A C O B E A N}

CHARLES 1I, 1660-1685. James 11, 1685-1689. William and Mary, 1689-1502.

$\mathrm{T}$ HROUGHOUT this entire period which is the end of the Jacobean epoch we have such a confusion of styles, adaptations of French, Flemish and Italian, that it seems absurd to attempt to distinguish definitely the beginning and ending of periods like the Cromwellian, which only lasted five years, or the James II, which only lasted four years, or the William and Nary, which lasted twelve years.

It is impossible to draw a strict line of demarcation between the end of the Jacobean and the beginning of the Qucen Anne. Queen Anne reigned I702-I7It, but what is known in art as the Queen Anne Period had its inception in 1660 . One may say of this intmediate period that it is Charles II if lirench influences are particularly strong, or William anc? Mary if Dutch influcinces are prevalent, but Queen Anne in its cutirety was strictly. Dutch and, as will be seen later on, had a style distinctively its own. Before reaching, however, the narrowed confines of the period that began in I702 we have to do with the French-Flemish and the Flemish-Dutch, which carries us through the late Jacobean and past the James II, I685-I689, and William and Mary, I6891702.

Flemish characteristics began to depart and the French details of Louis XIV were adopted in the reign of Charles II. History tells of the lavish extravagances of his mistresses, especially Louise de Queronalle, who was presented to Charles througl, the instrumentality of Lotis XIV, for whom she becane practically a spy. The tastes of the court were distinctly French. Chairs with heavily upholstered scats and backs became popular. The cane chair took on the scroll leg. In 1675 marefuetried fumiture came in. Lacquered furniture became popular. Again in that year we notice the flat serpentine stretcher, drop handles and brass key escutcheons to doors. Bedroom chairs would oilten be made in sets and covered with velvet to match the hangings of the bed. Double-seated chairs or settees came into use. The French leg and 
foot came in I680-the S-shaped leg, serpentine like.

In 1685 came James II and a marked development in furniture. With 1685 appeared the tallbacked French chair. It was a more severe style of furniture than that of Charles II. French diningroom chairs were tall, narrow-backed, without arms and with sometimes an upholstered seat. They had the French characteristics. Towards the end of James II and during the reign of William and Mary the crest at the top of the back was often placed as a finish to the back posts instead of between them.

The strong French characteristics were due largely to the work of Marot, a prominent decorator who fled from France at the time of the revocation of the Edict of Nantes, I685. Many other French artisans worked in England at this time, just prior to the Queen Anne period, introducing what appeared to be anachronisms.

While cushioned seats were not uncommon at an earlier period, chairs made with fixed upholstering did not come into use until about $155^{\circ}$, the period of Elizabeth in England and Francis $I$ in France. Henry VIII had gathered together a small a rmy of French, Italian and German workimen and at this early date the Italian and Flemish $X$ chairs were used, upholstered seats and backs. Prior to this

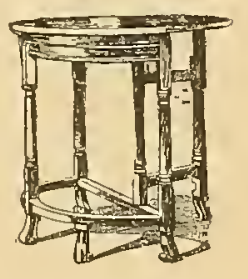

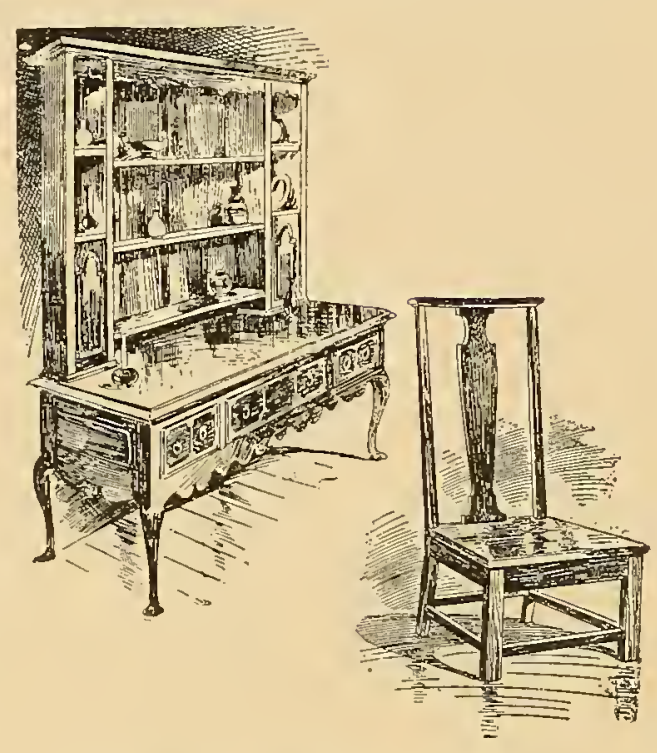

Above, types of inception Queen Anne; below, Cromwellian, I653-1659. rivalled the lacquers of China and Japan with a varnish which was hard and transparent, now known as Vernis-Martin. From I744 to I764 Martin was granted a monopoly to manufacture this lacquer.

Elizabethan and Jacobean oak furniture received only a light coat of dark oil varnish. The pieces were then rubbed with beeswax and given a rich tone.

It may be safely assumed that during the "Age of Oak," I 500-1660, and the "Age of Walnut," I660-I700, little varnish was used.

Italian Renaissance furniture, I400-I643, was of oak, lime, willow, sycamore, chestnut, ebony or walnut, and was wax polished, oiled or left natural.

The French, Flemish and Spanish Renaissance, I 500-I643, used a great deal of oak, chestnut and walnut polished, oiled or left natural. The Portuguese traders from about 1525-1576 and the Dutch traders subsequent to 1576 , brought into Europe a great many foreign woods, but they were not to any extent employed in the manufacture of furniture until the middle of the Seventeenth Century. The finishing of woodwork was hand polished. Indeerl, in England it was not until the Queen Anne style came in that we notice any efforts at even shellacing. The old-t ime cabinetmaker obtained his toned effects by exposing his woods to date the furniture backs being carved did not encourage arm and back upholsterings and movable cushions were common. The chairs were without arms to accommodate the monstrous skirts of the women. At the period of James I the Farthingdale chair was popular, it had no arms and allowed the dress to spread in all directions. By 1620 we have the type illustrated where the framc is entirely covered.

\section{CHARACTER OF THE WOOD-FINISH.}

The use of varnishes goes back 3.000 years. The Egyptians were expert in the use of varnish, but the Europeans learned their art from the Far East Old English term, vernish; French, vernis; Italian, vernice.

Italian Renaissance furniture probably received an oil finish. Martin, a carriage painter, born I726, the light until the surfaces had darkened, then he rtubbed in the oil and beeswax. Beginning about I680 a naphtha and shellac preparation was used. Then followed the Lotis XIV period and soon afterward Vernis-Martin and a host of imitation varnishes.

As early as I60I there are records of lacquer ware brought from China and Japan, hence the term japanned, as applied to lacquering. The Oriental method required a vast degree of patience and skill, sometimes requiring eighteen or twenty treatments and never less than three treatments. The Chinese and Japanese lacquer was derived from the juice of the varnish tree, which hardened into a black resin. Lacquer wares were brought into Holland, England and France in large quantities throughout the Seventeenth Century, particularly by the East Indian Com- 


\section{E N G L I H R E N A I S A N C}

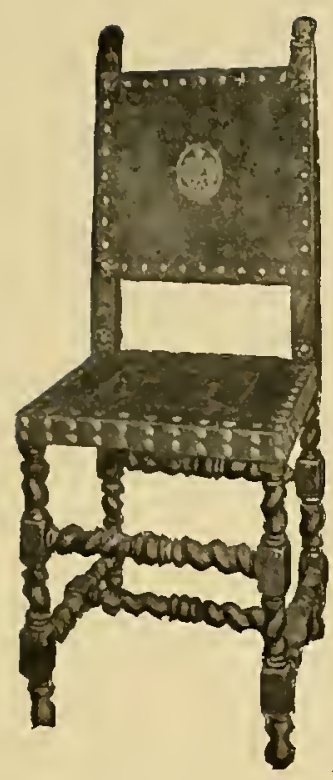

panies. Cane belongs essen-me prevailing woods tially to the Jacobean period, Fingland about 1650 and Tonis XIII France. The earliest long clocks belong to the period of Charles II and were inlaid.

Excellent marquetry work following Dutch styles was popular in England during William and Mary's regime. Veneering was first used in the reign of William and Mary, until which time furniture had been made solid.

The beginning of walnut in England was about the period of Charles II. During the Queen Anne period

A Farthingdale Chair, I6zo. See first column, page II8. were walnut, beech, holly, birch and yew.

Cerlar was used for room paneling ii) England as early as 1678; also for chests.

English elm has been always used, especially for chest drawers and tables. It has a plain straight grain and is not as attractive as oak. Sone of the Queen Anne dressing tables were elm. Laburnum, a native wood of the Alps, was excellent as a veneering.

William and Mary, I690
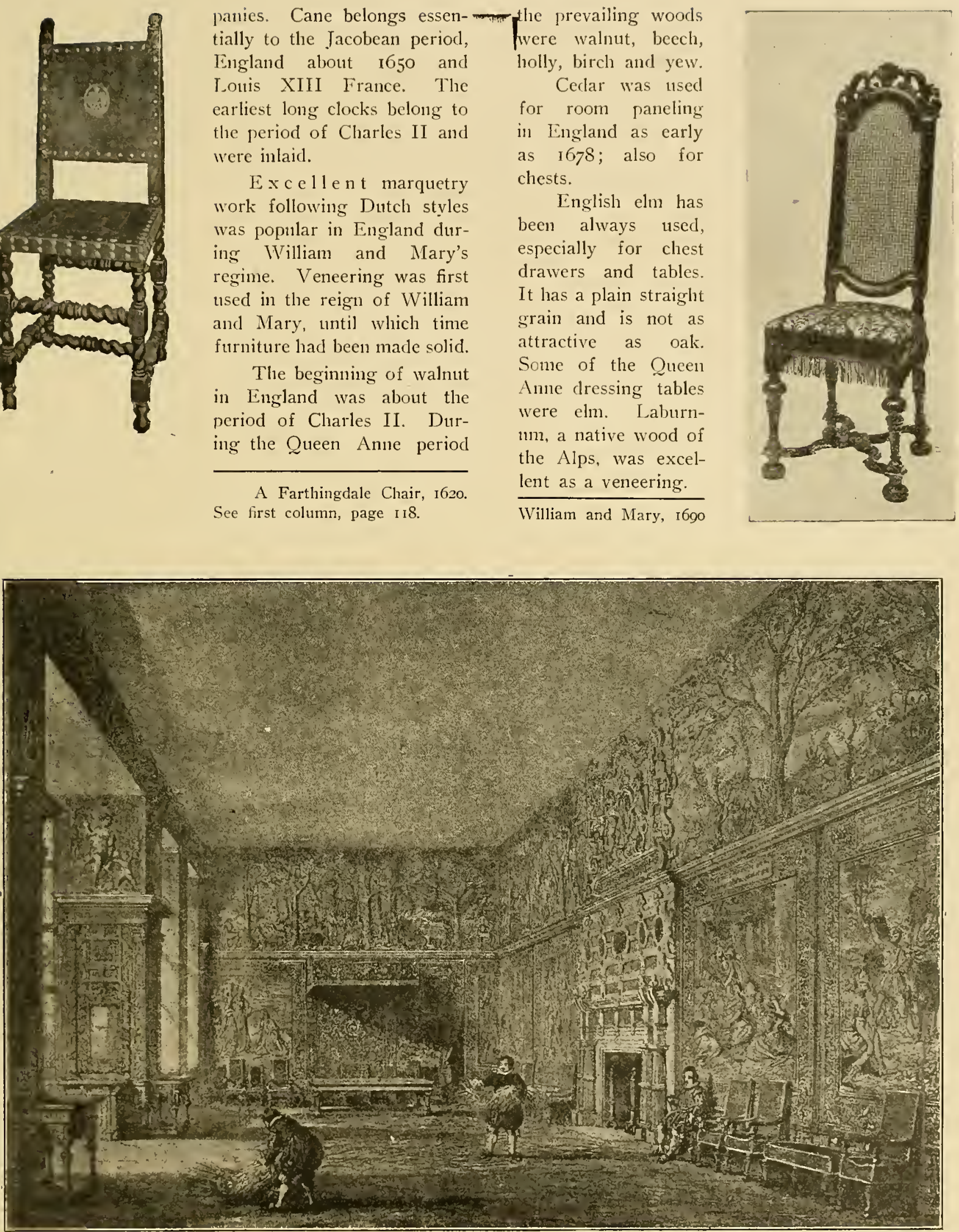

Hardwick Hall, Derbyshire, from an old print. The Presence Chamber. No carpetings used, the floors strewn with rushes. Tapestry on wall. 


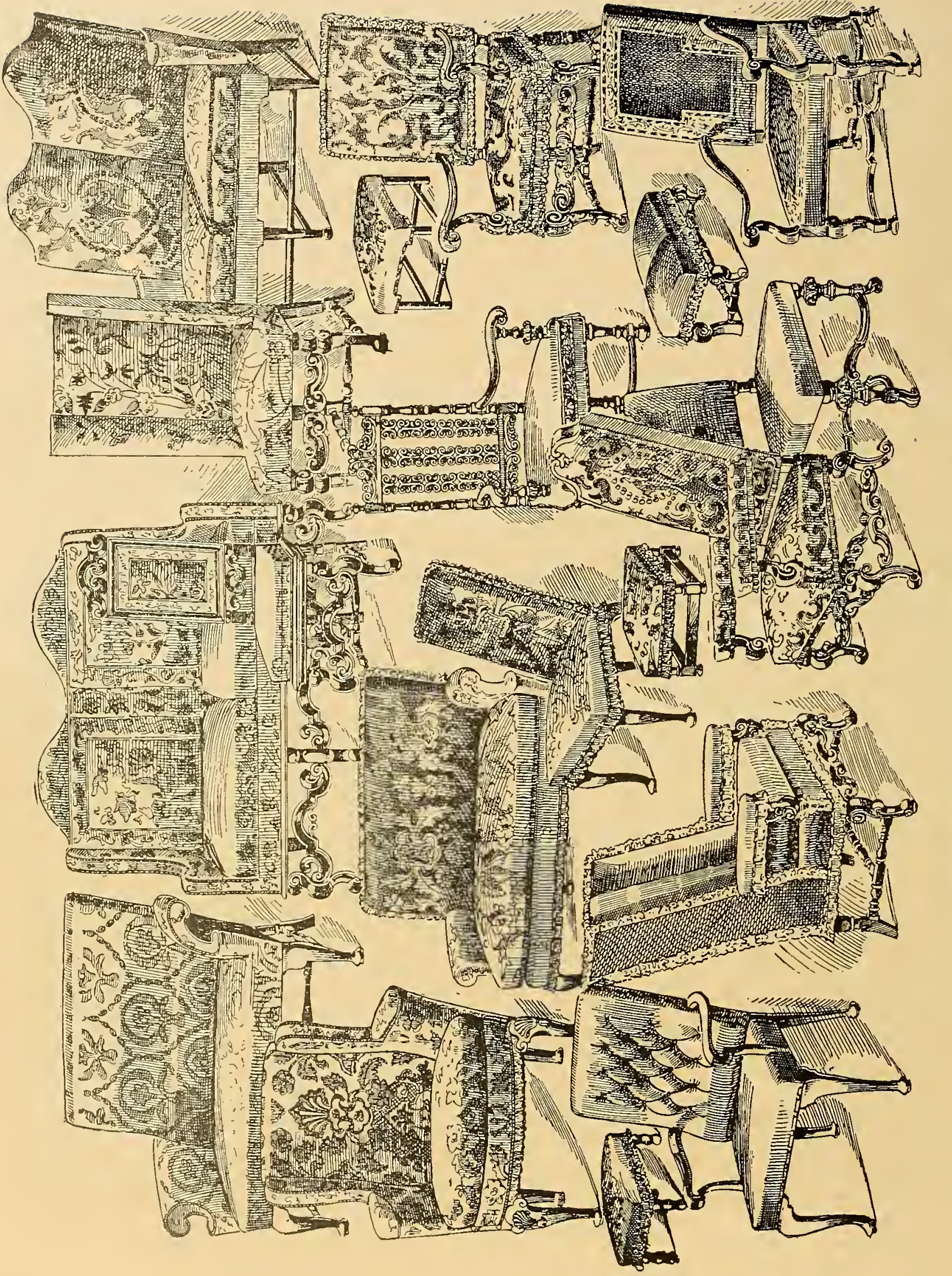




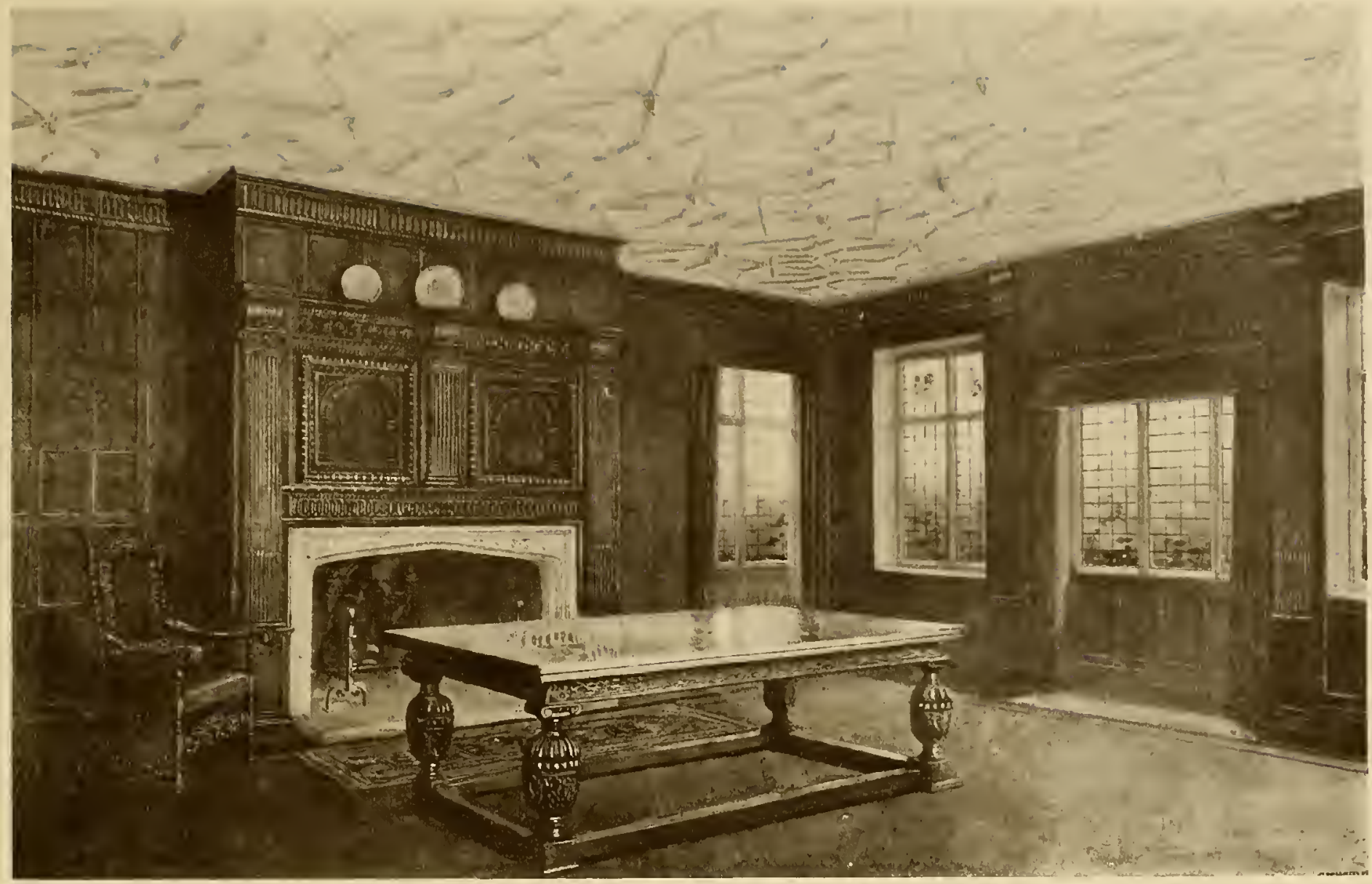

With the exception of the chair, a good Elizabethan type. Chair fifty years later.

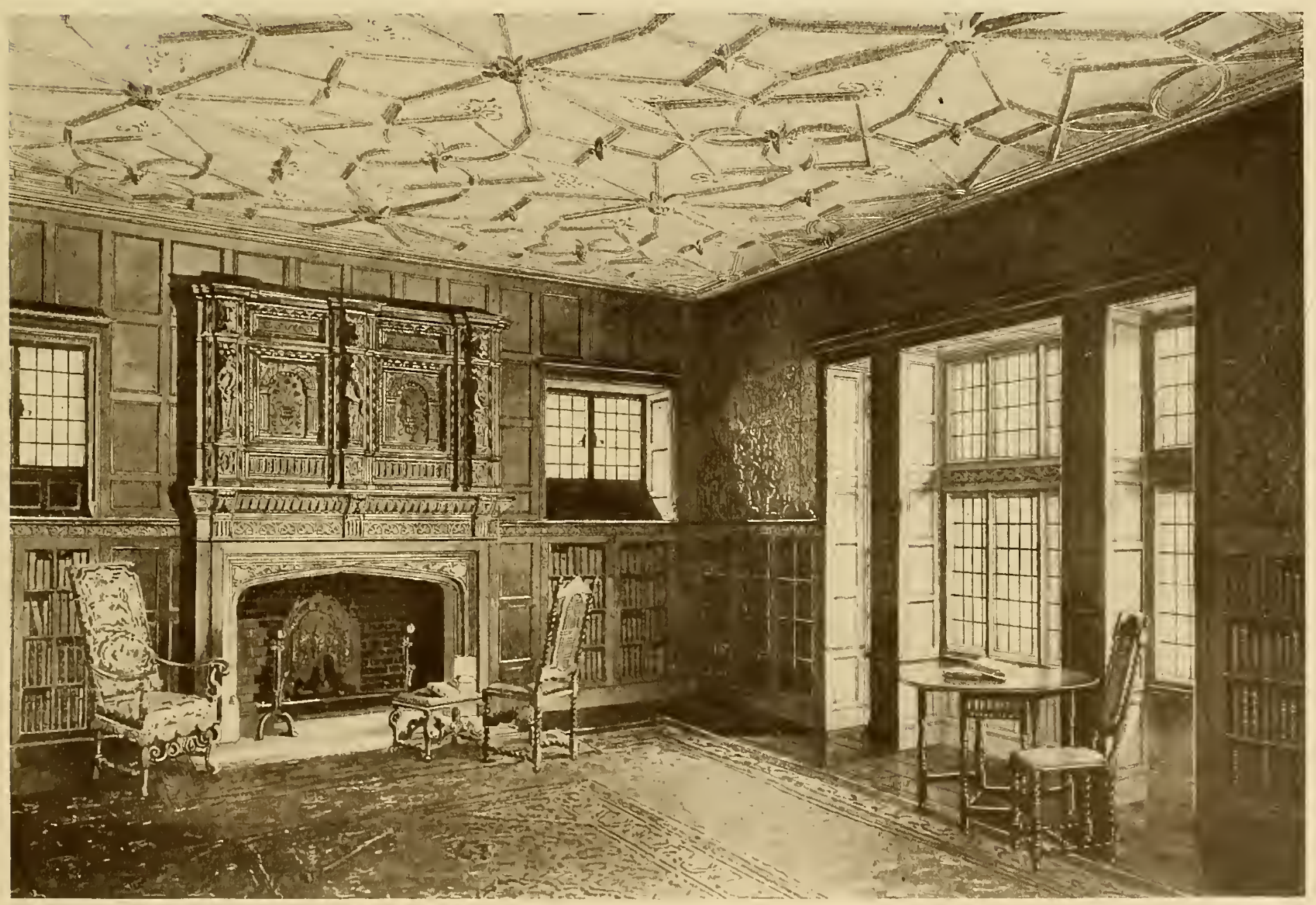





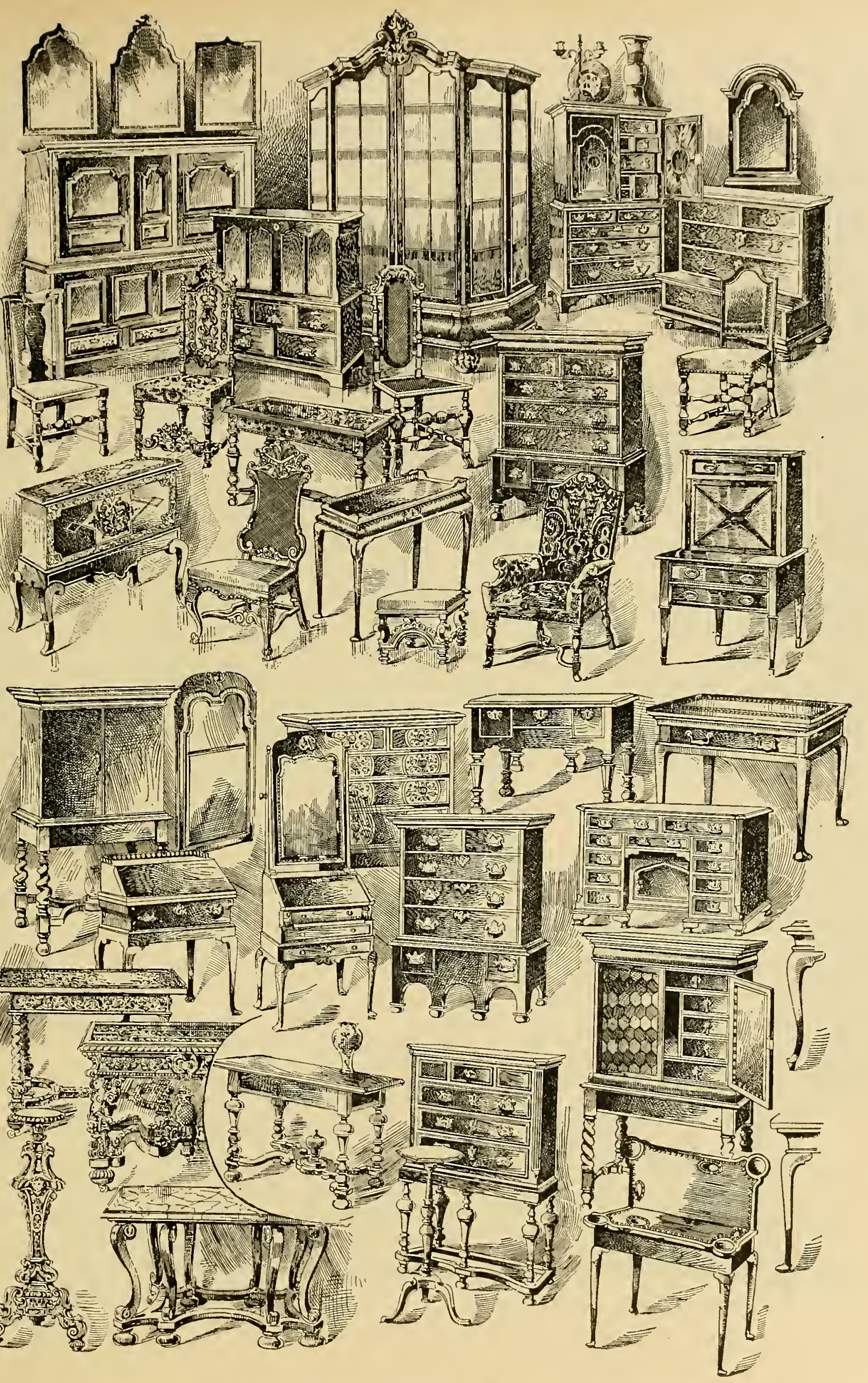




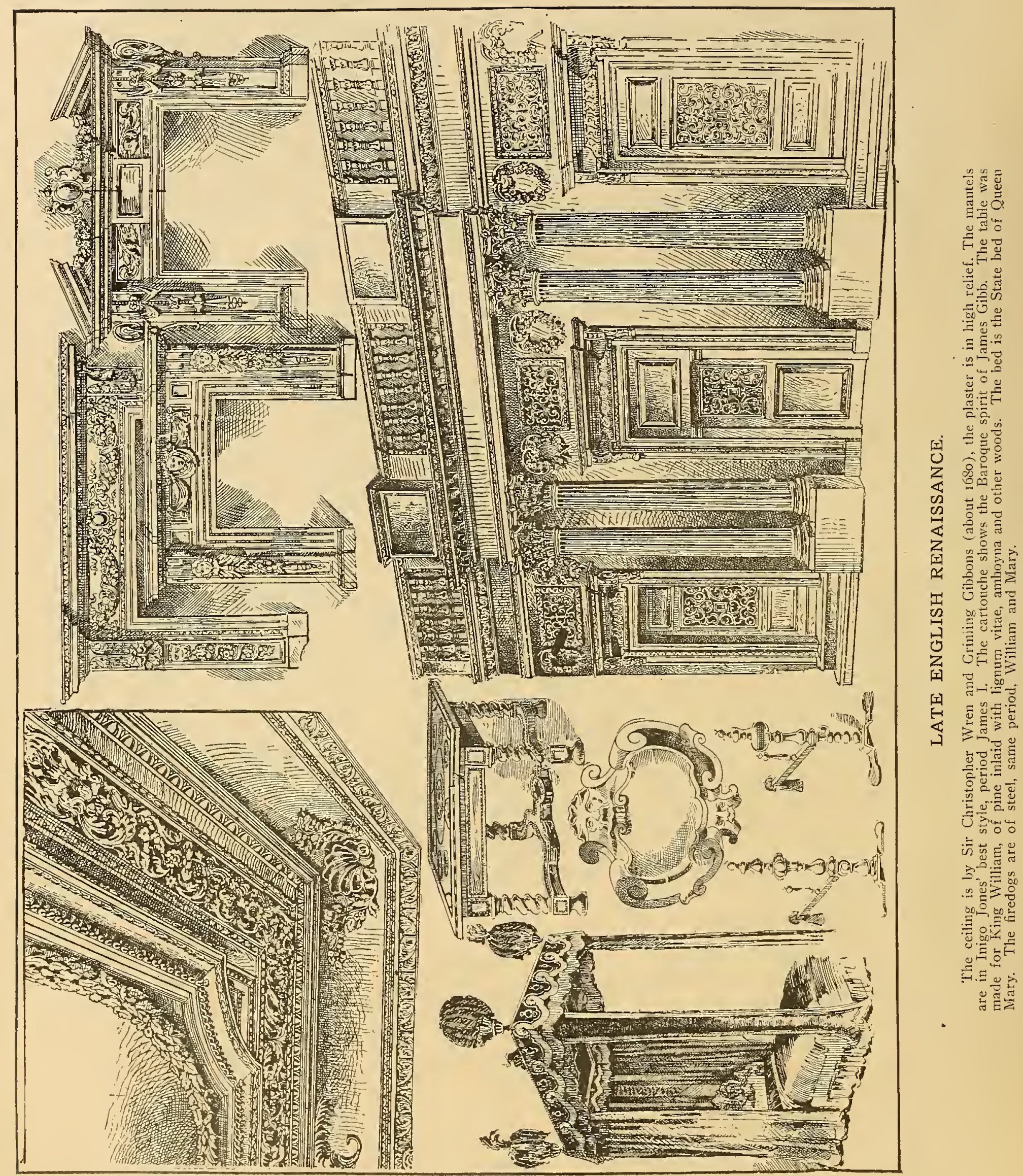




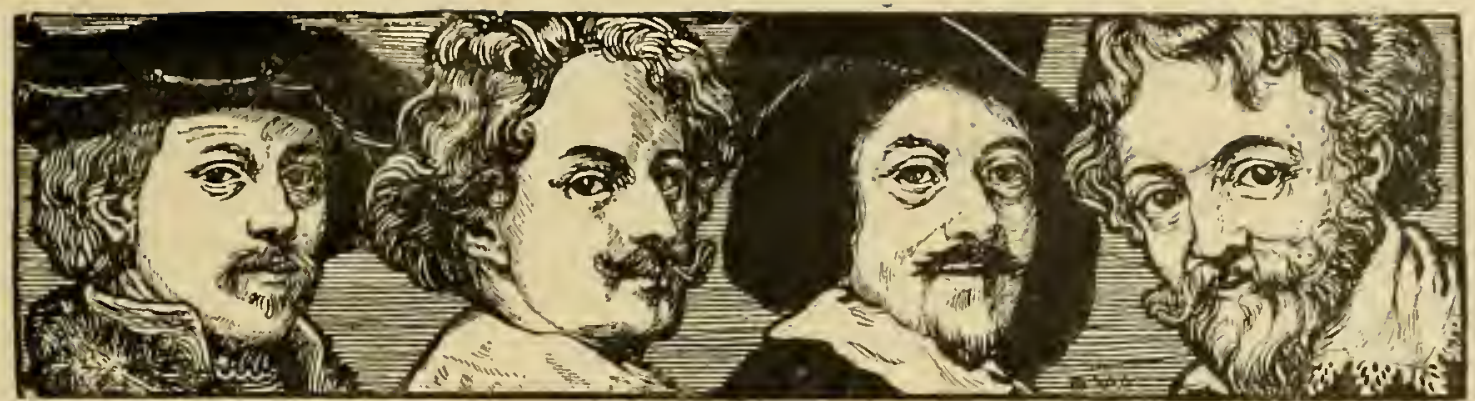

Reading from left to right, the portraits above are those of Rembrandt, 1607-1669; Van Dyke, 1599-1641; Fran\% Hals, I581-1666; Rubens, 1577-1640.

\section{THE END OF THE RENAISSANCE}

Development of Bareque in Roman Renaissance, 1540 -Clatsic Lnlluence of Inigo fonkes (James L), Sir (Jhristopher IIren (Charles ol, George 1), Lomis Xll1 of lintuce.

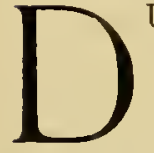

URING the period known as the Late Renaissance. Michacl Angelo, apostle of free thonght in art, broke away from the fetters of classicisin and produced some extraordinary results. These forms in the hands of a master were acceptable, but when others tried to follow the results were less pleasing and became known as Baroque.

Details were combined and superimposed in a fashion extravagant and frequently grotesque. It was the outcome of that universal spirit of unrest which revolts at rule or order, and the effort to do something different simply resulted in ornament that was impressive and astonishing at the sacrifice of taste and unity. The term Baroque became eventually an adjective expression for a corrupt style.

In France the Baroque was little in evidence.

In Germany it was passively accepted. We find little Baroque in England for the reason that apart from the work of John of Padua under Ilenry VIII there was no Italian influence until James I, and then the infunence became Palladian or Classic, for throughout the period of Michael Angelo. Palladio was equally active in maintaining the integrity of the pure style-Venetian Remaissance-and Inigo Innes in Englandl was a staunch I'alladian. 1 lis work as well ay that of Joln $W^{\prime} \mathrm{cbb}$, Edward Carter and Nicholas
Stone, expressed admirably the pure ltalian spirit.

The work of Sir Christopher W Vren and Nicholas Hawksmoor, Sir John Van Bruglı and Jannes Gibb, another eminent arclijtect, continuerl the classic spirit of the French style in architecture through the Cromwellian, Charles II, James ]l, William ancl Mary, Queen Anne and well into the period of George I. Sir Christopher dierl in 1723. Ceilings were all plastered, sunccoed, flat or in relief, divicled into panels and circles, hexagons, and rhomboids, the borders being curiched with flowers and fruits of all sorts, well raised, following the extraordinary carvings of Grinling Gibbons; borders were often flat ornaments of Greek and Roman design or flowing Renaissance: the panels were often painted. Indeed, painted ceiling were common throughout the Seventeenth Century, the great artists, even Rubens, lending their talents to ceiling painting.

Sir Christopher Wren's work for William and Mary and Queen Anne was angmented by the ceiling and wall decorations of Verrio, the Neapolitan, who also did wonderful ceiling work for Charles II, prolific with goddesses, saints, satyrs, muses, cupids and inspirations of the New Testament and Roman I Jistory.

There was little or no liarocpene in England; there was. little in Holland, and even where it existed in

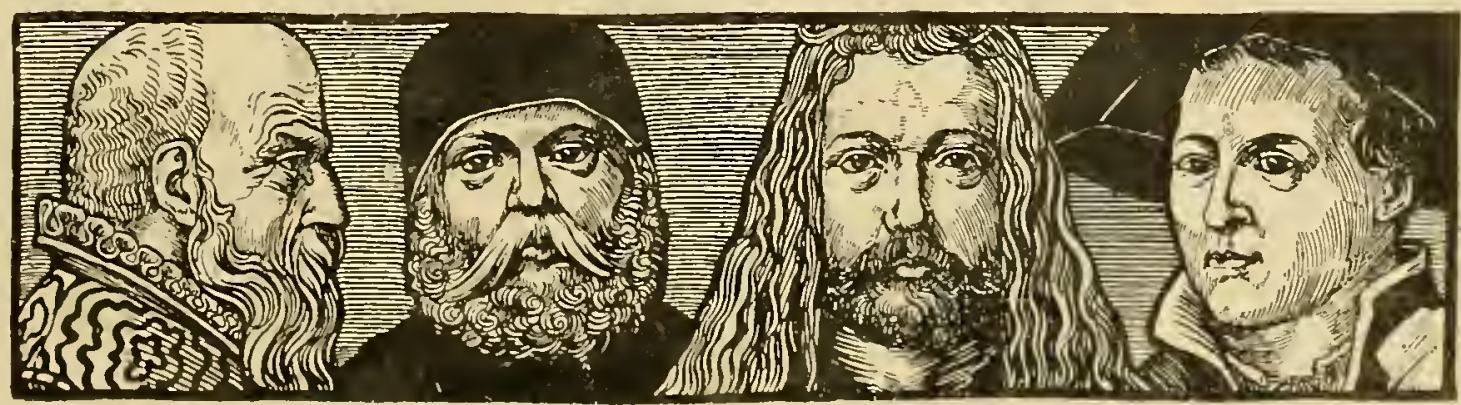

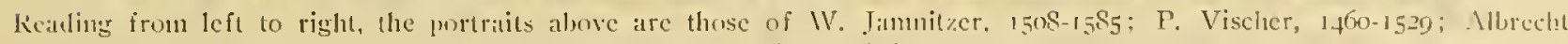




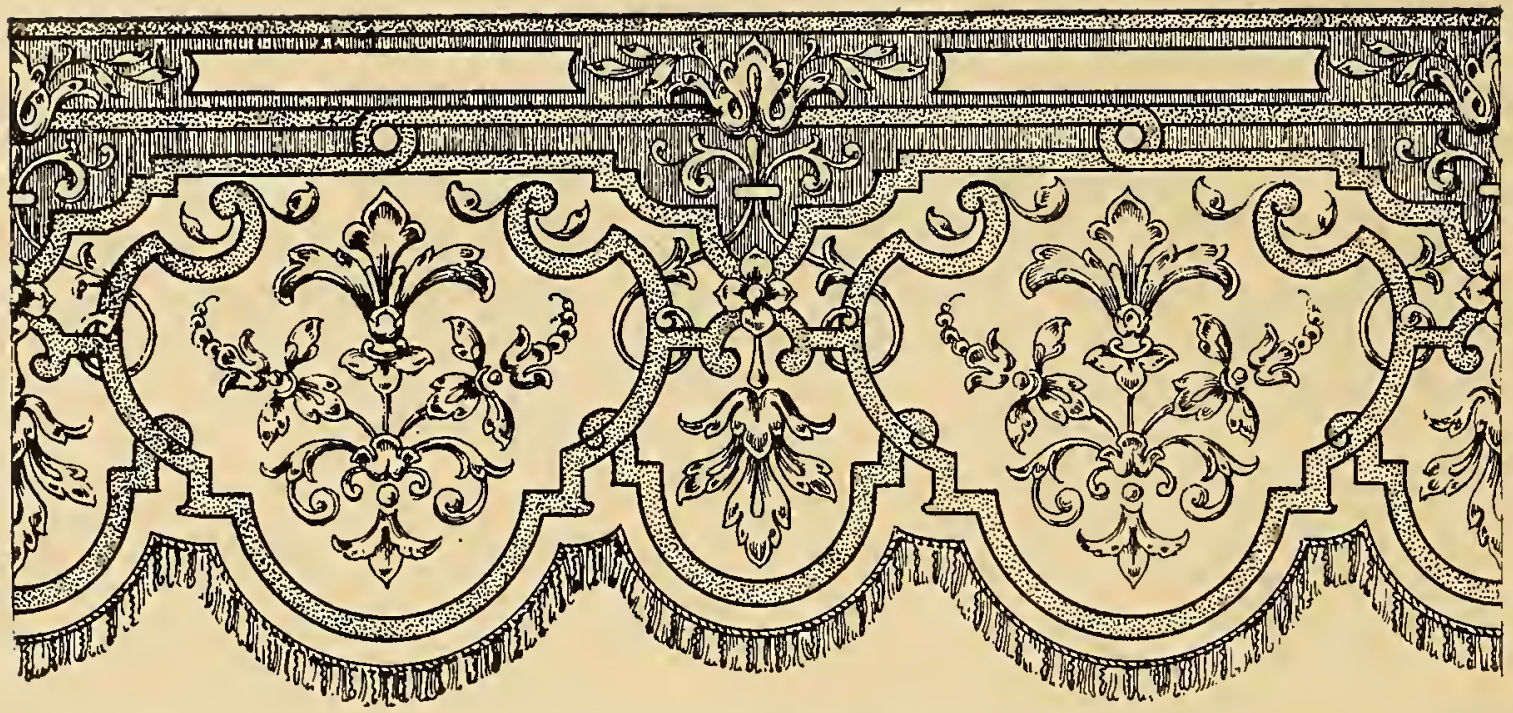

Above, lambrequin ornamentation in the style of Louis XIII-IV. Below, Baroque furniture of the end of the Renaissance.

France it cannot be said to have become a style; it was rather a decadent taste indulged by the few and condemned by the many.

With Louis XIII, I610-1643, the French Renaissance came to an end. It was a period of assimilation. French life under Henri II, Charles IX and Henri III, semi-Italian princes, was dominated by Catherine de Medici. Henri IV sent artisans to Holland to study carving, and at the time of Louis XIII, decorative art, as expressed by the work in his palace, was Italian, German, Flemish and Swiss. A definite French period did not develop until under Louis XIV.
In 1603 the Jesuits, who liad been expelled from France in I595, were recalled and in their religious zeal bent their efforts, especially in art, to the propagation of the classic styles. Not only marquetry, ebony furniture and painted furniture were made, but the Oriental spirit during the reign of Louis XIII became conspicuous in the woods that were used and the styles of the fabrics.

Cane was imported as seat coverings. Chairs were covered with leather or fabrics and upholstered heavily. The reception bed was introduced. Ladies received their guests en déshabillé, a fashion that pre-

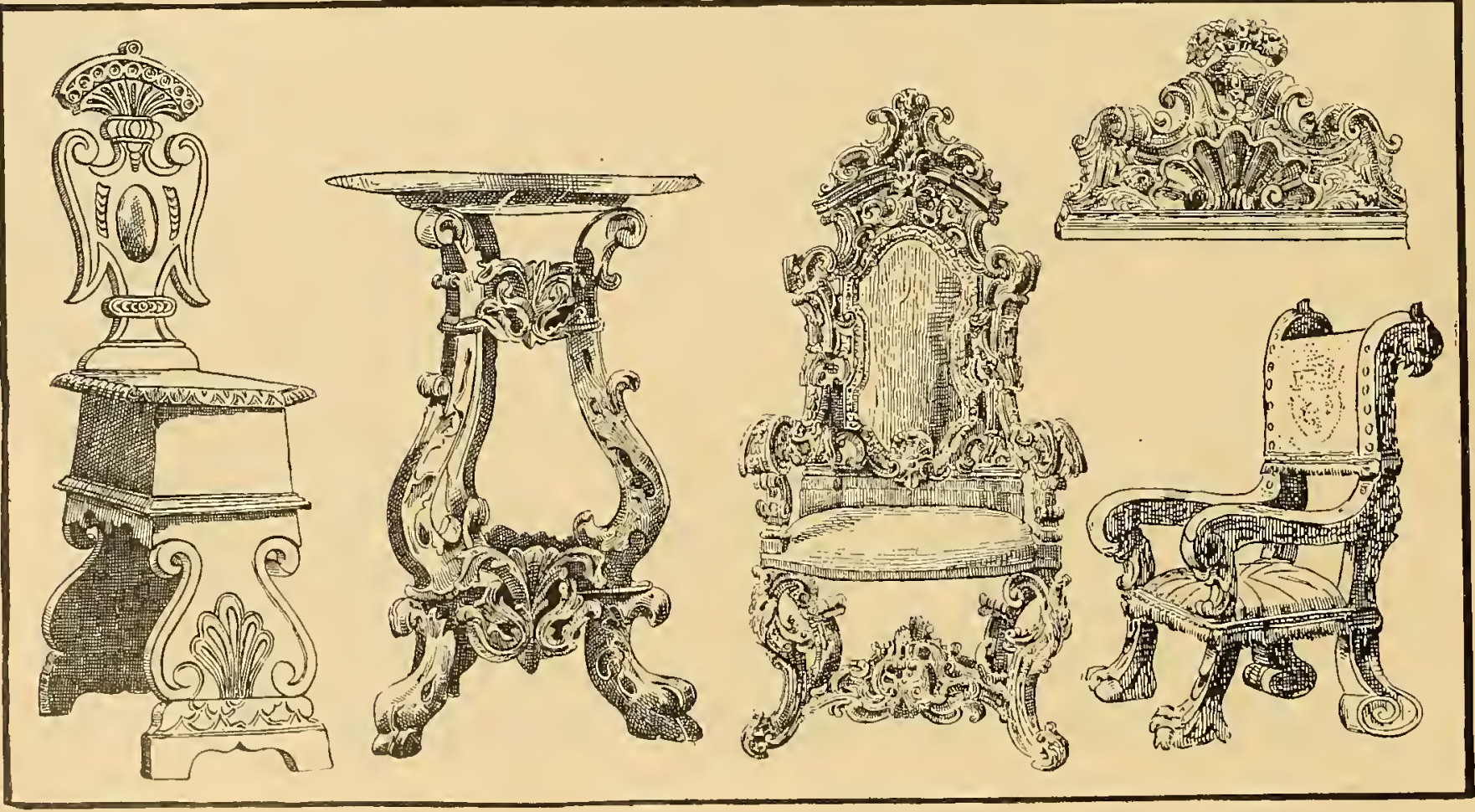


vailed in the reign of Louis XIV. The fashion of covering furniture with drapery can le traccl back to the Iiourteenth Century in Italy. Bed draperies were then used and canopies were in vogue; but the Louis XIII period may be said to have introduced the use of table covers and scarfs.

The French silk industry developed rapidly and quantities of costly materials were to be had in France; they were liung upon the walls and displayed over tables and screens. See page I 3 I.

The cultivation of the mulberry tree had been successful in the Soutl. Lyons was manufacturing great quantities of taffetas. Weavers had come from Anatolia to do embroidering in the Oriental style (largely Arabian and Ottoman), and before long France was also making its first typical design, employing as motifs the exotic plants found in the royal garden. By the beginning of the Sixteentli Century fancy silk manufacture, including cloths of gold, velvet, satin, silk and silk mixtures, had been introduced in France; into Tours by Louis XI, Lyous by Francis I, Paris by Henri IV, Avignon by the Popes.

In the Seventeenth Century, Colbert provided regulations covering the manufacture at Tours, Lyons, Paris and Nimes. Contemporaneously were famous Venetian damaslis, Luccan damascenes, Genoese velvets and mixtures called flatrices, poplins, feradines, Egyptian damasks, caffarts, Bruges satins, etamines, fustians and dimities.

Italian manufacturers lost a great deal of their German,

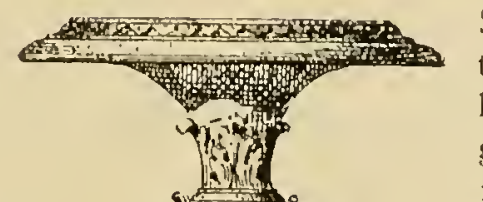

Swiss, Flemislı, English and Spanish trade. Soon the American colonies were heavy buyers of French stuffs. Paris gained supremacy in matters of fashion. The French styles were accepted in all the capitals of Europe.

Jacquard has always received credit for inventing a machine which bears his name, but in 1605 Dangon made a macline which produced great complication of color effects. Gallatier and Blache in 1687 made a loom which enabled one to make easily small patterns. Bonchon originated the idea of needles pressed back by a cardboard on whicli was traced the design.

Falcon, his assistant, increased the number of needles and made the cards revolve on two quadrangular prism cylinders. The municipality of Lyons recognized the superiority of this new loom and allowed to Falcon a gratuity of $\mathrm{I}, 500$ livres. Genin in I749 received 1,750 livres for having invented a loom on which one could weave small fancy stuffs without the help of a draw-boy. I'onson in 1766 invented the loom for the weaving of several armures at one time. Vezier in 1798 made still further improvements. Philip de LaSalle invented a machine for reeding designs, which brought about a considerable development in the composition of fabrics. He invented an attachment by the aid of which the draw-boy was able to do all his work while remaining seated. Finally he created the flying shuttle.

Jacquard's machine was an
Above, pedestal of the Louis XIII-XIV period. improvement on former inventions, but what was accom-

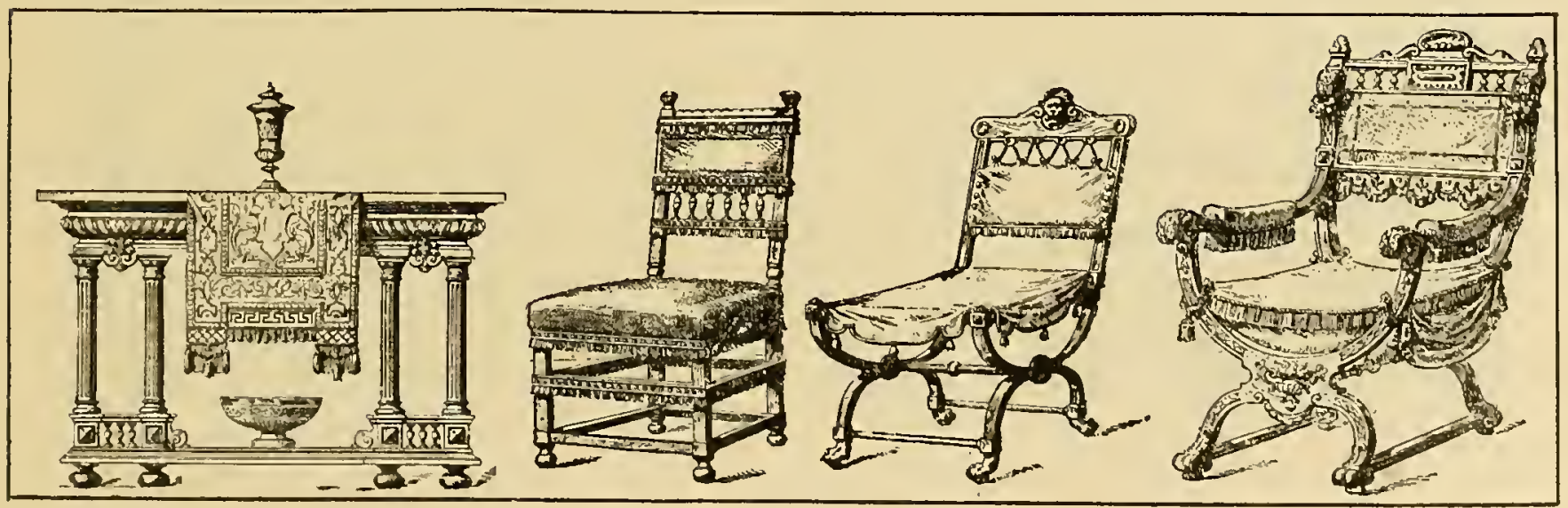

[125]

Lonis XIII. Note the scarf style. 

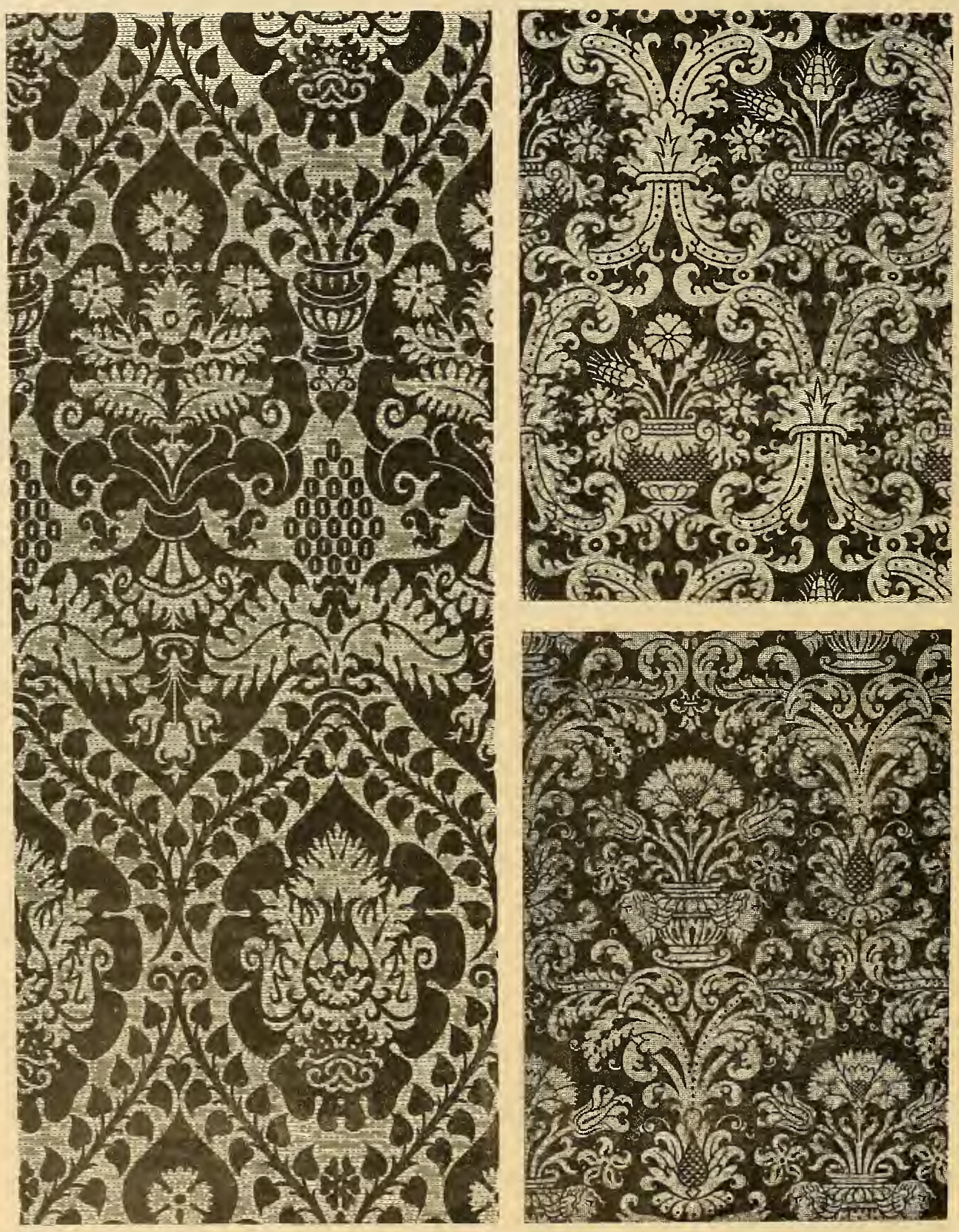


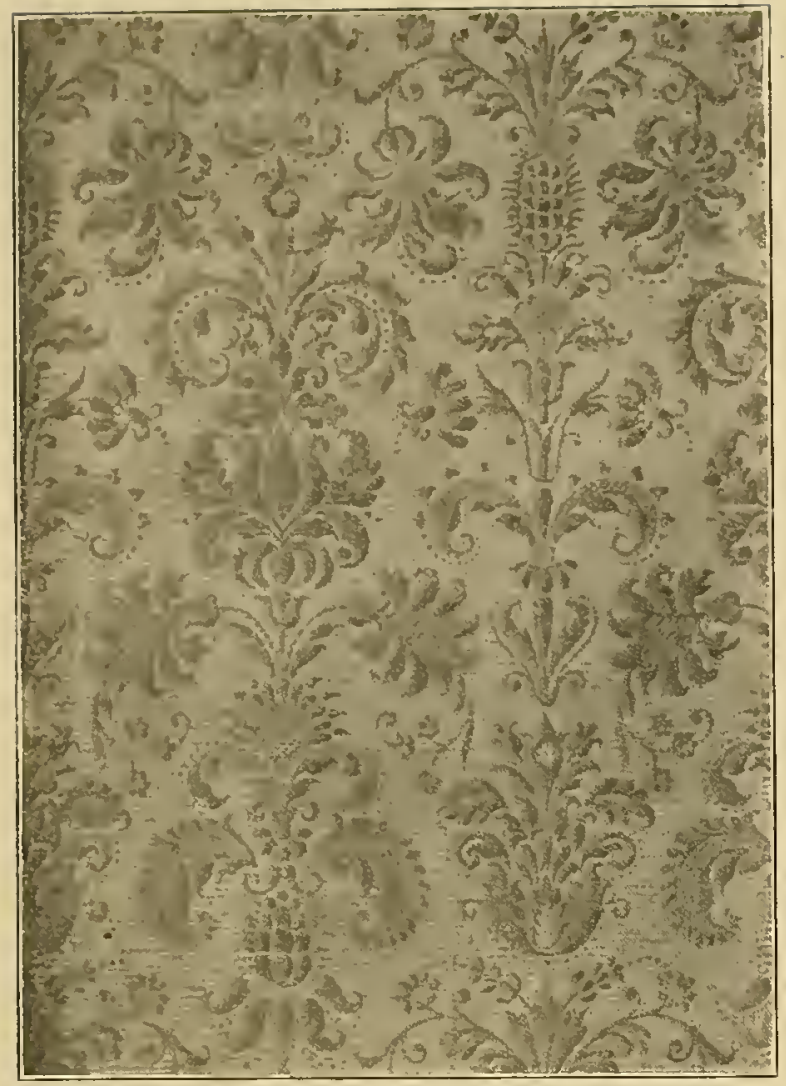

I710. Group VIII (U). Louis XIV.

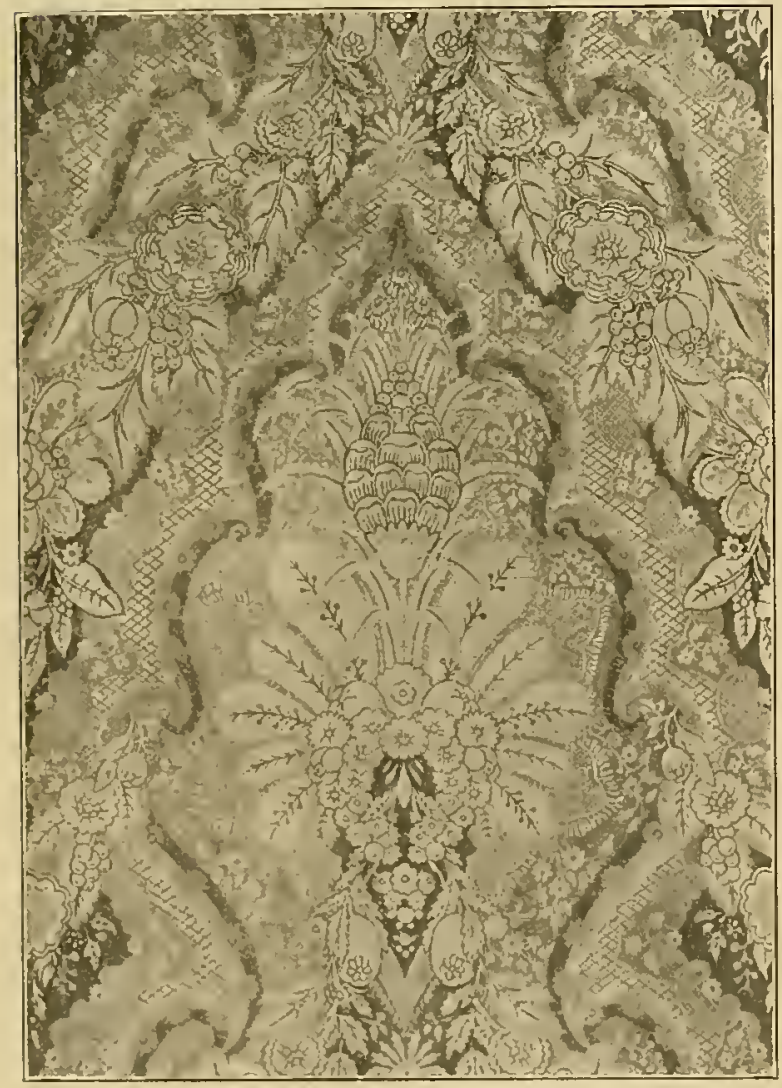

I670. Group VII (S). Louis XIV.

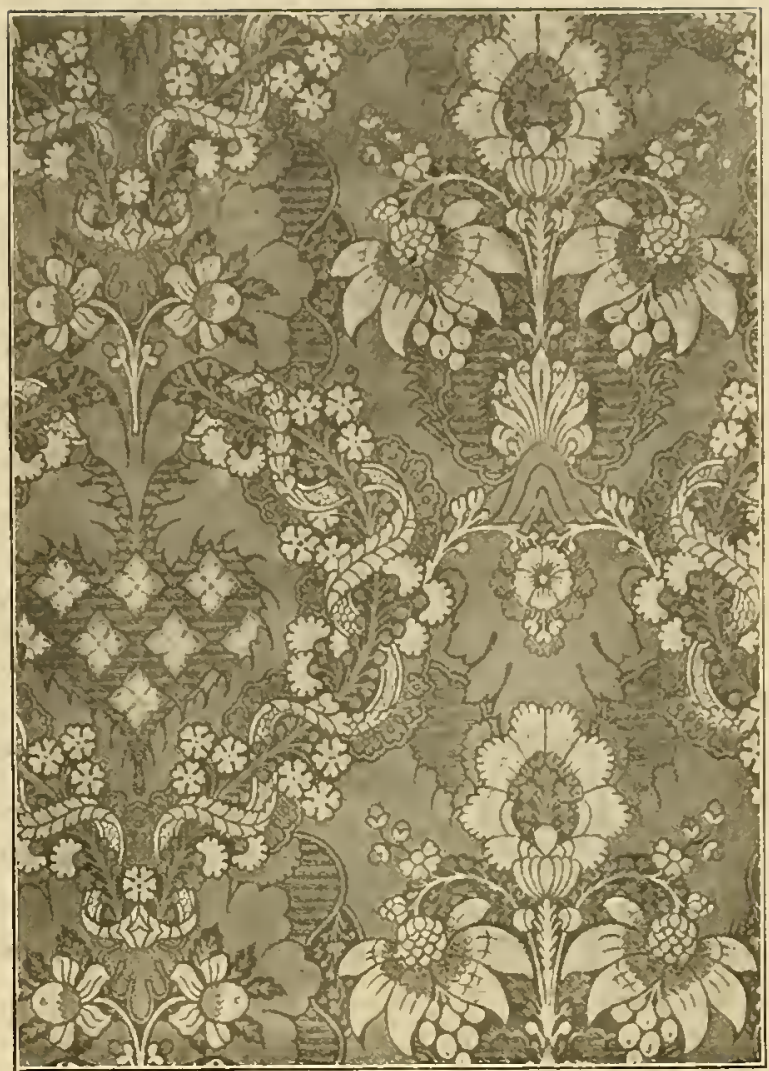

I7I0. Group VII (S). Louis XIV.

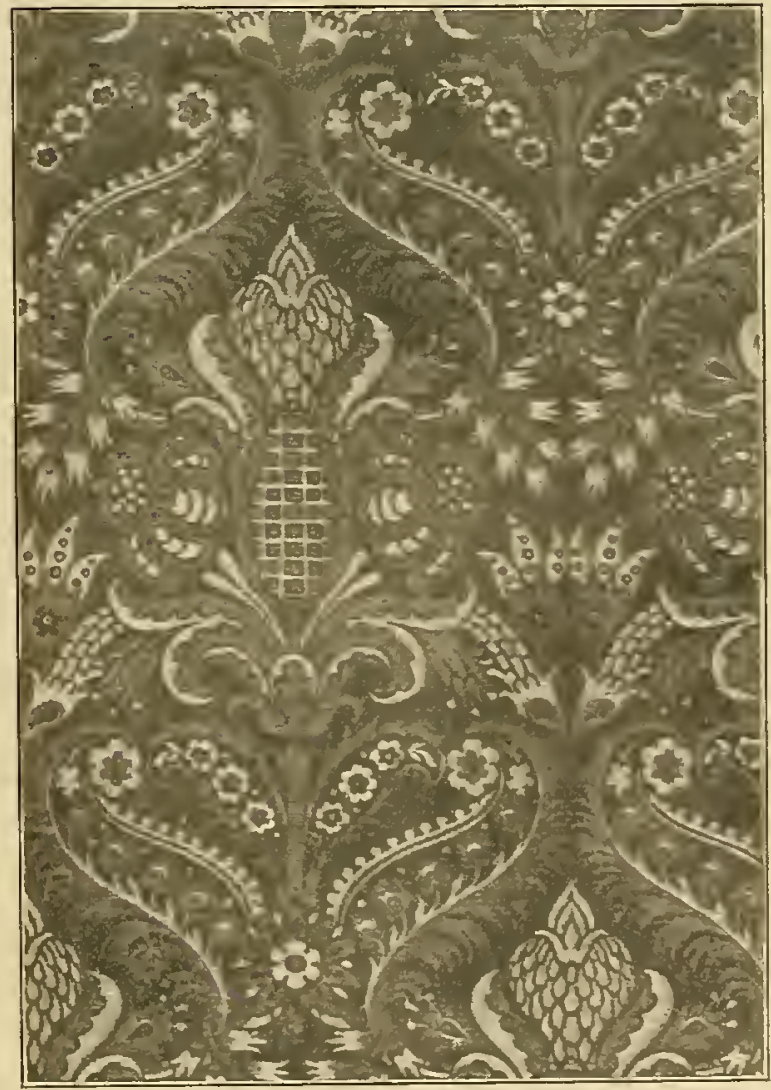

I550-1650. Group VII (P). Late Renaissance, Henri IILouis XIII. 


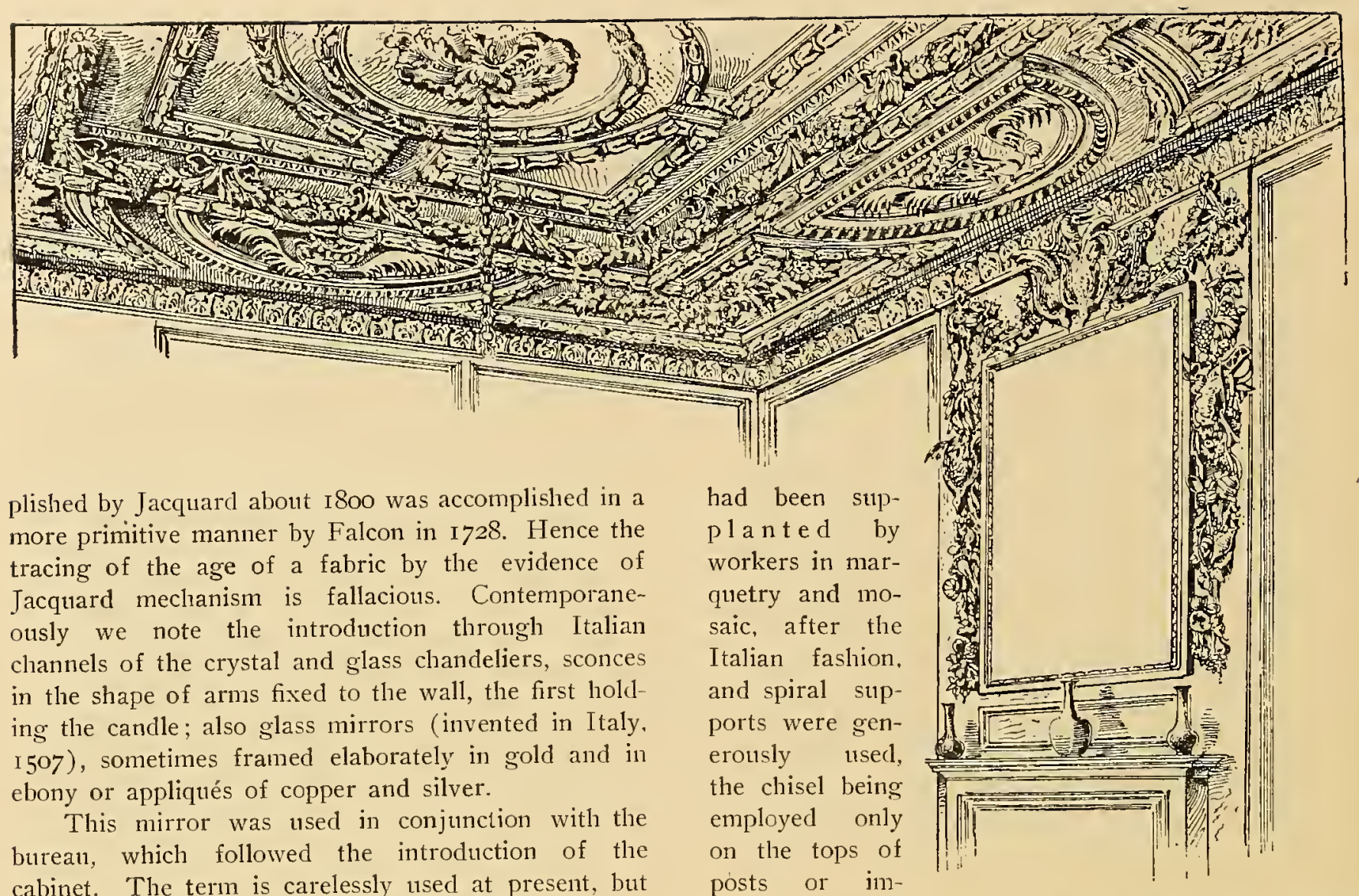
cabinet. The term is carelessly used at present, but in the time of Louis XIII the bureau was a chest set upon a table and pushed back to afford a rest for the hand of the writer. About ryoo this table was provided with drawers and to-day this combination of drawers and clests we call a bureau.

Good wood carvers were becoming scarce. They

posts or inportant places. The upholster. ing of the furniture was heavy and comfortable and fixed
Above, illustration of a ceiling by Sir Christopher Wren, showing the exquisite carving of Grinling Gibbons.

Below, panel ornamentation frequently referred to as Gibbons. masterpicce.

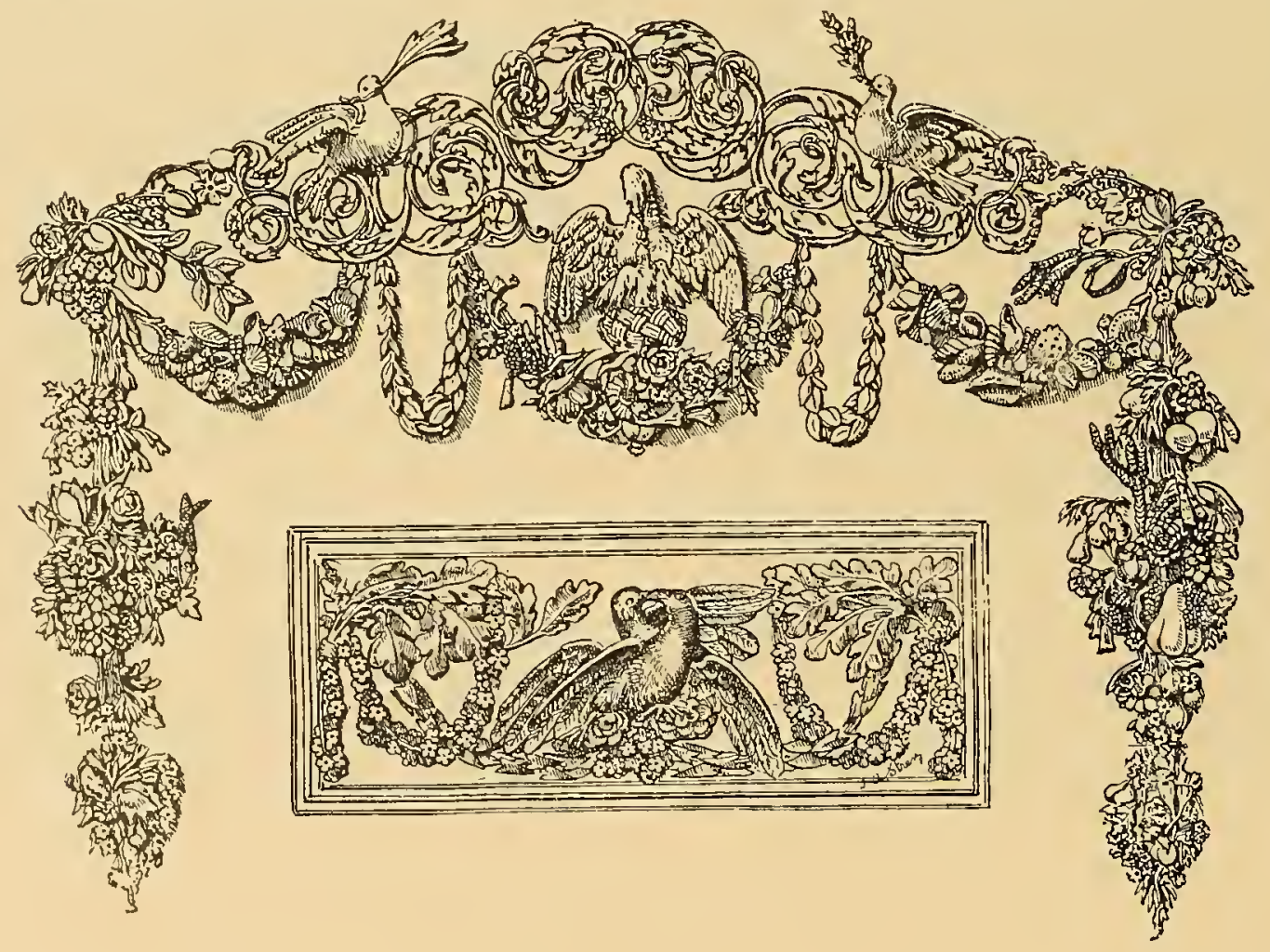




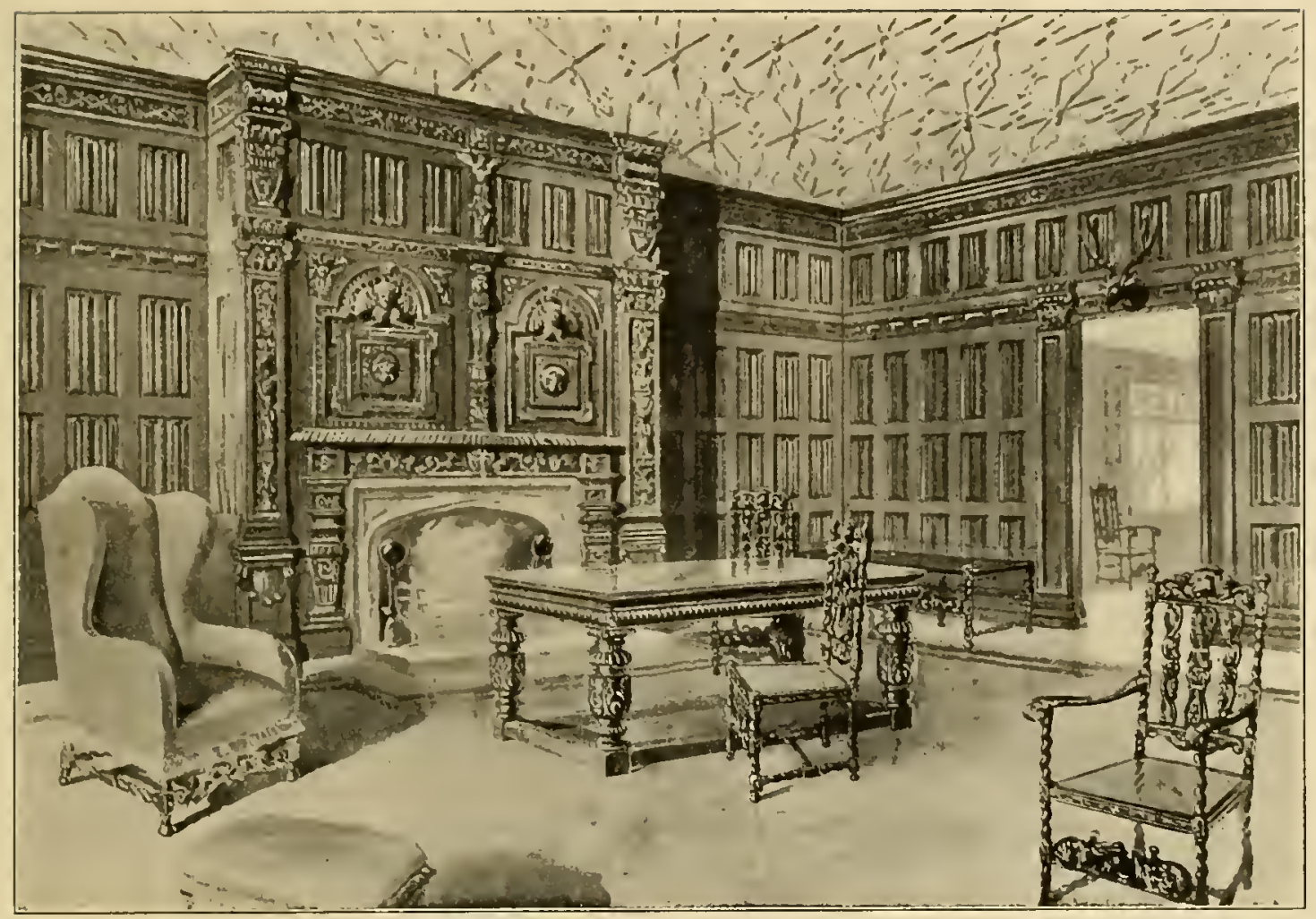

T620. Jacohean. James T. - England.

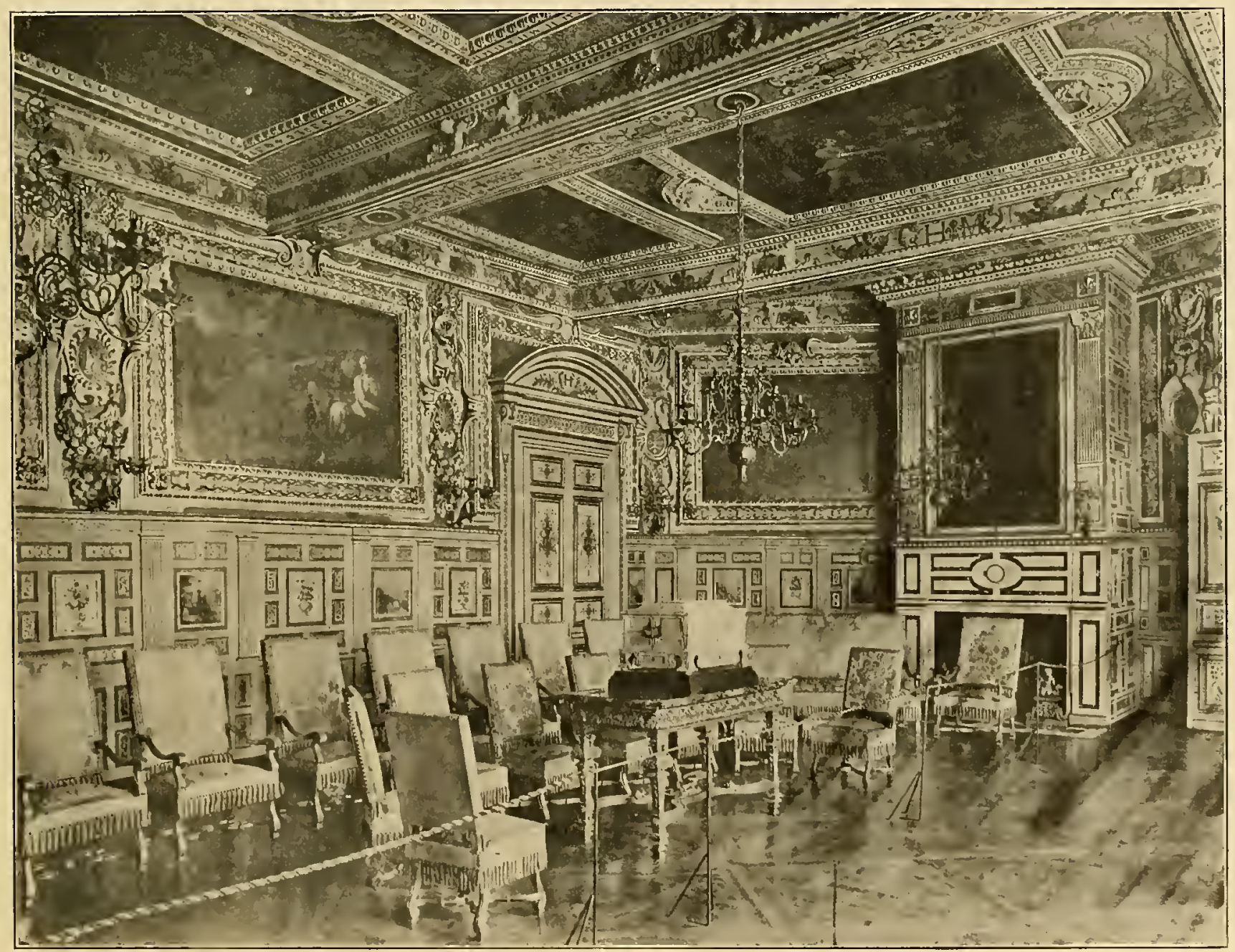

1620. Salon at Fontainebleau. Louis XI]I. 


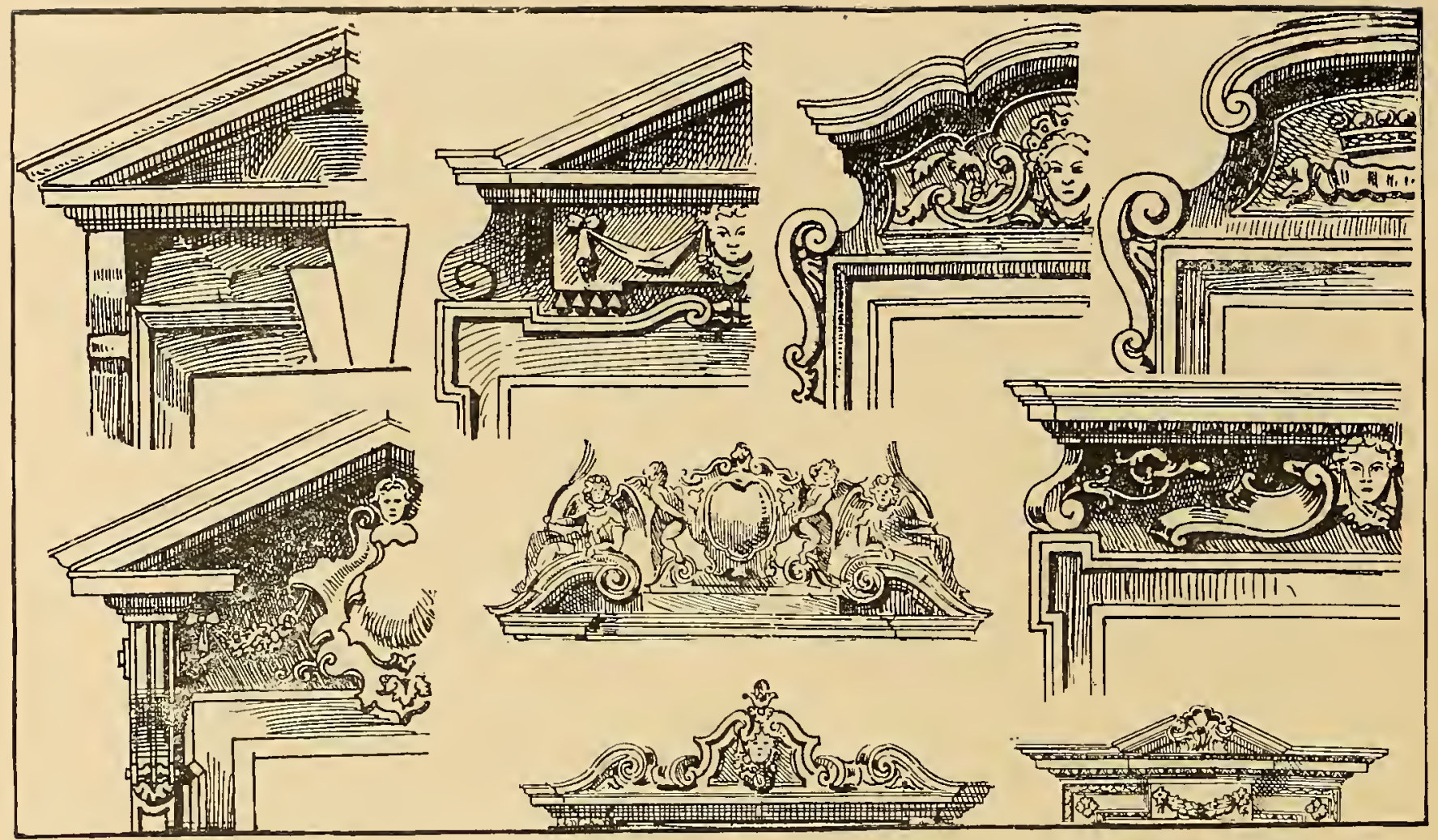

The pediment in the middle of the second row of illustrations shown above is the work of Inigo Jones. The two small pediments of the bottom row are attribtted to Kent. The others are the work of James Gibb.

to the structure. The room was draped and as the woodwork was no longer beautifully carved, curtains and fabrics were hung in profusion.

At the beginning of the Seventeenth Century France greatly prospered. Damasks, damascenes, fancy velvets, cloths of gold, taffetas, silk, wool, cotton and other fiber mixtures, poplins, brocatelles, dimities, fustians, filatrices and fcradincs. Fabrics, moreover, of low price were made, and Italy soon lost her ascendency. To cap the climax the discovery of the passage around the Cape of Good Hope (1579), turned from the Mediterranean the trade in silks from the Eastern part of Asia.

In the latter part of the Sixteenth Century and

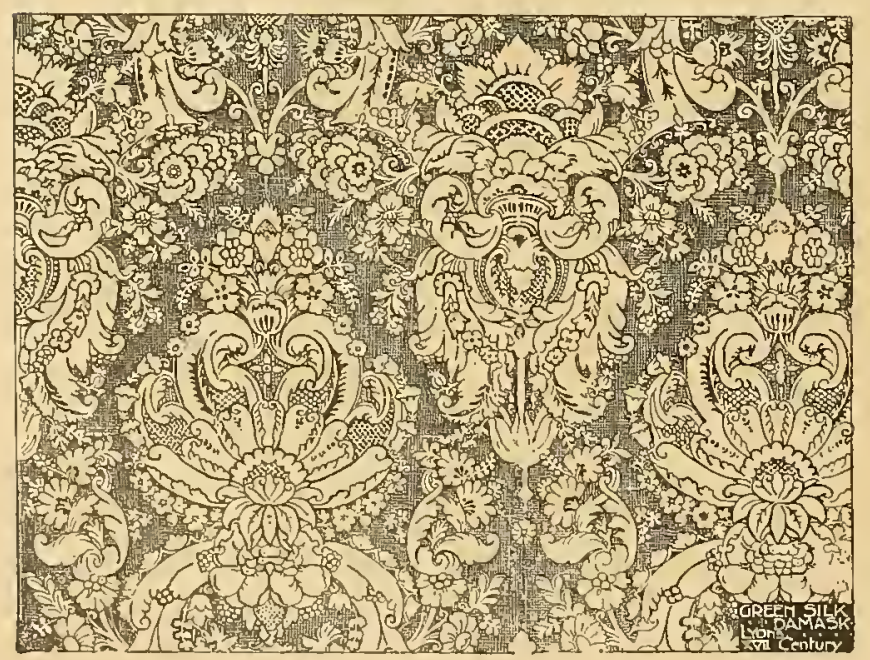

the beginuing of the Seventeenth, the closing of the Renaissance, we find in fabric designs a great many of the pure Renaissance types, including griffins, birds, vases, bouquets, garlands, branches of leaves and fruits, masks, serpentine meanderings, birds and hounds, Oriental motifs, flowers, sprays, spots and curly-cues. Typical of the Louis XIII is the Arabian style, a survival of the Arabian popular under Francis I, sometimes called Moresque or "Arabicque." As early as 1540 books of patterns were issued at Lyons and these "Arabicque" styles, which are conspicuous again in the Louis XIII period, were recommended as elegant and refined.

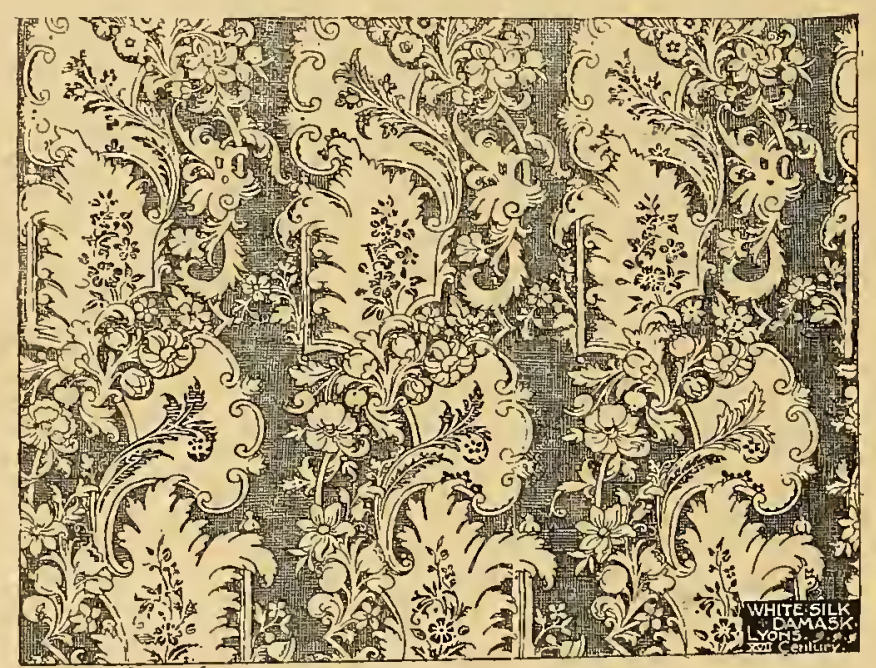




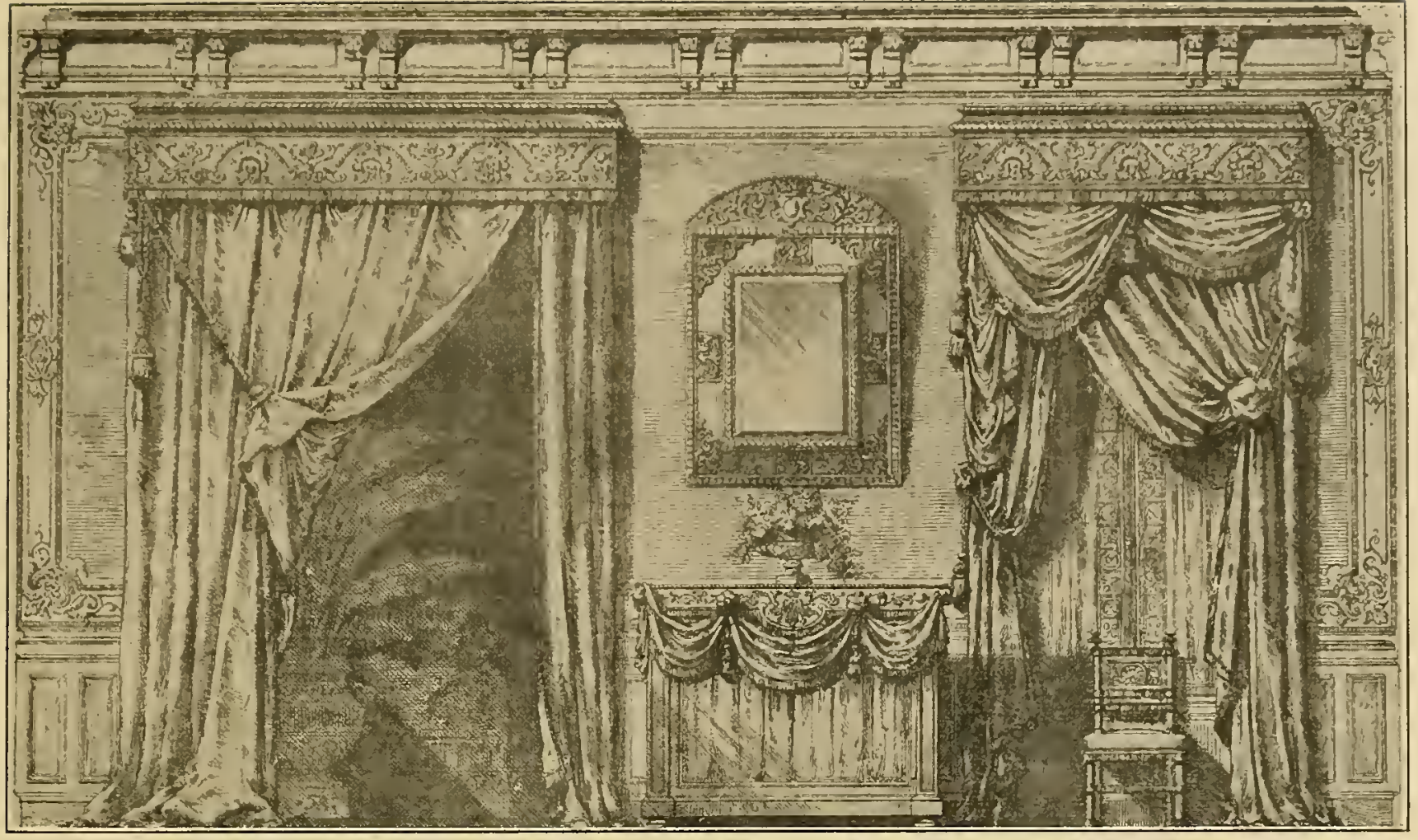

Louis XIII.
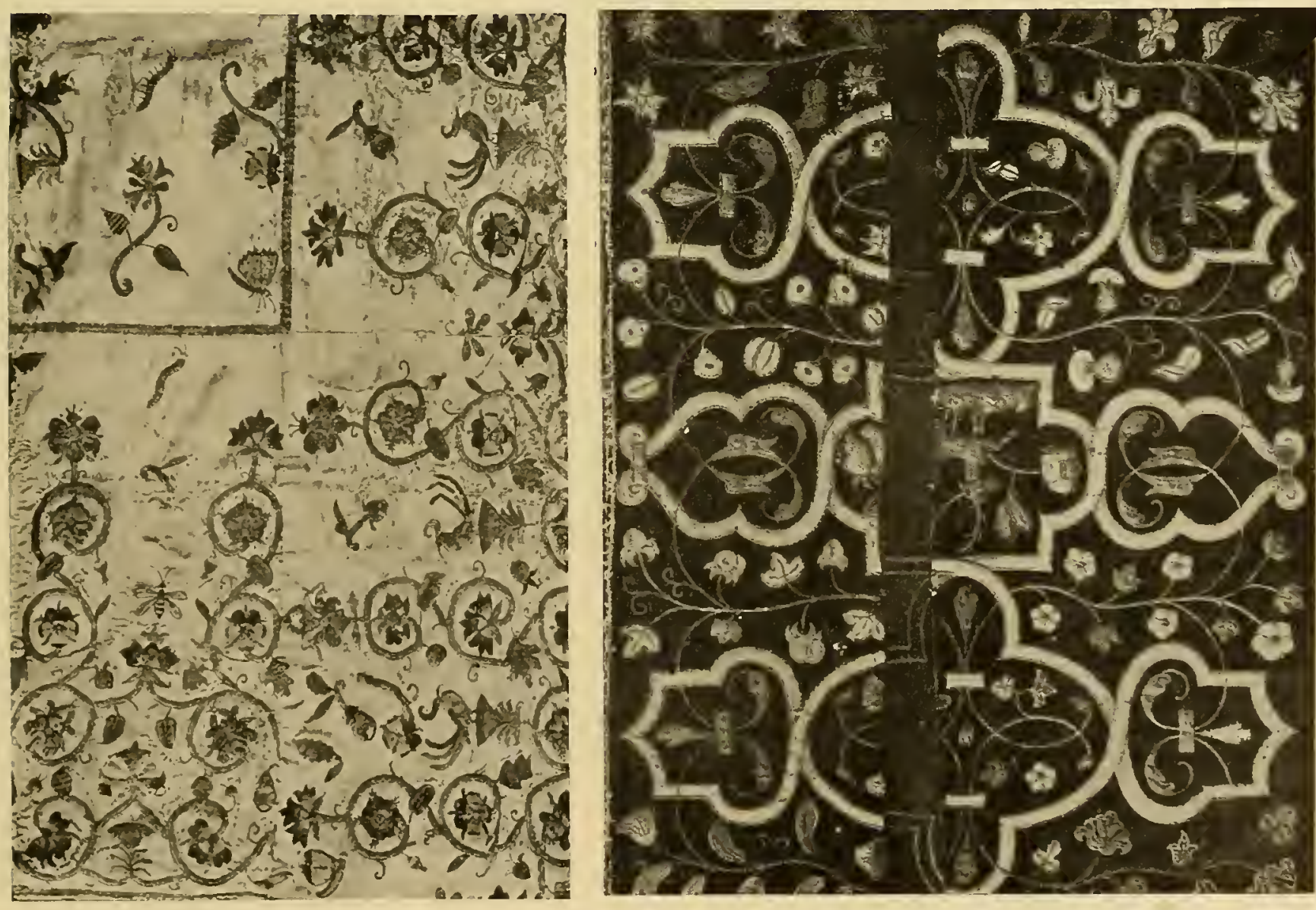

Under Louis XlIl silk manufacture enconraged.

Characteristic design. See page I27. 


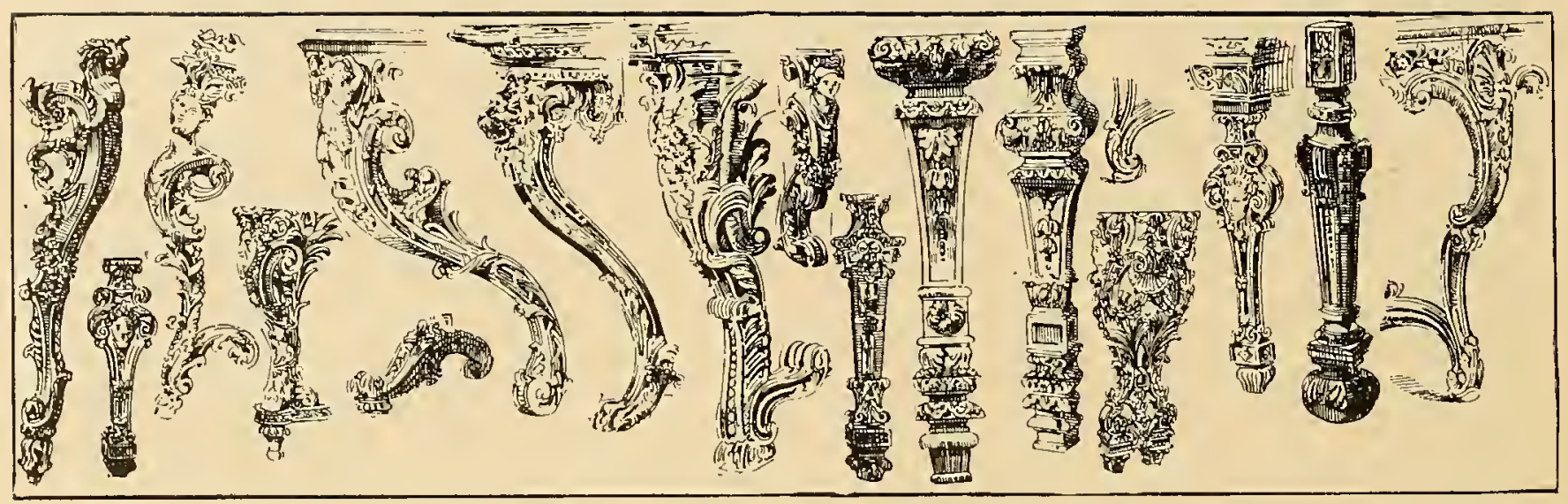

Characteristic furniture leg details of the Louis XIV Period.

\section{O U I S X I V}

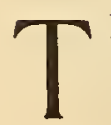

HE period of Louis XIV is supposed to have begun 1643 , when the king was but five years old. The art period starts properly at 1667 . when the Mamufacture Rovale des Meubles de la Couronne was established by Colbert, to promote the making of tapestries, jewelry, furniture and metal work. just as the Academy of Painting and Sculpture had encouraged the more dilettante arts. The Gobelin factory, and a little later the Beanvais works, were part of the enterprise. and French art may be said to have dated from this organization.

Le Brun, chief court painter to Louis XIV, became director of the Gobelin factory and gathered about him the most eminent artists of the day, Vanclermet1len, Mansart, $\mathrm{Hy}$ vart, Monnoyer, the tw o Boullognes, the Coypel brothers, the ebenists Cucci, Poitou and the tapestry makers Jans and son. In

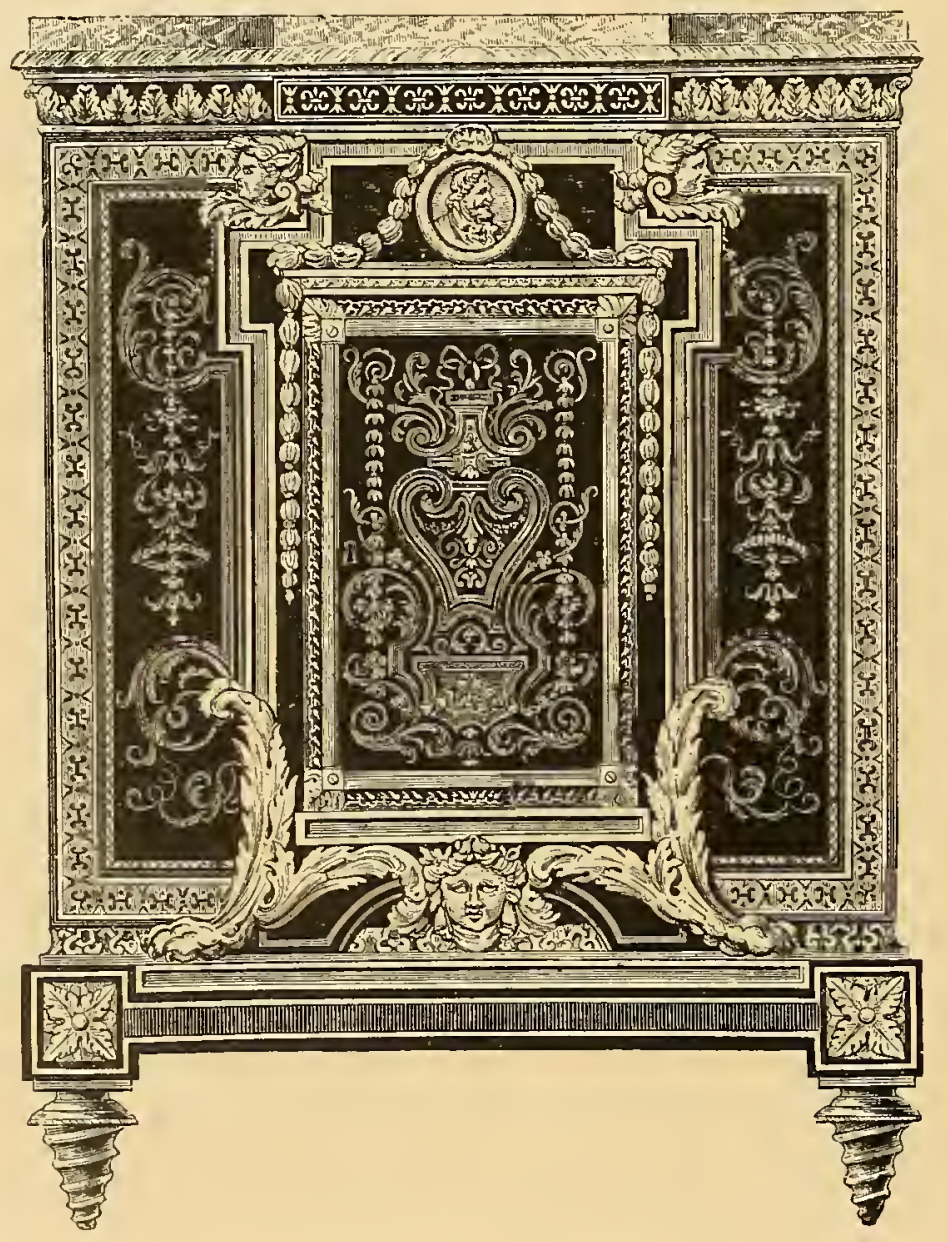

Boule Cabinet, Louis XIV.
I679 Jean Marot and his son Daniel, who left France for Holland and England, I685, did much to emphasize and popularize the Louis XIV type. Jean le $\mathrm{Pautre}$ and his brother Antoine became authorities in wood work, and the designs of Jean Berain became also a type.

Mazarin, himself an Italian, drew many Italian workmen to France and naturally Italian art strongly influenced the Louis XIV style which closely followed the Renaissance. In tapestry work particularly we find pomp and $\mathrm{much}_{\mathrm{ch}}$ dignity, $\mathrm{tableaus}$ of classic grandeur: "Victory and Battle," the spirit of "Valor and Conquest" and the "Purity of the Passions," the "Progress of the Arts and Sciences"-allcgories of an exalted nature.

It was an ambitious period, stimulated by the enthusiasm of the Crown, and artists held high position and there was great incentive to 


\section{LOUIS XIV}

royal favor. The art of the Italian Caffieri was gorgeous in gold and bronze. Andre Charles Bonlle or Bonle brought the arts of the inlayer to the highest possible degree. Called atso Bulst work.

Mignard's ceiling paintings were superb. The richest velvets, silks and Oricntal carpets were used. A great deal of gold stucco was employed together witl bronze, and damasks following the classic models in an elaborate spirit.

Berain gave great freedom to the exercise of Renaissance form, and towards the end of the Seventeenth Century contemporary scenic and genre details were introduced, including Chinese. Ceiling work was massive or dainty, hand-painted, wood molded or stuccoed. Walls were covered with fabrics or decorated in paint, leather or wood.

It was a period of luxury in the use of superb beds and tapestries, hand-painted fabrics, damasks, brocades and velvets, rich upholsterings, curtains. bronzes, mirrors, clocks, screens, sideboards, porcelains and consoles. Huge pier glasses of great height were employed, the frames carved in imitation of palms. Bronze and marble were combined in mantel pieces. Marble-top tables held superb vases. It was the period of Louis the Great, le grand monarque, and the decorations reflected that spirit. It was an age of conquest and naturally an age of absorption and adaptation.

In 1659 France received German and Flemish territory. In 1667 was the first war of conquest on account of the Spanish Netherlands. Then followed wars of conquest against Holland and the acquisition of territory. All this had its influence upon the character of the decorations. The style was classic and the Roman acanthus leaf was conspicuous until the Louis XV period when the rock and shell and even the stalactite forms were enployed.

Wall decorations were usually of historical or biblical or legendary character.

Companies were established to trade with the East and West Indies in competition with the Dutch. The façade of the Hotel De Ville, commenced by Francis I, was now finished. All France was adorned with parks and public buildings and wall panels and fabrics frequently presented scenic and architectural desigus. The French Academy was established. It was the age of Corneille, Racine, Molière and La Fontaine.

It has been said that Louise de la Valliere and

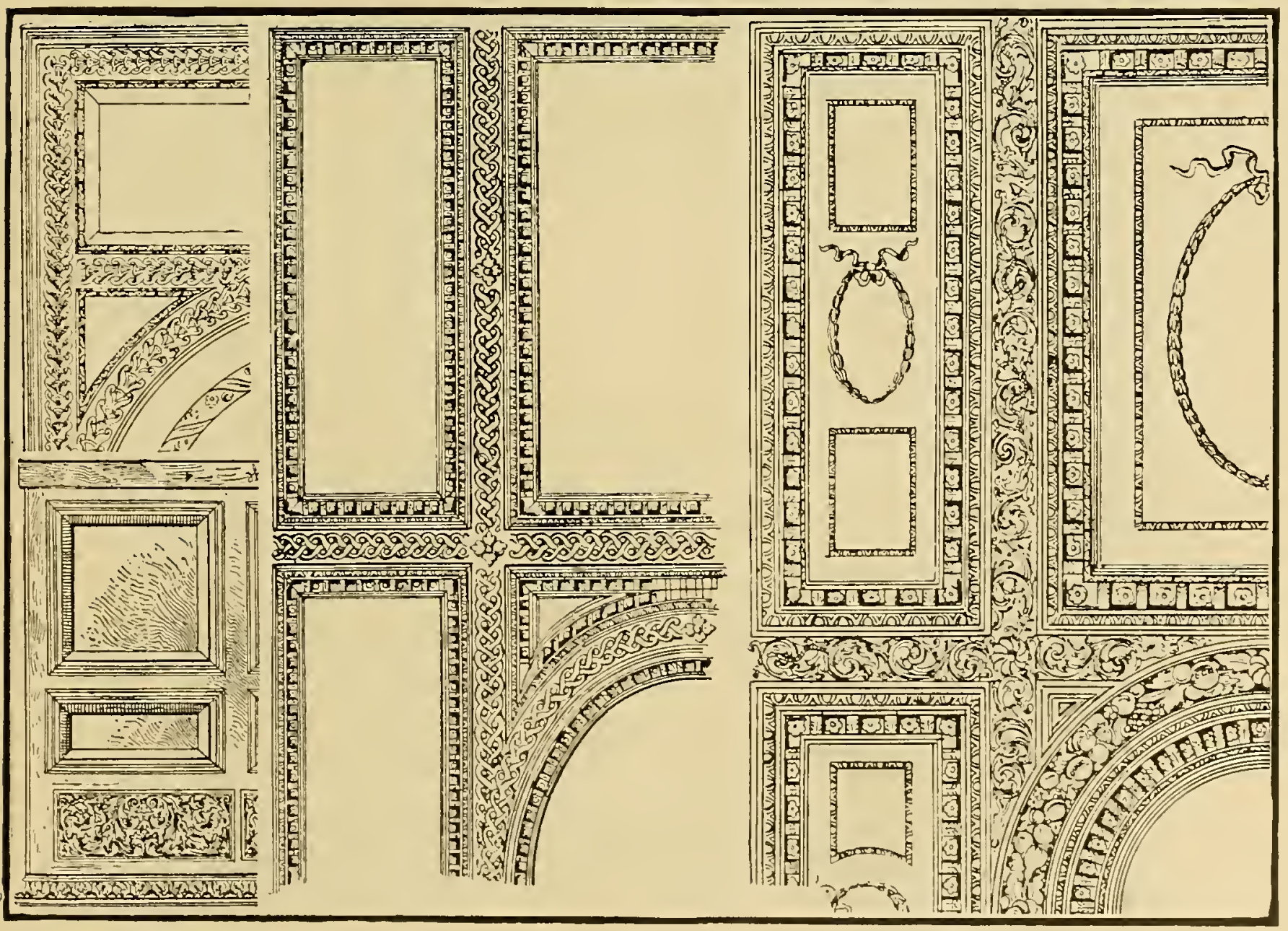

Ceiling and panels by Inigo Jones. English contemporary of Early Louts XIV. See page 103. 


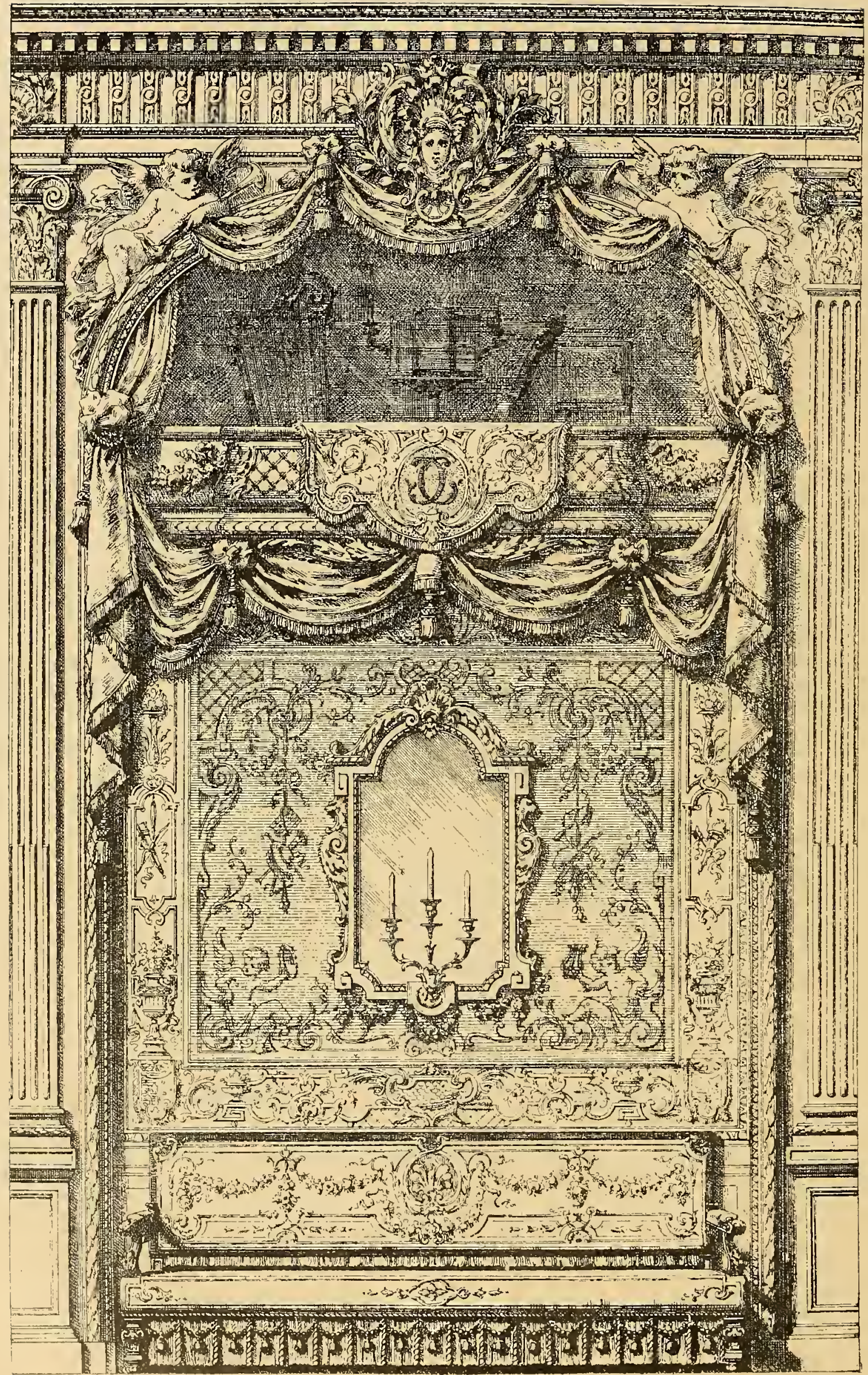




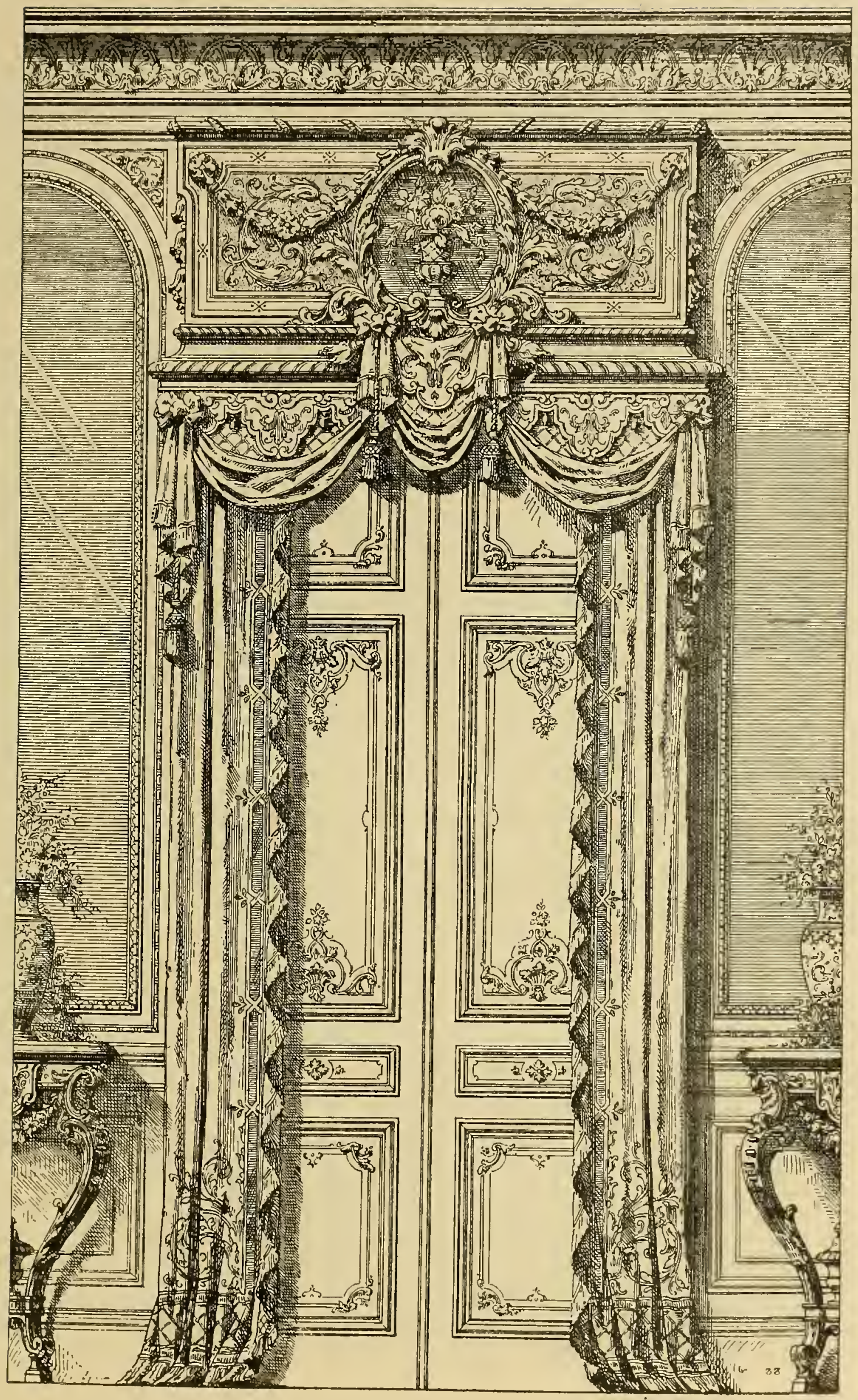




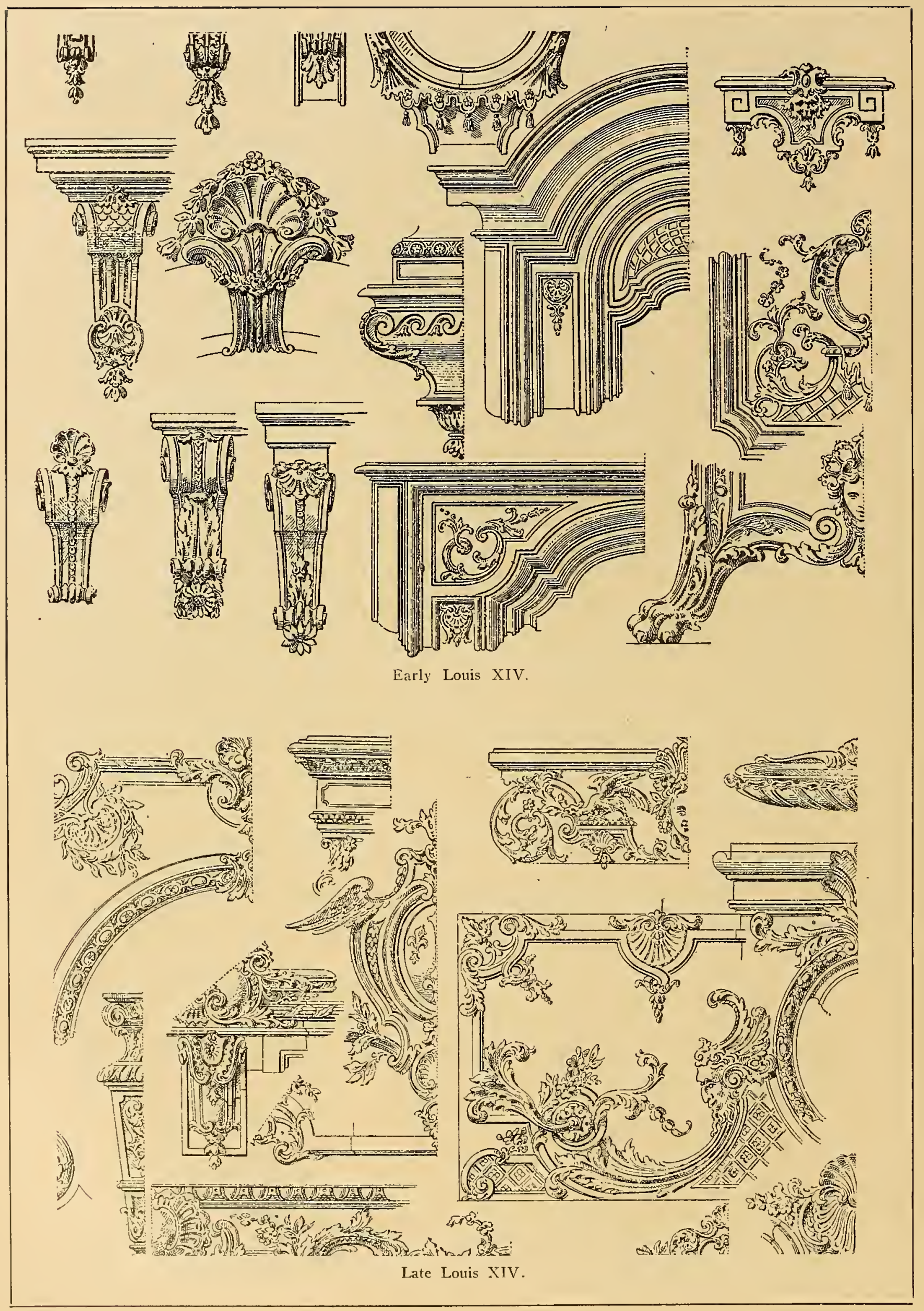




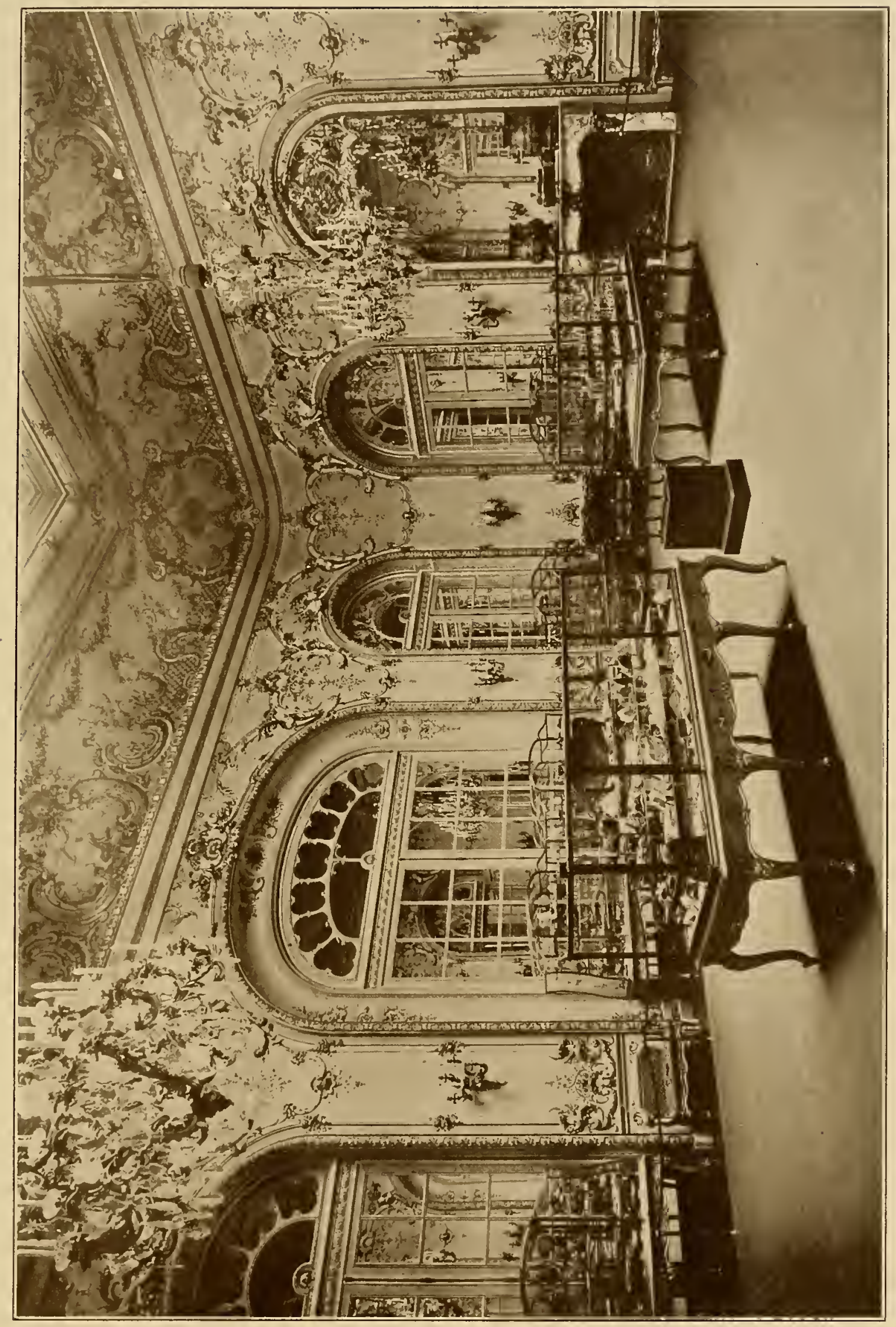

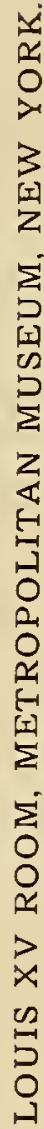






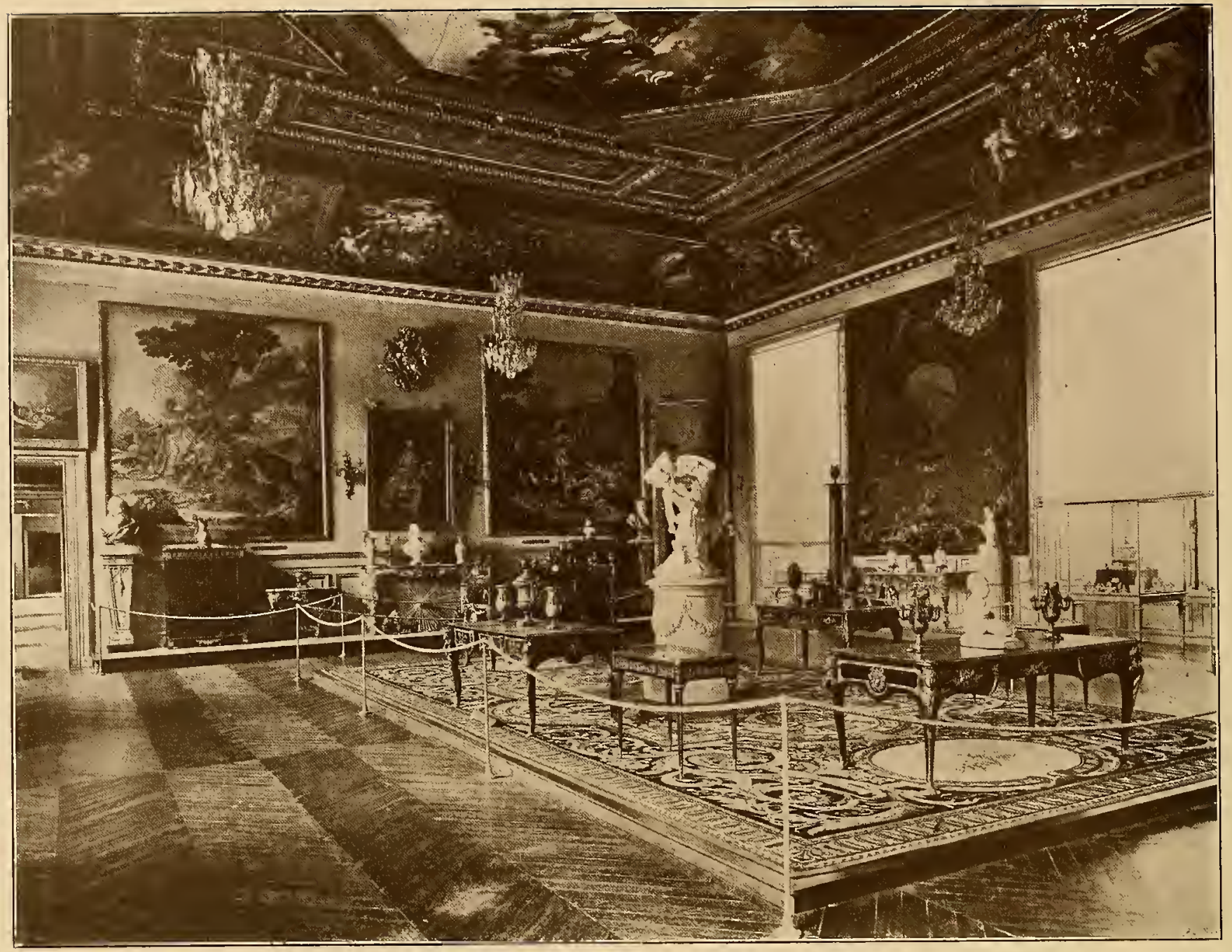

MUSEE DE LOUVRE. LOUIS XV.

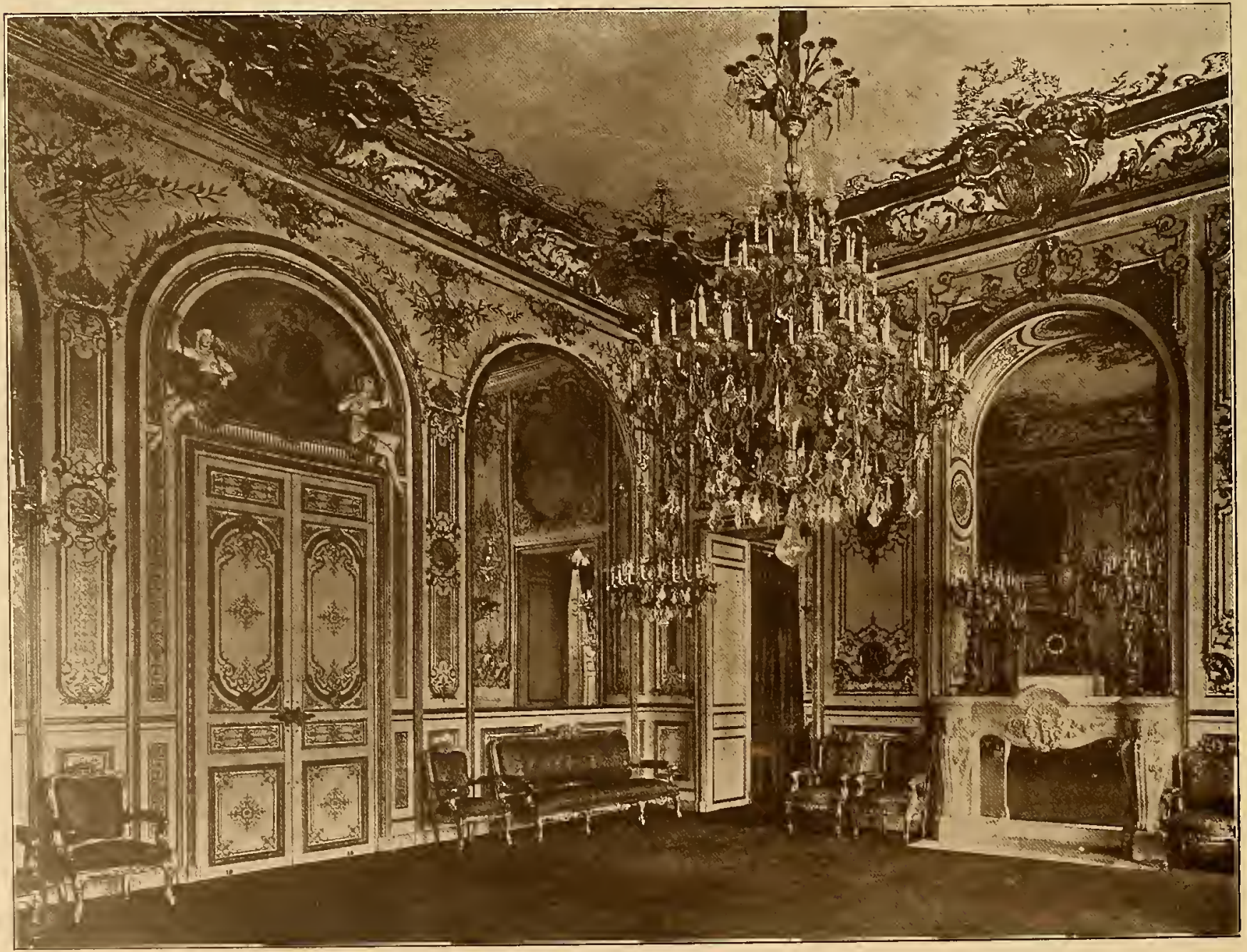

AN INTERIOR, I724. 
Matame de Maintenon influenced the arts of I.ouis IIV. ()n the contrary, the arts were stimulated by

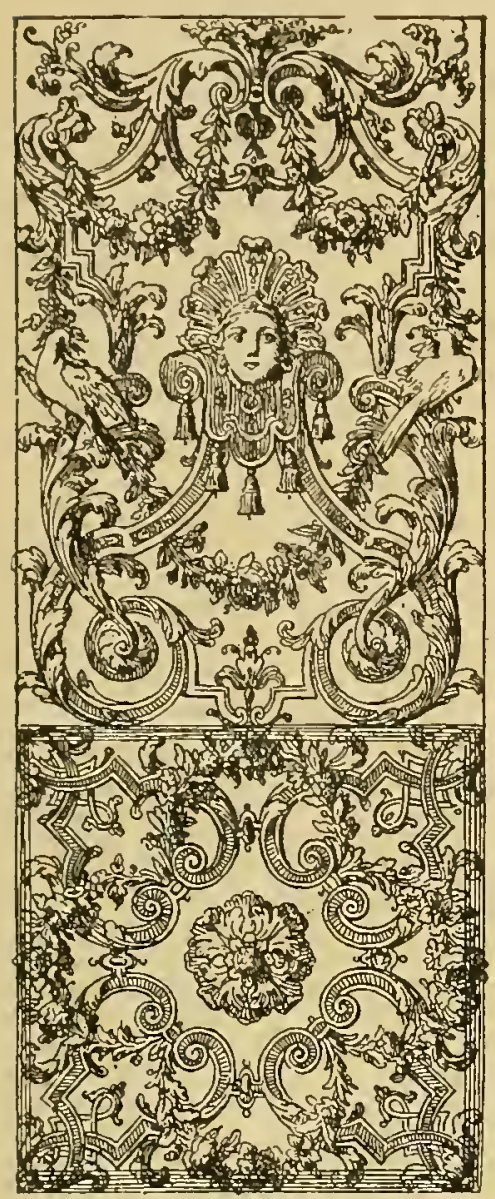

ostentation and extravagance.

Under Colbert, lace, silk and porcelain factories were established, and as a result designers introduced as details of their pattems ribbons, festoms, vases, pottery, placolues and statuary Magnificent warlens were built

43ी की (cis) (1) 3. 3 . 35 (i)

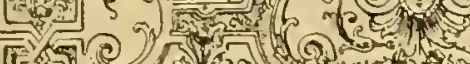
[T

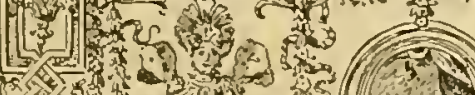
A

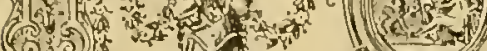
(3). (en)

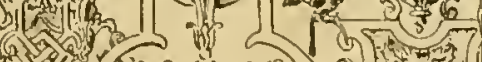

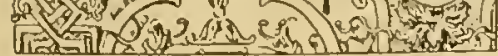

the world force of

state-craft, as dis-

tinguished $\mathrm{f} i() \mathrm{m}$

the arts of Louis

XY, which were

stimulated by so-

cial life, elaborate

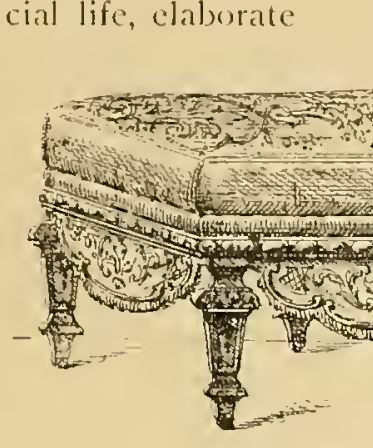

and European foriculture

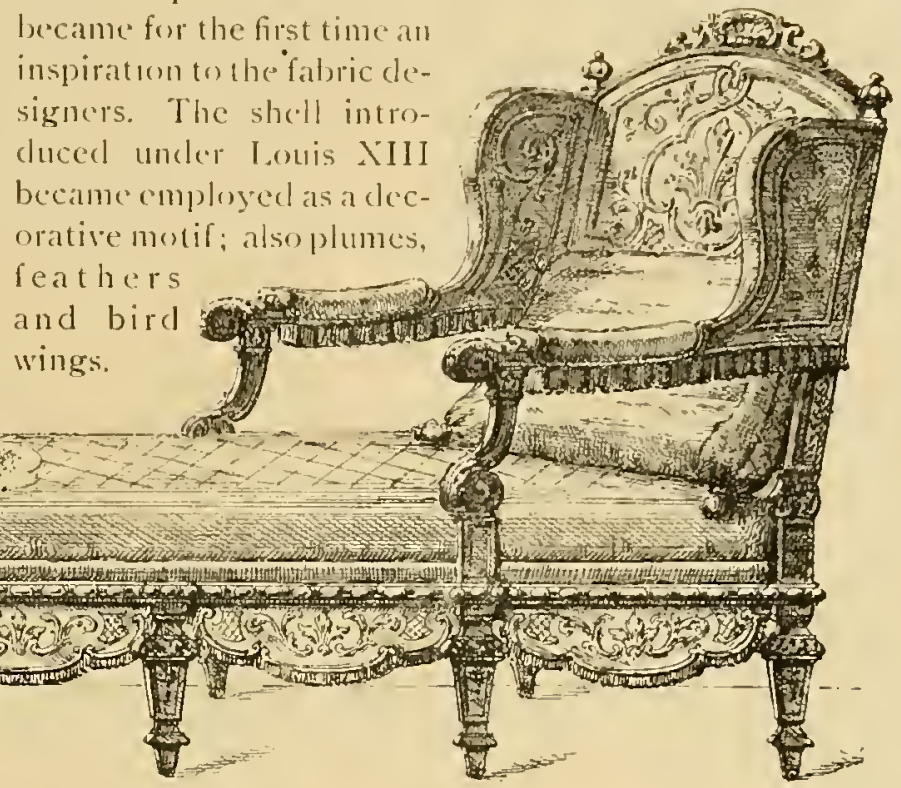

Chaise Lounge, Louis MIT

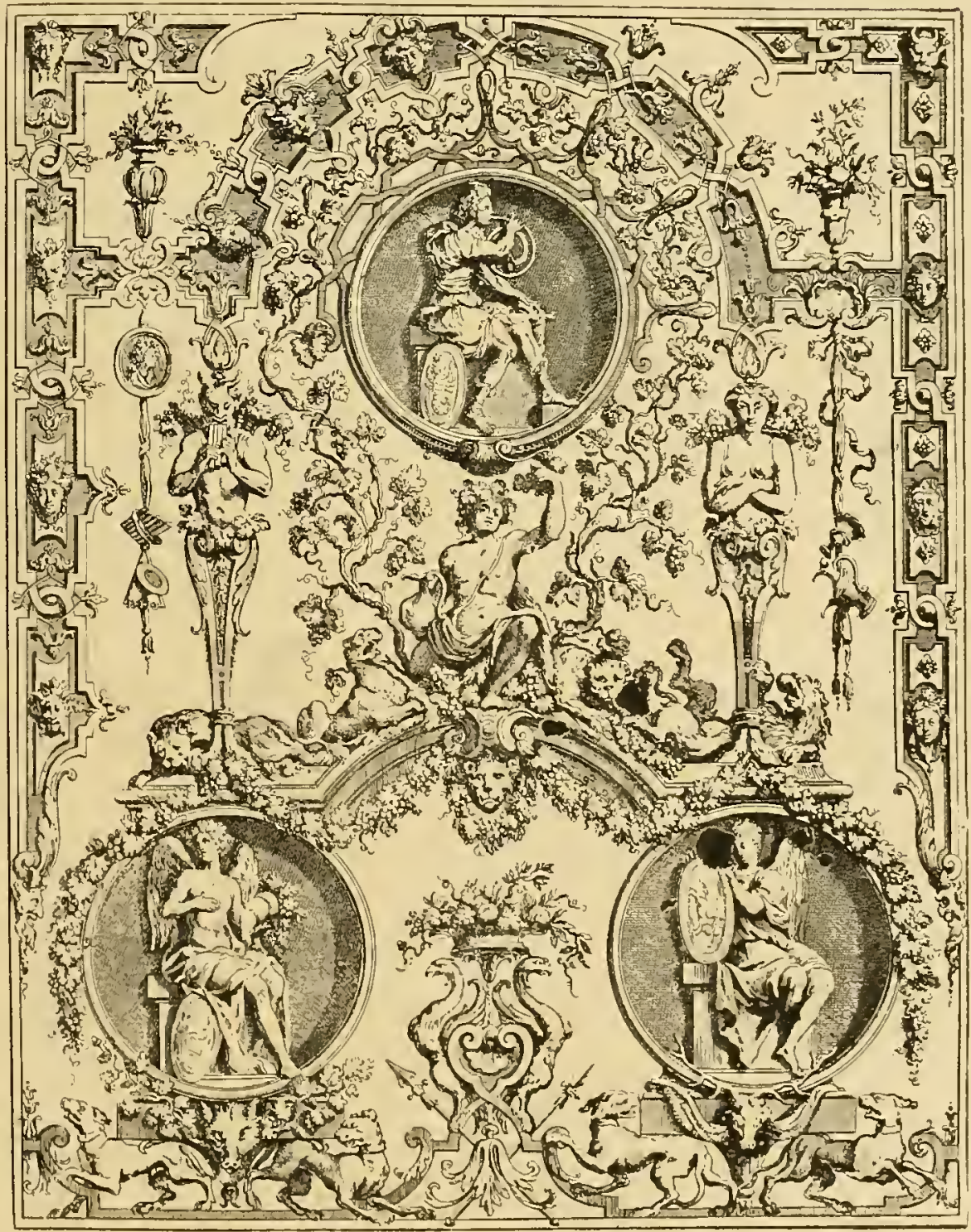




\section{ARTISTS AND ARCHITECTS.}

Aman.
Du Cerceau, Jacques An-
drouet.
Goujon, Jean.
Hainofer, Philippe.
Leonardo da Vinci, Seralio
and Cellini, Italians influ-
enced this period.
Martellange.

Bellin.

Berain, Claude.

Boullognes, The.

Coypel, Antoine and Noel. D'Avilier, J.

De Espouy.

Francart.

Hedouin.

Hongre, Louis le.

Le Brun, Manager Gobelins, I660.

Albadier, Jacques.

Audran.

Blondel, J. F.

Boucher.

Briseux.

Cotelle.

Dagley (Le Sieur).

Dantin.

De Cotte, Jules Robert.

De Cuvilles.

$>$ De La Salle, Philip.

Eissen, $\mathrm{Ch}$.

Fragonard.

Germain.

Gillot.

Gravelotte.

Huet.

Jouy.

Lancret, Nicholas.

Berthault.

Cochin, Chas. Nic.

ஜ Coysevox.

Le Pautre, Jean and Pierre.

Loir, Nicholas.

Mansart.

Marot, Antoine.

Marot, Jean and Son Daniel.

Mignard, Pat1] (Manager

Gobelins, I690).

Monnoyer.

Van der Meulen.

Yvart.

Lathuile, J. P.

Leclerc, Sebastian.

Le Moyne, François.

Le Prince.

Leroux, J. B.

Martin, J. A.

Meil, J. W.

Meissonnier.

Natoire, Joseph.

Niison, J. E.

Oberkampf.

Oudry, Jean Baptiste.

Patte, Pierre.

Le Pot, Jean.

* Caffieri.

* Cucci, Dominico.

Pineau.

Revel.

Rubo.

Slodtz.

Tessier.

Watteau.

Lagrenée.

* Lalonde.
T.e Dot1x.

Leleu, Jean François.

Leonard.

Moreau, J. M. (Le Jeune).

* Normond, Chas. Pierre Joseph.

* Percier.

5 Dugourc, Tean Denis.

* Fontaine, Pierre Francois * Riesener.

Fragonard.

Goudouin, Jacques.

* Gouthiere.

Greune, J. B.

Jouy.

* Rousseau, Jean Simon de.

Salembier.

Saunier, Claude Chas.

Soufflot.

Vanloo.
Auguier.

Baronniere.

* Caffieri, Jacques.

Coysevox.

* Cucci.

Lespagnandel.

Tulby.

Babel, P. E.

Boffrand.

Bouchardon, Edmé

Caffieri, Jacques.

Cressent, Charles.

Duplessis.

Gribal.

Hervieux.

Lemoyne, MI

Pigole.

Pineau, Nic.

Sally.

Winant.

Bardin.

Falconet.

* Gouthiere.

Hauré.

Martin.

Pajoul.

* Roentgen.

* Thomire.

Linereux.
Bachelier, Nicholas.

Breughels.

Fenerstein.
Baumgartner, Ulrich.

De Vos.

De Vriendts, Floris.

Francks, the.

Barbet, I.

Bordoni, Francesco.

Branchi.

Giacetti, Luigi.

Golle, Peter.

Migliorini, Fernando and Horatio.

Armand.

Boule.

Cucci.

Denis, Lonis.

Oppenordt.

Percheron.

Poitot.

Sommord.

Arnoult

Bernard.

Boudin, L.

Dautriche, Jacques.

De Lorme.

Denizat, Pierre.

Dubois.

Garnile, Pierre.

Germain.

Gillot.

Joubert.

Leatz, I. P.

L'Avasseur.

Loriot.

Mignon.

Oeben, Jean François.

Pillement.

Riesener, Jean Henri.

Sulpice.

Beneman, Guillaume.

Bergeman.

Bertrand.

Birlie.

Blucheidner.

Carlin, Martin.

Deganlt.

Frost.

Girard.

* Jacob (Bros.).

Toubert.

Lelen, J. Francois.

Levasseur.

Montigny.

Pasquier.

Richter, Chas.

Roentgen.

Saunier.

Schmitz, Peter.

Schneider, Gaspard.

Schwerdfeger.

Stokel. Josepl.

W'eisweiler.

Desmalter, Jacob.

* The asterisks indicate names of men who became famous in the Empire period. 

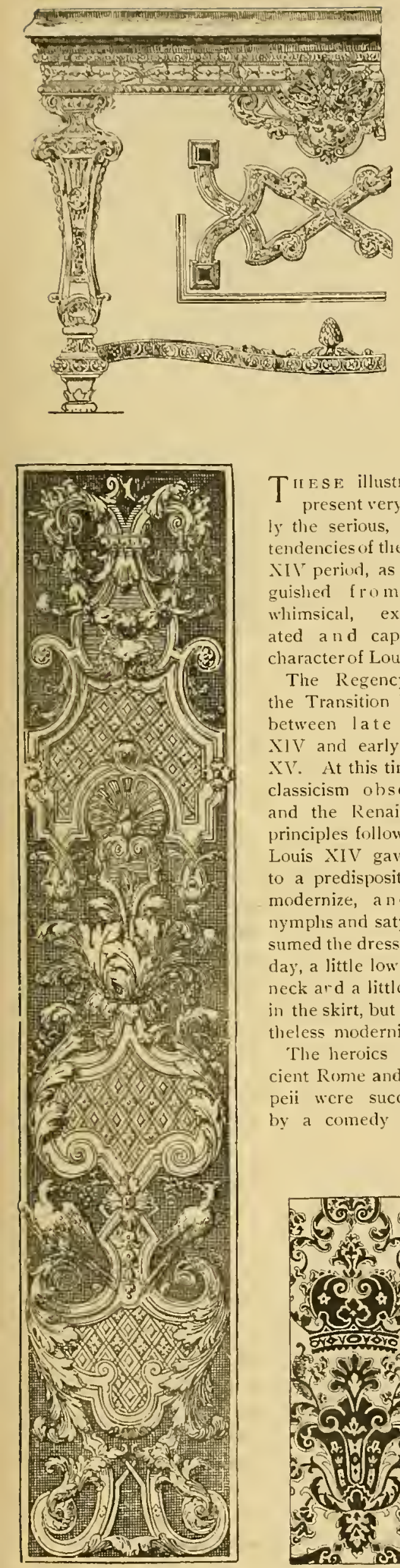

TIIESE illustrations

$y$ the serious, classic tendencies of the Louis XIV period, as distinguished from the whimsical, exaggerated a n d capricions character of Louis $\mathrm{N}^{\mathrm{T}} \mathrm{T}$.

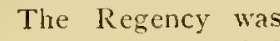

the Transition Period between late Louis XIV and early Louis XV. At this time the and the Renaissance principles followed by Louis XIV gave way to a predisposition to modernize, and the nymphs and satyrs as sumed the dress of the day, a little low in the neck ard a little short in the skirt, but nevertheless modernized.

The heroics of ancient Rome and Pompeii wore succeeded by a comedy spirit,

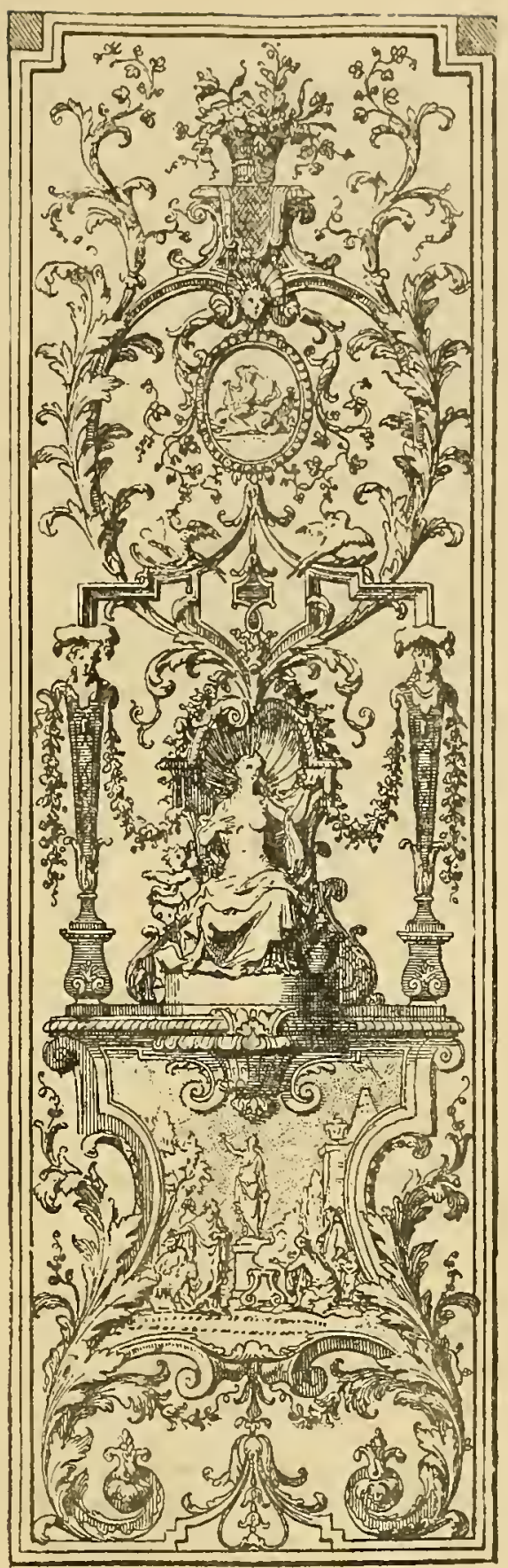

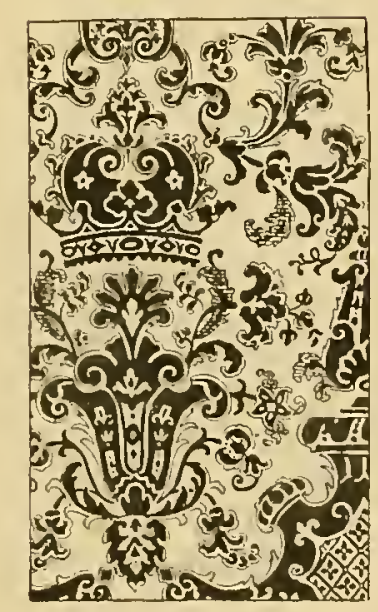

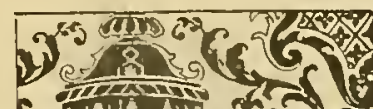

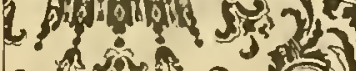
CA $x^{\circ}=9$ (O) द्री (ni)

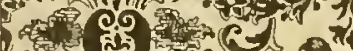
3. 2

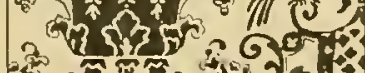

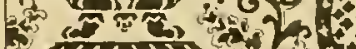

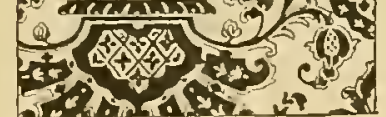

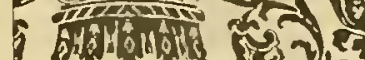
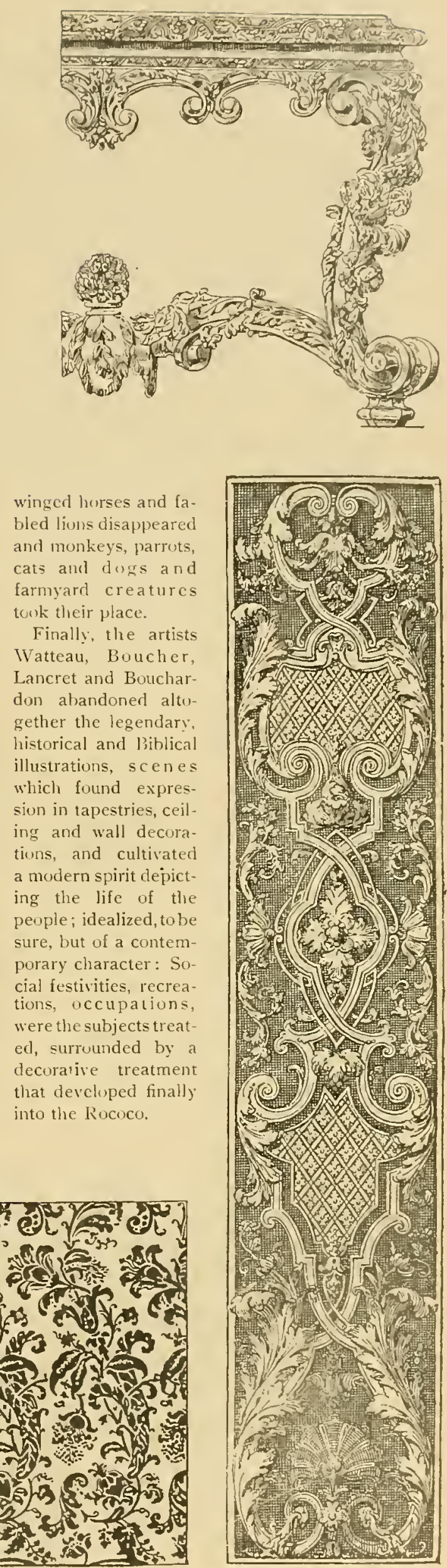

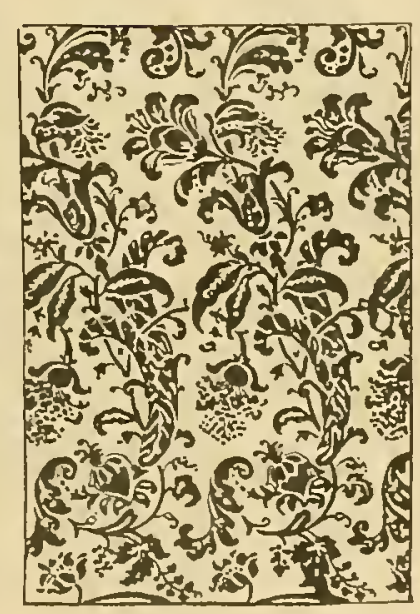




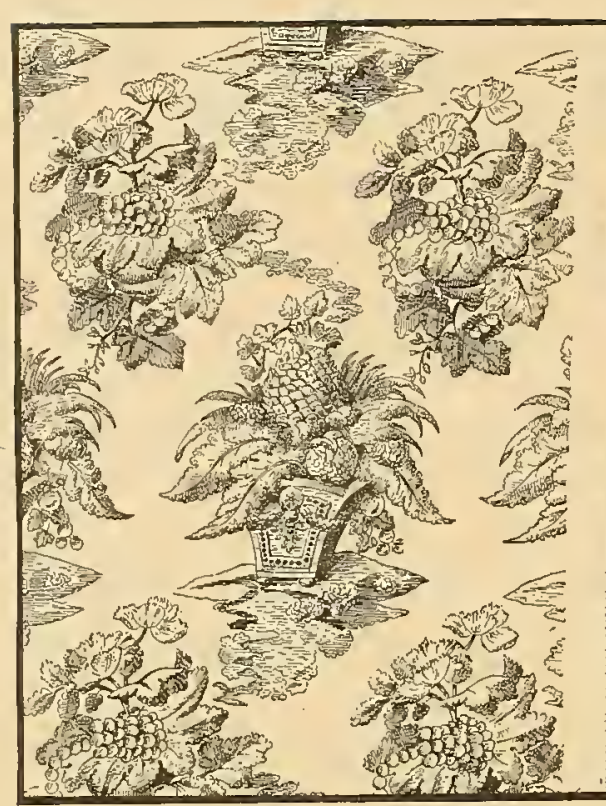

Fig. 4. Group VIII. Gros de Tours, rzoo. Sky-blue ground, flowers, fruits and leaves in blending shades broché. Design of Revel, the pupil of Lebrun. I700.

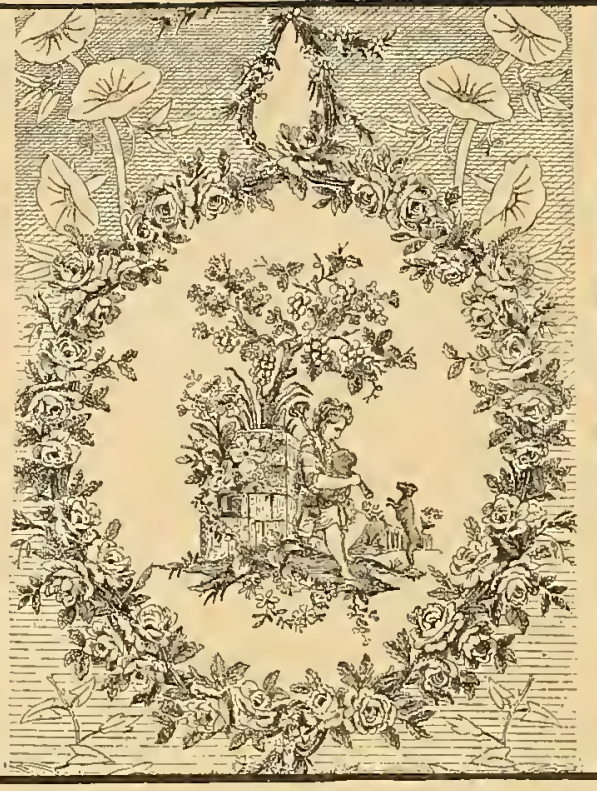

Fig. 6. Lonis XVI. Fancy fabric manufactured by Philip de la Salle. Medallion type. Ground of the medallion in yellow satin. The fancy design is in part broché.

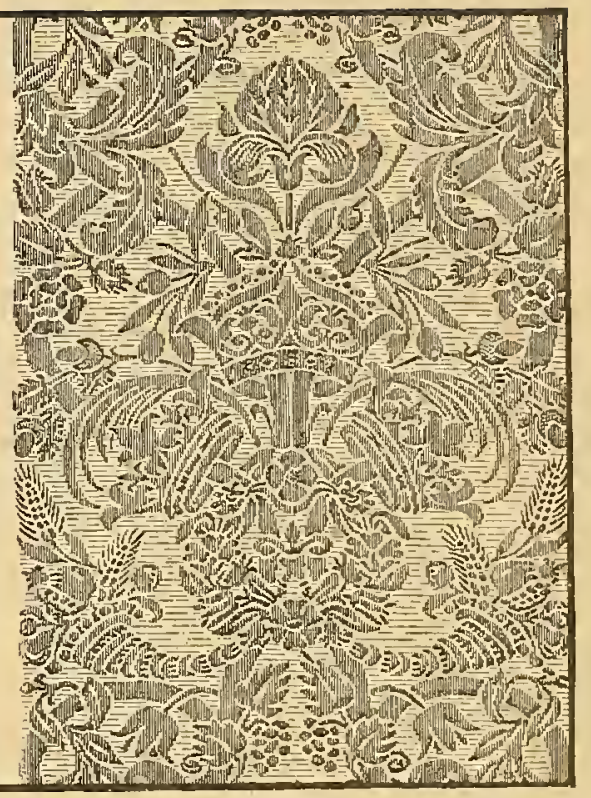

Fig. 2, Group VII. Brocatelle. Period of Louris XIII. The design is executed in crimson on a yellow ground.

\section{THE FABRICS OF THE XVI A ND XVII C E N T U R I E S}

$\mathrm{F}$ RENCH manufacturers of the Eighteenth Century were equipped to produce exceedingly rich stuffs; foliage velvets in imitation of the Venetian broché cut velvets, crêpes, etamines, mixed cottons, Levantines, plushes, fancy velvets, fabrics with three and five colors in Turkish, Milanese, Genoese and Venetian fashions. At the end of the Eighteenth. Century less metallic threads were used in weaving and the thick, heavy cloths of gold had fallen into disfavor.

Embroidery at the same time had done marvelously well. The refining and spinning of gold had been very successful in France, and in all the countries of Europe since the Fifteenth Century the art of embroidering official robes and ecclesiastical ornaments had developed considerably.

Oriental foliation and the vase which had for a long time.served both before and during the Renaissance in the decoration of fabrics are now revived; one finds this combination in Figure 4 , which shows a cut velvet on a gold ground. The warp threads of the

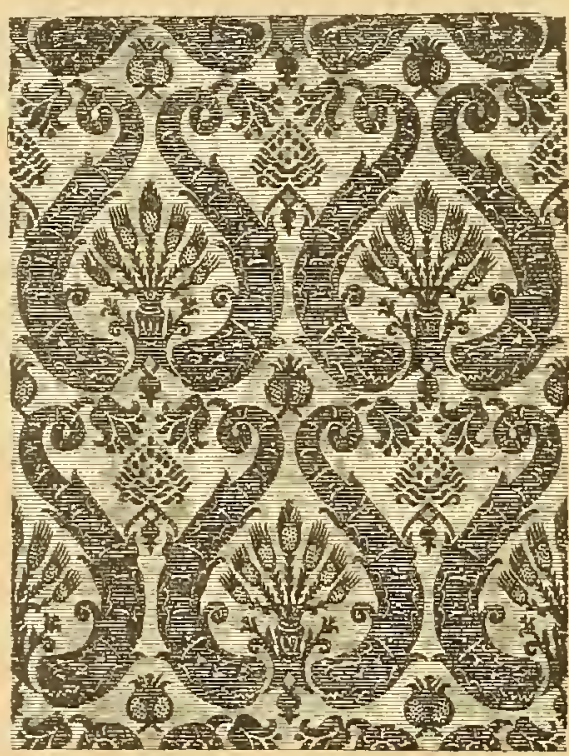

Fig. I. Gronp VI (B). Dolphin design, Executed under Henry IV. I6I0. velvets which make the fancy effects are crimson. It followed the Chinese taste of the period. (See page I H.) At the end of the Sixteenth Century, designs were of small dimensions--detached floral pieces, palms and fletr-de-lis. They corresponded with the less ample form of the garment. We reproduce (Figure I) the sketch of a fancy fabric with gold ground, date I6Io. The design is Gros dc Tours, raised on a gold ground in a deep green shade. Nany striped fabrics are noted at this period.

Under Lonis XIII and Lonis XIV, гбго-г7о0, the composition of fabrics took on a grandiose style. Brocatelle (Figure 2) is a beautiful specimen, Louis XIIT; red in color makes the body of the fabric, and a yellow silk tram thread is intertwined in a serge weave in such a manner as to give a brilliant ground; the design is raised and is worked out in a satin weave with the crimson warp threads.

This fabric may be assigned to the latter years of the Sixteenth Century. 


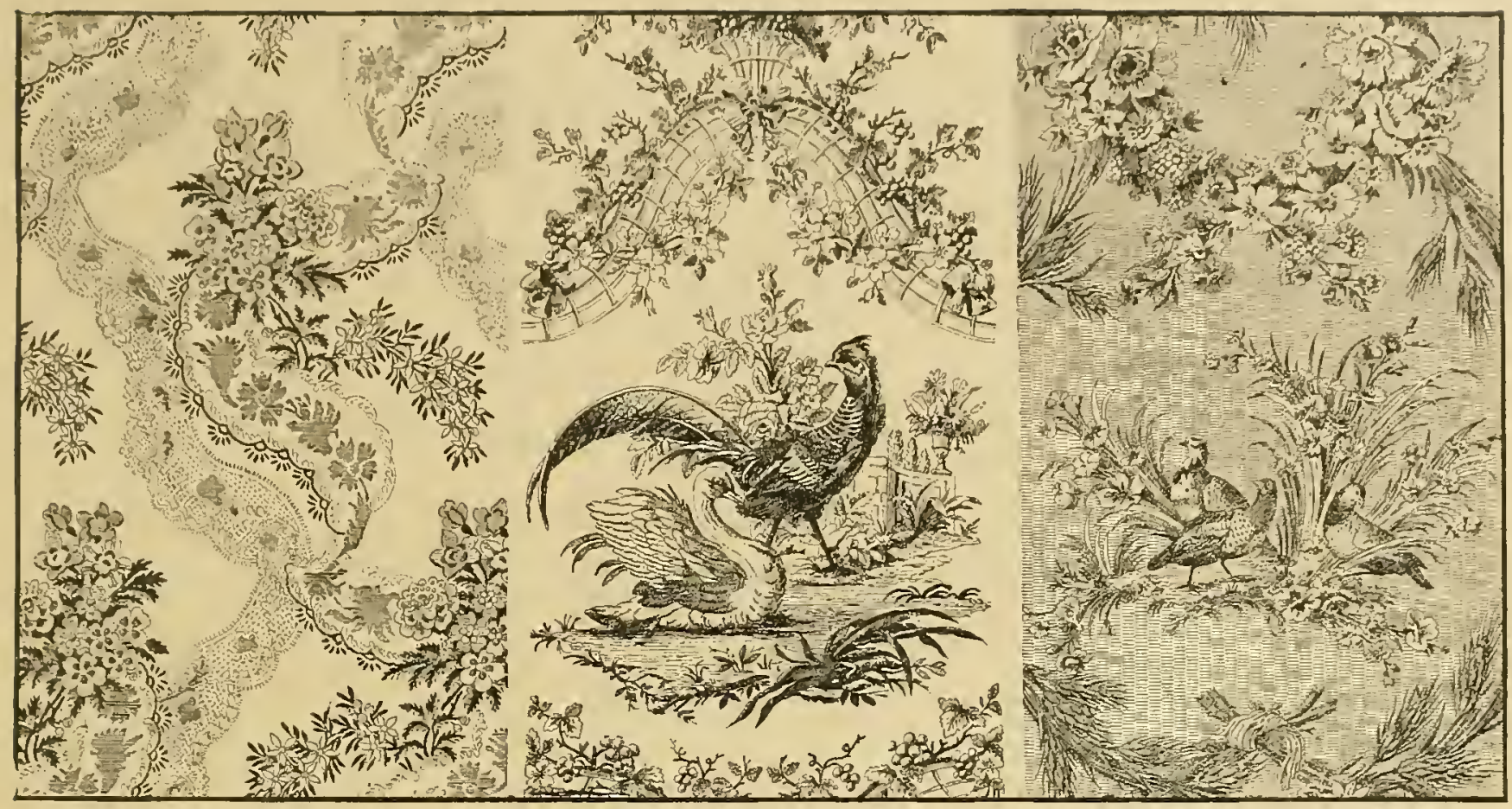

Fig. 5. Group VIII (U). Taffeta hroché, about 1740 , Louis XV. Rosecolnred ground with lace effect in white. Flowers in gilt.
Fig. 8. Group VIII (U). About 1750, Lonis XV, Pheasant design. Fancy fabric manufactured by Philip de la Salle. From the Lyons Industrial Museum of Design.
Fig 7. Groutp VIII (U) Partrirlge design. About 1750 , Lnuis $\mathrm{XV}$ Fancy fabric manufactured by Philip re la Salle. From the Lyons Industrial Museum of Design.
The great vogue of gardens under Louis XIV brought about the adoption of architectural designurcen arbors, trees in full leaf, bouquets, etc. Revel. the painter, a pupil of Lebrun, established himself in Lyons at the beginning of the Eighteenth Century. and gave a great impulse to this kind of ornamentation (Figure 4).

Under Louis XV rocks and shells entered into the ornamentation of fabrics in the Eighteenth Century. Fabrics reflecterl all the fantasies of fashion. One sees the feathers which women had placed in the coiftures, ribbons, knots, pastoral attrilutes, crooks, baskets, etc. fincly garlanded, also Chinese and Talmanese-whimsicalitics.

[nder Lonis XVI the poetic spirit of the designers was inexhanstible and it is impossible here to indicate the innumerable paths in which it was successfully eneagerl under the impulse of the passing caprices of fashion. Decorative art was admirably comprehended and taste in compnsition was exquninite

We have spolien of the numerous improvements in the art of weaving made by Philip de la

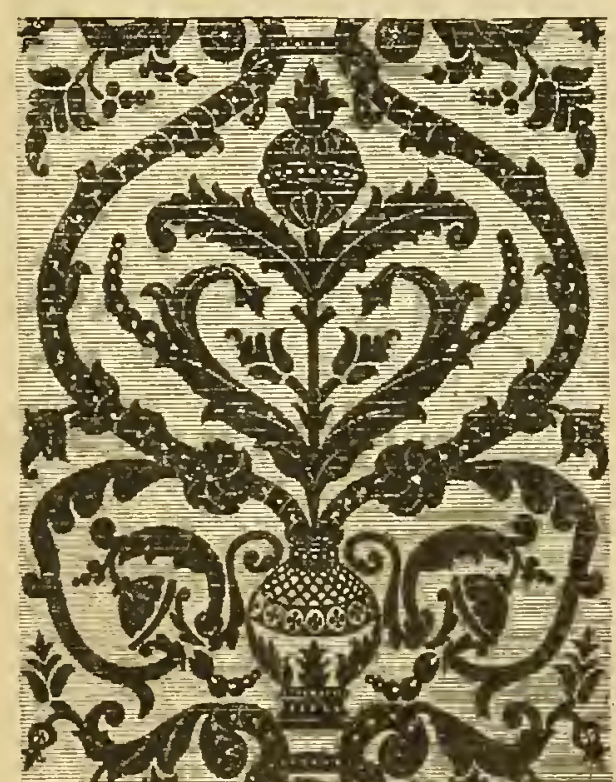

Fig. 3. Group VI (O). Pumegranate vase design. Latter part of Sixteenth Century.
Salle. In I 775 the Academy of Science commended his work in engrossed eulogies and presented him with a gold medal in 1783 . An entire glass case in the Industrial Museum of Lyons is reserved for this remarkable manufacturer. It includes all types of composition, arabesques, foliage, flowers, figures, trophies, allegories, landscapes, country scenes and Chinese ornaments.

$[14 \mathrm{I}]$ 


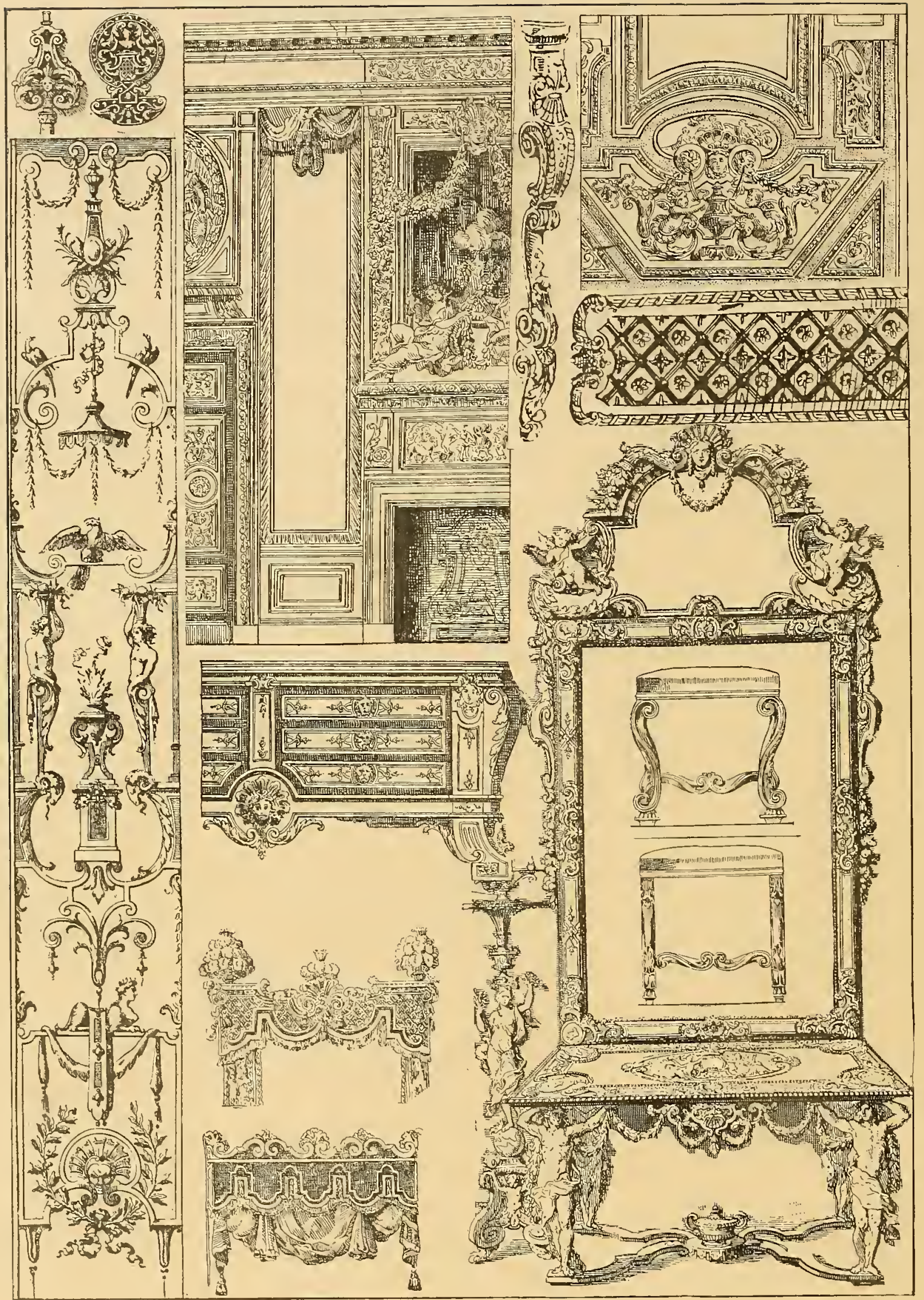

I643-I7I5. LOUIS XIV. 


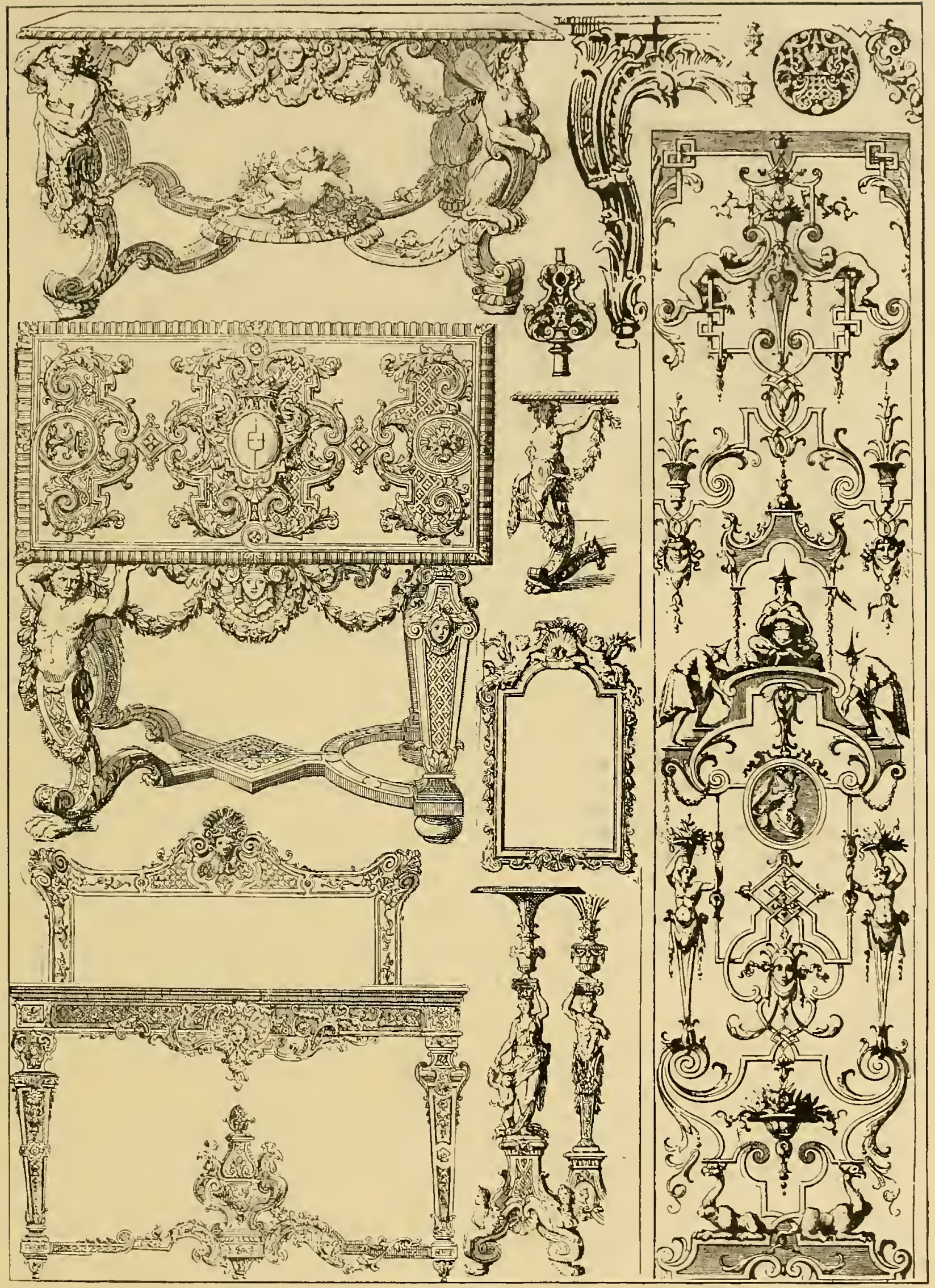

I643-I7I5. LOUIS XIV. 


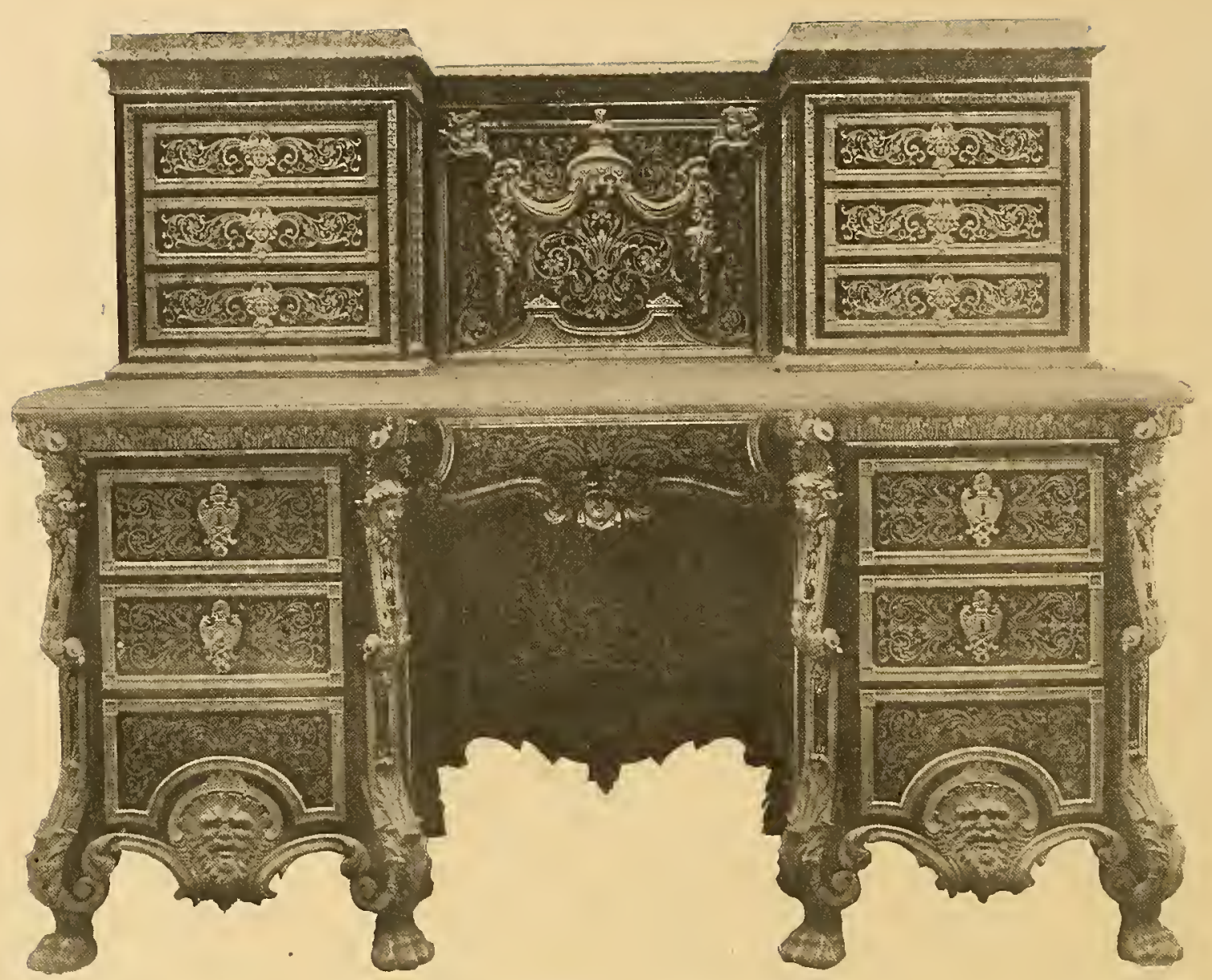

A fine old Buhl (Boulle) Secretaire, Louis XIV.

\section{O U I S X V}

I7I5-I 774 .

$\mathrm{S}$ ELDOM in the history of the world has there been greater exuberance of inflated wealth than that which prevailed during the early period of Louis XV. The first eight years constituted the Regency; medley of the mythological classic and modern: all parade and ostentation.

The anstere, the serious and the heroic of Lonis XIV became full of abandon, frivolity and extravagance. The monkey smpplanted the Renaissance masque, and the Chinese ntterly routed Pompeiian balance.

Then came another phase, the Rococo, ani impressionistic form which, following in some degree the curved ontlines of the late Louis XIV. displaced the acanthus floral motifs and substituted massings of rock and shell and stalactite shapes, and the independence of execution, already developed in the Baroque.

Carvers presented a flower the size of a man's head and beside it a pheasant no bigger than a canary. Occasionally the Lonis $\mathrm{XV}$ period showed phases rational and charming, but the Regency and the Rococo dominated the reign.

Perhaps the greatest maker 'of furniture was Charles Cressent, who rankert with Boulle. Other artists were Caffieri, Duplessis, Riesener, Le Ronx,
Oudry, Brisenx, Pineau, de Cuvilles, Gravelot, Boncher, Blondel, Babel, Germain and Joubert.

Oeben was a pupil of Bonlle and in great favor with Madame Pompadour. J. Henri Riesener was his foreman.

About 1720 Louis XV dispatched an embassy to the Emperor of China with goods of rare value, charged with a commission to encourage the opening of more extensive trade relations. The emperor was cordial in his reception of the king's messengers, and returned magnificent gifts lavishly decorated. This incident rendered the Chinese style fashionable in the upper circles of -France, and for some time thereafter Chinese vases appeared in French textile designs juxtaposed to dragons, birds, himan fignres, pagodas and bits of scenery. A great amount of lacquer work was imported and the lacquers thus introduced were soon copied, the Vernis-Martin becoming espec ally famous. Pronounced stripcs were affected as creations of Madame Pompadour.

The word apartment at this time meant a complete suite of living-rooms: vestibule, first and second ante-chambers (for the servants and attendants, sometimes used as a dining-ronm), principal chamber salon 


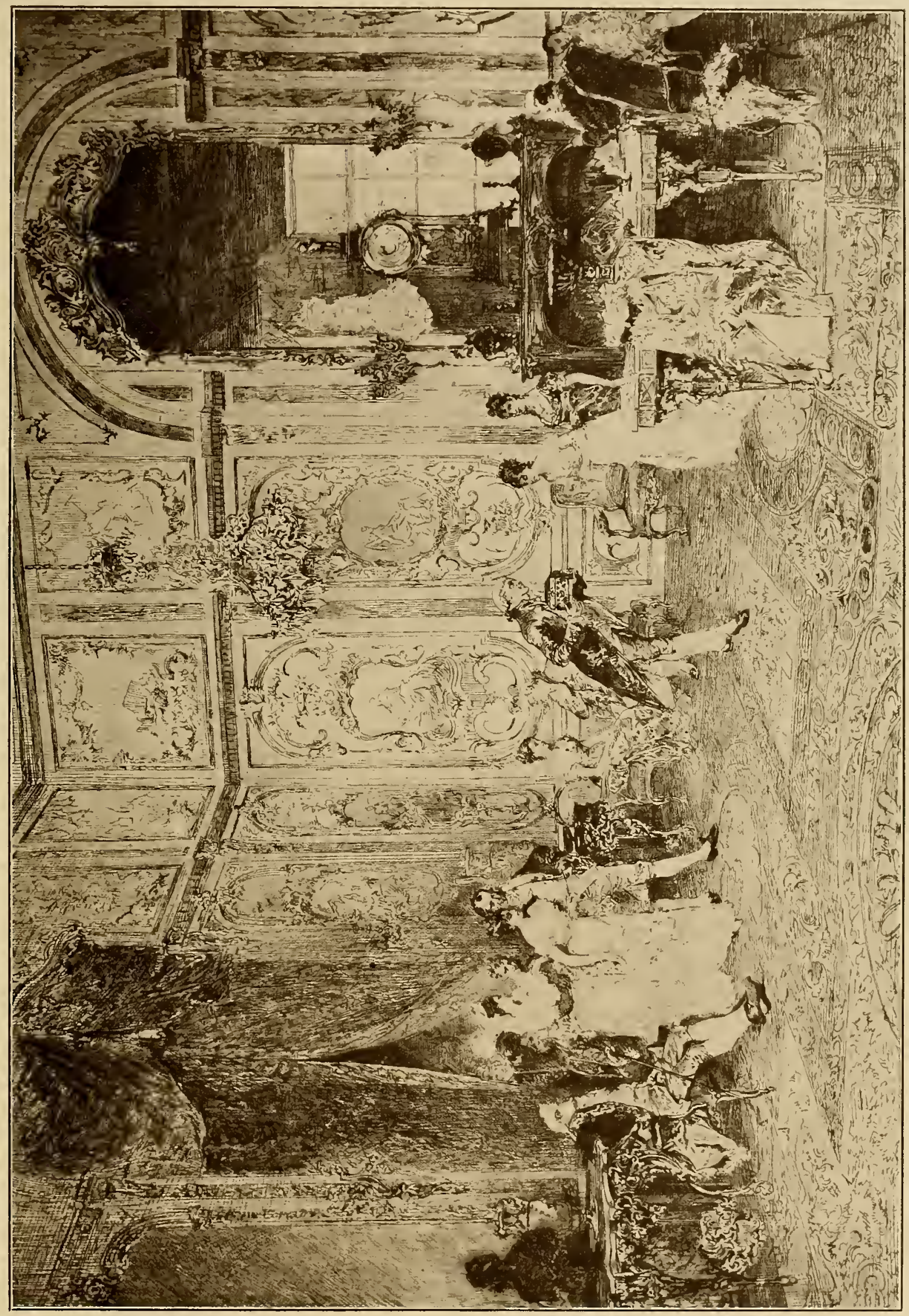

焉 




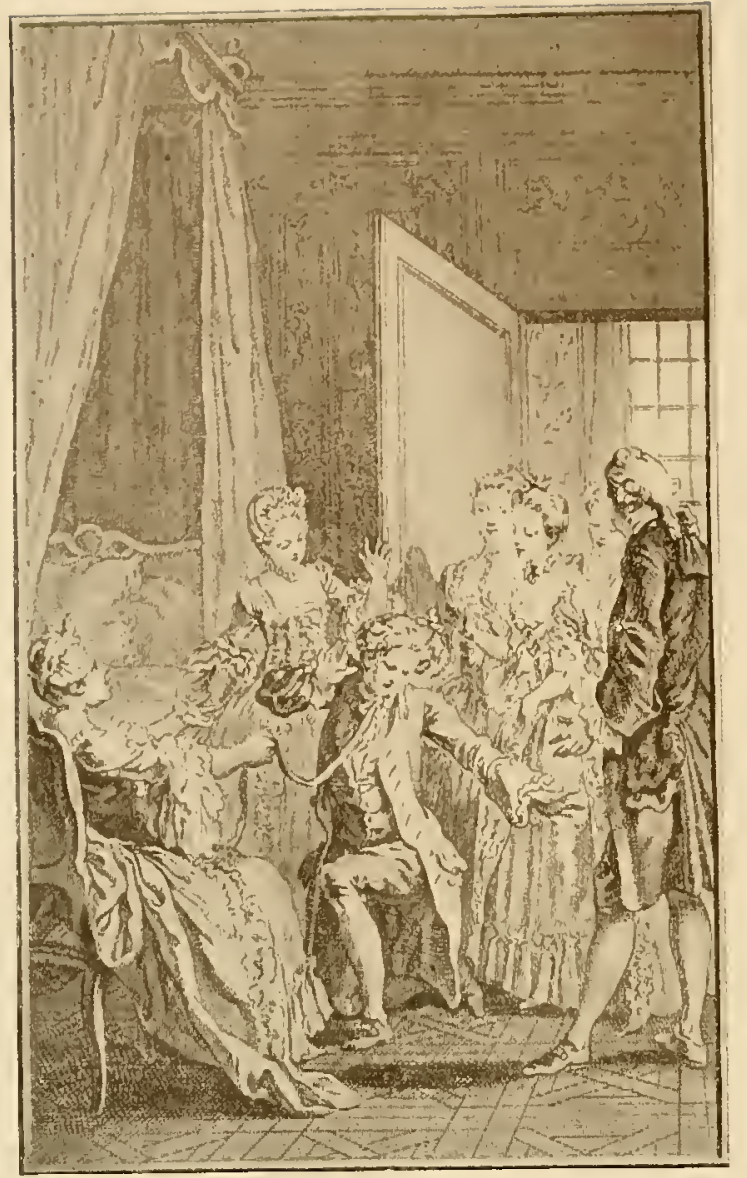

Above, an interior of Louis XV, 1765 ; below, chair made for the Empress of Russia, I741-1762, expressing the Baroque influence of Louis XV.

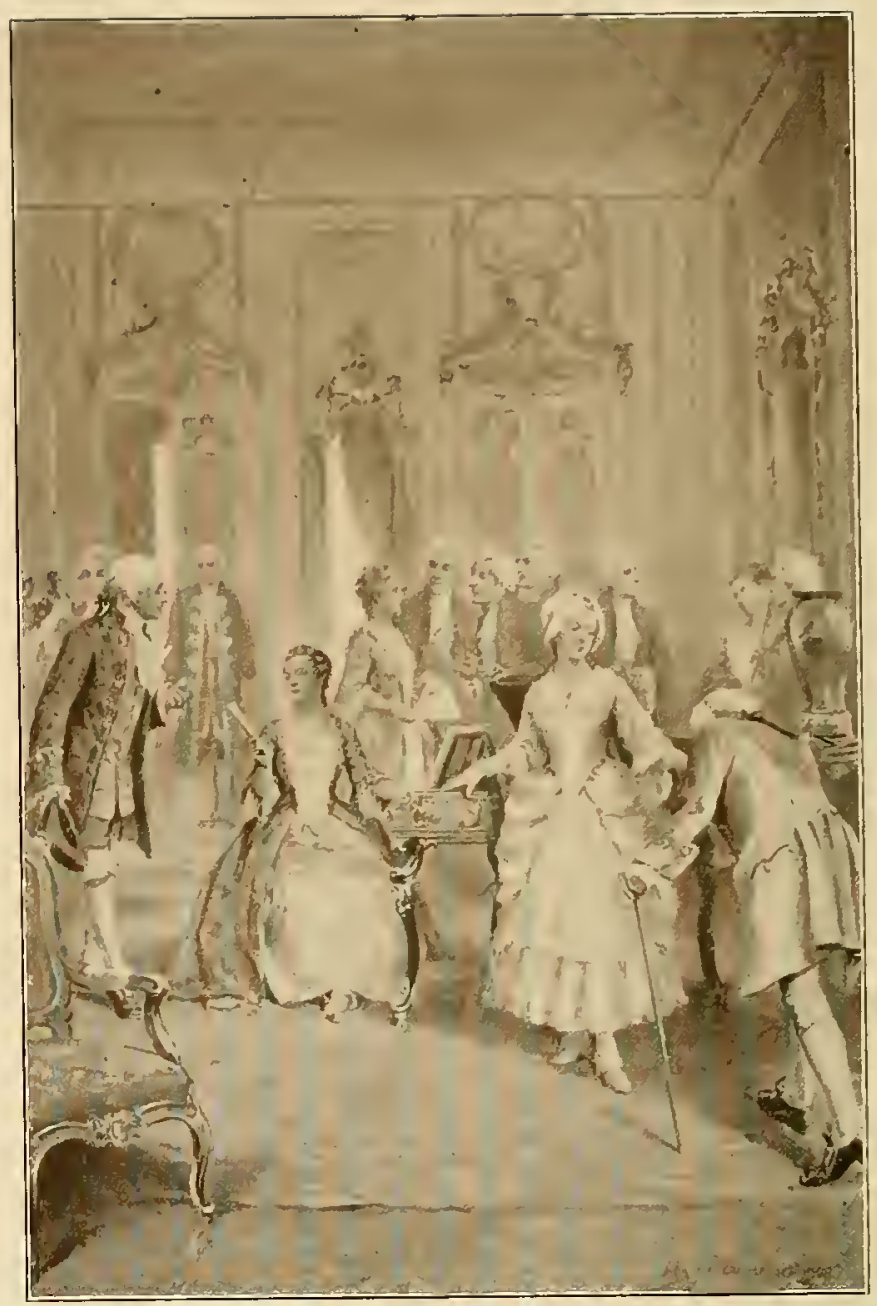

Louis XV Interior; Dress of IT/4.
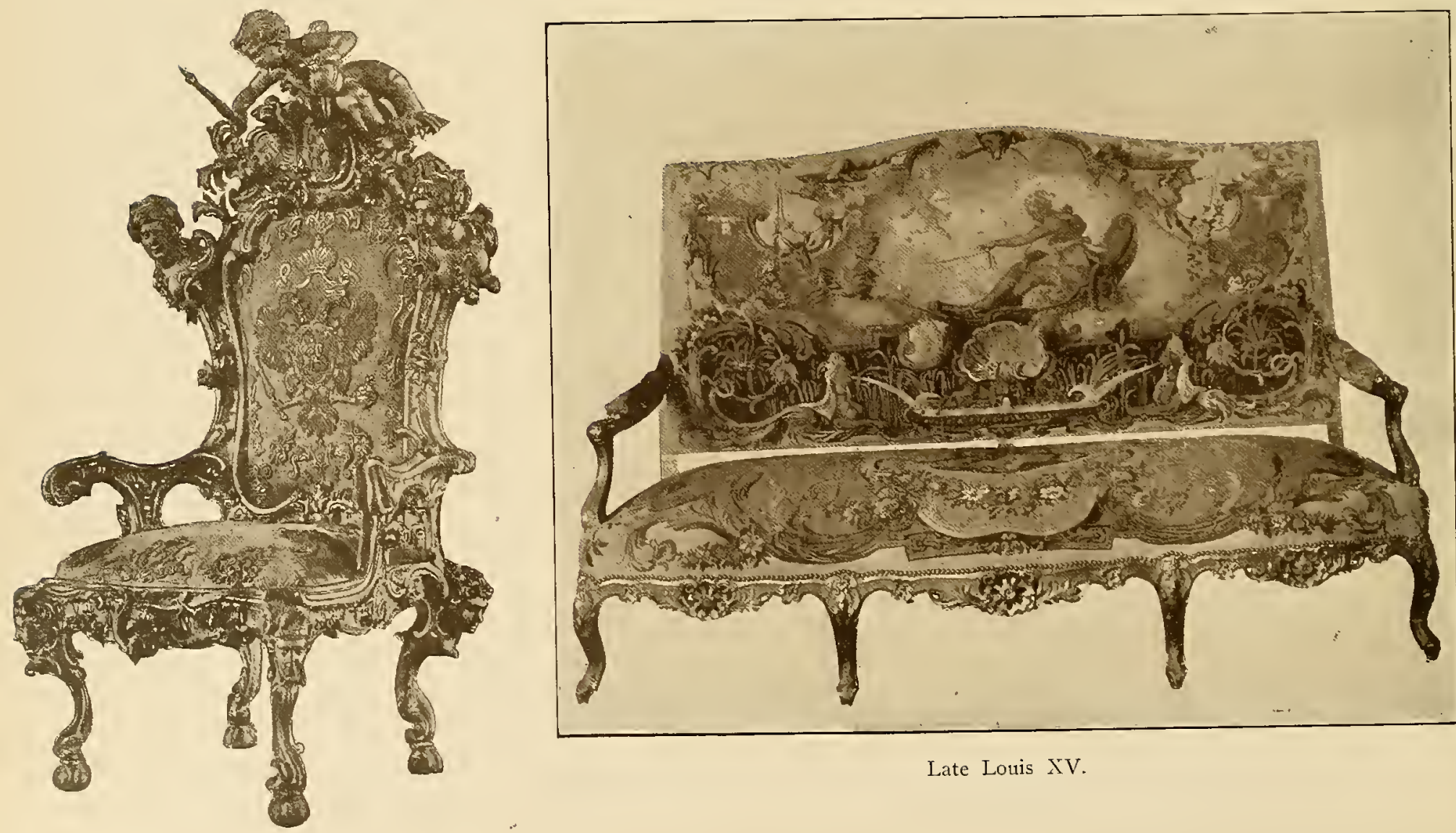

Late Louis XV. 
and company-room or reception-room, bedroom, several studies and wardrobe-room.

Each room had its own special decoration and coloring. The bedroom was usually hung with the same materials as the bed. Ceremonious visitors were received here. The ceiling was painted and pictures and mirrors wrought into it. White and gold was a iavorite composition, but bronzes and colors and ma- hoganies and all kinds ne wools were also used. "The room was ustrally longer than widle so that after the bed and side furniture were placed the balance of the room would be almost sfuare. A niche or alcove was often provirled to receive the berl. The walls were done often in hanl-painted scencs, Chinese lacfuered. Thick pile French carpets or Oriental carpets coycred the floors. Draperies were profusely used ant

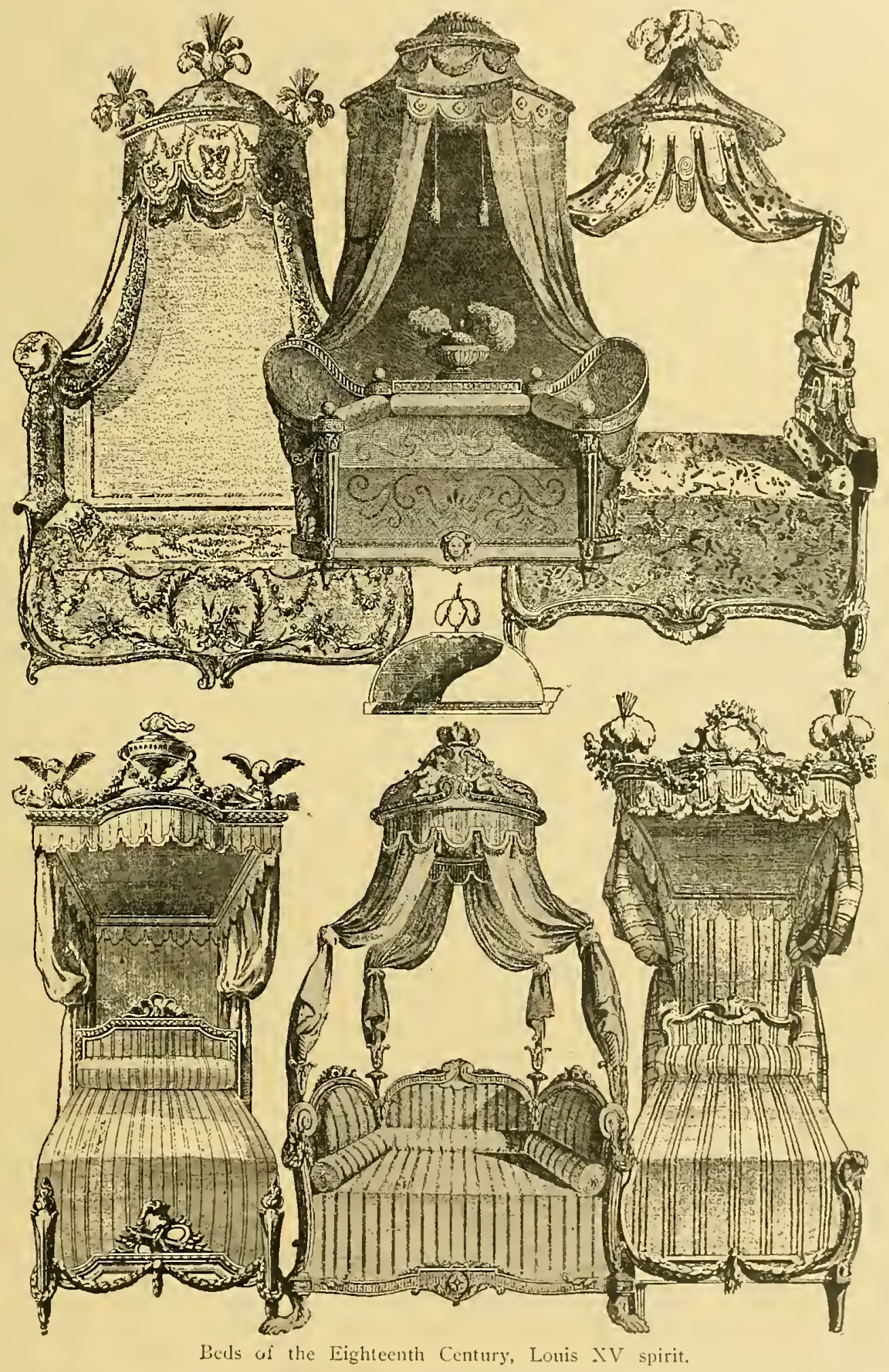



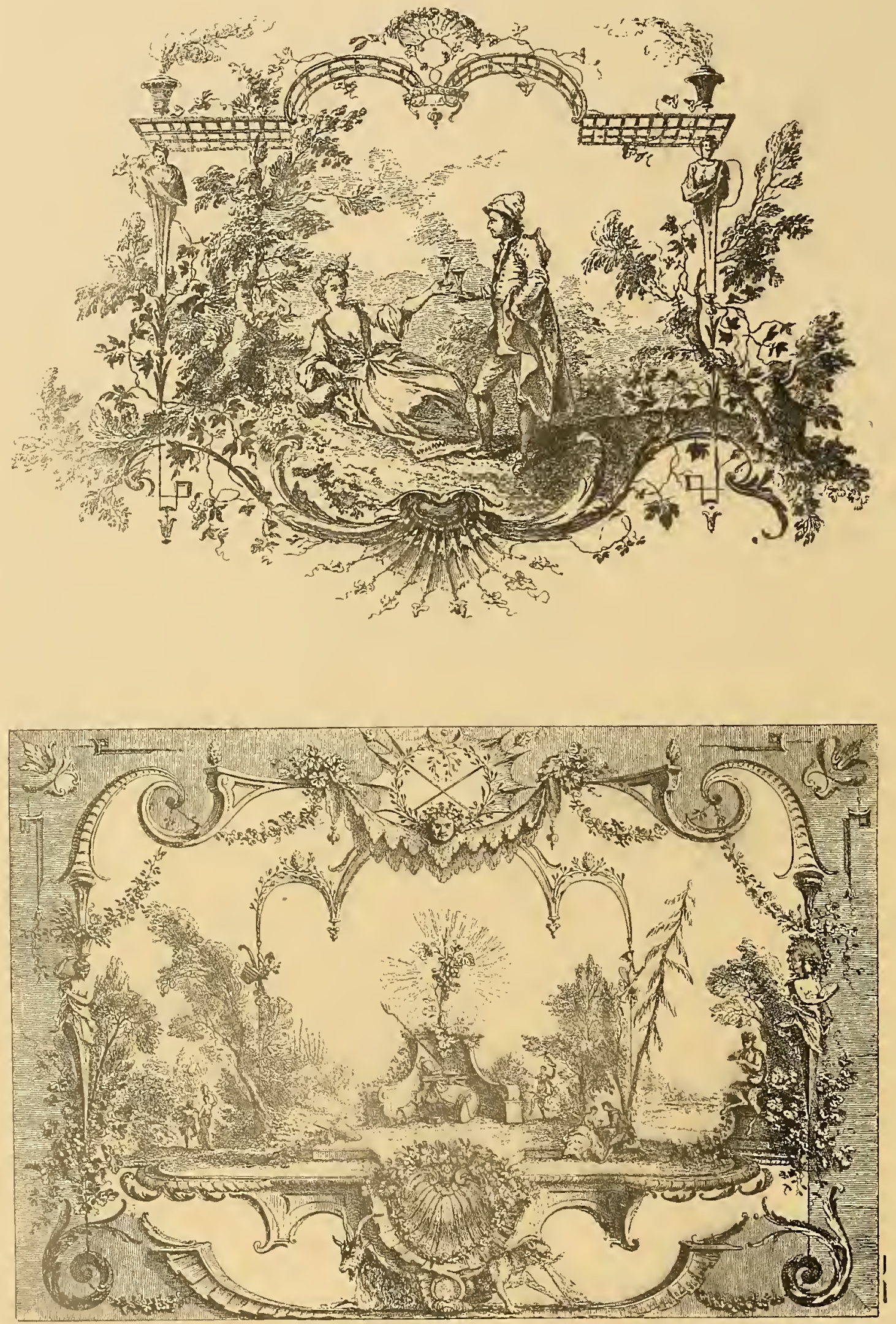

Designs by Antoine Watteau. Louis XV. 
Wattean's desions becane exceedingly poptlar. His laties were depicted in fashionalsle attire and rlainty bundscape secues were presenterl. Romance and fashiom were nerewl. Ilis subjects were "lhe Lably in the Sleigh," ".The Larly in the Swing," "lhe Courtier were introduced into his palace at Versailles by Louis Pllongre. Thus we find that before l,onis $X \mathrm{~V}$, the Chinese tendency was strong. Robert Martin, born 17or. as early as 1733 became known as vernisscur du roi l.onis XV. \ brother was engaged in making

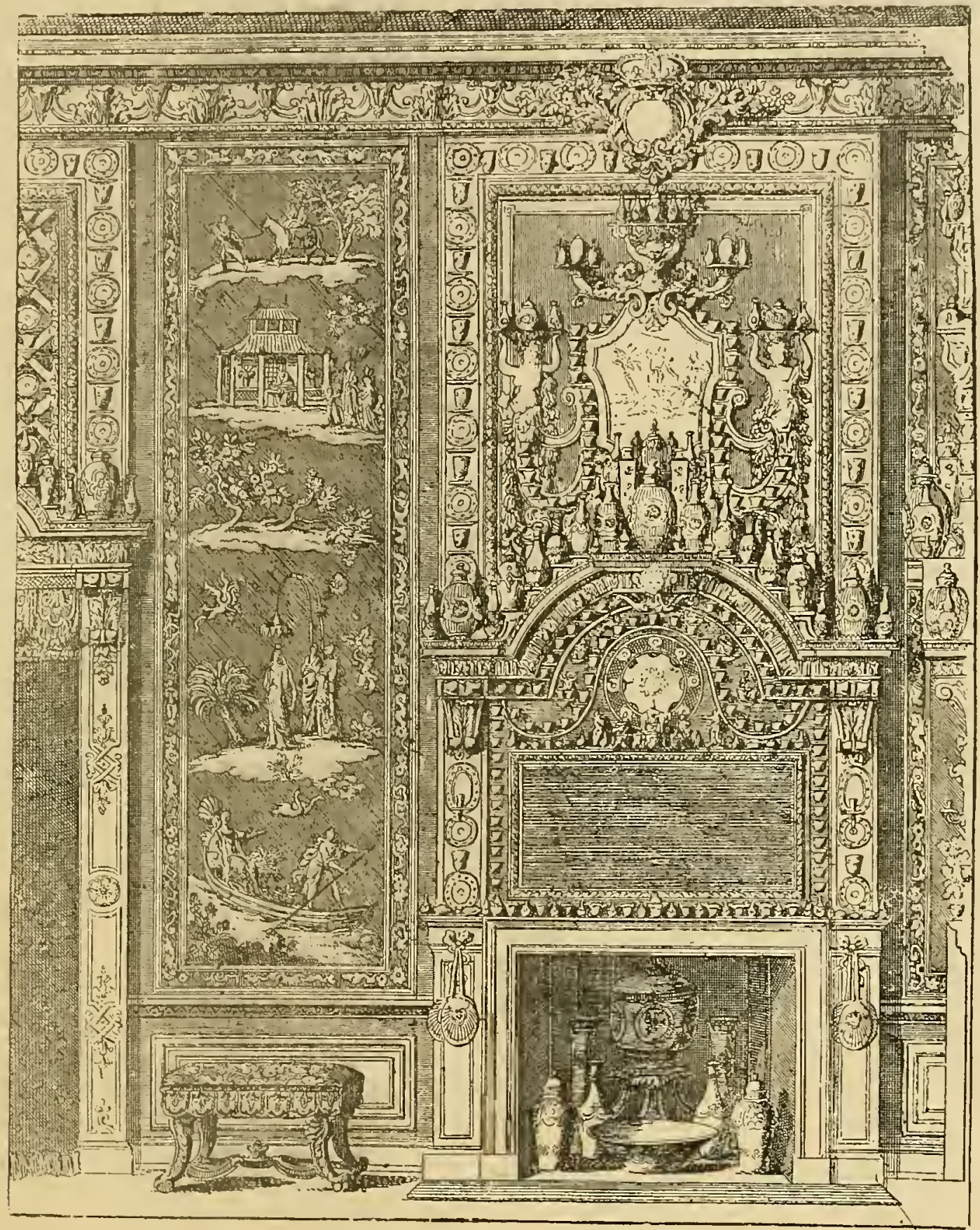

By Marot: Chinese influence. Louis XIV.

and the Sheplserdess," "Frolic," "Folly," "The Dancing Girl." The nude was liberally presented in the sreat works of Boucher, Babel, Natoire, Fragonard and Louchardon.

In 1 on 2 there was record of three factories in Paris making "lacquer work and furniture in the Chinese style:" again under Lonis XIV, Chinese lacquers relief work in the Tapanese and Chinese styles and two sons also followed the manufacture of lacquers. In 1744 the establishment of the Martin works, which in $I 7+8$ became a Royal Manufactory, is accredited to a Martin, born 1726, probably Simon Etticnne Martin Ir., doubtless a nephew of Robert, and the work of the family was bere concentrated. Vernis- 


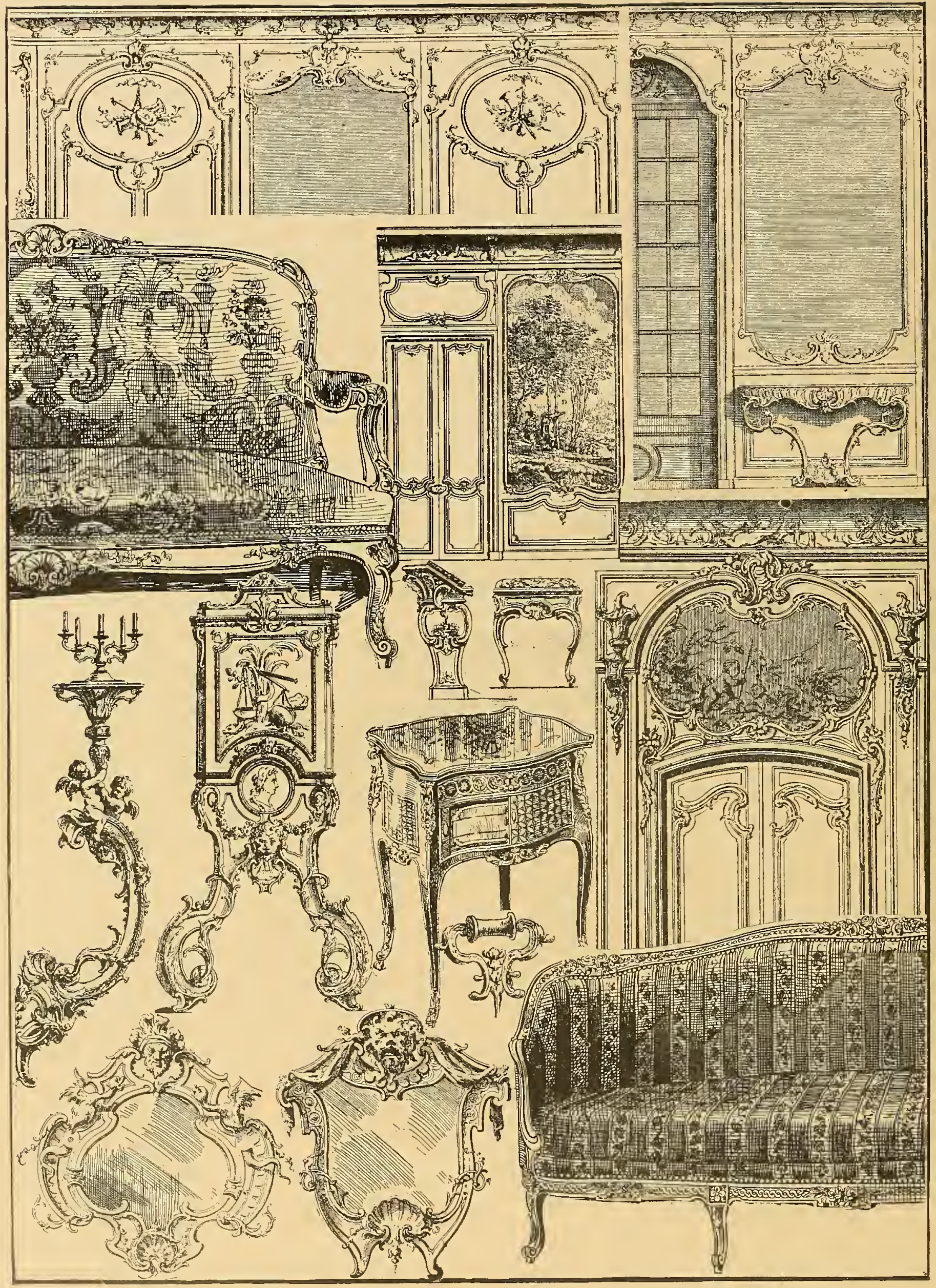




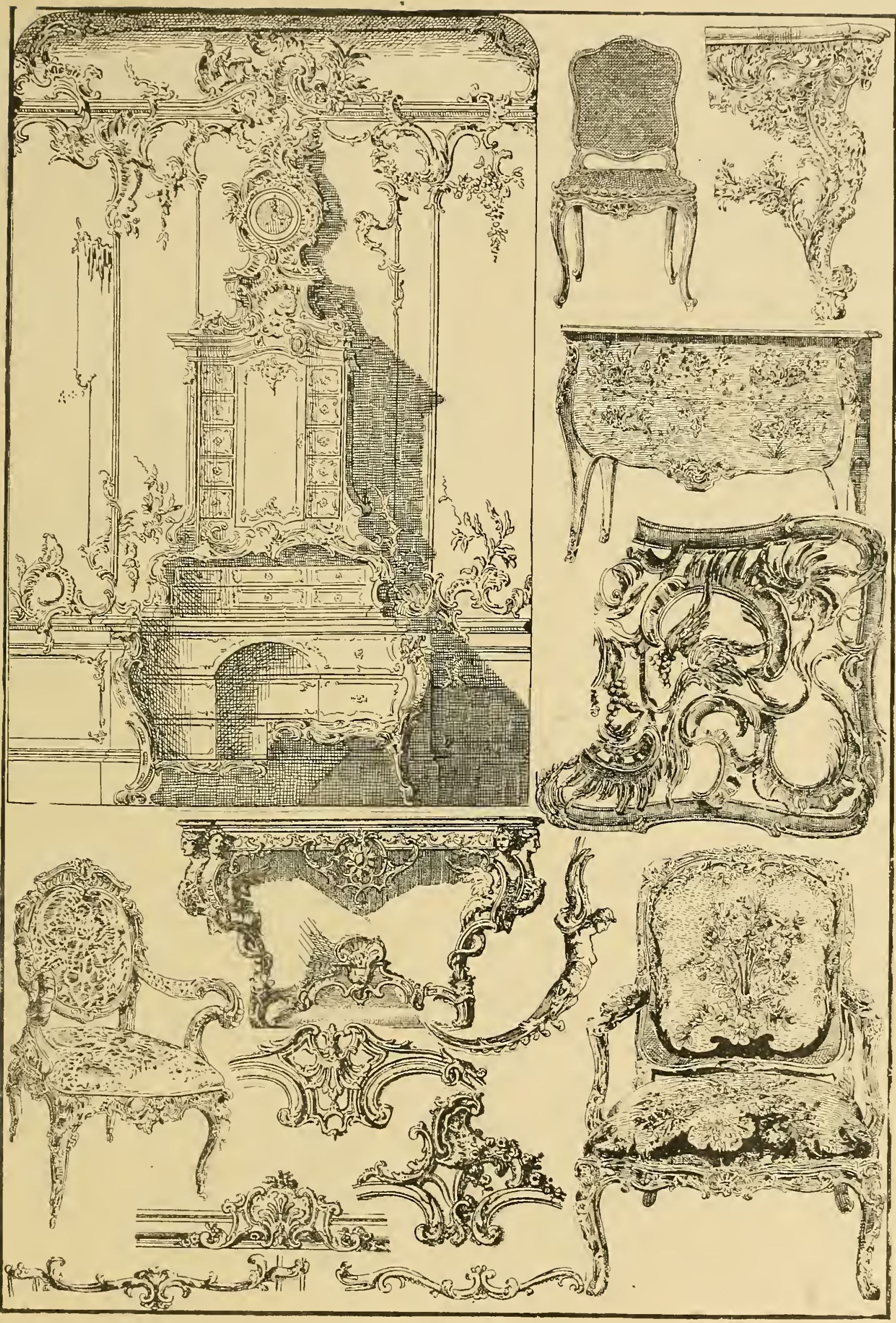


Martin, or Martin varnish, soon became the finish for Louis XV furniture and hundreds of people were engaged in making lacquers in the Martin style: red, brown, gold, speckled bronze, even black, and the walls of the daintiest boudoirs were finished in this composition.

Ornamental bronzes also were much in evidence. Corners of furniture pieces were ornamented in bronze; panels were decorated in great profusion, and upon all sides we note exquisite mantel ornaments, clocks, vases, candelabra and sconces. Some furniture was almost completely covered with bronze work and wood carving was abandoned for this form of decoration. Charles Cressent, famous in this period, studied the Boulle methods and we have in his work, not only bronze or ormolu decorations, but tortoiseshell and marquetrie of the finest character. (See table of Intarsia.) Probably the Rococo spirit was carried to its best expression by Messonnier, who brought with him from Italy the decadent baroque and idealized it. He was designer to Louis XV and to the royal houses of Germany, Portugal and Poland. His interpretation of what was finally known as the
Rococo style became fashionable about the year 1730 .

Walls and ceilings were decorated profusely with female faces and forms, costtmed and in the 11ude, by Boucher, Watteau, Huet, le Prince, Gravelot and Bouchardon. Glass chandeliers were of the most gorgeous character. Huge mirrors were used not only for wall panels but for ceilings, cut up and surrounded by moldings and juxtaposed to painted scenes or decorations. Oudry's famous cartoons, illustrating the La Fontaine fables, were executed about this time in Beauvais tapestry, and some of the finest work of the Gobelins was undertaken, but the nudities of Boucher and the frivolities of Watteau were the fashion, and gave lasting imprint to the Louis XV period.

During the late years of Louis XV, and while the wildest extravagances were being encouraged by him, his favorite, Du Barry, and her satellites, his grandson was exploring the sciences.

The Dauphiness was a picture of refinement amid ribaldry, culture amid chicanery, but she held aloof from contamination, and the style known later as the Louis XVI was a style which reflected Narie Antoinette's personality.

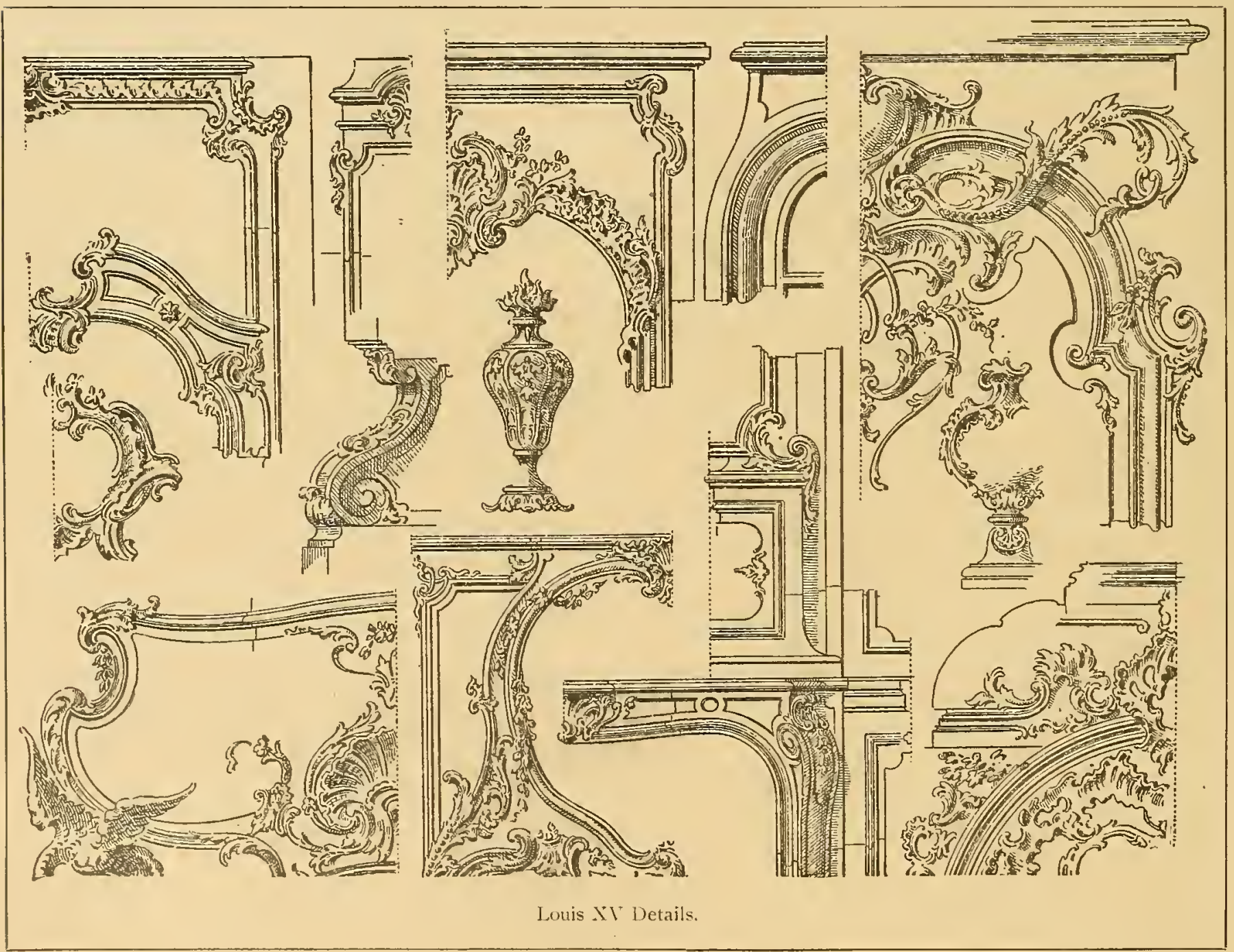




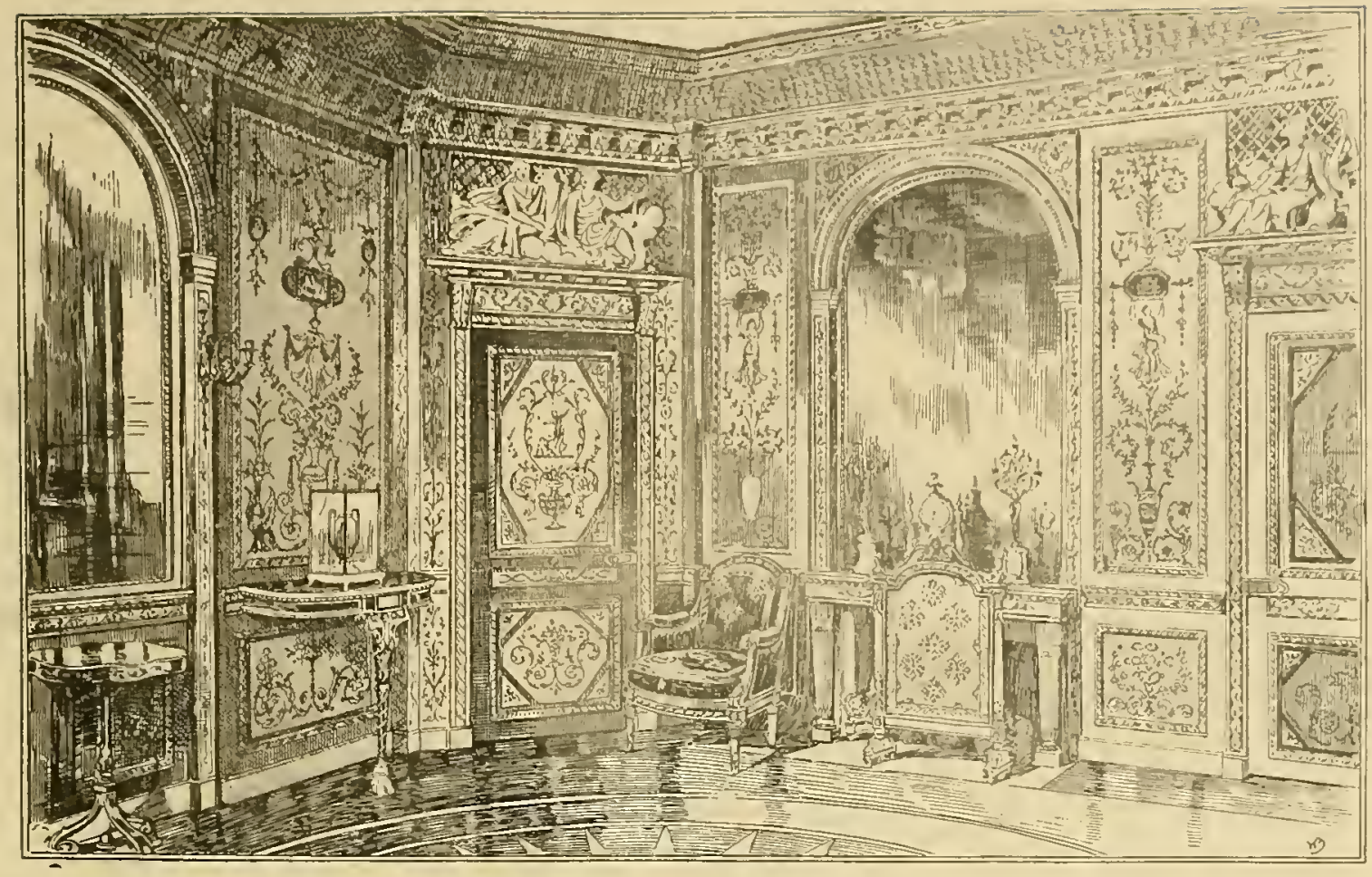

Loudoir of Maric Antoinette; Louis XVI-Transition.

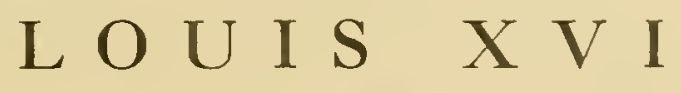

I 774-I 793.

$\mathrm{H}$ ERCULANEUM, for centuries buried beneath the ashes of Vesuvius, was discovered about r709. By $17+8$ Pompeii also had been discovered and excavations were successfully: undertaken in both cities.

The antiqu itics brought to light aroused great enthusiasm a mong French artists and in the latter half of the reign of Louis XV this purely. classic feeling. this restoration of pure lines, Pompeiian lines, was strongly in evidence.

In the closing vears of Louis XV's regime, the style hacl fully developed, and it continued under Lonis XVI, to which period its development is popularly attributed.

The Lonis XVI style was a reversion to

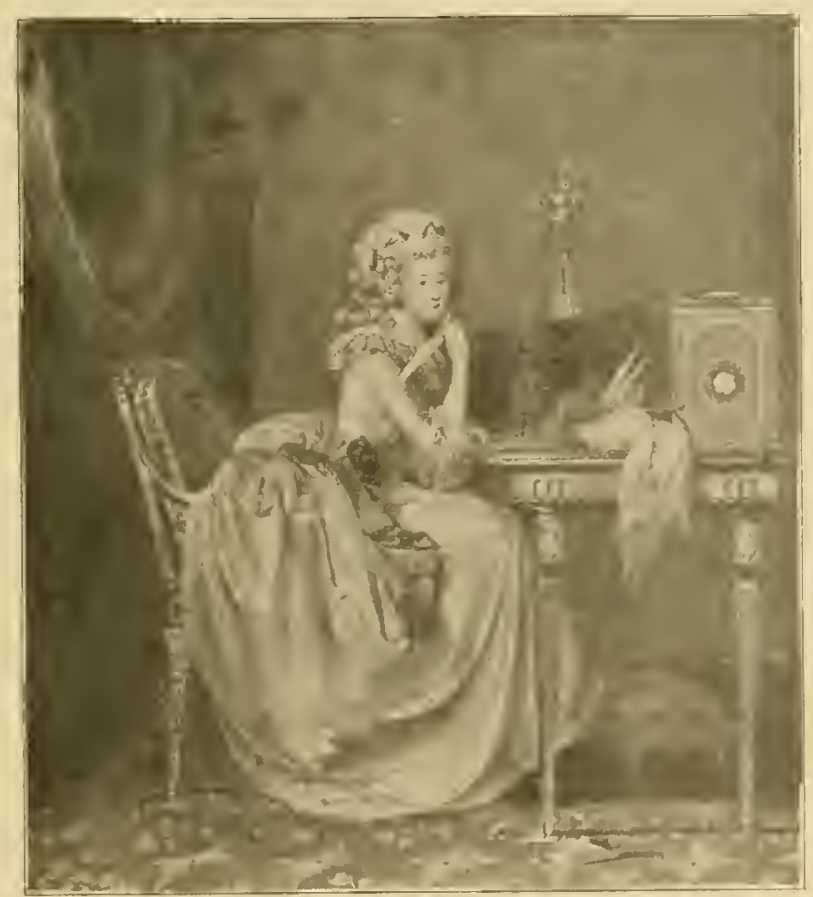

Costume and Furniture of the Louis XVI period. the early classic. It came back to the straight lesof the early Lonis XIV, but followerl the models of the architectural columns, rounded. but smaller at the base or foot instead of smaller at the top. 10 longer dicl they use curved lines, the S shapes or the exaggerated curres in the acanthus forms. There was a well-defined effort to purify decoration. which had rum the limits of extravagance. Noreover, the petit salon and bondoir harl becomc fashionable. hence a demand for refuced proportions. daintier figures, smaller furniture. The taste of Marie Antomette were simple ancl lee juelgment and patronge st im 11 lat teal the new styles. which following the lines of least resistance, allopted the 


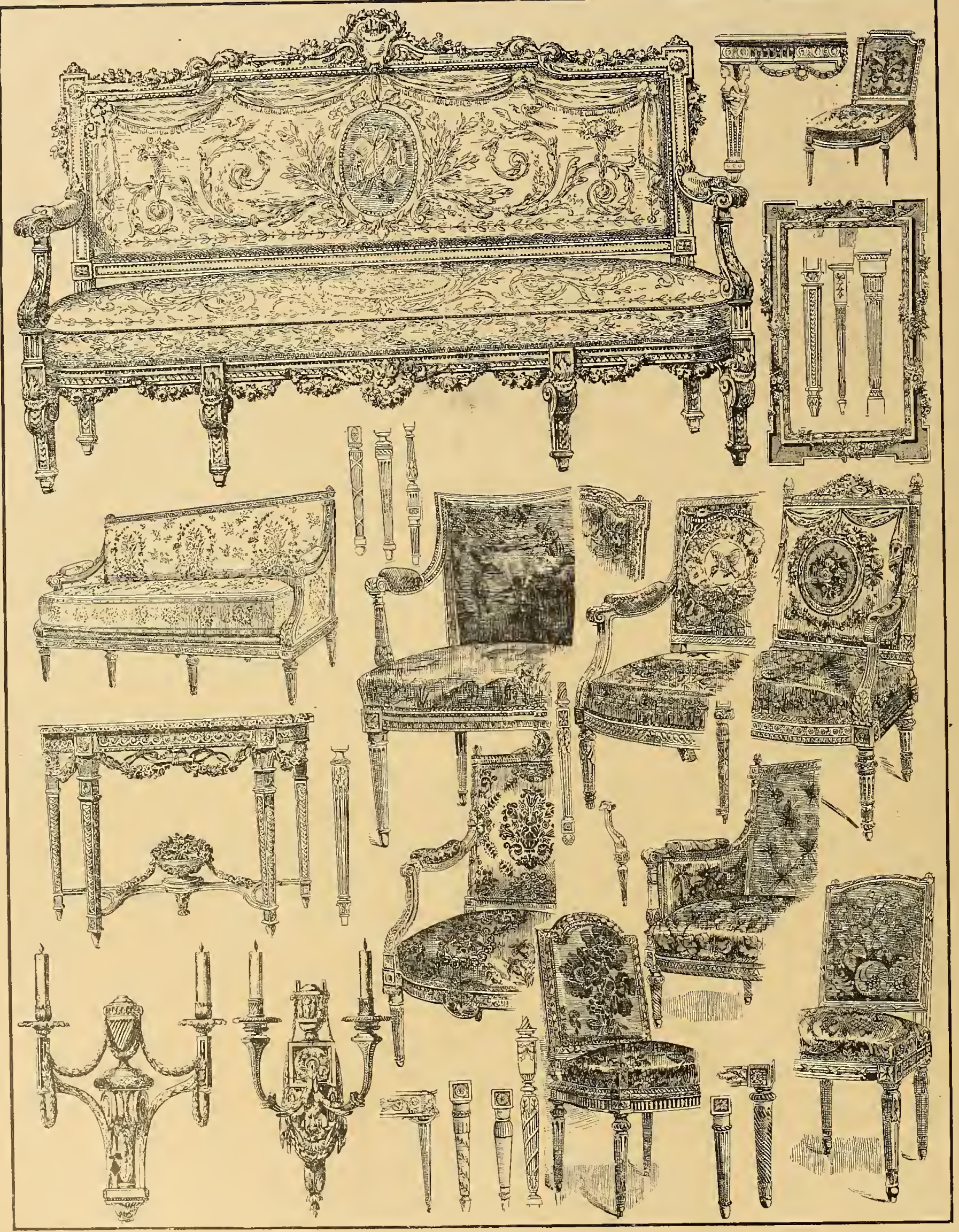

LOUIS.XVI FURNITURE DETAILS. 


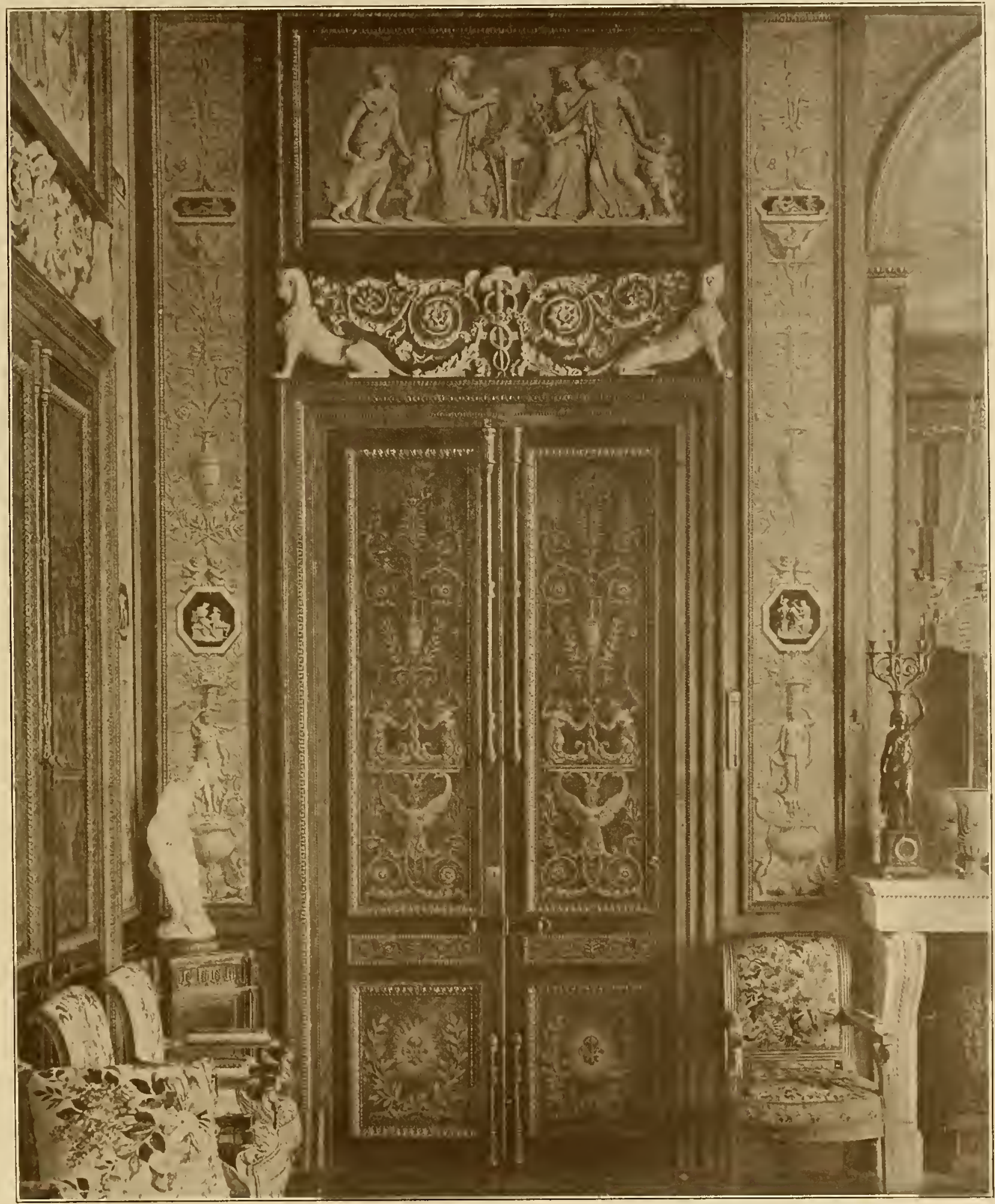

APARTMENT OF MARIE ANTOINETTE, FONTAINEBLEAU. 



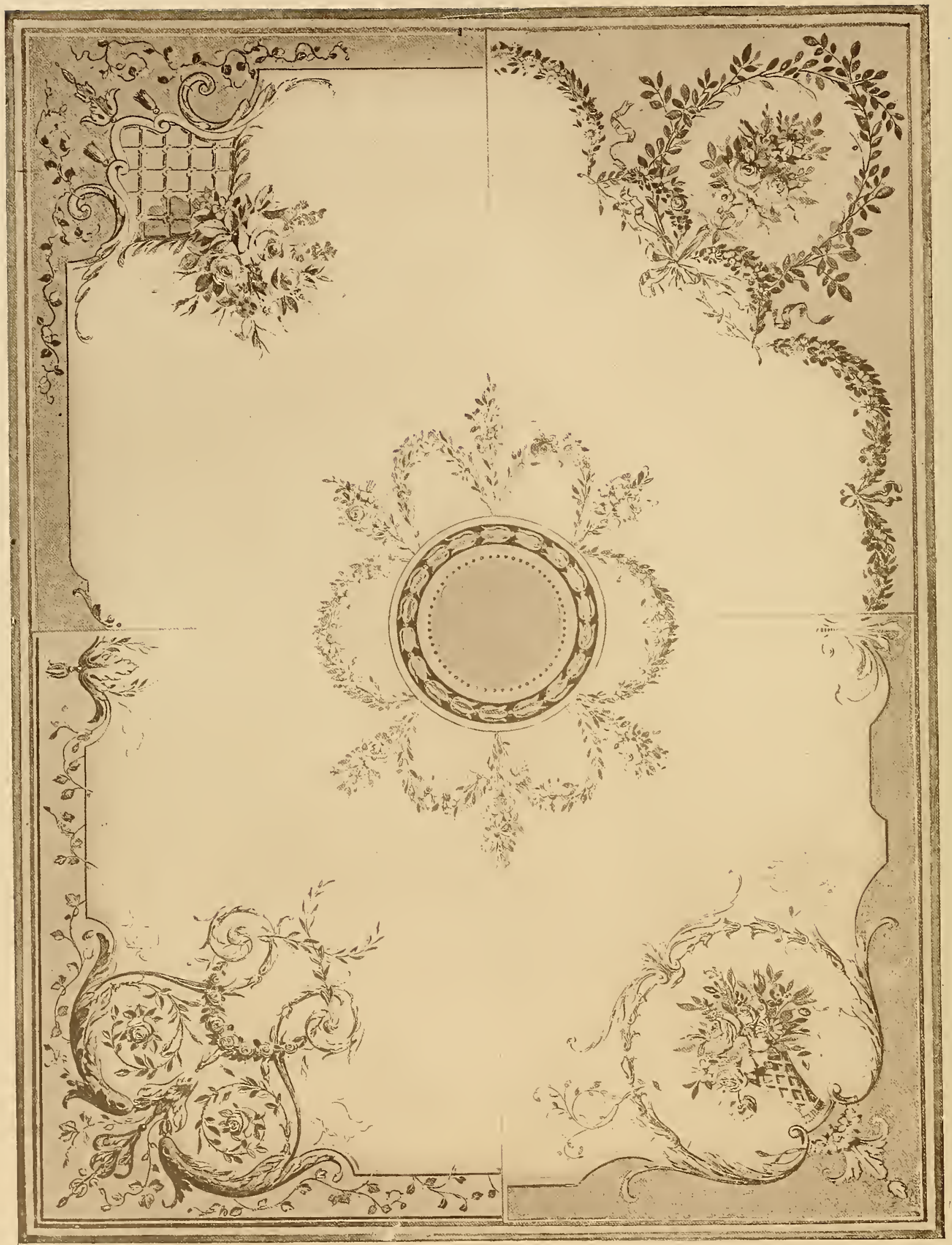




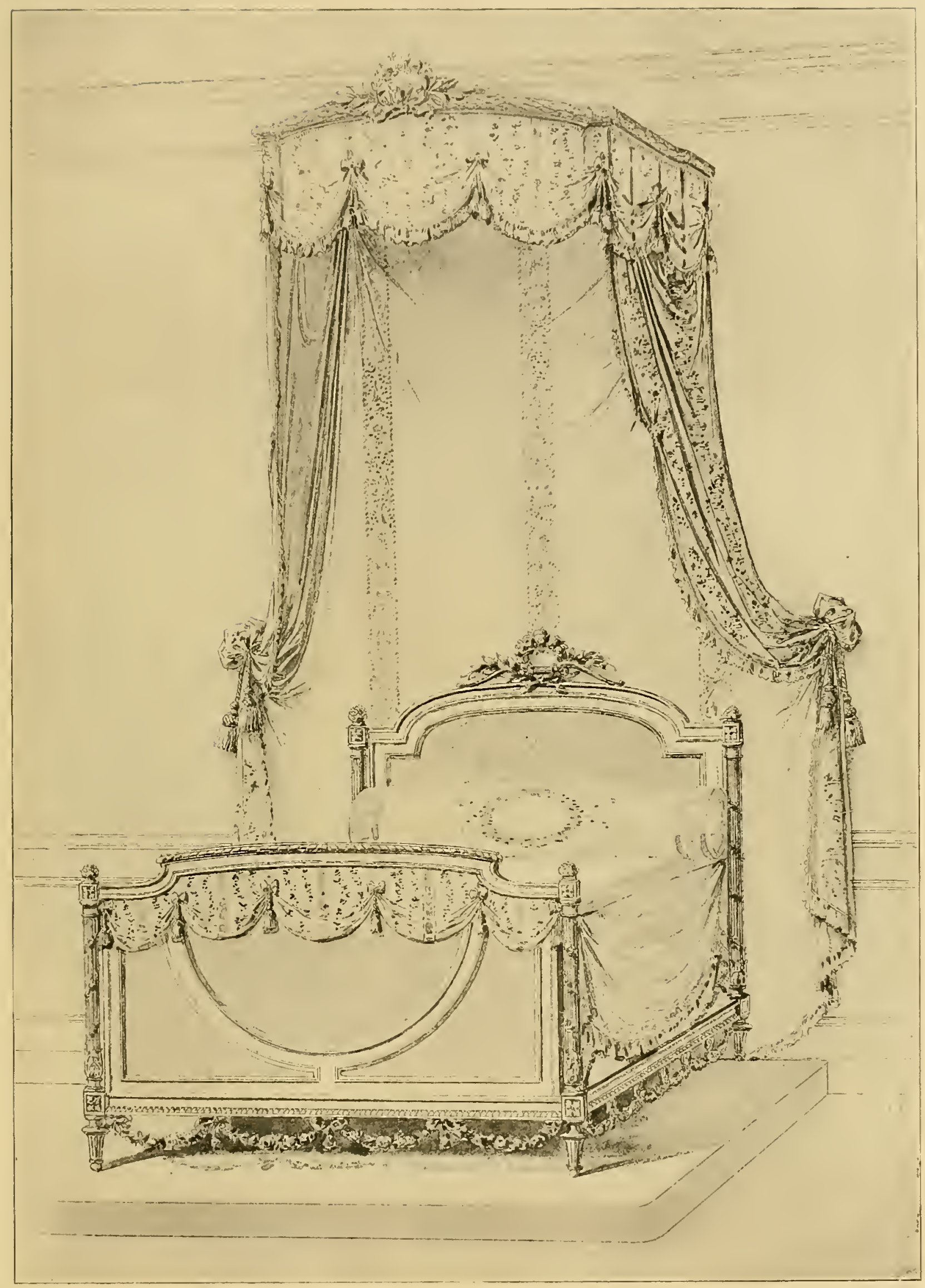

LOU IS XVI 
classicism displayed in the Restoration work at Pompeii. So strong did this feeling become that notwithstanding the fanatical hatred and destructiveness which followed in the path of the Revolution, the style continued through the Transition or Directoire and into the period of the Empire. We find the same spirit in the English styles of the Brothers Adam, Hepplewhite and Sheraton, modified but undisguised. Pagan deities, masks and caryatides were replaced by suggestions of pastoral simplicity: flowers, ribbons, festoons and the depiction of peasant life, a little unreal in the diminutive waist and high-heeled shoes and coiffures of the shepherdesses, but dainty and charming. Chinese lacquers were much in vogue and Chinese pictorial and scenic designs.

De la Londe published thirteen books of design during the Louis XVI period which he called "The Classic Taste." His work showed a fondness for the fluted leg laced with ribbon. He utilized the bow and quiver, the urn, lyre, garland, burning torch and the ribbon in many forms. Le Prince was particularly fond of pastoral accessories, groups of big pots, shepherds, crooks, spades, trowels, bird cages, thrown together in bunches with garlands and ribbons. Sometimes the oval frames of his chairs are supplemented by a quiver of arrows or a garland of roses wherein doves are nestled.

Salembier's books are devoted to the description of ornamental trailing foliage, the arabesque, the acanthus, and the thistle leaf. Although these are motifs which appeared for a hundred years previously they are treated now in a more delicate fashion. And this characteristic marks the style of the whole period-delicacy, minuteness, grace. Vases were reproduced after the fashion of the vases discovered in the restorations, all Greek or Early Roman and all slender and graceful.

In textiles we find ribbons and stripes intermingled with flowers, winding ribbons and feathers. medallions, columns, lyres, and occasionally heads of Minerva or other classic subjects; and ever conspicuous was the stripe. Indeed Mercier in 1788 wrote, "Everybody in the King's cabinet looks like a zebra." To be sure Madame Pompadour had already set the fashions for stripes, but Marie Antoinette sprinkled her stripes with flowers and interwove them with ornaments. It is a singular fact that while the Germans did little for their own country they established through Riesener and Roentgen the fame of Louis XVI furniture. Riesener was particularly happy in his marquetry, introducing often painted porcelain, chiselled copper and Sevres plaques. Roentgen's marquetry also was full of the most minute shadings and he together with a number of other noted cabinetmakers followed the Boule (Boulle) style, and also utilized plaques and china.

At this period it is sometimes difficult to find the dividing line between the beds and sofas. Frequently the head and footboards were of equal height and exactly alike. The canopy was erected at the side in-

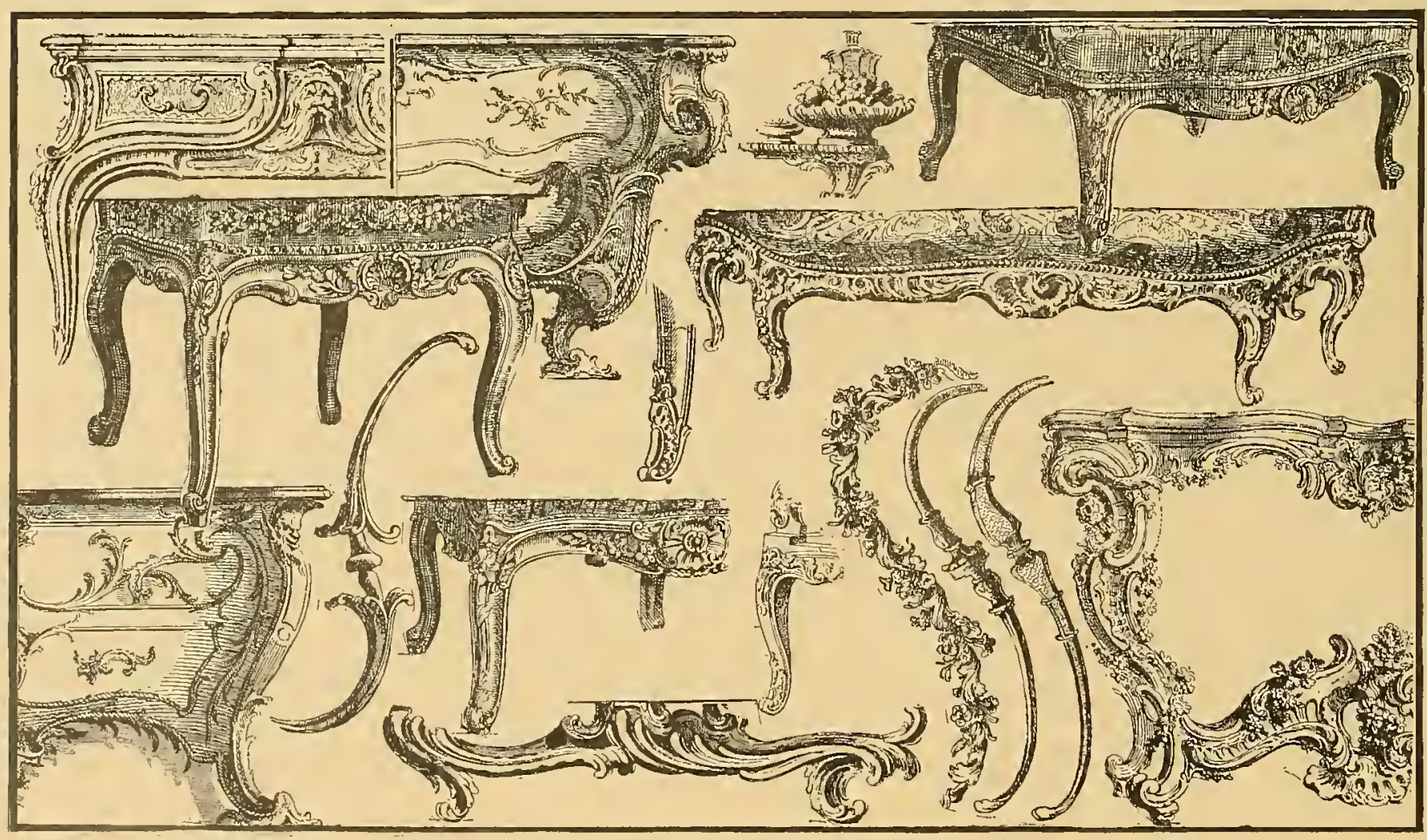

Louis XV Terminals. 


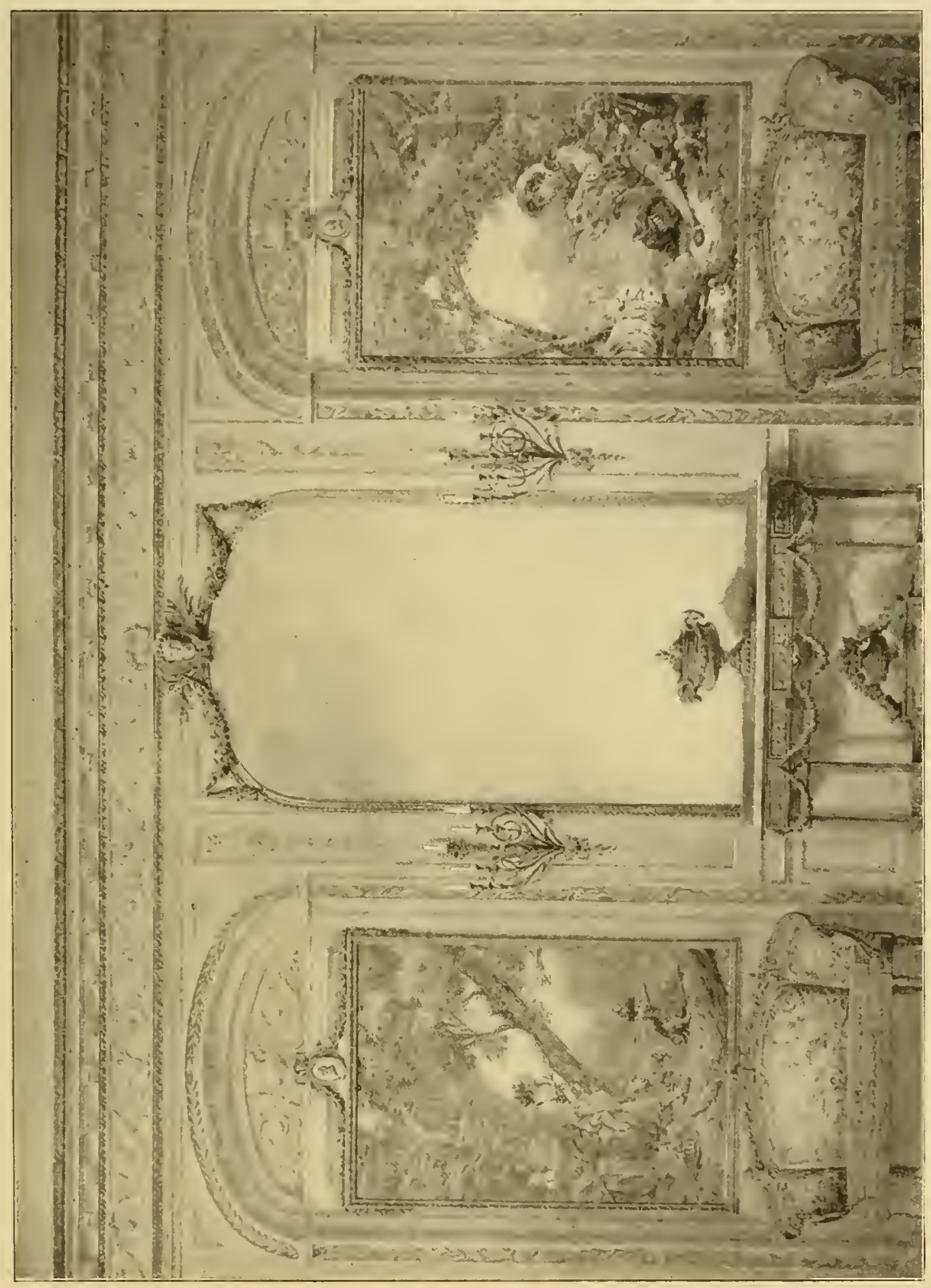

$n$
$x$
$n$
$n$
0
0 


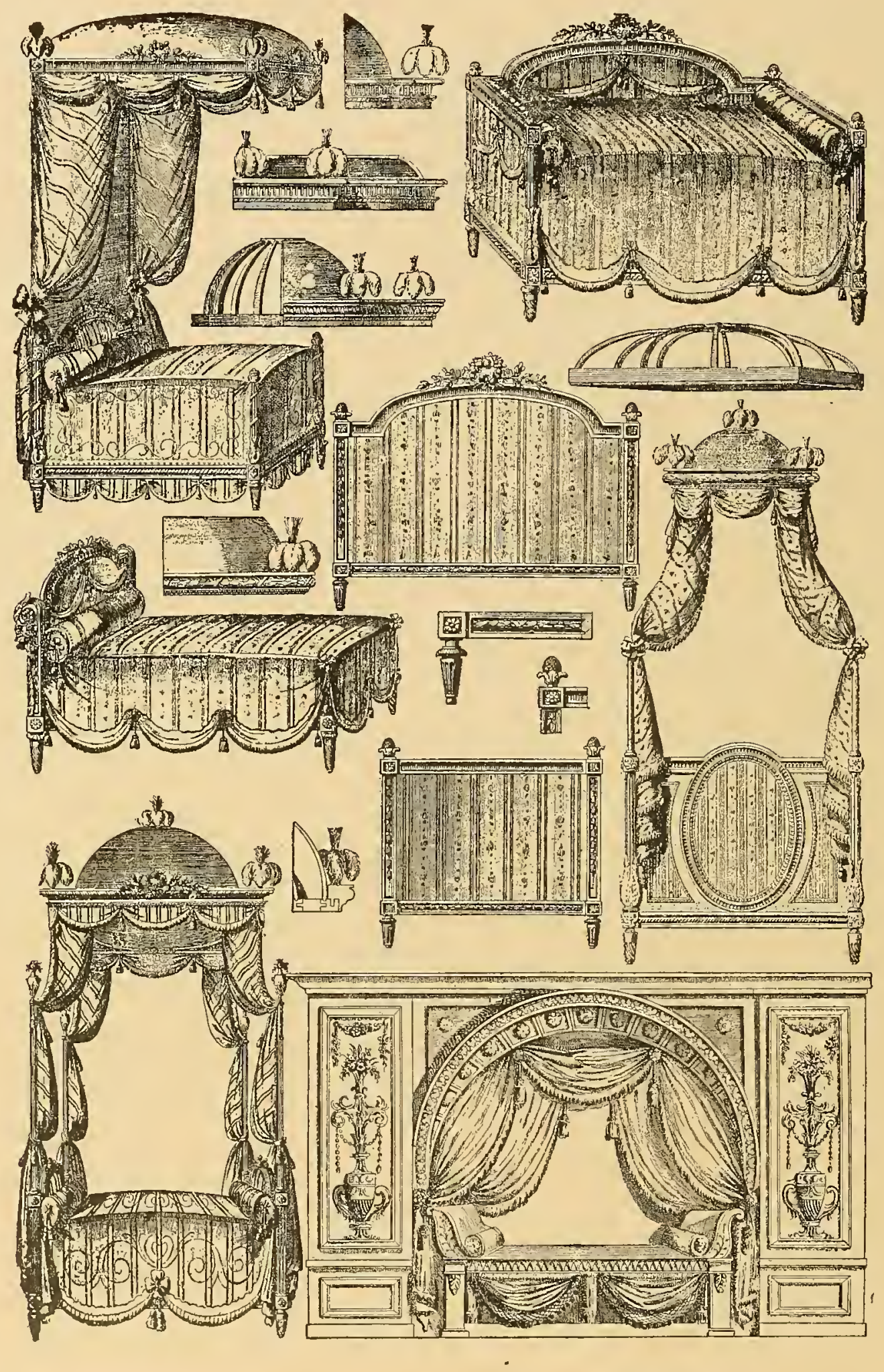




\section{O U I S X V I}

stead of the head of the structure. They were sometimes upholstered, sometimes lacquered, frequently gilded or all white and pancled with cane or left in natural wood, ormamented witl bronze, gilt or perliaps ormolu.

Muslins, prints and sillss were profusely used for curtains, trimmed with cords and tassels. The beds were usually curtained. Cornices were used gilded and lacquered or white and gold. The commode become popular and was often made of mahogany or amaranth wood. The console or pier table held its place, but was composed of straight lines, with fluted legs, tapered. In the boudoir we find the Chinese lacquer as well as the Vernis-Martin. Flower tables were popular, writing tables, work tables, card tables, and in this period was introduced also the extension table. Dining-room chairs frequently had cane backs or were covered with material to match the walls.

Low ottomans were introduced, and while all kinds of carpets were utilized Moquettes were the most popular.

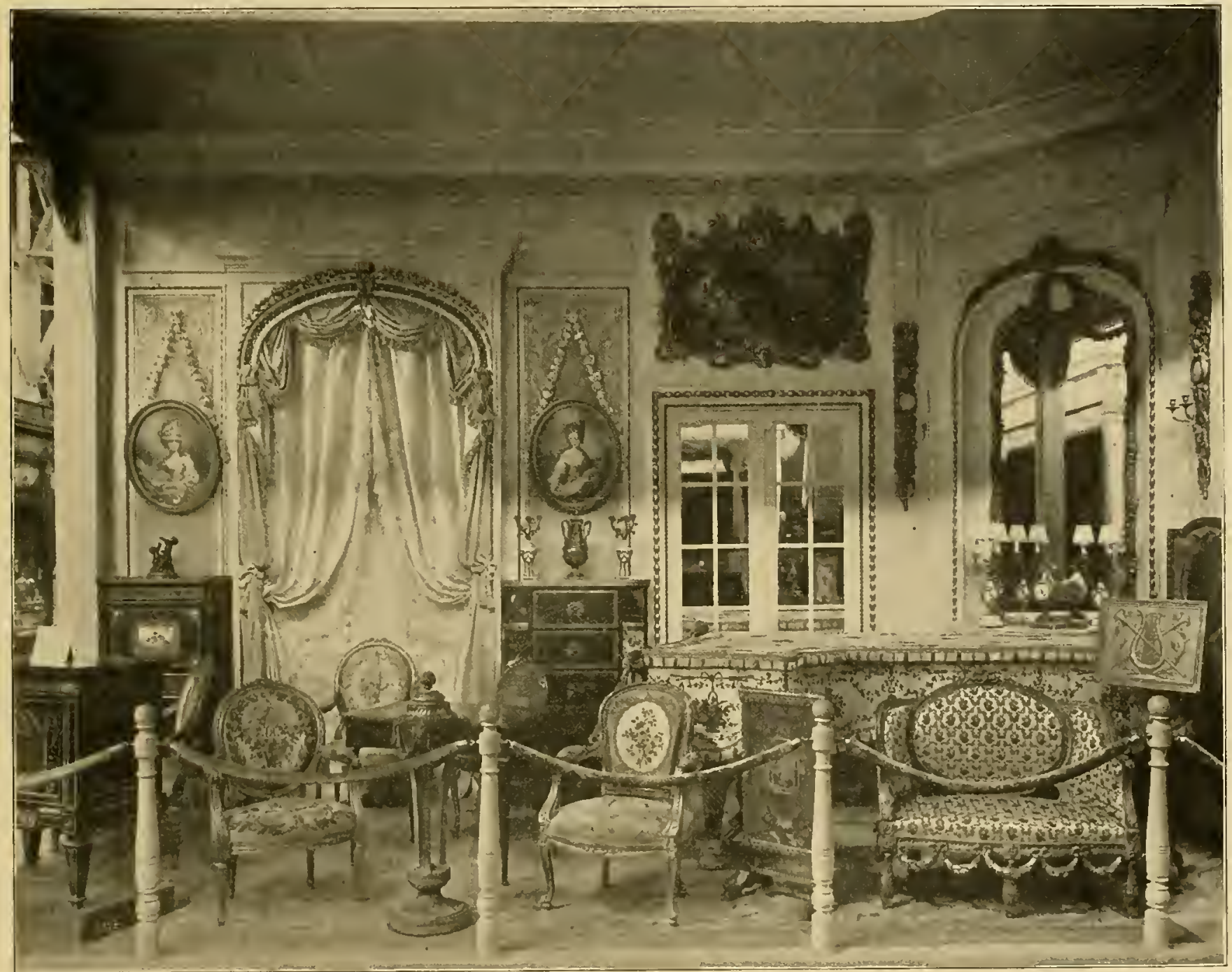

\section{O U I S X V I}

Display at Louisiana Exposition. 

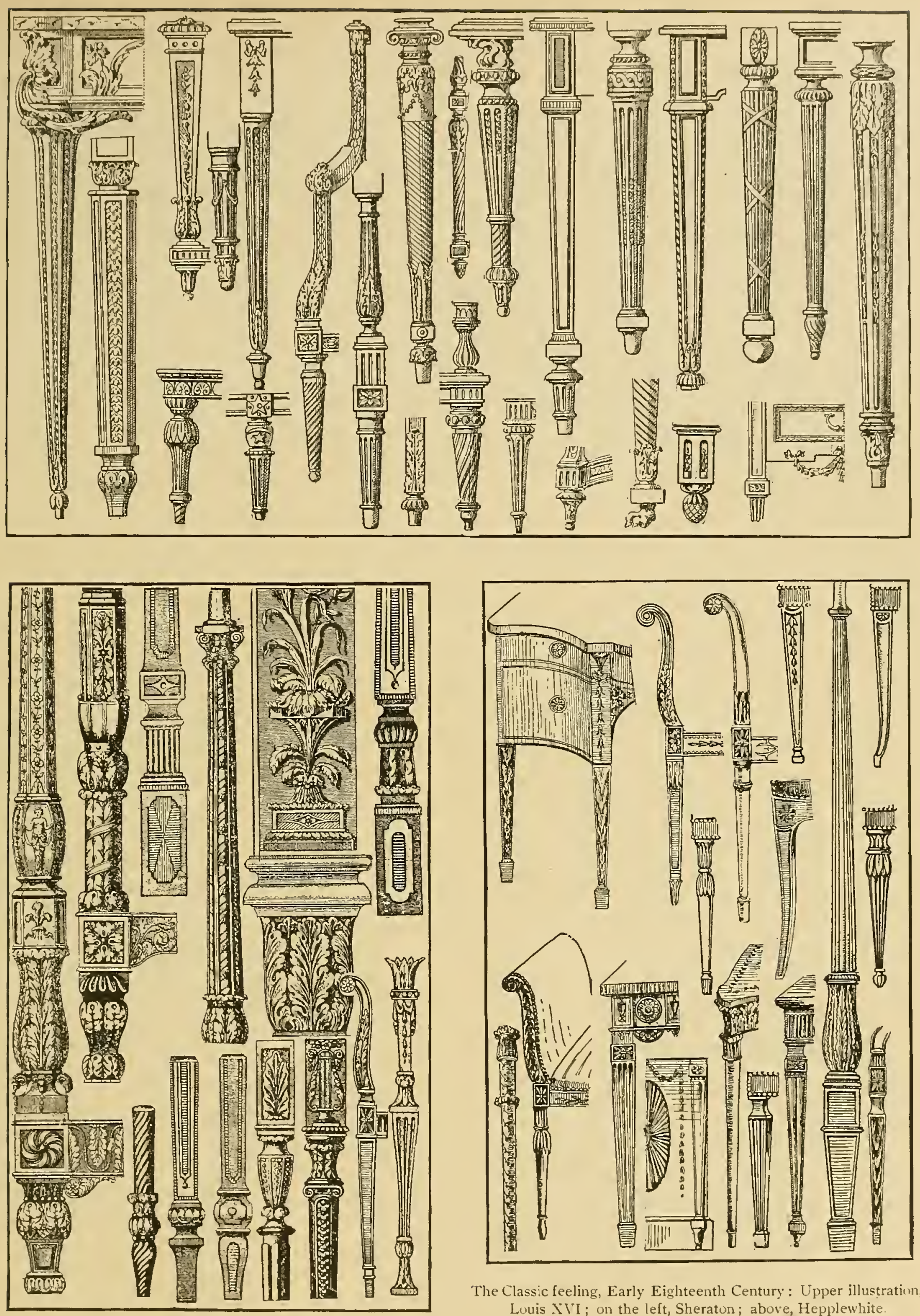

The Classic feeling, Early Eighteenth Century : Upper illustration, Louis XII; on the left, Sheraton; above, Hepplewhite 
ENGLISH.

Applewood.

Ash.

Beech.

Birch.

Bog or Black Oak.

Brown Oak.

Cedar.

Cherry.

Chestnut.

Elm.

Holly.

Lime or Linden.

Maple.

Oak (English).

Oak (Pollard).

Pearvood.

Planewood (Buttonwood or Lacewood).

Sycamore.

Walnut.

Willow.

Yew.

\section{EUROPEAN.}

Austrian Oak.

Baltic Oak.

Bircl.

Black Sea or-Circassian Walnut.

Borreood.

Cedar.

Cherry.

Chestinut.

Cypress.

Elm.

French Walnut.

French Oak.

German Oak.

Holly.

Italian Oak.

Lime or Linden.

Taple.

Olive.
Pcarwood.

Pine.

Polish Oak.

Planeivood.

Riga Oak (Rissian).

Spanish Oak.

Sycamore (colored varieties called Hairwood, Mouscwood, Greywood).

Walnut (Italian).

Willow.

\section{ASIATIC}

Andanan Redrood.

Cedar.

Calamander (Blackstripe, India).

Cherrv.

Coromandel (Yellow Ebony, India).

Ebony (India).

Grecn Ebony (India).

Indian Mahogany.

Ironwood (India).

Pearrood.

Porcupine, Pheasant or Partridge.

Roscruood.

Satinzeood.

Teak (Pheasant or Granitervare).

Zeen Oak (India).

WEST INDIAN AND SOUTH AMERICAN.

Angclique (Mahogany).

Cedar.

Cocobola.

Greenheart.

Grcen Ebony.

Kingrwood or Violct.

Lancervood.

Lignum-Vitae.

Mahogany.

Mora (Mahogany).

Purplezvood.

Rosewood.
Sabicu (Mahogany).

Santa Maria (Mallogany).

Santine (Maliogany).

Satin Walnut.

Satinavood.

Snakcrcood or Lcopard.

Tulip.

Yellow Oak.

Zebra.

Ash.

AMERICAN.

Basswood (Lime).

Beech.

Birch.

Bird's Eye Maple (Sugar Maple)

Black Walnut.

Butternut.

Cedar.

Cherry.

Chestnut.

Cypress.

Elm:

Hickory.

Holly.

Live Oak.

Maple.

Pine.

Poplar.

Planewood (Buttonwood or Lacewood).

Red Oak.

Redwood.

Sycamore.

Walnut (many varieties).

White Oak.

Whitewood (known as Tulip, Yellow Poplar and Canarywood).

African Oak. MISCELLANEOUS.

African Teak.

African or Golden Walnut.

Citron (Africa).

Mahogany (Africa).

INTARSIA OR MARQUETRY.

T NTARSIA-Tarsia, from the Latin, interserreve, to insert, applied to the inlaying of woods. When in metal, as practiced at Damascus, called damascening. MARQUETR - Synonymous term adopted by the Frencli from marquerter, to spot, to mark. PARQUETRY applies to marble and wood.

1 roo-Intarsia of marble and vitreous pastes produced in Southern Italy.

1259 - Beautiful examples of inlaying produced in Siena.

r $300-$ Germans worked in inlays, and beautiful examples were brought from India Arabia, Egypt, Venice and Spain.

1331-Famous stalls inlaid with ebony, boxwood, walnut and white poplar were produced by the Siennese and reached a high degree of artistic merit.

1416 -The Duc du Berri's furniture was il luminated with pictures in intarsia, doubtless of Italian workmanship.

1490 -Exquisite work done in France.

1500 - Germans understood intarsia work in colored woods.

550 - Italians revived the ancient styles of marquetry and the furniture of this Latin Renaissance or Baroque Period was often of marquetry arranged in the form of ac tual pictures. Sometimes furniture was
also painted, gilded or decorated with oil paintings.

$1550-$ Ebony and ivory work successfully un dertaken in Germany. Fine examples in Mosque of Cordova, Spain

1550-1650-Dutch marquetry, highly artistic, employing Asiatic woods in great number Rich chairs were commonly decorated with marquetry, usually huge tulips and

1600 - Marquetry made itself felt in the Netherlands and Flemisb artists copied the work in precious woods.

1603-Some excellent work was done by Eng Jean Macé of Blois is thought to be the first to practice intarsia in France under the name of marquetrie. He learned the art in the Netherlands. French designs usually ran to landscapes, ruins and classic scenes.

1650-Under Louis XIV Dutch marqueteurs were employed to teach the art to Frenchmen. The name Boulle has become indissolubly connectcd with the application of copper and tortoise shell mosaics upon wood. The Portuguese carried on the work in the Seventeenth Century, employing metal plates cut and pierced in elaborate and fanciful patterns fastened upon black wood, the beginning of Boulle work, which was characterized by the sinking of the metal into the wood.

1672-Andre Charles Boulle, born in $6_{42}$, was granted apartments in the Louvre as "joiner, marqueter, gilder and chiseler." Periods. J. F. Oeben was famous during the Louis XV Period, also J. Henry oo-Marquetry fashionable in England in the Queen. Anne Period. The designs were rich in foliage with bands of ivory and mother-of-pearl.

260 -Satinwood used for inlaid lines of Sher. aton furniture; also holly, tulipwood, decidedly reddish, ard

1770-All of the tropical woods utilized by the inlayers. Wonderful effects obtained by David Roentgen German, who secured shadings by subjecting woods to various shadings by subjecting wood

779-David Roentgen appointed by Marie
FINISH.

200-Gothic and early Renaissance furniture was left untouched. As the forms of furniture became more ornamental a deep colored varnish was applied or the wood was much oiled and waxed.

I500-Amber was known from time immemorial. It was a recognized commercial probable that it was used for the

- The gums used in the manufacture of varnishes coming from Asia, South America and the West Irdies, there was probably no commercial supp?y for the genin lly varishes bave been made at almost ably varnishes have been made at almost porities quantices they weres, violins, musical instruments. Japan and Chro the

$1700-$ Towards the close of 1600 the craze for laws to protect native industries.

I710-In I7I0 the French japanners, claiming that the lacquers and japans were equal to the Asiatic ware, asked for protection, and throughout this period there is constant reference to lacquered tables, fans and furniture.

33 - Imitations of lacquer found fame in the Netherlands through Huygens, and Martin (Vernis-Martin) Royal factory. I $74^{8}$. 


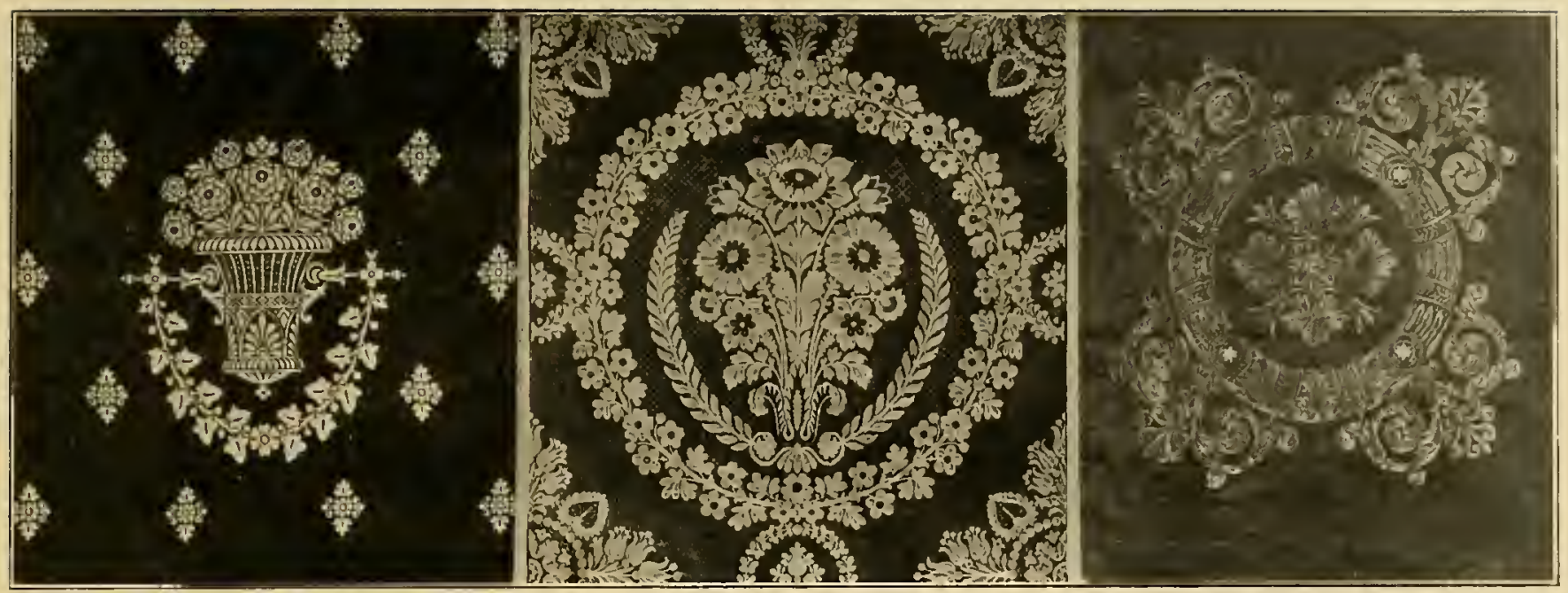

Showing the detached as distinguished from the connected classic compusitions of the Directoire and Acam work.

\title{
TRANSITION-DIRECTOIRE-EMPIRE
}

\author{
Following Louis XVl, the Revolutionary Period, 1793-1795. Direc'orate, 1795-1799.
}

Consulate, 1799-iso4.

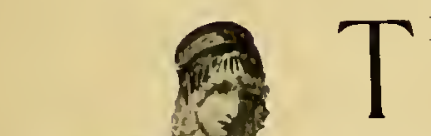

HE period inmediately before and after the Transition French was inspired by a common enthusiasm, the French and English developing the feeling contemporaneously. The English cabinetmakers, with the exception of Chippendale, who affected in many instances the Rococo spirit applied to Dutch structural lines, were especially active in this new classic school.

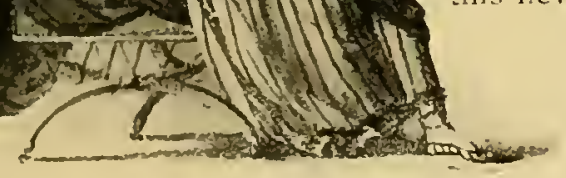

French Directuire.

In France

David was the renius whose taste prevailed at $\mathrm{the}$ close of the Louis XVI period.

Conning at this time, when the political atmosphere was infavorable to the presentation of the styles of Louis $\mathrm{X} \mathrm{V}^{\top} \mathrm{I}$, David found ready acceptance for his rendition of the classic revival. Ile had studied in Rome. where also the brothers Aclam of England harl spent mucli of their early lives and naturally were interested in the restoration work in the buried cities. Thus the development which followerl Louis XVI in liance, as well as the contemporary period in England, was saturated with the Italian spirit.

The art was Pompeiian iciealized.
Empire, $1804-814$.

Following the Louis XVI period came the Revolutionary, from I793 to 1795 ; then what is lnown as the Directoire, I795 to 1804 . This period, properly called the Transition, carried the delicate Pompeiian classicism of late Louis XVI into the more masculine type of the Empire.

It was a period that frowned upon all that was of royal suggestion, and designers and decorators en-

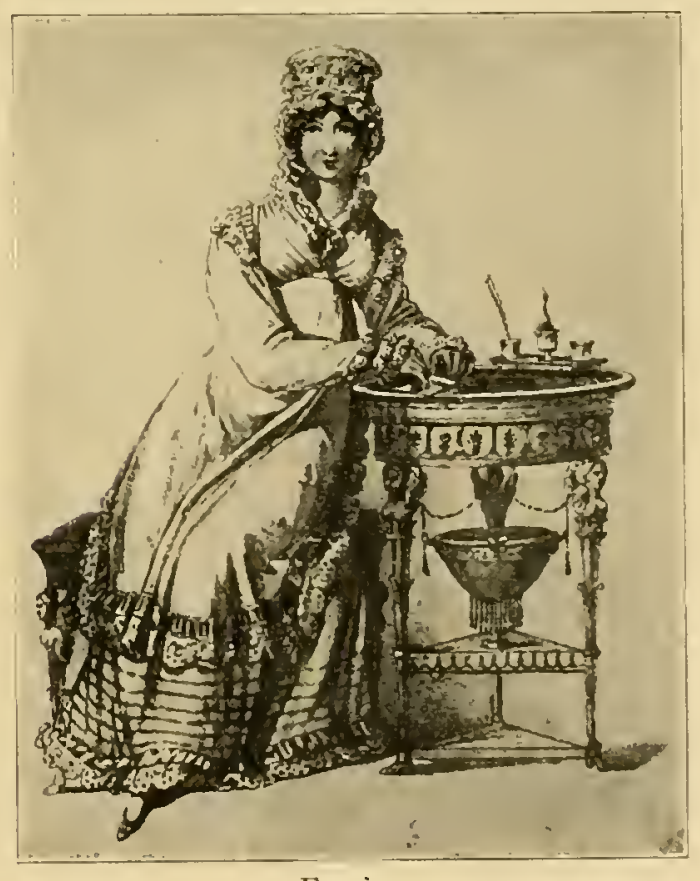

Enpire. 

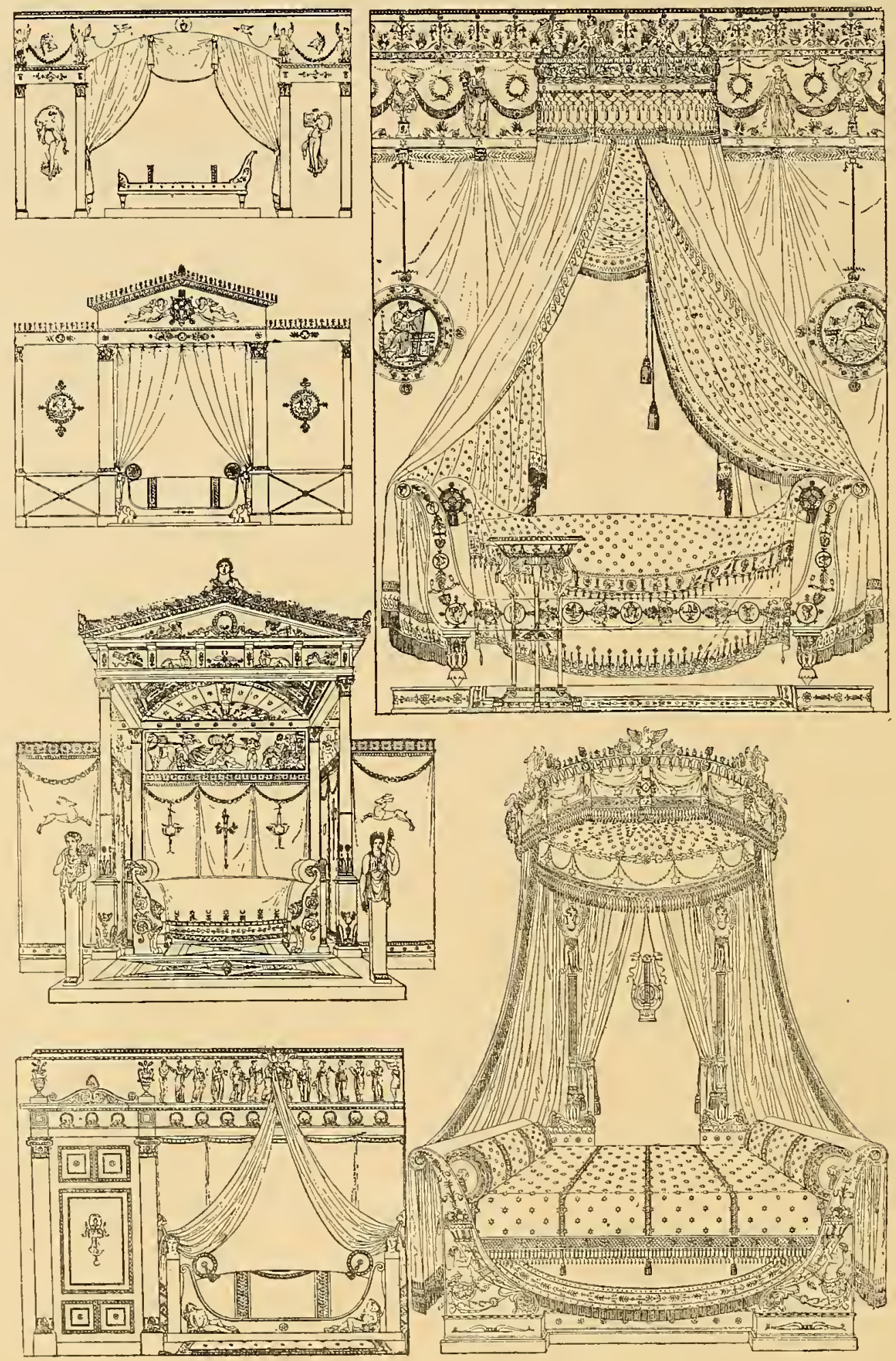

The Classic Inspiration in French Transition, Empire and Adam. 


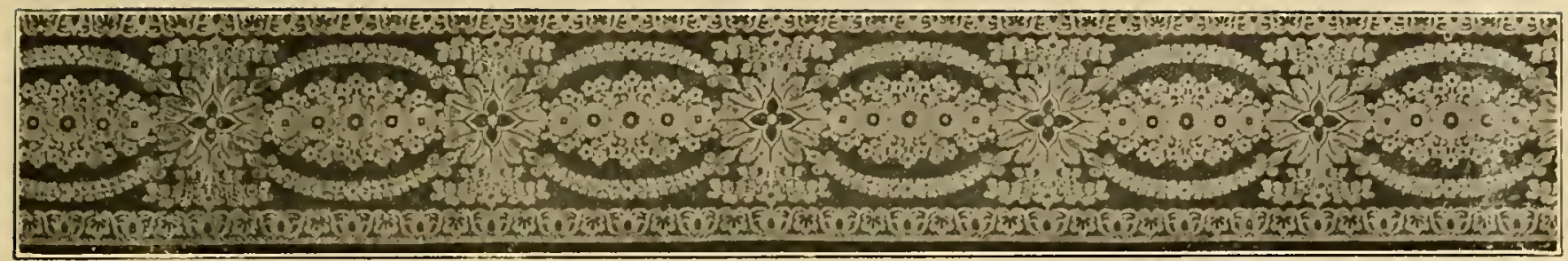

Empire.

deavored to procure a style essentially new. The ebony, with brass mountings. Sometimes the wood Transition periou was largely Roman; but witlı Napoleon we had not only the inspirations of Italy but Egypt. In woolwork there was little or no carving. The decorative motifs were classic applicunés on massive frames; the wreath and latrel branch. the torcli, Napoleonic bee and crown became conspicuons; winged figures were popular as emblematic of liberty ; heads of helmeted warriors, troplies of lances surmounted by the Phrygian cap were significant details.

After the Italian and Egyptian wars the Frencl adopted boldly all that was significant of conquest. Occasionally we find the sphinx carved into the arms of the chairs, a reninder of the French expedition in Egypt.

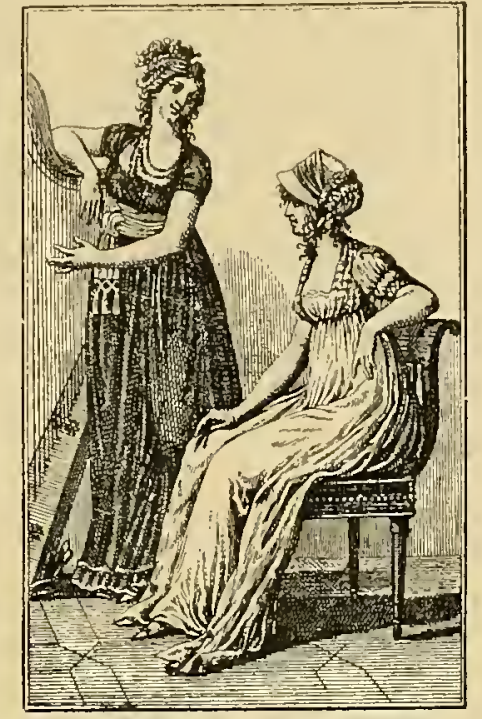

Directuire. was inlaid. Vases found in tombs were introducerl and the panther's muzzle and claw and other chimerical devices were introduced.

In some cases Egyptian and Roman examples were copied without alteration.

It was a style that was massive, ponderous and ostentatious, and may be broadly designater as modern classic.

Examples of ceremonial work are apt to be pompous, but private work along the Empire lines was usually no more affected by what might be called national motifs than American home decoration is influenced to-day by the star spangled banner or the spreading eagle. While it is true the flambeau and wreath are char-

The furniture was of mahogany, rosewood and acteristic of the Empire epoch, their absence is not in-

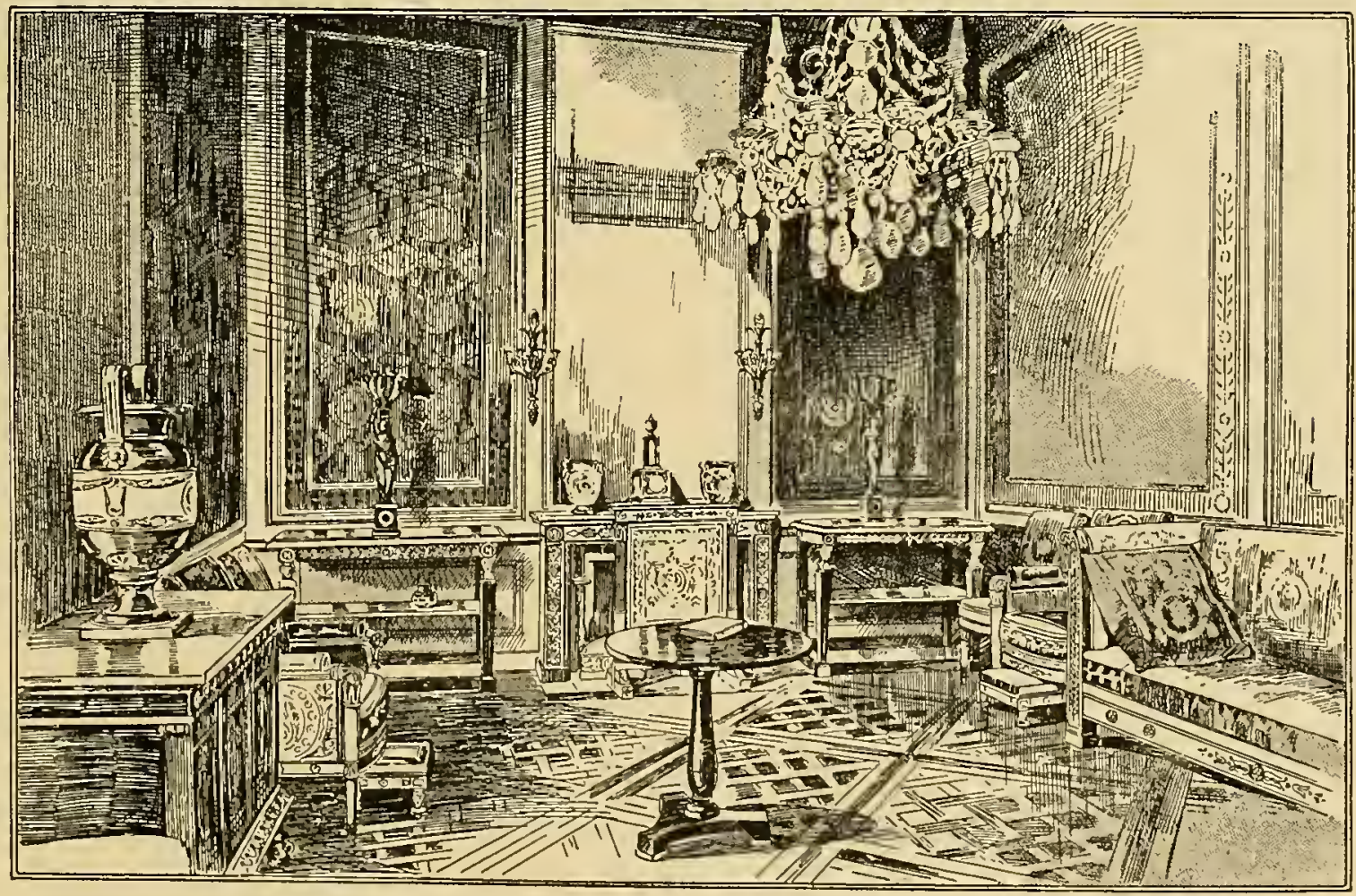




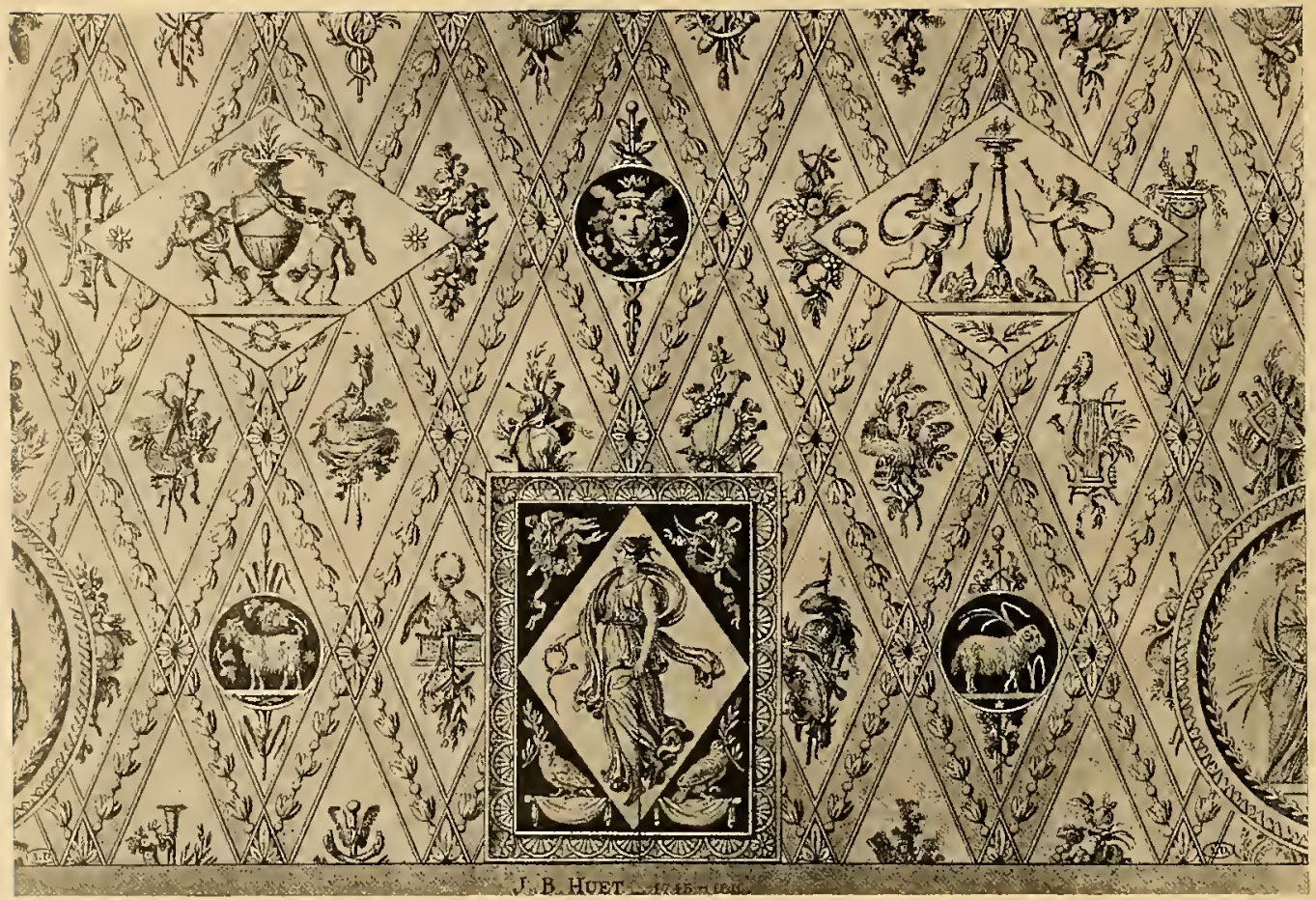

A Juur Priar.

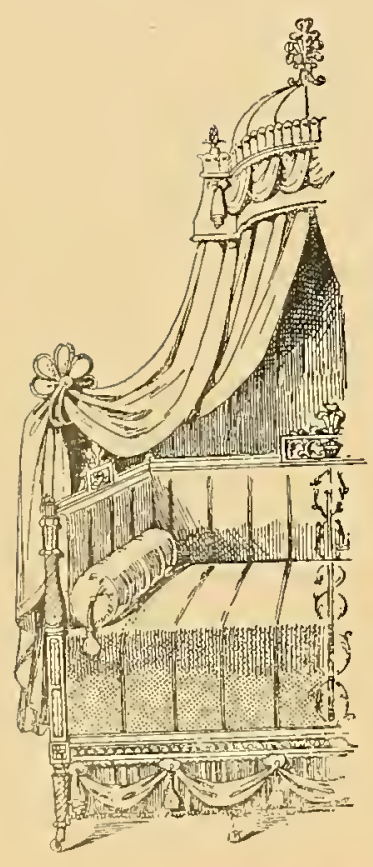

consistent with pure Empire decoration. The spirit of the Empire was largely influenced by a revival of the more dignified and pompous characteristics of Roman ornament, and its detection depends on the stately assembling of various decorative units in orderly and oft-repeated forms as distinguished from the more connected and elaborate ensemble effects in class:cism characterizing the Directoire style.
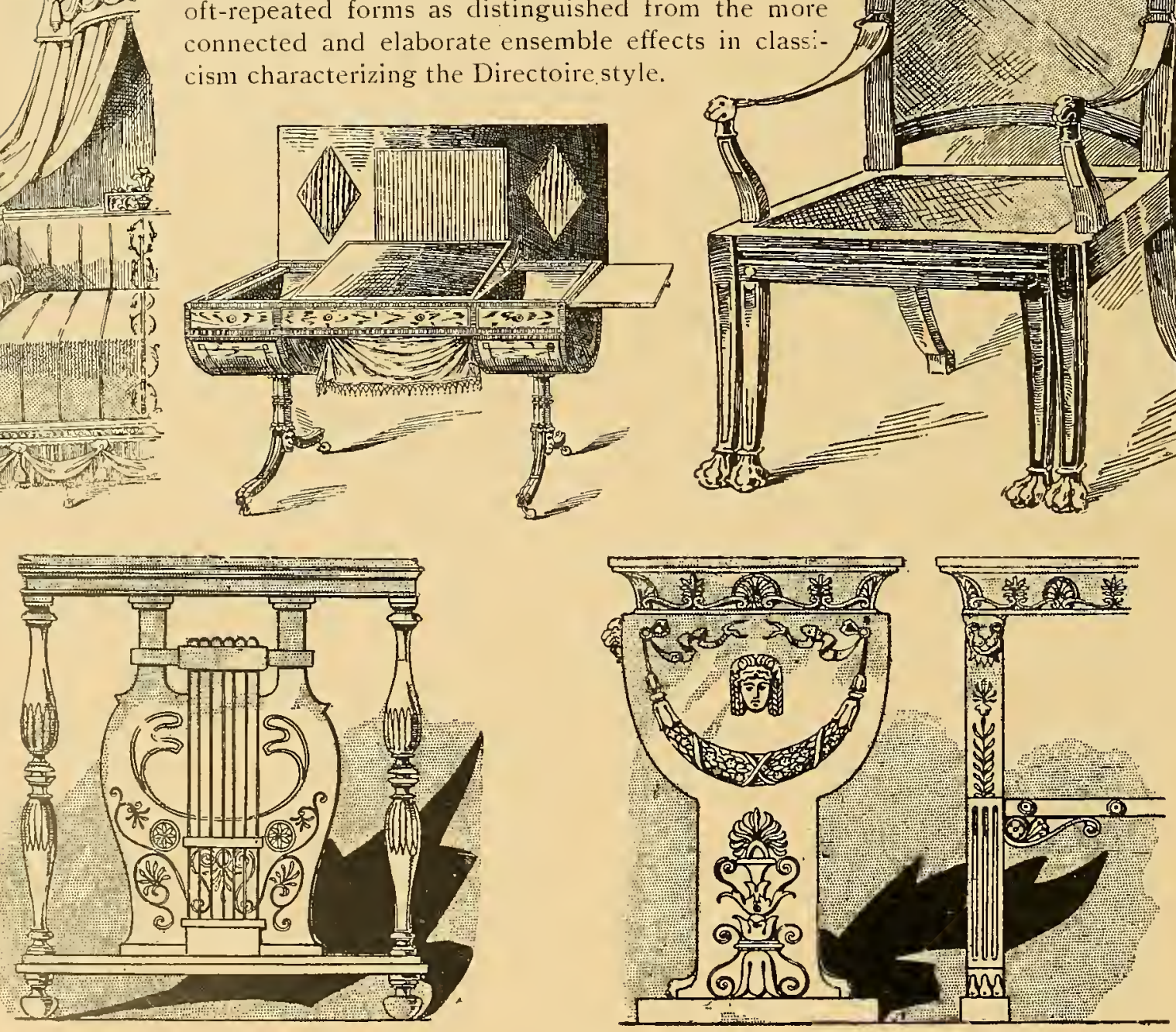


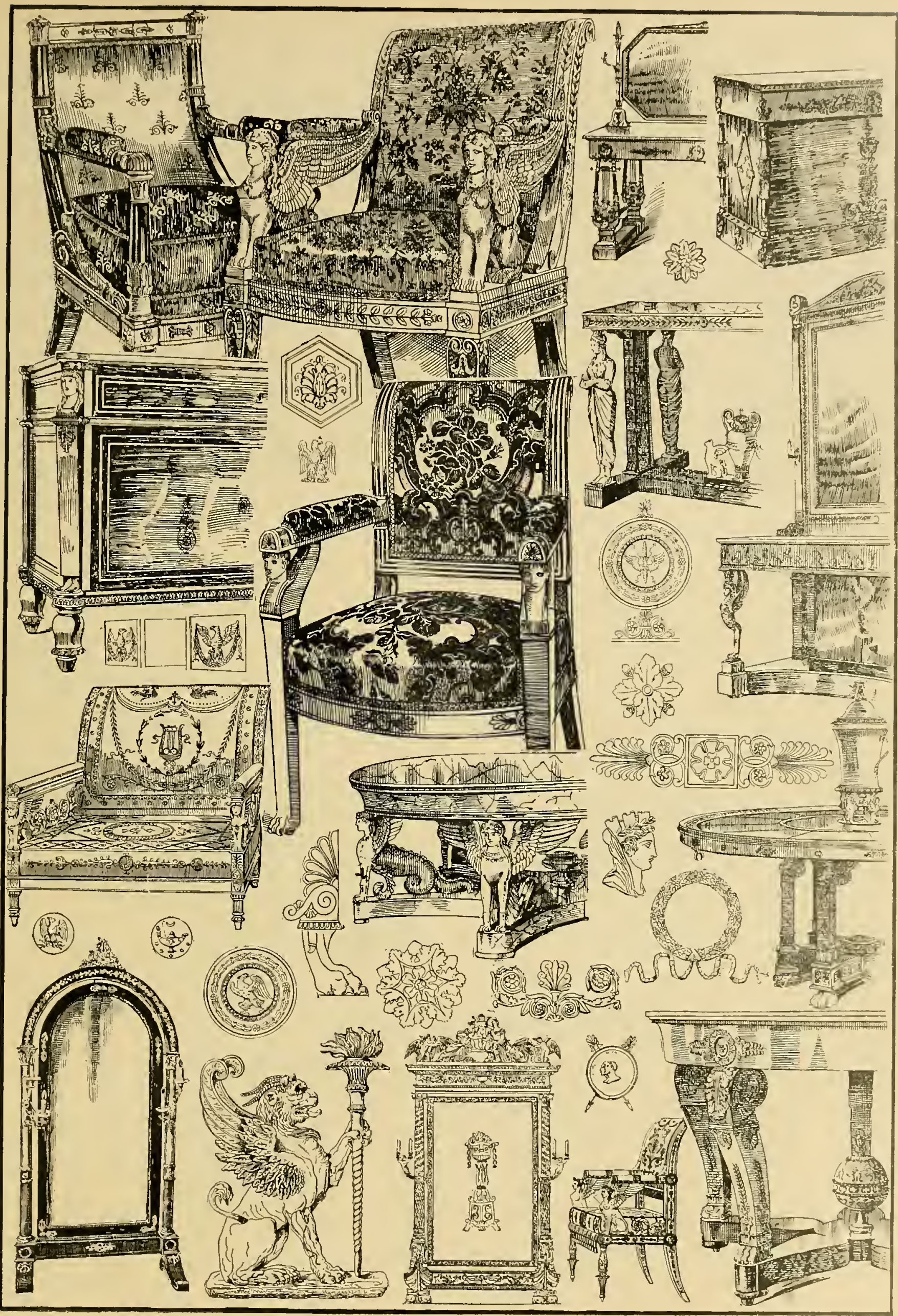



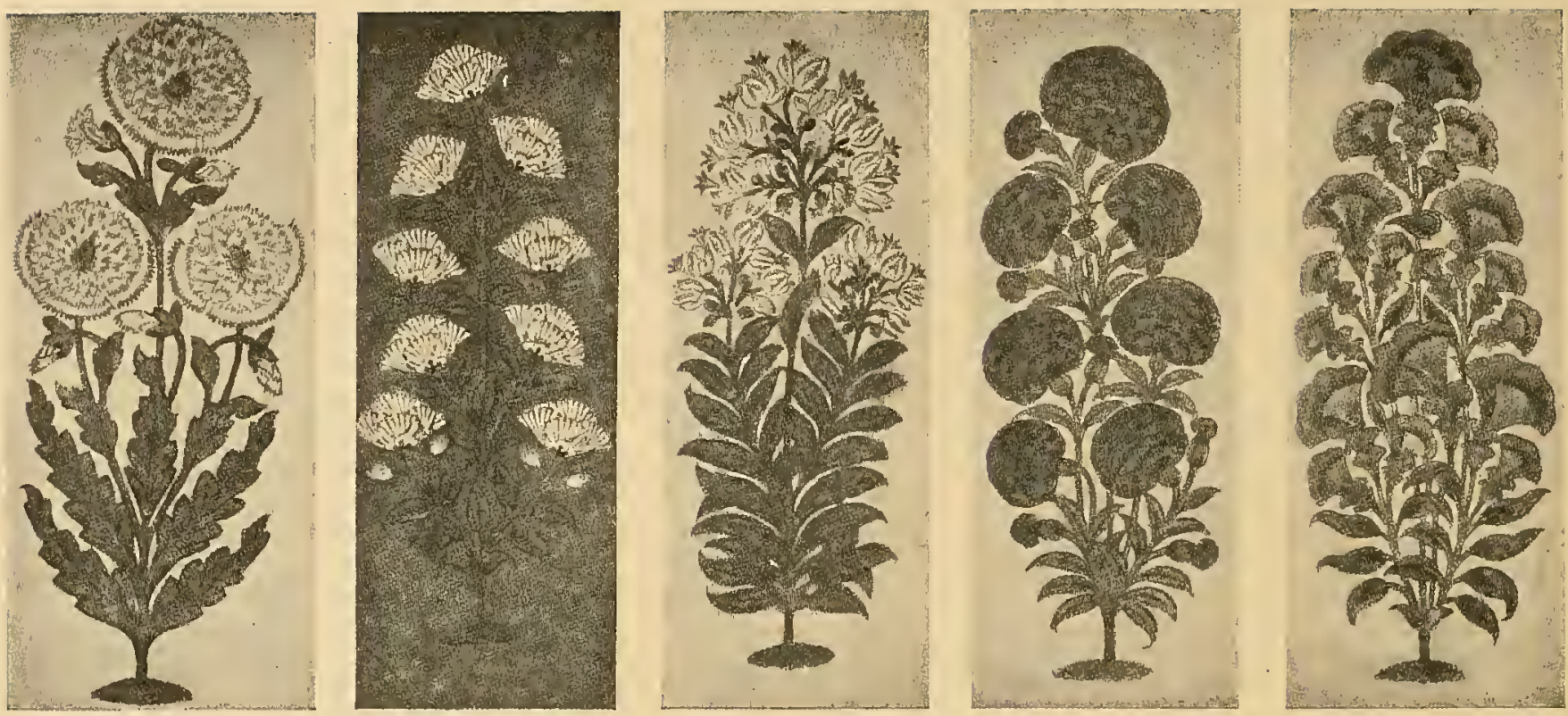

Examples of exquisitely-colored floral motifs, Indian.

\section{PRINTED FABRICS A N PAPER}

W

HEN one thinks of the steam-driven, mechanically engraved cylinders of the modern print factories, it seems incredible that so much could have been achieved by the primitive methods of the Persian and Indian printers, who in the late Seventeenth Century supplied all Europe with chintzes and calicoes.

There is no doubt that color printing was known to the early Eg y $\mathrm{pt}$ i a n s. Persians, and Chinese. Ancient Mosul in the early Christian Era was f a mous for its muslins; and colored fabrics. printed, as well as painted, were used in Europe at an early age, impossible to fix definitely by any reliable data. Block printing on fabrics was undertaken in Italy during the Thirteenth

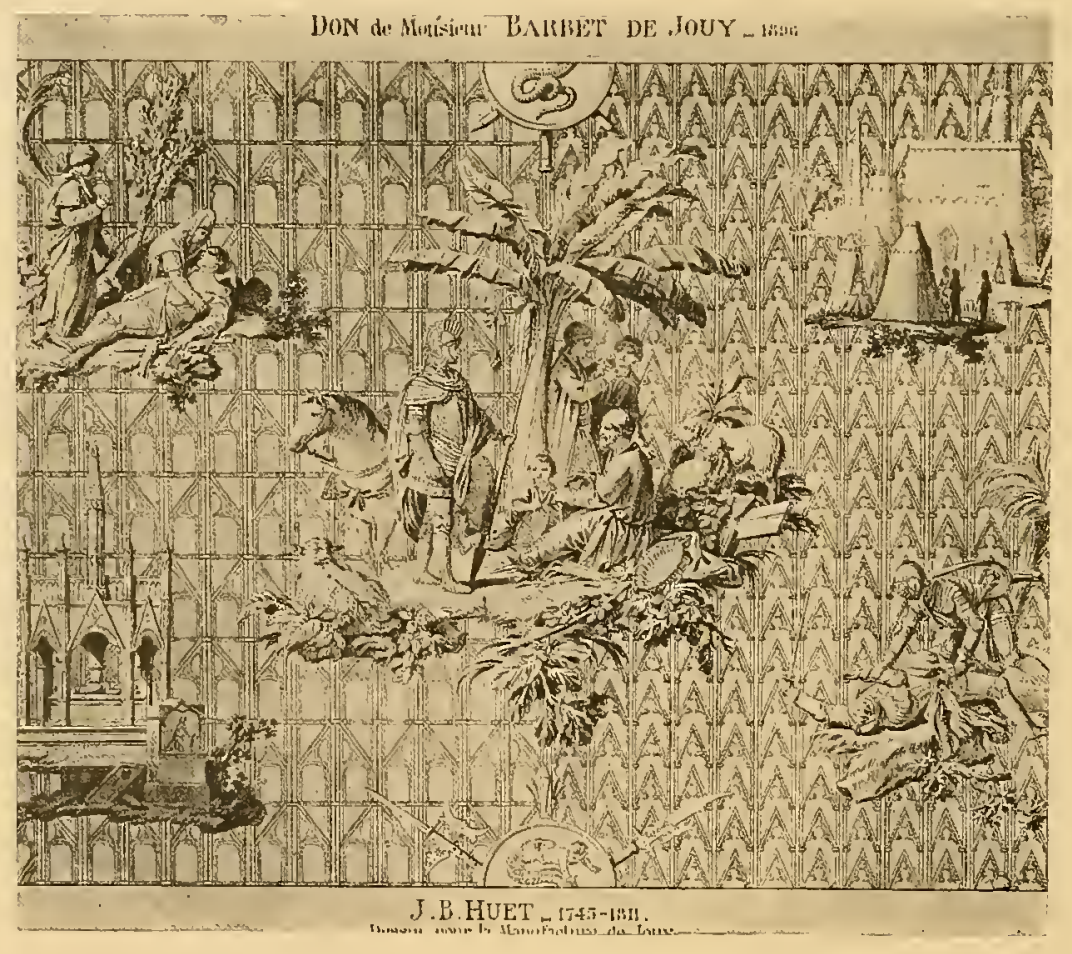

Toile de Jouy, engraved lrom museum example.
Century. In the Fourteenth Century printed linens were macle in Flanders.

Painted cloths with stories or legends came into use during the time of Henry IV, England, early in the Fifteenth Century; some of them were intended doubtless as models for tapestries; at a little later period they were dyed and painted, possibly stenciled and printed.

The Portuguese. early in the Sixteenth Century, I 530 , imported "painted" ha ngings from the East. but whether done by hand or by process and whether or not the term "painting" might now be regarded as printing, is a question. It is a noticeable fact that the French name for the early imitation of chintz was Perses, undoubtedly relating to the Persian 

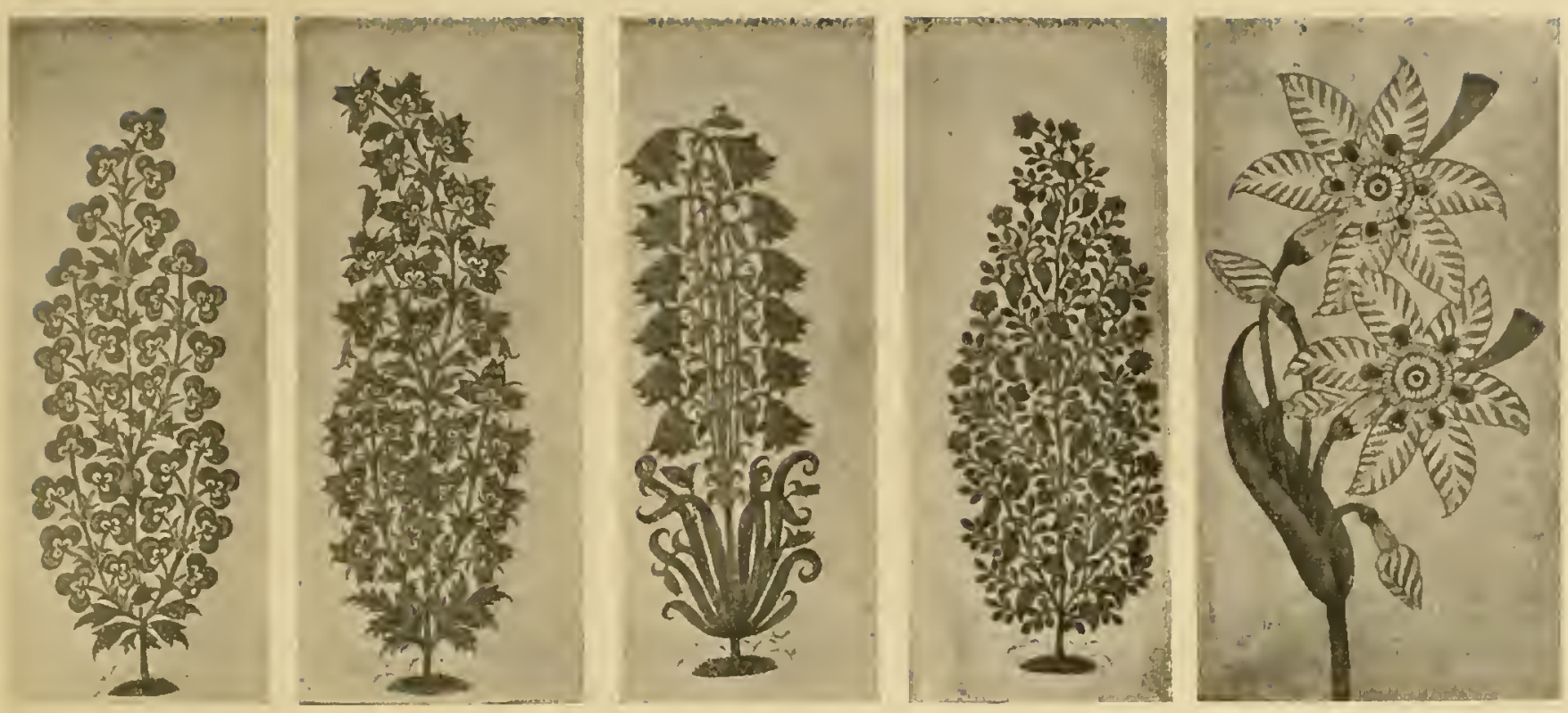

From an Indian cottun-printer's book of patterns.

origin of chintz, a fact reasonable to conclude when you consider that Persia was open to commerce at a period a little earlier than India or China.

While we are accustomed to examples of extraordinary richness of furniture and fabric during the reigns of Louis XIV and Louis XV-years of great decorative wealth-it is a fact little known that printed linens or painted linens, commonly called India prints, became so poptular in France and threatened so seriously the prosperity of the silk trade that many French factories took up the manufacture. and Colbert, to protect his pet organization, prohibited in I686. $11 \mathrm{ndler}$ pain of severe penalty, cither the manufacture or importation of printerl linen. Nevertheless they were $m$ a $n u f$ a $c$ tured clandestinely: and persistcutly: n11 il finally the anthorities instituterl a plan of searcling for and hurning everything in the nature of a printed linen.

But the popularity of the fabric was too much for the law to cope

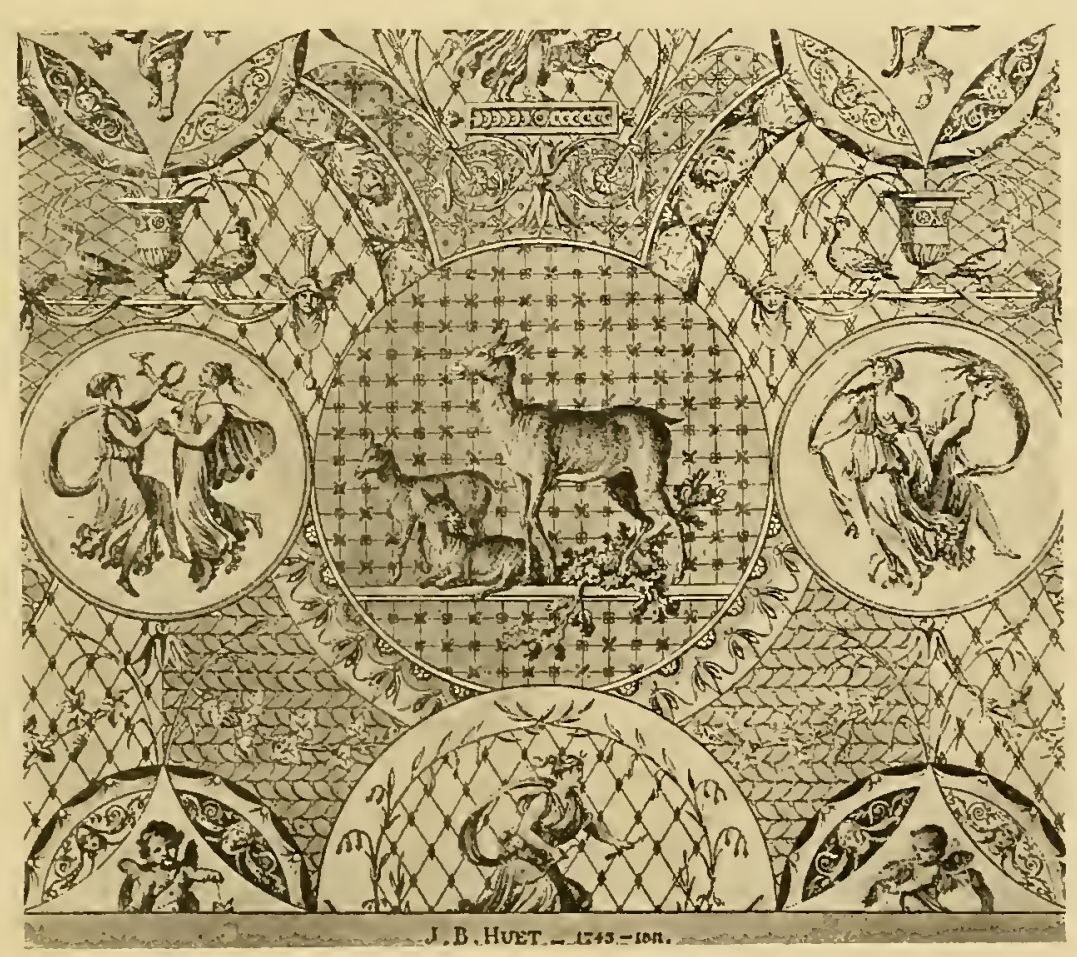

Intricate design worked out in colors; Jouy, 1745-1811. with. Even Madame Pompadour herself had her chatean at Bellevue decorated with contraband prints.

The term "painted" linen is often confusing. In 1759, when the French ministry decided to authorize the manufacture of linens and cottons, the French industry may be said to liave started, because lieretofore all that was done was done surreptitionsly. By 1789 a hundred factories were in operation and Clyristopher Philip Oberkampf, a German, had developed some new methods at Jouy, near Versailles. He introduced the "resist" method. The pattern was printed and the $n$ the whole fabric was dipped in a dye; a deep red, for instance. Again the fabric was submerged in an acid bath which withliew the red color wherever it toucher the lines of the chemically printed design, leaving the natural linen color. But at the beginning of the industry they knew only one mode of printing-that of the Orientals. $\quad \mathrm{T}$ h $\mathrm{e}$ linen was laid on a table and the workmen pressed upon it by hand a block of wood 


\section{PRINTED FABRICS AND PAPER}

engraved with the outline of the design. The piece then passed through the hands of the brushers, or painters, who filled them in with a brush of various colorings.

More slowly did they conceive the idea of printing uniformly certain colors with the aid of second plates which overlaid the lines or the outlines of the first plate. In 1780 printing by copper plates made its appearance. They were deeper plates and finer.

By 1797 such progress had been made that by cylinder printing, which at this date was introduced, they were able to print in one day, on one machine, the work ordinarily accomplished by forty-two block printers.

And now began not alone the art but the industry of linen printing. The vast amount of material now turned out was naturally of the French Transition or Empire character. France, during the period of Louis XV and Louis XVI, was rich in printed linens and they were used in enormous quantities.

Paper in quantity or size was not made until the Twelfth Century, and even then $13 \times 26$ inches was considered a large sheet. The first mention of rag paper we find is in Cluny, II 22.

Nobody knows when the first examples of wallpaper were made in Europe, but if the record of Herman Schinkel, the Dutch printer, is correct-that he actually made wall-paper in Holland in 1568 , "printing roses and stripes on the back of common ballad paper and applying it as a covering for his attic walls," he was undoubtedly inspired by something he had seen or heard of, possibly by the cloth prints of early Flanders; passibly by the "Domino" papers of Italy or by the Portuguese imports, because it is fair to conclude that Indian or Persian papers had been introduced by the Portuguese traders following Albuquerque's settlements in Persia, I505. The Dutch were not active in the East until the downfall of Spain and Portugal in I6oo.

To be sure we have heard of Jehan Boudichon and his fifty rolls of wall-paper for the King's bedchamber in $\mathrm{I}_{4} 8 \mathrm{I}$, but they were not rolls as we understand the term; at that time paper was made in squares about $36 x_{5}$ inches. Continuous lengths were not made until I780-I800. The Boudichon papers were scrolls and not fastened to the walls. We have heard of colored papers for decorations at the time of the entrance of Louis XIII into Lyons in 1507. They were pictures on paper not applied to the wall, but loosely hung.

The term "domino" was Italian and used in Italy in the Fifteenth Century in relation to marble prints. At first the paper was used only for box linings and was usually stained irregularly, but French taste introduced arabesques and finally figures and the manufacture continued steadily and developed eventually to papers of larger size, and we have record, 1586, of marbled papers and papers of all colors, and printed with figures.

By I700 there was hardly a house in Paris that did not utilize this domino work on walls or screens. They were printed from blocks of pear wood, finished off in distemper colors, or dusted with powder, or finished with a flock in imitation of flock cloths, sometimes referred to as velvets. In 1787 we find a decree of the King declaring that the art of painting and printing paper used in furnishings was a dependence of the governing board of the Merchants-Papetiers-Dominotiere-Feuilletinere, which shows that the term "domino" still clung.

We take exception to the theory that the Chinese were the first makers of wall-paper or that the Dutch were the first importers. The fact that a printer in Delft made paper in 1586 predisposes one to believe that something of the sort lad been already introduced. Indeed we know that "domino" papers were already made in Italy. However, Chinese trade had not been open at that early date, but the Portuguese early in the Sixteenth Century traded in Persia and India. There is no authentic record of Chinese paper until the reign of Louis XIV, I643, when we began to hear of "pagoda" paper for walls.

Towards the middle of the Eighteenth Century wall-paper manufacture began to develop in France and England. It is probable that the first factory was set up in France in $17+6$. The industry thrived, but Chinese papers continued in popular use. Some of them, highly artistic, were utilized by the wealthy classes. Exquisite compositions of foliage and flowers, birds and butterflies, landscapes, water and sky scenes, the work of the Japanese as well as the Chinese. The paper was printed upon squares; continuous rolls were not undertaken until about I790. The perfected process was patented in England about 180o, but our American records show that paper made in the roll was advertised in this country in 1790 . There is no reason to assume that we were behind the times; there was wealth in America and the wealthy classes, even at this early date, enjoyed the latest luxuries from Europe.

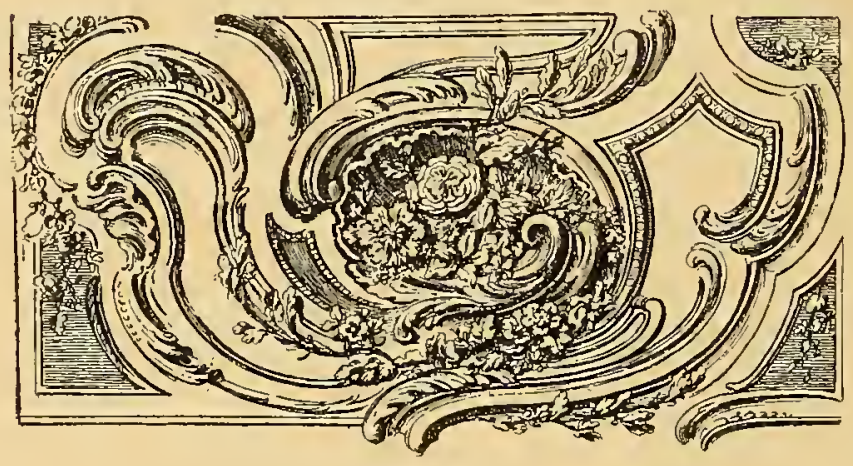

Rococus 


\section{QUEE N A N N E, $1702-1714$}

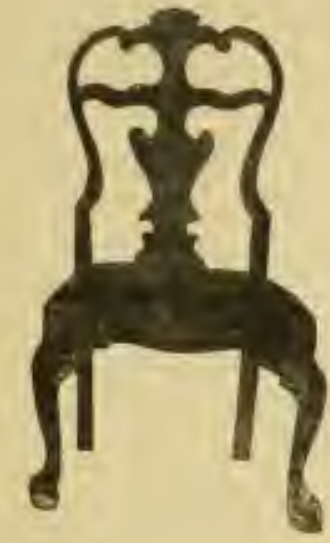

Hugarth type of Queen Anne chair.
$W$

HILE the term Quecn Anne begins naturally with the reign of Queen Annc, I 702, it had its inception with the close of the Jacobean. II'c have illustrated already a number of examples of late Seventeenth Century English furniture, which brings us up to the period 1702. The influences of L.ouis XIV were disseminated both in Holland and England by Marot and other French artists, who had fle d i 11 I685 at the time of the Revocation of the Edict of Nantes. Unlike the turned work, the bulbous forms of the periods from Charles II to IVilliam and Mary, we have the terminals, the cabriole leg, the stretchers and frequently the pediment forms of the French. The smooth splat is always a Queen Anne characteristic. The $\mathrm{smooth}$ stretcher instead of the carved and ornamented stretcher of the Charles II period was a natural development. There were probably no smooth splat-back chairs before i 700 . There was probably no smootl cabriole leg until 1702 .

While the canc clair was found in the begimning of Qneen Anne's reign it had becn identified with earlier work and was, subsequent to 1700 , succeeded loy upholstering of a substantial kind. Flat uprights were also used in the backs of the chairs which were now more comfortable than in previous epochs, being not only shaped to the back, but divested of carvings. The seat became broader and the top corners of the back were rounded. Shell details were conspicuous. The claw and ball finally came in about 1708 . To the comfort-giving qualities of the smooth-backed, fullseaterl chair were added comfortable upholsterings, and the grandfather chair became popular, a form that was begun as far back as I680, but was not developed to the full until well into the Queen Anne régime.

Double chairs or small sofas, called "love seats," were only wide enough for two. The sides were often in wings and when these wings extendęd very high they were called draught-chairs. The width of the chair seats at this time was due largely to the flaring voluminous costumes worn both by the women and the men.

As far back as 1680 we find many examples of record where the cabinetmaker has not used stretchers between the legs of his chairs, but one may say approximately that the use of stretchers was practically aluandoned by 1708 .

The tendency to simplicity of form expressed in the furniture was extended to other woodwork of the room. Over-door fitments were frequently of simple pediment type. The woodwork was in most cases walnut. There are records of mahogany as early as 1708 , but its use was unusual. Gilt ornament and marquetry and gilt furuiture were common. A great deal of Chinese wall-paper and Chinese and Indian prints were used.

Conmercialism prevailed to an extraordinary degree and both the Dutch and the English East Indian Trading Companies were active. At this period America naturally felt the effects of this commercialism and the colonies were saturated with the Queen Anne spirit. Indeed to appreciate fully the Colonial furnishings at this time one must understand the Colonial relations with the mother

country, for while many American cabinetmakers, upholsterers and decorators thrived in the larger cities of the new country they accepted the fashionable dictates of Europe and conformed to the contemporary styles.

While much Colonial furniture approximaterl the Queen Anne type, the same is true also of practically the entire Georgian period, so that any attempt to fix Colonial by its resemblance to Qneen Anne alone is apt tn be misleading.

Queen Anne Highboy.

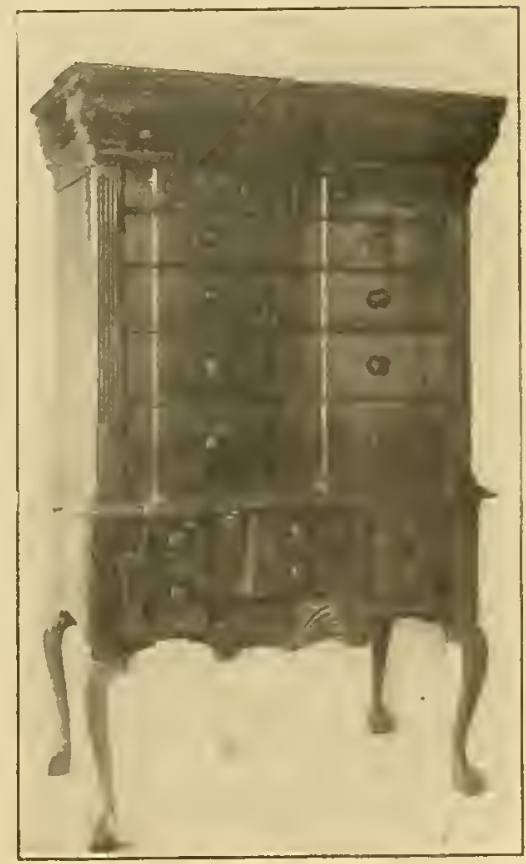




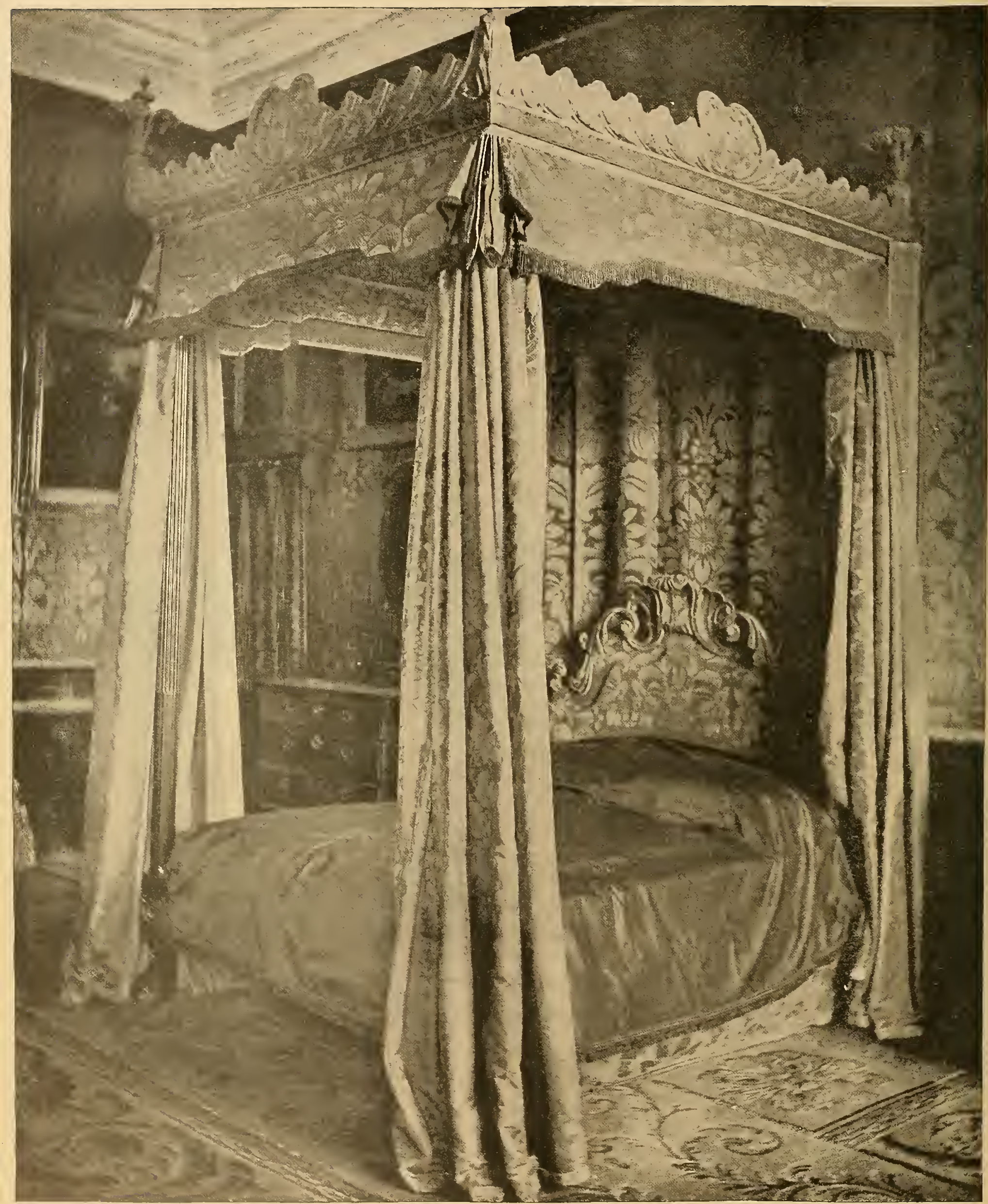

IN THE Q UEE N A N N PERIOD. 


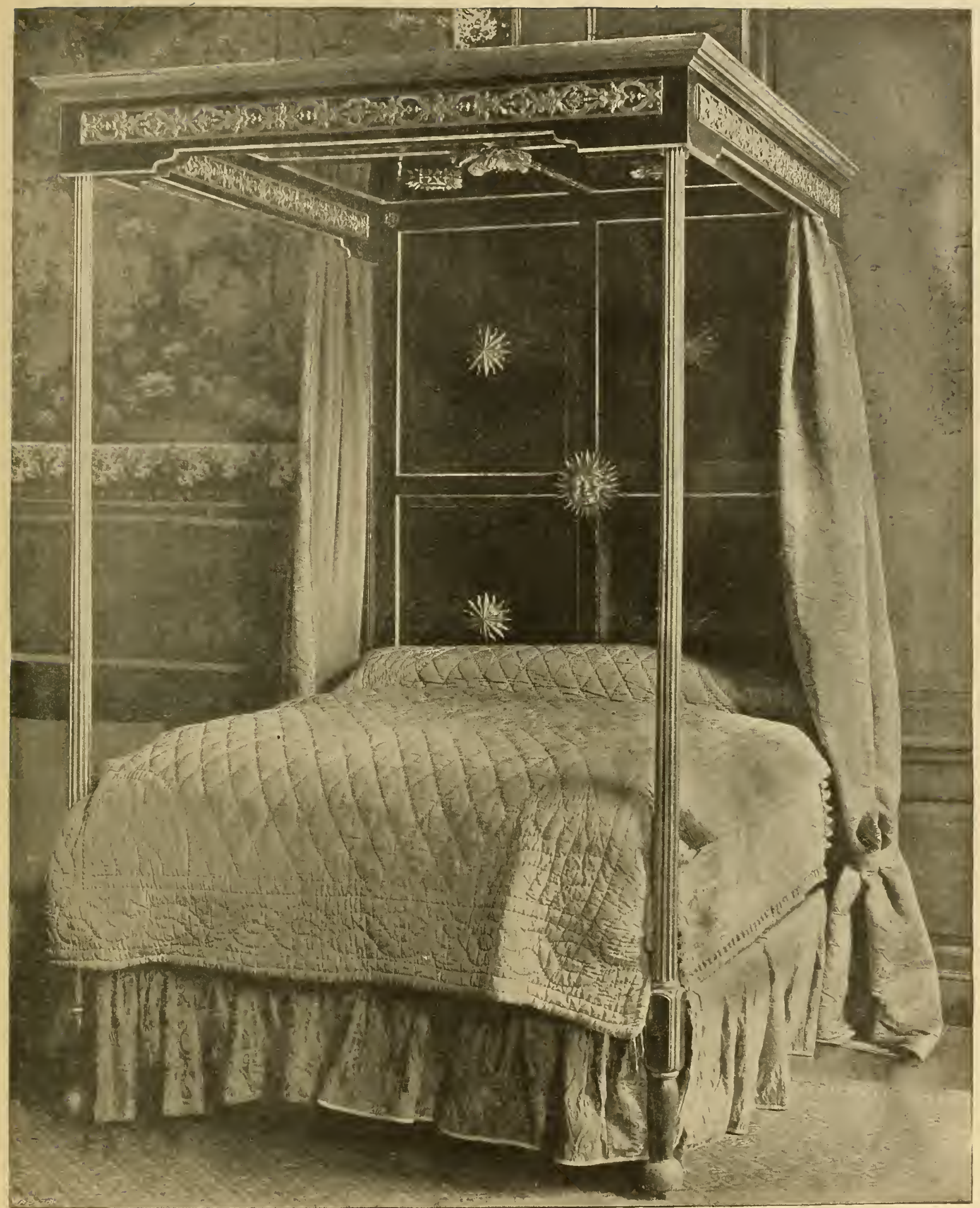

I N TH E Q UE E N A N N E P E R I O D. 


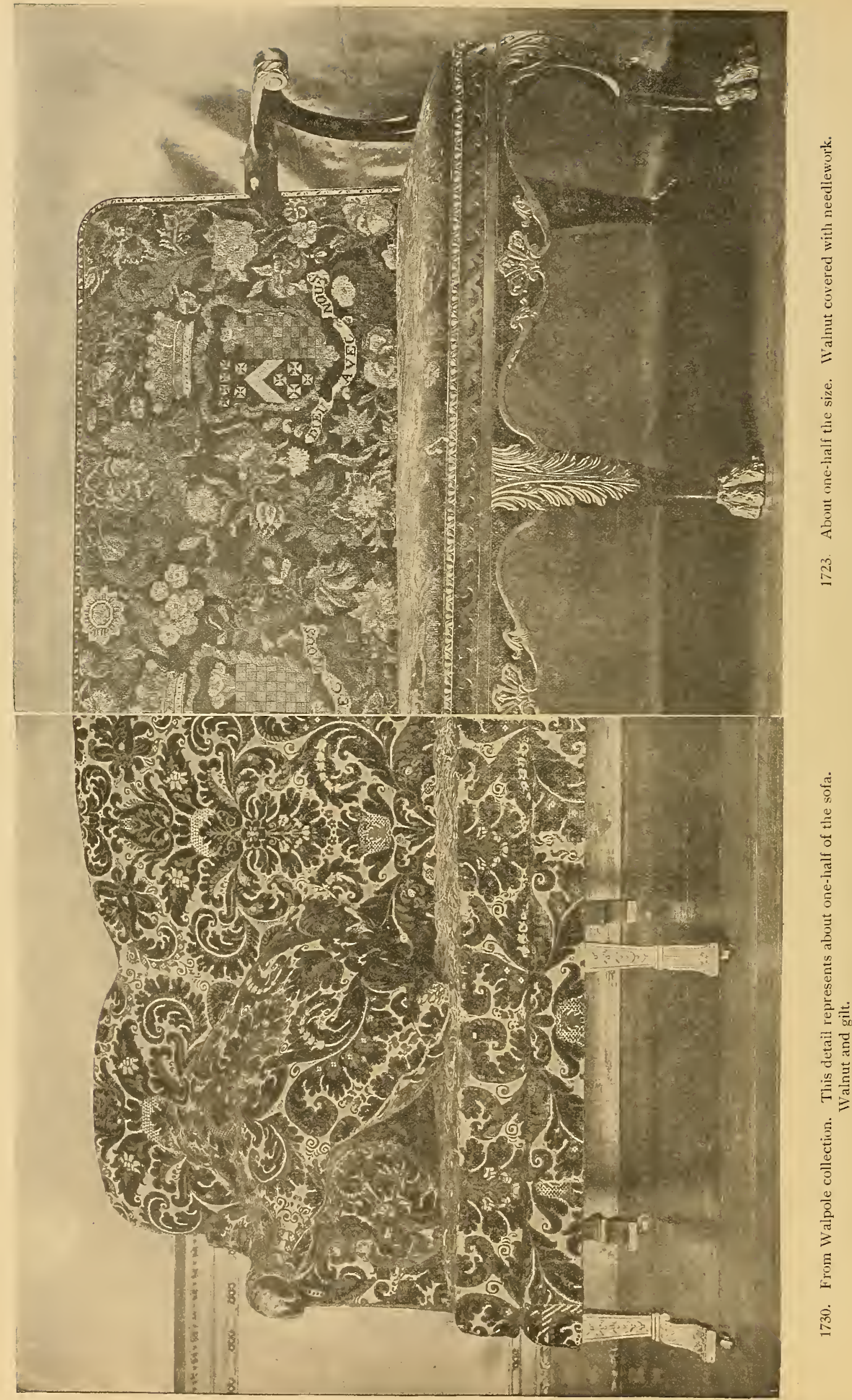




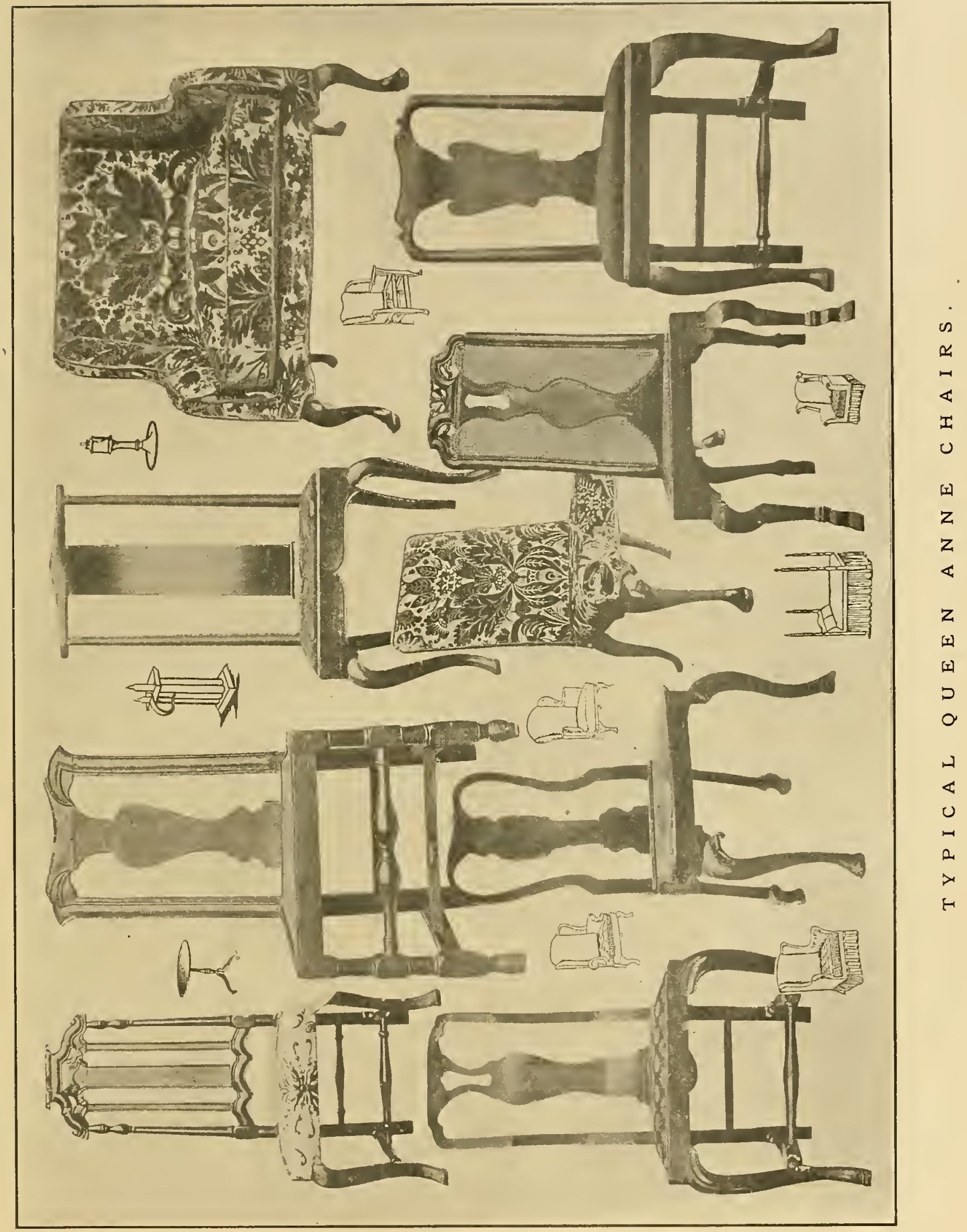




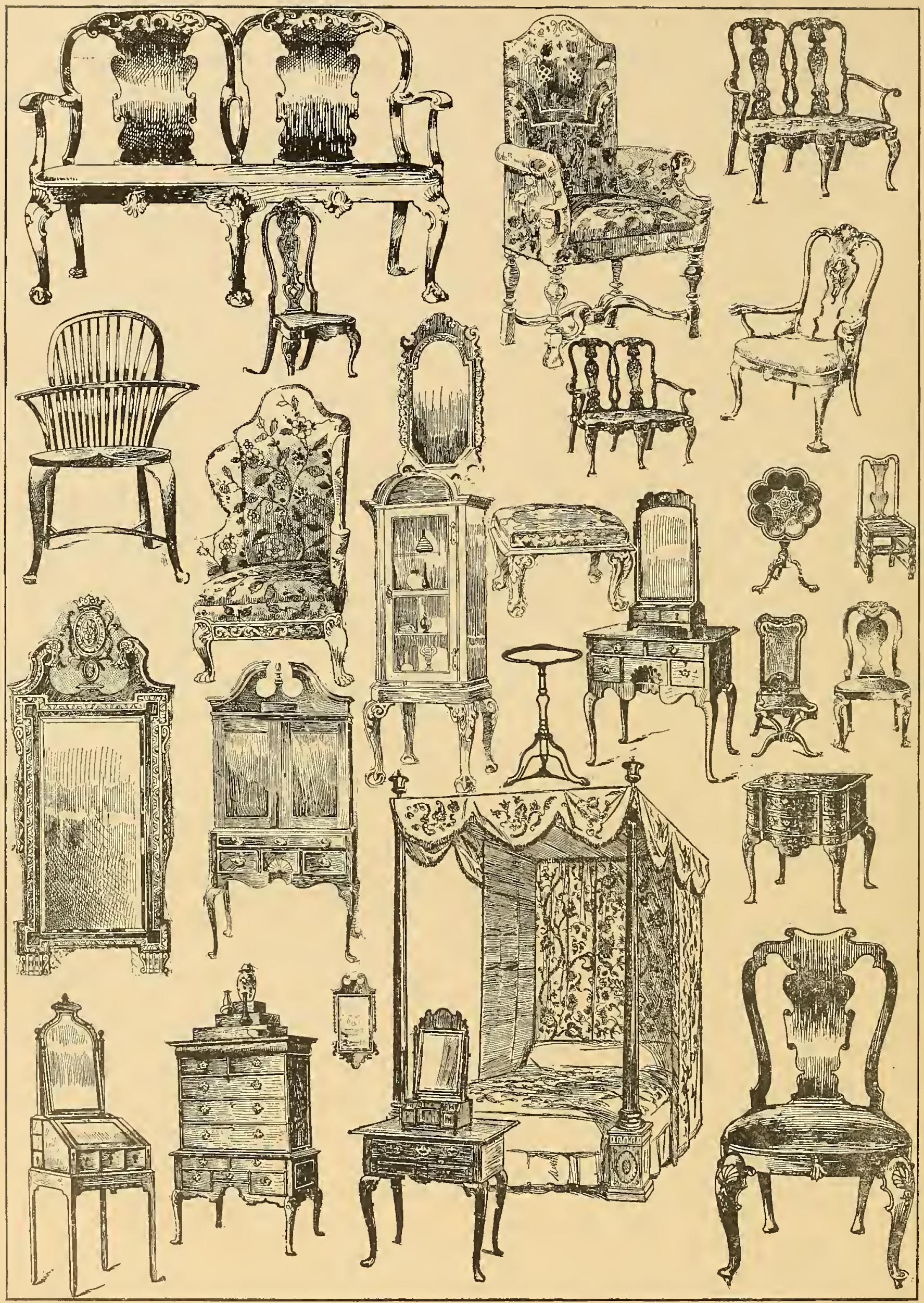



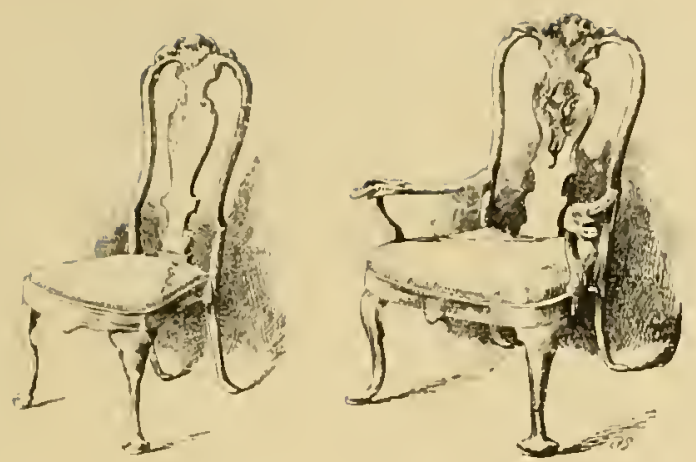

Queen Anne Chairs.

The term Colonial means anything from Tacobean to the end of the colonies and even beyond.

Indeed for a quarter of a ccnti1ry after the close of the colonies we have a refinite style. called late Colonial or sometimes Jeffersonian, that is simply a reflection of the French Empire, the same type being adopted in England by Thomas Hope. The term Colonial covers a wirle range of thought.

It was during the Jacobean period that the first settlers landerl in New England.

During the s $n$ m m o nwealth periorl of $1653^{-}$ I 659, Virginia and $M$ a $r y$ a d 10 profiter by the Royalist classes, out of power in E. $n$ gl and and many of whom we re in exile.

During the Oueen Anne pe-

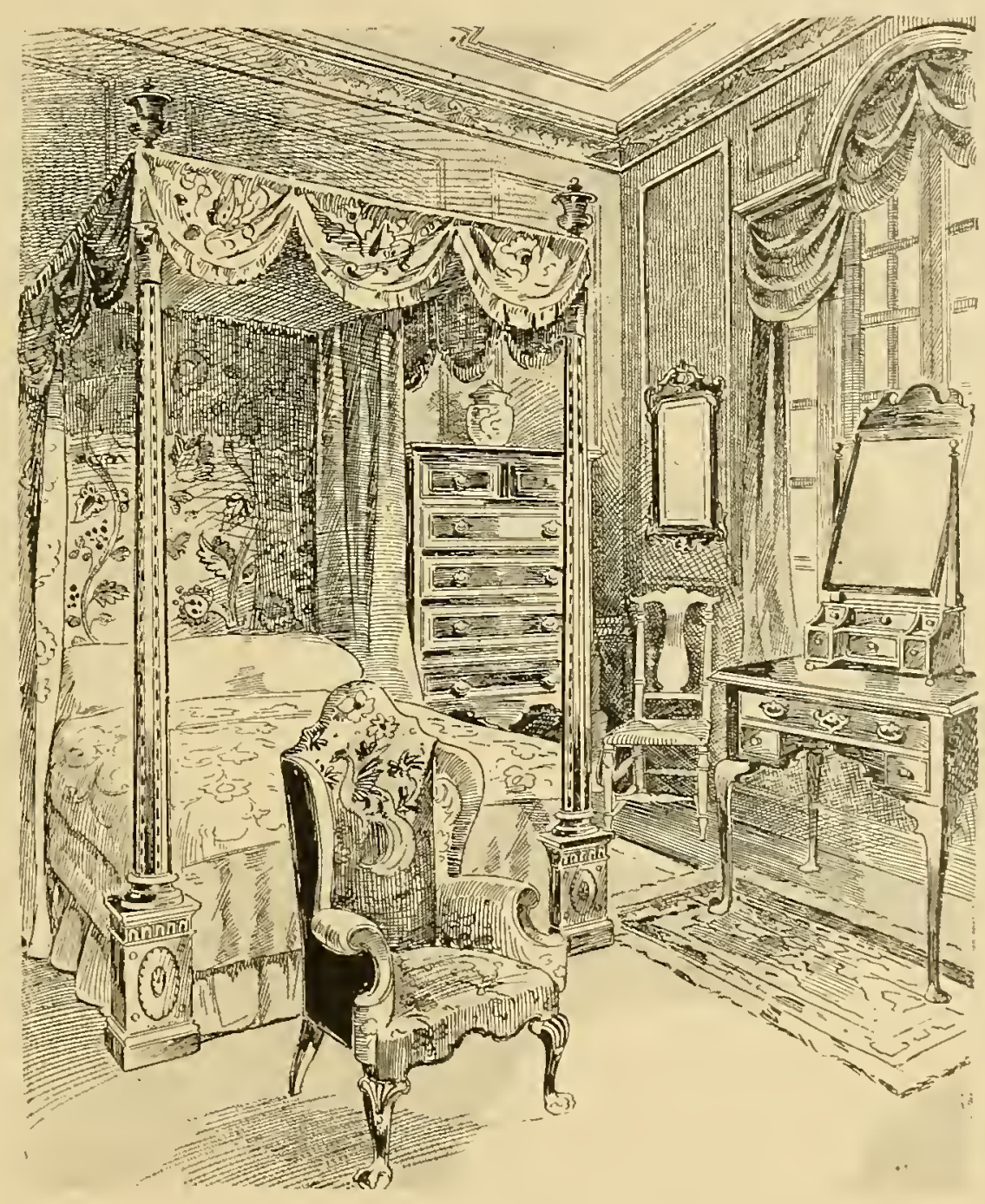

Queen Anne interior, showing characteristic furniture and draperies, riorl, whicls may be said to have had its inception with Charles II, 1660 ,
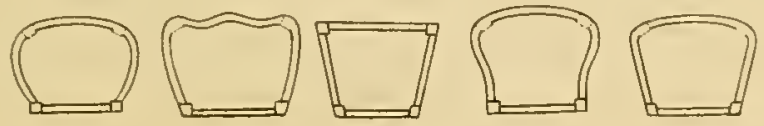

[175]

ropean chronology and fix pretty definitely the character of the Colonial style.

On the left, Oucen Anne chair seats. the English laws restricted . Mnerican improrts to England, and a great deal of liast Inclia gonde came into this country through English channels.

In 1685 the edict of Nantes caused French emigration, hut it was not mntil later under George III that the French spirit had any material infuence.

In considering the Colonial style we nust always analyze it. We must determine always date and locale. The Cottage Colonial of New England, late in the Seventeenth Century, had nathing in common with the Ceremonial Colonial of the late Eightecnth Century. The styles covered a period of two hundred years We copied from the English, the Dutch and the French. We benefited by the imports from L Lia, particularly from the East Indies, and l,eginning about the mirldle of the Eighteenth C'entury, from China. There was wealth here in many of the cities and a fashionable element that profiter by the best that Europe afforded. IJistory tells us of the progress of the American nation, and with the knowledge of the time and the classes we can tumn back to Eu-
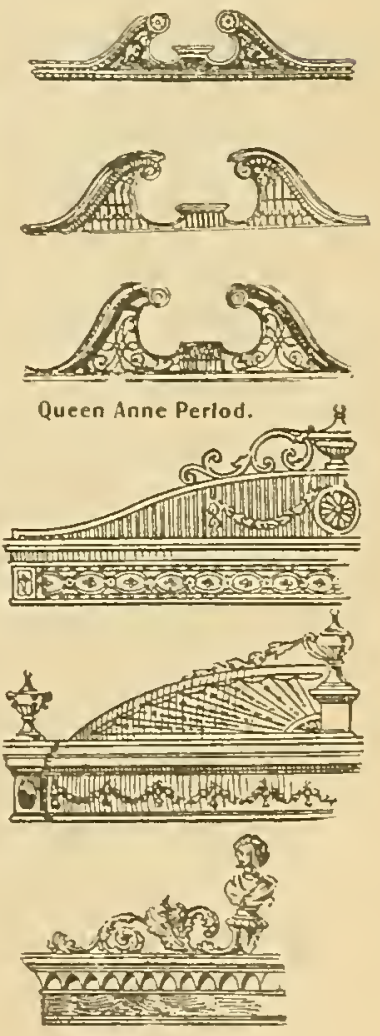

Georglan. 


\section{THE TRADES IN THE GEORGIAN PERIODS}

E ARLY in the century the gardens of the Emperor of China had been described by architects to assist the taste in landscape gardening. In I750 William Halfpenny produced a book of new designs for Chinese temples, triumphal arches, garden seats, and he says that at that time Chinese manner of building was already introduced in England with success. Another book, by Edwards and Darly, which appeared four years later, was overcrowded with Chinese suggestions, particularly frets.

The work of Mathias Darly belongs more properly to the post-Chippendale period because it was more in sympathy with the Adam school.

Were it not for the literature of the times, the catalogues issued by the various cabinetmakers and even the architects, we would know little of the subject.

We know that besides the great masters there was an organization called the Society of Upholsterers and Cabinetmakers, doubtless composed of many capable men. A volume issued by this body is undated, but probably came out before Chippendale's book, "The Director."

Horace Walpole's interest stimulated the public taste for the Gothic style and no book was complete without designs for Gothic furniture; the "Society of Upholsterers," published probably about I750, was full of Gothic suggestions.

Manwarning claimed that his book, published I765. showed the first suggestion for rural furniture made from twisted limbs of the yew and apple trees. Manwaring seems to have imitated all that was weak in Chippendale.

Ince and Mayhew published a book that seems like a caricature of the Chippendale style, and adopted all that was flamboyant and exaggerated. They illustrated card tables with places for counters and stands for candles.

The English architects, decorators and cabinetmakers from the time of Inigo Jones developed rapidly. He with John Webb, Edward Carter, and Nicholas Stone, expressed the Italian spirit up to Cromwell, I653. Sir Christopher Wren, Nicholas Hawksmoor, Sir John Van Brugh and James Gibb became famous up to and into the period of George I. From this point we can classify the great leaders as EARLY Georgian, Middle Georgian and Late Georgian.

\section{EARLY GEORGIAN.}

Period of George I, 1714-1727.

Hogarth, artist and critic, $1697-1764$.

Grinling Gibbons, I648-1721.

Sir Christopher Wren, 1632-1724.

Nicholas Hawksmoor, 1666-1736.

Isaac Ware, published "Complete Body of Architecture," I750.

James Gibbs, 1694

Sir John Brugh (contemporary).

Colin Campbell, published many books, I78 I, I795, I798.

Richard Harris, first connected the pendulum with a clock movement, I64.

Thomas Archer (contemporary of Kent).

Abraham Swan, published "The British Architect," 1745

William Kent, painter, architect and designer, I684-1748.

W. Jones, published "Gentlemen or Builder's Companion," I739.

Sir Robert Taylor (contemporary).

James Paine, 1725-I7\&9.

\section{MIDDLE GEORGIAN.}

Period of George II, 1727-1760.

Thomas Chippendale, 1708-I779; first known plates dated I753. His "Cabiretmaker's Director" came out in I754, I759, I762.

Robert Manwaring, published book, 1765 .

Edwards and Darly, published book, 1754 .

Ince and Mayhew, published their book, 1762.

Sir William Chambers, published book in 1760 .

Copeland, issued work I752.

Isaac Ware, best work about $1750-1756$.

Matthias Lock, issued books, 1752, 1765.

Thomas Jobnson, published volume of designs, I758.

J. Crunden, published books 1765,1770 , I776, 17966.

Milton (contemporary).

Josiah Wedgwood, fanous for placques and pottery, I730-I 795 .

Overton (contemporary).

Francesco Bartolozzi, born izio, removed to England I767.

Mathias Darly, published his book 1754-1769.

William Halfpenny, issued a book on Chinese architecture and furniture, I750.

\section{LATE GEORGIAN.}

Period of George III, 1760-I820.

R. \& J. Adam published their first volume on Italian art, 1764 . First general volume of architectural details appeared in 1773 , reflecting the classic taste following the discoveries of Herculaneum and Pompeii.

J. Carter, followed Adam style.

Antonio Zucchi, painter (worked for Adam).

Society of London Cabinetmakers, 17701800.

Angelica Kauffman, ceiling and wood painter (worked for Adam).

Cipriani, Italian designer; worked in England, $1732-1785$.

Pergolesi, painter, I775 (worked for Adam).

William Clement, made first long clock case, 1780 .

Columbani, 1775 .

Sheraton, published great book, I79I.

Shearer, published book, i787.

Hepplewhite, published book, 1789 .

$\mathrm{N}$. Wallis, published books of ornament, 1771.

George Richardson (contemporary).

Thomas Hope, published book in 1807 .

George Smith, published book in 1808 I 826 .

Richard Gillow, r8oo; improvements and methods of table slides.

W. Thomas and Joseph Rose, painters. and decorators. 


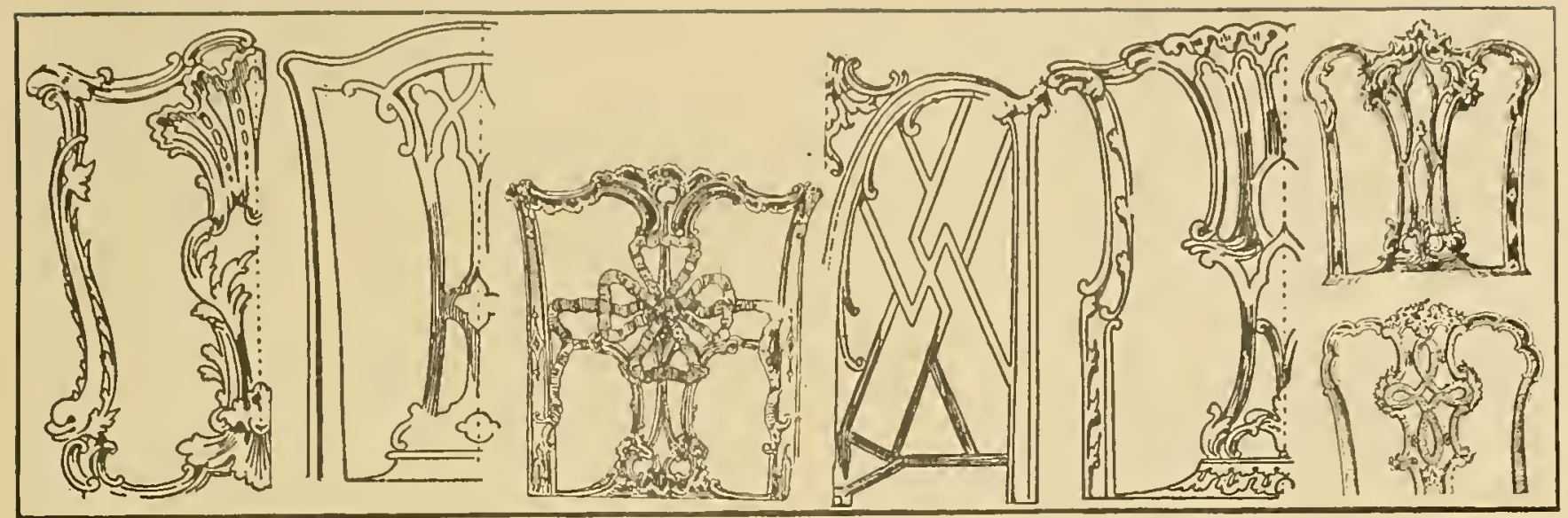

Chippendale chair backs.

\section{GEORGIAN-CHIPPENDALE-CHAMBERS}
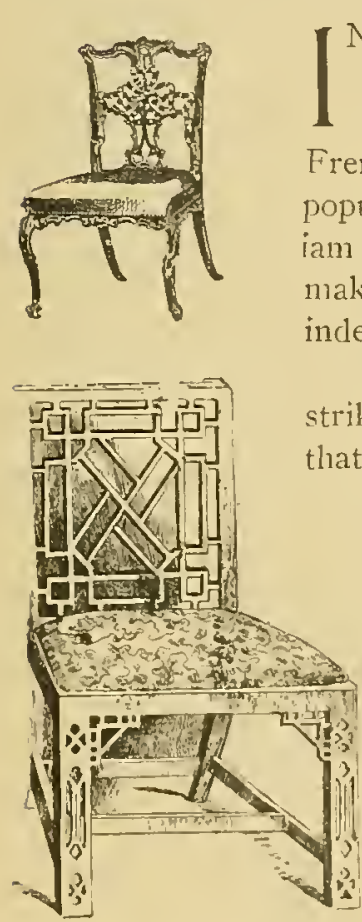

I THE reign of the early Georges, beginning I7 I t there

1 was a mania for everything French and for the Chinese motifs popularized in England by Sir William Chambers, to whom the cabinetmakers and architects were greatly indebted.

Chambers produced nothing strikingly new but adopted much that had gone before. He was decidedly un-English. He had made many voyages to East India and had spent much of his time in China studying the habits, customs and architecture of the people.

As early as 1757 Chambers described a Chinese room:

The side-walls are matted about thrce or four feet upward

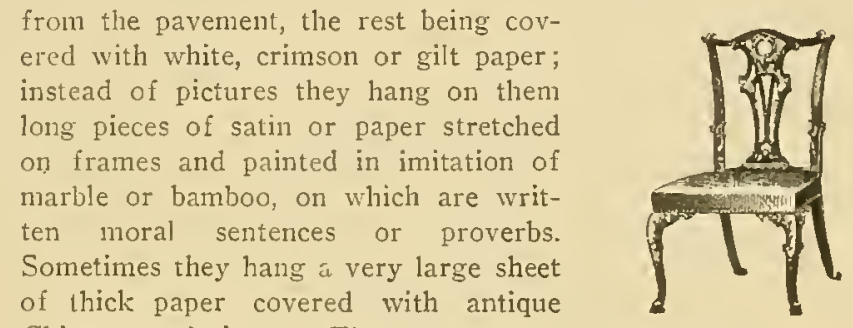

Chinese paintings. The mov-

ables consist of chairs, stools and tables, made sometimes of rosewood, ebony or lacquered work, and sometimes of bamboo only. When the movables are of wood the seats of the stools are often of marble or porcelain. In the corners of the room are stands four or five feet high on which they set plates of citron or other fragrant fruits, brancles of coral, vases of porcelain and glass globes containing gold

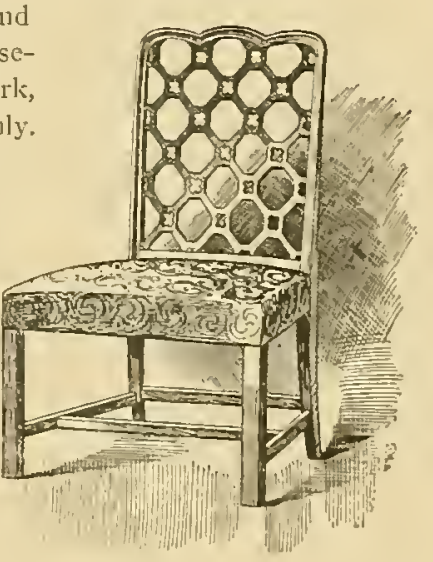

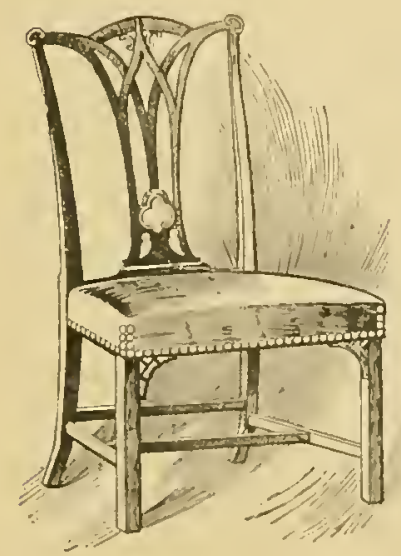
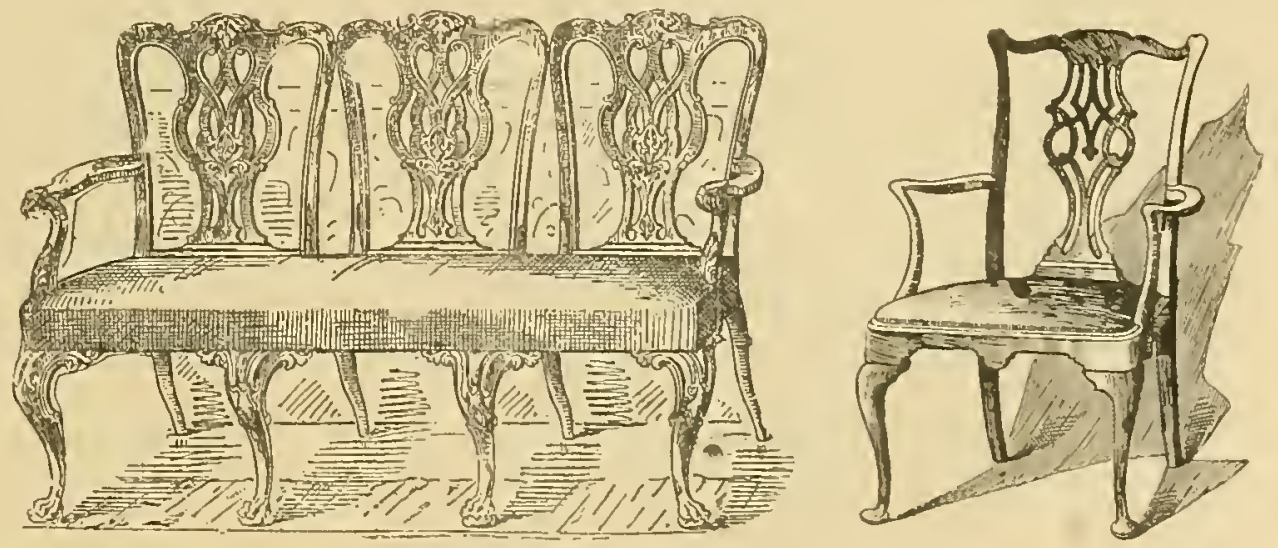

All Chippendale pieces. Square legs were made by Chippendale about 1750. 

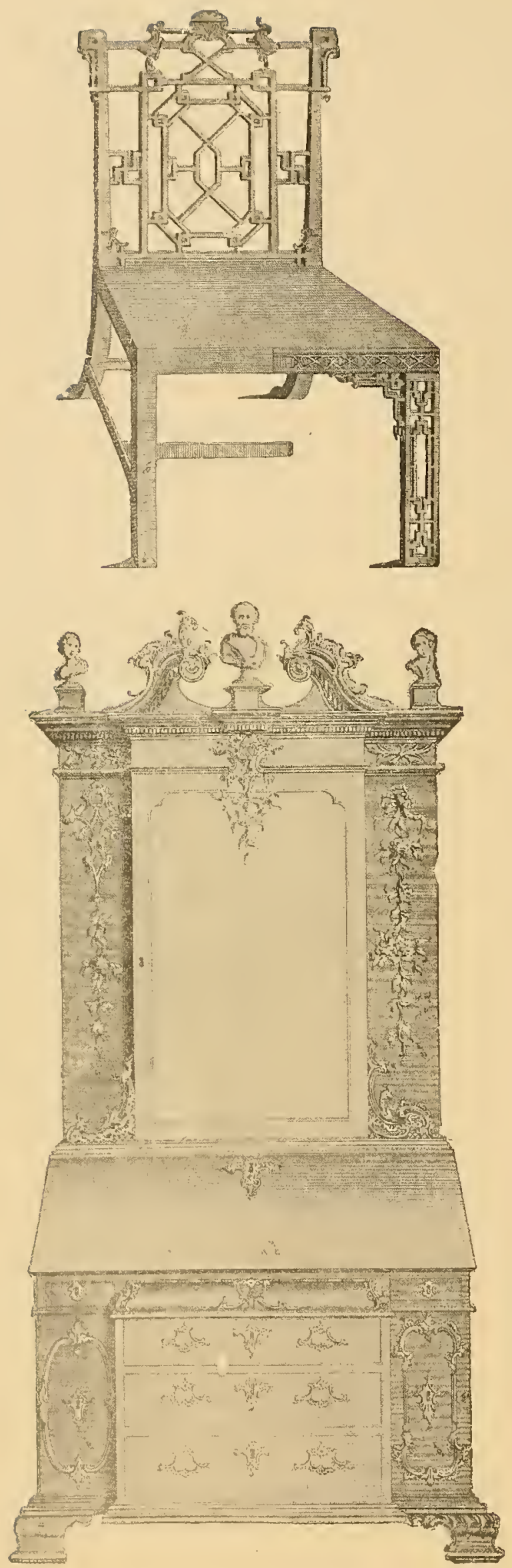
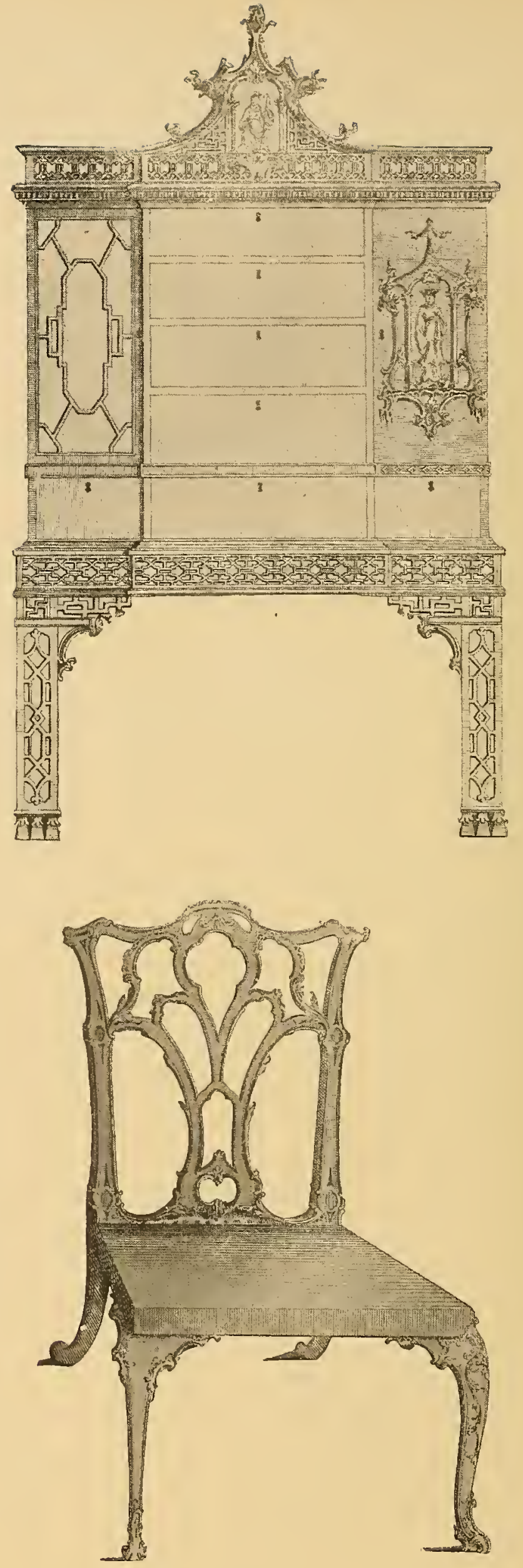

C H I P E N D A L E.

These illustrations have heen copied direct from Chippendale's first known book, "The Gentleman and Cabinetmaker's I)irectur," dated 175t. They illustrate three characteristic types, the Classic, the French and the Chinese. 
fish, logether with a certain weed somewhat resembling fenuel. On such tables as are intended for ornament they place handscapes composed of rocks, shrubs and a lily which grows among pebbles covered with water. but among the princibal ormaments are the lanterns, of which there are generally four, suspended from the ceiling.

Chambers had no irlea of the effect that his look wonld have, lont the Chinese taste grew to extraordinary dimensions.

In the reign of Queen Anne the custom of paneling was partially kept up. The chimney-piece, however, only went half-ivay up the wall. White woodwork was affected. Low, marble mantelpieces were used, but with the beginning of the Georgian we had the greatest possible variety of taste-classic, Roman, Turkish, Pompeiian, French. Royalty having set the fashion, Chinese also became a special fad. Not only were Sumner houses and other buildings erected in Chinese style, but it was mixed up with all the ornaments of the period. The walls of the rooms were simply covered witl scenes of Chinese life, bridges and boats and impossible staircases and mattings and lacquers being abundantly in evidence. All the furniture was marked by the Chinese influence, and Chippendale

affected with rare abandon the use of the pagoda, the bell, dragons, and mandarins. Other architects followed; even Lock, who was a student of the classic.

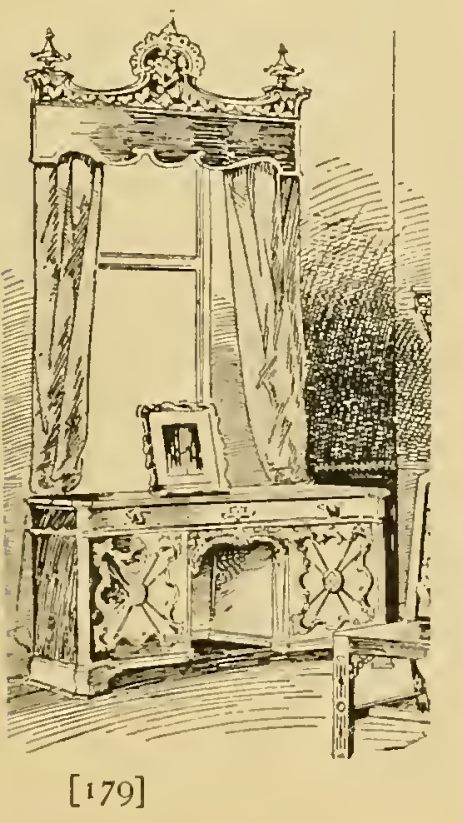
followed blindly with Ince, Mayhew and Manwaring, and satisfied popular clamor. Rounded wood was used. in the bamboo fashion, but of turned beech and painted in imitation of reeds or cane.

Gothic was also copied, and the flamboyant French was in evidence. Frequently in a room we find the Chinese spirit combined with Louis XV, just as in France this $\mathrm{s}$ a me combination was very successfully eff ected.

Just before the death of George I, in 1727, the elder Chippendale came to lingland and legan making furniture founded upon the QueenAnne fashions. He was accompanied by a son, a boy eighteen years of age, also called Thomas Chippendale, and the son absorbing the French taste of the Louis XV period, I7I5 to 1774, soon showed his talent as a carver and a joiner. Chippendale was

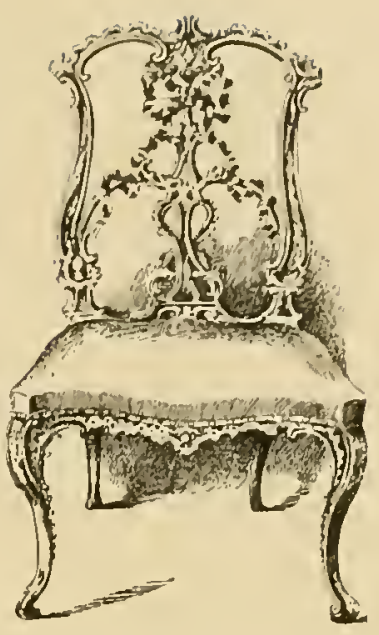

born 1708 and buried November 13, 1779. Probably he died November Io or II. His first plates are dated I753, and his book "The Gentleman and Cabinet-maker's Director," came out in 1754. The second edition was brought out in 1759 , and the third in 1762 . This was the first furniture catalogue and it sold for sixteen dollars a copy. It was issued under the patronage of a long list of subscribers, members of the nobility as well as cabinetmakers, among them Ince and his partner Mayhew.

Although Chippendale was successful, he was no more so than others and his reputation was largely posthumous. It is seldom that we find records of his name. Even Walpole, who left many memoranda concerning designers and decorators, never alludes to Chippendale, and old Americ a n advertisements fail ever to mention his name. His cont e m poraries were Manwaring, Mayhew, Edwards, Darley, Mathias

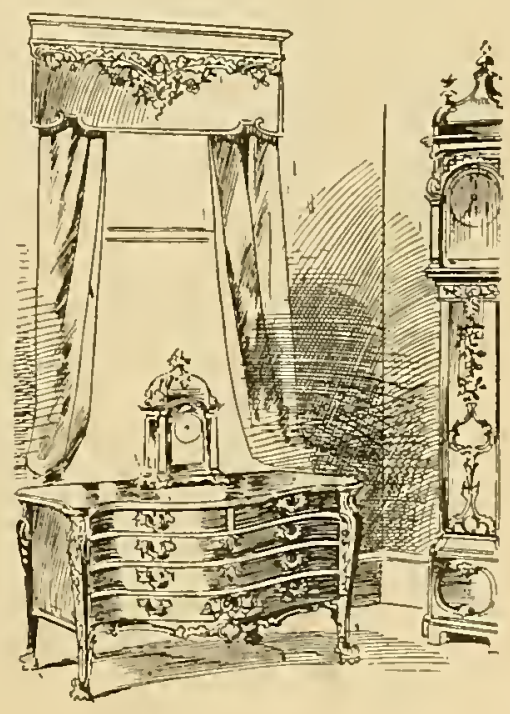


Lock, Copeland, Thomas Johnson, and Crunden.

The years of the first George, King of England, were the transition years of wal nut and mahogany. I7I4 to I727. From I7I5 to I720 Queen-Anne styles became a little more squat and heavy.

From 1720 to 1730 there was a great deal of elaborate, gilt furniture and about this period we find what is known as the lion pattern, lions' heads on the knees of furniture legs. Sometimes the lion's head or mask is used as a center decoration. The lion's paw was used in place of the claw and ball for the foot of the leg.

As early as 1720 we find veneered mahogany, because from 1715 to 1720 the solid wood was not only very expensive but hard to manipulate. By I72 I Walpole was in power and set the fashion for mahogany in his use of it for the magnificent doors at Houghton, which he began to build in I72I. Kent was the architect. Much elaborate gilt furniture was used following the models of the French fashions. The splat back was universal but this back was often elaborately carved. Middle-

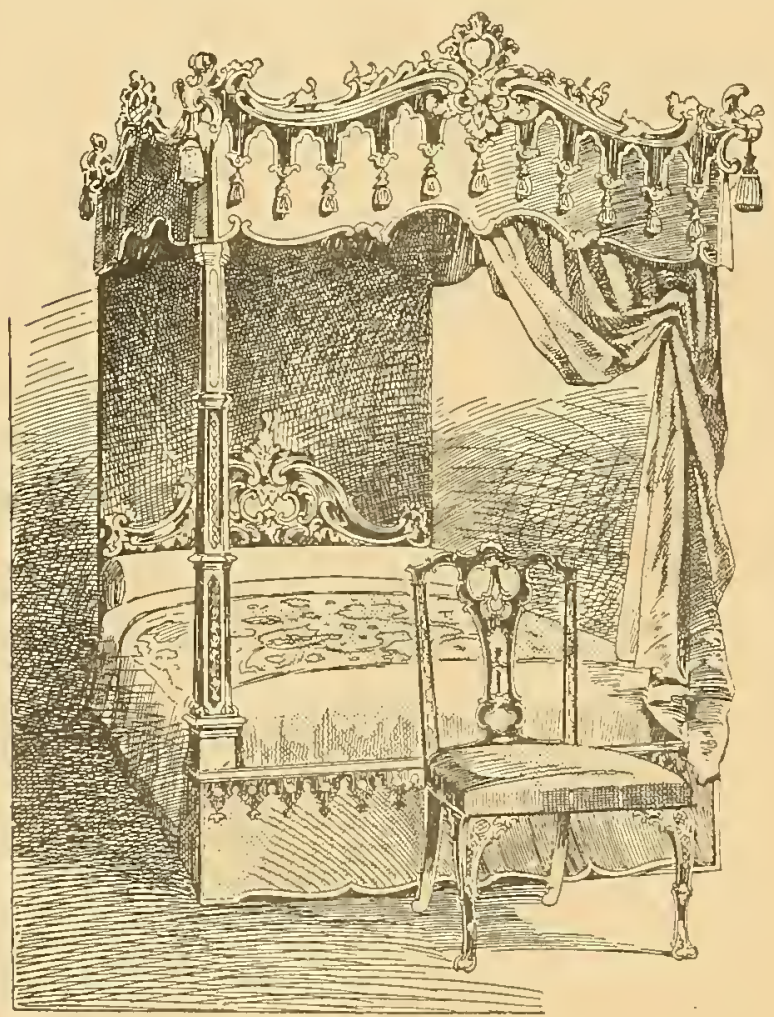

class homes were furnished with furniture simplified by the use of straight legs.

By 1733, Walpole succumbed to the demands of the cabinetmakers and took the duty off mahogany, and from this date mahogany became generally used. By I733 the lion's head was elaborated by the addition of a ring in the mouth.

By I735, we find the splat back opening out into slits, sometimes vase shaped. The hooped or rounded top of the back departed and it curled up at the corners. This squaring up of the chair back caught the fancy of the trade gencrally. It seemed to lighten the appearance of a piece. The cresting also of the back became like a cupid's bow. This bow effect together with the claw-and-ball foot, dates between 1730 and 1750 .

By 1740 , the cabriole leg had shed its masks and lion's heads and was carved in low relief with the acanthus and similar effects. The splat-back was now being cut into strap devices which led up to the ribbonback of I750. The years 1737 to I750 saw the rise of Chippendale and the full evolution of the squarebacked chair as distinguished fron the hooped back. Little by little the back had been punctured; little by little the corners of the back were lifted syuare. Then the puncturing of the back became more complicated until it developed finally the ribbon back typical of the late period.

We note also pierced rails and elaborate ornamention, frequently uniting Chinese and Louis XV motifs.

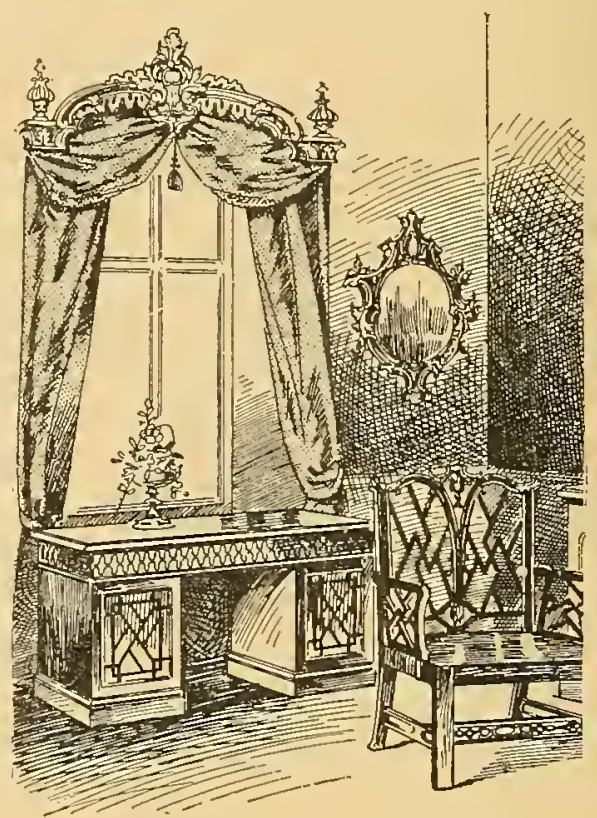

[ 180$]$ 

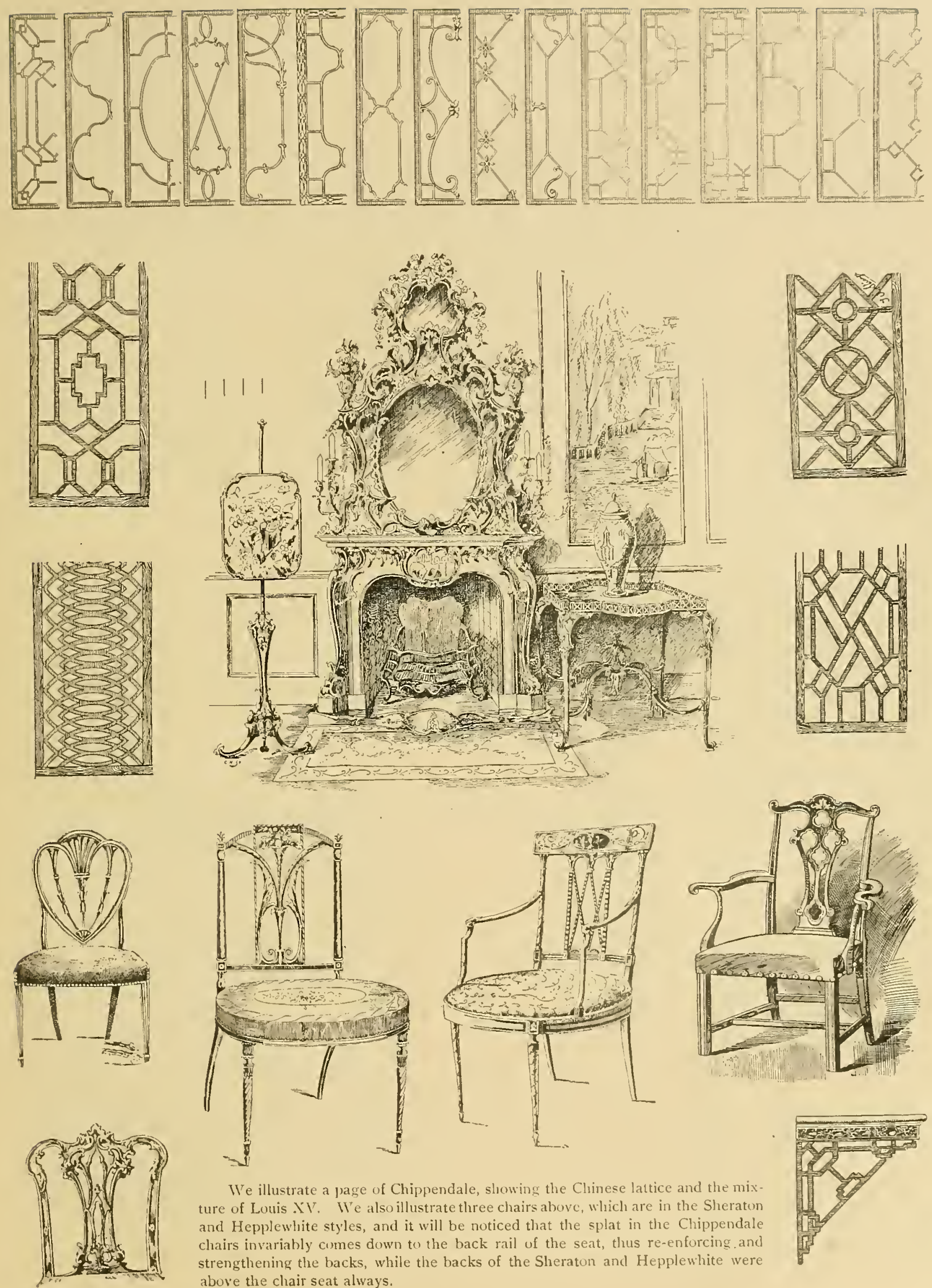

We illustrate a page of Chippendale, showing the Chinese lattice and the mixture of Louis $\mathrm{XV}$. We also illustrate three chairs above, which are in the Sheraton and Hepplewhite styles, and it will be noticed that the splat in the Chippendale chairs invariably comes down to the back rail of the seat, thus re-enforcing and strengthening the backs, while the backs of the Sheraton and Hepplewhite were above the chair seat always.

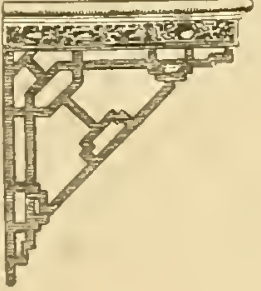



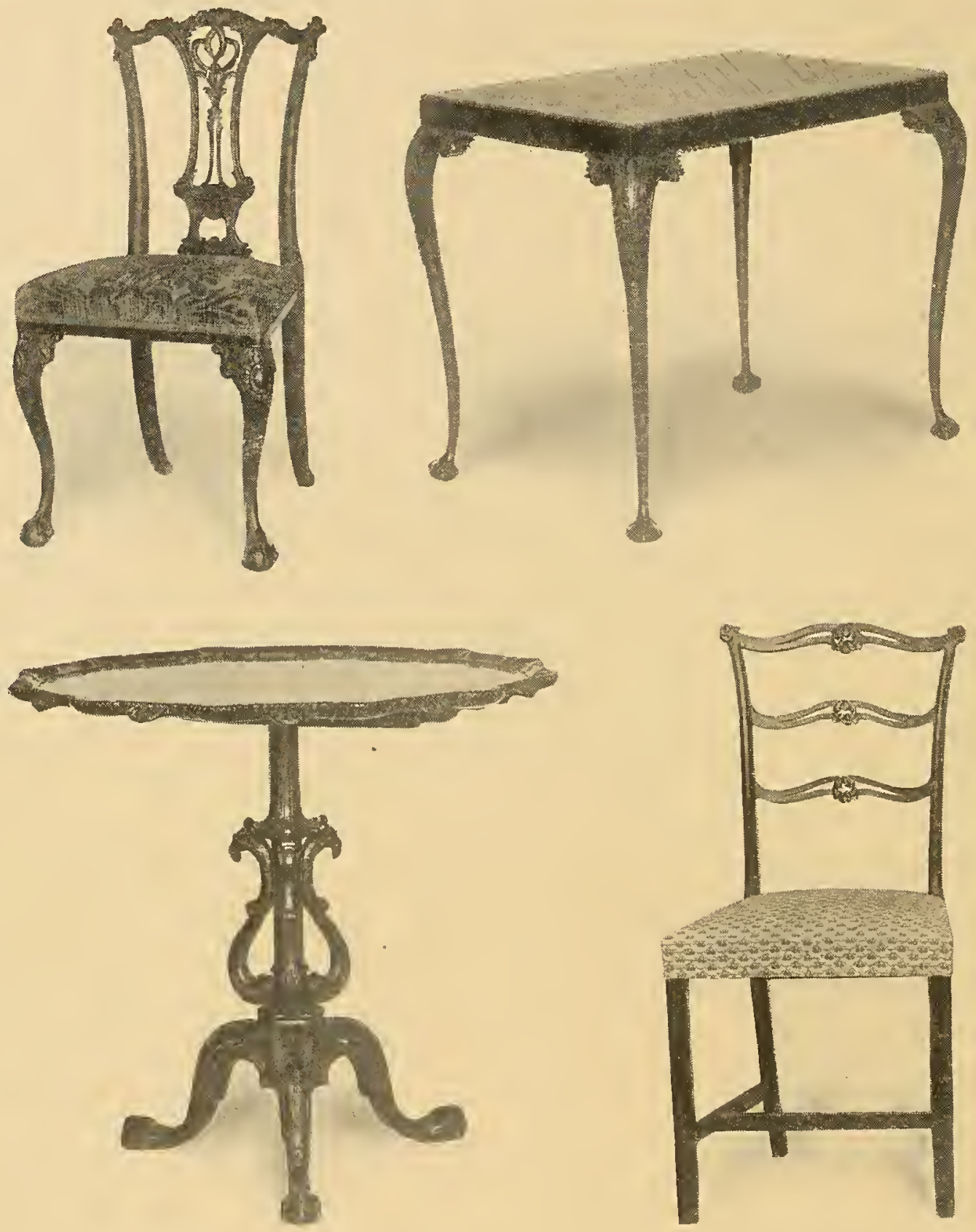

CHARACTERISTIC CHIPPEN D L E EXA M P ES.

The chair in the upper left-hand corner shows the decorated knees and the decorated pierced splat which eventually developed into the ribband form. The table beside it shows the claw-and-ball foot. The table in the lower left hand corner, sumetimes called a "pie-crust" table, shows modified Chinese influence, while the ladder-hack chair on the right is a form common in Colonial, and of correct Chippendale, 1765 . It is interesting to note that a chair almost a replica of the lastmentioned piece is in the historical Washington home at Mount Vernon. 
THE CHINESE SPIRIT

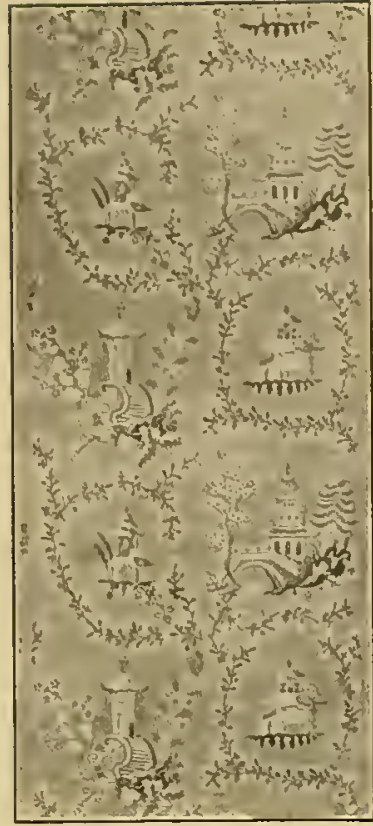

England can be attriluted to Clambers, the taste was felt as early as William and Mary, 1689; and even carlier in France. 1660, under Mazarin (I.ouis $\mathrm{NTT}$ ). In $1 \%$ ? 0 . Lotvis XY dispatcherl an embassy in China to encourage greater tracle relations, and this step was followed by a rage for Chinese stuffs.

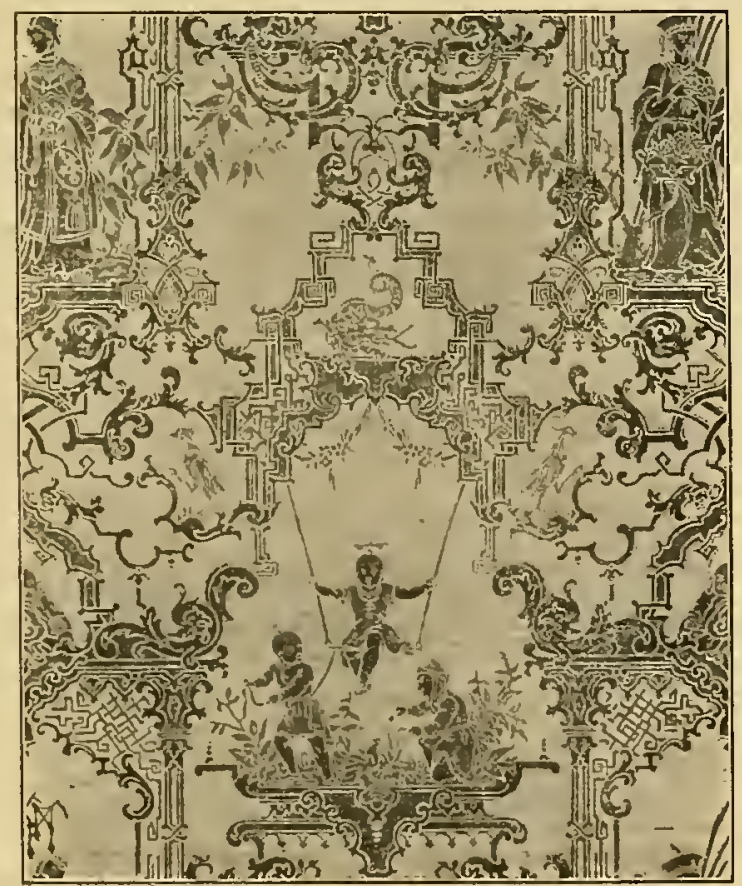

$W_{\text {hire the pop- }}^{\text {ular adop- }}$ i $i$ 1) of Chinese decoration in

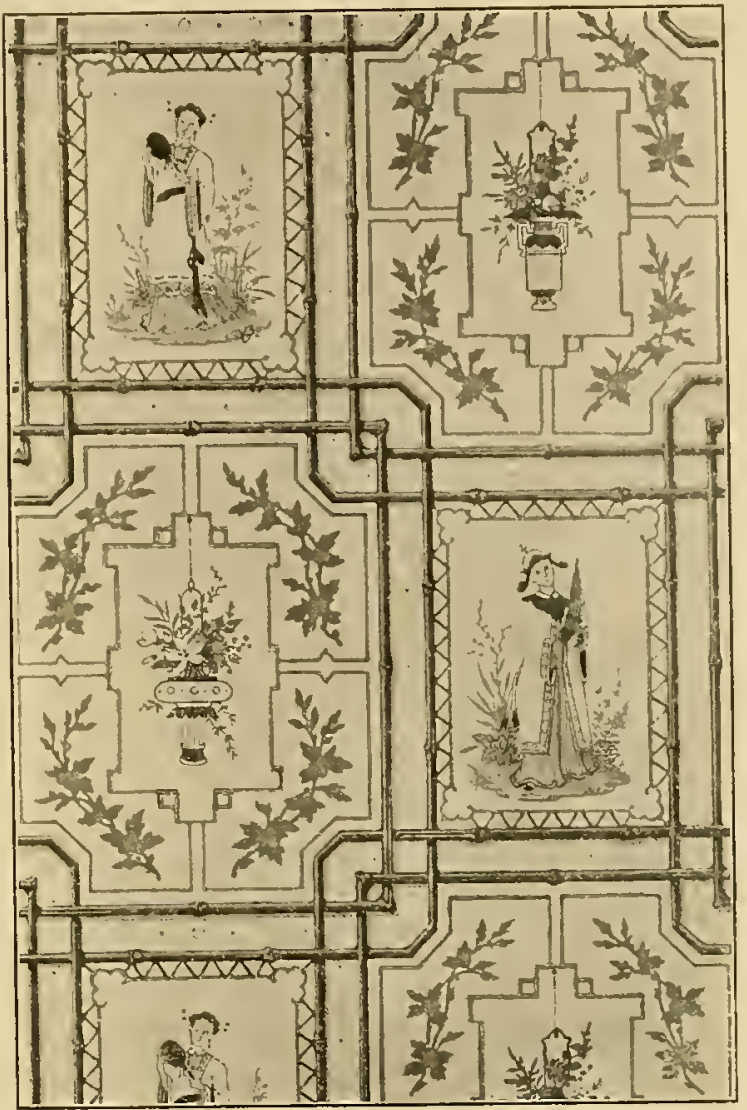

Indeed the pure Chinese spirit, as shown. particularly in the rugs of China, was seldom seen. The form utilized was the adapted form wherein the Gothic, I.ouis $\mathrm{XY}$ or some conventional backiground was treated in Chinese motifs, plucked from the pottery and projected upon European composition. In the same way the architects reproduced bits of landscape and laid garden iv a $1 \mathrm{ks}$ and grottoes, from the suggestions found in pottery. effecter a treaty between

I a p a n and the [nited States, followerl eight months later lyy Japan's treaty with Great Britain. a vear later witl Russiet and three rears later with France

What we regaril as the Clinese spirit is not necessarily pure Chinese. Fremently the chinese spirit was merged with the Fothic or with louis $\mathrm{XT}$, or with some other French and English style.

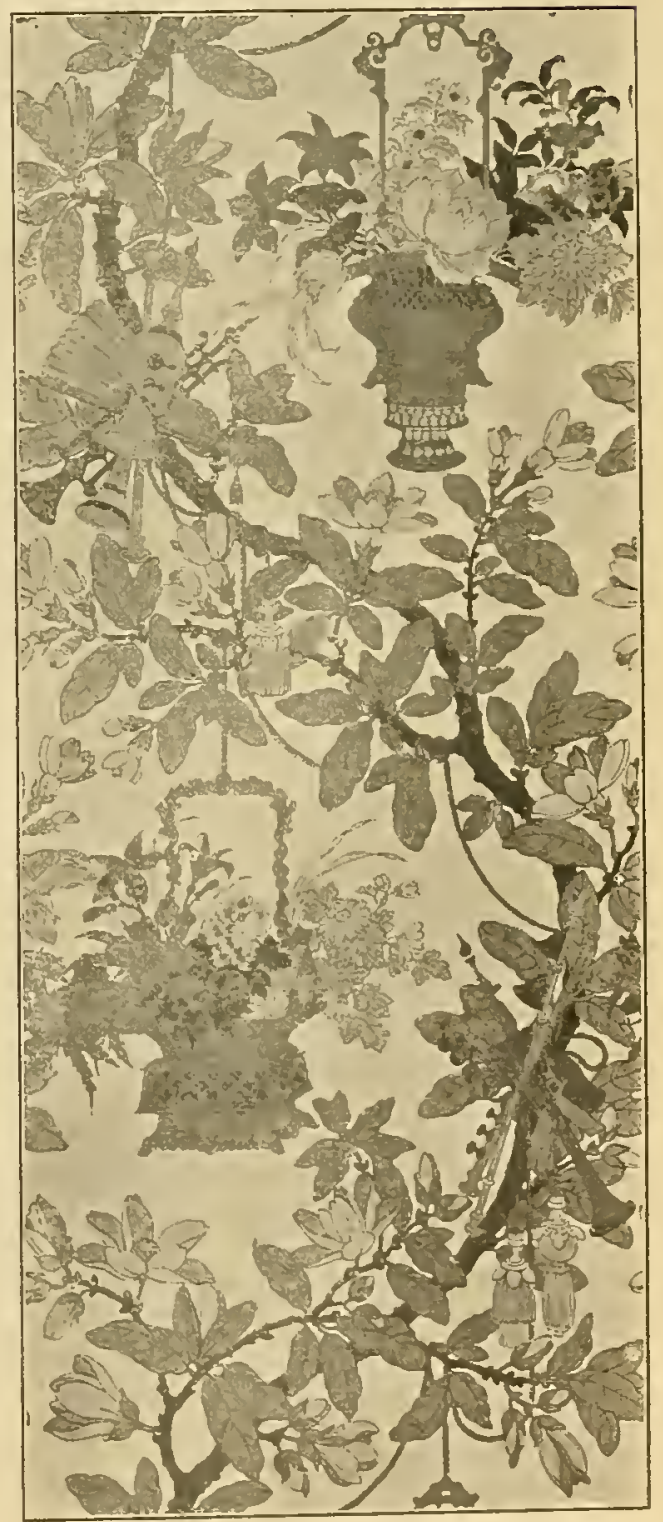




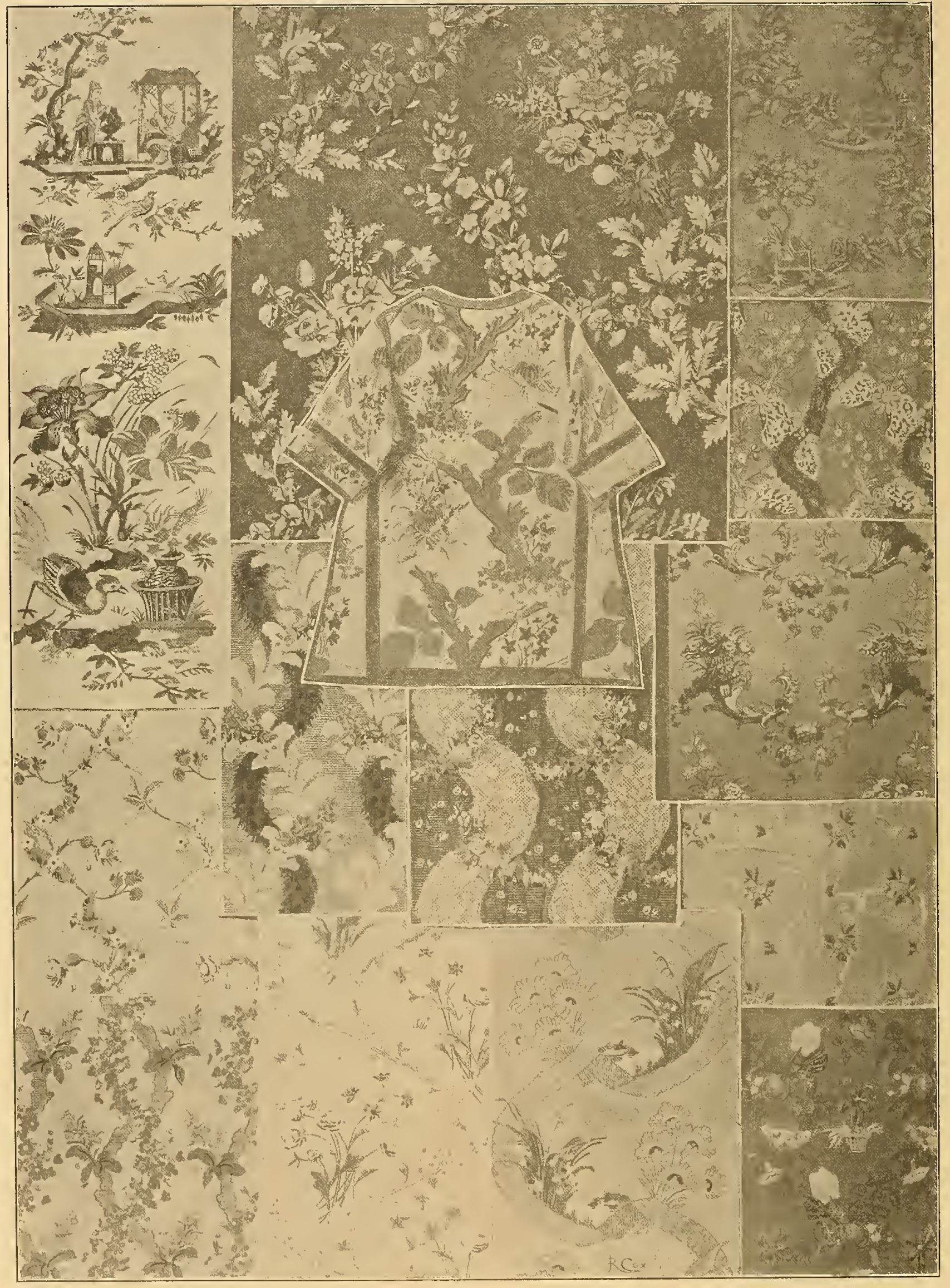

CHINESE INFLUENCE IN THE LOUIS XV AND CHIPPENDALE STYLES. 


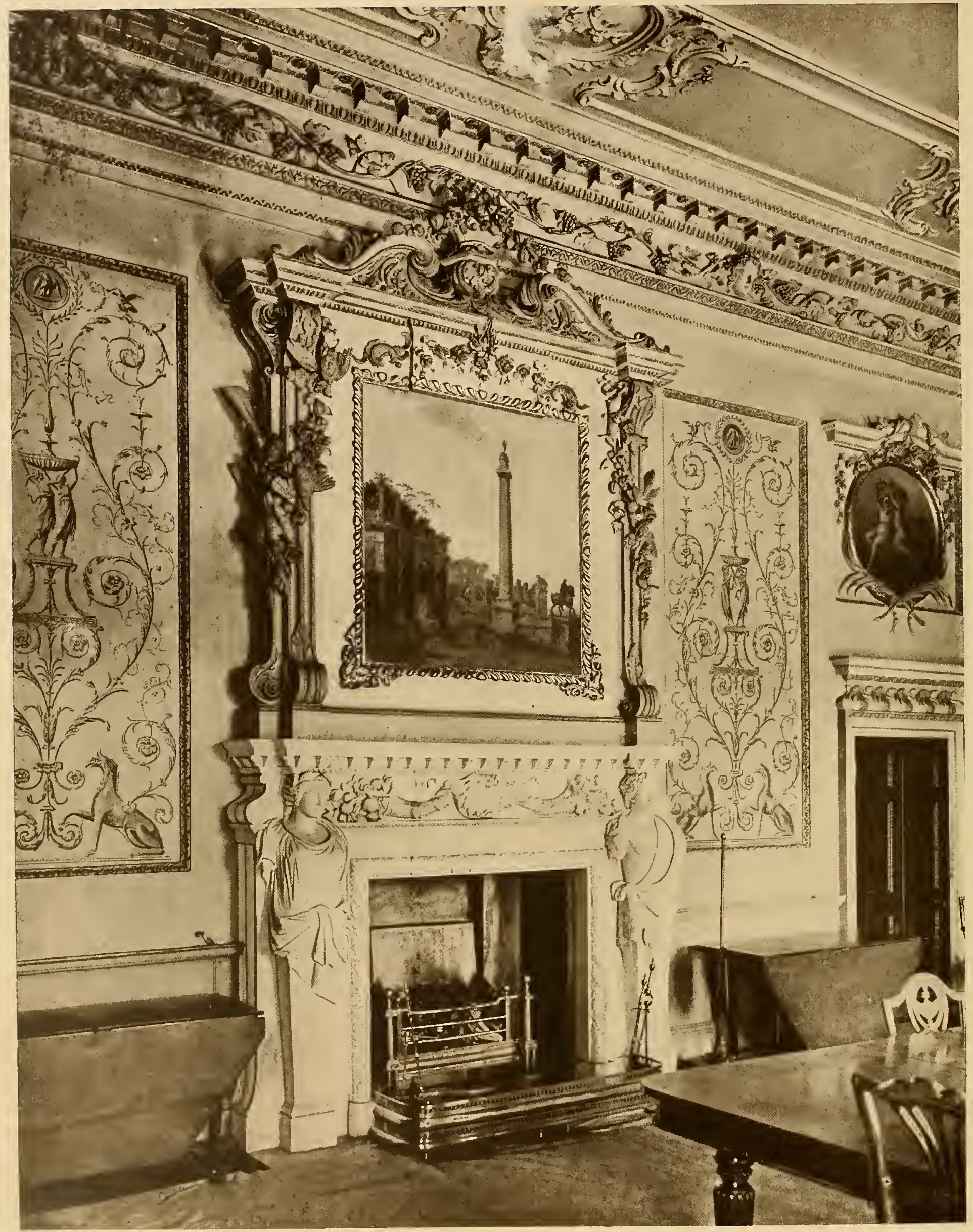

DRAWING-ROOM AT NOSTELL PRIORY.

The painted panels on either side of the mantelpicce emanated from the hand of the brothers Adam, who 


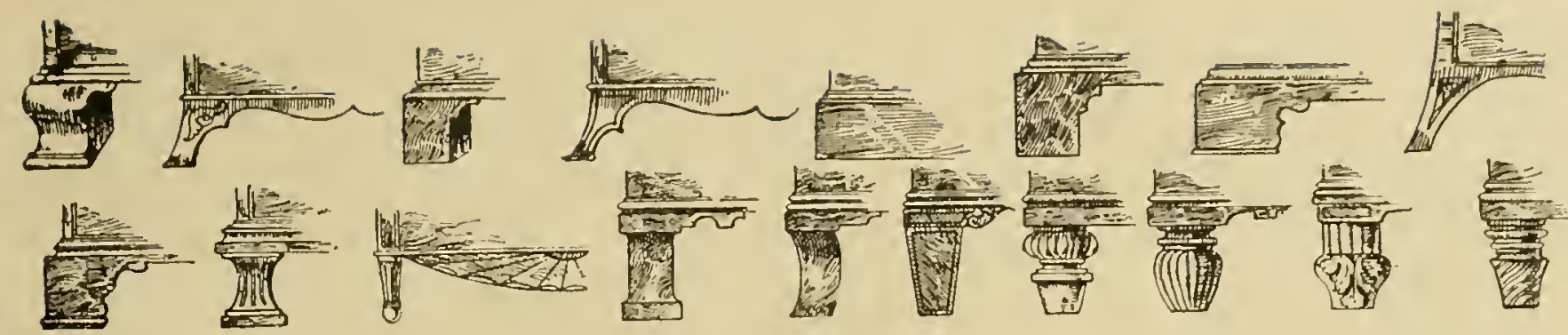

Hepplewhite and Sheraton desk, wardrobe and cabinet feet.

\section{H E P P L E W H I T E}

Chippendale's great book, 1754. Hepplewhite's book, 1789. Sheraton's Cabinetmaker and Uplolsterer's Drawing Book, 1791.

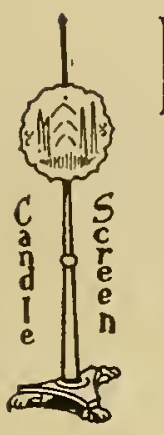

$P$ RIOR to Queen Anne chimneypieces were carried to the ceiling as part of the wood-trims, but by 1700 the climiney-piece never went above half the height of a room. IV h j t e trinus were also introduced at this period and have clung, more or less, especially to small roons recuiring greater liglut, to this day.

In I755 Chambers, returning from Italy with Cipriani, bronglit back a nutuber of Italian sculptors who made mantels. These mantels were put into a house independent of the architect and established a new height, sometines four, five or even six feet, but independent of the woodtrins ancl usually marble or other stone. They became an article of general trade and were sold by the fireplace fixture dealers.

Another change came with Hepplewhite when wood mantels were introluced. Wreaths of flowers and classic cletails were painted on natural wood with plaques introduced. Fantastic elegance became the fashion, and plain woorl was elaborately colored. Satinwood and mahogany were mainly used, painted, gilded and inlaid.

Contrary to the popular belief, glass knobs were not made at this period, but during the late Colonial period in America and introduced later into England, just as the use of mahogany was common in America for many years before utilized by the English cabinetmakers. Inventorics and wills in this country dated

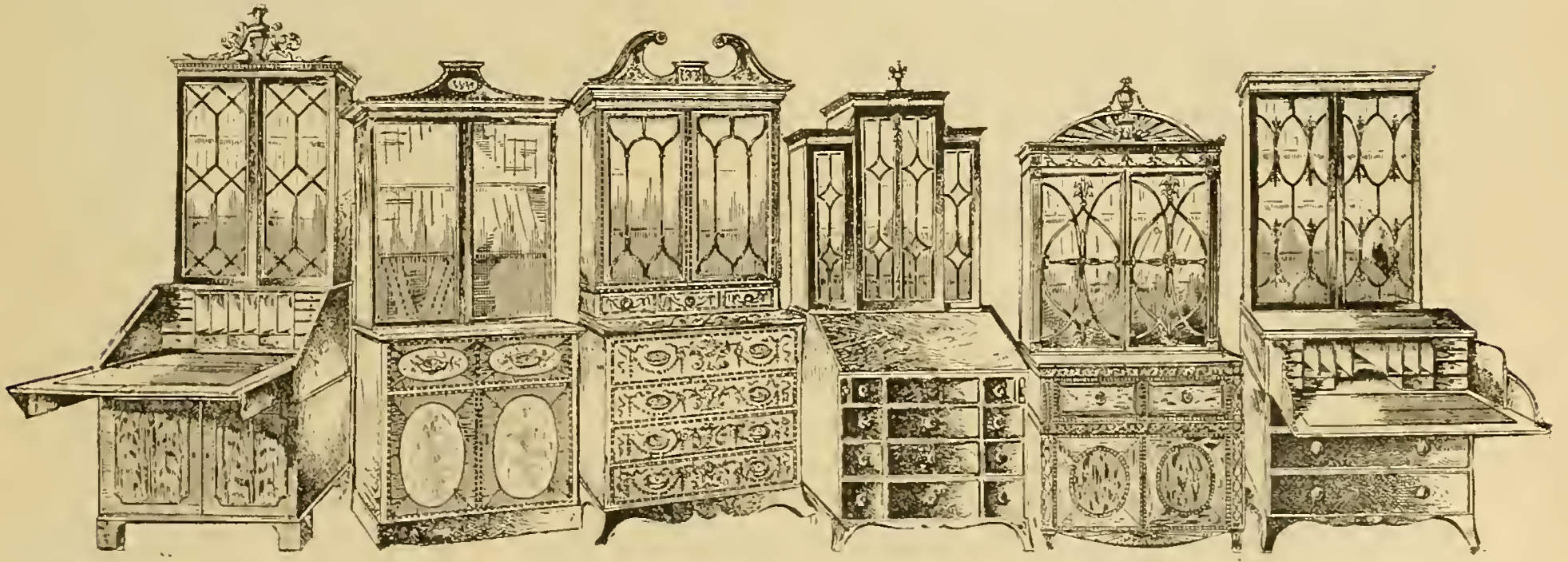




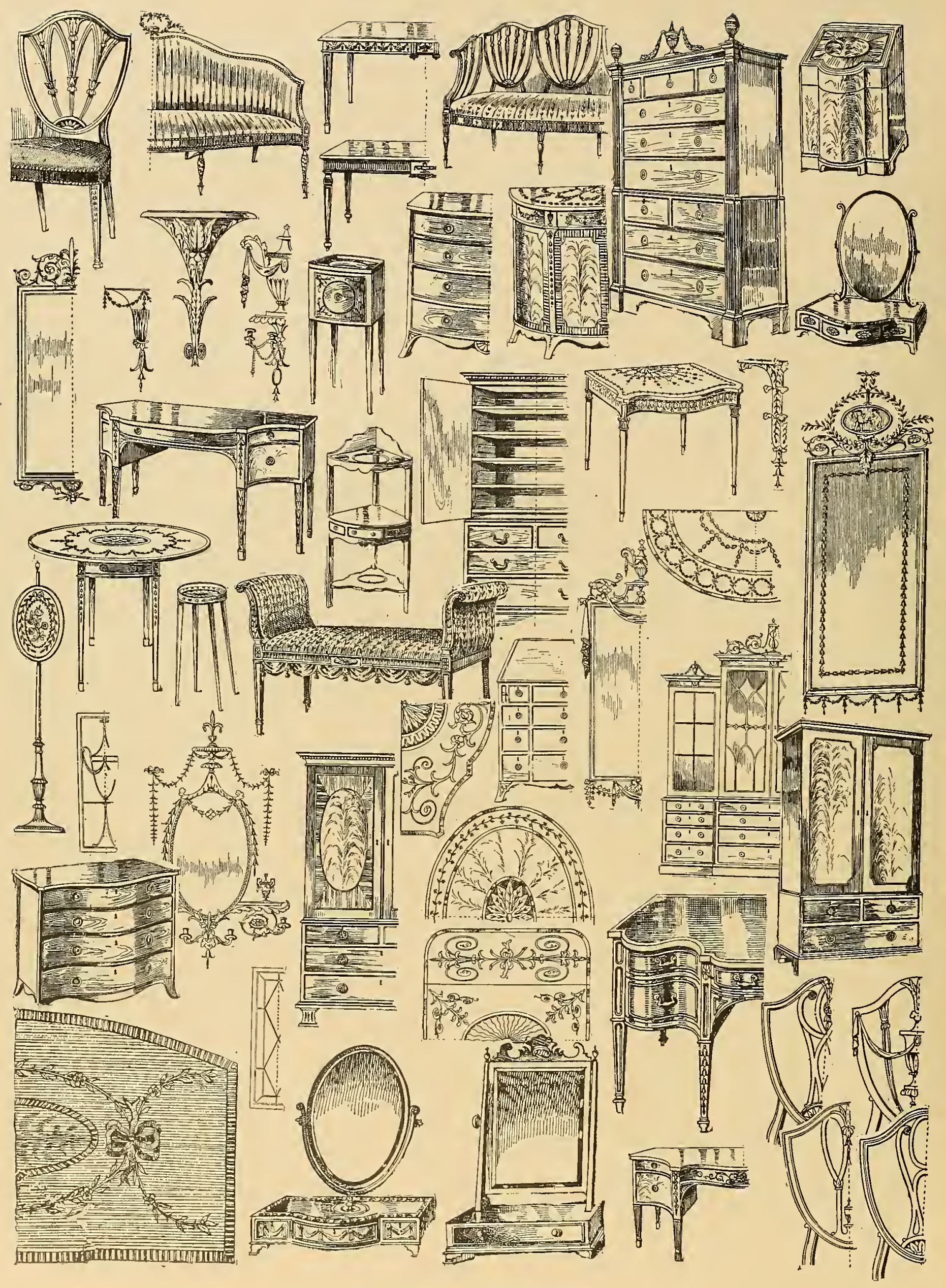

H E P P L E W H I TiE* 
I 7o8, refer to mahogany furniture, such pieces being solid and frequently in desks of the Queen Anne style, with claw-ancl-ball foot and serpentine front. Ifepplewhite had many contemporaries, few of whom have survivel in history. Among the cleverest was Sliearer, a member of the Calinetmakers' Society. He probably was as well known in his day as Hepplewhite. It is a curious fact that while Hepplewhite's book was full of chairs Shearer makes no reference to a chair, a fact possibly due to an understanding with Hepplewhite to avoid his s p e cialt $y$. Shearer's furniture, like Sheraton's, was full of concealed drawers, hidden receptacles. There were no safe deposit vaults in those days and one had to depend upon the cabinetmaker for devising hiding

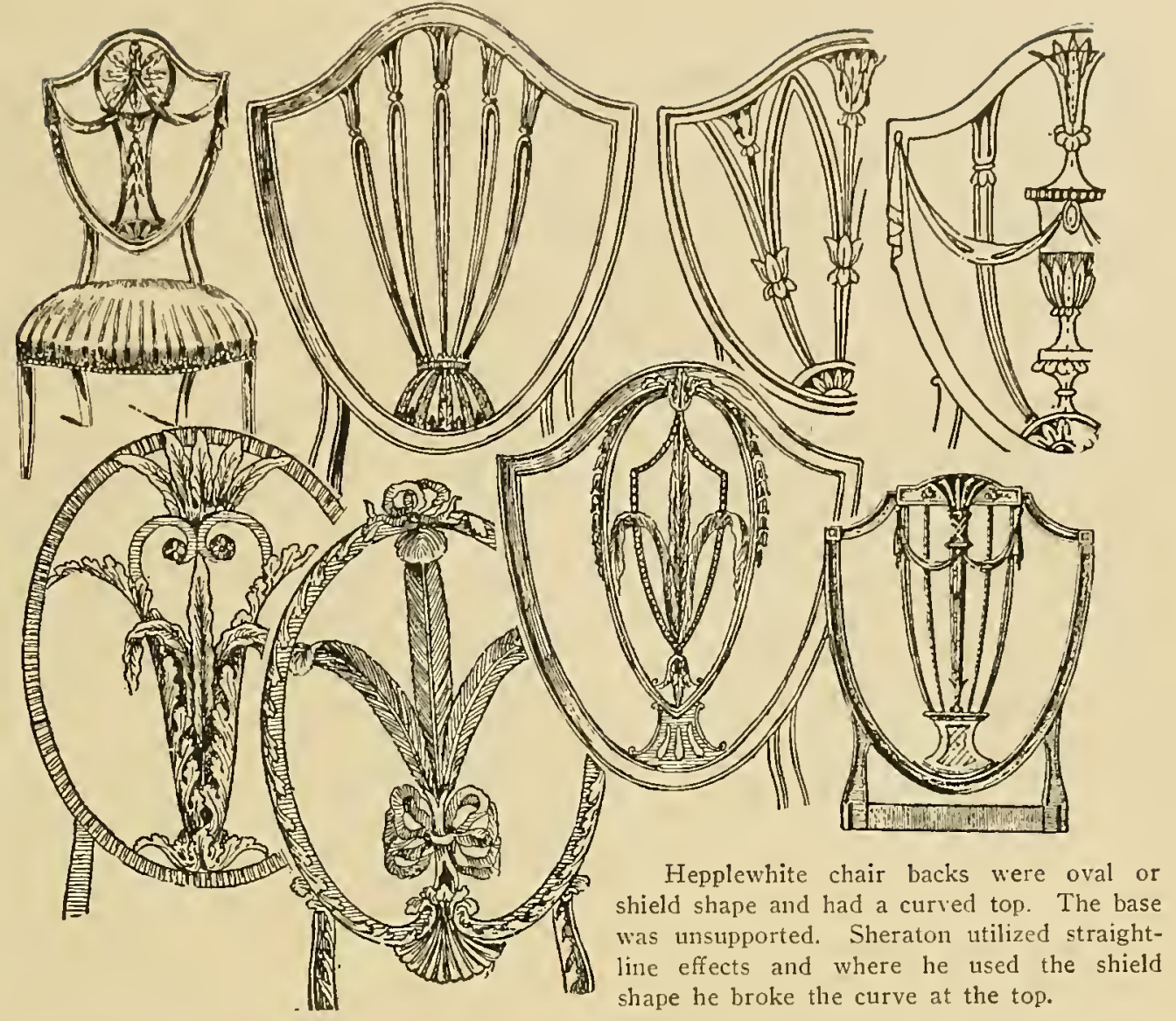

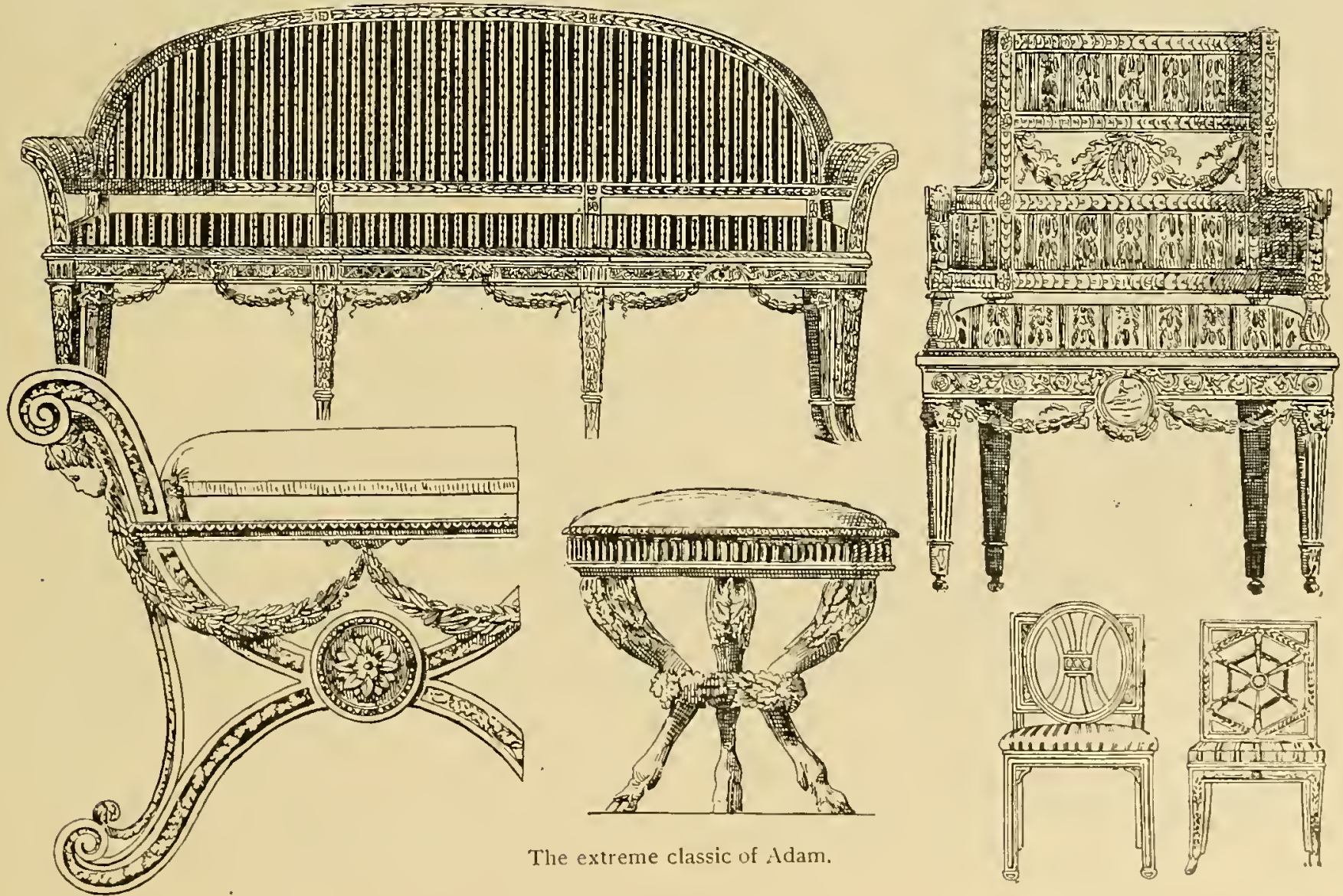




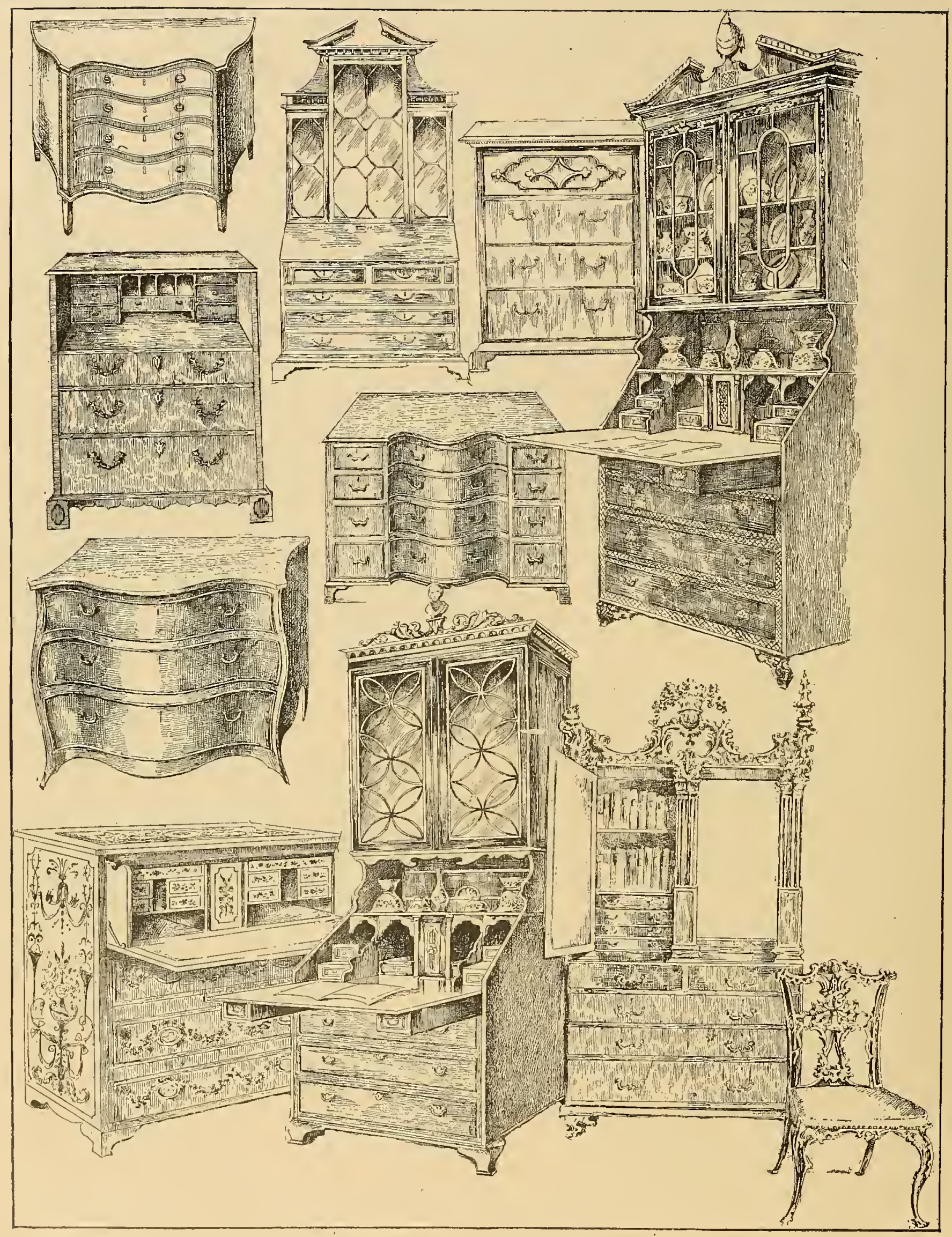

The illustration on the left-hard at the bottom of this page is an Adam piece; the second illustration is a Sheraton; the third and fourth Chippendale. The illustrations above are by Shearer. 


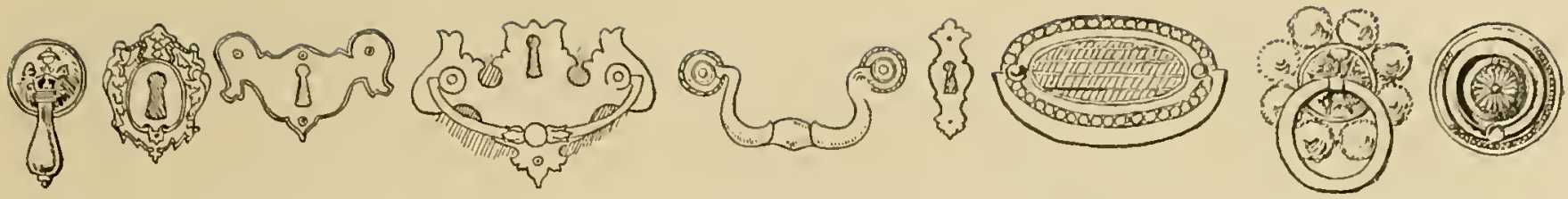

The first and second illustrations represent the hardware used from about 1660 to 1720 . The second and third illustrations were used in the first half of the Eighteenth Century. The solid drop handles, as shown by illustration 5 , were conmimly used until about $1 \pi 90$, at which time the pressed brass became popular, shown in illustration 7 From this date through the Empire and late Colonial up to 1820 rosetes witl inserted rings were used and in America glass knobs were common.

places. Shearer was not as well echucated nor harl he the artistic fceling of IIepplewhite; his furniture was heavy and he repeatedly utilizcd the Prince of Wales' feathers. His ingenuity in the invention of furniture was quite as great as Hepplewhites.

It was about this time that the wardrobe came in. Hepplewhite produced wardrobes that supplanted in practical usefulness the highboy.

Hepplewhite's chairs were mainly for the room known then as the "parlour," a term that has clung.

We first heard of parlors in the Nedieval times when it was part of the common hall but screened off for the privacy of the family. It gradually became a separate room often used as a bedroom. I.ater it was synonymous with the modern dining-room. Accordto Johnson, 1755, it was "A room for receiving con1pany." Sheraton and Hepplewhite used the words parlor and dining-room as interchangeable terms. The chairs were frequently covered with horsehair in colored stripes and check designs, the edges finished with a close line of brass headed nails; sometimes they were cane-seated.

The Duchess chair of Hepplewhite was an arrangement of two armchairs facing with a thircl chair or ottoman placed between them continuing the seats along one level and making one piece of furniture.

Higl1 clocks were very popular. The history of clocks would take us back to the Nedieval ages-indeecl, if specifically dealing with timepieces to the prehistoric years. Our interest in the subject starts with the first making of household clocks. In the beginning of the Seventeenth Century clocks were made at a moderate price and were known as bird-cage, bedpost and lantern clocks. They were the kind that were wound by pulling down opposite ends of ropes on which weights were hung. None of them would run more than thirty hours. The pendulum was not introduced until $I 6 \% 0$, and it is at this time that we fix the origin of the grandfather's clock. The bracket clock having a handle on top enabling one to carry it around, came in about 1675 . Mantel clocks were another type, introduced at about the time of banjo clocks, so called on account of their shape, produced just after the American Revolution, about I805, and very popular in America where they originated.

The Hepplewhite and Sheraton styles followed the Adam tendencies strongly and yet there was individuality in each man's work which gave character eagerly followed by their contemporaries.

In the mind of the modern decorator the differences are not clear. Broadly considered, while Hepplewhite and Sheraton were both infuenced by their contemporary Adam, Sheraton leaned to Louis XVI.

To simplify the subject we have arranged the characteristics of the two schools in parallel columns.

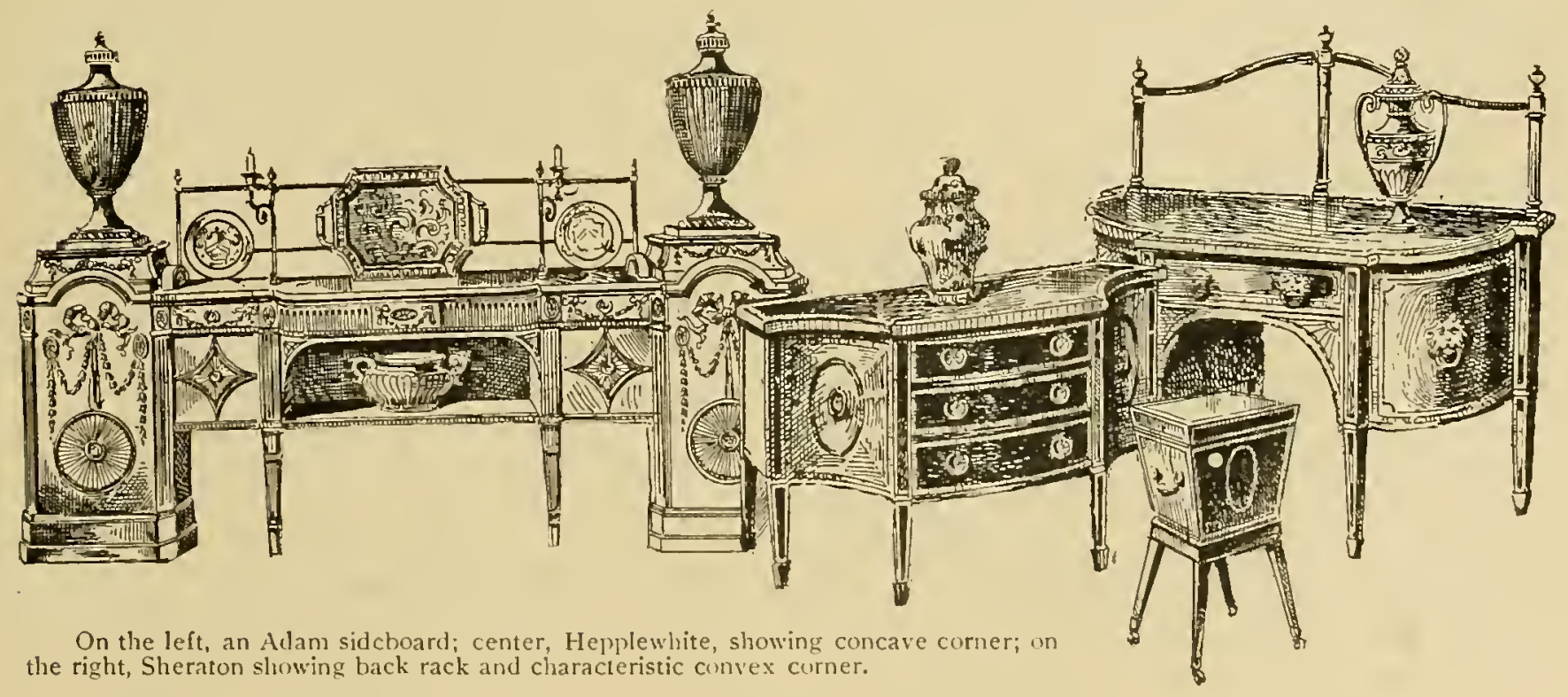




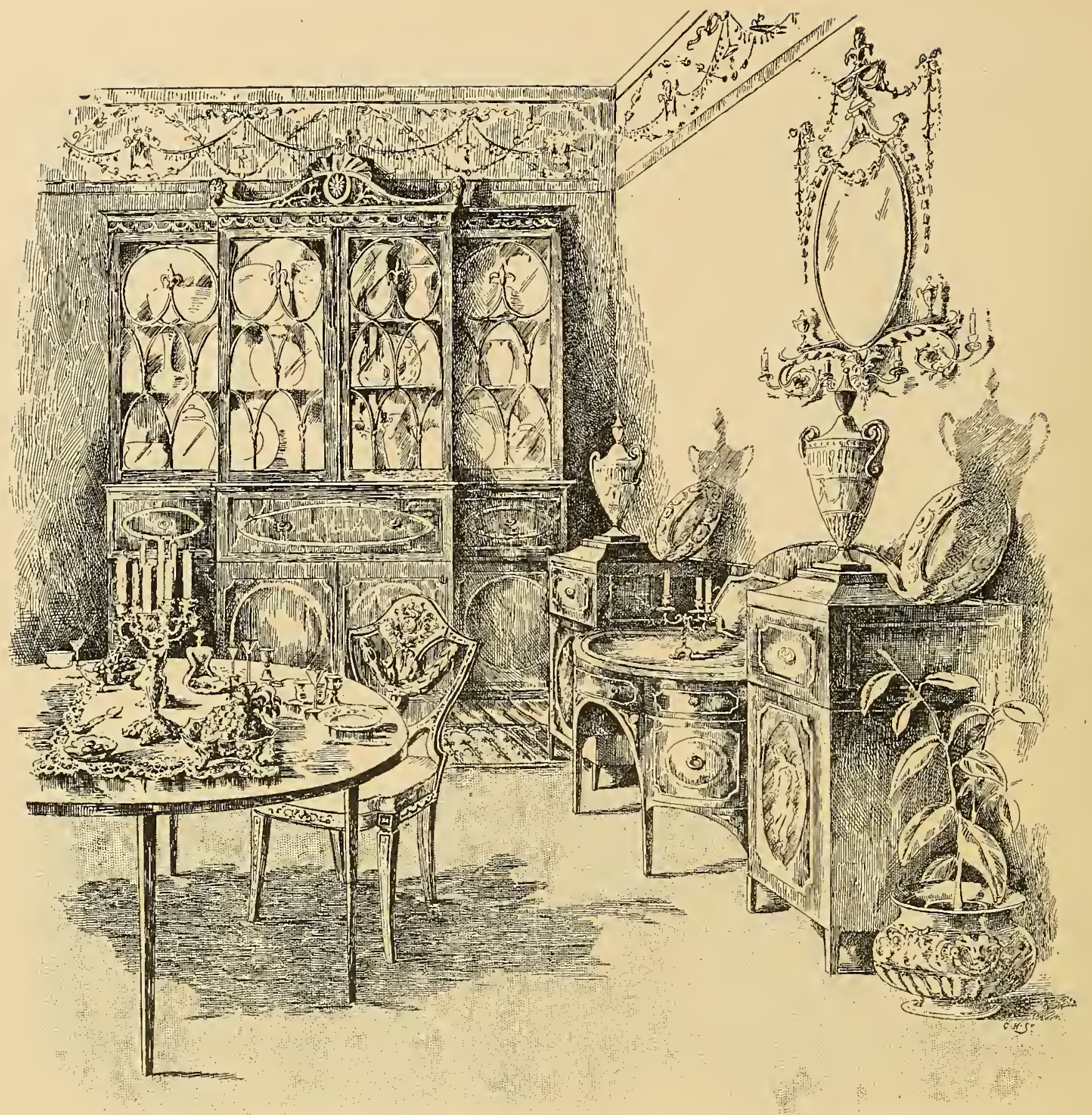

Shearer furniture, with Hepplewhite mirror and chair of the period.

HePPlewhite.

I. The Hepplewhite chair backs are as a rule heart or shield shaped, and the bottom is unsupported by any rail. The top of the back of a Hepplewhite chair shows a sweeping curve.

II. The arms move out with a swing and join the leg as a part thereof. All Hepplewhite work is in sweeps and unbroken lines.

III. The chair legs are in most cases square. In the inexpensive chairs they are plain or with a simple reed or inlaid at the corners. In some chairs of the better type we find fluted legs.

A characteristic of most Hepplewhite chairs was

\section{SHERATON}

I. The Sheraton chairback is usually in straight lines and supported by a botton rail. While occasionally Sheraton used a shield back, he broke the sweep at the top by some sharp straight line.

II. Sheraton arms moved out with a swing and joined the legs as independent parts, pedestal-like.

III. The chair legs run strongly to the Louis XVI style. Sheraton strengthened the back and ignored the under framing of his chairs. He used reeded and fluted legs, twisted pillars, festoons, husks, cornucopias. He carved swags of drapery and flow- 
the under-framing: Hepplewhite left the back weak and the legs strong. Maliogany and inlays were mucli used. The seats are upholstered frequently in horse hair, leather, canc, or in any kind of fabric.

IV. Sideboards were ustually made with concave corners because of the clecorative effect.

1. He became famous for his Pembroke tables. He indulged not only in inlays and carving, but in painting, japanning and brought into hisservices Angelica Kaufman, Cipriani, and Pergolesi. The pole fire screen was just becoming popular. It was intended simply to screen the firelight from a lady's face and the screen itself was frequently no wider than eight or ten inches; a bit of embroidery, a mat, or bit of needle-work. The feet of the pole were loaded with lead to prevent its upsetting. Tea caddies were very popular. The Dutch did not introduce tea drinking until about $\mathbf{1 6 6 0}$, and it was fully 1690 when the custom became prevalent.

VI. Hepplewhite's bookcases were furnished with glass doors, the glass being cut into patterns. They were called traceried doors, the lines or traceries being of mahogany or satinwood, brass or lacquered wood. These traceried forms in Hepplewhite doors were usually angular.

VII. His pediments over doors or windows were usually fragile and finnicky.

While Chippendale was one of the first to introduce the higliboy, Hepplewhite improved it. He made also secretaries, secretary bookcases, bureau bookcases, toilet tables, washstands, chests, shaving stands, side tables, girandoles, wall mirrors, brackets, and innumerable other pieces, all treated from a decorative standpoint.

While bedsteads were draped in anything, Hepplewhite in his book commends particularly Manchester prints to be lined with white cotton. He also recommends specifically green silk as appropriate for mahogany. ers; he used the vase and rendered all these motifs beautiful in carving. Occasionally he painted. $\mathrm{He}$ introduced the conversation chair, the sort of thing which one straddled facing the back upon which one leans.

IV. Sheraton sideboards had the added superstructure of a brass railing against which dishes rested. Sometimes the railing was balanced with candelabra, a plan, seldom, if ever, adopted by Hepplewhite, who did not consider comfort and convenience so much as decoration. The interior of the sideboard was full of conveniences.

Sheraton's sideboards were made with convex corners, thus giving a little more room. In other respects many of the Hepplewhite and Sheraton sideboards are almost identical.

V. His Pembroke tables were furnished with scrap bags. As an instance of his ingenuity one of his tables was called a Harlequin table, so termed because in. Harlequin exhibitions there is generally a great deal of machinery introduced. Some of his desks had disappearing drawers and pigeon holes, leaving a space free for the breakfast table.

VI. In Sheraton traceried-doors curves were generally utilized, the oval and the vase being frequently used as centerpieces.

VII. Pediments were of a substantial character and lacked fragility.

Sheraton introduced a form of horse screen, a larger lower set piece than the pole screen. Sometimes these screens were furnished with swinging toilet boxes on the side, or receptacles for odds and ends of the dressing table, also candle holders.

While he showed a preference for the round or turned leg for chairs, he followed the square shape of the Louis XII style very largely with his tables, sicleboards and other cabinet work.

His grandfather's clocks were generally inlaid.

Sheraton's work will frequently be recognized because of its extraordinary ingenuity. $\mathrm{He}$ was an inventor and produced many pieces of convertible furniture, tables with concealed stepladders, bureaus with convertible desks. He made many little pieces of utility furniture. He considered not only grace of style but comfort. He anticipated the American roll-top desk by producing something almost identical. 


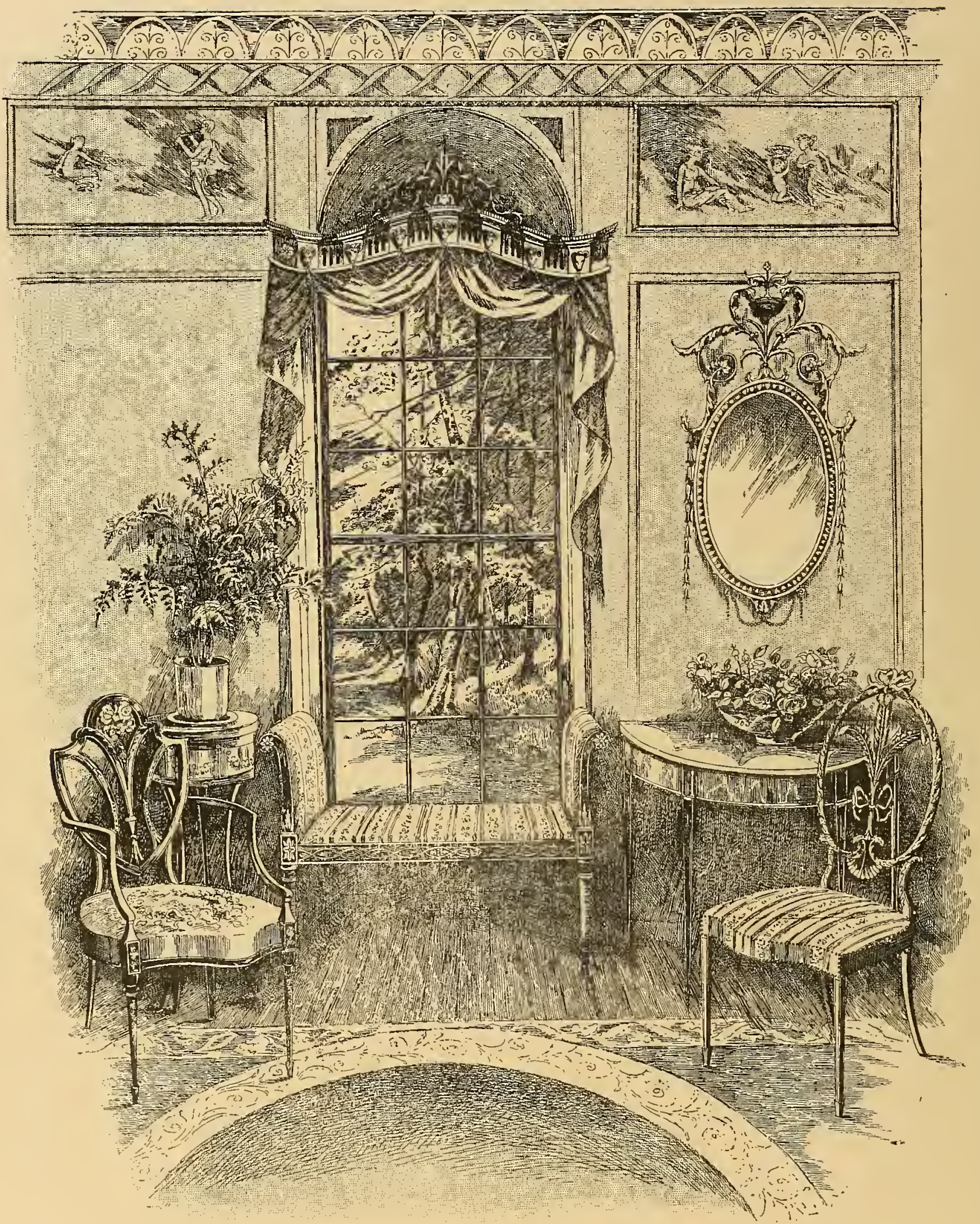

A HEPPLEWHITE INTERIOR. 


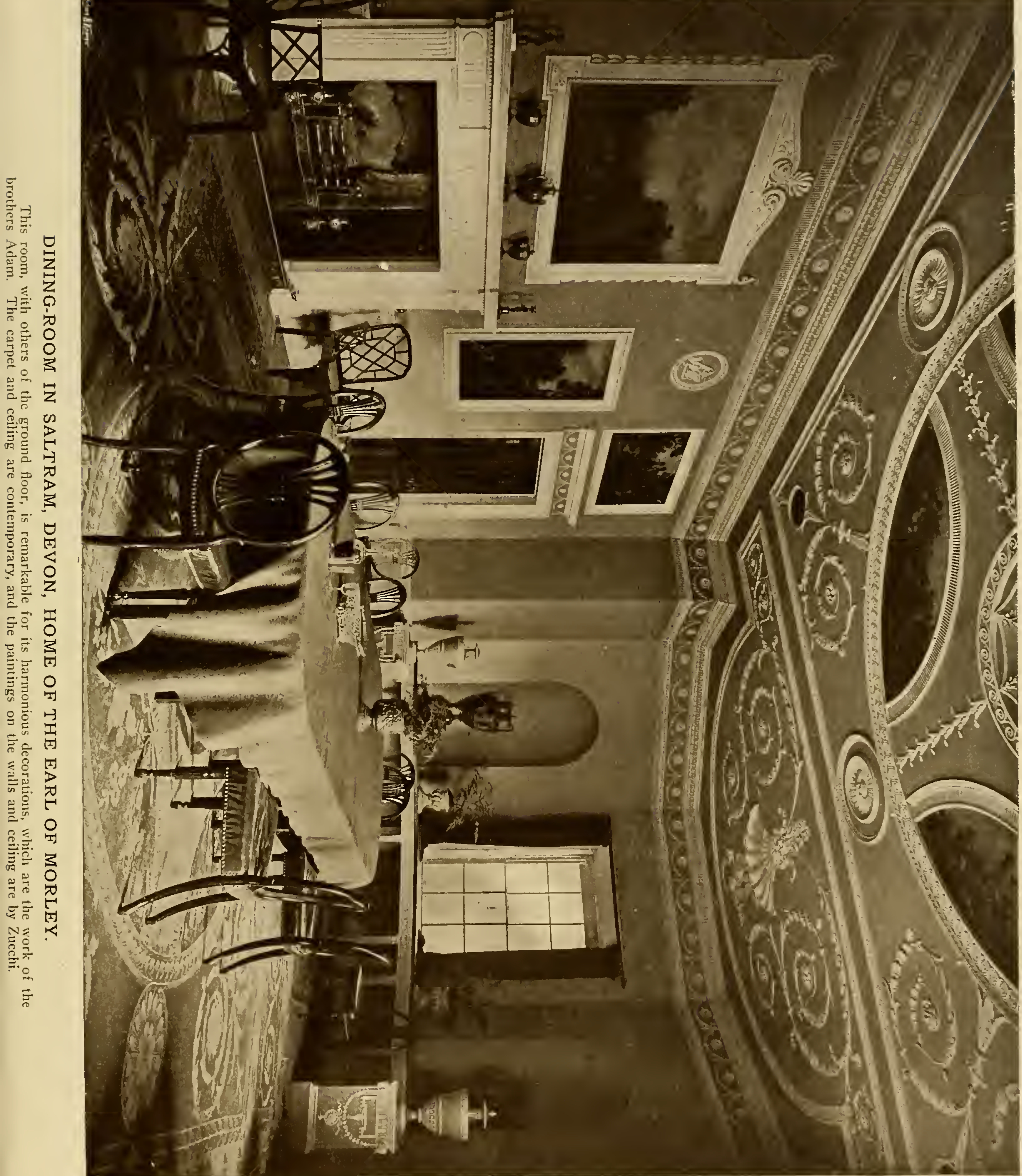





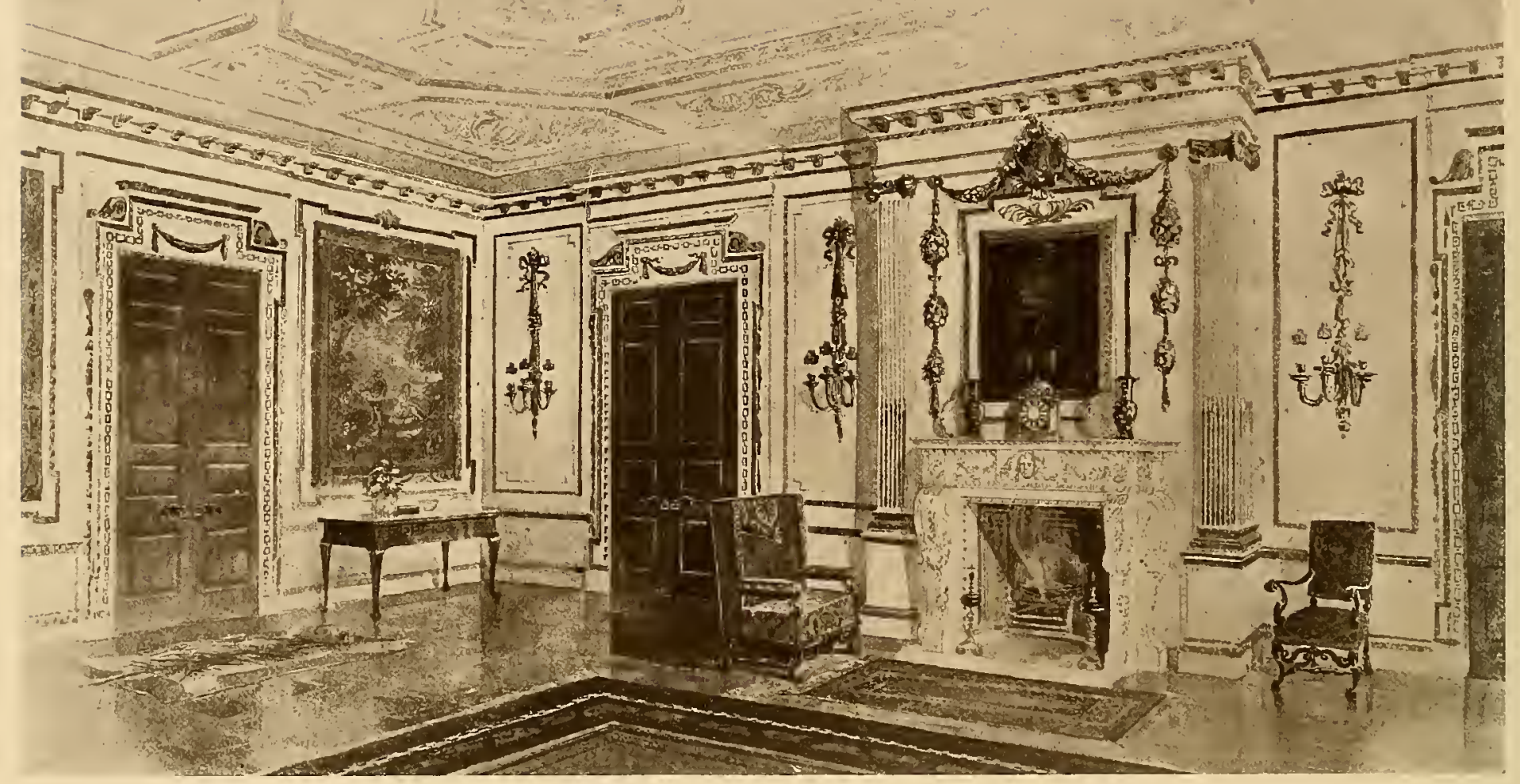

An early Georgian room, showing the spirit of Sir Christopher Wren and Grinling Gibbons. Furniture is of an earlier period.

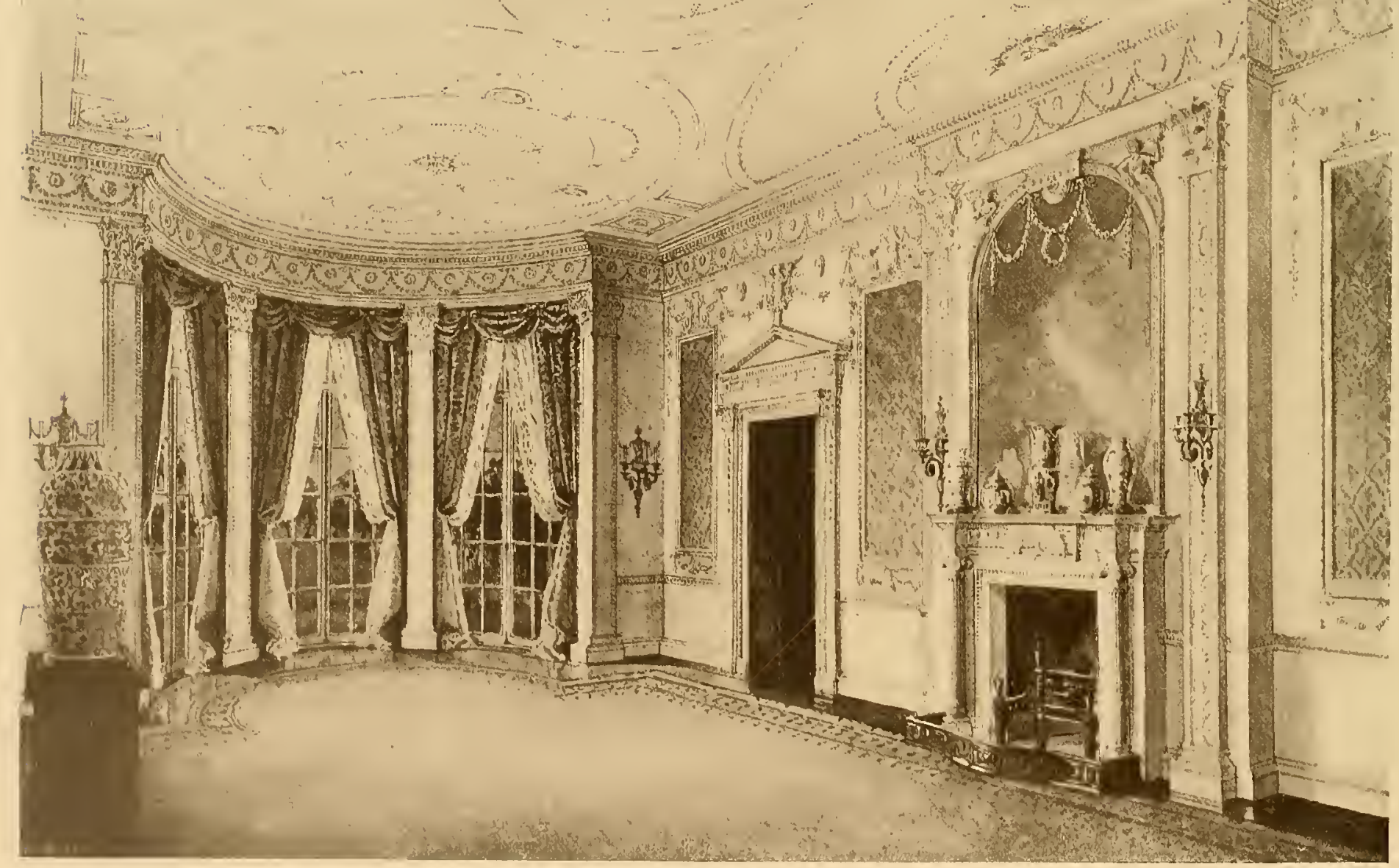




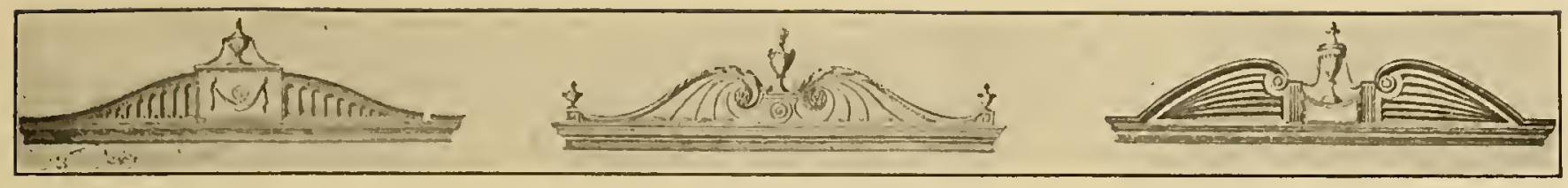

Sheraton's pediments, though showing sumewhat the same characteristics as Hepplewhite's, were more substantially constructed.

\section{SHERATON}

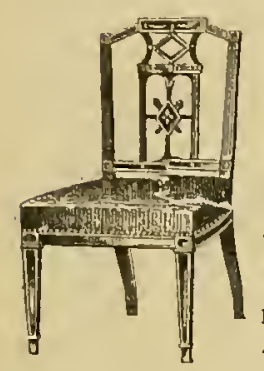

$A^{\text {on }}$

QUICK understanding of the character of Sheraton furnishings may be had in the knowledge that Sheraton cabinet work was a little more ornamental, a little more profuse, than Hepplewhite; the fabrics used were in harmony; little figure details of the Lonis XVI order were particularly favored. Both IIepplewhite and Sheraton upholsterings and draperies were of a light and filmy type and rich in every possible variety of fine weaves. Sheraton leaned toward the French, although the decoration of houses into which the Sheraton furniture entered was frequently in the pure Adam. The styles of Sheraton and Hepplewhite were closely associated and the distinction is not always clear. Our previous chapter points to many of the differences.

Sheraton employed often the lyre form in his chair backs and used a form of needlework in bunning or engraving panels of satinwood with rosewood inlaid; all of his work was at first of an original type, but little by little he copied slavishly anything French.

He originated intricate ornaments for legs and backs of chairs and turned work as well as inlay was much affected.
Ie picked out designs with gildings and employed cameo-like panels. He suggested in his book that ornament may be white and gold, japanned or painted, and advises that the cove and ceiling be richly ornamented in paintings and gold. His use of satinwood or white mahogany was extended even to the production of mantelpieces. His drawing-room schemes provided for wall panels, mirrors and draperies a little more stiff than those of Hepplewhite, as a foil to the complexity of his furniture details.

When we consider that Sheraton designed many rooms and furniture for the Prince of Wales, afterwards George $I V$, and for most of the nobility, we can understand that he was not worried by any considerations of economy.

He confessed to an admiration for Shearer, and there are many examples of simple Sheraton inlay that strongly resemble Shearer.

Both men made the same little corner washstands and toilet accessories. Sheraton was an extraordinary inventor and not only introduced beantiful pieces, but pieces of great originality and far in advance of the times, full of quaint combinations, hidclen drawers, parts that were convertible, turning from one use into another, cleverly hidden accommoclations for boxes or writing materials or toilet articles-desks that

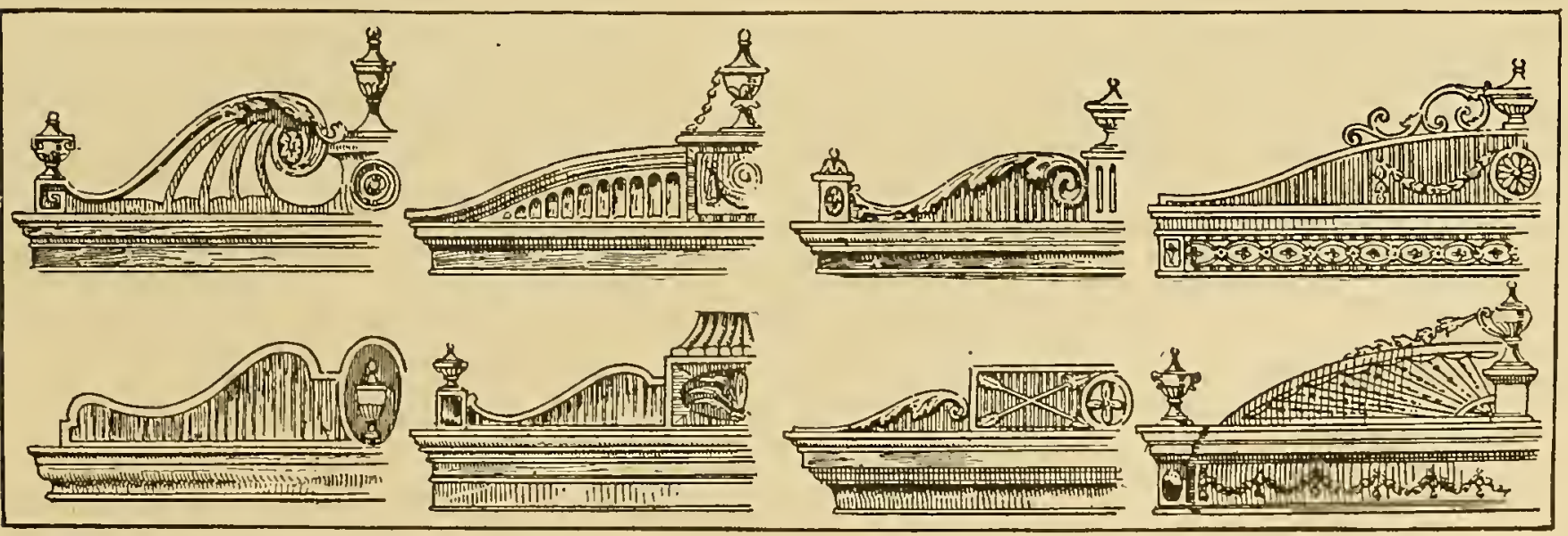




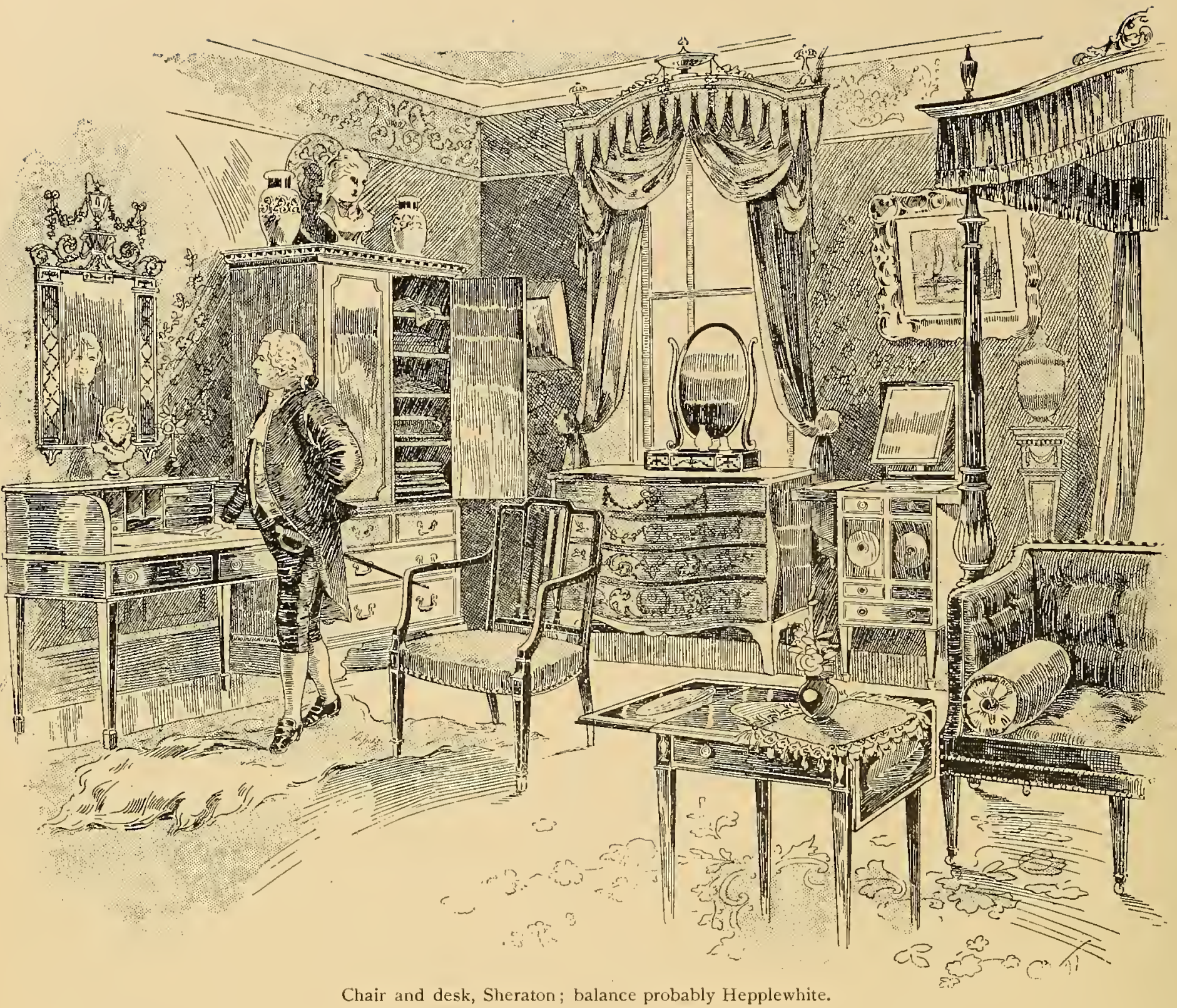

became dressers and fancy tables that became washstands.

If he had never made a reputation as a cabinetmaker and designer, he would have become famous as a mechanician.

It was a period when bedrooms were frequently used as sitting-rooms and very many ingenious pieces of bedroom furniture were concealed in bookcase forms or desks or writing stands.

Even washstands folded up and became cabinets. It is well to remember tlat in 1750 thousands of silk weaving looms were established in England at Spitalfields, Cheshire, Yorkshire, Essex, Derbyshire, Lan- castershire and Norfolk. Moreover, at this period up to the beginning of the Nineteenth Century an enormous lot of Indian silks and cottons were used; in 1759 the manufacture of printed linens was authorized and encouraged by the French. (See page $16 \%$.)

Sheraton died in what might almost be called poverty. He was not a good business man and his style was at its best in the beginning of his career. If he failed to gain material compensation for his art it was because he was unable to progress beyond the limitations which hedged him in and the work of innumerable competitors who had no hesitation in copying his style. 


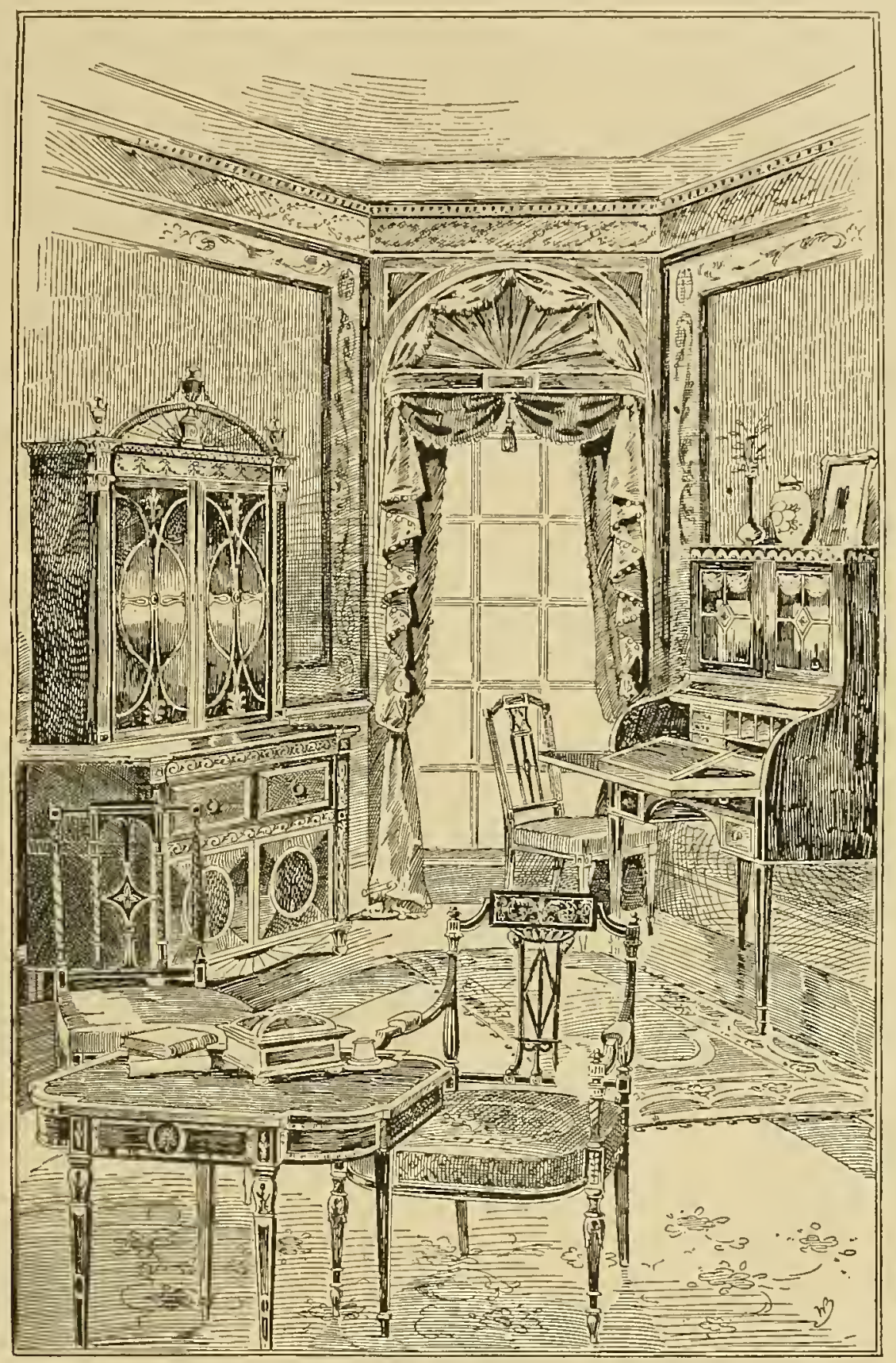

SHERATON.

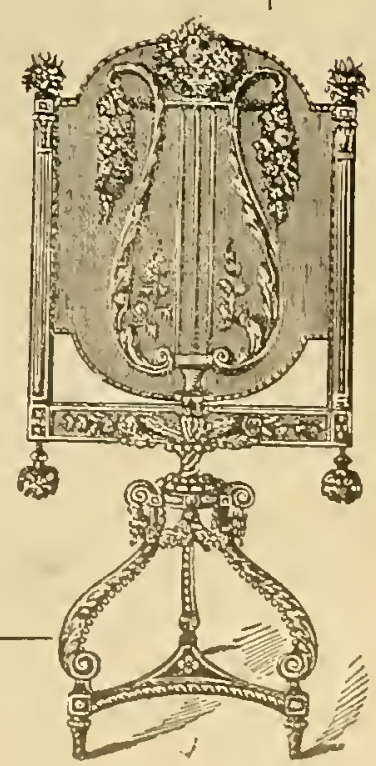



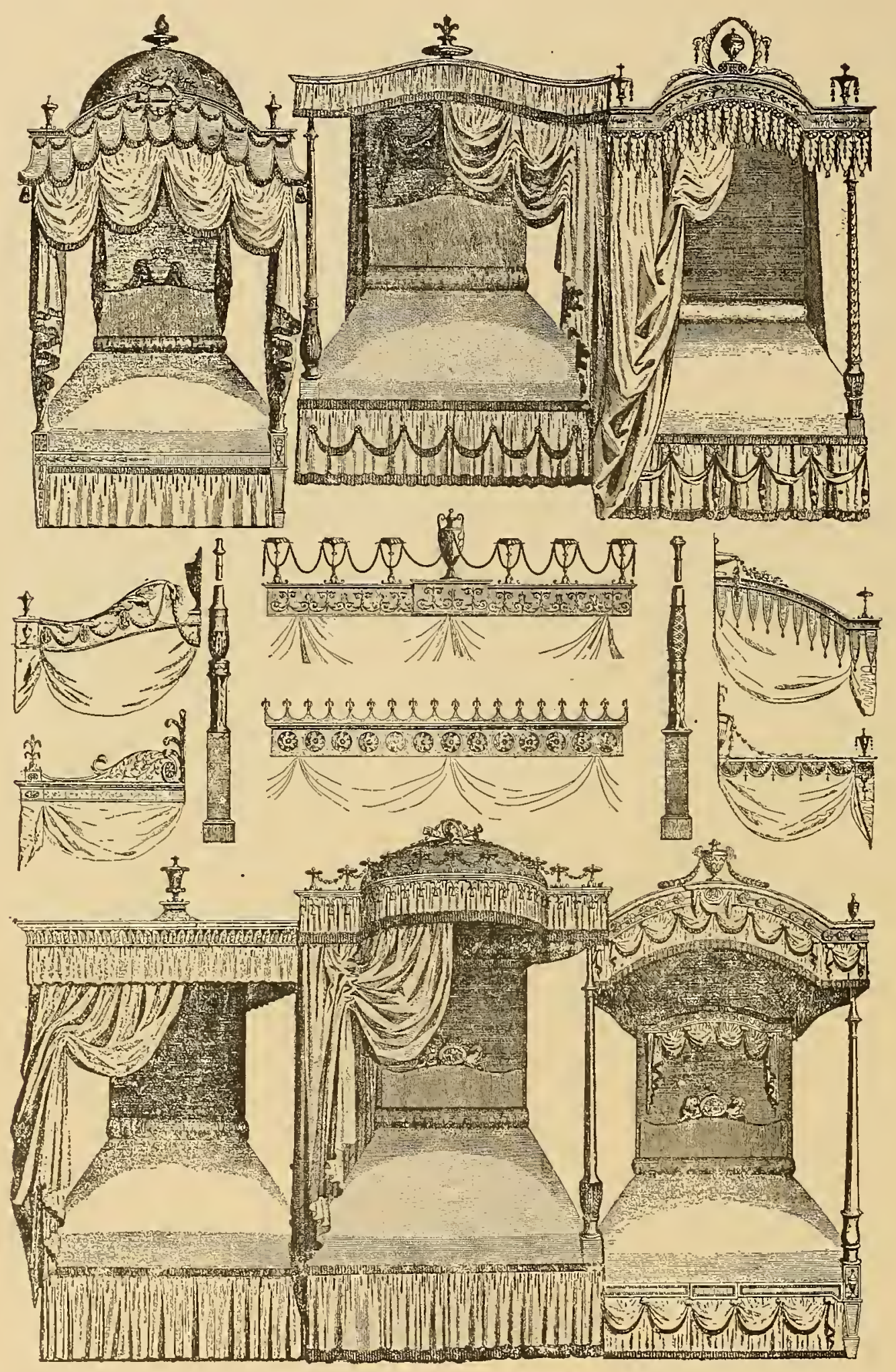

THE ADAM SPIRIT WHICH INFLUENCED CONTEMPORARY FURNITURE MAKERS: HEPPLEWHITE, SHERATON, SHEARER 

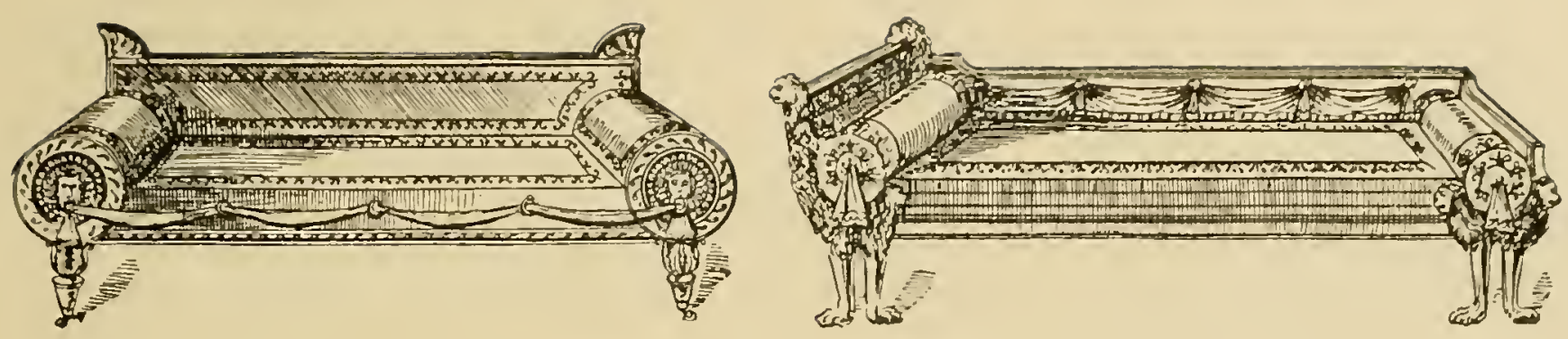

Adam furniture in which the classic spirit is emphasized.

\section{R. AND J. ADAM-1765-1790}

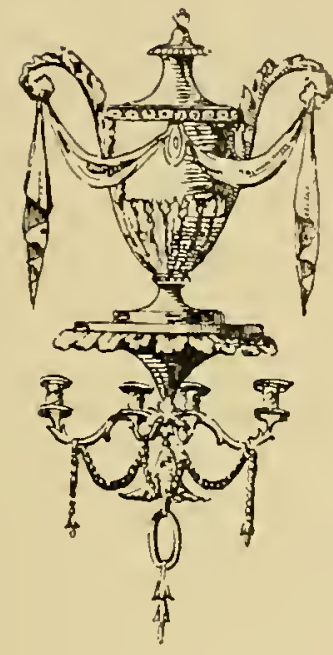

The Adam brothers were not furniture makers but architects, recorators and designers, employing Angelica Kauffman and her hus band Antonio Zucchi, Cipriani, Pergolesi and a host of ather's. They built palaces for the nobility, houses for the middle classes, terraces, bridges, even streets and squares, and in almost every instance their work was classic. The Chinese craze cropped out now and then, but its popularity waned from the inception of this epoch. Their style, reflecting the spirit of Pompeii

\section{$\mathrm{R}$ OBERT ADAM, the elder of the two brothers, $R$, and $J$..} was born in Scotland 1728 . He was educated in the University of Edinburgh, studied in Italy under a French architect, became F. R. S. and F. S. A. and before he was forty he was architect to the King of England. He died in I792 and was buried with high honor in Westminster Abbey. His brother was closely identificd with him in all his work. and Herculaneum in a purer type than was expressed in the late Louis XVI adaptations, left its deepest impressions on ceilings, side-walls and mantelpieces produced under the architects direct. They were tinted usually in jasper or palest gray colors. Circles and ovals were used as frames for pictures.

They utilized mythological ormament, the hexagon, circle, octagon and lozenge-shaped panel, wreath, fan, medallion, draped or with figures, the sphinx, griffin, sea horse, goat, faum, ram's head, the caryatid and innumerable other classic motifs found in Roman, Pompeiian and Etruscan work. They designed walls, ceilings, mantelpieces, even door knobs, escutcheons, locks-everything that went into a room, including table tops and furniture panels. While they were by

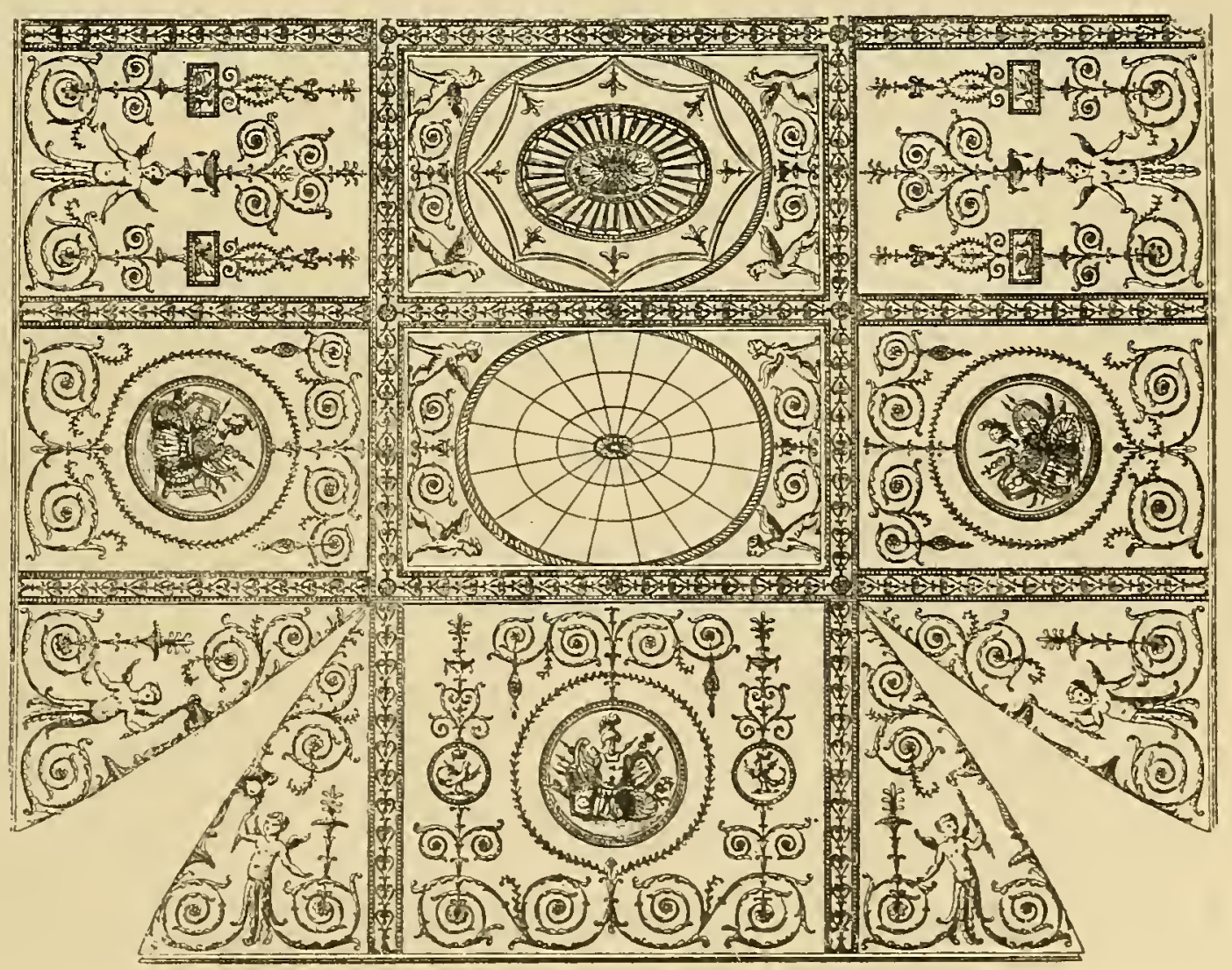




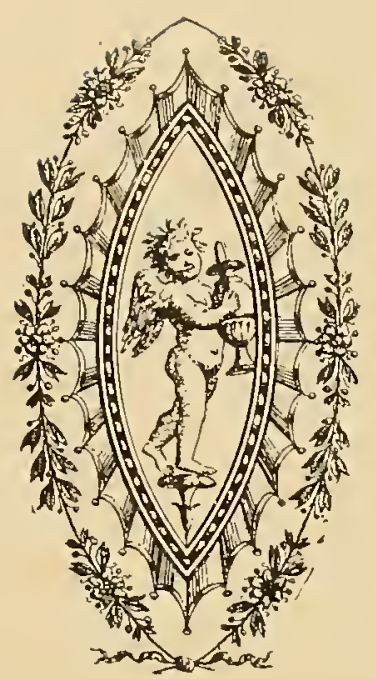

By Cipriani.

no means furniture-makers, the brothers Adam always designed furniture to fit their rooms: many sideboards with urn-shaped knife-boxes and classic brackets, pedestals, clock cases ancl mirrors were designed by them. They even designed the carriages, the plate and the sedan chair for Queen Charlotte. Their style was a complete departure from the massive and ponderous compartment ceilings of the Jacobean. Instead they adopted light moldings, delicate stucco frames and painted ornaments. They advanced the theory that the dining-rooms being so often ntilized for extended conversation should be finished with stucco and adorned with statues and painting and never liung with tapestry or damask, "which retains the smell of the victuals." As a result many of their rooms so largely depending on the work of the painter and sculptor $1 \mathrm{acked}$ cosiness.
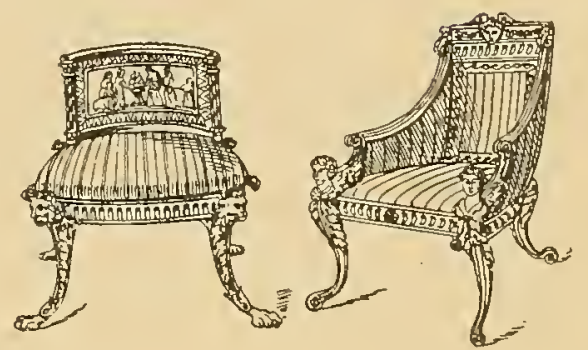

By Adam.

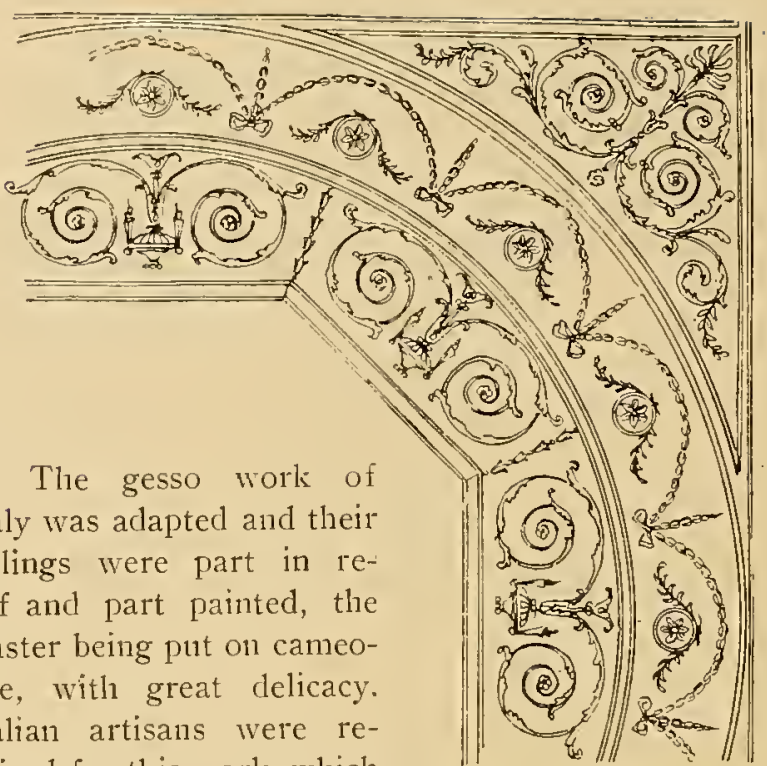

quired for this work, which preceded the use of plaques

and friezes furnished for late Adam work by Wedgwood, who caught the Adam craze and commercialized it. The brothers were so earnest' in imparting their spirit to the entire room that they insisted upon even the carpets being in unison with the surroundings. The palest tints of color and neutral tints of carpets to matcl were utilized. Even the table clotlis corresponded in with circular recesses.
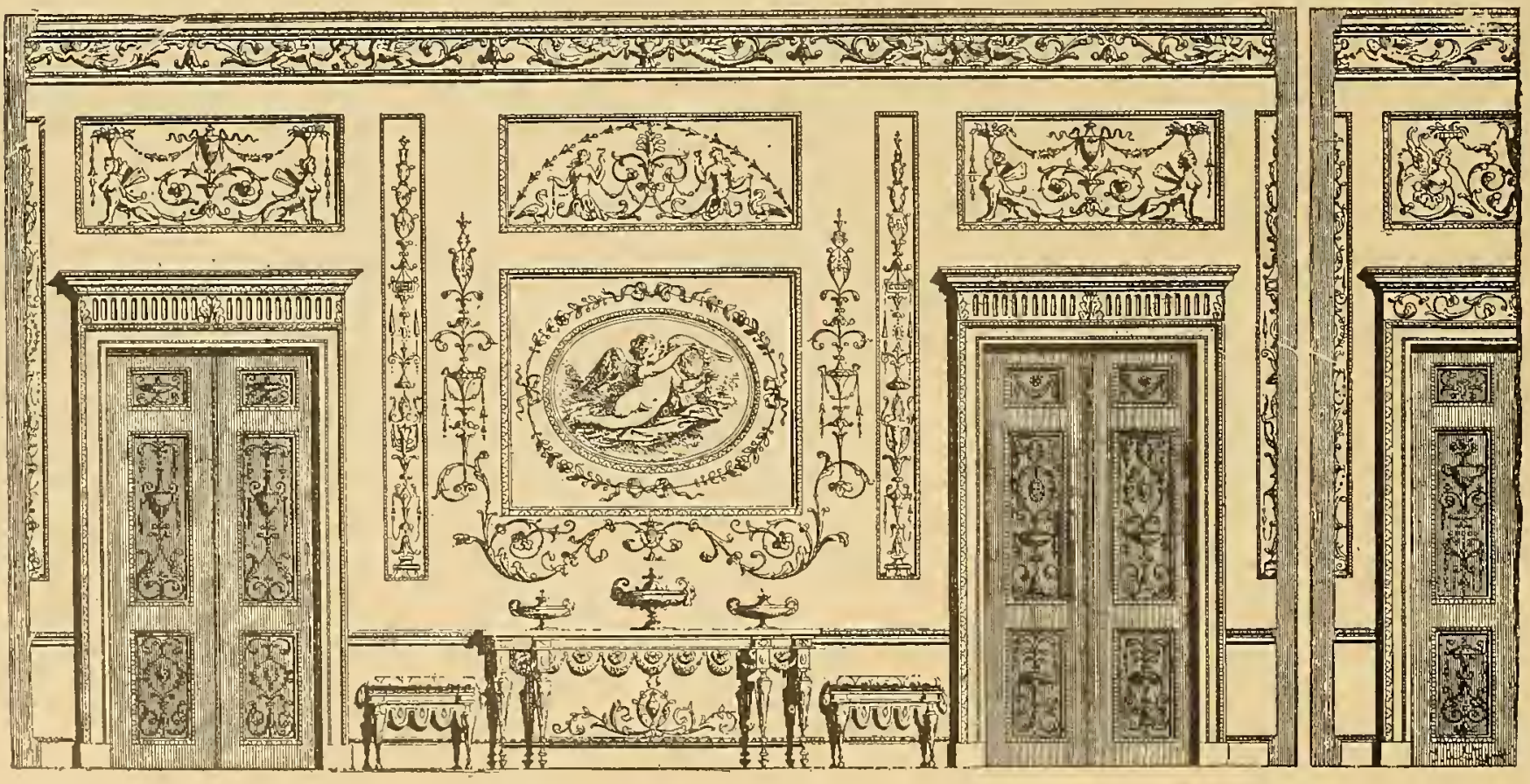

Paneled side-wall and furniture by Pergolesi. 


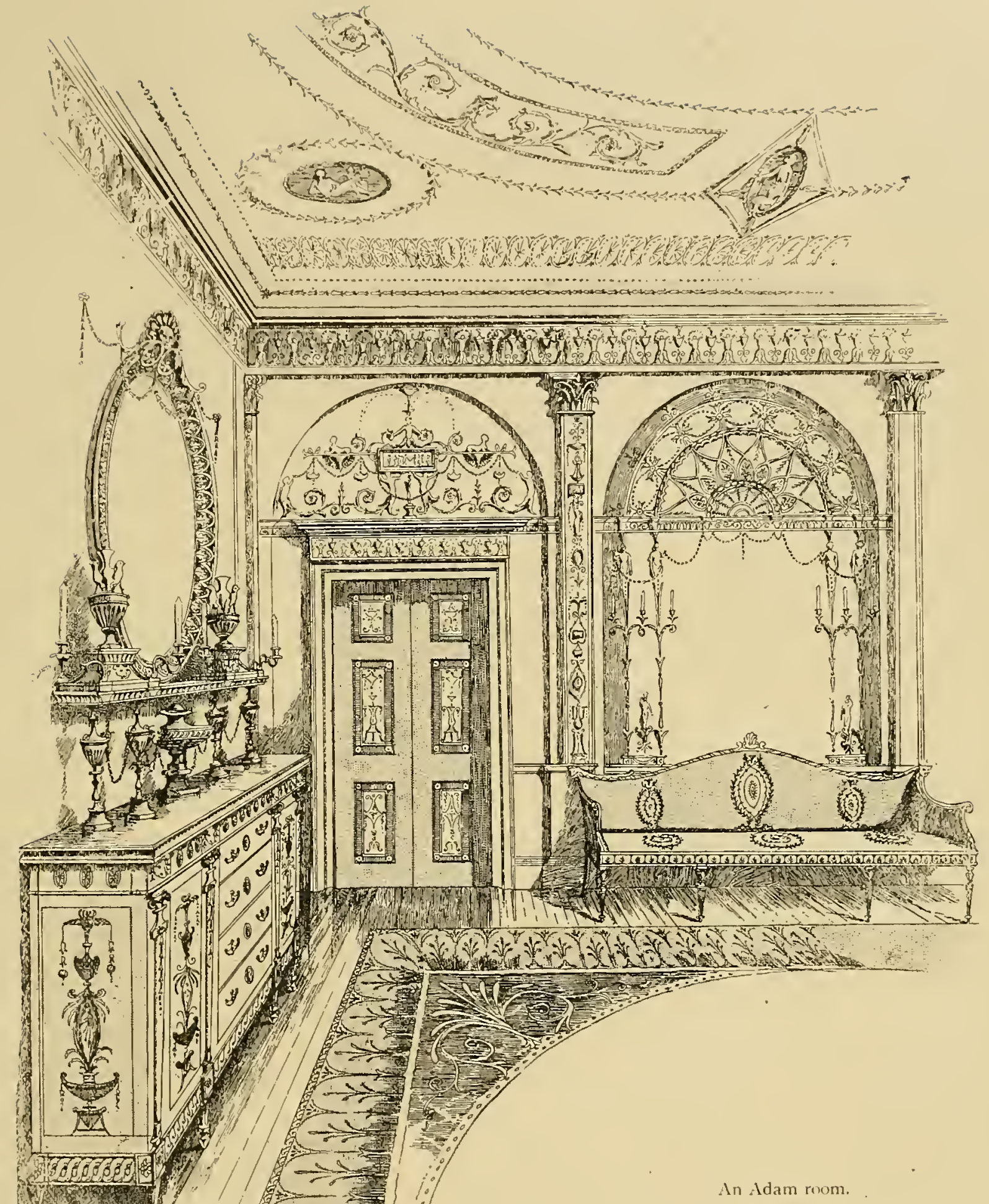

pattern and the unity scheme was carried out in the silver plate, the table-tops, even the suuff-boses. Their first published volume on Italian art is dated. I764; next volume almost purely Pompeiian,

I773. The period of their greatest success was contemporary with Chippendale. Hepplewhite and Sheraton. Being primarily architects, their mantels and side-walls are conspicuous examples. Their moldings arc usually of simple classic order; the rase and urn are favorite details, gcnerally accompanied by swags or festoons of drapery, leaves or husks. While acanthus scrolls and chimerical creatures characterize their 

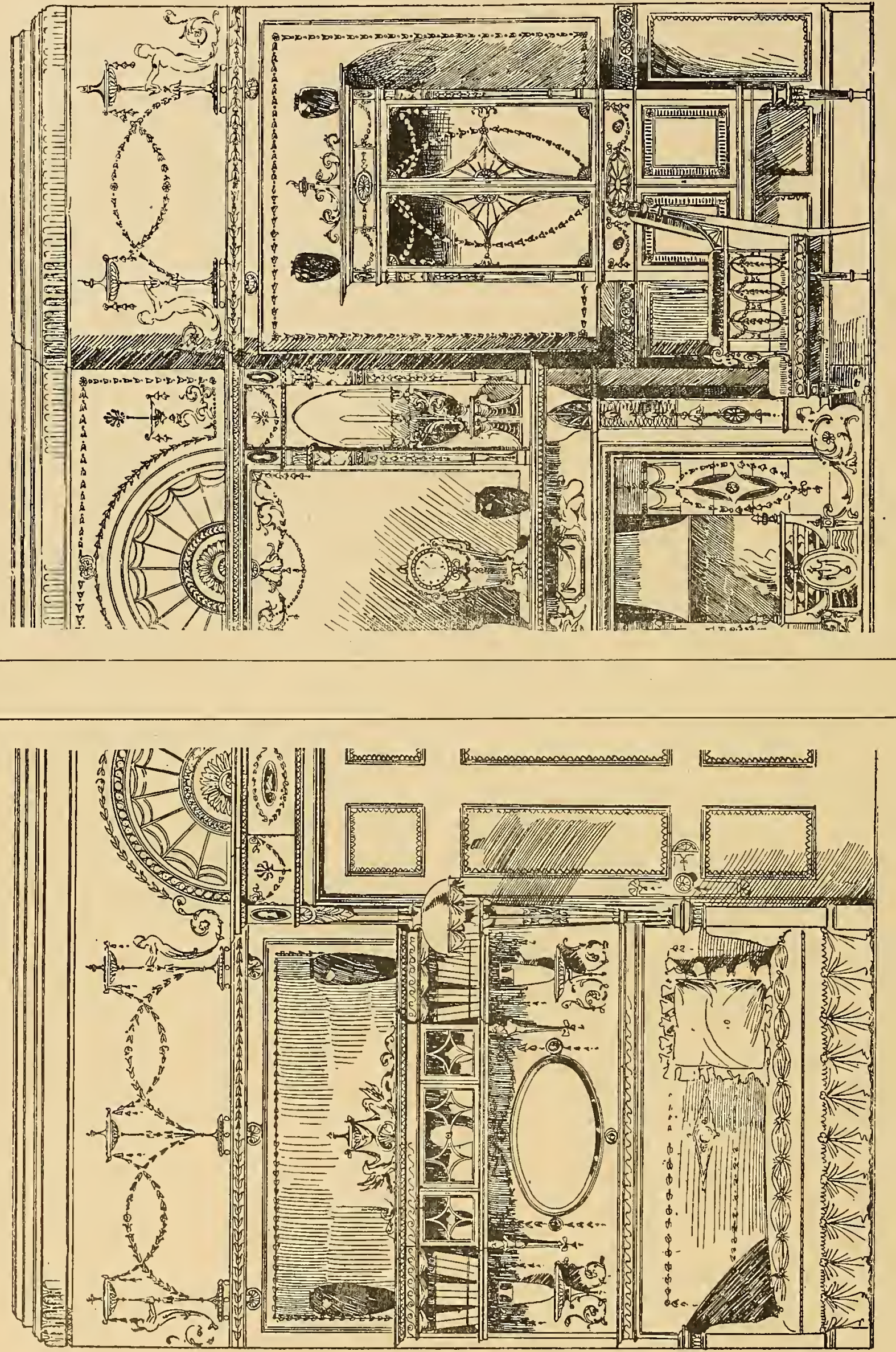
work, they were not treated in the heavy Roman school, but with delicacy. IVedgwood ware was frequently utilized, in panels and plaques.

Michael Angelo Pergolesi is responsible for much of the fame which attaches to the name of the brothers Adam. In 1777 Pergolesi published a perfect storehouse of Italian rlesigns covering plaster friczes. borders for painting on furniture, doors, sides of rooms, pier tables, settees and silver platc. Often he left a center of his panel work blank to be painted by Cipriani or Angelica Kauffman in scenes of child life or nymplss. The same idea was often repeated in marquetry and painted furniture.

IV. Thomas, a contemporary, followed the Adam style, together with N. Wallis, Columbani and George Richardson.

Richardson in 1792 published a work on wall treatment that was exceedingly interesting. He followed very closely the scenes from Greek mythology or Roman history, and bacchanalian figures and nymphs usually decorated the corners.

The same thing was frequently done by Zucchi, the Venetian painter, whose fame was gained in England. His walls were often tints of the lightest character, paneled.

To fix the relative influences of the conspicuous styles of this period we woutd explain that the first illustrated book bearing directly on furniture was that

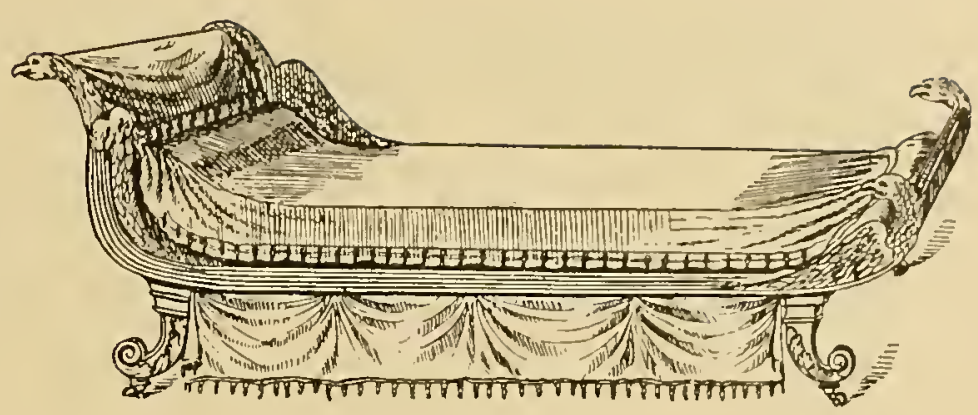

An Adam lowige or dayberl.

of W. Jones, who published the "Gentleman or Build er's Companion" I739.

Chippendale's first book was published 1754 .

Adam's influence was approximately I765-1790. George Richardson's book was published in 1776 ; Columbani's 1775; John Crunden's 1765, 1768, I770; Wallis' I771.

Hepplewhite's epoch-making book appeared 1789

Sheraton published the book which made his name in $\mathbf{I 7 9 1 .}$

There were in all four Adam brothers. John inherited the father's business as architect. R. and J. were the second and third sons, while IVilliam Adam, who died in 1822 , was the youngest brother.
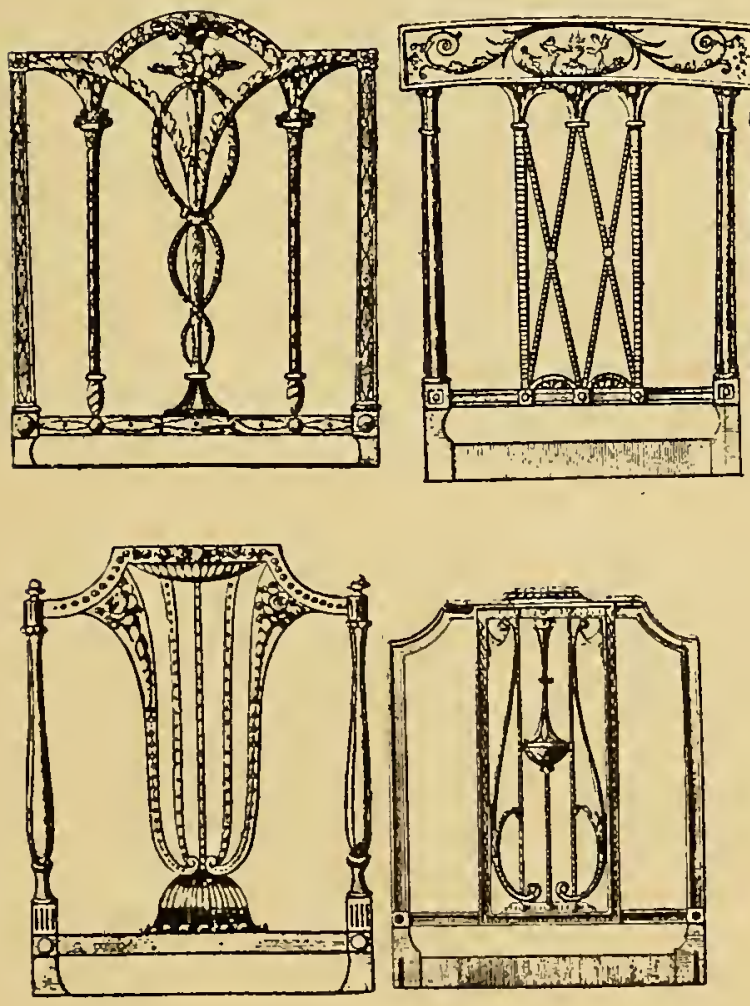

Sheraton chair backs and screen which show the influence of the Adam brothers' classic decoration.

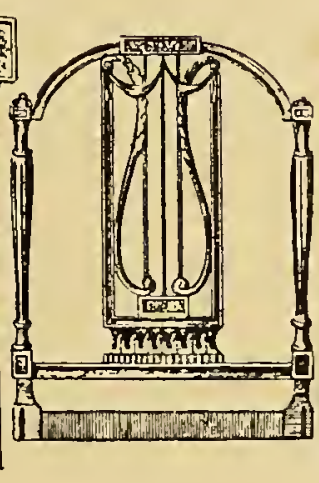

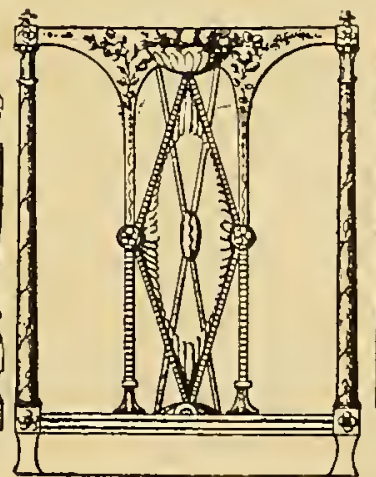
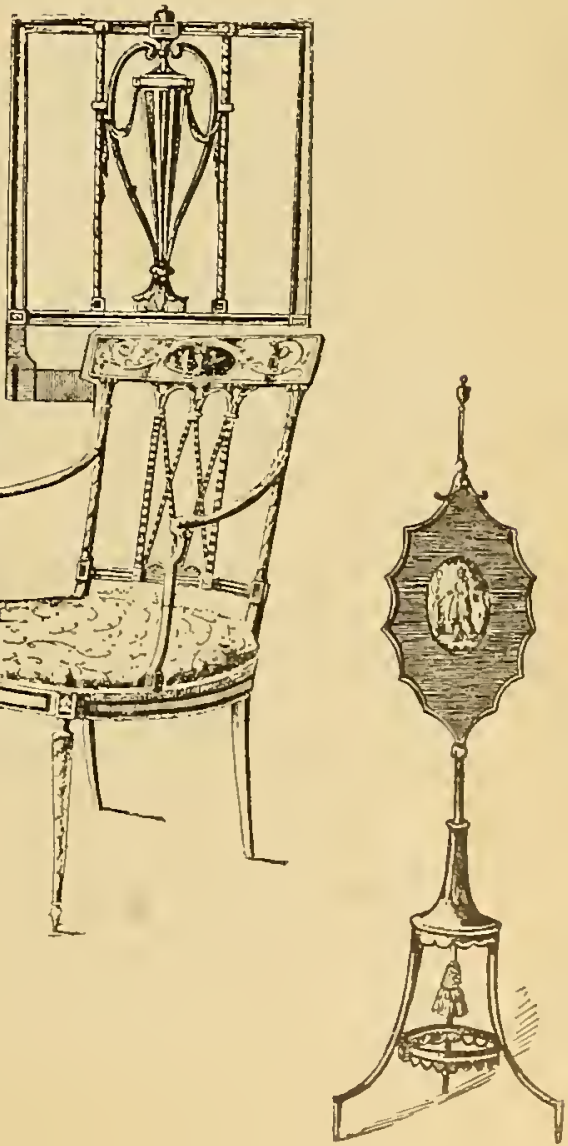


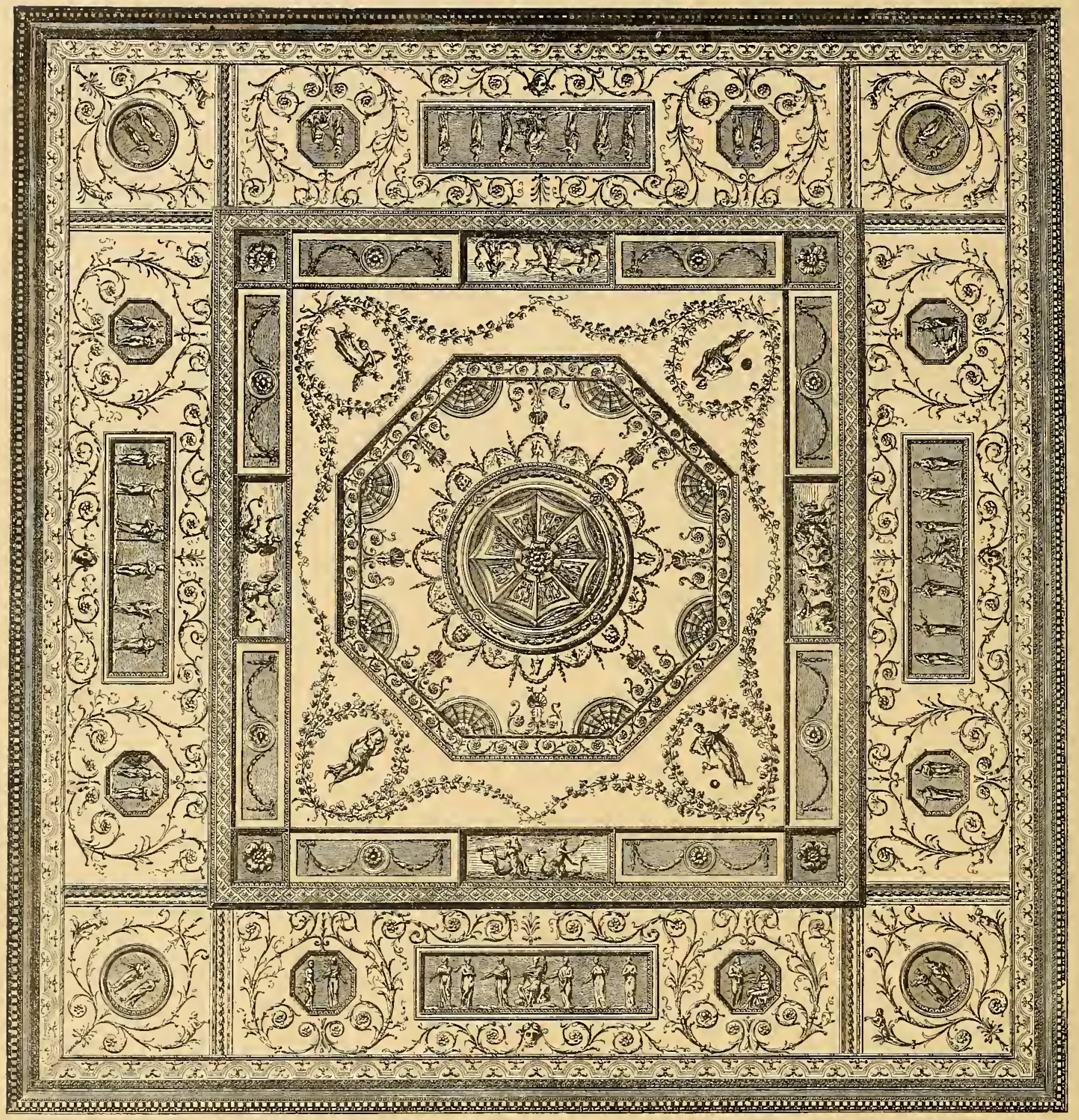

ADAM-CEILING DETAIL FROM AN OLD ENGLISH HOME. 


\section{O L ON I A L}

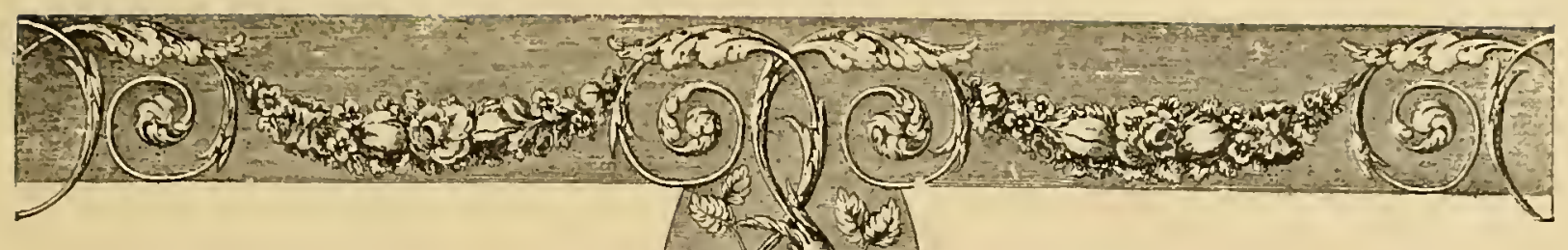

C

OLONIAL furniture is simply the furniture used in the colonies. We can differentiate in the phases of Colonial furniture by localizing, and then we have New England Colonial, Dutch Colonial, Southern Colonial and the periods Seventeenth, Eighteenth or Nineteenth Century.

It is a mistake to assume that Colonial furnishings were necessarily primitive. Historians give ample record of wealth in the Southern States long before the beginning of the Eighteenth Century.

Pory, writing of Virginia as early as 1617 , spoke of the growing wealth of the Sonthern colonies.

In 1607 Jamestown was settled by the English; in 1613 New York was settled by the Dutch; in I620 the Puritans settled in New England. From 1650 to I66o, during the period of the Commonwealth in England, the Southern States profited by considerable immigration drawn from the Cavalier and Royalist classes then out of power. In 1674 the Dutch settlements of America went into English possession.

From this record we can form a fair idea of the character of Colonial furniture. The South was influenced by French styles, especially at the period of Charles II when the French styles prevailed in England.

New York and the Middle States were largely influenced by the Dutch.

New England took inspiration from all the periods, and from the beginning, skilled craftsmen, joiners, cabinetmakers and carvers settled in New England and during the Eighteenth Century a very small proportion of the furniture used in New England was imported. New England cabinetmakers were numerous and expert, and New England furniture from 1700 to 1776 found a ready sale all through the colonies. The principal woods used were oak, ash, elm, walnut, maple, pine and red cedar. Goods were brought to the colonies so quickly from abroad that the new fashions appeared in American homes quite as quickly as in the country houses of England.

Readers of history need not be told of the great wealth in the country even in the earlier half of the Eigliteenth Century. Esther Singleton has gone into this subject very thoroughly and John Fiske, the eminent historian, says:

"The Puritan exodus to New England, which came to an end about 1640 , was purely English. Like the best part of the emigration to Virginia, it consisted largely of country squires, thrifty and prosperous.... The best part of the New England immigration consisted of people prosperous in their old lomes, from which their devotion to an idea (religious) made them voluntary exiles."

Again quoting from this authority: "Up to I688 there were 26,000 New Englanders, and from this number, in the following one hundred and fifty years, there have descended at least one-quarter of the present population of the United States.

"The laws of the early colonies were discouraging to the poor people, who went to the Barbadoes, Honduras or elsewhere. Even as late as $\mathrm{I} 7 \mathrm{I}+$ the immigration laws of the New England colonies were strictly enforced, forbidding one to enter who was unable to furnish proof of financial responsibility. During the fifty years preceding the American Revolution there was much wealth in the colonies, measured by the stanclard of wealth in those days. A fashionable social life centered about the representatives of the Crown, and the pride of the wealthy found expression in handsonely decorated homes. In Maryland and Virginia, where the High Church adherents and the Catholics settled, there was an aristocratic tendency, the happy combination of climate and agricultural facilities enabling the people to support a generous style of living as landed gentry."

There are no authentic records of mahogany fur- 


\section{O L O N A L} fact that mahogany was part of the inventories of that date indicates that the wood was used at an earlier period.

The Colonial styles followed closely the English. We used wall-paper at a time contemporaneously with that of England.

Mahogany trims for banisters, mantels, cornices and furniture were not generally introduced until I $75^{\circ}$.

A t $\mathrm{th} \mathrm{a} \mathrm{t}$

period Isaac

Ware wrote:

"The decora-

$\mathrm{t}$ ion of an

A merican

room is of

three kinds;

first, where

it is coated

with a plastic

$\mathrm{m}$ a $\mathrm{t}$ e $\mathrm{r}$ i a 1

shaped into

o r $\mathrm{n}$ amental

details; sec-

ond, covered

by wainscote;

and third,

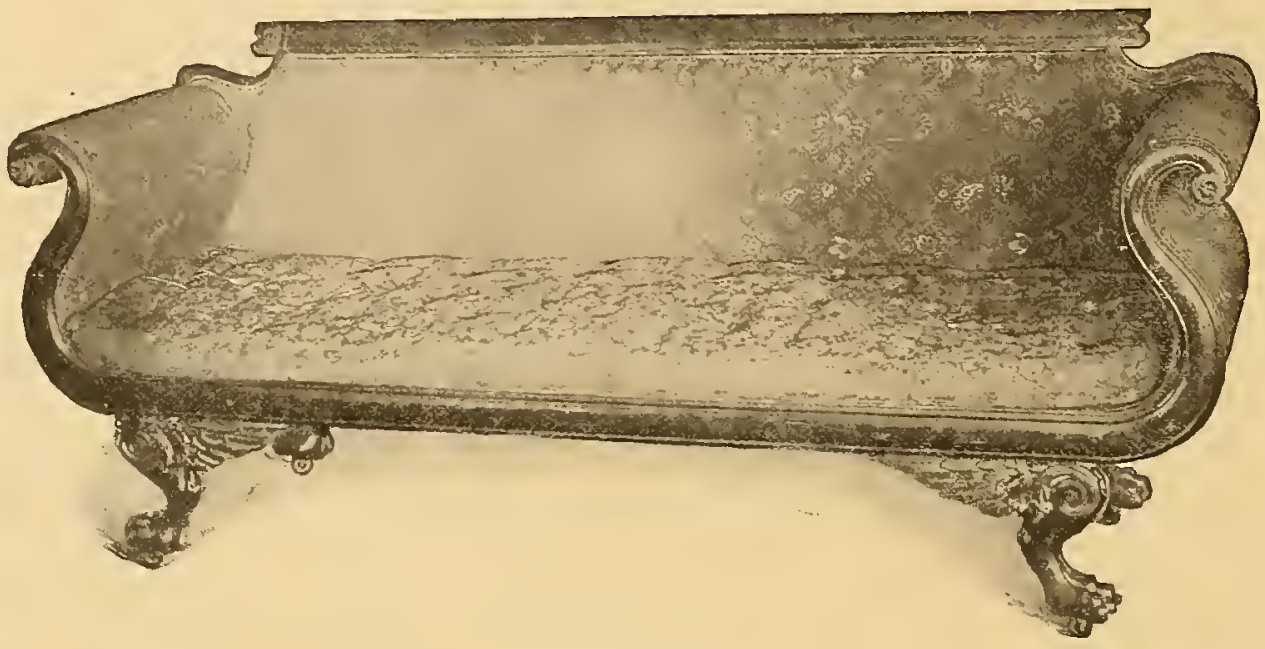

Colonial, 1810-1820. can cabinetnaker of great skill. niture in American inventories prior to 1708 , but the

ing Elizabethan influence, the principal characteristics being wainscoting, flat carving, turning, straight legs and heavy underbracing, rails and stiles mortised, and the tenons pinned with wooden pegs. Other periods are also well represented, including twelve pieces grouped under the first decade of the Nineteenth Century and attributed to Duncan Phyfe, an Ameri-

It is very interesting in this connection to note the fact that $s \mathrm{~m}$ a 11 tables were not thought of in England until the a b a n d on ment of great halls and the construc$\mathrm{t}$ i o $\mathrm{n} \quad \mathrm{of}$ smaller rooms also the introduction of $\mathrm{t} h$ e $\mathrm{n}$ e w drinks, tea, coffee, ' and chocolate, from 1645 to where hung with silks, tapestries or paper." As early as 1745 , Charles Hargraves was advertising wall-paper in Philadelphia, and a very few years later Peter Fleeson was making paper-hangings, although paper made in the roll did not appear till I790, the same year it appeared in England.

At the Metropolitan Museum there are many examples of excellent American-made furniture covering the Jacobean types and at least forty pieces show-
1658 , and at that period they appeared also in this country.

Chests came over with the colonists, and when the use of chairs became common and the chest was no longer needed as a seat, it was raised upon a trestle and soon after drawers were introduced and we have then "a chest of drawers."

By way of Holland came the Chinese fashion of lacquering furniture.

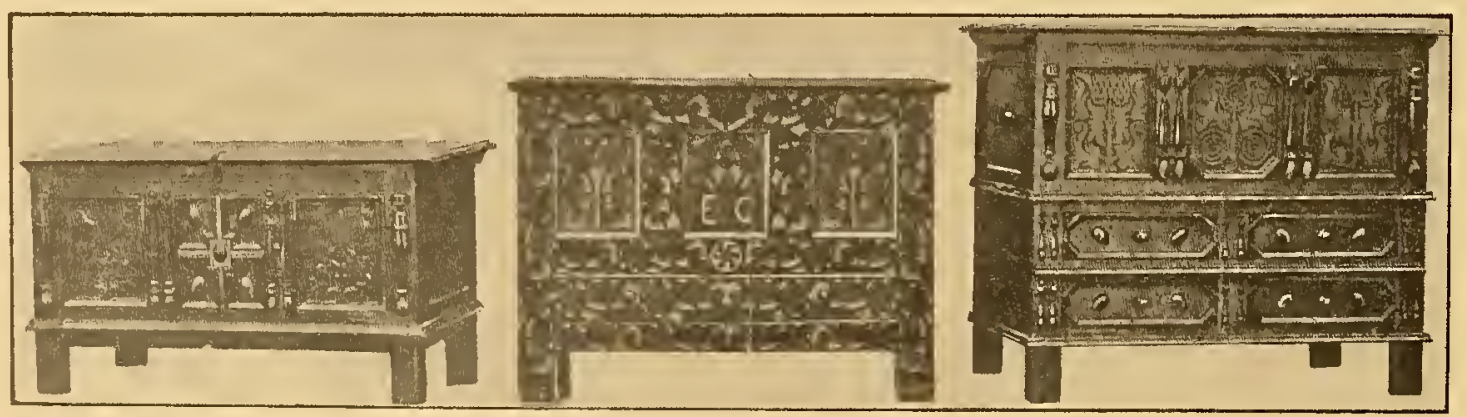

On the left, chest, Connecticut type, front in three panels, end ones having floral pattern in flat carving, center one divided into four sections with applied moldings and bosses.

In the center, "Hadley" chest with one drawer. Front covered with all-over design in flat carving; three sunken panels with conventionalized leaf and flower clesign.

On the right, chest with two drawers. Chest part divided into three panels with flat carving. Called the Connecticut pattern. American oak, with top, bottom and back of pine. 
As early as 1650 we find Connccticut quite famons for its chests. One in Ladley, Mass., was provided with a drawer and became a type. So many were made that they became known as the Hadley chest. See illustration.

Towards the close of Colonial history we have Colonial, which was a de ve lop ment of the Late Empire, in France developed by David and in England adopted by $\mathrm{T}$ 1 $0 \mathrm{~m}$ a $\mathrm{s}$ Hope.

In $\mathrm{th}$ is country, especially during the Jefferson regime, $\mathrm{L}$ a-

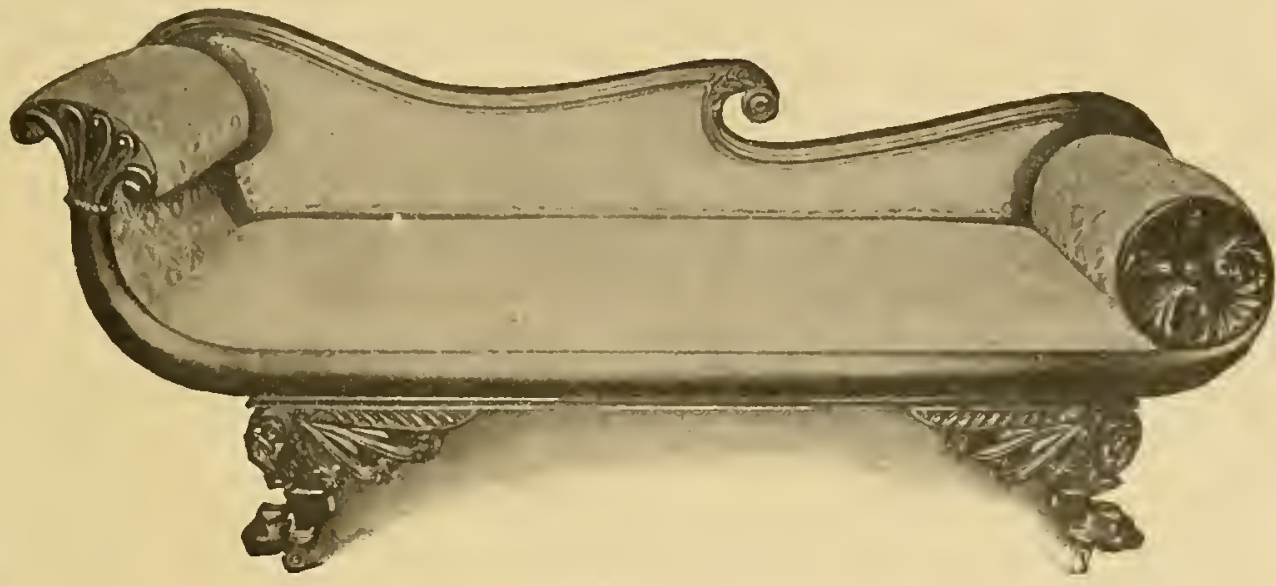

The Empire influence, 1810-1820. form. character. a type of furniture and furnishings called Late

chair backs and as central pediments. If there is any one distinctive form of Colonial lurniture it is this

Bureaus, sidcboards, tables and sofas lecame famous and are still popular types of strictly Colonial

Colonial chronology begins with James I, but the American homes by 110 means adhered to the earty Jacob e a $n$ ex amples in a r c hitecture. The sidewalls in the Elizabethan and Jacobean homes were largely wainscoterl and often hung with tapestry. trobe, the decorator and architect appointed as surveyor of public buildings in Washington, exercised a great deal of influence. He eliminated the very extreme character of the Empire school, the personal elements interpolated by David, and the Egyptian and Roman symbolisms of victory and conquest, and retained the classic simplicity, notably the classic column, and in many cases the eagle's head appeared in the

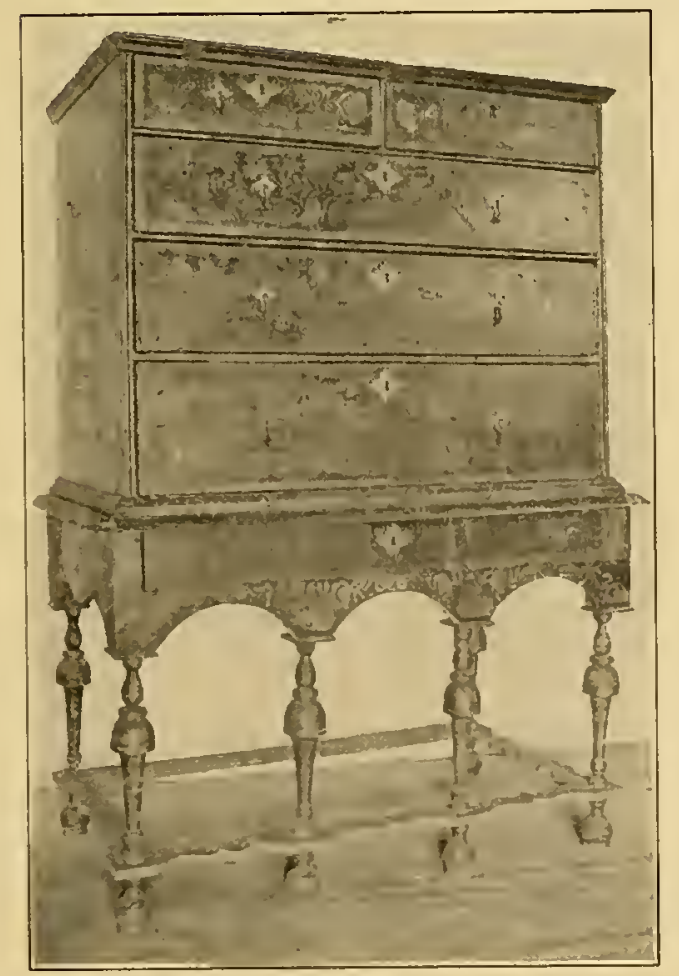

The ceilings were in stuccoes frequently colored and in heavy relief. These features were not adopted in? the colonies. The country was too young. Jacobean furnishings were in other respects in common use, and cotton, linen, chintzes and other fabrics were much utilized.

Architectural features of the English home began to be copied with Queen Anwe, and from that period down to the Georgian, we find many homes of distinction in America.

None more beautiful can be imagined than the

Below, on the left, Dutch marquetry chest of drawers, 1675; on the right, sofa and table, 1810-1820.

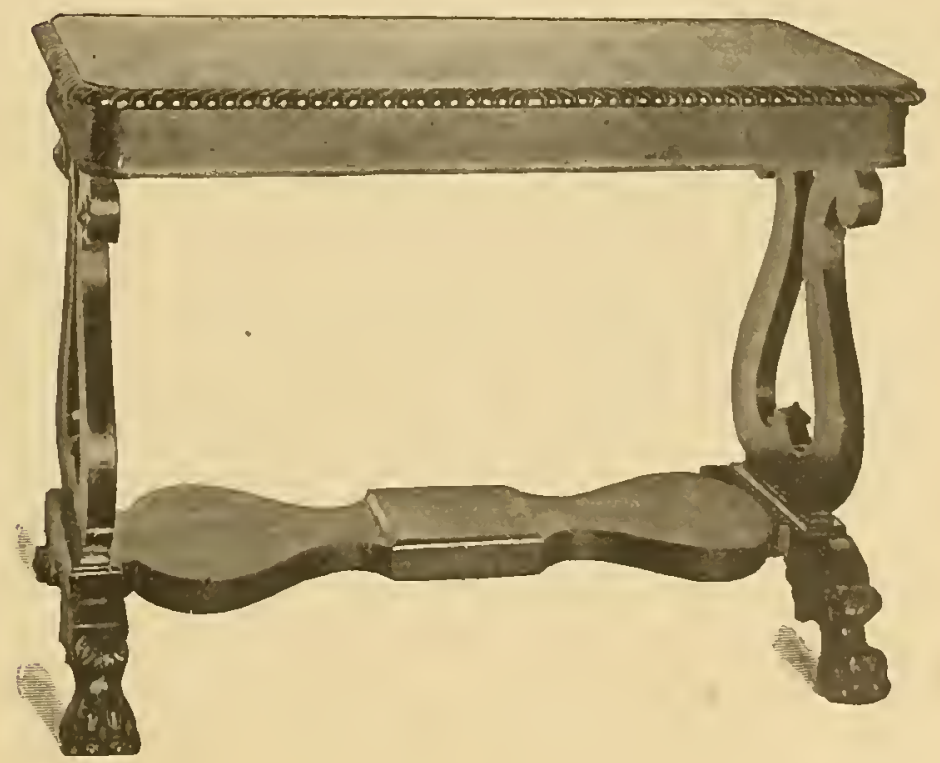




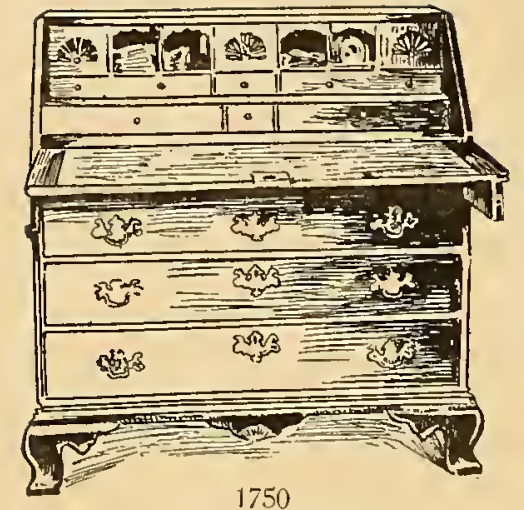

1750

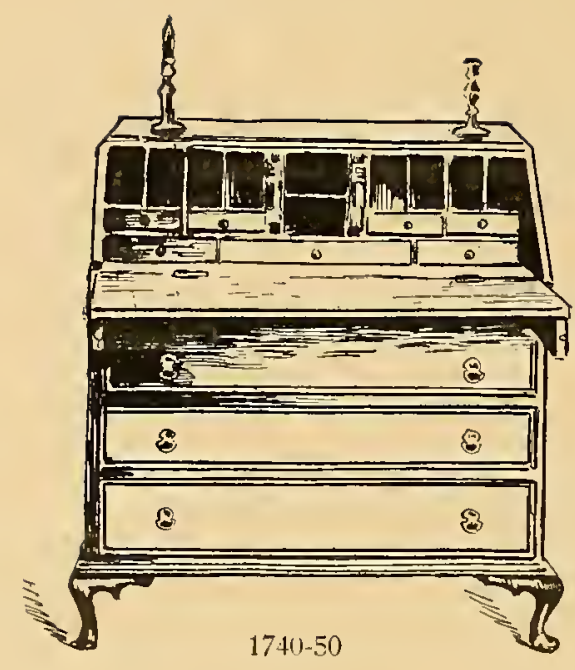

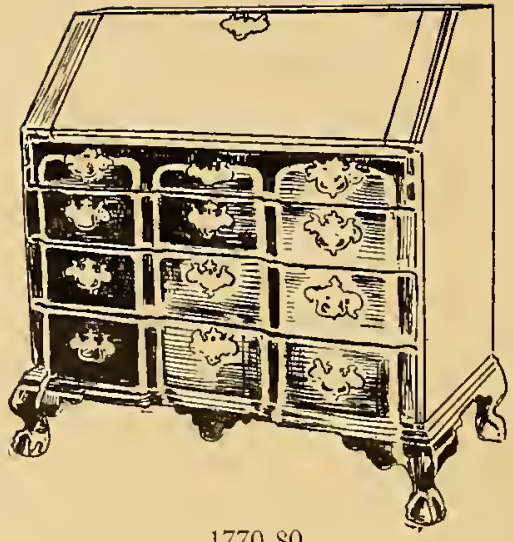

$1770-80$
Chase House, the Harwood House, the Hammond, the Lockorman, the Bryce-Jennings House, Byrd's, Carroll's or hundreds of other homes in Salem, Providence, Bristol, Annapolis, and other thriving towns and cities.

As early as 1674 there was great wealth in the Colonies, a condition obvious when we consider that it was from private sources that most of the money was obtained that sustained the eight years' war with England.

The variety of fabrics produced was unlimited. In silks Spitalfields was a vigorous rival to Lyons. From

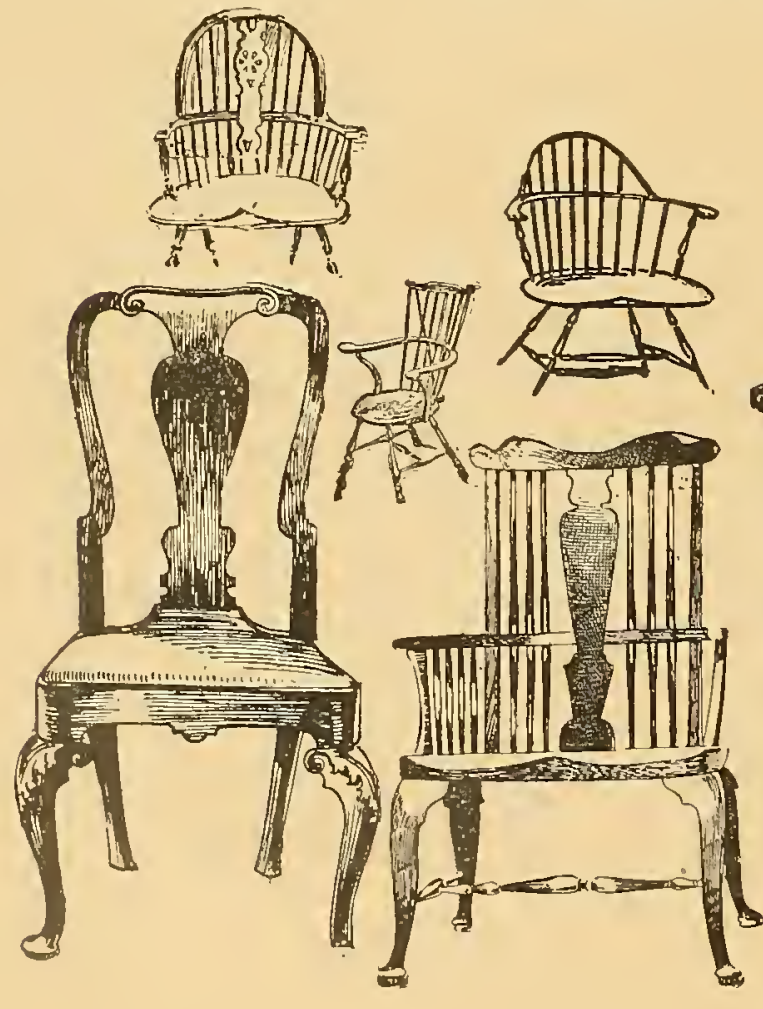

The earliest example of a Wincsor chair is found in an old Jacobean interior of Windsor Castle. It is estimated that the chair dates 1650 . It was a common American article in cottage use in 1700 . The illustration in the left-hand upper corner is the first example found. Imnediately below it is the well-known Hogarth chair of about 1720 , and to the right is a development of the Hogarth with turned rail back and Hogarth splat, about 1720 . From this directly comes the type in the upper right-hand corner. The large chair is one used by Thomas Jefferson. Until 1830 various kinds of Windsor by Thomas were common in America.

1727 to $175^{\circ}$ innumerable silken fabrics were made, as: brocade lutestring, brocade tabby, brocade tissue, brocade damask, tobine, flowered tabby, figured tobine, four-comber damask, double tissue, gold stuff, double tabby, brocade satin, Venetian brocade, India figured brocade, tobine tabby, tobine lutestring, and so forth. The style of their patterns closely corresponds with that of contemporary Lyons silks.

In East Indian stuffs alone we have a list of forty terms.

In 1759 "flowered damask for furniture"

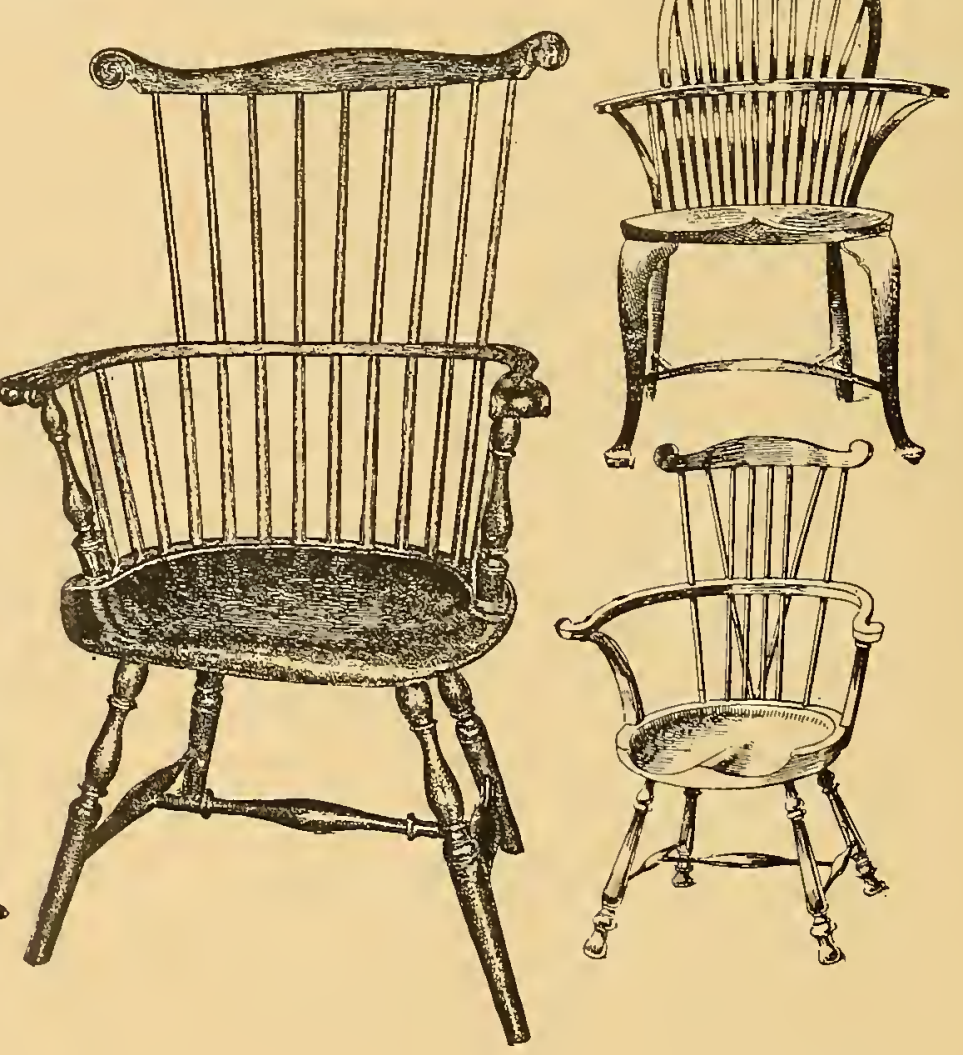




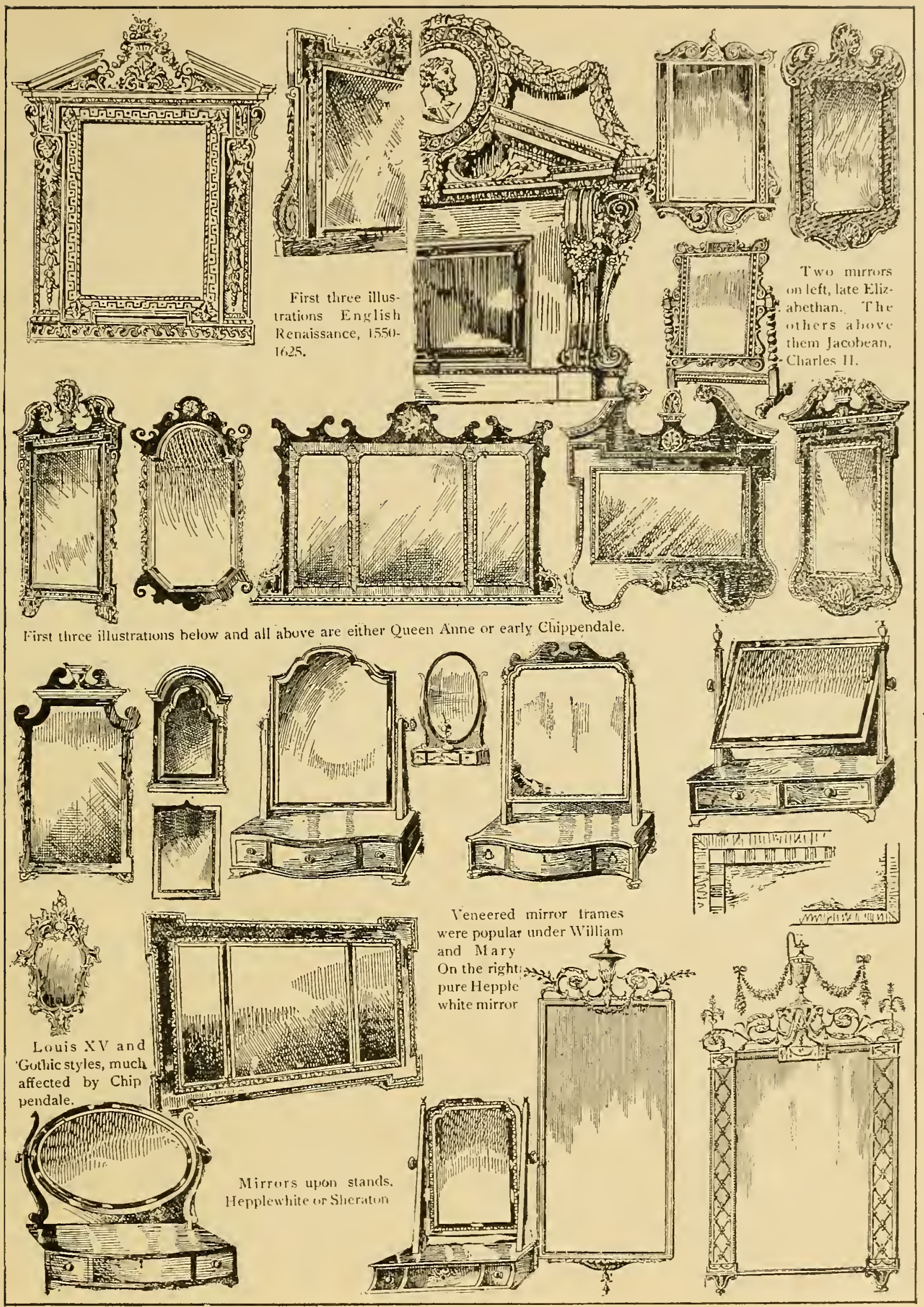


was imported. In I760 "crimson, blue, green and yellow harrateens with tassels" were imported.

1762, Indian gimp and binding. quilts.

I768, fine striped lutestring (plain silk) Marseilles

I770, moreens, stout woolen curtain stuffs.

Harrateen cloth was made of combing wools.

Printed cotton, hand-printed, frequently of very large bird and animal designs.

Scarlet and crimson cassimere, calico and dimity.

Durance, a stout worsted cloth.

Calamanco, a glazed linen stuff.

Turkey work, a coarse, plain ground with pattern tufted like a rug pile.

Paduasoy, a strong silk.

Green cloth, crimson worsted, red cloth, red damask.

Shalloon, soy, watchet, linsey woolsey, fustian.

Silk muslin, chintz, Indian calico, tabby, sarcanet, taffeta, horsehair.

Camak, or Comacoa, was silk and camel's haii mixed.

Bancours, a kind of tapestry.

Shalloon was a coarse woolen cloth.

Darnix or darneck, coarse, taking its name from Dorneck, the Dutch for Tournay.

Damask, first made in Damascus in such a way that "what is not satin on one side shows satin on the other side."

Perpetuana ( 1650 ), a very durable woolen.

Green and red paly is the heraldic term for alternate stripes of these colors.

Camblet was a woolen, hair or silk twill, sometimes waved or watered.

Tabby, a kind of coarse watered taffeta.

Seersucker, a thin ridged and puckered material.
THE FOREIGN INFLUENCE ON COLONIAL STYLES.

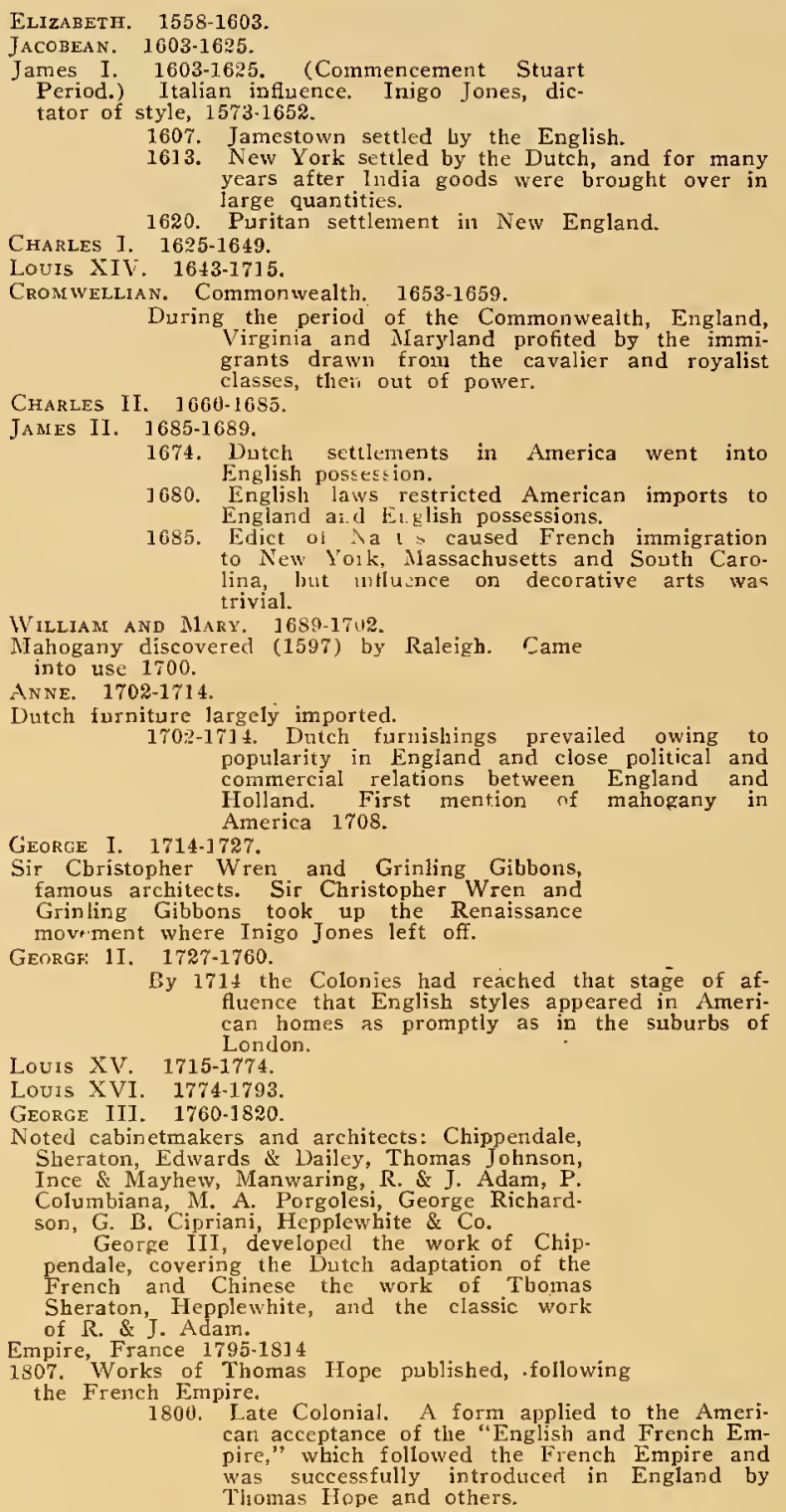
fluence that English styles appeared in American homes as promptly as in the suburbs of

Noted cabinetmakers and architects: Chippendale, Sheraton, Edwards \& Dailey, Thomas Johnson, Columbiana, M. A. Porgolesi, George Richard. son, G. B. Cipriani, Hepplewhite \& Co. car acceptance of the "English and French Empire," which followed the French Empire and was successfully introducer in England by Thomas Hope and others.

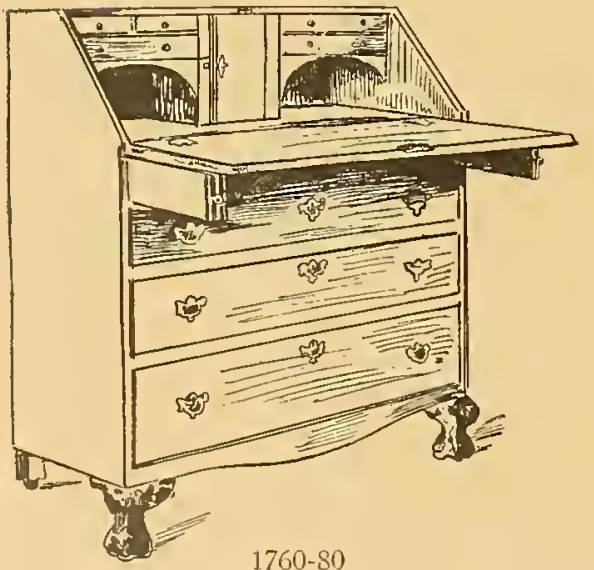

$1760-80$

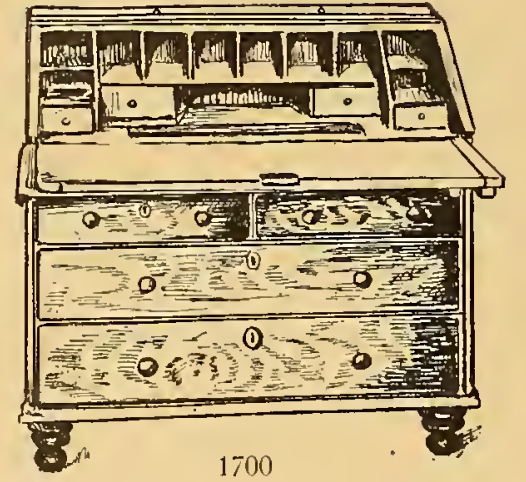

1700

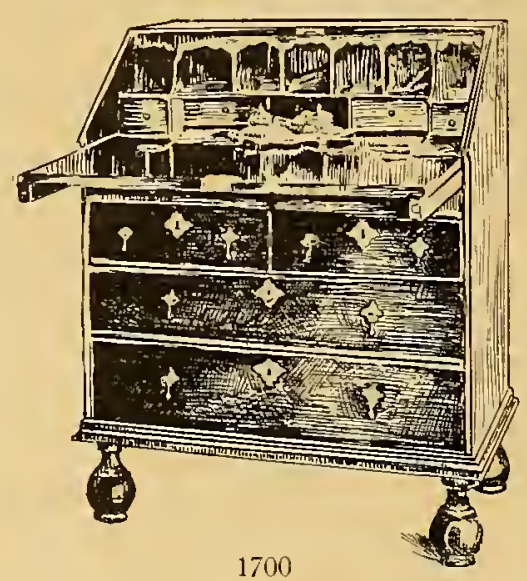

1700 


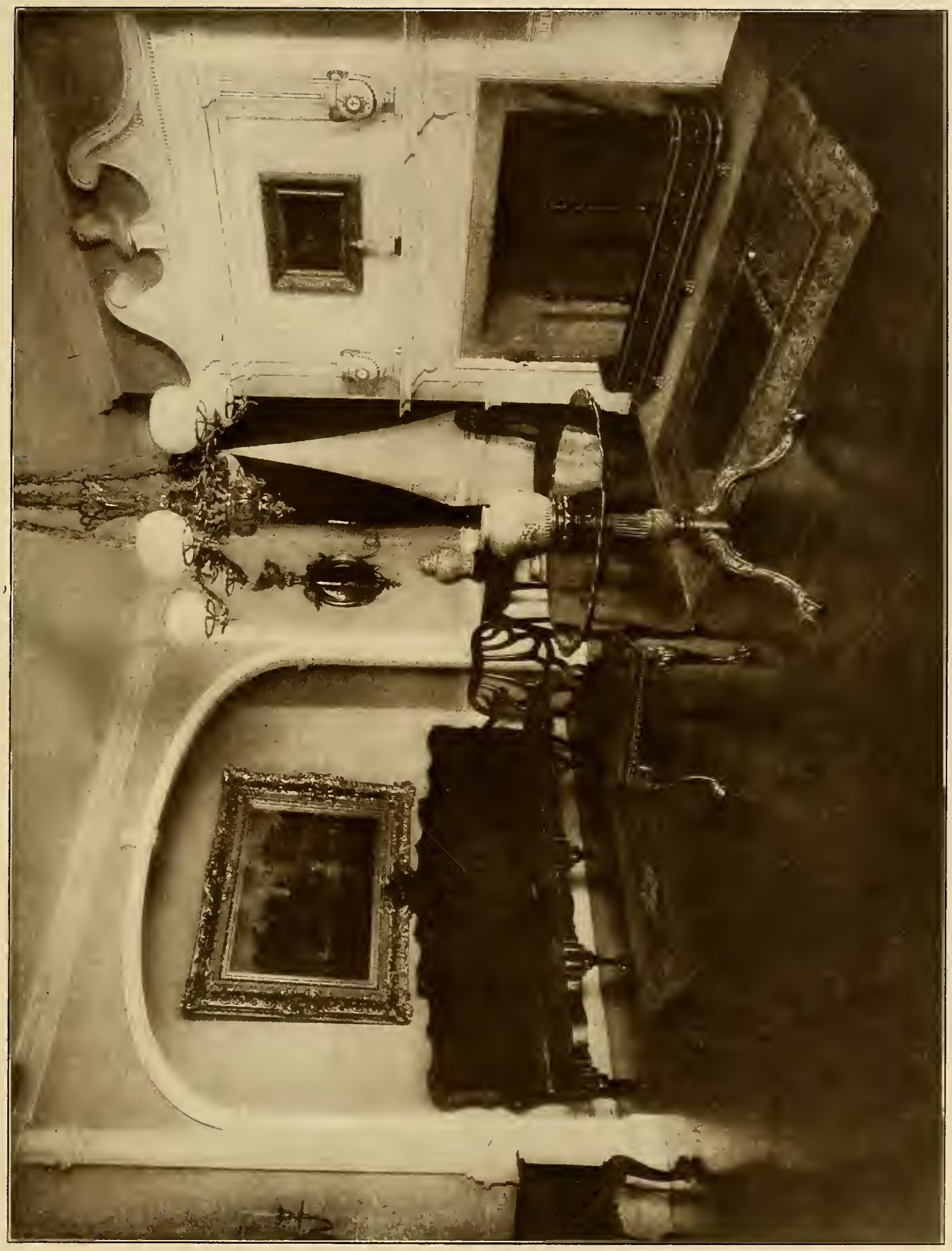

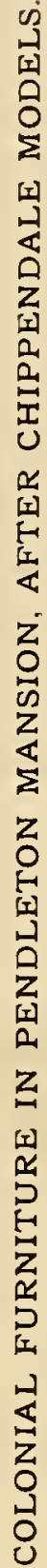


. 


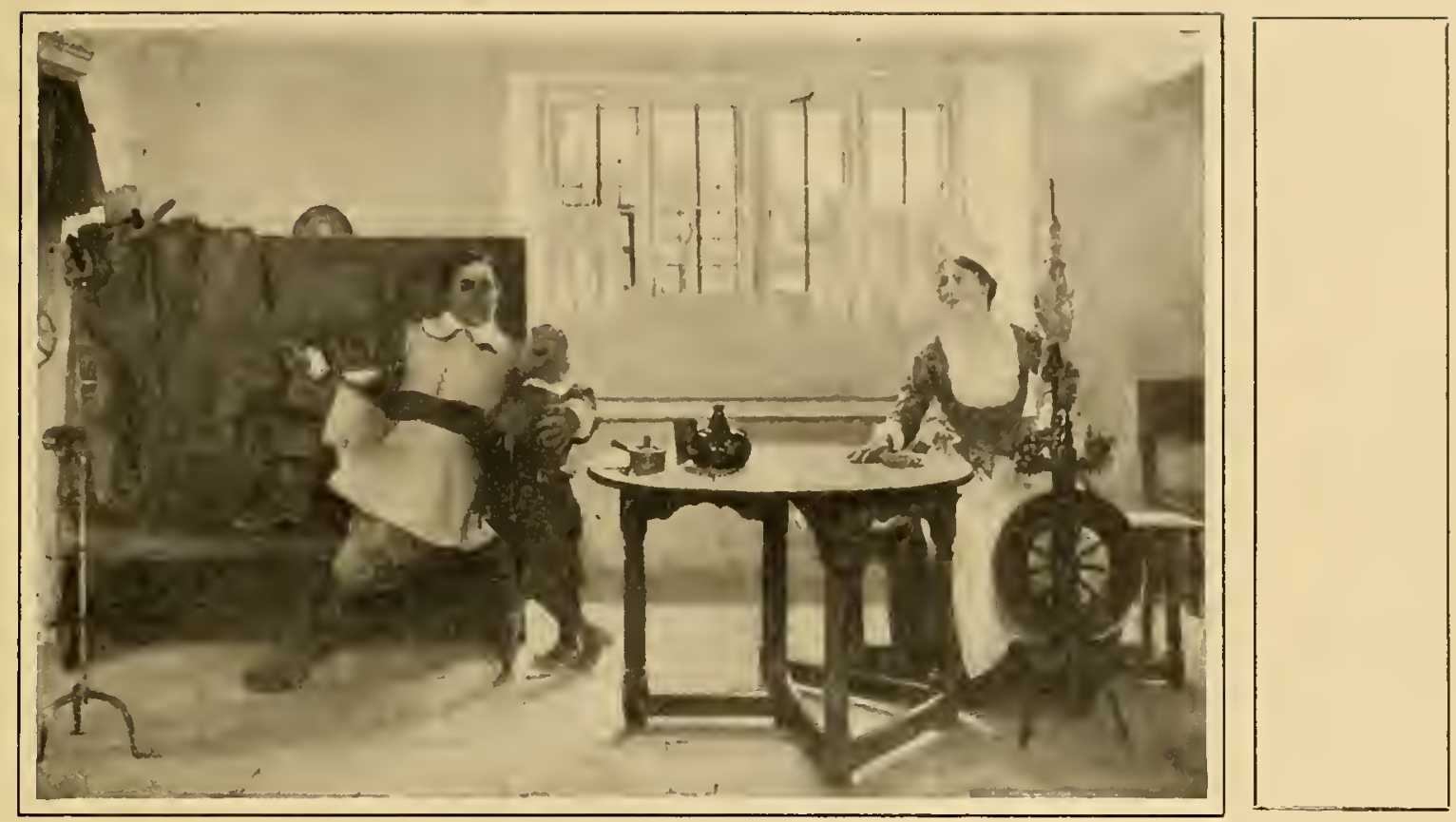

A Colonial interior of about 1630 .

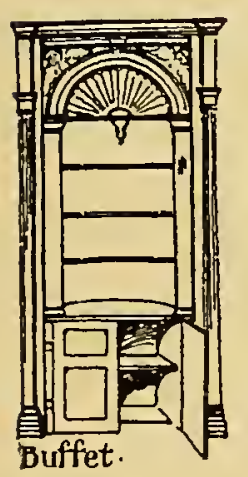

$\mathrm{T}$

O DEFINE the term Colonial we must fix the period not only chronologically, but geographically. We must discriminate between New England and the South. between carly and late. We must understand the conditions, whether of town or country, because the types varied.

One is prone to regard in this
England it was broadly claracterized as Queen Anne.

The early colonists enjoyed the same comforts as their English brothers, and surprising as it may scem, the earliest settlements were furnished with window glass, at a period in England called Jacobean, when window glass was a luxury.

In 1629 one of the Salem settlers, Higgins, wrote to a friend in England, "Be sure and bring with you a supply of window glass." country the ciaracteristic Colonial form as that form wh ich presented Oriental furnishing $\mathrm{s}$, bras ses, Chinese porcelains, cotton prints, conspicuous in birds and flower details, rich lacquers, coppers and pewter. But $t \mathrm{l}$ is form lasted only from I690 to 1740 ; in

Kitchen at V'anCortland Manor.

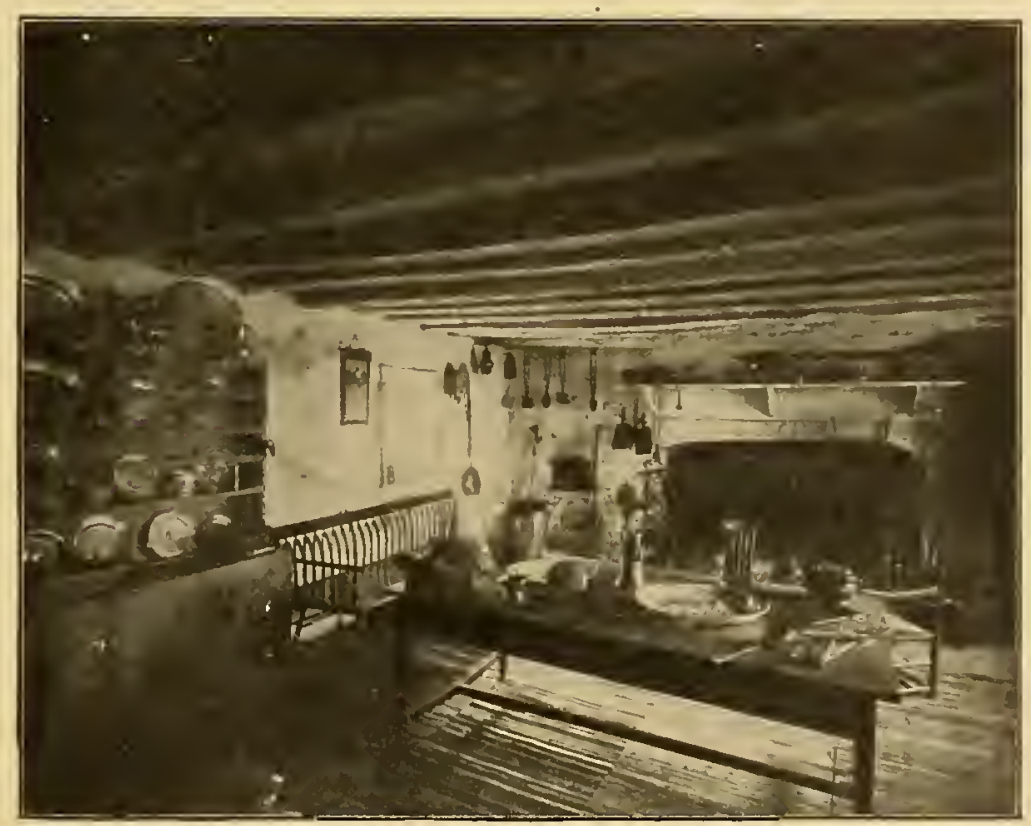

The use of glass in dwelling houses began about the Fourteenth Century, although we have records of window glass used in Pompeii 79 A. D., and frequent references to window glass in the Fourth and Fifth Centuries; in the latter periods, however, the glass was an inch and ahalf and two inches thick, sometimes discs or fragments

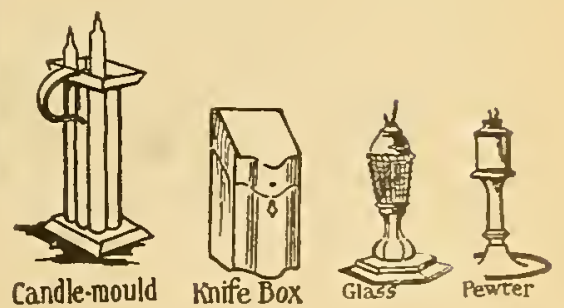


joined. In the Fifteenth Century oiled linen was generally used. The Dukes of Burgundy used oiled paper, and as evidence of the general use of glass it will suffice to say that at the close of the Eighteenth Century, r79o, there existed in Paris itself a corporation for making window sashes filled with oiled paper. ("Glass Making," by Sauzay. Scribner.) Up to this date all glass used for mirrors or winclows was limited in size to the lung power of the glass blower, which explains the little glasses in mirrors and cuplosards.

It was not until the beginning of the Eighteenth Century that a method was produced for making larger sheets and for a 10 is while the cost was very heavy. In 1702 a yard of looking glass cost \$32.10. In 1802 a yaril cost $\$ 39.90$. In 1862 a yard cost \$8.75.-Ed.

American patriotic societics have preserved not only many olel landmarks and old buildings of Colonial reputation, but old furnishings. One must always bear in mind, however, the nature of a collection, whether a collection from the farmhouse, or the city house, the cottage or the mansion.

In the Northern States, where Winter comfort was considered, the rooms were smaller in size, the ceilings were lower, the windows were smaller than we find in the South, where weather conditions were diametrically opposite.

We hear a great deal of the rush-strewn floors of the Elizabethan homes; but they were only the floors that were open to the tenantry and the servants-rooms of a public character. We hear of the $s$ and ed floors through Pennsylvania, but the y were the kitchen floors

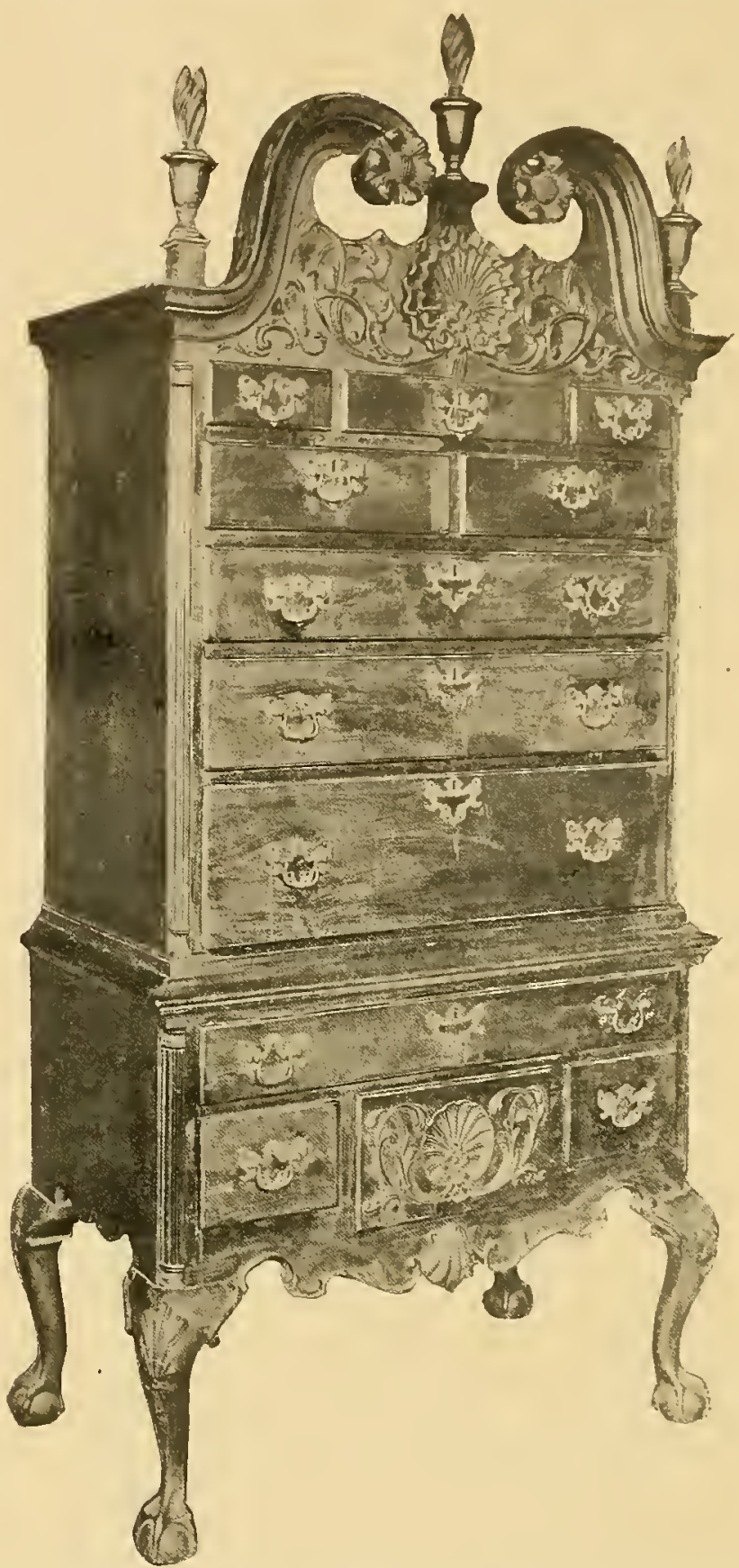

Highboy, latter half Eighteenth Century. The cabriole leg became popular with William and Mary, and continued with shell ornamentation and the French influences, with many modifications, down to the period of classic revival by Adam The swan-neck or broken-arch cornice made its appearance in architecture about 1700 , and was soon used in furniture.

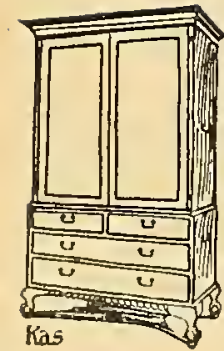
and inn floors. The same tastes prevailed here as prevailed abroad. All social grades were represented, and to those who are interested in the study of Colonial sociology we recommend the ivotks of John Fiske, the eminent American historian, "The Beginnings of
New England," "Child Life in the Colonial Days," "John Hancock, His Pook," and "Examples of Colonial Architecture," a volume of interiors and exteriors of South Carolina and Georgian homes by E. A. Crane and E. E. Soderholz, published in Germany. The decorations of the ceilings. the sirle-walls, the flowers, even the wood linisly followerl the European styles. white woodwork coming in with Nilliam and Mary. aljont íngo. In I749 Isaac Ware wrote: "The decoration of an American ruom is of three kinds-first, where it is coaterl with the plaster material wrought into ornamental details; second, where covered by wainscot, and third, where hung with silks, tapestries or paper," for in that year dealers in America were advertising "to hang rooms with paper or fabrics in the very newest fashion." Indeed, Charles Hargraves advertised wall-papers in Philadelphia in 1745 , and only a few years later Peter Fleeson was making paperhangings in squares, corner of Fourth and Chestnut Streets, Pliiladelphia. Nantucket, Portsmoutl and St. Johnsbury, Vt., have yieldied to the collectors some exquisite examples of wall decorations. Thomas Hancock in I757 wrote to an English friend to send him some paper-hangings showing a great variety of birds, animals, fruits and flowers and he adds to his letter: "I think these papers are handsome, beiter than painted walls." Colonial characteristics were simply the cliaracteristics of modification or adaptation. Duncan Phyfe, in his time more famed in America than Chippendale in England, followed his English models with modifications. Latrobe followed the Empire styles, but with modifications. The larger cities and towns of this country were well equipped 
with cabinetmakers, who, at the time, were more famous than Chippendale, Sheraton or Hepplewhite, but they followed the English prototypes.

We have before us an extract from a New York paper of $177 \mathrm{I}$, which dwells upon the expuisite work marle by a New Jersey cabinctmaker who "served his time and was for eleven years foreman to the great cabinctmaker Hallet." If this advertisement is a mere catch-penny scheme it is evident the name of Hallet was consiclererl a great bait in New York.

And so also American architecture was an architecture of modification modeled upon the work of Inigo Jones, who in turn modeled his style upon that of Palladio. But where the work of Jones was superb and elaborate, in America we followed his lines simply in mucl the same way that our late Colonial furniture followed the lines of the Empire, eliminating the specific ornamentation which in France made the style Napoleonic.

Not only in the South, but

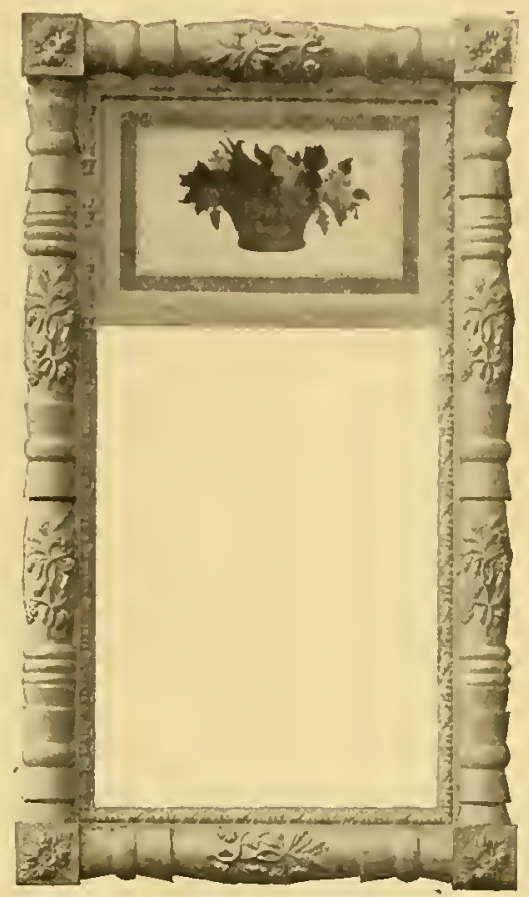

Above, mirror frame, about 1790; beluw, interior in Cowles house, Deerfield, Mass., 1752.
America, Classic pillars were reared in front of every porch and by 1800 pillars appeared tyon the ends and fronts of silleboards and bureaus. The fuil development of this movement was felt in the latter part of the lighteentl Century, and if there is any onc form of arelitecture that may be said to be particularly Colonial and any onc type of furniture that may be similarly claracterized. it is the architecture and furniture of 1800 to 1820 when simplilierl classicism was universally affecterl. Some of the old lonffets and sideloards and bureaus of what we now call the Jeffersonian Perior! were purely American levoid of the limpire ornamentation whicl appeared in contemporary lirench and English work.

Up to 1 sio the claracteristics of our Colonial styles were built upon European prototypes, alterer! frequently, as Duncan Phy fe altered the Chippendale models, or as Latrobe altercd the David models. Our cuitured classes followed closely the prevailing fashtiaroughout the East also the Palladian spirit was well expressed. As early as 1738 the discoveries made in Pompeii and Herculanium still further promoted interest and was received with great enthusiasm in ions, and our American cabinetmakers and decorators learned in almost all instances their arts abroad.

Phyfe had a shop at 35 Partition Street, now Fuiton Street. New York. His work from I802 to

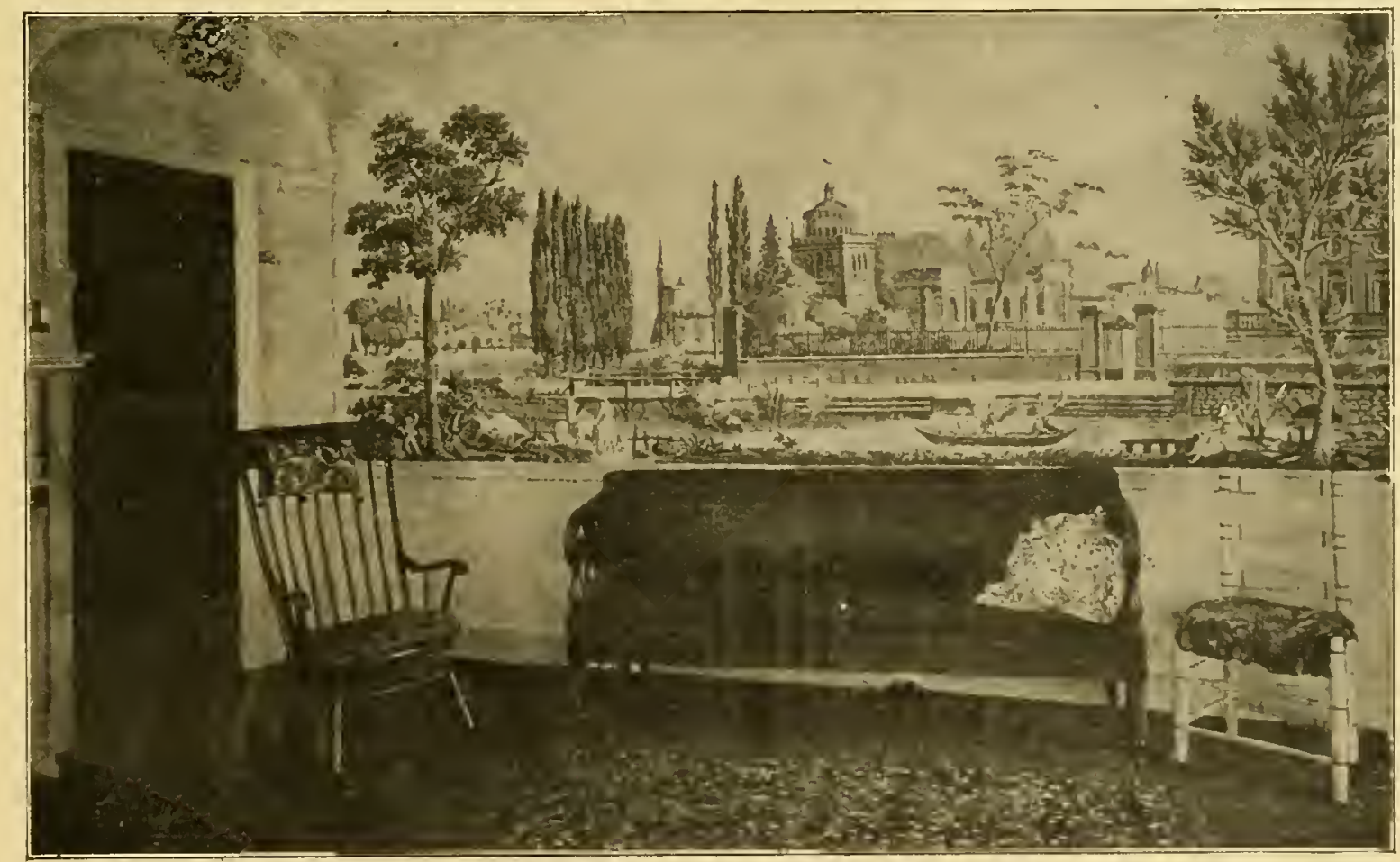



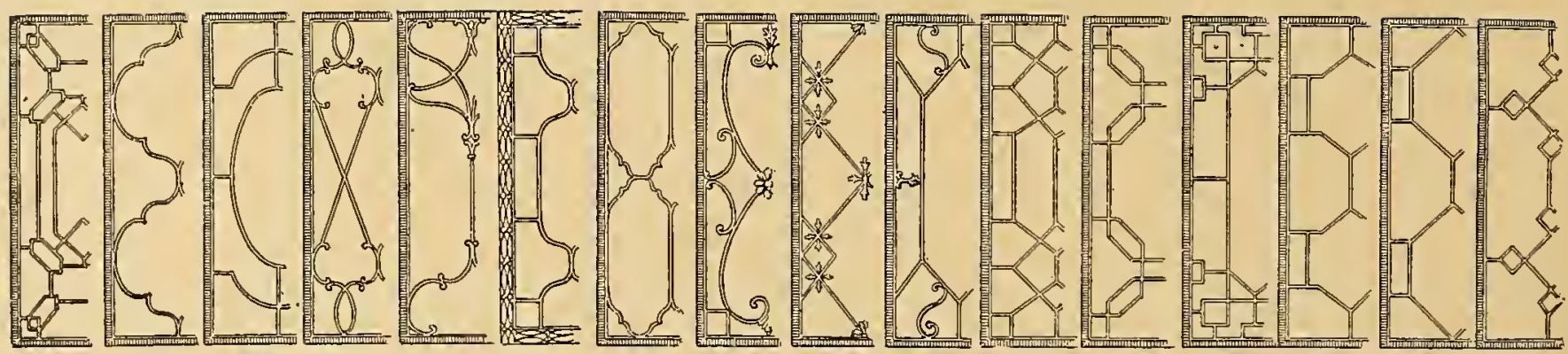

Window and door traceries.

I810 was well known, following the Empire school.

The Dutch "kas" was a linen cupboard used largely in New York; seldom found elsewhere in this country; sometimes carved walnut, frequently of pine, cherry or maple, paneled or painted.

The heavily carved malogany beds with designs of acanthus leaves or pineapple. with high or low posts, came into use about I790, following the Sheraton and Empire styles.

The butterfly table, which appeared about I70o, was so called because the leaves were supported by wings which swung either way.

Turned woodwork came into America with the first settlers; from I 575 to I 620 we find a great number of examples of turned work in England, a development of the spiral work of the earlier Sixteenth Century.

The cradle that came over in the Mayflower, used for Peregrine White, was vicker, unquestionably made in Holland.

The first mention we have of tea-

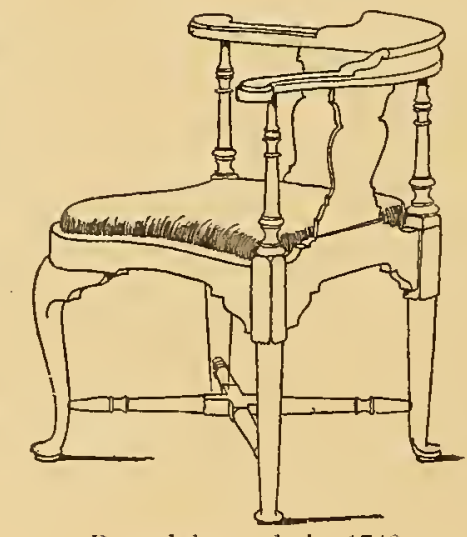

Roundabout chair, 1740
South where French furniture was used to any extent was Louisiana. That section had been settled by the French, who brought with them French fashions of the Louis XV and Louis XVI periods, and the French styles were adopted here in their purity. See page 203.

Chests, while utilized merely for travel, serving the purpose of trunk and bureau, for years also served aś seats and tables. They developed in decoration and usefulness in America as they did in England, becoming finally chests with drawers and ultimately bureaus.

The use of the word form or bench applying to the primitive seats still used in some schools, has survived the style of seat that succeeded the chest. Frequently a room contained two or three forms and perhaps one chair.

At the dining table these forms were commonly used, excepting at the head of the table, where the master's chair was placed. Chairs of turnedwood and wainscotted chairs followed; then rush and cane chairs, then upholstered chairs, in the same order they tables in Amcrica was 1660 . We hear often of the French furniture of the South; the only part of the

appeared in Europe.

Rush seats continued popular. until i $8_{3}$ O.

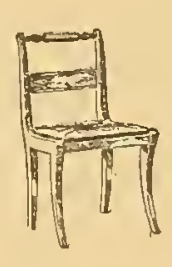

1820
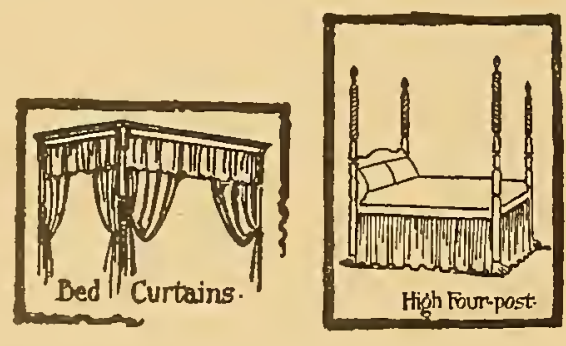

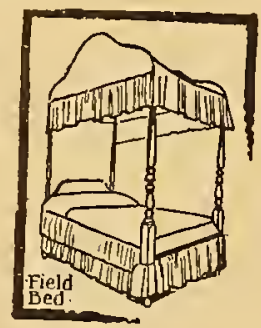

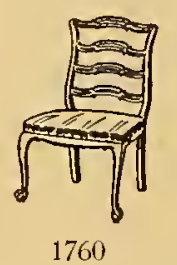

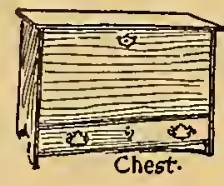

1760 


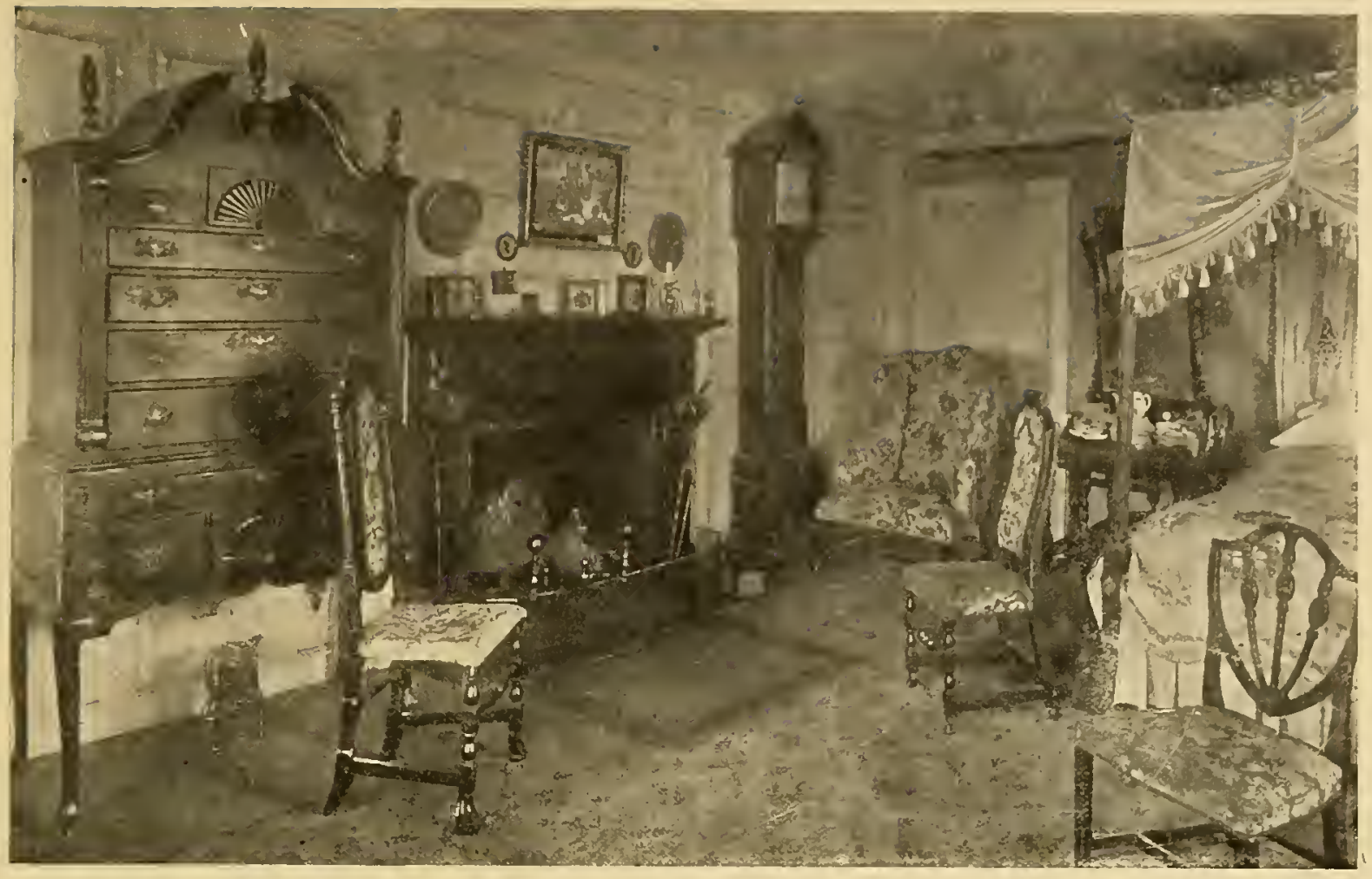

Colonial Grouping-Everything except the bed and the right-hand chair of early Queen Anne or late William and Mary.

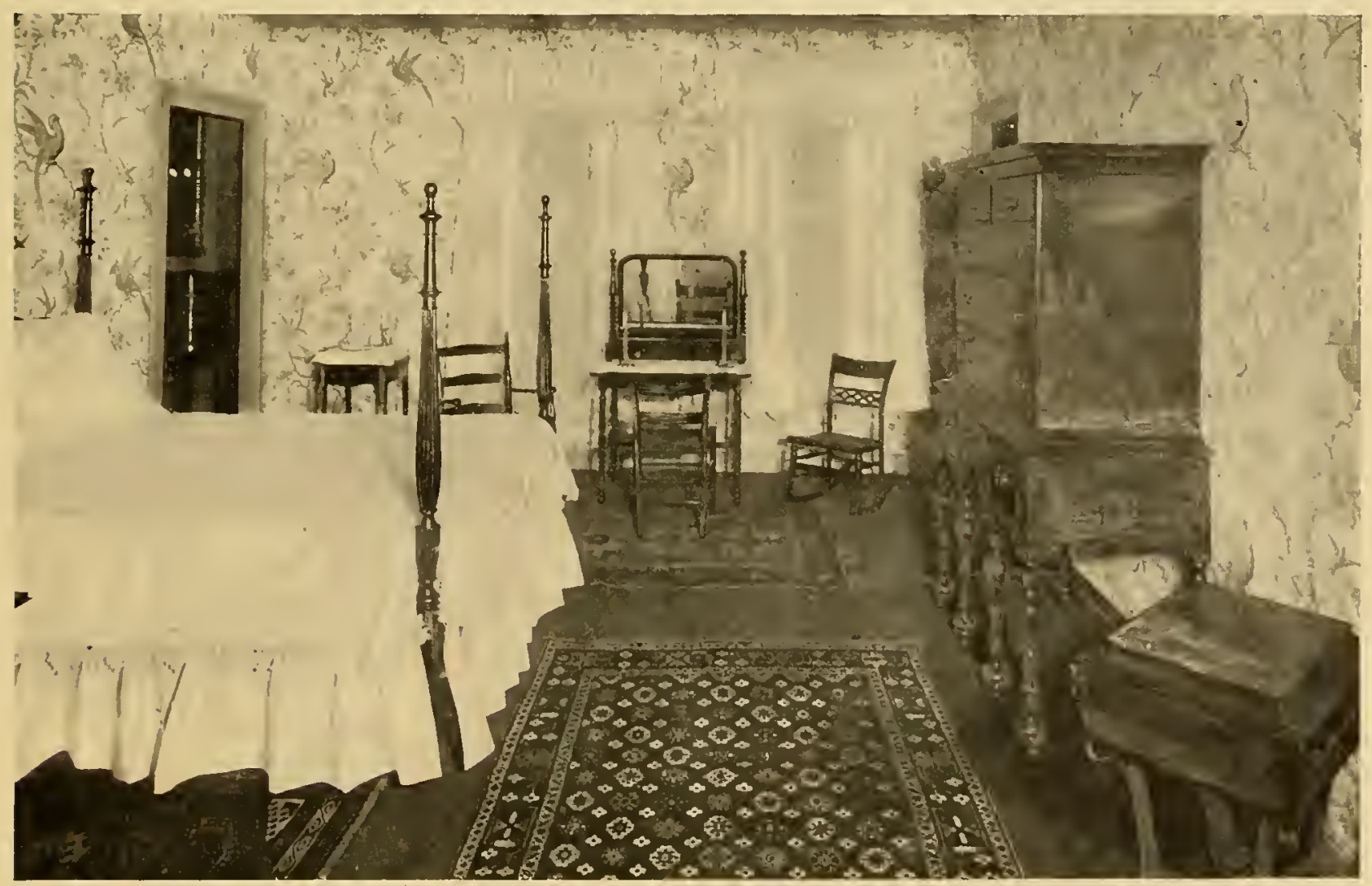

Late Colonial Room-Using William and Mary highboy. 


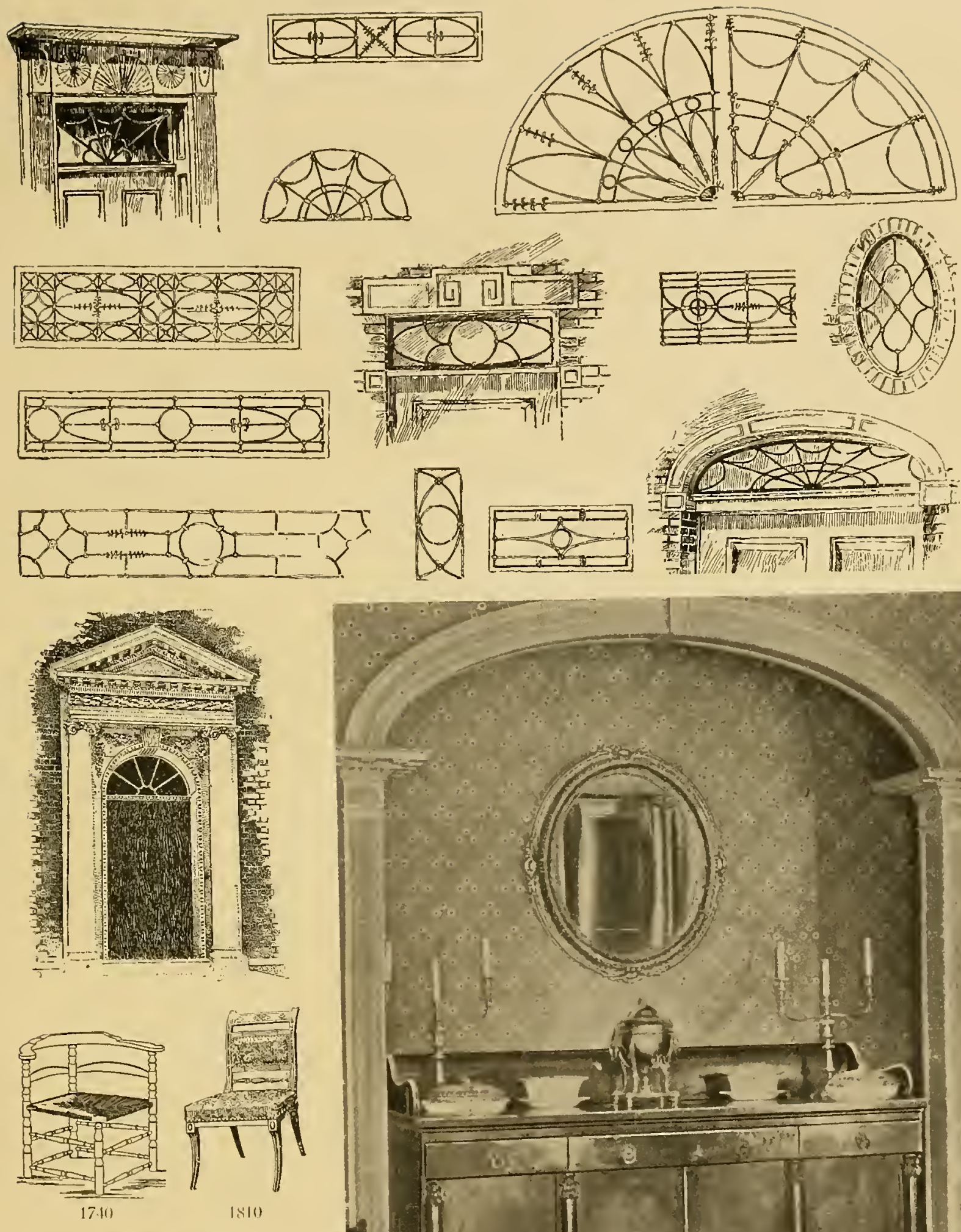

At the head of this page is shown a number of examples of Colonial transom window traceries.

Ahove in this column, Colonial doorway, about 1790 , followed by two Colonial chairs.

On the right, a buffet showing the characteristic column construction of late Colonial times, made in New York, 1807.

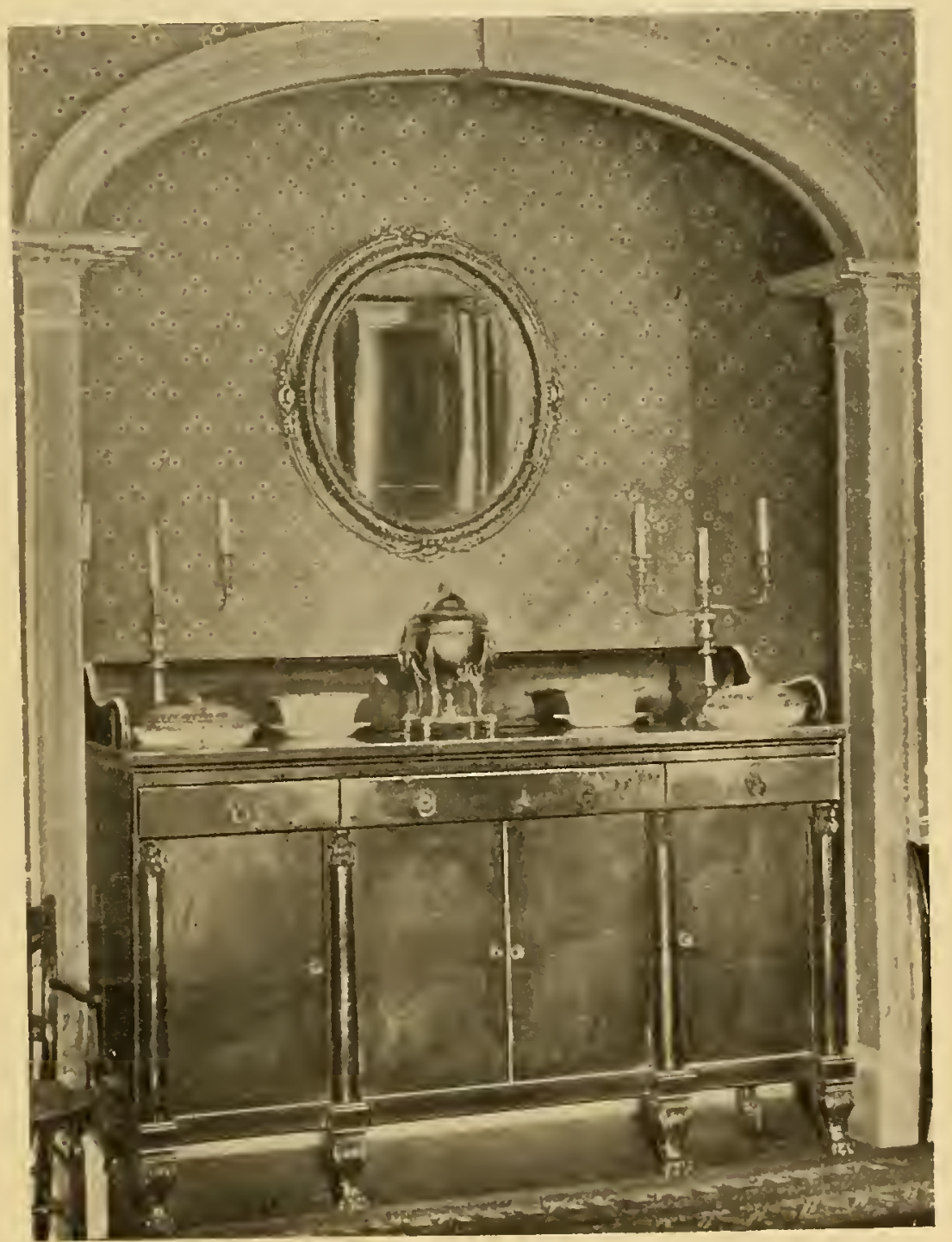




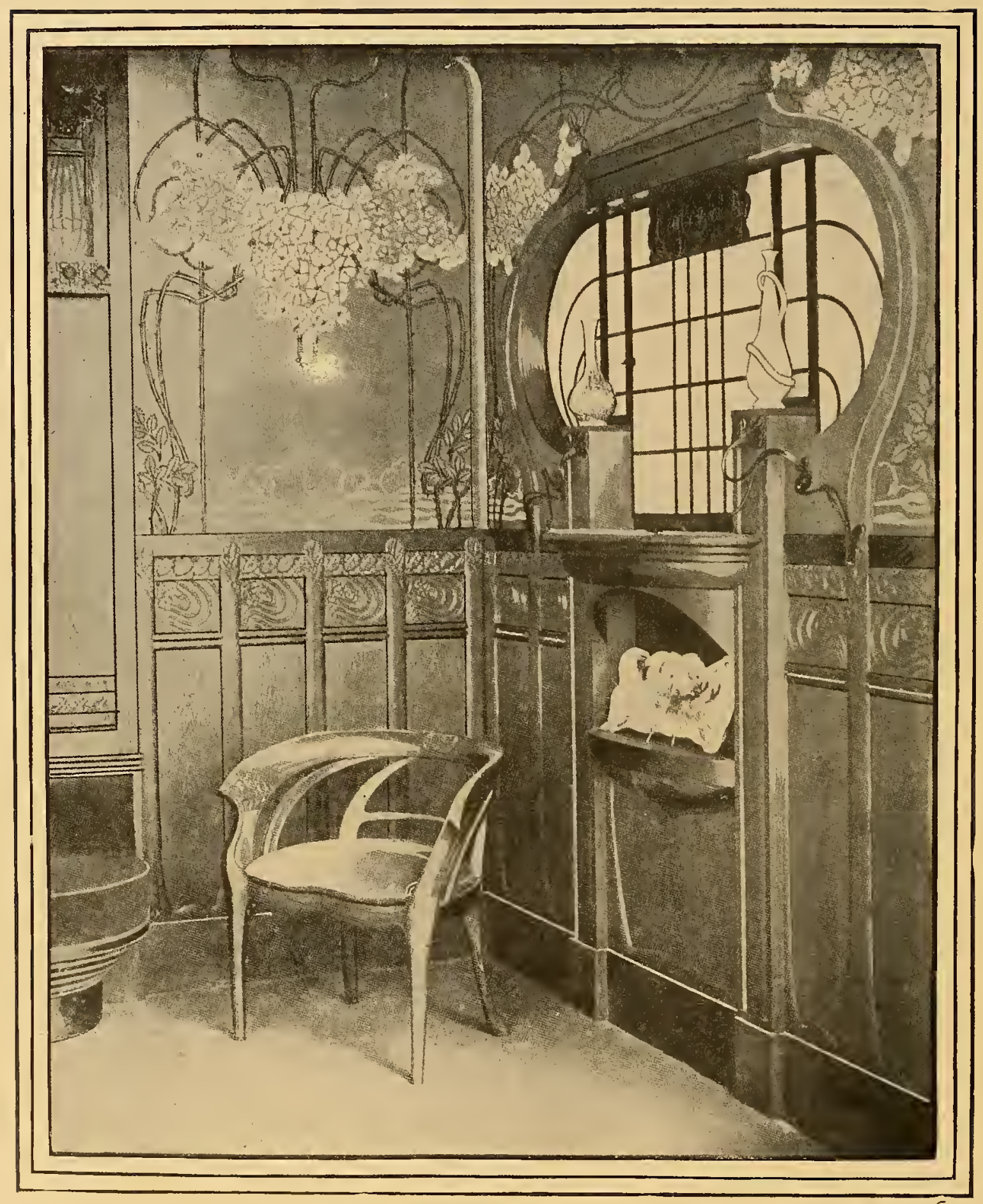

A TYPICAL L'ART NOUVEAU INTERIOR. 


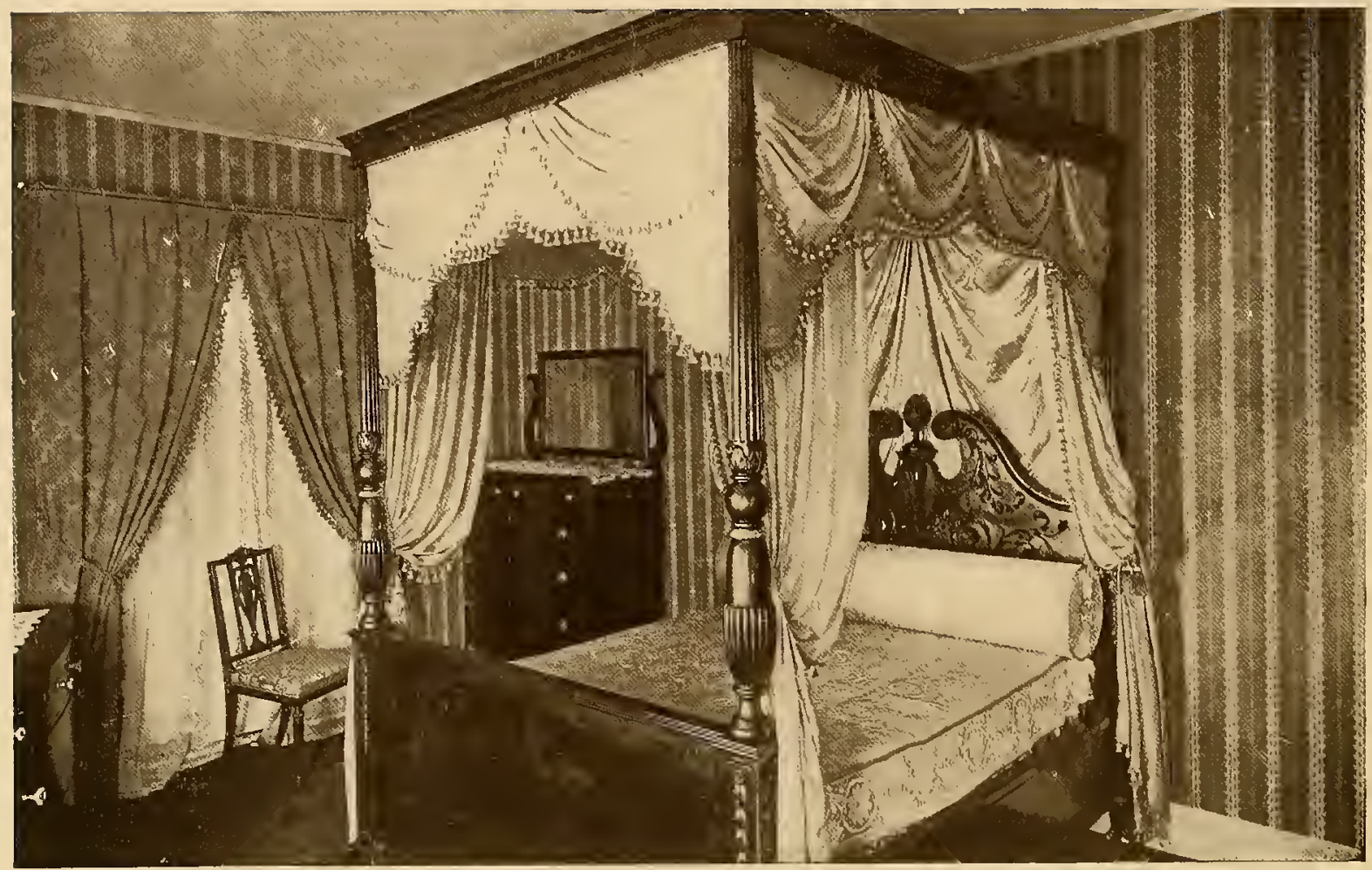

Colonial, 1790, in the English spirit.

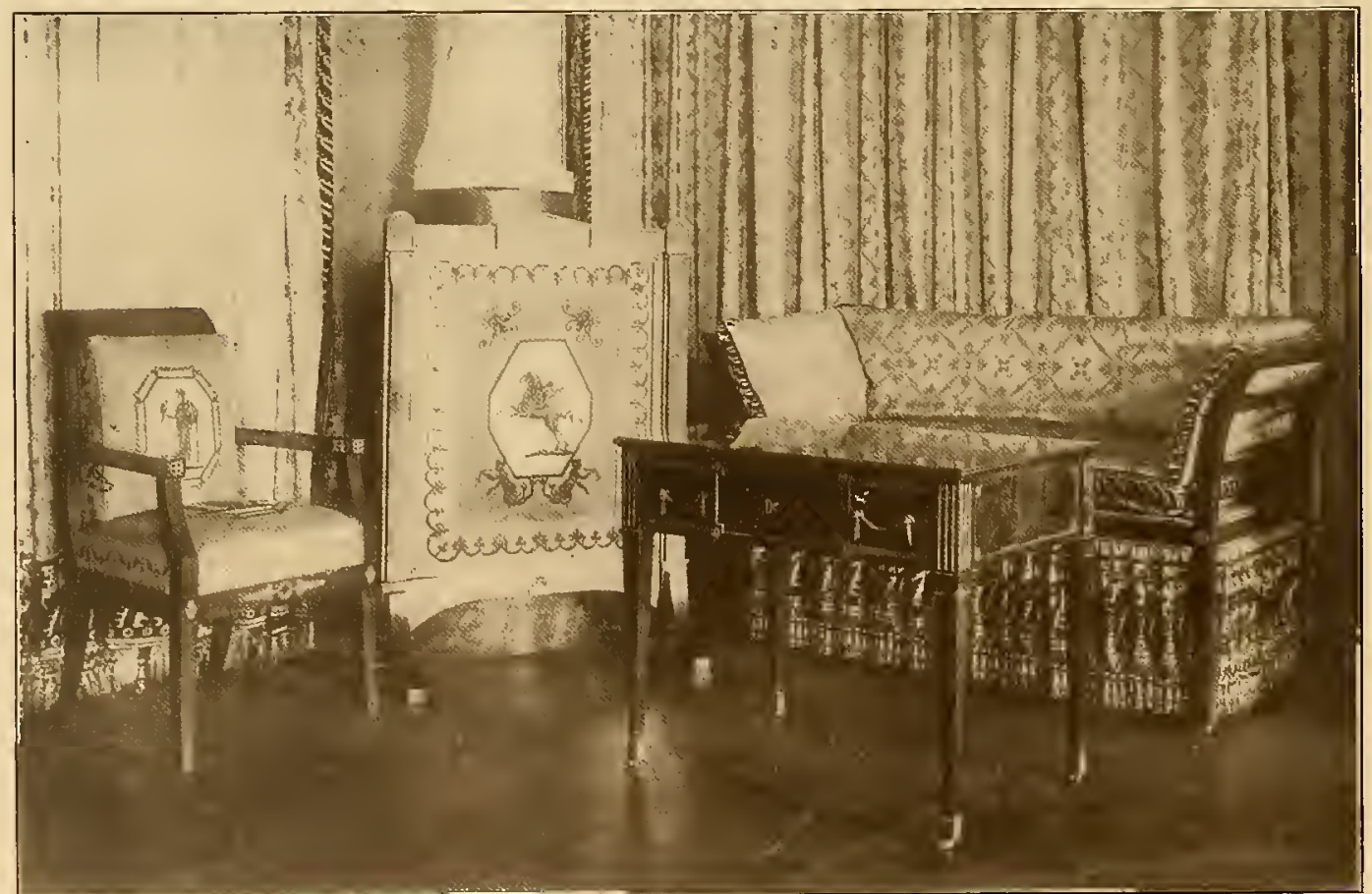

A Biedermeier interior fron the Royal Palace at Ludwigsburg.

See definition of Biedermeier. 


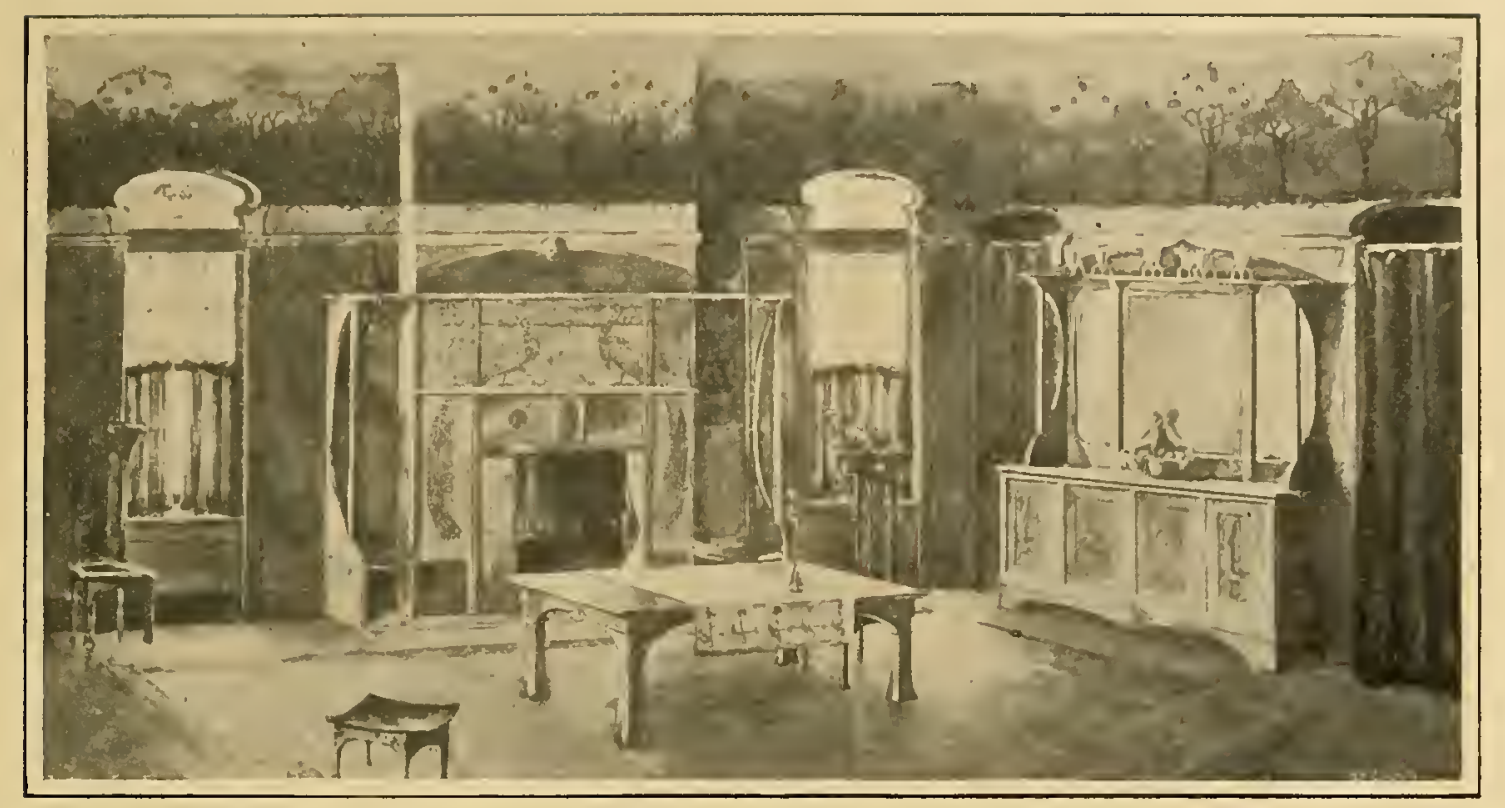

Modified L'Art Nouveau.

\section{MORRIS, BIEDERMEIER, L'ART NOUVEAU}

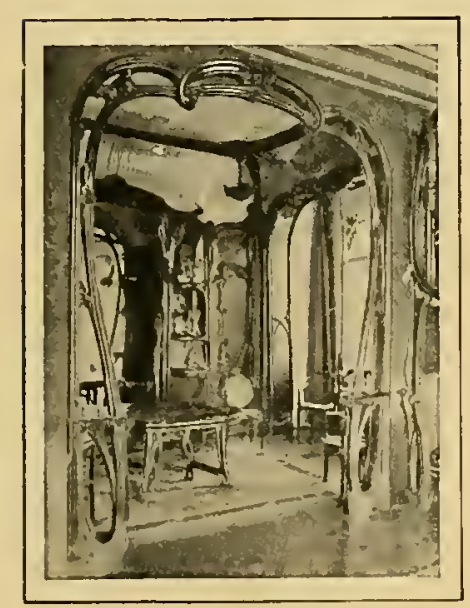

Extreme L'Art Nouveau.

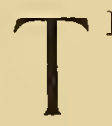

HE development of the E m $p$ i $r e$ Period in France inspired, coincidentally, a certain decorative feeling in Fngland, Anerica and Germany. In England the style had little vogue, but in America it developed structurally into what is pop ularly called " I, a te Colonial." From a recent issue of the Bulletin of the Metropolitan Museum of Art, over the signature of Luke Vincent Lockwool, we quote the following:

The evolution of style and decoration in furniture is one of the most fascinating and instructive of studies, and Anerica is especially rich in specimens showing the varions transition stages. In no other comntry has a style been so completely worked ont as it has here. . . Having once acquired the style the Colonial workman, adapting it to the needs of the people, developed it mintil it had reached a perfection not attained in Europe. The truth of the statement is particularly well illustrated in the development of the high chest of drawers. In England this article of furniture was abandoned, while yet in it rather crude state, for the French commorle on the order of the modern buteau, but in America it was developed and the commode form remained comparatively scarce.

This statement was confirmed by the late Sir Purclon Clarke, who informed us that some of his best ex-

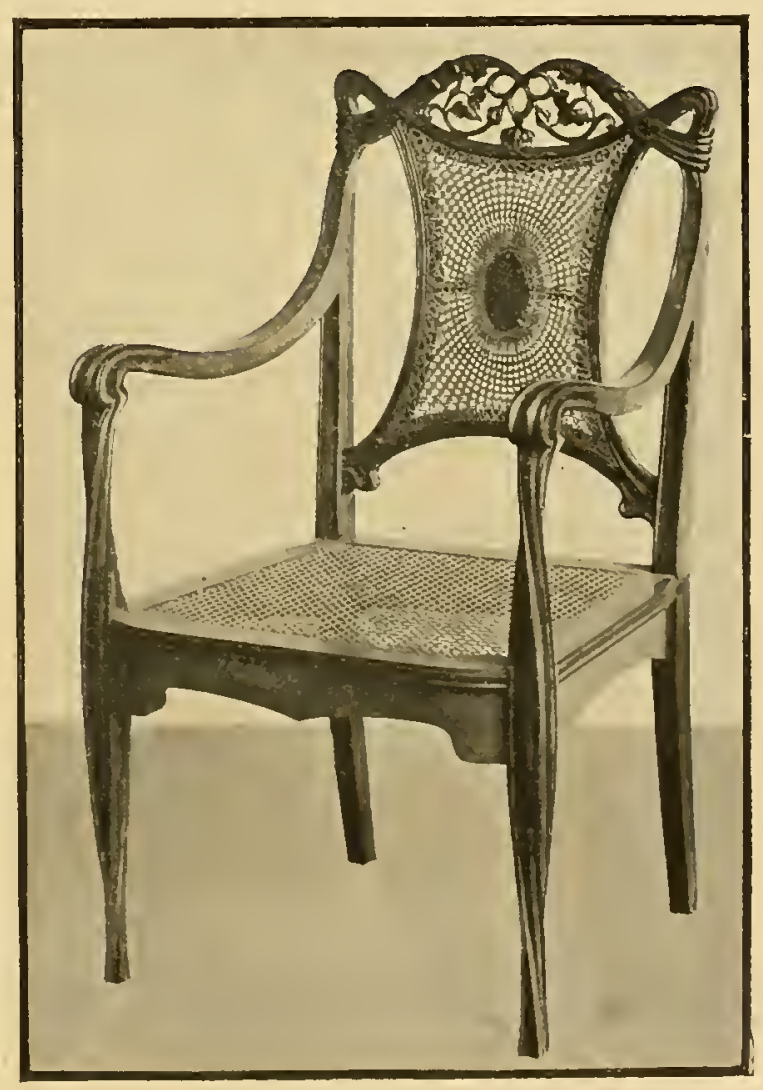

On the right, restrained L'Art Noureau. 
amples of furniture he found in America. The development of the Empire in this country resulted in great good, while in Europe all efforts at an absorption of this style became a failure. In Germany the Empire school was so distorted by the effort to popularize it that it soon became known as the Bieclermeier, a term of reproach.

Biedermeier was a fictitions character invented for the pages of Flicgende Blättcr, a goodnatured bourgeois with no aesthetic perception. Germany, after the Napoleonic wars, was either too poor or too prejudiced to follow the prevailing fashions in French furniture; hence the Biedermeier style which eliminated the ormolt mounts and expensive $\mathrm{carving} s$ naturally symbolic of

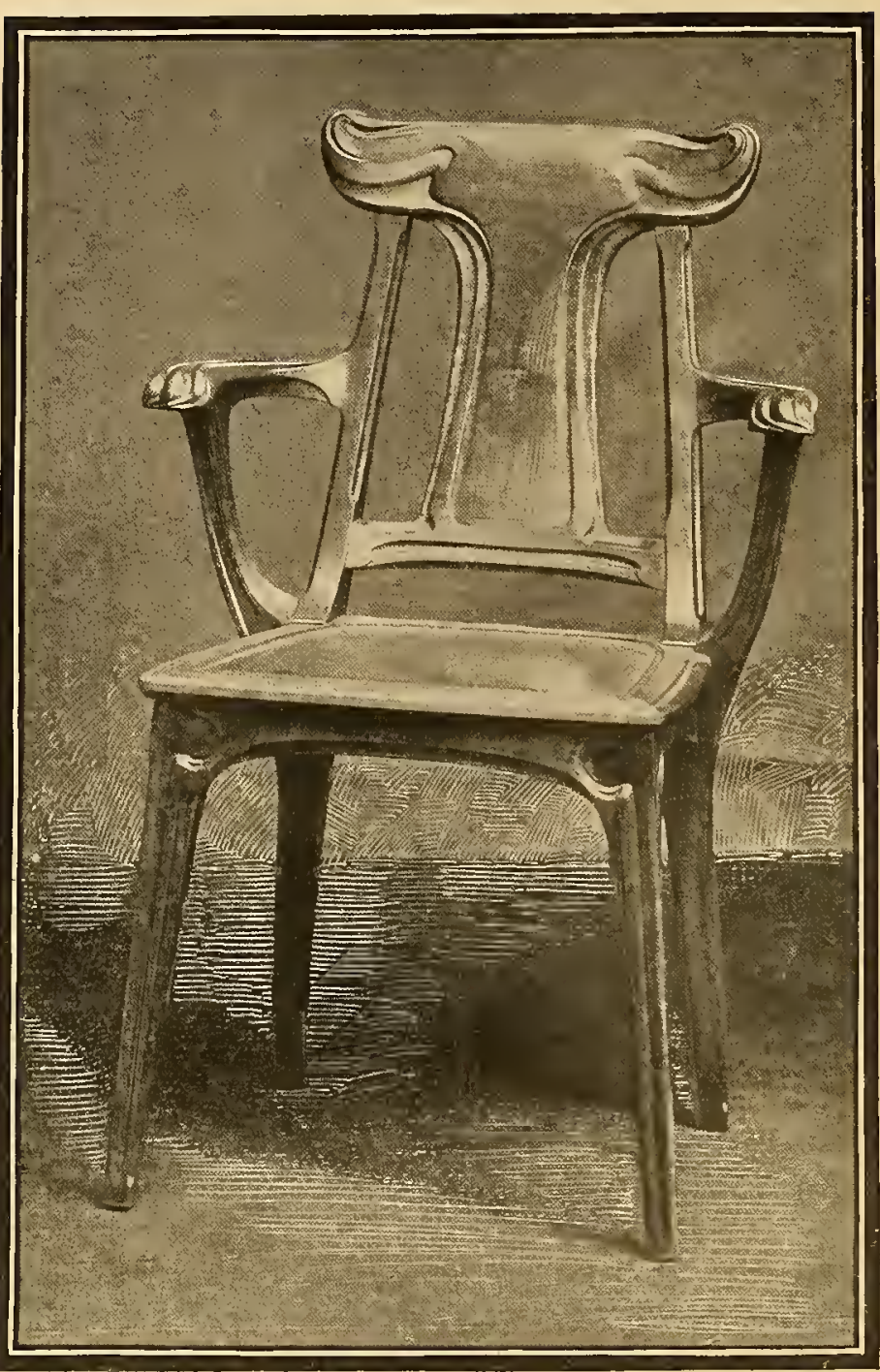

Above, L'Art Nouveau chair; below, modern German-Empire or Biedermeier chairs.
Empire decoration, and substituted merely pretty forms, pretty details, unmeaning and weak. Not only was the studious work of Fontaine, Percier, David and the brothers Adam pruned by the Biedermeier gardener, but a lot of petty florals were grafted in a sort of Dutch garden style. The acanthus, the vitruvian scroll, the lotus and the palmette were all displaced by a sort of barnyard flora. Symbolic animals were driven out and tame creatures adopted. The Biedermeier period began with $\mathrm{I} 800$ and ended about I830.

"With the glory of the Napoleonic era," writes Herr Li1x, "vanished also the aristocratic Empire style. "From cosmopolitanism and its political katzenjammer people fled back to the old land. of

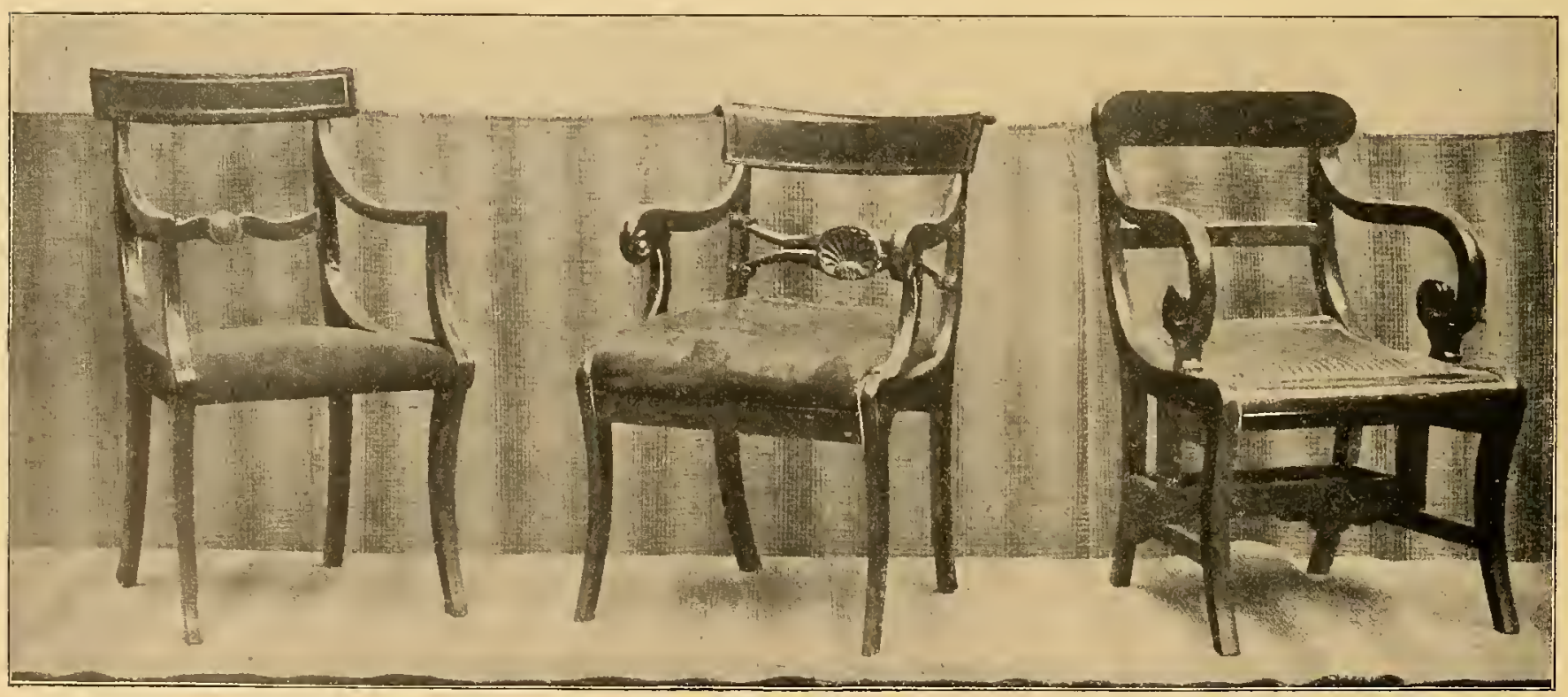




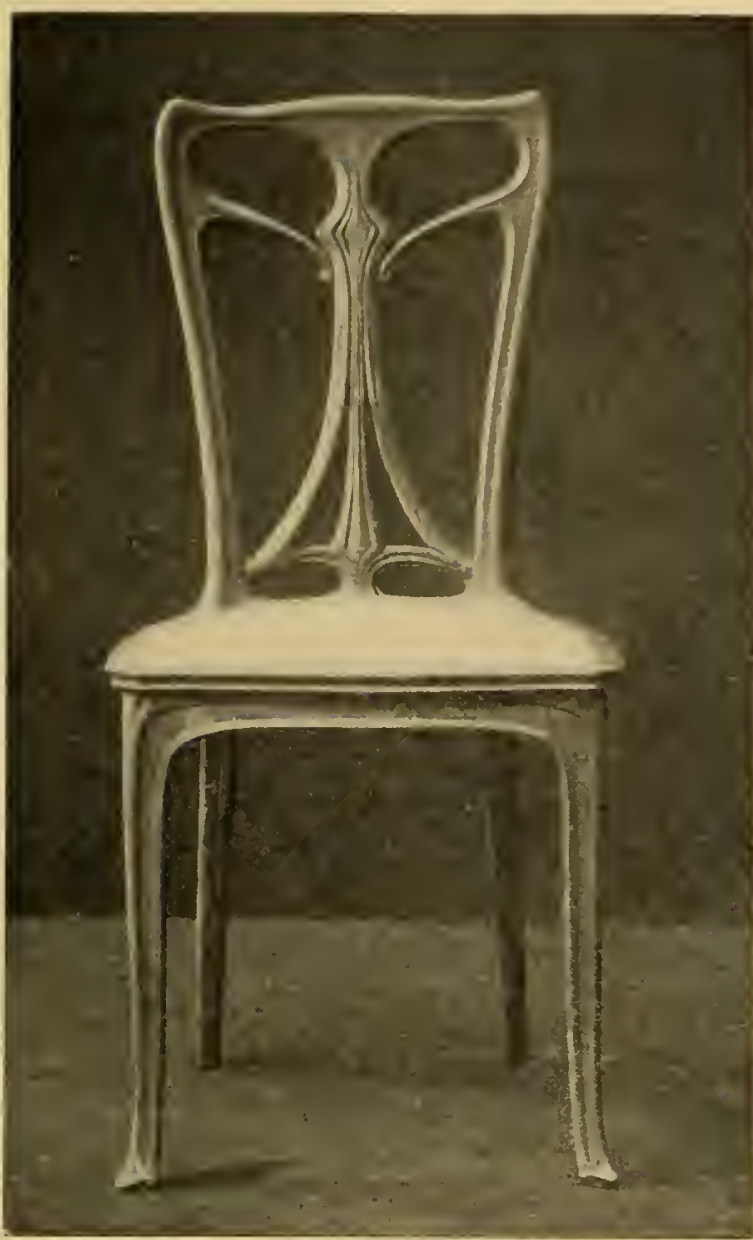

Two chairs which show modified L'Art Nouveau forms.

romance. Uhland, Eichendorff and Schubert aroused enthusiastic love for nature. And the introduction of the moral element, as well as the influence of England in matters of style, led to the solid, square and cylindrical forms of Biedermeier furniture, to which reminiscences of the Baroque and Empire styles remain attached as decorative details."

In England Thomas Hope made an ephemeral reputation with a rather clumsy adaptation of the Empire, but its vogue was brief.

In America, contemporaneously, the Empire grew and thrived; its influence was felt even in the farni districts, and elassic pillared houses were erected with chaste doorways, colummed and pilastered furniture was built and a taste was generally observed for lines that were simple, substantial and refined.

With the close of the Georgian period the great redivivus of art was ended, and while the Victorian period (Queen Victoria, 1837 ) has indulged in fitful spurts, nothing substantial has resulted and no phase developed that may be clearly defined.

We have had Eastlake and the Eastlake craze. William Mlorris and the Morris vogue. Sir Edward Burne-Jones, Walter Crane, Ruskin and the Arts-andCrafts movements, but neither in Englandl, France nor Austria, where Art Nouveau for a brief period became hysterically popular, and in Germany, where the top-lueavy form of the Art Mloderne prevailed, has there been any liealthy or well-founded style.

In America a simple type known as the Mission school has been arlopted fuite generousiy, but it has represented not so much a school of ornament ats a school for the elimination of ornannent.

About 1870 a band of artists in lienna, led by Wagner, produced a style of design arising out of the use of curved as opposed to straight lines. The underlying principle was based upon nature forms and Gothic and Japancse were drawn upon, and sinuous tree trunks and exaggerated vines produced occasionally such pleasing results that in the minor arts a great deal of encouragement was given to the movement. When applied to toilet articles and table desk and dress accessories or even silverware there was little to offend, but when the same character of design was applied in broad and emphatic forms upon the walls and floors, it failed. Little by little Art Nouveau has been chastened, refined and simplified under various "movements," Secession, New Art and Art Moderne; some of the curves have been straightened out and the weird nature forms are no longer part of the structural character of furniture but are

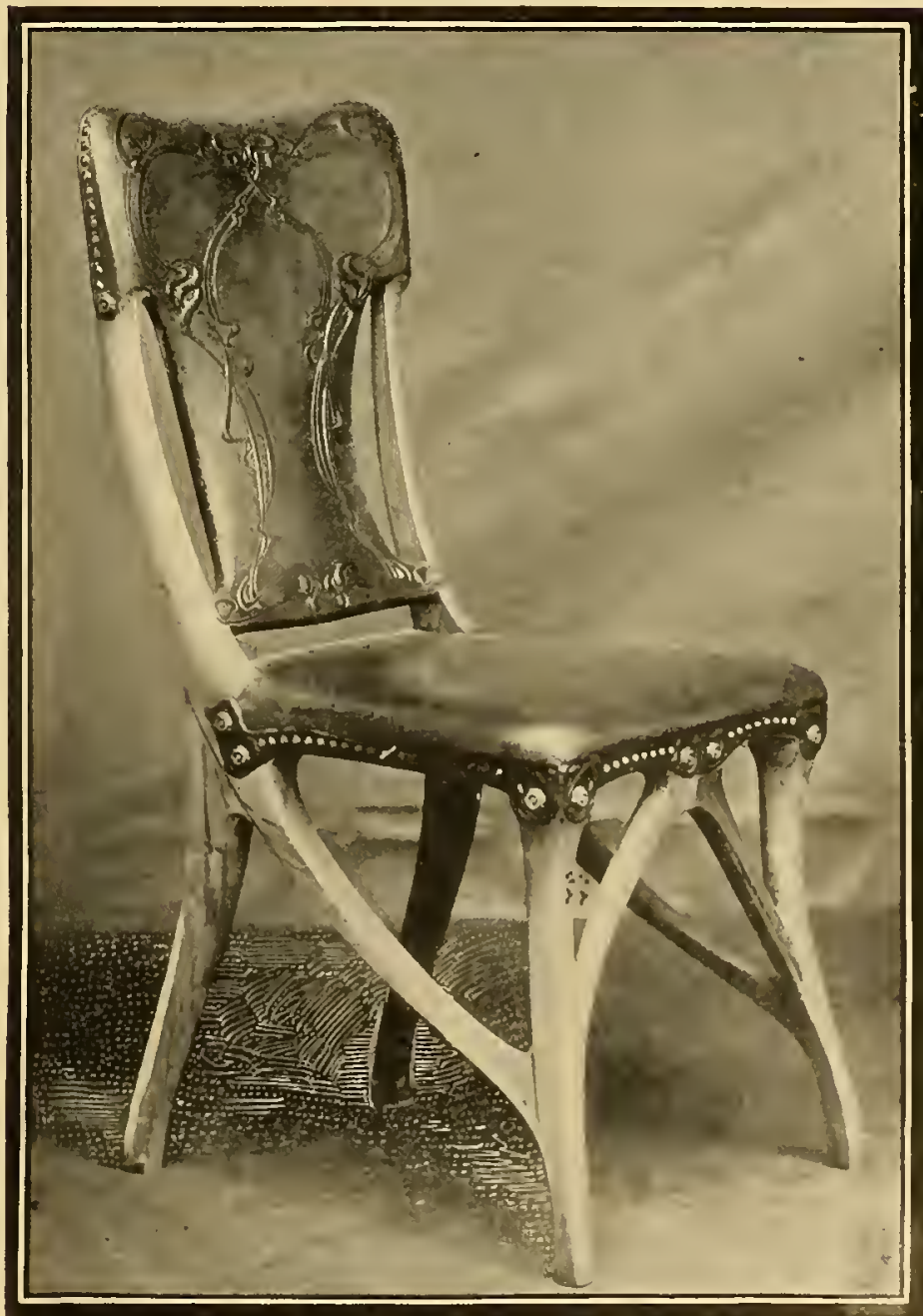


utilized only as decorations. In Germany this new development has made great strides; but not elsewhere.

It is surprising when we look back over the serious utterances of Eastlake, whose book was written in 1870 , that any success whatever attended his efforts. We are aware of the fact that much was produced by the manufacturers of Eastlake furniture which would have shocked the sensibilities of the author. The Eastlake school represented a simplification of Elizabethan and Jacobean. It was the application of factory labor and was full of jigsaw corners and cheap ornamentation, with metal and tile panels and squares inserted, and conspicuous hinges and handles obviously introduced for decorative effect. Sometimes the convex carvings were daubed with contrasting paint. Little by little this ornamentation became so vulgar and the operations of the jigsaw became so conspicuous that the Eastlake style died out.

While Eastlake was a man of education his work suggested nothing higher than the vaulting ambitions of a boss carpenter.

The work of William Morris and his confrères was important and far-reaching, establishing as it did the craftsman spirit in England. The Morris movement, so-called because Morris was the managing head of affairs, employed the services of men who will live forever in the history of art.

William Morris was born in England, March 24. I834. He died October 3, I896. He went to Oxford

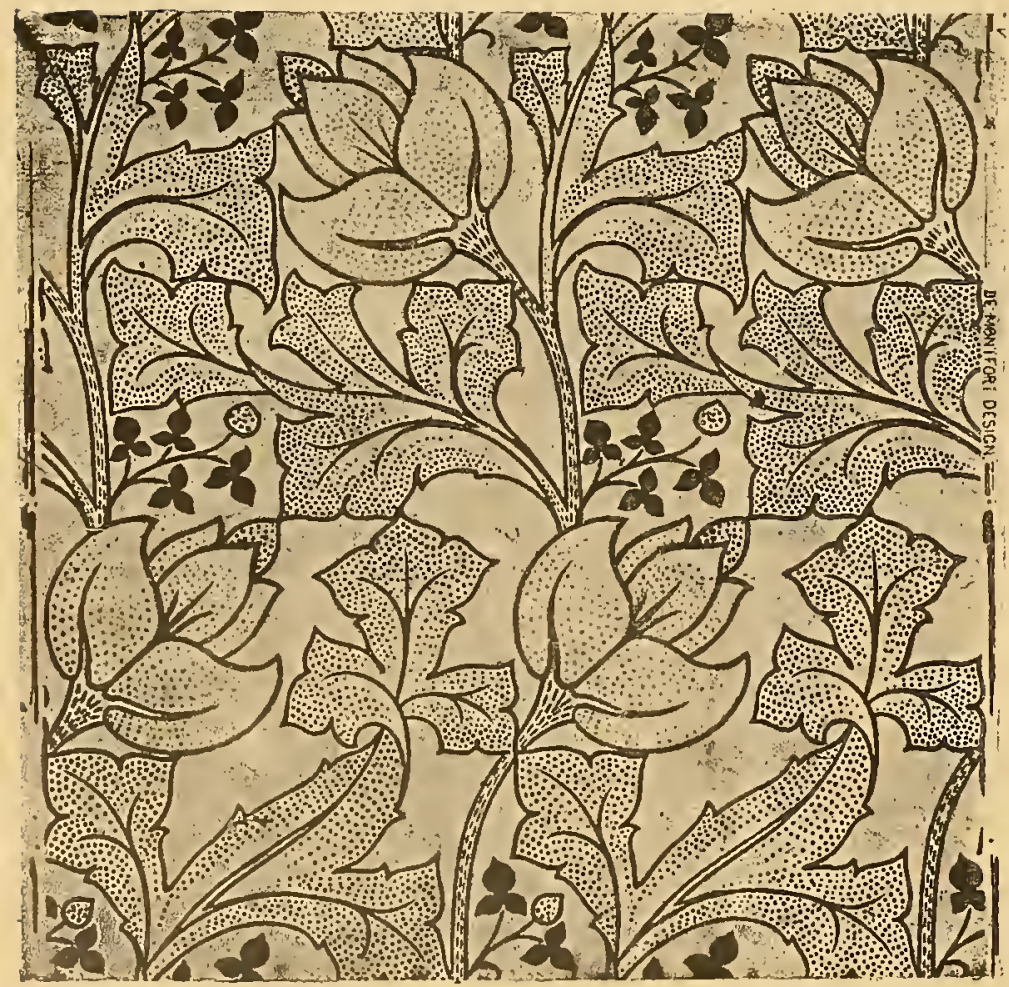

in the fifties and beside him at the examinations sat Burne-Jones, who became his life-long friend.

He intended to study for the church. He knew nothing of art but became interested while traveling through Belgium and Northern France studying the churches of Amiens. Beauvais and Chartres. He had become acquainted with the work of the pre-Raphaelites, a brotherhood cultivating the Gothic arts and preaching the theory of individualism. Dante Gabriel Rossetti was the head, Ford Madox Brown, Holnian Hunt and John Mullais were active members assisted by Ruskin's writings. Subsequently the coterie admitted William M. Rossetti, James Collinson, F. J. Stephens and Thomas Wolner.

As a child, Morris was possessed of a vivid imagination and a romantic, poetic temperament. At an early age he became a poet. Buildings had interested Morris from his childhood. The Gothic period appealed to lis nature, the beauties of the Gothic art stimulated it and before he was through Oxford he had decided to study architecture and Burne-Jones was to beconne an artist. Morris studied under George Edmond Street, an architect whose enthusiasm for the Thirteenth Century made the foumdation for all of Morris's work. Street was engaged at the time Morris went to him in restoring ancient churches and designing Gothic buildings. While never an artist in the broad sense - in the ability to depict the human form-and while never an architect, Morris developed along lines of adornment or ornamentation. In I855 Burne-Jones and Morris took lessons in painting under Rossetti, and in 1856 Rossetti wrote enthusiastically of Burne-Jones predicting his fame as an artist, and of Morris he said that "in all illumination work of

A Voysey design showing the pre-Raphaelite influence of Morris and his colleagues. 


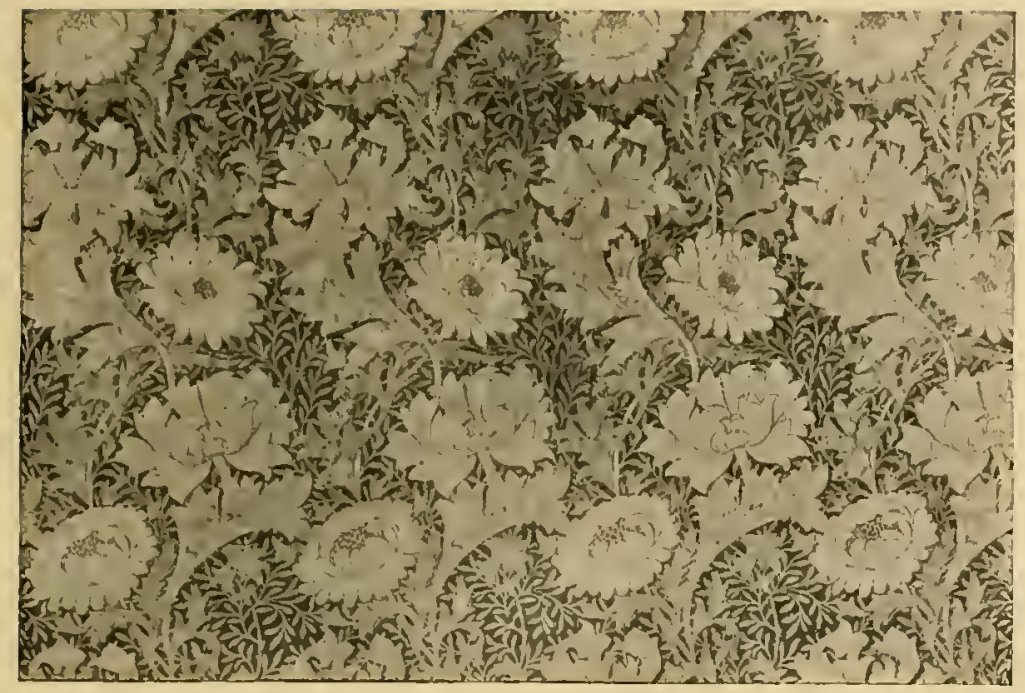

Chrysanthemum design, by William Morris.

that kind he considered him quite unrivalled." When he was twenty-five Morris married Jane Burden, and the house into which they moved, known afterward as "The Red House," possessed many furnishings contributed by their artistic friends.

The firm of Morris, Marshall, Faulkner \& Co., as it was first called, appears to have followed their success of this early effort at decoration. Rossetti explains that the suggestion to organize a firm was a whim. "One evening a lot of us were together, and we got to talking about the way in which artists did all kinds of things in olden times-designed every kind of decoration and most kinds of furuiture, and someone suggested that each put down five pounds and form a company. This was done. Morris was elected manager simply because he was the only man among us who had time and money to spare."

The associates were Morris, Rossetti, BurneJones, Madox Brown, an artist of reputation, Webb, the architect of the Red House, also a designer of furniture, Peter $\mathrm{Pa}$ u 1 Marslall and $\mathrm{Charles}$ Faulkner.

Naturally their work was of the highest character, covering mural decoration, carving as applied

A typical Morris treatment; designed by William Morris for St. James's Palace. to architecture, stained glass, metal work, furniture, fabrics, stamped leatlicrs and decorations generally, including draperies and wall-paper.

They affected full luscious colorings, tabooed fadey effects and lingy colors were abhorred by them.

In 1858 some of the furniture made by Ford Madox Brown was described by hiijs:

"Adapted to need of solidity and of a kind of homely beauty; above all, free of false display in carving, veneering and the like."

He tried to exhibit his furniture at the Hogarth Club, but the work was rejecterl as not fine art. But he persevered, and today his masterpieces, the frescoes in the Manchester Town Hall, are recognized as unequalled. Rossetti describes a room which he was furnishing for his bride:

"Our drawing-room is papered from a design printed on common brown packing paper. The trees stand the whole height of the room; the stems and fruits are of Venetian red; the leaves are black; the iruit will have a fine line of yellow to indicate roundness."

The Morris factory took up finally printing on wall-papers or fabrics, which, together with the furniture, was based upon Gothic lines influenced in the modern spirit. Occasionally his floral treatment was classic, utilizing the acanthus or flora of England. His wood tones predominated as a background for vivid

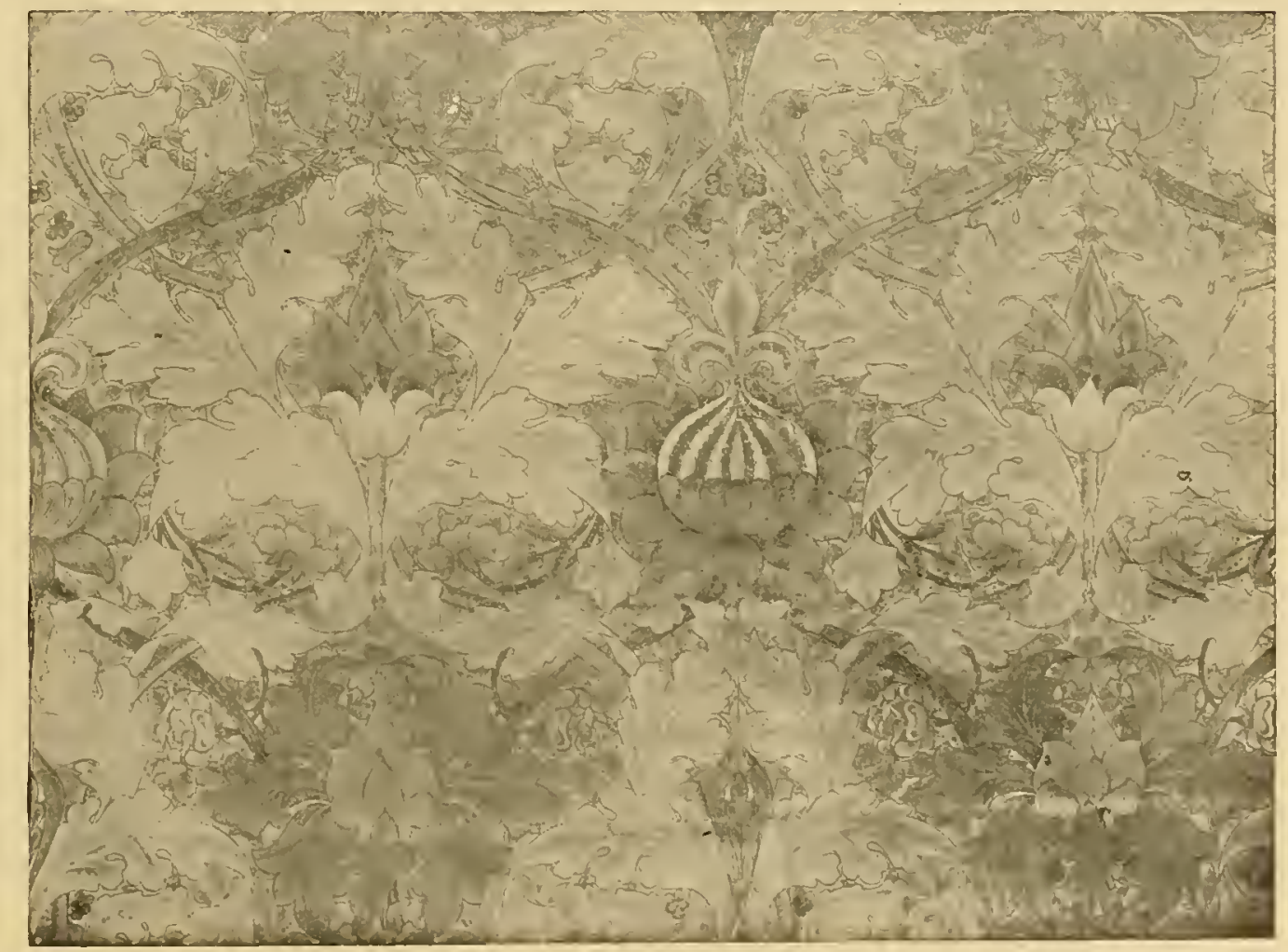


colors. His designs were never in straight lines and were always Medieval, and even where his motifs were modern flora the colorings and technique were Medieval.

In 1875 the original firm of Morris, Marshall, Faulkner \& Co. was dissolved and Morris carried on the business alone, though Burne-Jones and Webb continued to help him with designs for stained glass and furniture. His enthusiasm was aroused in 1877 (in spite of his great interest at this time in public affairs), by the establishing of calico and chintz printing, the manufacture of brocades in silk and silk and wool, a Frenchman being got over to teach brocade work. He also began to think of tapestry, though this could not be attended to till later in the year, and it was when he took Kelmscott house, on the upper mail, Hammersmith, that he had a tapestry loom put up in his bedroom, rising early to practice the art of tapestry weaving. Carpet looms were built in the stables and here the first Hammersmith carpets were made.

The most important development perhaps was the production of printed cotton goods, i. e., "Morris' chintzes," which are more used than any of his other fabrics.

Between seventy and eighty wall-paper designs and nearly forty chintzes were invented and carried out by Morris, though if the various colorings were counted separately his designs would amount to 400. The sum tatal of his designs for paper-liangings, chintzes, woven stuffs, silk damasks, stamped velvets, carpets, and tapestries (excluding the hand-made carpets and the arras tapestries, which were each specially designed, and as a rule not duplicated) which were actually car-

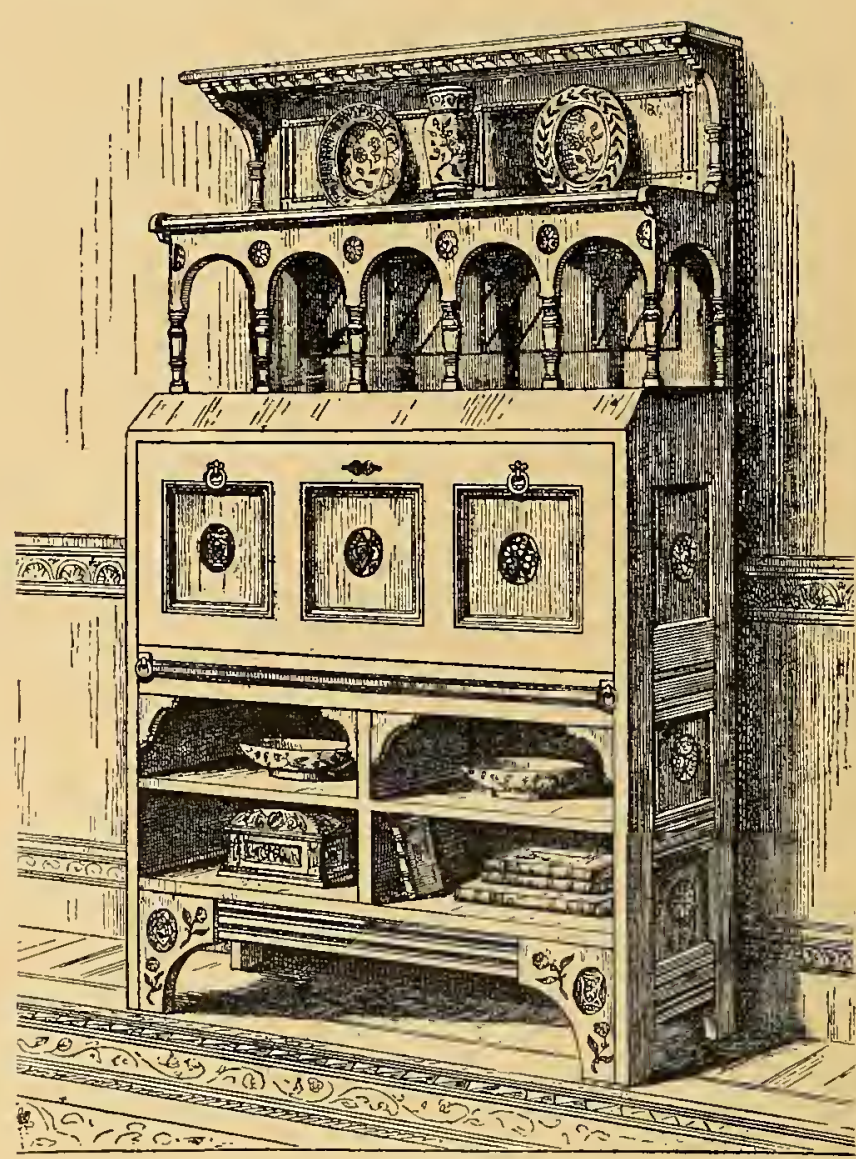

Cupboard designed by Charles L. Eastlake. Frequently we find this furniture with tiles or brass panels inserted in place of the oval omaments. In this case the carving is intaglio painted.

ried out, amounts to little short of 600 , besides countless designs for embroidery.

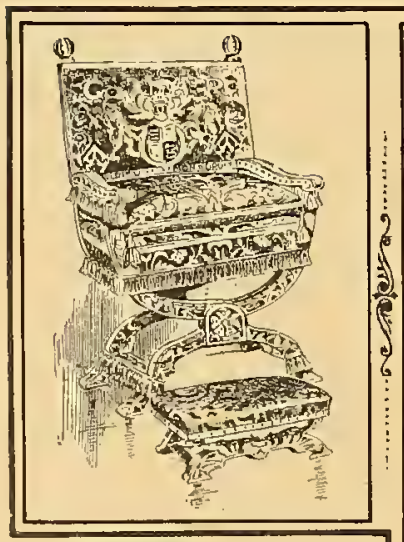

Throne chair, one of the pair in which the King and Queen were enthroned after the crowning.
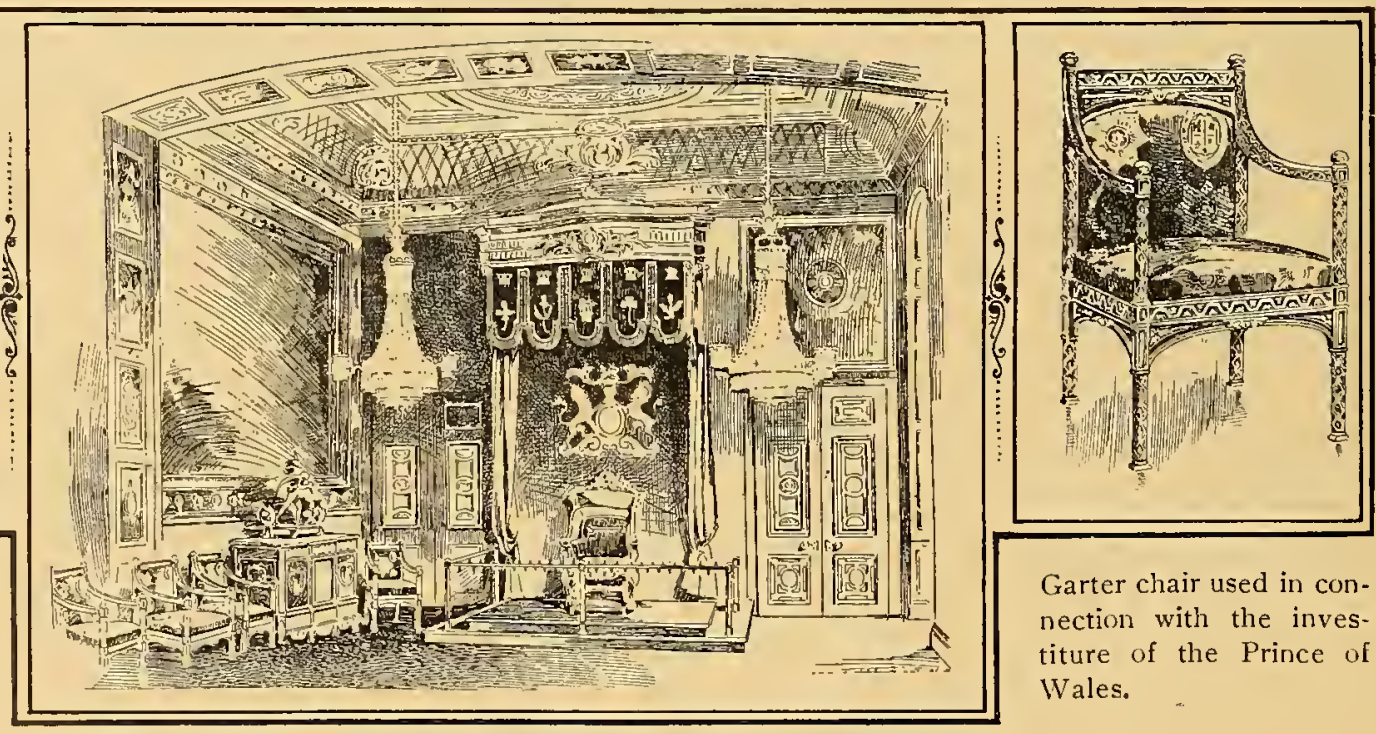

Garter chair used in connection with the investiture of the Prince of Wales.

Throne room in Windsor Palace. 


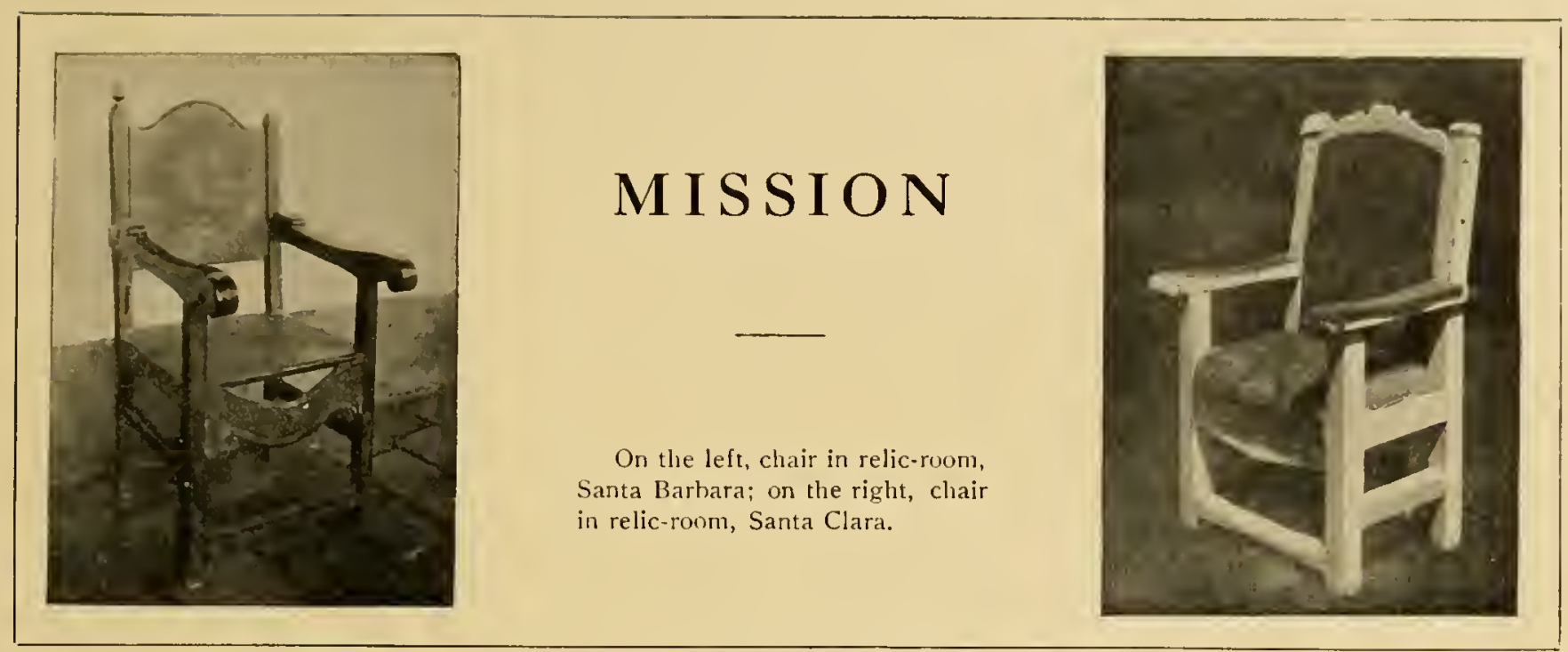

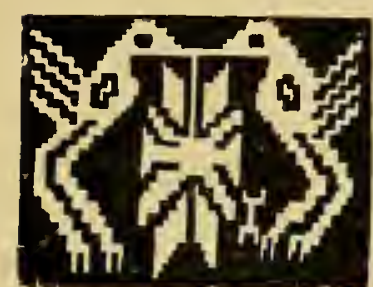

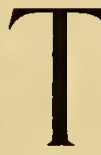

HE Mission style is a commercial style. Originally it made pretense to reflect the character of the furniture found in the missions of old Mexico and the countries now New Mexico, Arizona, Texas and California; but there was never any serions effort to conscientiously follow the style which, after all, was simply primitive Gothic-the simplest style of carpenter work made for or by the missionaries under conditions which neither invited nor permitted the exercise of an artistic touch. It was simple, crude furniture bearing naturally the influences of the Spanish architecture which constituted the environment. The woods used were those most easily manipulated and obtained in the neighborliood.

Ponce de Leon discovered Florida in 1512; in I5I3 Balboa discovered the Pacific; in 1519 Cortez set forth to conquer the countries of Mexico.

In the early part of the Sixteenth Century Mexico proper and all the newly-established Central American provinces were being flooded with missionaries from Spain; churches by the hundred were built and missions established on every hand, in what are now the Mexican provinces.

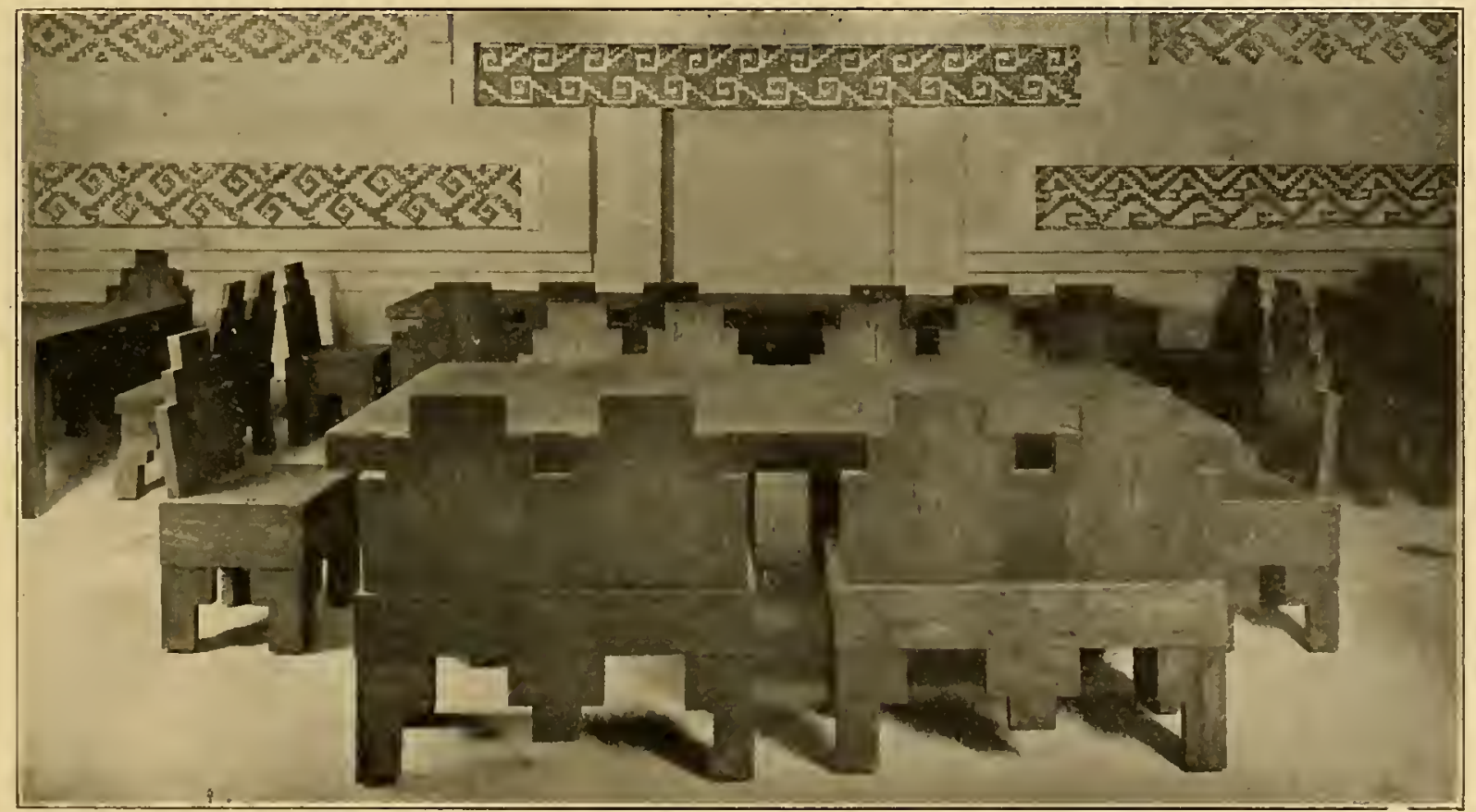




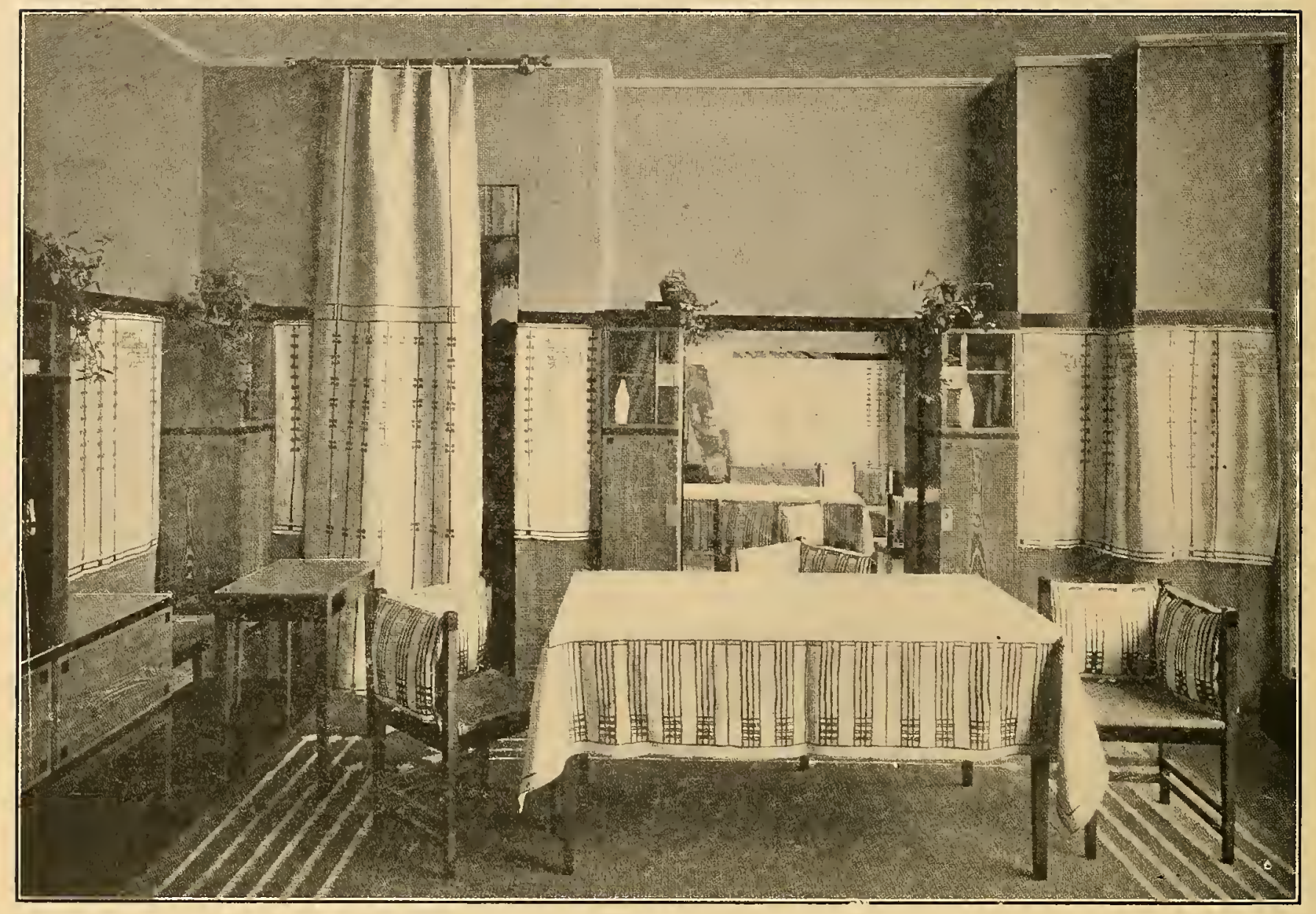

An Arts and Crafts Interior, from the German School.

The colonization of Mexico by Spain naturally meant the introduction of Catholic missions. In the early times the furnishings of these mission chapels were crude in the extreme, but in the Eighteenth Century the missions gathered strength and prosperity.

It has been often claimed that the Mission style was a purely American style. Unfortunately, the Mission style could have been historically accurate were it not that it was at an early age subjugated to the exigencies of commercialism.

Lumholtz, in his extraordinary work on Mexico, gives a vast store of illustration and data regarding the work of the Aztecs, that dominating people who possessed a civilization in Mexico before the Spanish invasion under Cortez, I 519.

One finds a very good example of this work at the American Nuseum of Natural History. While the furniture is probally not anthentic in style, it approximates tile character of furniture which even at this early datc was found by the missionaries, and with slight alteration, was adapted to their ideas of Gothic structure. In the Missions of Mexico tropical woods were used.

Mission ornament was necessarily ecclesiastical and to present the old Mexican or Aztec decoration as a background to the Mission furnishings is wrong, for whatever the charm of Aztec decoration, we doubt if the representatives of the Christian Church adopted it in any particular.

The United States Department of Agriculture is authority for the statement that the woods of California covered a wide variety, and it is illogical to assume that Mission furniture was made of any one particular wood.

In Southern CaLifornis what is known as the Pacific Coast forest yields Donglas fir, spruce, larch, western red cedar (arbor vitae), hemlock, redwood and big-tree, yellow and white pine, incense, port Oxford and yellow cedar, fir (balsam), juniper, yew, cottonwood, maple, alder, birch, madorna and laurel.

In Arizona, Colorado, New Mexico and Northern Mexico, what is known as the Rocky Mountain forest yields yellow pine, Douglas fir, fir (balsam), spruce, juniper, pinon pine, aspen, cottonwood and oak.

In other parts of Lower Mexico we find all of the sub-tropical and tropical woods, mahogany, pine, prima-vera, santa maria, logwood, Mexican rosewood, zebrawood, mesquite, aliso (alder), ash, elm, mulberry, cottonwood, silk cotton tree or ceiba, linden, china, pimienta, John Crow wood, buttonwood, black maba and saln-wrood.

In Central America and West Indies, mahog- 
any, lignum vitae, logwood, sabicu, rosewood, fustic, quiebra hacha, zebrawood, calabash, cocobola, corkwood, panama, jaqua, amarillo, laurel, sarsaparilla and cocoa-wood.

It is doubtful if any Spanish furniture was brought over by the early missionaries for the furnishing of their pioneer structures. Their work was attended with great hardships, long marches and struggles for a living and a foothold in the interior of a new country. And it is unreasonable to suppose that they added to the liardships of their progress any unnecessary burdens. The famous missions of to-day are the missions of California, and in their construction the builders utilized black oak, laurel, juniper, live oak, red wood, scrub oak, sycamore and walnut.

The Arts and Crafts style has gradually become a general term for any furnishings of an umperiodic and unconventional character. Originally, it stood simply for individuality. It represented a movement that advocated the association of art and labor and had its first practical inception some forty years ago, when Morris built his famous Red House, ignoring the prevailing styles and factory products and producing through individuals an independence that was effective. But the work of Morris and his confrères was saturated with the spirit of Medievalism, hence the move- ment at the very beginning presented a consistency of decorative thought.

Morris developed along the idcas instilled loy Carlyle and Ruskin, who preached what was practically the socialism of art, expressing contempt for thic purely artificial, the carving that is plaster, the luster that is varnish, the bronze that is sheet brass, the painted woods-all the dictates of commercialism or tradition, and in no way representing an individual ambition. In the beginning the movement was undertaken by men who had something worth saying.

But to-day the movement simply expresses a contempt for all rules of order.

While Carlyle and Ruskin advocated the application of individual thought, the movement would never have developed were it not that the individual thought was born of culture, and followed with respect the preRaphaelite traditions.

The doctrine that no man can accomplish anything worth accomplishing if he is not free to express all that is in him, is good theory if the man is an artist, but it is dangerous to extend this encouragement to the inexperienced and uneducated.

As a resuit the Arts and Crafts movement has become simply a cloak behind which one hides his inability to produce a period style.

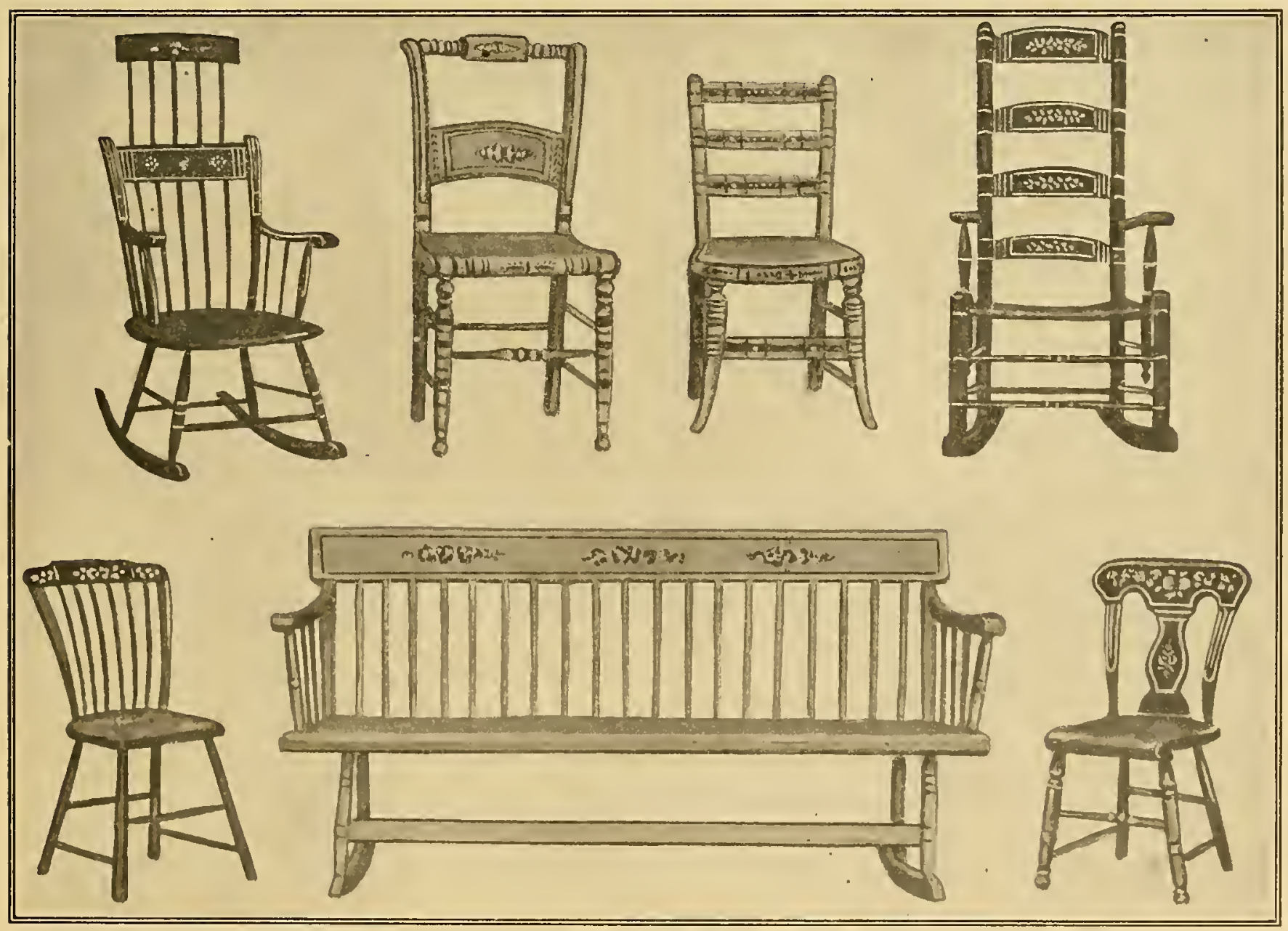




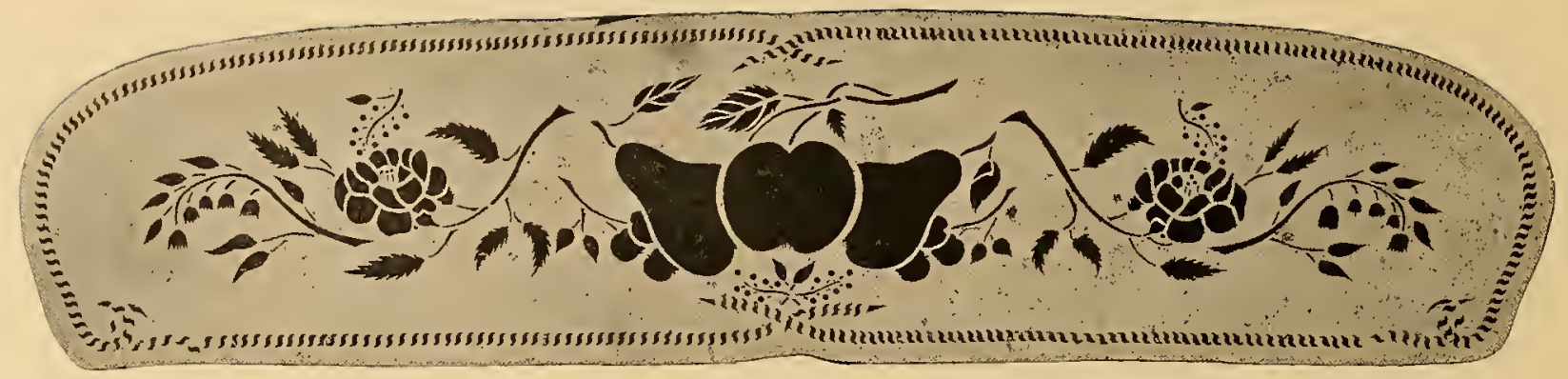

Chair-back stencil pattern of eighty years, a photographic reproduction of the original stencil plate.

\section{PAINTED FURNITURE}

I

N OUR "chronology of inlays and marquetry" we covered the subject from 1100 , when marble and vitreous paste were much used in Southern Italy, to 1779 , when David Roentgen, appointed by Marie Antoinette as "marqueteur to the Qucen," produced extraordinary work. The Dutch marqueteurs were famous in the middle of the Seventeenth Century and in England as well as France they practiced the art of intarsia-the inlaying of woods.

We have already gone into the distinction between intarsia, márquetry and parquetry.

In the Queen Anne epoch the designs were rich in colors, obtained through the use of tropical woods, and lustrous with the use of ivory and mother-of-pearl. But from the latter part of the Eighteenth Century down to date, little. has been done until the School of Nancy (France), stimulated by the vogue of Art Nouveau, introduced intarsia of quaint and unusual form.

Contemporaneously the Austrians, Germans, French and English went in for this style during the latter part of the Nineteenth Century.

After the Revolution many types of painted furniture were brought to America, not only from England, but from the South of France. They were frequently called japanned work, but the term is a misnomer, for the decoration is usually an ordinary paint and not lacquer work or japanned work, so called because at an early period it came from Japan and China.

On the right, typical painted rockers of the Nineteenth Century.
The Dutch about 1750 took up the fashion for painting furniture, much after the style of VernisMartin, painted under lacquer, not unlike the work of carriage panels. All sorts of subjects were followed, from flowers to ship scenes, a type familiar even to those of the present generation is the work of the New York stage coaches, sleighs of the old seventies, and snow chairs, which of late have been much sought. The work was frequently of a highly-artistic character.

In Holland of late years dealers have bought up old sleighs by the thousands, utilizing the painted work for cabinetwork. Similar work was done in Norway and Sweden.

Lacquered f urniture was brought into England and France in large quantities throughout the Seventeenth Century, particularly by the East India Company. It gave inspiration to much of the work of Adam, Hepplewhite and Sheraton, who, however, made no pretense to do lacquer work; they simply applied good painted motifs to certain parts of their furniture.

Angelica Kauffmann and Pergolesi were particularly successful, and in some cases their work was highly lacquered or japanned; but the hosts of unknown artists who followed this style and painted humbler types of furniture, bedsteads, washstands, chairs and toilet articles, used common paint, and some exceedingly simple effects, which finally deteriorated into stencil work, became popular and continued in vogue well into 1830. Indeed, the work became so common that the broad splats were introduced in chairs especially to give space for decoration. 


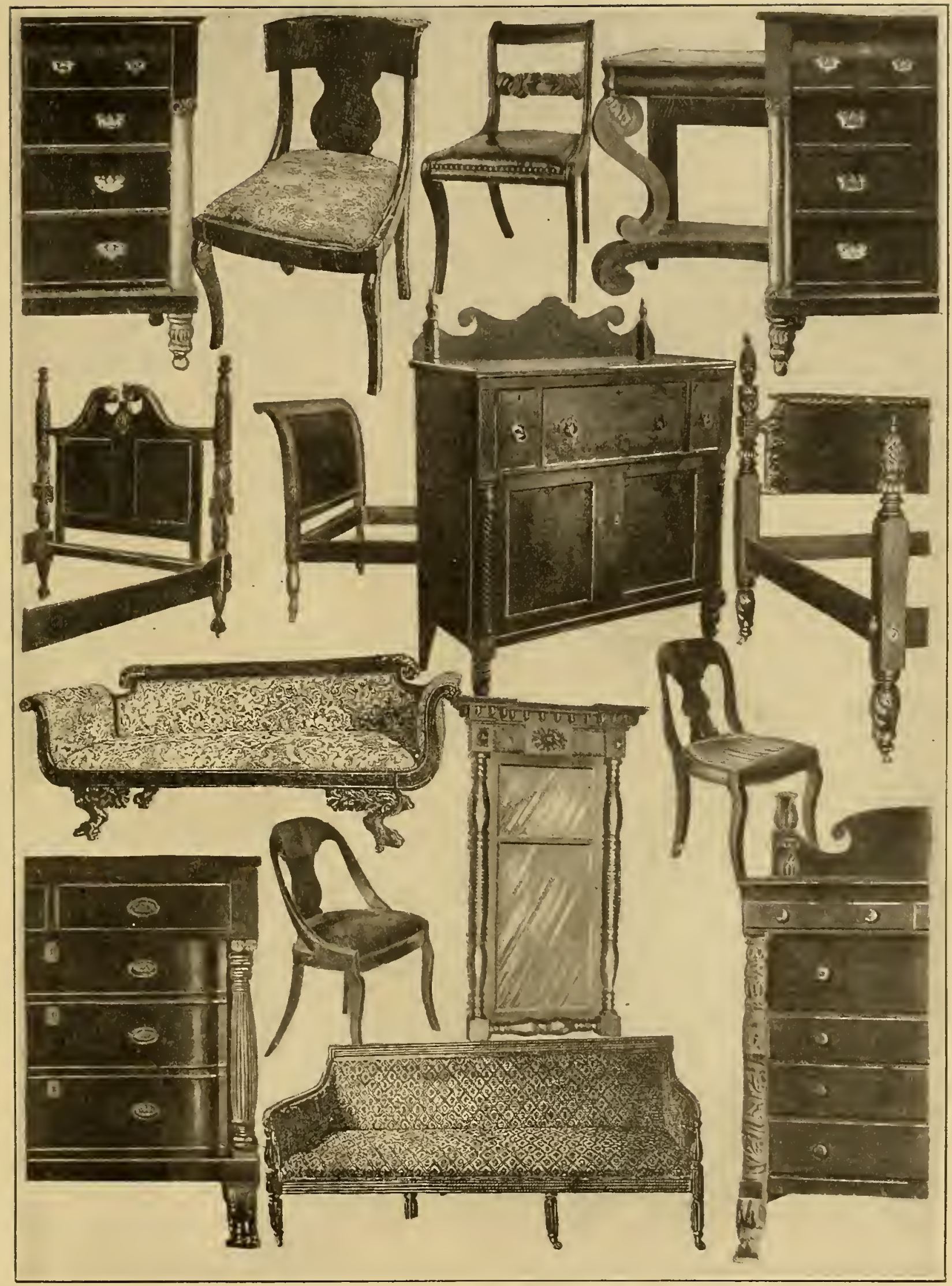

AMERICA'S MOST DISTINCTIVE NATIVE FURNITURE TYPE. 



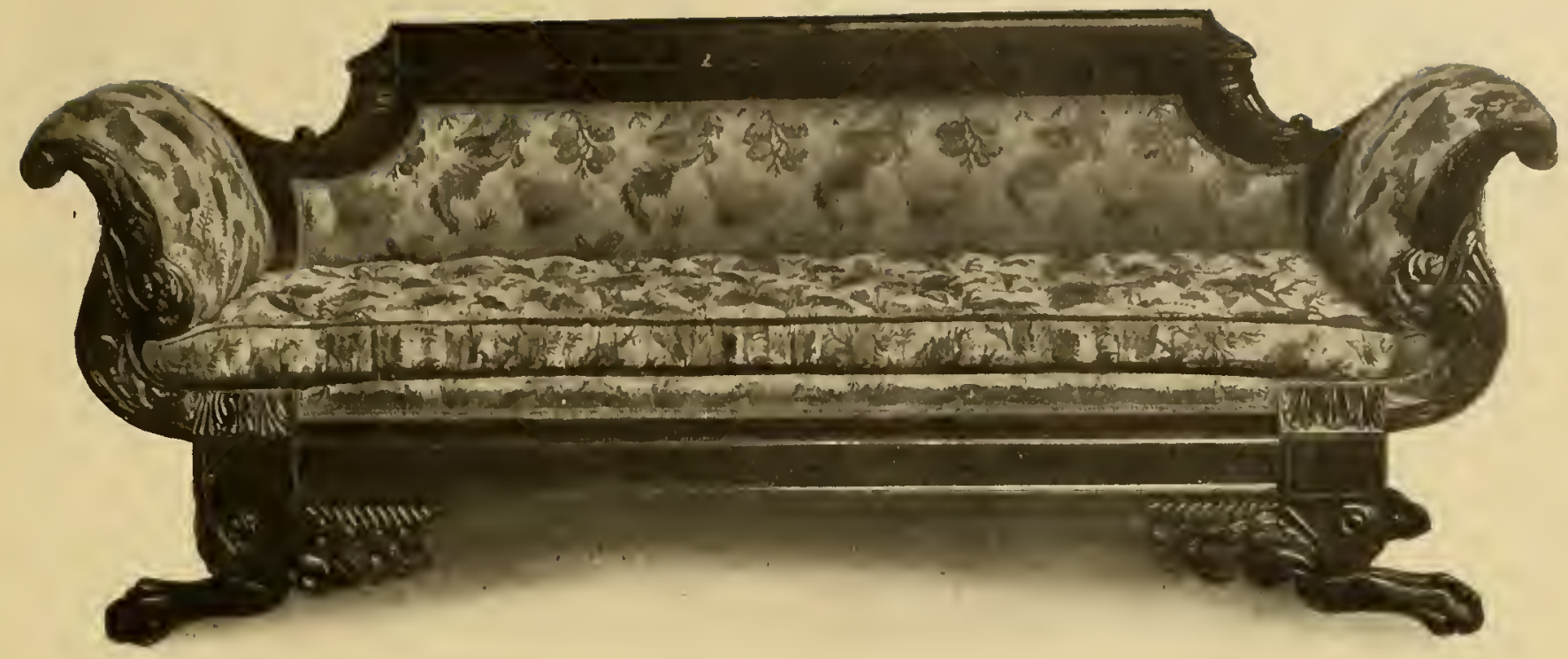

\section{A M E R I C A'S MOS T D I S T I N C T I V E F U R N I T U R E T P E}

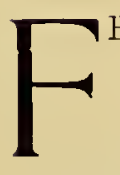

EW authorities have covered the subject of furniture and furnishings in America 1790 to 1830 . English authors stopped with the early Georgian. They felt that with the end of Sheraton and beginning with the abortive efforts of Thomas Hope, who in some degree followed the Empire, there was an end to the periods. and the Victorian age was approacherl apologetically.

Nevertheless there was a distinctly American type produced early in the Nineteentl Century, the outgrowth of the Empire form, simplified and beautified.

The Chippendale, Sheraton and Hepplewhite schools we re dainty and delightful examples of carving. painting and inlaying. Empire shapes were more massive and employed brass appliqué. From the beginning the Americans elimi-

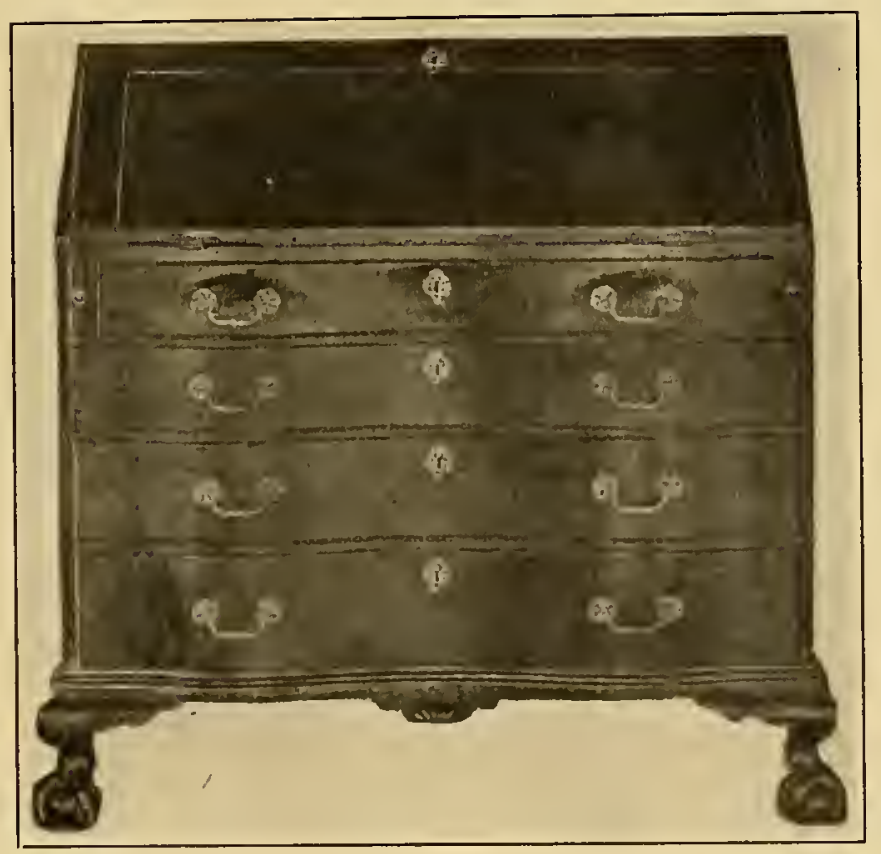

A type of 1770. nated the brass or Ormolu ornamentation, and while there was considerable carving on the backs of lounges and on the table legs, little by little this disappeared and only the simple shapes remained with broad flat surfaces made beautiful by veneers highly finisherl and polished. Prior to the Nineteenth Century veneering was an expensive art: the wood was cut by hand and it was impossible to cover large surfaces excepting at heavy expense.

In the pieces of William and Mary and Queen Anne veneering was used frequently as an economy. It was applied very often as a surface to cheap woods, but the veneerings of the late Colonial period were not applied because cheap, but because of the possibilities of a ligh lustrous finish, and the veneers were often attached to a solid mahogany base. 


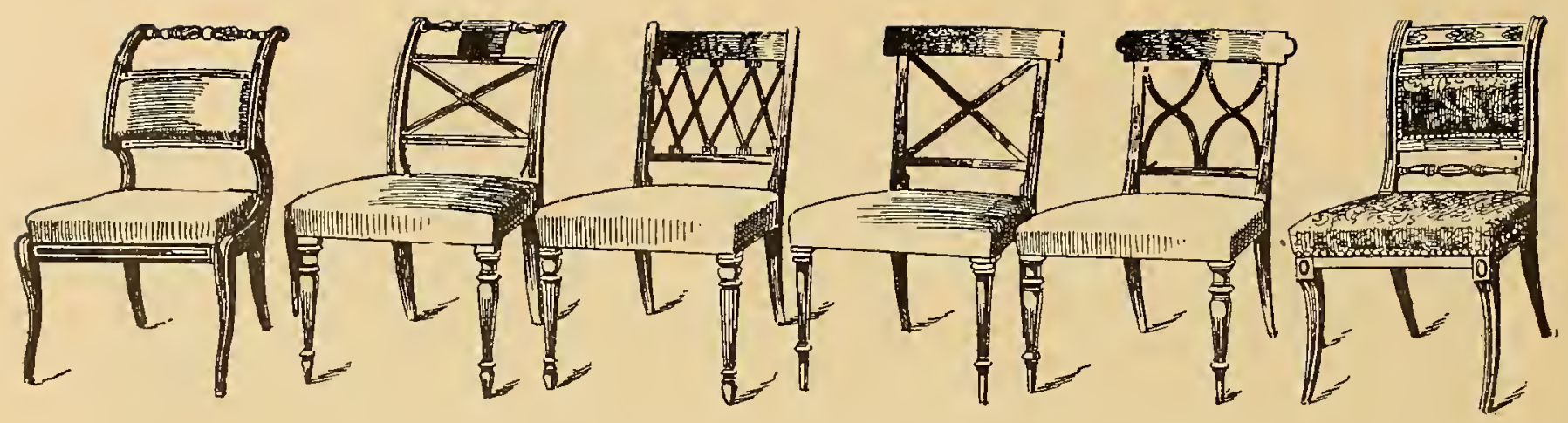

Above, American chairs of the period 1790-1830; below, tables of the same epuch.

It is a mistake to assume, as so many do, that veneer is shoddy and undertaken as a pretence and deception. Veneering is one of the oldest arts and in some form or other, as marquetry or as inlaying, has been practiced throughout all periods. Moreover, it gives strength to the frame, as best illustrated in Queen Anne work when frequently walnut was veneered on oak or yellow deal.

Venecrs are cut in two grades-saw-cut and knifecut. The first vary in thickness from $1-32$ to $1-16$ of an inch and are cut from a $\log$ with a large circular saw producing twelve or fourteen sheets to the inch. Knife-cut veneers are thinner. Before the introduction of machinery veneers were almost invariably an eighth of an inch thick and the decorative beauty of some of the veneers used is due to cutting through the burrs or excrescences of the tree. The "curls" and "feathers" are produced by the separation of the heart at the junction of a branch with the main trunk.

Mottles and figures, which are noted particularly in maple and mahogany, come from certain conditions of the wood when cut across the grain. Nachine-made veneers opened up a wide field of usefulness and constituted a type conncicent with the beginning of the Nineteenth Century.

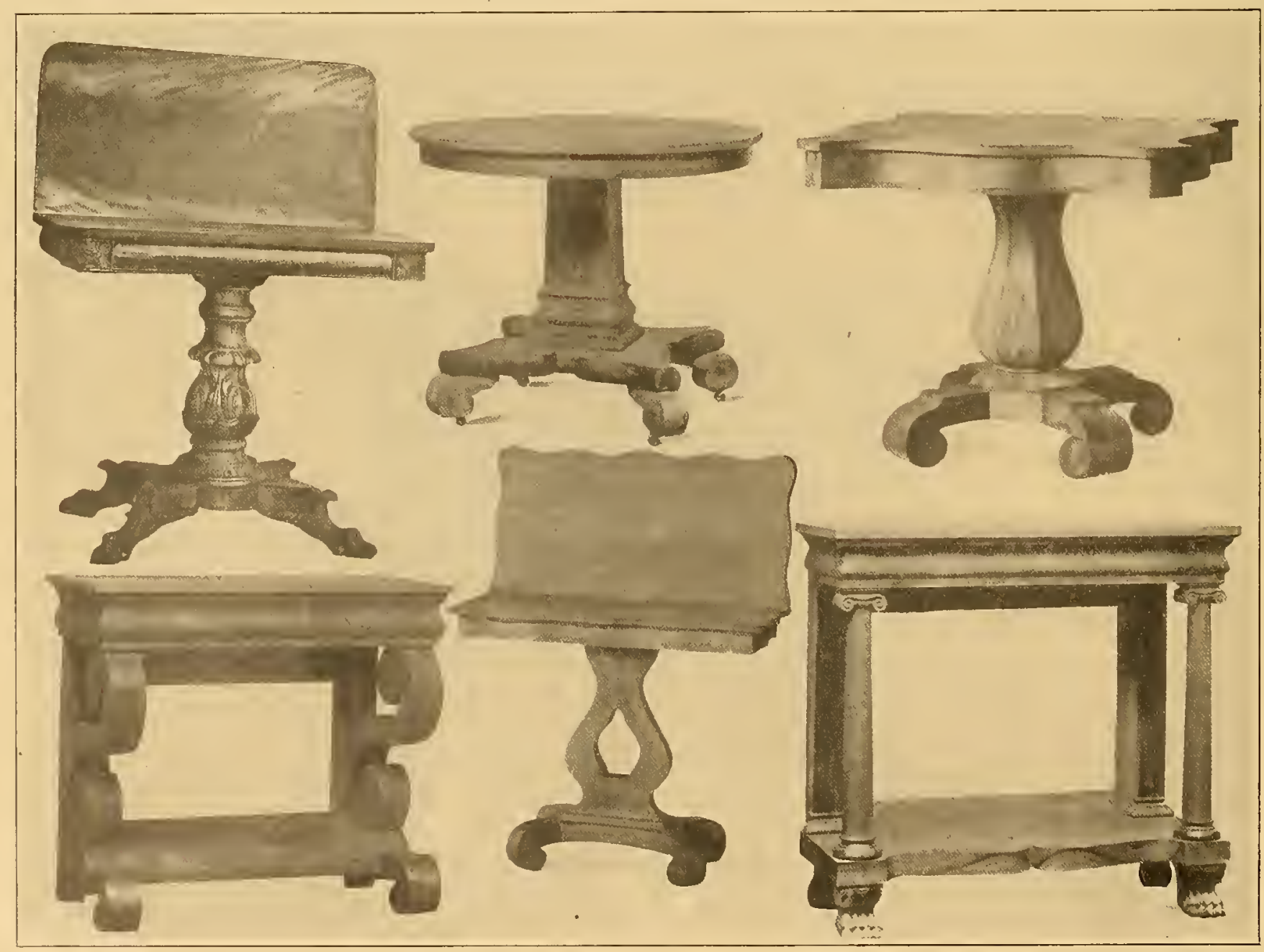




\title{
CHRONOLOGY OF WALL AND CEILING TREATMENTS
}

\author{
[4500 B. C. -1603 A. D.]
}

Egyptian, 4500 B.C.-324 B.C.

W ALL treatments confined to frieze decoration on plain walls; full of gold and brilliant colors; ornaments frequently hieroglyphics and Egyptian symbols; beautifully land-painted stucco and fresco work much in vogue; illustrations representing industries.

\section{Chinese, 3500 B.C. -238 B.C.}

Modern art described by Chambers $175 \%$. Sidewalls, matting four feet high, the rest colored or gilt paper, overhung with pictures and proverbs.

\section{Assyrian, 2286 B.C. -608 B.C.}

Stone work overwrought in bronze and gold; human faces showing profile; Assyrian symbols used, following largely the Egyptian. Walls of King Solomon's temple were covered with carved cedar and olive wood.

\section{Greek, 1900 B.C. -168 B.C.}

Fresco on plaster in strong colors, usually in deep friezes and dadoes; also stucco, fresco and tempera or distemper painting practiced; borders frescoed and painted in religious and legendary subjects, full of color; painting of still life, city and country shown; ceilings elaborate, divided into geometric sections; mosaics brought to perfection.

Similar to Greek.

Pompeiian, 100 B.C. -455 A.D.

Following the Greek and Roman style, but walls were also completely covered with paintings, sometimes divided into panels with small pictures and fine mosaics; sometimes wall space divided into dado, middle and upper section and ornamented with delicate garlands, fruit, masks. In England the Adam style almost reproduced the Pompeiian.

Byzantine, 328-1451.

Closely related to Roman. Magnificent in tiles, largely Oriental.

Romanesque-Effected materially by the Byzantine and Saracenic. Tiles and tile treatment; stained glass windows recorded 525 A.D. Tapestries made by Flemish weavers, 1170 A.D. In the Eleventh Century Cordova leathers, superbly gilded and painted were introduced from Flanders. The term was also applied to similar leathers produced in Portugal, France and Italy.

$$
\text { Gothic, } 1100-1550 \text {. }
$$

Beginning with 1200 walls of houses were wain- scoted and painted, often decorated with romantic, biblical or legendary subjects. In the Thirteenth Century walls were treated with tiling forms called Cosmatic mosaic, and frequently hung with tapestries. IVall-paper used prior to 1500 was simply pictures on paper and was hung like banners and not stuck to the wall.

About 1500 large hall of house was generally sitting-room, reception-room and dining-room combined. Raftered ceilings were common.

\section{Italian Renaissance, 1400-1643.}

Discoveries of the stuccoes of ancient Rome aroused Italian architects to the spirit of emulation and Ronian and Greek and mural work was generally adopted. Ground colors were laid on while the stucco was wet. Raphael and his followers applied themselves to wall decoration. Superb friezes and panels, the best the world has ever seen, was the result. Both wainscoting and rich tapestries, leathers, gold and silk fabrics were liberally used in all the phases of the Renaissance. Marbleized paper called "domino" was made in Italy during the Fifteenth Century in small squares and used on walls.

French Renaissance, $1500-1643$.

Covering practically the same characteristics as the Italian Renaissance, years of great magnificence embracing the reigns of :
Francis I., 1515-1549.
Henry II., 1549-1559.
Francis II., 1559-1560.
Charles IX., 1560-15\%4.
Henry III., 15\%4-1589.
Henry IV., 1589-1610.
Louis XIII., 1610-1643.

The domino papers of Italy were improved and instead of being marble or plain papers were printed in figures, and by 1700 there was hardly a house in Paris that did not utilize "domino papers."

Continuation of the use of fabric side-ivalls, rich paneling, stuccoed ceilings, carvings, rich paintings. Louis XIV., 1643-1\%15, side-walls frequently paneled in fabric. Ceilings painted or in rich plaster.

\section{Elizabethan, 1558-1603.}

Reflected the Italian spirit. Moldings were much used and strap work carvings, wood side-walls clear to the ceiling, stucco ceilings. Oak prevailed. Period lasted from 1500 to 1660 . Painted linens and hangings, tapestries, embroideries. 


\section{CHRONOLOGY OF WALL AND CEILING TREATMENTS}

[1603-1800.]

Jacobean, 1603-1643.

Continued the Elizabethan style. Still the age of oak. Side-walls of oak but in some of the finest residences the ceilings were beamed. Side-walls hung with tapestries. Magnificent stuccoes. Ceilings frequently of the most elaborate type, often colored. Heavy relief work, massive reproductions of panels full of heraldic devices and in small rooms chintzes from India were used. Cotton and linen embroideries were hung on the wall. Embossed and gilded linens, cloths of gold, painted cloths.

\section{Louis XIV, 1643-1715.}

Gobelin Tapestry Works became royal property. Beauvais Tapestry Works established. Richest silks used on the walls, damask, brocade and embroidery. Magnificent ceilings, paneled, painted and stuccoed. Magnificent Chinese papers poptlar for walls.

\section{Louis XV, 1715-1774.}

Chinese characteristics introduced. Wealth of his predecessor contintued. Paneling rich in gold and bronze. 1746-First factory established in France for the manufacturing of wall-paper squares. French Ministry, 1759, authorized the manufacture of printed linens, and by 1789 one hundred factories were in operation, some of them working from copper plates. Wood side-walls disappeared. Everything rich in fabrics.

\section{Louis XVI, $1774-1792$.}

Continuation of fabric effects following the daintier classic feeling; ceilings beautifully hand painted, cleverest artists of the day contributing to the work. Walls paneled in fabrics, surrounding the same with elaborate compositions of plaster and molding work. White and gold conspicuous. Continuous rolls of wall-paper were undertaken in 1790.

In $178 \%$ we find a decree of the king declaring that the art of painting and printing paper used in furnishings were a dependence of the governing board of the Merchants-Papetiers-Dominotiere-Feuilletinere, which shows that the term "domino" still clung.

$$
\text { Empire, 1804-1814. }
$$

Walls stronger in gold effects. Continuation of fabric treatment with the added use of bronze and gold in profusion. Walls hand painted on plaster or canvas.
Charles II., 1660-1685.

James II., 1685-1689.

William and Mary, 1689-1702.

Wainscoted side-walls began to come lower in height and by Charles II's time began to disappear; the French method of treating walls in fabric came in. The ceilings, however, continued to be of magnificent proportions, elaborate in stucco and relief work divided into panels, circles, hexagons and rhomboids, borders enriched with flowers and fruits similar to the extraordinary carvings of Grinling Gibbons. Borders were often flat ornaments of Greek or Roman design. Ceilings were magnificent reproductions following the Renaissance, also prolific with goddesses, saints, muses and Cupids.

\section{Queen Anne, 1702-1714.}

Frequently side-walls followed the French style. The custom of paneling the side-walls was partially kept up. Chimneypieces, however, only went halfway up the wall. White woodwork was effected. Walls were often without any paneling or wainscoting and covered with squares of Chinese wall-paper or painted directly on or hung with fabrics, particularly prints.

Colonial, $1700-1800$.

The American colonies adopted the European styles. White woodwork was popular, little wainscoting was attempted about 1690. In 1749 Isaac Ware wrote: "The decoration of an American room is of three kinds-first, where it is coated with the plaster material wrought into ornamental details; second, where covered by wainscot, and third, where hung with silks, tapestries or paper," for in that year dealers in America were advertising "to hang rooms with paper or fabrics in the very newest fashions." Indeed, Charles Hargraves advertised wall-papers in Philadelphia in 1745 , and only a few years later Peter Fleeson was making paper-hangings in squares, corner of Fourth and Chestnut Streets, Philadelphia. Nantucket, Portsmouth and St. Johnsbury, Vt., have yielded to the collectors some exquisite examples of wall decorations. Thomas Hancock in 1757 wrote to an English friend to send him some paper-hangings showing a great variety of birds, animals, fruits and flowers and he adds to his letter: "I think these papers are handsome; better than painted walls." Fabrics were used on the walls contemporaneously with the European use of them. 


\section{N D E X}

NOTE:-The innumerable racial names, divisions and nationalities, not indexed hereunder, will be found comprehensively grouped under the charts, "Developments of Nations," pages 3 to 6.

The asterisks indicate illustrations.

Adam, 72, 161,* $162,{ }^{*} 176,184 \mathrm{~b}, *$ $187, * 188, * 189, * 192 \mathrm{a}, * 196,{ }^{*} 199, *$ $200 * 201,202 *$

Acanthus, 27, 60, 73, 201*

Age of Bronze, 15

Age of Copper, 15

Age of Iron, 15

Age of Oak, 8, 118

Age of Stone, 15

Age of Walnut, 8, 80, 118

Ainos, 50

Alberti, 77

Alhambraic, 8, 38

Animal Forms, 15, 17, 24, 27, 28, 45

Anthemion, 60, i3

Appliqué Work, 28

Arabian, 7, 38, 41*

Arabic, 130

Architectural Design, 141

Armorial Bearings, 49

Armures, 75

$\Lambda$ rras Tapestries, 222

Artists and Architects, 138

Art Moderne, 219

Art Nouveau, 8, 72, 216*, 21\%*, 218*, $219^{*}$

Arts and Crafts, 219, 223, 225*

Asiatic, 38

Assyrian, 3, 7, 15, 16*

Aztec Ornament, 224*

Babel, 144, 147

Babylonian, $3,7,15,16^{*}$

Ball Foot, 111

Bands, 34

Baroque, 123, 124*

Bartolomeo, 177

Bartolozzi, Francesco, 176

Beauvais, 40, 132

Beds, 22

Bed Draperies, 125, 212*

Beech, 119

Beetle, 15

Beidermeier, 216b*

Beidermeier Chairs, 218,* 219

Berain, Jean, 132, 133, 137*

Biblical Subjects, 28

Bird Forms, 27, 28, 49, 137

Blache, 125

Block Prints, 49, 166

Blois, 83

Blondel, 144

Bobbinet, 40

Bonchon, 125

Borgognone, 77

Botticelli, 77

Bouchardon, 139

Boucher, 139, 144, 147

Bondichon, Jehan, 168
Boulle, Andre Charles, 83, 133, 154

Boulle Cabinet, 113, 132*

Boulle Secretaire, 144*

Boullognes, 132

Brass Mountings, 163

Brass Nails, 80, 113

Briseux, 144

Broad Splats, 227

Brocades, 45, 89,* 90,* 222

Broclies, 75

Lroken-Arch Cornice, 210

Brown, Ford Madox, 220

Bronze, 28, 133, 145, 150

Bruges Satins, 125

Brunelleschi, 77,78

Buffets, 57, 93, 215*

Bulb Foot, 111

Buonarroti, Michael Angelo, 77

Bureau, 128, 217

Burne-Jones, Sir Edward, 219, 220

Butterfly Table, 212

Byzantine, 4, 7, 27, 29*, 30*

C Curve, 103

Cabinet Work, 99

Cabriole Leg, 111, 169, 180, 210

Caffarts, 125

Caffieri, 133, 144

Calico Printing, 222

Campbell, Colin, 176

Candle Stand, 211*

Cane, 119, 124, 169

Cane Seats, 105, 189, 212

Canopies, 125

Card-Tables, 157, 176

Carlyle, 225

Carpets, 222

Carter, J., 176

Carter, Edward, 123

Carvers and Bronze Workers, 138

Catherine de Medici, 83, 124

Cedar, 17, 119

Ceilings, $109,{ }^{*} 123,128, * 202, * 204$

Celtic, $3,7,24^{*}$

Ceremonial Colonial, 175

Claise Lounge, 137*

Chaldean, $i$

Chambers, Sir IVilliam, $176,17 \%$, 185

Chambord, 83

Chandeliers (crystal and glass), 128,150

Charles I, 105

Charles II, 8, 117

Charles IX, 83

Chestnut, 118

Chests, 57, 212

Chimerical Devices, 163

Chimney-Pieces, 185

Clinese, $7,38,45,47, * 183,184$

Chinese Ornament, 141, 144
Chintzes, 110

Chintz Printing, 222

Chippendale, 161, 176, 177,* 178** 180* ${ }^{*} 181, * 182, * 184, * 185,188$ * 201

Christian (Early), 31

Chronology of decoration by Centuries, 7,8

Chronology of wall and ceiling treatments, 227, 228

Chronology of Woods, 160

Cipriani, 176, 185, 197, 198,* 201

Circle, 27, 31, 34

Clarke, Sir Purdon, 217

Claw-and-Ball-Foot, 111, 112, 169. $150,182 *$

Clement, William, 173

Clocks, 110, 119, 189

Coffer, 57, 78

Colbert, 40, 125, 137

Collinson, James, 220

Colonial, 8, 169, 175, 203, 208, 208a * 209 , $211, * 213$,* 217

Colonial Bed, 216b*

Colonial Doorway, 215

Colonial Sofa, 204*

Colored Glass Windows, 57

Color Printing, 166

Columbiani, 176,201

Commode, 157, 217

Commonwealth, 105

Composite, 7

Connecticut Chests, 204

Console, 157

Copeland, 171, 176, 180

Cordova Leathers, 89. 93

Corinthian, 7

Corneille, 133

Cornices, 157

Cottage Colonial, 175

Cotton, 28

Couches, 15, 19

Coypel, 132

Crane, IValter, 219

Cranes, 50

Cressent, Charles, 144, 150

Cromwellian, 8, 49, 99, 104

Cross, 27

Crown, 2ז, 49, 60

Crunden, 176, 177, 180

Crusades, 7, 34

Cucci, 133

Cupboard, 222*

Curve-back Chair, $15 \%$

Cushions (Movable), 118

Cushioned Seats, 118

Cylinder Printing, 168

Dagobert, 28

Damasks, 28, 75, 133

Dangon, 125

Darley, 176, 177 
Date Palms, 15

Dates, 18, 39

David, 161

Da Vinci, Leonardo, 77

Day Bed, 201*

De Cuvilles, 144

De LaSalle, Philip, 125

Del Sarto, Andrea, 77

De Maintenon, Madame, 137

De Queroualle, Louise, 117

Derbyshire Chair, 105*

Designs of Conquest, 163

Desks, Colonial, 208*

De Valliere, Louise, 133

Development of Floral Types, 72,* 73

Development of Mechanical Textile Design, 64

Development of Nations, 3,6

Development of Textile Weaving, 35

Diamond-Paned Windows, 112

Dimity, 113, 125

Directoire, $8,72,154,161,163$

Domino, 168

Donato, 77

Doric, 7

Dossier, 57

Double-Seated Chairs, 117

Dove, 27

Dragon, 25, 27, 50

Draperies, 145

Draught Chair, 169

Drawn Work, 17

Dressoir, 93

Drop Handles, 117

Du Barry, 151

Duchess Chair, 189

Duplessis, 144

Durer, Albrecht, 77, 123*

Dutch (Early), 6, 8, 93*

Dutch Embroideries, 95

Eagle Heads, 18

Eagle-Headed Lions, 18

Eagles, 17, 28

Early Christian, 27

Early Renaissance, 6

East India Trading Co., 110

East India Goods, 175

Eastlake, 219, 220, 222*

Ebenists and Inlayers, 138

Ebony, 118, 124, 163

Edwards, 176, 17\%, 179

Egyptian, 3, 7, 15

Egyptian Damasks, 125

Eichendorff, 219

Eight-Legged Chair, 113

Elizabethan, 8, 99, 100,* 102,* 104,* $106,{ }^{*} 107, * 108, * 120 a^{*}$

Elizabethan Embroideries, 98,* 99*

Elm, 119

Embroideries, 22, 23, 28, 31, 98*

Empire, $72,161,162$; 163 , * 165,* 219

Enamels, 28

English Gothic, 6, 7, 8, 53, 58,* 59*

English Renaissance, 6, 8, 77, 99, 109 , $122^{*}$
English Romanesque, 27

Escutcheons, 117

Etamines, 125

Etruscan, 3, 7

Extension Tables, 157

Fabrics, 28, 56,* 61, 65, 112, 126,* $127, * 140, * 141, * 206$

Fabrics of the Sixteenth and Seventeenth Centuries, 140

Fabrics of Northern Italy, 75

Falcon, 125

Fan-Shaped Chairs, 105

Fan-Shaped Ornaments, 15

Farthingdale Chair, 119*

Feathers, 15, 137

Feradines, 125

Fern, 18

Field Bed, 212*

Fifteenth Century, 56b*

Fig Tree, 18

Filatrices, 125

Fir Cones, 18

Flambeau, 163

Flanders, 8

Flemings, 83

Flemish, 5, 6, 7, 79

Flemish Chairs, $82^{*}$

Flemish Dutch, 6, 117

Flemish Frieze, 103*

Flemish Renaissance, 77, 89

Flemish Strap Work, 87

Fleur de Lis, 53, 60

Floors, 210

Floral Motifs, 28, 60, 72

Florentine Renaissance, 8,77

Floriated Forms, 24, 43

Florid Gothic, 58

Flower Tables, 157

Fluted Foot, 111

Fontainebleau, 83, 88,* 129, ${ }^{*} 163^{*}$

Four-Post Bed, 212*

Fra Angelico, $\tau 7$

Fra Giaconda, 77

Francis $\mathrm{I}, 72 \mathrm{~b}, * 88 \mathrm{~b} *$

Francis II, 83

French, 3, 4, 6

French Carpets, 145

French Chair Foot, 117

French Flemish, 117

French Gothic, 7, 53, 54,* 62*

French Renaissance, $6,8,77,82,83$, $86,{ }^{*} 87, * 88^{*}$

French Romanesque, 27, 31

French Saracenic, 31

Frets, 19

Friezes, 103,* 198

Frieze Decorations, 15

Gallatier, 125

Garter Chair, 222*

Genin, 125

Georgia, 31

George I, II, III, 176

Georgian, 8, 175, 176

Germain, 144

German Empire, 7, 218

German Gothic, 52, 63,* 68*

German Renaissance, 8, 77, 92*
German Romanesque, 31

Gesso Work, 198

Giacomo, Barozzio, 77

Gibb, James, 122, 123, 130,* 176

Gibbons, Grinling, 104, 122, 123, $128,{ }^{*}, 176,192 \mathrm{~d}^{*}$

Gilded Parchment, 49

Gillow, Richard, 176

Gilt Furniture, 169, 180

Gilt Ornament, 169

Glass, 31, 209

Glass Knobs, 185

Gobelin, 8, 40, 132

Gold Leaf, 49

Gold Ornamentation, $17,18,28$

Gothic, $6,7,51,55,60$, $61,88,88 b^{*}$

Gothic Fabric Designs, $64^{*}$

Goths, 27

Græco-Pelasgic, 7

Grandfathers' Clocks, 110

Gravelot, 144

Grecian, 3, 7, 19

Greek Ornament, $19^{*}$

Griffins, 28

Group System of Classifying Textiles, 34,64

Guilloche, 22

Hadley Chests, 204*

Halfpenny, William, 176

Hallet, 211

Hals, Franz, 123*

Hammersmith Carpets, 222

Hardware, 189

Harris, Richard, 176

Harts, 49

Hawksmoor, Nicholas, 123, 176

Hebraic, 3, 18

Henri II, $7,78, * 83, * 126,127 *$

Henri III, 83

Henri IV, $8,83,91, * 117, * 126 *$

Hepplewhite, $159, * 176,185,189$, $^{*}$ $190, * 192, * 193, * 201$

Heraldic Forms, 34

Herbs, 15

Herculaneum, 151

Hexagons, 28

Highboy, $169, * 210$,* $213^{*}$

Hispano-Saracenic, 31

Hogarth, $1 \% 6$

Hogarth Chair, 169, 206*

Holbein, H., 103, 123*

Honeysuckle, 22

Hope, Thomas, 175, 176, 219

Horsehair, 189

Human Faces, 15

Human Figures, 25, 45

Hunt, Holman, 220

Hyacinths, 39

Hyvart, 132

Iberia, 31

Ince, 176,179

Indian, $7,18,45,46,{ }^{*} 50$,* 73,112 , $166^{*}, 167^{*}$

India Prints, 110

Inlaid Wood Floors, 112

Inlays, 83,105 
Intarsia and Marquetry, $23,80,{ }^{*} 83$, 160

Inscriptional Work, 41

Interiors, 51, 57, 81, 89, 93, 106, 107, $108,119,129,135,145,152,163$ $175,192,194,195,209,210,211$ $213,222,223,225^{*}$

Interlacements, 27,34

Interlacing Circles, 28

Interlacing Crosses, 28

Interlacing Guilloches, 28

Intersection Design, 27

Ionic, 7

Iris, $73^{*}$

Islam, 31, 38, 39

Italian, 4, 6, 70, 75, 78*

Italian Chairs, $82^{*}$

Italian Gothic, $53,60,67^{*}, 74^{*}, 76$, 80, 112

Italian Renaissance, $8,77, * 78,79, *$ $81,{ }^{*} 83,84,{ }^{*} 85,{ }^{*} 200 a^{*}$

Ivy, 22

Jacobean, S, 80, 99, 100, ${ }^{*}, 101,{ }^{*} 109$, $^{*}$ $113,11 \pi, 129^{*}$

Jacobean Chest, $99^{*}$

Jacobean Embroideries, 98*

Jacquard, 125

James I, 105, 129*

James II, 117

Jamnitzer, W., 123*

Jans, 132

Japanese, $7,45,48, * 50,183$

Japanned, 118

Jeffersonian Period, 175, 211

John of Padua, 77, 99, 123

Johnson, Thomas, 176, 177, 180

Jones, Inigo, 103, 122, * 123, 130, 133

Jones, W., 176, 201

Joubert, 144

Jouy Prints, $141,{ }^{*} 164, * 166, * 167^{*}$

Kas, 210, 212

Kauffmann, Angelica, 176, 191, 197, 201, 226

Kent, William, $130,{ }^{*} 176,180$

Laburnum, 119

Lace, 17,137

Lacquer, 118, 144, 145

Lacquered Furniture, 117, 226

Ladder-Back Chair, $182^{*}$

La Fontaine, 133

Lancashire Chair, 105*

Lancet Gothic, 55

Lancret, 139

Latrobe, 205, 210, 211

Laurel Leaves, 60, 163

Leathers, 89, 93, 110, 112, 124

Le Brun, 132, 141

Le Pautre, Jean and Antoine, 132

Le Roux, 144

Lily, 15, 17

Lime, 118

Linens, 22, 31

Linenfold Panels, 57, 61

Lions, 17, 28, 45, 180

Lobed Leaves, 76

Lock, Mathias, 176, 177, 179
Lockwood, Lukc Vincent, 217

Lombards, $2 \tau$

Lombardic Romanesque, 27

Looking Glasscs, 110, 207

Lotus, 15,17

Lot is XI, 49

Louis XIII, 8, 123, 125,* 127,* 129,* $131 *$

Louis XIV , 8, 113, 125,* $126,{ }^{*} 127, *$ $132, * 134, * 135, * 137, * 142, * 143$, * $144^{*}$

Lonis XV, 131,* 136,* 136a,* 136d,* $144,144 a, * 144 d, * 145, * 148, * 154, *$ $184^{*}$

Louis XVI, 8, 151, 152d, ${ }^{*} 155,{ }^{*} 156,{ }^{*}$ $157, * 158, * 159^{*}$

Love Seats, 169

Lozenge Pattern, 28

Lucca della Robbia, 77

Luccan Damascenes, 125

Lyre-Form Chair Backs, 193

Mahogany, 8, 105, 145, 163, 180, 187, 204

Mansart, 132

Nantels, 185

Manwaring, 177,179

Marble Couches, 23

Marble Prints, 168

Marie Antoinette, 151, 1522*

Marot, Daniel, 118, 132, 137,* 169, 176,177

Marot, Jean, 132

Marquetry, 119, 124, 160

Marquetried Furniture, 117

Marshall, Peter Paul, 221

Martin, Robert, 118, 147

Martin, Simon Ettienne, Jr., 147

Mat Plaiting, 28

Mattresses, 19

Mayhew, 176, 177, 179

Mazarin, 132,183

Medieval Art, 27, 222

Medieval Furniture, 33*

Messonnier, 150

Metal, 28

Mexican Decoration, 224

Michael Angelo, 123

Mignard, 133

Milanese Renaissance, 8, 77

Millais, John, 220

Milton, 176

Mirror Glass, 209

Mirrors, 22, 80, 110, 128, 150, 207*

Nirror Frame, 211*

Mission, 219, 223*

Mission Woods, 224

Mohammedan, 7

Noldings, 105

Moliere, 133

Monnoyer, 132

Moorish, 5, 7, 38, 39, 42*

Moquette Carpets, 15 T

Moresque, 130

Morris, William, 219, 220, 221

Mortlake Tapestry Works, 40, 112

Mosaics, 23

Mythological Subjects, 28, 197

Napoleonic Bee, 163
Napolconic Crown, 163

Natoirc, 147

Ncedle-Point Lacc, 40

Netherlands, 68

Nctherlands Gothic, 68*

Nettings, 17

New Art, 219

New England, 211

Norman, 7

Norman, England, 27

Norman Romanesque, 27, 32*

Northern, 7, 25

Norwegian Renaissance, 95

Nude Figures, 15

Oak, 8, 118

Oak Leaf, 76

Oberkampf, Christopher, Philip, 167

Octagons, 28

Ogival Form, 27,* 34, 35, 70

Oiled Linen, 210

Oiled Paper, 210

Oriental Motif, 111*

Oriental Rugs, 110, 133, 145

Ormolu, 150

Otter, 25

Ottoman, 8, 39, $144^{*}$

Ottomans, 157

Oudry, 144

Ovals, 34

Oval Chair Backs, 18r*

Overton, 176

Paine, James, 176

Painted Cloths, 166

Painted Furniture, 124, 226

Painted Linens, 167

Palladio, 77

Palm, 18, 22, 39

Rane1s, 23

Paper, 168

Papyrus Buds, 15

Parthian, 7

Peacock, 27, 2S, 50

Pea Forms, 39, 44, 61

Pediments, $130,{ }^{*} 193$

Pelasgic, 7, 22

Pembroke Tables, 191

Perforated Doors, 57

Pergolesi, Michael Angelo, 1r6, 191, $197,198, * 201,226$

Perpendicular Gothic, 55

Persian, 3, 7, 1 $7,18,35,{ }^{*} 43^{*}$

Perso-Byzantine, 31

Phœnician, 3, 18

Phyfe, Duncan, 204, 210, 211

Pictorial Tapestries, 40

Pie-Crust Table, 182*

Pierced Rails, 180

Pier Table, 157

Pillars, 211

Pineapple, 22, 39

Pineau, 144

Pines, 39

Plagues, 198

Plumes, 137

Point Venice Lace, 40

Poiton, 132 


\section{N D E X}

Polish, 95

Pomegranate, 38,39

Pompadour, Madame, 144

Pompeii, 7, 151

Pompeiian, 7, 19, 20, ${ }^{*} 23,161,197,199$

Ponson, 125

Porcelain, 137

Portieres, 28

Portuguese, 3,6

Portuguese Chair, $89^{*}$

Portuguese-Persian, 73

Portuguese Renaissance, 95

Pre-Raphaelites, 220

Printed Fabrics and Paper, 166, 222

Printed Linens, 40, 93, 167, 194

Queen Anne, 8, 105, 117, 169, 170,*

171 * 173 * 174 , 175 , $213 *$

Queen Anne Highboy, $169^{*}$

Queen Anne Love Seat, $169^{*}$

Racine, 133

Rag Paper, 168

Raphael, 77

Rayed Stars, 49

Rectangular Patterns, 34

Reeds, 15

Regency, 139, 148*

Rembrandt, 123*

Renaissance, 77,102 , 127 *

Renaissance Development, 77,114

Revel, 141

Revocation of the Edict of Nantes, 104

Rhodian Rose, 38

Ribbon-Back Chair, 180

Richardson, George, 176, 201

Riesener, 144, 154

Rock and Shell, 133

Rocking Chairs, 227

Rococo, 8, 77, 139, 150, 168*

Roentgen, David, 154, 226

Roman, 3, 4, \%, 19, 21*

Romanesque, $7,27,31,34, * 36 *$

Romanesque Gothic, 53

Roman Renaissance, 8,77

Ronezzano, 99

Rope Seats, 15

Rose, Joseph, 176

Rosewood, 163

Rossetti, Dante Gabriel, 220, 221

Rossetti, William M., 220

Roundabout Chair, 212**215*

Rounded Wood, 179

Round-Head Gothic, 53

Rubens, 103, 123*

Rush Floors, 57, 110, 119,*210

Rush Seats, 15, 212

Ruskin, 219, 225

Russian, 5, 27, 69

Russian Renaissance, 95, 97*

S Curve, 103

S Shaped Chair Leg, 118

Sacred Tree, 15, 18

Sanded Floors, 210

Saracenic, $28, * 38$

Sarcenets, 28

Sassanian, 7

Satin, 40,125

Satin Damasks, 40

Scandinavian, 5, 7, 25

Scarfs, 125

Schinkel, Herman, 168

Schubert, 219
Sconces, 128

Scroll Feet, 111, 167

Secession, 219

Seralio, 77

Serpentine Stretcher, 117

Settees, 117

Seventeenth Century English Furniture, $120, * 121^{*}$

Shah Abbas, 39

Shearer, 176, 187, 188, * 189, 190,* 193

Shellacking, 118

Shell Shapes, 105, 137

Sheraton, 159 * $176,181, * 184,185$. 188 , $189, * 190,193,195$, * 201 , * $202^{*}$

Shield-Shape Chair Back, 187*

Sicilian, 49

Siculo-Saracenic, 49

Sideboards, $189, * 191,215$

Silk, 19, 28, 34, 35, 39, 40, 49, 75, 113 $125,131^{*}, 133,194$

Silver Ornamentation, 18

Sixteenth Century Fabric Designs, $71^{*}$

Smith, George, 176

Smooth Splat, 169

Solomon's Temple, 17

Southern Homes, 211

Spade Foot, 111

Spanish, 3, 5, 6, 7

Spanish Gothic, 66*

Spanish-Portuguese, 6

Spanish Renaissance, 6, 8, 95, 96*

Spinning Machine, 75

Spindle-Backs, 227

Spiral-Framed Chairs, 80

Splat Back, 180

Squares, 28, 34

Stalactite Forms, 133

Stephens, F. J., 220

Stencil Work, 226, 227

Street, George Edmond, 220

Stretchers, 112, 169

Stripes, 28, 34

Stone, Nicholas, 123

Stools, 15

Stuart, 8, 99

Stuccoes, 80 , ${ }^{*} 103,133$

Swan, Abraliam, 176

Swan-Neck Cornice, 210

Swiss Renaissance, 97

Sycamore, 118

Syria, 3

Taffetas, 28

Tapestries, 22, 28, 31, 35, 39, 40, 72, 93

Tapestry Weaving, 222

Tarsia (See Intarsia)

Taylor, Sir Robert, 176

Tea-Tables, 212

Teutonic, 3, 4

Textile Design, 64

Thomas, W., 176, 201

Throne Chair, $222^{*}$

Tiles, 31,34

Toile de Jouy, 141, 164, 166, 167

Torch, 163

Torrigiano, 99

Tortoise Shell, 150

Transition, 72, 139, 151, 154, 161, $162^{*}$

Transition Gothic, 57

Tudor Gothic, 8, 55, 61, 109*
Turkish, 8, 39

Turned-Rail Furniture, 95*

Turned Wood, 28, 212

Tuscan, 7

Tyrol Gothic, 53, 61, 68*

Uhland, 219

Upholstered Chairs, 117, 118, 124, 212

Urns, 60

Van Brugh, Sir John, 123, 176

Van Dyke, 103, 123*

Valances, 113

Vandermeulen, 132

Varnish, 118

Velvet, 22, 28, 40, 75, 89*, 90, 113, 125,133

Veneering, 23, 119, 125

Venetian, 70

Venetian Damasks, 125

Venetian Renaissance, 8, 77, 123

Vernis-Martin, 118, 144, 147

Verrio, 123

Vezier, 125

Victoria (Queen), 219

Victorian, 8

Vine, 17, 22, 27

Vischer, P., 123*

Vitruvian Scroll, 22

Voysey Design, 220*

Wagner; 219

Wainscotted Chairs, 212

Wainscotting, 57

Wallis, N., 176, 201

Wall Paper, 168, 204, 210, 222

Walnut, 8, 113, 119

Walpole, 179

Wardrobes, 189

Ware, Isaac, 1\%6, 210

Washstands, 193, 194

Watteau, Antoine, 139, 146*

Waves, 50

Webb, John, 123

Webb, 221

Wedgwood, Josiah, 176, 198

White Trims, 185

White Woodwork, 179, 210

Wicker, 105, 212

William and Mary, 8, 113, 116, 213*

Willow, 118

Window Glass, 209

Windsor Chairs, 206*

Winged Bulls, 18

Winged Dolphins, 22

Winged Horses, 23

Winged Human Figures, 15, 18

Winged Lions, 49

Wolner, Thos., 220

Wood Carving, 83

Woods, Chronology of, 160

Wood Finish, 118

Wood-Paneled Chairs, 104

Wool, 28, 31

Woven Tapestries, 93

Wreath, 60, 163

Wren, Sir Christopher, 103, 122,* 123,128 , * 176

Writing Tables, 157

$\mathrm{X}$ Chair, 118

Yew, 119

Yorkshire Chair, $105^{*}$

Zigzags for Water Ways, 15

Zucchi, Antonio, 176, 197, 201 

, 

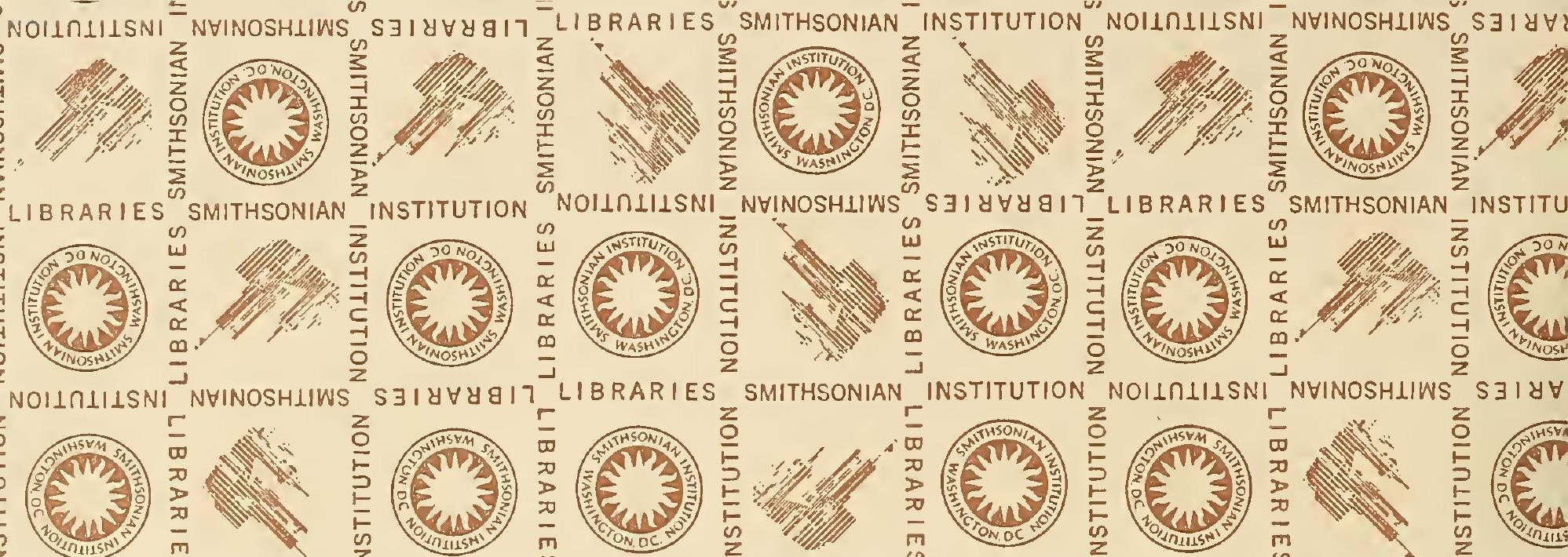

IBRARIES " SMITHSONIAN INSTITUTION NOILNLILSNI
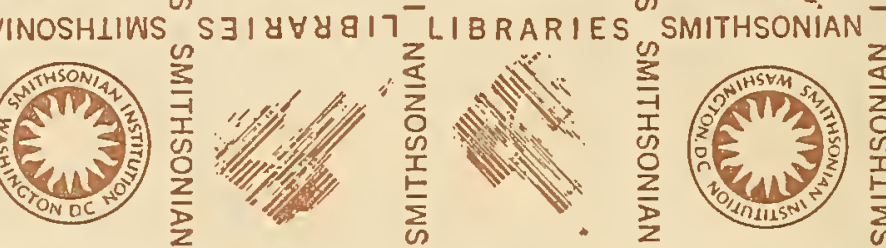

INSTITL
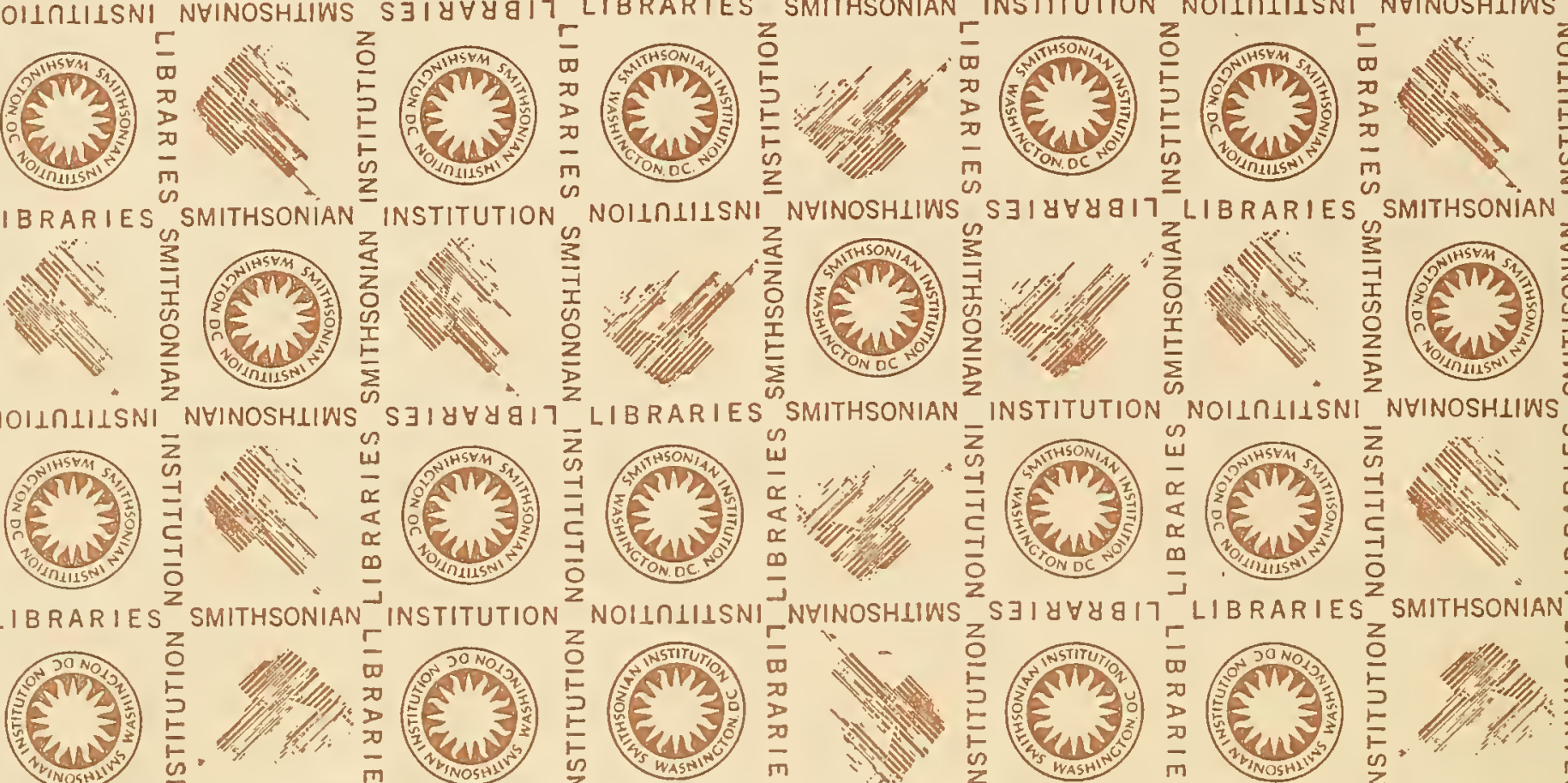

2 SMITHSONIAN INSTITI
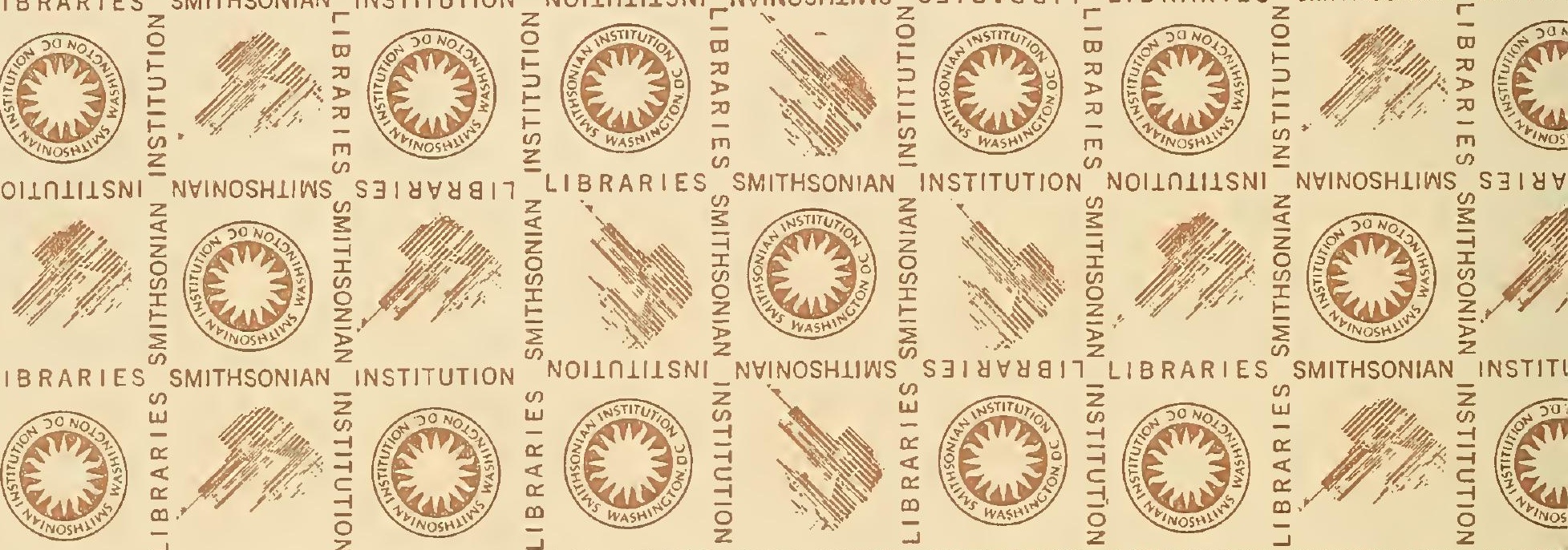

$S \exists I y \forall$
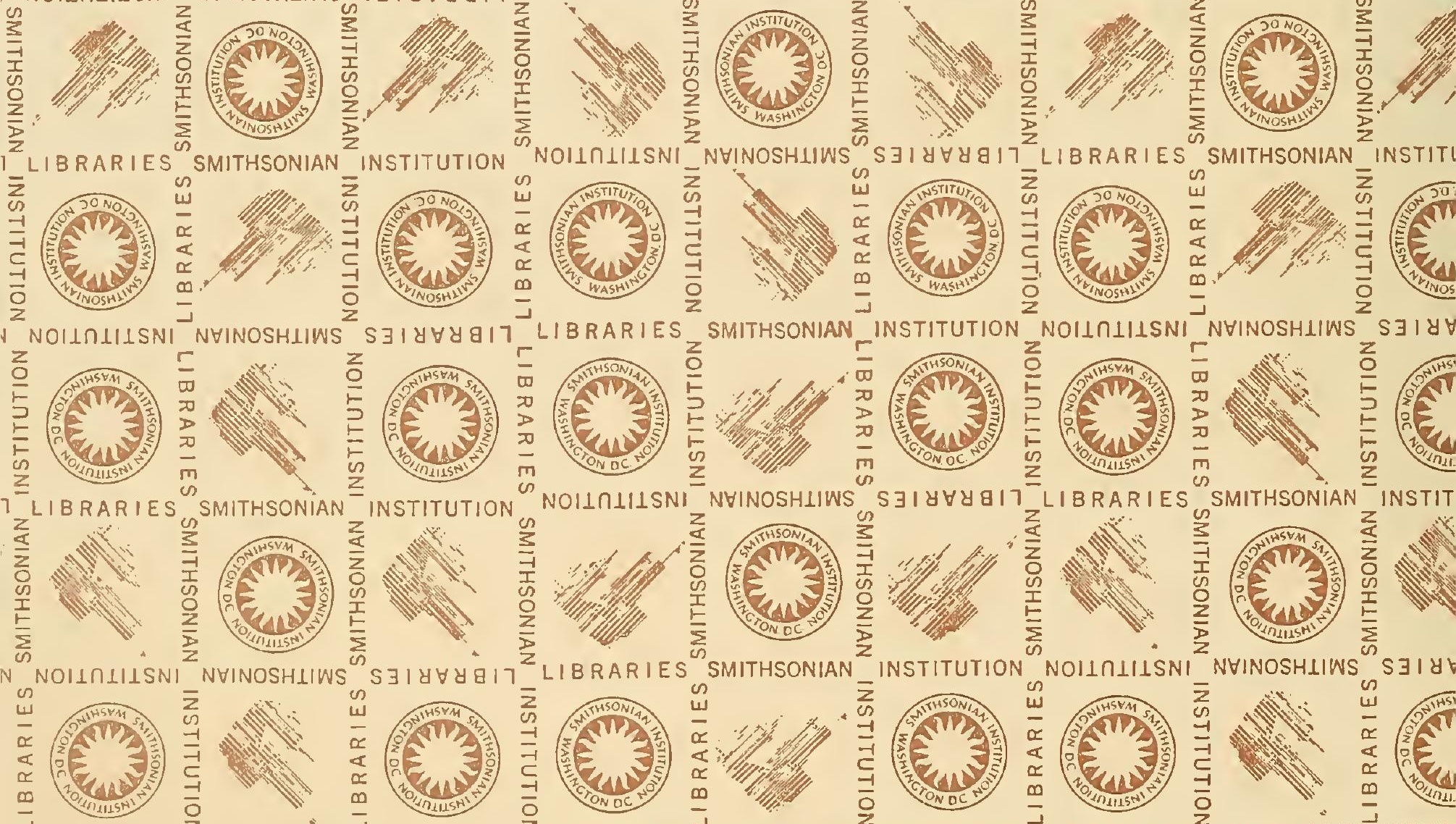

INSTIT
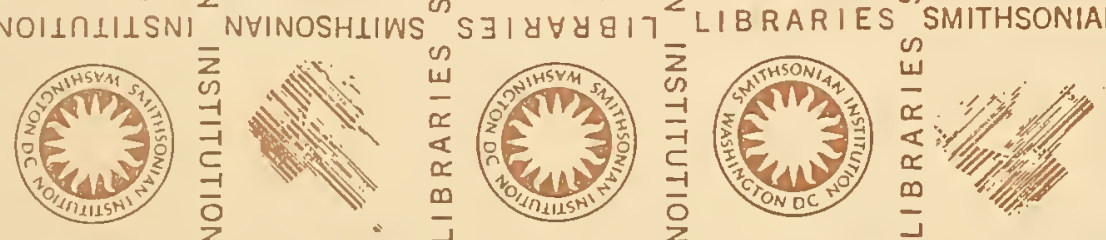

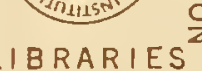

.10.4.

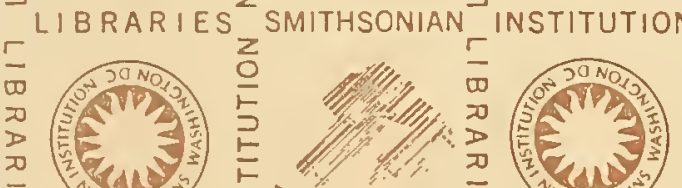

)

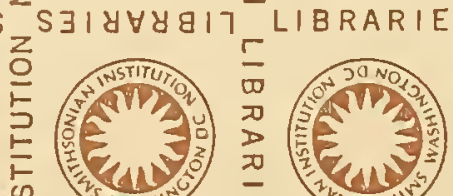



